UNIVERSIDADE DE SÃO PAULO

FACULDADE DE EDUCAÇÃO

DANIEL ANGEL LUZZI

\title{
O papel da educação a distância na mudança de paradigma educativo: \\ da visão dicotômica ao continuum educativo
}


DANIEL ANGEL LUZZI

\section{O papel da educação a distância na mudança de paradigma educativo:}

\section{da visão dicotômica ao continuum educativo}

Tese apresentada à Faculdade de Educação da Universidade de São Paulo para a obtenção do título de Doutor em Educação.

Área de Concentração: Educação - Opção: Estado, Sociedade e Educação

Orientador: Prof. Dr. Pedro Roberto Jacobi

São Paulo 
Ficha Catalografica elaborada pelo Serviço de Biblioteca da FE/USP

\subsection{Luzzi, Daniel Angel}

L979p O papel da educação a distância na mudança de paradigma educativo: da visão dicotômica ao continuum educativo/ Daniel Angel Luzzi; orientador Dr. Pedro Roberto Jacobi.---São paulo, SP: s.n., 2007 400 p.: il; grafs; tabes.

Tese (Doutorado - Programa de Pós-graduação em Educação. Area de concentração: Estado, Sociedade e Educação. Faculdade de Educação da Universidade de São Paulo.

1. Educação a distância. 2. Universidade. 3. Formação de conceitos. I Jacobi, Pedro, orientador. 
Tese apresentada à Faculdade de Educação da Universidade de São Paulo para a obtenção do título de Doutor em Educação.

Área de Concentração: Educação - Opção: Estado, Sociedade e Educação

Aprovado em:

Banca Examinadora:

Prof. Dr.

Instituição:

Assinatura:

Prof. Dr.

Instituição:

Assinatura:

Prof. Dr.

Instituição:

Assinatura:

Prof. Dr.

Instituição:

Assinatura:

Prof. Dr.

Instituição:

Assinatura: 
A Andrea Luswarghi, agradeço o apoio e a colaboração visionária ao longo destes anos. 


\section{AGRADECIMENTOS}

Aos meus pais, que deram todo o possível para me proporcionar uma educação de qualidade.

Ao povo brasileiro, que me recebeu tão generosamente em sua terra.

A Profa. Dra. Cecília Pelicioni e ao grupo da FSP-USP, que abriram as portas da faculdade e de seus corações.

A Andrea Luswarghi pelas intermináveis horas de discussão e pelo apoio incondicional para que esta tese viesse a luz.

A Viviane pela força que me deu sempre que necessitei e pelo apoio logístico.

A Edna e Paulo pela valiosa e acurada contribuição acadêmica.

Ao Prof. Dr. Pedro Jacobi, pela enorme paciência.

Especialmente a todos os meus alunos que ao longo de todos estes anos tanto me ensinaram. 


\section{RESUMO}

Este trabalho investiga o papel da educação a distância na transformação do paradigma educativo tradicional e sustenta que esta modalidade de ensino-aprendizagem é uma oportunidade para repensar o papel da educação no atendimento das demandas da Sociedade do Conhecimento, que provoca transformações em todas as esferas sociais no início do século XXI. A tese defende que a educação a distância não deve ser tratada como um modelo compensatório do ensino presencial e sim como parte integrante, como importante elemento que pode impulsionar a transformação das práticas educativas em todos os níveis de ensino. Através do estudo analítico quantitativo e qualitativo das principais mega universidades existentes no mundo, especialmente aquelas dos países continentais, como é o caso de Índia e China, com características próximas ao caso do Brasil, o trabalho busca disponibilizar dados e reflexões para o planejamento de políticas públicas de educação, que integrem o uso de tecnologias de comunicação e informação às práticas pedagógicas, como estratégia para desenvolver recursos humanos preparados para lidar com os desafios econômicos e socioambientais da atualidade.

Palavras-chave: educação a distância, sociedade em rede, mega universidades, novos paradigmas educacionais, função social da educação. 


\begin{abstract}
This work investigates the role of the distance education on transformation of traditional educational paradigm and sustains that this modality of teaching-learning is a great opportunity to rethink the role of education to attend the demand of the Knowledge Society, that are transforming all the social spheres in the XXI century begin. The thesis defends that the distance education must not be treated as a compensatory model to the traditional system but as an important element that might promote the transformation of educative practices in all the teaching levels. Through the quantitative and qualitative analysis of the main existing mega universities in the world, specially those of the continental countries, like India and China, with characteristics close to the Brasil's case, the work tries to provide information and reflexions to plan and design public educational politics, which integrate the use of communication and information technology to the pedagogic practices, as a strategy to develop human resources prepared to deal with the economic challenges and environmental sustainability.
\end{abstract}

Keywords: distance education, network society, mega universities, new educational paradigms, social function of education. 


\section{Lista de tabelas}

Tabela 1: Síntese da metodologia utilizada nesta pesquisa 19

Tabela 2: Boletim sobre a Educação na América Latina 67

Tabela 3: Tabela comparativa dos conceitos de Educação a Distância 90

Tabela 4: Análise de 43 definições de EaD, de 1960 a 2006. Tabela elaborada pelo 95 autor

Tabela 5: Características Conceituais da Educação a Distância 96

Tabela 6: Análise de 23 definições de EaD, de 1991 a 2006

Tabela 7: Tabulação de dados de 43 definições de EaD, de 1960 a $2006 \quad 102$

Tabela 8: Tabulação de dados de 22 definições de EaD, de 1991 a 2006

Tabela 9: Estudos de Casos descritos por Daniel 105

Tabela 10: Shift in the instructional media. In IGNOU 1987-2001 115

Tabela 11: Crescimento da produção acumulativa de áudio e vídeo-cassete na IGNOU 116

Tabela 12: Produção de lições em radio, áudio e vídeos BRAOU 129

Tabela 13 - Estatísticas de e-learning no $1^{\text {o }}$ semestre de 2002 na Universidade de Tsinghua. $\quad 153$

Tabela 14: Número de alunos da Universidade Terbuka 194

Tabela 15: Universidades Virtuais na Corea 206

Tabela 16: Critérios de notas para os cursos de graduação da STOU 230

Tabela 17: Critérios de notas para os cursos de mestrado da STOU 230

Tabela 18: Custos dos exames oferecidos pela UNISA 238

Tabela 19: Distribuição 2004 e evolução das inscrições por níveis e tipos de formação 253

Tabela 20: Utilização dos diferentes suportes nos produtos de formação do CNED 256

Tabela 21: A Universidade Virtual no Brasil, Os números do ensino superior a distância no país em 2002. 318

Tabela 22: Recursos Humanos para atender atividades da UAB 321

Tabela 23: Cátedras da UNESCO em diversos países 340

Tabela 24: Crescimento de Megauniversidades entre sua fundação e 1995 e entre 1995367 e 2004 


\section{Lista de Figuras}

Figura 1: Web site do Instituto Nacional de Educação Aberta (NIOS) 108

Figura 2: Portal da Indira Gandhi National Open University (IGNOU) 109

Figura 3: Sistema Instrucional na IGNOU $\quad 118$

Figura 4: EDUSAT 119

Figura 5: Modelo de desenvolvimento de cursos $\quad 121$

Figura 6: Portal da Dr. B.R. Ambedkar Open University (BRAOU) 125

$\begin{array}{ll}\text { Figura 7: Estratégia Instrucional } & 128\end{array}$

Figura 8: MANA TV 130

Figura 9: Terminais de recepção instalados para a MANA TV 131

Figura 10: Sistema de Tutoria da BRAOU 132

Figura 11: Sistema educativo da China $\quad 140$

Figura 12: Portal CCRTVU 142

Figura 13: Sistema de transmissão de satélite e rede baseada em computadores $\quad 146$

Figura 14: Estúdio de transmissão/ sala de aula de transmissão ao vivo 149

Figura 15: Sistema de financiamento do sistema $\quad 150$

Figura 16: Portal da Universidade de Tsinghua na China 153

Figura 17: Tsinghua on-line lyceum $\quad 154$

Figura 18: Sistema do "mainframe" da escola na web da Universidade de Tsinghua 155

Figura 19: Organograma funcional da escola on-line da Universidade de Tsinghua 156

Figura 20: Uso da ponteira laser para dar permissão para usar a palavra para estudantes remotos apontando para suas imagens no quadro de estudantes $\quad 160$

Figura 21: Uso da ponteira laser para dar permissão para usar a palavra para estudantes remotos apontando para suas imagens no quadro de estudantes 161

Figura 22: Centros de Estudos da Universidade de Tsinghua 162

Figura 23: Centro Municipal de Educação a Distância de Guizhou Nawei 163

Figura 24: Estudantes no centro de ensino do município de Shanggelila aprendendo a reparar motores em Beijing $\quad 163$

Figura 25 - Organização do Sistema Educacional Japonês (MEXT) 166

Figura 26: Portal da University of the Air 168

Figura 27: Fluxograma dos cursos regulares 172

Figura 28: Fluxograma para os outros estudantes, que não irão receber o grau de Gaikushi ao final do curso 173

Figura 29: Representação esquemática do processo de transmissão de aulas através da $\begin{array}{ll}\text { TV e rádio } & 174\end{array}$

Figura 30: Portal da SOI/ School of internet Asia Project 177 
Figura 31: Representação esquemática de aula através da internet

Figura 32: Portal da SOI/ School of internet Asia Project

Figura 33: Instituições e Universidades que se uniram ao projeto SOI

Figura 34: Portal da Allama Iqbal Open University

Figura 35: Infraestrutura da Allama Iqbal Open University

Figura 36: Portal da Universidade Virtual do Paquistão

Figura 37: Estúdio de transmissão Universidade do Paquistão

Figura 38: Portal da Universidade de Terbuka

Figura 39: Relação de Centros de Estudos da Universitas Terbuka

Figura 40: Versão em língua inglesa do Portal da Korea National Open University

Figura 41: Portal da Korea National Open University, na língua coreana

Figura 42: Modelo multimídia da KNOU

Figura 43: Modelo tutorial da KNOU

Figura 44: Modelo de Trabalho Prático da KNOU

Figura 45: Portal da Payame Noor University

Figura 46: Portal da Sukhothai Thammathirat Open University

Figura 47: Locais de realização dos exames da STOU

Figura 48: Portal da Universidade da África do Sul

Figura 49: Centros de Estudo da UNISA

Figura 50: Portal da UK Open University

Figura 51: Página da UK Open University que indica os passos para se planejar o estudo e seus objetivos

Figura 52: Portal do Centre National d'Enseignement à Distance

Figura 53: Portal da Universidad Nacional de Educación a Distancia (UNED)

Figura 54: Portal da Universidade Virtual do Centro Tecnológico de Monterrey

Figura 55: Portal da Athabasca University

Figura 56: Portal University of Phoenix

Figura 37: Apresentação da Universidade Aberta do Brasil (UAB)

Figura 18: Portal da The Virtual University and e-learning

Figura 59: Portal AVICENNA Virtual Campus

Figura 60:Portal da Global Distance Educatio.net

Figura 61: Centro de Cooperação Regional para a Educação de Adultos na América Latina e no Caribe (CREFAL/UNESCO)

Figura 62: Portal do Instituto Latino-americano da Comunicação Educativa 


\section{Lista de Gráficos}

Gráfico 1: Taxa de homicídios e suicídios por regiões da OMS. $2000 \quad 44$

Gráfico 2: 106 países ofereceram cursos de EaD nos últimos 10 anos 104

Gráfico 3: Growth of IGNOU Fresh Enrolamente of Students over the year 110

Gráfico 4: Crescimento das graduações outorgadas pela IGNOU 111

Gráfico 5: Registro de admissão e teste padrão dos últimos seis anos 111

Gráfico 6: Crescimento anual, programas, cursos e centros da IGNOU 114

Gráfico 7: Crescimento anual de conselheiros da IGNOU 123

Gráfico 8: Concentração de estudantes por ano na BRAOU 125

Gráfico 9: Número de estudantes que obtiveram diploma por ano na BRAOU 127

Gráfico 10: Número de Centros de Estudo por ano da BRAOU 134

Gráfico 11: Fluxo de estudantes da CCRTVU 143

Gráfico 12: Meios mais populares de comunicação com o tutor na Universidade de Tsinghua 157

Gráfico 13: Strategies for enhancing instructor immediacy in e-learning 158

Gráfico 14: Perfil de idade dos estudantes da University of the Air 168

Gráfico 15: Perfil de sexo dos estudantes da University of the Air 169

Gráfico 16: Perfil de ocupação dos estudantes da University of the Air 169

Gráfico 17: Divisão dos estudantes entre os cursos da University of the Air 170

Gráfico 18: Registro de Estudantes da UA 170

Gráfico 19: Número de graduados 1989-2002 na UA 171

Gráfico 20: Enrolment in Allama Iqbal Open University 1993-2003 186

Gráfico 21: Número de alunos da Universitas Terbuka 194

Gráfico 22: Divisão de estudantes por área na Universitas Terbuka 195

Gráfico 23: Gráfico 23: Número de alunos inscritos por ano na Universidade da Corea 211

Gráfico 24: Relatórios anuais da UNISA dos anos 2001, 2002, 2003, 2004 e 2005.

Gráfico 25: Número de alunos graduados pela UNISA nos anos 2001, 2002, 2003, 233 2004 e 2005

Gráfico 26: Distribuição dos alunos nos diferentes cursos da UNISA 236

Gráfico 27: Crescimento da Open University de 1970 a 2005

Gráfico 28: Número de estudantes de graduação e graduados da Athabasca University 286 (2003-2004)

Gráfico 29: Estudantes de graduação da Athabasca University contendo dados 287 relativos à sua localização, idade e gênero

Gráfico 30: Registro do número de estudantes presenciais e on-line da Universidade $\quad 300$ 
de Phoenix

Gráfico 31: Entrada de estudantes por etnia. Universidade de Phoenix, 2003

Gráfico 32: Cálculo de estudantes por média de idade da Universidade de Phoenix de 1995 a 2003

Gráfico 33: Cálculo de estudantes por idade e nível de curso. Universidade de Phoenix, 2003

Gráfico 34: Número de acessos ao Portal Educacional das Américas por mês nos anos de 2002, 2003 e 2004

Gráfico 35: Número de acessos ao Portal Educacional das Américas por países

Gráfico 36: Número de Participantes Capacitados por País 2001-2004 Portal Educacional das Américas. 


\section{SUMÁRIO}

RESUMO

ABSTRACT

LISTA DE TABELAS

LISTA DE FIGURAS

LISTA DE GRÁFICOS

INTRODUÇÃ

GÊNESE DA PESQUISA...............................................................................

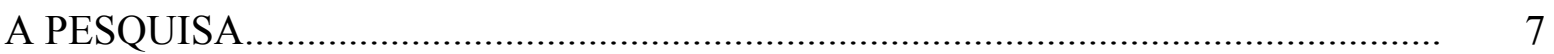

Objetivo e problema da pesquisa........................................................................ 7

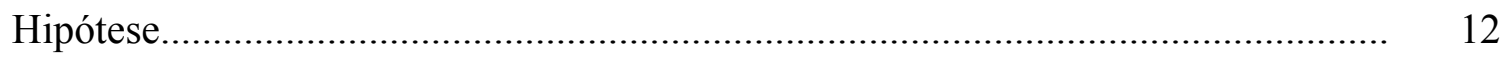

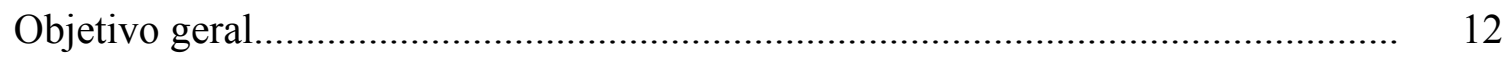

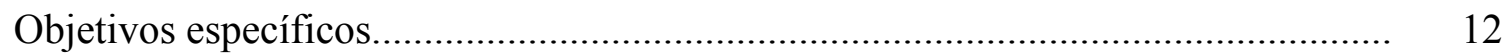

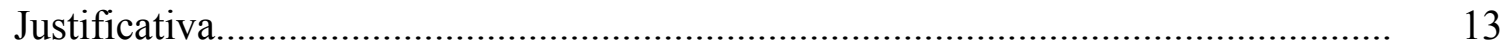

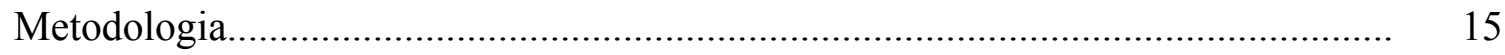

CAPÍTULO 1: PAPEL DA EDUCAÇÃO NO SÉCULO XXI 20

1.1 Educação e contexto: adequação ou inadequação? .................................................... 21

1.1.1 A educação nos diferentes períodos históricos.................................................. 22

1.1.2 Fins e meios, uma relação intrínseca......................................................................... 26

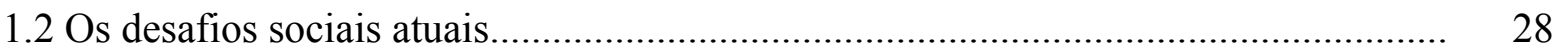

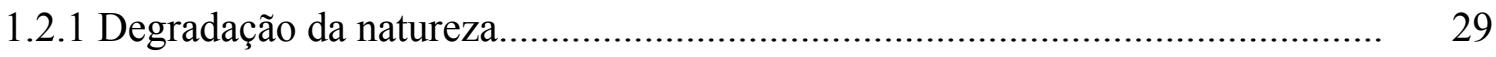

1.2.2 A degradação da qualidade de vida............................................................. 30

a) Pobreza, desigualdade extrema e fome........................................................ 31

b) Desemprego de jovens e violência urbana.......................................................... 35

c) Saúde física e mortalidade evitável................................................................... 37

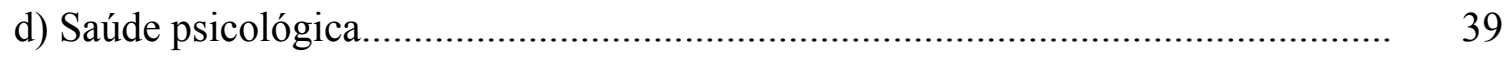


- A degradação da dignidade humana.

- Individualismo e a crise do ser no mundo.................................................... 41

- Consumismo como valor e indústria cultural como veículo........................ 42

- $\quad$ Suicídio e estresse ocupacional.................................................................. 44

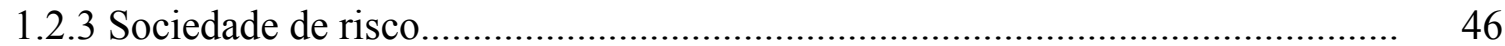

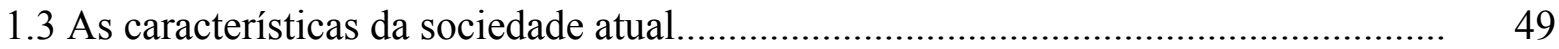

1.3.1 Sociedade da informação, sociedade em rede................................................. 49

1.3.2 Cibercultura e tecnologias aplicadas à educação............................................... 52

1.3.3 Sociedade da Aprendizagem: da sociedade da informação às sociedades do conhecimento.

1.3.4 Epistemologia do conhecimento.

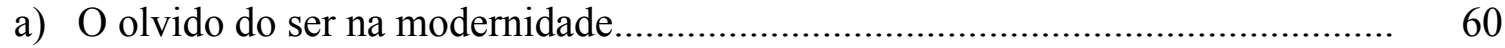

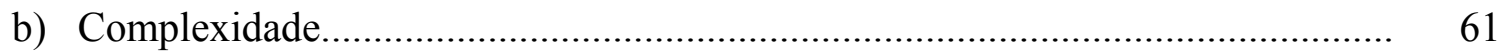

c) A redução do pensamento ao pensamento instrumental, a razão objetiva e a razão subjetiva.

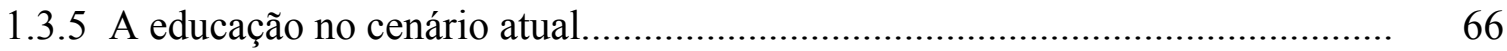

a) Expansão da matrícula e baixa qualidade educativa............................................... 66

b) Enfoque centrado em competências e mercantilização educativa.......................... 68

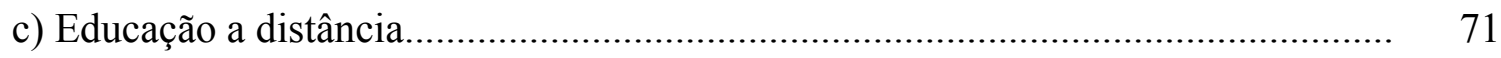

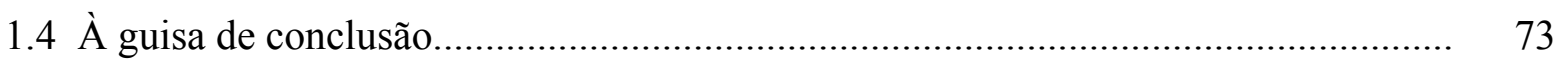

\section{CAPÍTULO 2: EDUCAÇÃO A DISTÂNCIA - DA VERSÃO DICOTÔMICA} AO CONTINUUM EDUCATIVO

2.1 Aproximação histórica da educação a distância....................................................... 75

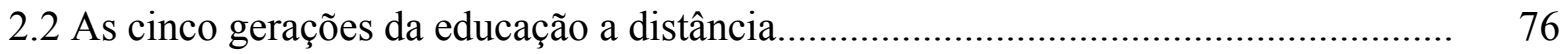

2.3 Conceituação de educação a distância........................................................................ 78

2.3.1 Definiç̧ões de educação a distância de 1960 a 2006............................................ 79

2.3.2 Estudo comparativo das definições de educação a distância............................. 89 
2.3.3 Análise histórica das tendências teóricas.

2.3.4 Análise das principais características presentes nas definições de educação a distância.

2.4 Definição de Educação Aberta.

98

2.5 À guisa de conclusão

99

2.6 Tabulação de dados de 43 definições.

101

2.7) Tabulação de dados de 22 definições

103

CAPÍTULO 3: EDUCAÇÃO A DISTÂNCIA NO ENSINO SUPERIOR

GLOBAL - MEGA OPEN-UNIVERSITIES

104

3.1 Panorama geral 104

3.2 Panorama no Ensino Superior.

3.3 Megauniversidades

106

3.4 Ásia

106

3.4.1 Índia: Contexto Nacional.

106

a) Indira Gandhi National Open University (IGNOU)......................................... 108

b) Dr. B.R. Ambedkar Open University (BRAOU) ............................................... 125

3.4.2 China: Contexto Nacional.......................................................................... 136

a) Central Broadcast Television University - China TV University........................ 140

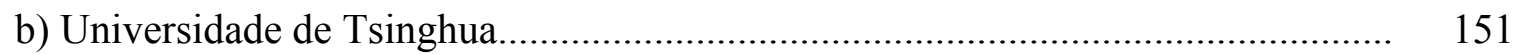

3.4.3 Japão: Contexto Nacional............................................................................. 164

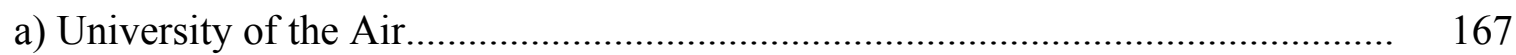

b) Projeto WIDE: SOI - School on the Internet.................................................. 176

3.4.4 Paquistão: Contexto Nacional.................................................................... 183

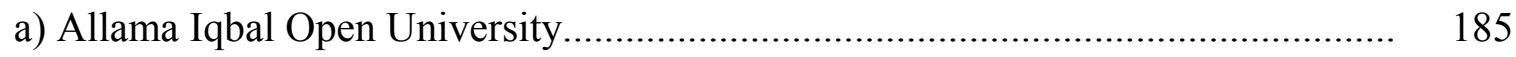

b) Universidade Virtual do Paquistão.................................................................... 190

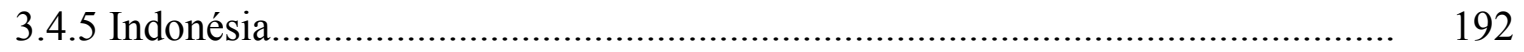

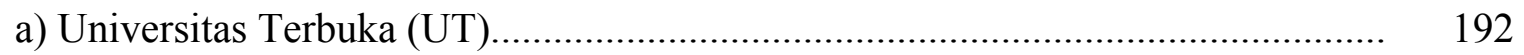

3.4.6 Coréia: Contexto Nacional......................................................................... 205

a) Korea National Open University (KNOU)...................................................... 208

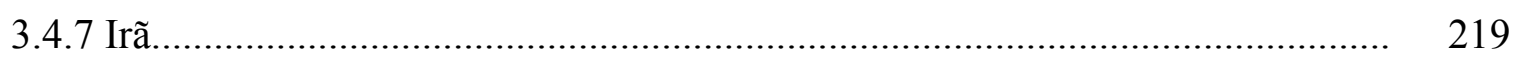

a) Payame Noor University (PNU) .................................................................. 219

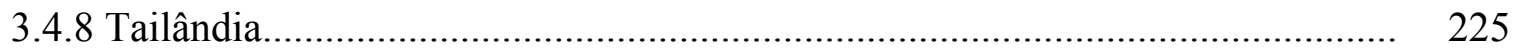


a) Sukhothai Thammathirat Open University (STOU)......................................... 225

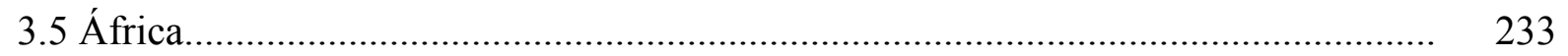

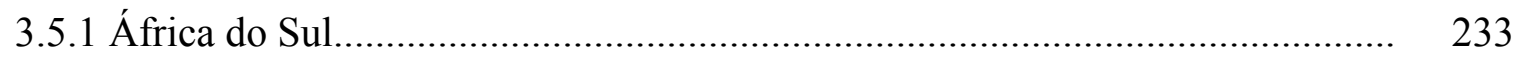

a) University of South Africa............................................................................ 233

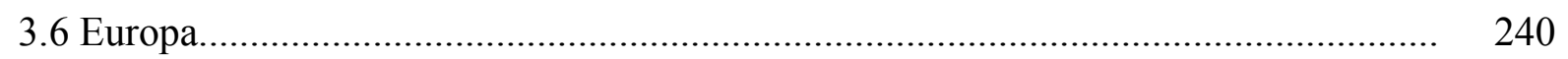

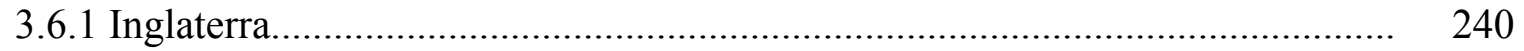

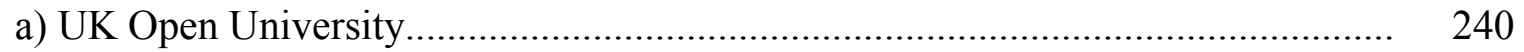

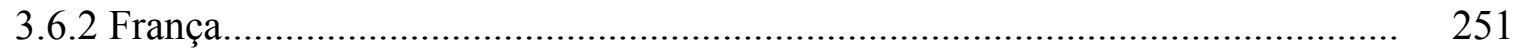

a) Centre National d'Enseignement à Distance (CNED)...................................... 251

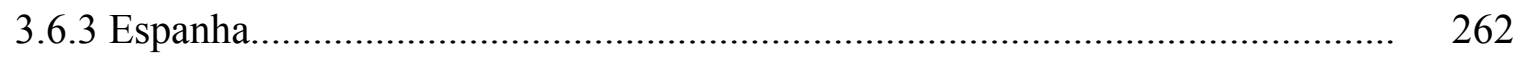

a) Universidade Nacional de Educação a Distância................................................. 262

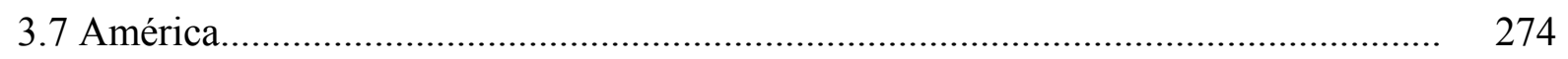

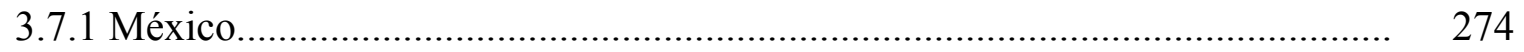

a) Universidad Virtual - Tecnológico de Monterrey................................................ 274

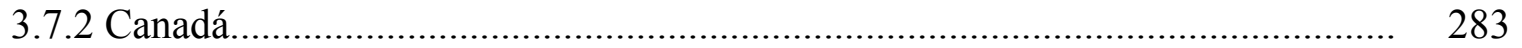

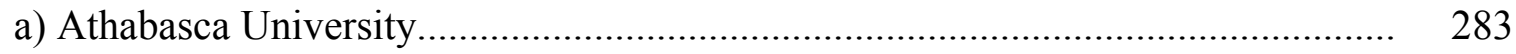

3.7.3 Estados Unidos...................................................................................... 296

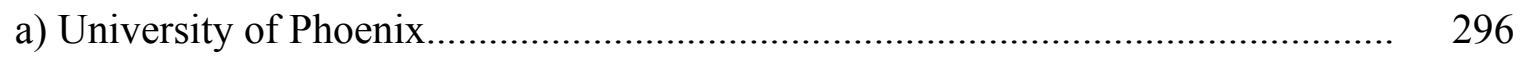

3.7.4 Brasil: Contexto Nacional............................................................................ 312

a) Universidade Aberta do Brasil.......................................................................... 319

3.8 Associações profissionais de educação aberta e a distância........................................ 331

3.9 Posição dos Organismos Internacionais ....................................................................... 332

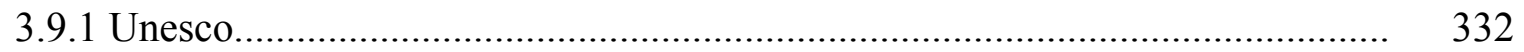

a) Posição Global........................................................................................... 332

b) The Virtual University and e-learning............................................................ 333

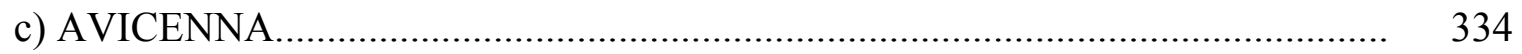

d) Global Distance Education............................................................................... 335

e) Centro de Cooperação Regional para a Educação de Adultos na América 335

Latina e no Caribe (CREFAL/UNESCO).

f) Instituto Latino-americano da Comunicação Educativa (ILCE/ UNESCO)........... 336

g) Instituto para a Conectividade das Américas (ICA)......................................... 337

h) Cátedras UNESCO de Educação a distância.......................................................... 338

3.9.2 Organização dos Estados Americanos (OEA)................................................ 340 
4.1 O papel da educação no século XXI.

4.2 Meios, a ciência, a tecnologia e a cultura..

4.3 Conceitualização de Educação a Distância

a) A distância como eixo diferenciador..................................................................... 359

b) A tecnologia como eixo principal: o enfoque mediacional centrado no 361 computador.

4.4 Educação a distância na educação superior..

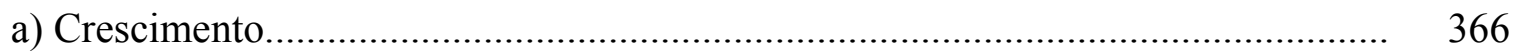

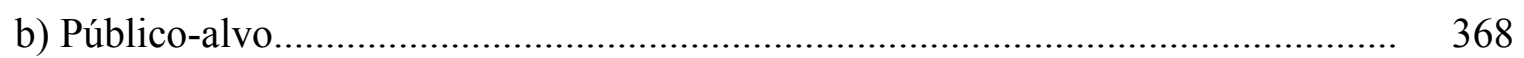

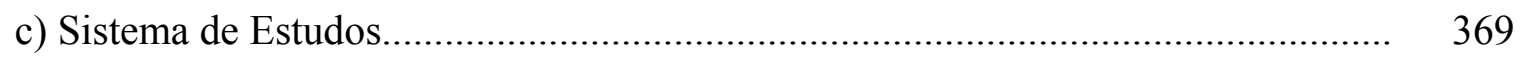

d) Materiais de estudos e estratégia educacional................................................. 370

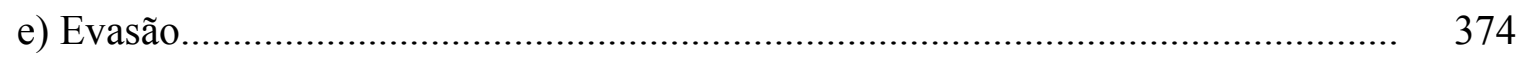

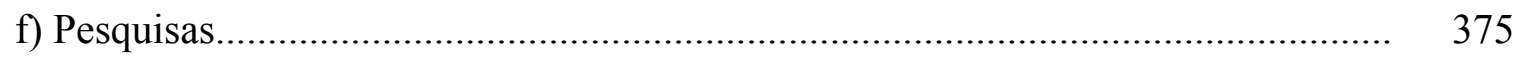

g) Financiamento e estratégias de articulação....................................................... 377

4.5) Conclusões e recomendações....................................................................... 376

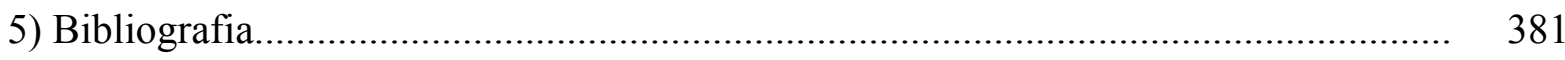




\section{INTRODUÇÃO}

Em uma fase de transição de uma época a outra, como a que estamos vivendo, instala-se o debate epistemológico em um processo cuja dialética se define entre o certo e o incerto, o estável e o instável, o contínuo e a ruptura.

Definir a sociedade atual representa um enorme desafio. Na pesquisa sobre os estudos relacionados ao tema, encontramos infinitas análises e posições que envolvem diversos recortes da realidade, que, articuladas, possibilitam enxergar a complexidade do mundo. Assim, em uma primeira aproximação, podemos entender o momento atual como aquele que se caracteriza por alguns elementos: crise socioambiental; sociedade de risco; sociedade do indivíduo; sociedade de consumo; sociedade da informação; sociedade do conhecimento; sociedade da aprendizagem; sociedade em rede, entre outros.

A realidade é que estamos em pleno processo de construção de uma sociedade tecnológica digital global que se configura como uma sociedade profundamente dinâmica e comunicativa (comunicacional/midiática), com novas linguagens, novos códigos, novas condutas, novos costumes e novos valores.

A educação não é exceção. Também se encontra envolvida em uma profunda crise ${ }^{1}$, tanto do ponto de vista de seus fins quanto de seus meios e estratégias, abrangendo a dimensão quantitativa - igualdade de oportunidades no acesso à matrícula - e a dimensão qualitativa eficácia em alcançar os objetivos educativos.

Um bom exemplo disso pode ser observado no estudo realizado pelos Institutos Americanos de Pesquisa (American Institutes for Research, 2006) ${ }^{2}$ sobre o nível de conhecimento dos estudantes e graduados nos Estados Unidos, publicado no ano de 2006. Este documento apresenta um quadro preocupante: $20 \%$ dos estudantes de faculdades que completaram estudos de 4 anos de duração e 30\% dos estudantes que fizeram estudos de 2 anos de duração, nos Estados Unidos, possuem somente habilidades básicas de alfabetização matemática. Isso significa que esses estudantes norte-americanos são incapazes de estimar se o carro tem

\footnotetext{
${ }^{1}$ Etimologicamente, a palavra "crise" vem do verbo grego Krinein, que significa "decidir". Em chinês, a palavra equivalente a "crise" é wei-ji, termo que combina os conceitos "perigo" e "oportunidade". Entendemos crise como um estado temporal de transtorno e desorganização, caracterizado, principalmente, pela incapacidade para abordar situações particulares utilizando métodos habituais para a solução de problemas. Uma crise é tanto um risco quanto uma oportunidade.

${ }^{2}$ Disponível em: <http://www.pewtrusts.com/ideas> Acesso em: 25 fev 2006.
} 
bastante gasolina para chegar ao próximo posto de gasolina ou calcular o custo total para providenciar a compra de materiais para escritório.

Neste momento da civilizacão, é de enorme importância a reflexão sobre o papel que a educação e o pensamento educativo podem ter na construção de uma sociedade de aprendizagem sustentável, justa e equitativa.

De acordo com Pozo (1996, p. 37), a cultura atual demanda formação permanente e reciclagem profissional em todas as áreas produtivas, como conseqüência de um mercado de trabalho "complexo, mutável, flexível e, inclusive, imprevisível”, que, associado a um acelerado ritmo de mudança tecnológica, nos leva sempre a aprender coisas novas. Enfatiza o autor, ainda, que a dificuldade não está só na dimensão quantitativa, mas também na qualitativa, ou seja, não se trata apenas de aprender muitas coisas, mas de estudar coisas diferentes em um tempo escasso, dado o grande volume de informação que precisamos processar e a velocidade das mudanças e inovações que nos exigem aperfeiçoamento constante ao longo de toda a vida. Por isso a necessidade de "aprender a aprender" é uma das características que definem essa cultura, pois temos que estudar temas variados e complexos e aplicá-los a contextos diversos, que se mantêm em evolução permanente.

A educação enfrenta uma série de desafios em um mundo que se transforma, por isso deve rever sua missão e redefinir muitas das suas tarefas substantivas, em especial aquelas que se relacionam às necessidades da sociedade em matéria de aprendizagem e formação permanente.

Uma das alternativas que está se consolidando para possibilitar a distribuição eqüitativa das oportunidades educativas é, sem dúvida, a chamada educação a distância: uma modalidade que tem mostrado uma grande flexibilidade tanto para atender ao crescimento do número de matrículas como para gerar estratégias que possibilitem tornar realidade a formação contínua que a sociedade do conhecimento tanto demanda. A UNESCO (2002, p. 5) ressalta a importância da educação a distância na sociedade atual como uma força que pode contribuir para o desenvolvimento social e econômico. 
Isso se deve, entre outros motivos, ao fato de que as modalidades educativas tradicionais baseadas no modelo universitário de Paris do ano de $1200^{3}$ (um modelo presencial, centrado no professor, com ênfase na transmissão unilateral de informação partindo do especialista para o aprendiz) não oferecem mais respostas às demandas formativas da sociedade da informação e do conhecimento, o que está gerando um crescimento da modalidade de ensinoaprendizagem virtual, factível de ser visualizada tanto no interior das universidades tradicionais, através de sistemas semipresenciais e a distância, quanto no surgimento das chamadas universidades abertas.

No entanto, além do problema que resulta no desenvolvimento desta modalidade como uma alternativa compensatória à educação presencial, apresentam-se outras dificuldades, como estudos fragmentados e centrados na dimensão tecnológica e uma visão de curto prazo, já que

la gran mayoría de los trabajos de investigación realizados hasta ahora en los campos de la educação, la investigación científica y las nuevas tecnologías siguen siendo tributarios de un gran determinismo tecnológico y de una visión demasiado fragmentada de las interacciones existentes. El interés por los efectos a corto plazo de la introducción de las nuevas tecnologías en la enseñanza y el aprendizaje puede conducir a que se deje de lado un estudio más profundo de los nuevos contenidos de la educação, así como de su calidad y sus modalidades (UNESCO, 2005) ${ }^{4}$.

Esta forte concepção tecnológica é acompanhada de uma escassa reflexão acerca das metodologias utilizadas. Desta forma, está-se reproduzindo o modelo de ensino tradicional utilizando-se novas tecnologias de informação e comunicação.

O grande desafio está em conceber uma proposta didático-pedagógica que se apóie nos meios tecnológicos e os transcenda, superando as visões dos tecnólogos educativos. A educação tem que repensar seus paradigmas, sua função social, suas estruturas, suas estratégias, seus conteúdos e suas metodologias. Acreditamos que já não é possível enfrentar os problemas do presente com uma solução cosmética, superficial... Trata-se da necessidade de uma reforma em profundidade.

\footnotetext{
${ }^{3}$ No manual universitário de Juan de Garlandia, professor de Paris, lemos: "tenemos aquí los instrumentos necesarios para los escolasticos: libros lo primero, un pupitre con atril, una lámpara de noche con sebo y un candelero, una linterna y un embudo con tinta, una pluma, una plomada y una regla, una mesa, una silla, una pizarra, una piedra pómez, un raspador de pergaminos y una tiza". In: RODRIGUEZ DE LA PENA, 2000, p. 120.

${ }^{4}$ Disponível em: $<$ http://firgoa.usc.es/drupal/node/23044>. Acesso em: 9 mar 2006.
} 


\section{GÊNESE DA PESQUISA}

Em 1984 começamos nossos estudos de Licenciatura em Ciências da Educação na Universidade de Buenos Aires. Desde essa época vimos analisando a função social da educação, indagando sobre as temáticas sociais emergentes que configuram os desafios de cada época, determinando o sujeito social a formar, tanto da perspectiva do conhecimento como dos procedimentos e valores, não só no que se refere ao mercado de trabalho mas também no que diz respeito à cidadania.

Entre 1989 e 1993, exercendo a função de Assessor do Governo do Estado de Buenos Aires, no programa "Proteção do Meio Ambiente na Comunidade Organizada", começou a nos ficar clara a relação entre crise ambiental e função social da educação, fato que se identifica como uma das demandas prioritárias da sociedade para a formação de cidadãos ambientalmente responsáveis.

Assim, entre 1992 e 1994, trabalhando na reforma educacional do estado da província de Buenos Aires, no Programa das Nações Unidas para o Desenvolvimento, o foco de nosso trabalho centrou-se na análise das relações entre sociedade e educação, para gerar recomendações para a elaboração de políticas educacionais. Nesse contexto, o eixo foi colocado na educação ambiental, como uma resposta da educação à crise que a humanidade enfrentava, elaborando diretrizes conceituais, procedimentais e valorativas que possibilitassem formar um cidadão ambientalmente responsável.

Posteriormente, entre 1996 e 1999, atuando como Coordenador Pedagógico no Banco Interamericano de Desenvolvimento (BID), num projeto-piloto de consolidação da educação ambiental na região sul-americana, surgiu-nos a preocupação sobre a formação de professores, pois havíamos chegado à conclusão de que, para gerar uma verdadeira mudança significativa, não eram suficientes a pesquisa metodológica e a elaboração de políticas públicas. Tornavam-se necessárias, sobretudo, a formulação e a implementação de uma boa formação de professores que pudessem operacionalizar as políticas públicas.

Depois de alguns anos de trabalho, houve a constatação de que, apesar dos esforços, tinha se alcançado um número ínfimo de professores e que nesse ritmo se levaria mais de uma década para formá-los em sua totalidade. Assim, começamos nossos estudos sobre a modalidade de educação a distância na busca de uma alternativa educativa que permitisse formar os 
professores de maneira rápida e efetiva, para impulsionar uma verdadeira mudança nas salas de aula. Como resultado deste processo, foram elaborados dois cursos de educação ambiental a distância para formação de professores, com formato impresso, uso da técnica de casseteforo (com uso de áudio em fita, ou enviada por correio) e encontros presenciais.

Posteriormente, em 1998, já no curso de Mestrado em Gestão Ambiental da Universidade Nacional de General San Martín, na Cátedra UNESCO/COUSTEAU em ECOTECNIA (Ecologia e Gestão Ambiental), continuamos explorando as relações entre educação e sociedade, a partir de uma pesquisa que buscava analisar as possibilidades de transformação educacional na inserção da educação ambiental no sistema formal, abordando tanto a dimensão curricular quanto a problematização epistemológica do conteúdo das disciplinas, a dimensão organizacional, criadora de cultura, bem como as aproximações psicológicas, pedagógicas e didáticas, avançando na configuração de uma pedagogia da complexidade.

Esse trabalho deu origem a um convite do Instituto de Estudos Interdisciplinares da Universidade Autônoma do México, no ano de 2000, para a participação em um estudo internacional sobre a complexidade na educação, com foco na incorporação de variáveis como a metacognição e os avanços da ciência cognitiva; a relevância do pensamento produtivo sobre o reprodutivo (à luz dos desenvolvimentos da psicologia da Gestalt); a aprendizagem significativa; a epistemologia genética e a perspectiva social (conforme os estudos de D. Ausubel, J. Piaget e L. Vygotsky). O resultado deste estudo foi publicado em forma de artigo - Ambientalización de la educación formal: un diálogo abierto en la complejidad del campo educativo - no livro La complejidad ambiental, em espanhol, pela editora Século XXI, no México, no ano de 2000, e, em língua portuguesa, pela editora Cortez, no Brasil, em 2003.

Desde então estamos desenvolvendo uma pesquisa teórico-prática da educação a distância, focando as metodologias pedagógicas, os sistemas de avaliação, as arquiteturas de informação, os objetos de aprendizagem, os sistemas semânticos, os mapas conceituais de navegação, entre outros, como pesquisador e a partir de nossas atividades profissionais: no ano de 2001, como coordenador pedagógico da Universidade Virtual Brasileira (UVB); em 2002, como consultor de e-learning da UNESP e do IBMEC; a partir de 2003, como consultor no SENAC e posteriormente como diretor de e-learning da Unip, e, ainda, como consultor do MEC para avaliação de instituições para credenciamento da modalidade de educação a distância, entre outras atividades. 
Posteriormente e paralelamente aos estudos de doutorado iniciados na Faculdade de Educação da USP, no ano de 2003, realizamos várias atividades programadas que, associadas às disciplinas cursadas, contribuíram para o desenvolvimento da pesquisa:

a) A criação de um produto de tecnologia educacional, para ensino superior, com técnicas de exploração guiada e aprendizagem por descoberta, que foi utilizado na disciplina de Pedagogia Ambiental do curso de Especialização em Educação Ambiental do Núcleo de Informações em Saúde Ambiental da Faculdade de Saúde Pública (NISAM-USP).

b) Uma pesquisa orientada à arquitetura de informação e conhecimento, que culminou na apresentação de uma palestra sobre a "Estrutura Pedagógica dos Learning Objects", realizada no Congresso E-learning \& E-training 2003, organizado pela Sucesu-SP e pela Ideti, na Faculdade Sumaré, no período de 24 a 25 de junho de 2003.

c) O desenvolvimento de um curso de educação ambiental a distância para formação de professores, disponibilizado pela Cidade do Conhecimento, do Instituto de Estudos Avançados da USP, e que, após três anos de experimentação e ajustes, acabou sendo aplicado num projeto-piloto com 500 professores da rede pública da Secretaria de Educação do Estado de São Paulo e avaliado pela Faculdade de Saúde Pública da USP, no ano 2006-2007.

Nutridos com todos estes conhecimentos e experiências, começamos o trabalho de pesquisa da tese de doutoramento, focando as mudanças da sociedade atual, os desafios presentes para os sistemas educativos e as tecnologias educativas, em particular a chamada educação a distância.

A pesquisa, com suas análises, buscou compreender como a educação a distância, além de possibilitar um maior acesso à educação, pode também colaborar para a mudança dos paradigmas educacionais, respondendo assim às reais demandas educacionais da sociedade atual. 


\section{A PESQUISA}

Os conhecimentos, as destrezas e as atitudes necessárias para satisfazer os desafios do século 21 dependem de que os sistemas educativos distribuam oportunidades de aprendizagem eqüitativamente. (UNESCO, 2003, p. 5)

\section{Objetivo e problema da pesquisa}

Um dos discursos mais difundidos na literatura de educação a distância destaca as vantagens que ela apresenta em relação à análise custo-benefício e a importância que adquire como uma alternativa "compensatória" de educação para as pessoas que, por diversos motivos, não podem aceder a um sistema de educação presencial. ${ }^{5}$

Esse é o enfoque que predomina fortemente no mercado, a tal ponto que já não se limita a referenciar a relação entre o custo de desenvolvimento de programas e a matrícula de acesso: aplica-se também à produção dos programas a distância. Assim, busca-se permanentemente baratear os custos de produção e aplicação dos programas para maximizar os lucros, desenvolvendo-se produtos de qualidade duvidosa, sem tutoria, planejamento pedagógico e estratégias educativas, sob a responsabilidade de pessoas sem experiência e formação necessárias.

Essa forma de pensar, na qual a maximização do lucro prima sobre a qualidade dos objetivos a alcançar, pode ser visualizada em todas as esferas humanas. Marcuse já assinalava em 1968 que vivemos em uma sociedade na qual

a [...] irracionalidade se converte em razão, razão como desenvolvimento frenético da produtividade, como conquista da natureza, como incremento da riqueza de bens; mas irracional, porque a alta produção, de domínio da natureza, e a riqueza social se convertem em forças destrutivas [...] (MARCUSE, 1998, p. 117).

No discurso existente, afirma-se que qualquer um pode fazer educação a distância, sendo até mesmo ofertados no mercado kits tecnológicos como o faça você mesmo (ferramentas de autoria), dando a idéia de que qualquer professor pode planejar, desenvolver e implementar um programa educacional a distância. A experiência acumulada até agora desmente esta

\footnotetext{
5 Ver: Terzian, Françoise. SENAC. Ensino a distância ajuda a cortar custos. Disponível em: http://www.rj.senac.br/ead/portalcte/areas/ajuda\%20a\%20cortar\%20custos.htm. 2005; Moran, José Manuel. Tendências da educação on-line no Brasil. Disponível em: http://www.eca.usp.br/prof/moran/textos.htm. 2005; Chaves, Eduardo. Tecnologia na Educação, Ensino a Distância e Aprendizagem Mediada pela Tecnologia: Conceituação Básica. Disponível em: www.chaves.com.br/TEXTSELF/EDTECH/EAD.htm . 1999. Acesso em: 18 nov. 2005.
} 
afirmação: o planejamento, o desenvolvimento e a aplicação de um programa de educação a distância requerem um conjunto de profissionais de diversas áreas do conhecimento pedagogia, comunicação, arte, programação, entre outras.

Assim, existem propostas de faça em dois dias seu curso a distância, quando, evidentemente, em dois dias, dependendo da carga horária do curso, só é possível analisar a estrutura do curso em relação ao público-alvo, desenhar uma metodologia pedagógica e didática e elaborar uma estratégia educativa para a implementação, com atividades mínimas, no sentido de garantir a qualidade do programa.

Esse modelo de maximização do lucro encontra-se na base cultural dos problemas socioambientais que gera a sociedade de risco na qual vivemos. Por isso, na educação, não se trata simplesmente de analisar qual alternativa é melhor para gerar maiores lucros, e sim de saber quais os tipos de alternativas são os mais adequados para facilitar os processos educativos dos alunos, potencializando suas possibilidades de aprendizagem.

O problema central é que se está construindo uma educação a distância baseada numa visão mercantilista da educação, na qual ensinar é sinônimo de transmissão de informação; aprender significa decorar o conjunto de informações que o professor questionará na prova; pensar é achar os melhores meios para se aproximar dos fins (pensamento instrumental); conhecer é explicar como funciona algo (mecanicismo) e abordar a complexidade é separar em partes para compreender o todo (pensamento simplificador).

Nesse paradigma, a tecnologia deixou de ser um "meio" para se tornar um fim em si mesma. Gomes dos Santos e Pazzetto (2001) ${ }^{6}$ mostram que o problema se situa na mera aquisição de tecnologias para o simples repasse de conteúdos por um meio diferente, sem alterar a forma de relacionamento com o aprendiz, com o conhecimento e com a sociedade. Este foco tecnológico, esta fascinação pela máquina, a idolatria da tecnologia produz, segundo o antropólogo francês Bréton (2000, p. 137), uma troca no papel da função da ferramenta em relação às suas finalidades, a inversão de papéis, na qual "a comunicação não é feita para o homem, mas o homem para a comunicação".

\footnotetext{
${ }^{6}$ Disponível em: http://www.abed.org.br/publique/cgi/cgilua.exe/sys/start.htm?infoid=187\&sid=102\&UserActiveTemplate=4abed. Acesso em: 2 fev 2004.
} 
Nos projetos de educação a distância, as ferramentas tecnológicas passaram a ser a finalidade, sendo esquecidas muitas vezes as dimensões educativas (filosóficas, pedagógicas, didáticas, culturais) e as comunicacionais (linguagem, metalinguagem, mídias, códigos), bem como os sujeitos educativos (características e necessidades das pessoas). Entende-se que, com um designer gráfico, com um conteúdo e com uma boa ferramenta tecnológica, o ensino a distância está resolvido.

De acordo com Hack Catapan e Fialho (2001, p. 3):

Raramente, as propostas de trabalho pedagógico que exploram as novas tecnologias superam o modelo tradicional do ensino. Coloca-se em um sistema avançado de comunicação a forma tradicional do professor ministrar aulas expositivas. A diferença se limita ao veículo de mediação. [...] Os alunos fazem suas leituras e exercícios na Internet, e quando estabelecem uma interlocução (e-mail, fóruns etc.), na maioria das vezes não é para aprofundar o assunto e sim para suprir as necessidades básicas de interação humana, como trocar informações e reconhecer-se ${ }^{7}$.

Candau (1996, p. 129) identifica um dos problemas que se agravam no ensino a distância: "os projetos de implantação de novas tecnologias na educação, em grande parte, são realizados por pessoas de formação tecnológica e não pedagógica", replicando os cursos presenciais na modalidade a distância, fazendo uma "conversão" dos conteúdos e das apostilas impressas aos meios eletrônicos.

Muitos autores (Holmberg, 1990, 1996; Winn, 1990; Garrison, 1993) têm assinalado que, nos sistemas de educação a distância, uma parte substantiva do desenho instrucional tem apresentado, em suas propostas, escassa ou nula inclusão da interação entre os alunos, estando ela baseada, explícita ou implicitamente, nas teorias de aprendizagem associonistas, que se sustentam na administração das contingências do reforço através da correção das respostas do aluno pela ação interativa do docente, ou através do material auto-instrutivo pré-empacotado. Em ambos os casos, por isolamento ou pela prescrição, existem poucas possibilidades de negociar os objetivos de aprendizagem, de tomar decisões em colaboração, ou, para os aprendizes, de assumir a responsabilidade de construir significados próprios, baseados nas estruturas de conhecimento prévio.

\footnotetext{
${ }^{7}$ Disponível em: $<$ http://www.abed.org.br/antiga/htdocs/paper visem/araci hack catapan.htm> Acesso em: 01 fev 2005.
} 
Fazendo um paralelo entre os modelos explicativos da "vida na sala aula" e a situação atual do ensino a distância, poderíamos dizer que foi criado, a partir de uma inter-relação entre as visões teóricas e as construções práticas do ensino a distância, um "modelo mediacional ${ }^{9}$ centrado no computador" ${ }^{\prime 10}$. Para este modelo são determinantes as ferramentas tecnológicas de administração de conteúdos e o tipo de conexão (largura de banda) utilizado pelos alunos para explicar os fatores que intervêm nos processos de ensino-aprendizagem nos grupos de alunos a distância.

Nesses sistemas, uma vez escolhida a tecnologia, exige-se dos professores a elaboração de apostilas de conteúdos - as quais serão "convertidas", por uma equipe de produção, em uma nova linguagem -, para serem introduzidos nos gerenciadores de conteúdo e, assim, distribuídos aos alunos. Na base deste modelo considera-se a informação como conhecimento, sendo um dos seus principais objetivos a elaboração de pacotes informativos em formato multimídia para distribuição massiva.

Na sociedade das novas tecnologias, confunde-se informação com conhecimento, e continua se perpetuando, agora com tecnologia de vanguarda, o modelo enciclopedista do Iluminismo francês. Os cidadãos, paradoxalmente, estão cada vez mais informados, mas cada vez com maior dificuldade para expressar um ponto de vista sobre a informação recebida.

Não estamos criticando as tecnologias, mas sim o uso que é feito delas. As novas tecnologias, quando bem aplicadas ao ensino, podem oferecer importantes avanços: têm potencial para ativar a participação do receptor das mensagens nos processos instrutivos; podem facilitar a memorização conceitual e a aplicação do que foi aprendido na resolução de problemas reais ou simulados, entre outros. Mas é preciso ter em conta que o uso das novas tecnologias de comunicação e informação não é um recurso inapelavelmente eficaz para a aprendizagem.

\footnotetext{
${ }^{8}$ Vida de sala de aula: Conceito que envolve os diversos modelos explicativos sobre as relações e as trocas físicas, afetivas e intelectuais que constituem a vida do grupo na sala de aula e condicionam os processos de aprendizagem (SACRISTAN, J. \& PEREZ GÓMEZ, A. 1998, p. 70).

${ }^{9}$ Entre os conceitos explicativos das inter-relações na sala de aula, encontramos os modelos Processo-Produto, que se desenvolvem entre os anos 40 e 70 e sustentam uma explicação simples dos fenômenos de ensino-aprendizagem que ocorrem na sala de aula. Neste modelo, podem se reduzir as relações que se estabelecem entre o comportamento observável do professor quando ensina e o rendimento acadêmico do aluno.

A inconsistência das investigações no âmbito do modelo processo-produto originou modelos mediacionais que incorporam a variável mediadora do aluno e a do professor como principais responsáveis pelos efeitos da vida na sala de aula. Neste modelo encontra-se uma variedade de pontos de vista: os mediacionais centrados no professor, os mediacionais centrados no aluno e os modelos ecológicos.

10 "Mediacional centrado no computador" - conceito por nós elaborado -: conceito que descreve a visão mais comum no campo da educação a distância atual, na qual se considera como variável independente a tecnologia utilizada, que poderia explicar as relações entre aluno, conteúdo, grupo e professor; é dizer a vida da sala de aula virtual.
} 
Torna-se, portanto, necessário integrar as novas tecnologias em programas educativos bem fundamentados, fazendo uso pedagógico destas ferramentas. Afinal, são as metas, os objetivos, os conteúdos e as metodologias que permitem dar um sentido educativo aos programas baseados em tecnologias, e não o contrário, como, via de regra, observa-se na maioria das experiências analisadas.

Neste trabalho, da mesma forma como o faz Heidegger (apud LELF, 1998, p. 150), tentaremos voltar-nos com o pensar para o já pensado, ficando a serviço do por pensar. Para isso, serão utilizadas as categorias de análise de Dilthey ${ }^{11}$ sobre a história da pedagogia:

Los sistemas de enseñanza se desarrollan con el progreso de las ciencias. Si se apoyaran únicamente en éstas, crecerían incesantemente con ellas. Sin embargo, advierte, este no es el caso: [...] la educação depende de un segundo factor, el estado cultural de una generación determinada (DILTHEY 1968, p. 14).

Nesse sentido, o capítulo 1 desta tese foca sua atenção na reflexão sobre a missão da educação na sociedade, em função dos desafios do momento histórico e das características que apresenta a sociedade em que estamos vivendo, com o claro objetivo de analisar o nível de adequação ou inadequação da educação que está sendo oferecida hoje em relação às demandas e características da sociedade atual.

Posteriormente, no capítulo 2, procuraremos realizar uma análise crítica sobre os conceitos de educação a distância que guiam as práticas educativas na sociedade do "desencaixe" "espaço do fluxo" 13 , tentando capturar os pressupostos básicos ali subjacentes, com o intuito de criar novas visões que potencializem um novo modelo educativo.

A seguir, no capítulo 3, serão analisadas diversas experiências de ensino superior a distância no mundo, considerando algumas das mais importantes universidades abertas da Ásia, da África, da América, da Europa e da Oceania, a partir do conceito de mega universidades de Daniel (1996), com o intuito não só de compreender a verdadeira dimensão da educação a distância no ensino superior, mas também identificar possíveis estratégias que possam

${ }^{11}$ DILTHEY, G. (1833-1911), considerado o fundador e maior representante do historicismo, é possivelmente o filósofo alemão que mais tem influenciado, juntamente com Dewey, a pedagogia contemporânea.

${ }^{12}$ Desencaixe - Este conceito faz parte das três fontes dominantes do dinamismo da modernidade, segundo Giddens, a saber: a separação entre tempo e espaço, a apropriação reflexiva do conhecimento e os mecanismos de desencaixe, que retiram a atividade social dos contextos localizados, reorganizando as relações sociais através de grandes distâncias tempo-espaciais (GIDDENS, 1991, p. 58).

${ }^{13}$ A existência de uma forma de intercâmbio social que não se encontra baseada no espaço físico, mas no espaço dos fluxos (CASTELLS, 2000). 
colaborar na elaboração de políticas de educação a distância, com o objetivo de fortalecer o sistema educativo como um todo, tanto do ponto de vista pedagógico como do ponto de vista organizacional e financeiro.

Por último serão esboçadas algumas linhas que poderiam alimentar novas pesquisas, projetos piloto e políticas educativas em educação diretamente orientadas ao século XXI. Nosso desafio, portanto, não está só na análise da inserção das tecnologias na educação por meio da educação a distância, mas também na análise das oportunidades históricas que surgem neste momento e que podem permitir aos países em desenvolvimento se inserirem na sociedade do conhecimento de forma plena.

\section{Hipótese}

Nesse sentido, defendemos a hipótese de que a educação a distância não deve ser considerada como um método alternativo ou compensatório do ensino presencial, mas como uma oportunidade para repensar a educação como um todo.

\section{Objetivo Geral}

Investigar o papel da educação a distância na mudança de paradigma educativo no contexto da sociedade do conhecimento.

\section{Objetivos Específicos}

Analisar o papel da educação a distância na mudança de paradigma educativo que a sociedade do conhecimento está impulsionando em todas as esferas sociais. Para isso, abordamos o estudo do contexto social, seus principais problemas e elementos constitutivos e analisamos as características que assume a demanda educativa.

A seguir analisamos criticamente as definições mais conhecidas de educação a distância e as suas relações com a educação presencial no contexto atual.

Segue um estudo exploratório sobre as principais Universidades Abertas do mundo, tentando caracterizá-las tanto do ponto de vista quantitativo como qualitativo, colhendo as experiências 
tanto negativas como positivas que possam ser aproveitadas no desenho de políticas educativas na área.

Por último, procuramos analisar o papel que a educação a distância pode representar na sociedade atual e futura, bem como as possibilidades que a tecnologia educacional fornece para consolidar um paradigma educativo agora já não focado no professor, como especialista em conteúdo, mas na figura do educador, como um facilitador pedagógico e didático da aprendizagem.

\section{Justificativa}

Em 1996 já existiam as mega-universidades, “instituições de ensino espalhadas pelos países dos diferentes continentes: China, Indonésia, Índia, Coréia, Tailândia, Turquia, Reino Unido, Espanha, França e África do Sul, que atendiam, juntas, a aproximadamente dois milhões e seiscentos mil alunos".( MACHADO SOUSA, 1996, p.9)

Atualmente, segundo o Centre National D'Enseignement à Distance (CNED), da França, existem 80 milhões de pessoas que estudam no mundo por meio da educação a distância, sendo 3.200.000 na Europa - das quais 700.000 estudam na França, e, destas, 350.000 no CNED. ${ }^{14}$

O Portal Educativo das Américas, elaborado pela Organização dos Estados Americanos (OEA) em 2001, recebeu mais de 30 milhões de visitas provenientes de professores, estudantes, pesquisadores, profissionais e público em geral de 120 países, realizando buscas entre os 4.500 programas de educação a distância que o portal oferece. ${ }^{15}$

Como o Programa das Nações Unidas para o Desenvolvimento (PNUD, 2003) aponta, as redes tecnológicas estão transformando a configuração tradicional do desenvolvimento, ampliando os horizontes das pessoas e criando o potencial necessário para plasmar em um decênio o que no passado levaria várias gerações.

\footnotetext{
${ }^{14}$ Disponível em: $<$ http://www.cned.fr/. $>$. Acesso em: 24 mar 2005.

${ }^{15}$ Disponível em $<$ http://www.educoas.org/portal/es/acerca/documentos/documentos.aspx? culture=es\&navid=27 $>$. Acessado em: 24 mar 2005.
} 
O Brasil encontra-se numa fase de consolidação da EAD, principalmente no ensino superior. Mais de 217 instituições deste nível estão desenvolvendo ações de educação a distância, autorizadas e credenciadas pelo MEC, com 504.204 alunos fazendo cursos superiores.

Além disso, existem as experiências fora do âmbito acadêmico, como as universidades corporativas, os projetos da Secretaria de Educação do Estado de São Paulo, as fundações, como a Roberto Marinho, entre outras, somando um número de alunos que chegou, em 2005, a 1.278.022 (ABREAD, 2006).

Acompanhando este cenário, o Ministério da Educação está em pleno desenvolvimento da Universidade Aberta do Brasil, com o objetivo de consolidar e ampliar a oferta de ensino superior gratuito de qualidade. O Projeto Universidade Aberta do Brasil (UAB) foi criado pelo Ministério da Educação, em 2005, no âmbito do Fórum das Estatais pela Educação, para a articulação e a integração de um sistema nacional de educação superior a distância, em caráter experimental, visando sistematizar as ações, os programas, os projetos e as atividades pertencentes às políticas públicas voltadas para a ampliação e a interiorização da oferta do ensino superior gratuito e de qualidade no Brasil.

Porém concordamos com Moran $(2005)^{16}$ no que tange a sua preocupação por este crescimento, já que ele se baseia numa visão de ensino a distância como uma ação supletiva do Estado em relação às pessoas que não têm acesso ao ensino presencial. Especialmente por ser uma modalidade que historicamente possui uma média de evasão de mais de $40 \%{ }^{17}$ - que pode chegar aos 90\% (POTANSLUCK; CAPPER, 2002, P. 22) -, em que o sucesso é medido pelo número de alunos no sistema, pela avaliação de satisfação dos usuários e pelas técnicas objetivas e quantitativas do tipo múltipla escolha ou verdadeiro/falso.

Com a inclusão das TIC (Tecnologias de Informação e Comunicação), as primeiras experiências de educação a distância mantiveram sua forma baseada em textos autoinstrutivos e comunicação impressa.

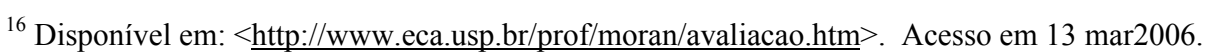

17 "En 1982 solo un 56\% de los estudiantes que ingresaron en 1971 a la Open University habían obtenido su grado (Rumbe y Harry, 1982). Sobre la UNED de España, por su parte, James (1982) informa sobre un 48\% de abandono, mientras que Moclus (1981) trae tasas de deserción del 55\% para 1973, 50\% para 1974, 56\% para 1975, 37\% para 1976 y $62 \%$ para 1976-1977. Estas cifras son bastante similares a la del 52.6\% que es la deserción acumulada del Programa EDI entre 1980 y 1984". Disponível em: <http://www.innova.udg.mx/redes/docs/proyecto/desercion.pdf> Acesso em: 13 mar 2006. (VASQUEZ MARTINES, 2006)
} 
Por isso é necessário refletir sobre os conceitos de ensino e aprendizagem subjacentes a esta modalidade de ensino, que se refletem essencialmente nos materiais, nas tecnologias, nas estratégias adotadas, bem como no papel do professor, etc.

Qualidade é a palavra-chave nesta fase de desenvolvimento da educação a distância. Se ela estiver presente, as TICs, sem dúvida, podem significar algo positivo para a educação no Brasil; se for baixa, estaremos diante de um cenário muito preocupante.

\section{Metodologia}

Não antecipamos o mundo dogmaticamente, mas tentamos achar o novo mundo mediante a crítica ao antigo; [...] ainda que a construção do futuro e a sua culminação perpétua não sejam a nossa missão, a que nos corresponde nestes momentos é tanto mais clara: a crítica infatigável de todas as condições existentes, infatigável no sentido de que a crítica não teme a seus próprios achados, como também não teme conflito com nenhum poder, seja qual for [...] (MARX, 1988, p. 150)

Este trabalho tem fundamento na ciência social crítica ${ }^{19}$, já que o propósito final está orientado para a realização de uma reflexão que possibilite a transformação dos entendimentos educativos e dos valores dos atores, dando início a uma mudança das práticas educativas.

Esta postura crítica é adotada não só por manifestar o desacordo com as visões sociais do momento, mas também por procurar se libertar das condições sociais que atualmente colaboram para distorcer os significados dos conceitos de educação e de educação a distância. Por isso nesta tese refletiremos sobre os processos históricos e as suas profundas relações com a criação dos significados subjetivos dos conceitos analisados.

Este estudo tem em sua concepção um entendimento de sujeito, de aprendizagem e de interação com base no paradigma sócio-histórico e da complexidade, pretendendo superar a visão determinista, linear e homogênea da realidade.

Neste sentido, o trabalho será baseado em um estudo teórico de cunho descritivo, analítico e reflexivo, adotando uma abordagem qualitativa em educação a partir de um enfoque

\footnotetext{
${ }^{18}$ Marx, C. Writing of the Young Marx on Philosophy and Society. Em: CARR, W.; S. KEMMIS. Teoría crítica de la enseñanza. La investigación-acción en la formación del profesorado. Libros universitarios y profesionales. Barcelona: Martínez Roca, 1988. p. 150

${ }^{19}$ Ciência social crítica: uma teoria social que emerge dos problemas cotidianos e se constrói com o olhar posto em como solucioná-los. (CARR; KEMMIS, 1988, p. 169)
} 
metodológico hermenêutico, dado que permite incorporar a intersubjetividade como ferramenta de análise e admite as características de rigorosidade necessárias aos processos de compreensão e interpretação.

No desenvolvimento da pesquisa, utilizaremos uma ampla variedade de métodos articulados: exploratório, descritivo, explicativo ${ }^{20}$ de análise de conteúdo, círculos hermenêuticos, entre outros $^{21}$. E um amplo conjunto de variáveis e indicadores, como podemos observar abaixo:

\section{Capítulo 1}

- Degradação da Natureza
o Aquecimento global
o Desastres naturais
o Recursos florestais
o Biodiversidade

- Degradação da qualidade de vida

o Pobreza, desigualdade extrema e fome

o Desemprego de jovens e violência

o Saúde física e mortalidade evitável

o Saúde psicológica

- Degradação da dignidade humana

- Individualismo e a crise do ser no mundo

- Consumismo como valor e indústria cultural como veículo

- Suicídios e estresse ocupacional

o Sociedade de risco

\section{Capítulo 2}

- Processo didático-pedagógico

o Autonomia do estudante

o Metodologias didáticas

o Estratégias, planejamento e organização

o Tutoria ou supervisão educativa

- Relação professor - aluno, no tempo e no espaço
o Separação
o Continuidade

\footnotetext{
${ }^{20}$ Pesquisa Exploratória: desenvolver, esclarecer e modificar conceitos e idéias, tendo em vista a formulação de problemas mais precisos. (GIL, 1999, p. 43)

${ }^{21}$ Cf. GADAMER, 1998.
} 
o Presencialidade

- Comunicação

o Meios

- Impresso

- Mecânico

- Eletrônico

- Cinematográfico

- Som

- TV

- Multimídia

o Bidirecionalidade e interatividade nas comunicações

o Comunicação massiva

- Forma industrial

\section{Capítulo 3}

- Contexto Nacional

o Importância da EAD no ensino superior do país

o EAD para outros fins (treinamento de trabalhadores, ensino médio, etc.)

- Características e objetivos das Universidades Abertas
o Ano de origem
o Localização
o Origem (pública/privada)
o Objetivos
o Público-alvo
o Site

- Cursos oferecidos

o Tipo de cursos

o Cursos tradicionais ou também de formação para trabalhadores

- Alunos
0 Idade
o Sexo
o profissão

- Crescimento
o Inscrição anual
o Número de graduados ao ano
o Aumento de programas e cursos
o Crescimento de centros de estudo
o Crescimento de conselheiros acadêmicos
o Evasão 
- Sistema de estudos

o Organização

o Créditos

o Flexibilidade de estudos

o Exame de ingresso

- Materiais de estudo e estratégias instrucionais
o Desenvolvimento de cursos
o Avaliação
o Centros de estudo
o Estratégias utilizadas

- Finanças

o Preço cobrado

o Relação com o custo da universidade

o Recebimento de subsídio

- Avaliação qualitativa

o Problemas mais importantes detectados nos sistemas

o Principais eixos de sucesso

o Principais elementos a considerar no desenvolvimento de política pública 


\begin{tabular}{|c|c|c|c|c|}
\hline Objetivos específicos & Métodos & Instrumentos utilizados & Dados coletados & Análise dos dados \\
\hline $\begin{array}{l}\text { Analisar quantitativa } \mathrm{e} \\
\text { qualitativamente } \\
\text { crescimento da educação } \\
\text { superior a distância no } \\
\text { mundo, atualizando a tabela } \\
\text { proposta pelo pesquisador } \\
\text { inglês Daniel (1995), a } \\
\text { partir da incorporação de } \\
\text { dimensões como: } \\
\text { estratégias educativas } \\
\text { desenvolvidas, } \\
\text { metodologias utilizadas e } \\
\text { resultados alcançados. }\end{array}$ & $\begin{array}{l}\text { a) } \\
\text { Exploratório- } \\
\text { descritivo; } \\
\text { analítico; } \\
\text { b) Estatístico. }\end{array}$ & $\begin{array}{l}\text { a) Leitura, descrição e } \\
\text { análise dos sites das } \\
\text { megauniversidades; } \\
\text { b) cálculo de porcentagem de } \\
\text { crescimento; cálculo de } \\
\text { média amostral. }\end{array}$ & $\begin{array}{l}\text { a) Estratégias } \\
\text { educativas } \\
\text { desenvolvidas, } \\
\text { metodologias } \\
\text { utilizadas e } \\
\text { resultados } \\
\text { alcançados; } \\
\text { b) Número de } \\
\text { matrículas, de } \\
\text { centros, pólos, } \\
\text { tutores entre } \\
\text { outros indicadores. }\end{array}$ & $\begin{array}{l}\text { Será realizada à luz } \\
\text { da teoria da análise } \\
\text { de conteúdo da } \\
\text { autora Laurence } \\
\text { BARDIN. } \\
\text { Análise categorial } \\
\text { temática e semântica. } \\
\text { Descrição analítica. }\end{array}$ \\
\hline $\begin{array}{lrr}\text { Analisar os } & \text { conceitos } & \text { de } \\
\text { educação } & \text { presencial } & \text { e } \\
\text { educação a distância } & \text { na } \\
\text { Sociedade } & & \text { do } \\
\text { Conhecimento. } & \end{array}$ & $\begin{array}{l}\text { Descritivo, } \\
\text { Analítico, } \\
\text { Interpretativo. }\end{array}$ & $\begin{array}{l}\text { Leitura de fontes primárias e } \\
\text { secundárias. } \\
\text { As fontes principais são: } \\
\text { Definições de educação a } \\
\text { distância: G. Dohmem, } \\
\text { Ochoa, France Henri, } \\
\text { Ramón Martinez, García } \\
\text { Llamas, Rowntree, Keegan, } \\
\text { Moore, Garcia Aretio, } \\
\text { Landim. } \\
\text { Análise sócio-histórica das } \\
\text { definições: Dilthey, } \\
\text { Vigotsky. } \\
\text { Análise interpretativa }\end{array}$ & $\begin{array}{l}\text { a) Definições de } \\
\text { educação a } \\
\text { distância. }\end{array}$ & $\begin{array}{l}\text { Análise categorial } \\
\text { temática e semântica. } \\
\text { Círculo } \\
\text { hermenêutico. }\end{array}$ \\
\hline $\begin{array}{l}\text { Analisar } \\
\text { estratégias de educação a } \\
\text { distância, tentando } \\
\text { identificar os seus limites e } \\
\text { potencialidades, e definindo } \\
\text { possíveis caminhos a } \\
\text { percorrer para a elaboração } \\
\text { de políticas educativas no } \\
\text { tema. }\end{array}$ & $\begin{array}{l}\text { Analítico, } \\
\text { Interpretativo. }\end{array}$ & Não se aplica & Não se aplica & $\begin{array}{l}\text { Análise categorial } \\
\text { temática e semântica. } \\
\text { Círculo } \\
\text { hermenêutico. }\end{array}$ \\
\hline $\begin{array}{l}\text { Analisar os problemas } \\
\text { centrais e as características } \\
\text { principais que determinam } \\
\text { os desafios da educação na } \\
\text { sociedade atual. }\end{array}$ & $\begin{array}{l}\text { Exploratório, } \\
\text { Descritivo, } \\
\text { Analítico. }\end{array}$ & $\begin{array}{l}\text { Leitura de fontes primárias e } \\
\text { secundárias. } \\
\text { As fontes principais são: } \\
\text { História da pedagogia } \\
\text { (Dilthey e Gadotti); } \\
\text { Relatórios do PNUMA, } \\
\text { PNUD, FAO, UNICEF e } \\
\text { UICN; } \\
\text { Sociedade de risco (Beck e } \\
\text { Giddens); } \\
\text { Mal-estar da modernidade } \\
\text { (Taylor) } \\
\text { Sociedade de consumo (De } \\
\text { la Gándara) } \\
\text { Estresse ocupacional (Codo) } \\
\text { Complexidade ambiental de } \\
\text { Morin } \\
\text { Saber ambiental de Leff } \\
\text { Sociedade do conhecimento } \\
\text { de Drucker } \\
\text { Sociedade em rede de } \\
\text { Castells } \\
\text { Cibercultura de Levy }\end{array}$ & $\begin{array}{l}\text { Evolução sócio- } \\
\text { histórica da } \\
\text { educação } \\
\text { Crise } \\
\text { socioambiental } \\
\text { Sociedade de risco } \\
\text { Mal-estar da } \\
\text { modernidade } \\
\text { Sociedade do } \\
\text { consumo } \\
\text { Estresse } \\
\text { ocupacional } \\
\text { Complexidade } \\
\text { ambiental } \\
\text { Saber ambiental } \\
\text { Sociedade do } \\
\text { conhecimento } \\
\text { Sociedade de rede } \\
\text { Cibercultura }\end{array}$ & $\begin{array}{l}\text { Será realizada à luz } \\
\text { da teoria da análise } \\
\text { de conteúdo da } \\
\text { autora Laurence } \\
\text { Bardin } \\
\text { Análise categorial } \\
\text { temática e semântica. } \\
\text { Descrição analítica (a } \\
\text { função deste } \\
\text { procedimento é a } \\
\text { exploração do } \\
\text { próprio texto, tendo } \\
\text { como base uma } \\
\text { codificação que é } \\
\text { constituída por um } \\
\text { certo número de } \\
\text { categorias, sendo } \\
\text { cada uma composta } \\
\text { por vários } \\
\text { indicadores). }\end{array}$ \\
\hline
\end{tabular}

Tabela 1 - Síntese da metodologia utilizada nesta pesquisa 


\section{Capítulo 1}

\section{O papel da educação no século XXI}

Com o intuito de analisar o papel que a educação a distância pode cumprir na mudança de paradigma $^{22}$, que a globalização e as sociedades do conhecimento estão impulsionando em todas as esferas sociais, abordamos neste capítulo o estudo do contexto social atual, seus principais problemas, suas características e seus elementos constitutivos.

Toda esta análise está mediada pelo marco de referência do qual se parte, por isso acreditamos que não é possível questionar, criticar, apoiar ou haver oposição a novas modalidades e aproximações tomando como única matriz de referência o que a educação atual é, como se ela fosse um fenômeno imutável e perfeito, incapaz de evoluir e de se transformar. Preconceito, tradição e autoridade são velhos baluartes da educação que atuam como fatores inibidores da mudança.

Entendemos que a única forma de podermos nos aproximar da compreensão sobre o papel da tecnologia educativa, em geral, e da educação a distância, em particular, é estudando as características que assume a demanda educativa de nossa época e, por conseguinte, o papel da educação no contexto atual.

Uma rápida olhada na história da sociologia da educação parece reforçar a idéia de que a educação está influenciada pela sociedade (Durkheim, apud MARDONES, 1994, p. 19-57); ou pelas necessidades sociais (funcionalismo); ou pela economia, pelo sistema de classes e pela ideologia (marxismo); ou pelos grupos de poder (reprodutivismo).

Inclusive os enfoques microssociológicos, que questionam as visões macrossociológicas pelo seu determinismo - como as teorias interpretativas: o interacionismo ${ }^{23}$, a

\footnotetext{
${ }^{22}$ Os estudiosos da História das Ciências assinalam que, de tempos em tempos, ocorrem verdadeiras "revoluções" na maneira de encarar os fenômenos da realidade, fato que Kuhn chama de mudança de paradigma. A mais dramática destas revoluções foi a que passou a ser chamada de "revolução copernicana": os sábios, de repente, perceberam que a Terra não era o centro do sistema solar (geocentrismo), mas o Sol (heliocentrismo). Segundo a definição de Tomas Kunh, o paradigma, que é um esquema básico de interpretação da realidade, compreende: supostos teóricos gerais, leis e técnicas que são adotadas por uma comunidade científica. (MARDONES, 1994, p. 19)

${ }^{23}$ Para Vygotsky, as funções psicológicas superiores - que são características do ser humano - estão ancoradas, por um lado, nas características biológicas da espécie humana e, por outro, são desenvolvidas ao longo de sua história social. É o grupo social que fornece o material (signos e instrumentos) que possibilita o desenvolvimento das atividades psicológicas. Isso significa que devemos analisar o reflexo do mundo exterior no mundo interior dos indivíduos, a partir da interação destes com a realidade.
} 
fenomenologia e a etnometodologia ${ }^{24}$ - apresentam interações entre os atores sociais que configuram as diversas realidades educativas, possibilitando inferir uma forte influência social sobre a educação.

A educação em um determinado momento histórico resulta da visão de mundo dessa sociedade, dos desejos e dos sonhos dos diferentes grupos que a formam. Vale dizer: a educação varia segundo o tempo e o meio. Isso significa que a educação pode ser adequada ou inadequada ao contexto social de inserção, já que ela não é absoluta, imutável, mas relativa ao tempo sócio-histórico.

O que se questiona é que tipo de educação se necessita, neste princípio de século, para responder aos desafios do presente e do futuro. A pobreza, a falência do conceito de crescimento econômico como base do conceito de desenvolvimento; a emergência socioambiental; as novas formas de comunicação e de cultura; a incerteza do conhecimento; a multidimensionalidade dos fenômenos, a superação do pensamento dicotômico e a construção de um olhar compreensivo por si só já demandam uma releitura completa do fenômeno educativo.

\section{1) Educação e contexto: adequação ou inadequação?}

Já expressava Horkheimer (apud MARDONES, 1994, p.19) na sua crítica ao positivismo pela ênfase na captação direta do empírico, que a percepção está mediada pela sociedade na qual se vive: quando nos recusamos a perceber esta mediação da cultura de momento histórico, estamos condenados a perceber só aparências.

Tomar como modelo a educação tradicional para julgar as novas aproximações metodológicas, ou modalidades educativas, significa se ancorar no passado, desconhecendo não só a totalidade social da era atual mas também a dinâmica histórica da educação como fenômeno profundamente social.

Ainda que a educação atual fosse um absoluto sucesso, coisa que sabemos que não é, não poderia permanecer imutável, desconhecendo a evolução das idéias, das visões de

\footnotetext{
${ }^{24}$ Os etnometodólogos privilegiam o estudo do sentido que os atores e os agentes sociais atribuem à sua própria prática social, rompendo assim com as tendências que tendem a considerar o sentido que os sujeitos atribuem à sua ação como mero reflexo deformado das determinações estruturais do sistema social.
} 
mundo, dos valores, das novas tecnologias, das novas linguagens, das novas formas da cultura e dos novos problemas a enfrentar em cada período histórico.

Acreditamos que a educação é filha de um modelo de desenvolvimento, de condições culturais, econômicas e sociais concretas. Fatores como a situação histórica, cultural e científica e a estrutura social, política e econômica têm influência sobre a educação. Pode se dizer, então, que, em um lugar determinado, considerando as variáveis tempo e espaço, a educação será mais ou menos adequada de acordo com os condicionantes que existem em torno dela.

A educação reflete a sociedade na qual se desenvolve tentando dar resposta aos desafios específicos e representando as visões de mundo que emergem em cada período histórico, tanto para a reprodução como para a transformação social.

\subsubsection{A educação nos diferentes períodos históricos}

Se definirmos educação como um "conjunto de atividades mediante as quais um grupo assegura que seus membros adquiram a experiência social historicamente acumulada e culturalmente organizada" (ROCHA, 2003, p.8), poderemos identificar no percurso histórico da humanidade diversos modelos educativos, correspondentes aos diversos olhares sobre o mundo que foram se apresentando em cada período histórico.

Assim, segundo Gadotti (1992), no Império Romano, a educação foi considerada pela primeira vez como uma política de Estado, organizada pelas pessoas livres para formar os setores dirigentes, ou seja, uma educação utilitária e militarista.

Na Idade Média, já com a igreja no poder, a educação é utilizada para difundir sua mensagem e crescer territorialmente. Inclusive a partir de Constantino (século IV), o Império adotou o cristianismo como religião oficial e fez a escola, pela primeira vez, ser considerada um aparato ideológico do Estado, mudando a visão das culturas anteriores.

Entre 1350 e 1550, no chamado Renascimento, a sociedade européia ocidental vivenciou uma revolução espiritual, uma crise em todas as ordens da vida, mudando do sistema feudal para o sistema de monarquia absoluta: 
Uma transformação dos valores econômicos, políticos, sociais, filosóficos e religiosos que tinham constituído a velha civilização medieval... o Renascimento é, por conseguinte, uma época cujo denominador comum foi a transformação, a renovação e a criação de novos códigos de conduta.(ARTEHISTÓRIA, 2006) ${ }^{25}$

O lançamento do sistema capitalista e a gradual ascensão da burguesia sintetizam uma nova mudança na visão de mundo. Começa a se valorizar o indivíduo em si mesmo, o individualismo e a aventura. Com uma nova concepção do homem e de seu papel na sociedade, os indivíduos agora são protagonistas, podendo exercer sua capacidade para intervir e transformar o mundo. A educação vem cumprir o papel de formar o homem burguês; uma educação que resulta contrária aos estudos teológicos medievais, valorizando os estudos clássicos e as ciências do homem.

A segunda metade do século XVI e o século XVII representam um período de conquista da natureza: Galileu, com a teoria heliocêntrica; Kepler, com as órbitas elípticas; Descartes, com o Discurso do Método; Bacon, com o método indutivo de investigação científica.

Desde Aristóteles até o final da Idade Média, o caminho para o conhecimento foi o da análise dialética, ou seja, o raciocínio por dedução lógica, na busca de novos conhecimentos. A partir de Galileu se começa a adotar uma atitude de observação e interpretação, que dá origem à Corrente Empirista, que haveria de afetar profundamente a filosofia e criar o Positivismo, ou seja, o tratamento científico de todos os fatos e fenômenos, inclusive em Política, Sociologia e Educação.

A educação nesse período reflete as mudanças da sociedade e possibilita o surgimento da chamada pedagogia moderna, a Didática Magna de Comênio, que postula que, em vez de ensinar palavras, devemos ensinar o conhecimento das coisas, tomando a observação e a experiência como ponto de partida do método de ensino e de proposta de organização escolar. Um contexto no qual Locke, em seu ensaio do entendimento humano, registra a visão de uma época: nada existe em nossa mente que não tenha sua origem nos sentidos. A educação então assume dois papéis principais. Por um lado, as classes dirigentes recebem uma educação humanística, para a sua inserção nas cortes; por outro, as classes populares recebem uma educação prática, para trabalhar nas fábricas.

\footnotetext{
${ }^{25}$ Disponível em: http://www.artehistoria.com/historia/contextos/1848.htm. Acesso em: 18 mar2006.
} 
O século XVIII significa um novo período de ruptura, o fim do absolutismo; uma época na qual a ilustração pretende iluminar com a razão todos os problemas de seu tempo, combatendo erros e preconceitos da Idade Média; construindo uma sociedade com bases racionais. "A ilustração, em verdade, é um movimento econômico, social, político e cultural no qual confluem os movimentos contrapostos, o empirismo e $\mathrm{o}$ racionalismo"(STRAMELLO, 2003) ${ }^{26}$. Uma época na qual as camadas populares reivindicam mais saber e educação pública, e quando, pela primeira vez, o Estado institui a obrigatoriedade escolar.

"O iluminismo educacional representou o fundamento da pedagogia burguesa, que até hoje insiste predominantemente na transmissão de conteúdos e na formação individualista. A burguesia percebeu a necessidade de oferecer instrução mínima para a massa trabalhadora. Por isso a educação se dirigiu para a formação do cidadão disciplinado". (GADOTTI, 1992, p. 87 )

No interior do iluminismo e da sociedade burguesa, duas forças antagônicas tomam forma desde o final do século XVIII: o movimento burguês e o socialista. Estas linhas opostas chegam ao século XIX sob os nomes de marxismo e de positivismo, representadas por Augusto Comte e Karl Marx.

A concepção socialista da educação se opôs à versão burguesa, reclamando uma educação igual para todos. Para Marx e Engels a educação é determinada pelas relações sociais; os objetivos e as tarefas da educação, assim como seus métodos e conteúdos, mudam em diferentes épocas, ao mesmo tempo em que, numa mesma época, são entendidas como diferentes pelas diversas classes sociais.

Desde princípios do século XIX e a partir do triunfo do movimento independentista, a educação foi concebida como um dos fatores principais da integração e do crescimento nacional. Essas perspectivas impulsionaram durante mais de 150 anos a convicção de que a educação era o pilar fundamental da modernização do país. "Diversos autores (Tedesco, 1986; Weinberg, 1986) destacam que o principal papel que a educação desempenhou a partir de fins do século XIX foi mais político que econômico" (FILMUS, 1999) ${ }^{27}$ : integrar populações, incorporar a cultura e a história aos imigrantes, que traziam valores e costumes diferentes, e dotar de hegemonia um Estado que ainda era muito fraco. A consolidação dos Estados Nacionais foi um dos principais

\footnotetext{
${ }^{26}$ Disponível em: http://www.ideasapiens.com/filosofia.sxx/feducacion/hist\%20educ.II la._\%20ilustracion.htm. Acesso em: 23 Out 2006

${ }^{27}$ Disponível em: http://www.oei.org.co/oeivirt/fp/cuadla06.htm. Acesso em: 22 Out 2006
} 
papéis da educação neste período, pela imposição de símbolos pátrios, rituais e próceres, ritos que ainda sobrevivem em muitas escolas.

Depois da Segunda Guerra Mundial, por um lado, os Estados Unidos e a URSS entraram na guerra fria, e ambos os países tentaram, através da educação, produzir os cientistas necessários para vencer a carreira armamentista e espacial. Por outro, necessitava-se de recursos humanos para a reconstrução do pós-guerra. Tudo isso somado à crescente mudança tecnológica gerou uma enorme demanda de especialistas e experts; ao sistema educativo foi concedido o papel de treiná-los e selecioná-los.

Essa preocupação com os recursos humanos caracterizou a teoria funcionalista nos anos de 1950. A educação assumiu um papel mais relevante, porém instrumental à economia e à política. $\mathrm{O}$ pensamento pedagógico se orientou ao pragmatismo e ao instrumentalismo através da Escola Nova, corrente da qual John Dewey $(1859-1952)^{28}$ foi um destacado representante.

A Escola Nova acompanhou o progresso da sociedade capitalista. A pedagogia norteamericana recorreu ao método de projetos para globalizar o ensino a partir de atividades manuais e também a outros métodos, como o método de centros de interesse, do belga Decroly (1871-1932).

Nesse panorama, além das funções de socialização e de formação, a educação deveria dar "status" às pessoas. A educação representava a possibilidade de ascensão social e começava a ser considerada o motor do desenvolvimento econômico, como postula a Teoria do Capital Humano de Schultz (1960): “a educação deve ser tratada como qualquer outra forma do capital físico, como investimento com uma rentabilidade determinada; existe uma relação entre crescimento econômico e as taxas de escolarização, e uma relação positiva entre ingressos e nível educativo" (SOBRAL, 2000, p. 8$)^{29}$.

Já a partir dos anos 70 começa uma era de desencanto: renuncia-se à idéia de progresso, à idéia da educação como possibilidade de ascensão social. As instituições começam a perder influência. Uma época na qual emerge a teoria crítica da educação como uma

\footnotetext{
${ }^{28}$ Para Dewey, no processo educativo, devia-se aumentar o rendimento da criança, servindo aos interesses da sociedade; a escola deveria formar os jovens para o trabalho, para a atividade prática, para o exercício da competição.

${ }^{29}$ Disponível em: <http://www.scielo.br/scielo >. Acesso em: 23 Out 2006.
} 
alternativa às chamadas teorias não críticas ${ }^{30}$. Essa corrente crítica encontra-se integrada por três linhas teóricas: a análise do sistema de ensino enquanto violência simbólica de Bourdieu e Passeron; a teoria da escola como Aparato Ideológico do Estado, liderada por Althusser, e a teoria da escola dualista de Baudelot e R. Establet.

Nesse contexto é que emerge Paulo Freire, com uma proposta que, em parte, acreditamos, se opõe ao reprodutivismo, no sentido de que este educador acredita na possibilidade de uma ação, crítica e libertadora, na construção de uma pedagogia que ajude as pessoas a serem livres, ao contrário de Bourdieu e Passeron, que vêem em toda ação educativa uma reprodução do sistema, não sendo possível a sua solução; ou de Althusser, que só vê a solução na luta de classes.

Para Freire (1984), sempre é possível criar uma nova pedagogia, um novo homem e um novo amanhã, já que o cruzar de braços implica que o homem se deixe vencer diante do poder dos fatos, perdendo a capacidade crítica que lhe fará transformar a realidade em prol do bem-estar comum.

\subsubsection{Fins e meios, uma relação intrínseca}

Como podemos observar, os sistemas educativos apresentam em seu devir histórico uma dinâmica que pode ser justificada, ao menos em certo grau, em função das variáveis do contexto. Nas distintas épocas da história da humanidade, identificam-se nas instituições educativas mudanças nos objetivos, nos conteúdos, nos métodos, nas tecnologias utilizadas, nas estratégias, entre outros.

Significa dizer que a educação que um povo assume num determinado momento do seu processo histórico é resultado do diálogo de um conjunto de forças sociais em conflito, que representam concepções sobre o conhecimento, a aprendizagem, a sociedade e o mundo.

Já apontava Mizukami (1986, p.87) que "a história consiste (...) nas respostas dadas pelo homem à natureza, a outros homens, às estruturas sociais, de ser progressivamente cada vez mais sujeito de sua práxis, ao responder aos desafios de seu contexto".

\footnotetext{
${ }^{30}$ Essa teoria crítica refere-se à pedagogia tradicional, à pedagogia nova e à tecnicista, que entendem o fenômeno educativo como um instrumento de igualação social, de superação da marginalidade; e analisam a marginalidade como uma distorção que deve ser corrigida pela educação.
} 
A educação emerge dessa história e se traduz na resposta organizada a esses desafios e aos sonhos que os diferentes grupos sociais trazem em seu imaginário coletivo.

Isso não significa de modo algum assumir uma posição utilitarista, de reduzir a educação a um papel instrumental dedicado à satisfação das necessidades atuais através de conhecimento e ação, mas de reconhecer que toda sociedade, ao menos em parte, define as suas ações educativas com vistas a resolver problemas sociais emergentes.

No entanto, uma aproximação mais detalhada revela que a análise das demandas sociais desvenda só uma parte da história da educação; a outra podemos identificar no avanço da ciência, da tecnologia e nas características da cultura predominante em cada momento histórico.

Nesse sentido, Dilthey ${ }^{31}(1968$, p.14) já identificava que

los sistemas de enseñanza se desarrollan con el progreso de las ciencias. Si se apoyaran únicamente en éstas, crecerían incesantemente con ellas. Sin embargo, advierte, este no es el caso: ...la educação depende de un segundo factor, el estado cultural de una generación determinada.

Para ele, a história da educação depende de dois fatores essenciais: o progresso da ciência, que afeta todos os meios da educação, possibilitando dar aos indivíduos a sua máxima capacidade, e o estado cultural de um povo, ou uma geração, que determina o ideal educativo.

Desta maneira, Dilthey começa a diferenciar os meios da educação (que estariam dados pelo conhecimento e cresceriam juntamente com a ciência) dos fins da educação (que remeteriam aos costumes, aos ideais e às necessidades de uma sociedade).

Este ideal encontra-se relacionado com aquele de vida de uma sociedade que educa. Assim, a educação e os sistemas de ensino baseados nela teriam que crescer, amadurecer, se transformar, mudar e, às vezes, desaparecer junto com os povos que os criam. Nesta perspectiva, contextualizada no enfoque sócio-histórico, o conhecimento nas ciências sociais não é objetivo, universal e independente dos fatores socioculturais de uma época.

\footnotetext{
${ }^{31}$ DILTHEY, G. (1833-1911) possivelmente seja o filosofo alemão que mais tem influído, com Dewey, na pedagogia contemporânea, sendo considerado o fundador e maior representante do historicismo.
} 
Sem lugar a dúvidas, neste princípio de século, a sociedade apresenta aos sistemas educativos desafios sem precedentes, que geram muitas interrogativas: será que a educação atual pode dar respostas eficientes? E que papel terão a chamada educação a distância e a tecnologia educacional?

Para responder a estes questionamentos, temos que, em primeiro lugar, identificar o contexto atual, os desafios e as características que a sociedade apresenta, para, então, podermos nos concentrar na análise da correspondência entre os desafios e as alternativas geradas, tentando compreender de que forma transformar os sistemas educativos, para responder não só às necessidades atuais mas também às necessidades futuras da humanidade.

A pergunta que surge então é: quais são os desafios atuais? E com ela nos perguntamos se é possível que nosso sistema educativo - criado no Império Romano, baseado na segmentação do sistema em ensino fundamental, médio e superior, com uma universidade que ainda reflete o modelo de Paris do ano 1200, e em uma metodologia pedagógica criada nos princípios do século, na qual há uma centralidade na figura do professor, na bibliografia e no repasse simples de informações - ainda possa dar conta destes desafios, ou se se fazem necessárias profundas reflexões e questionamentos, não só dos fins, mas também dos meios, para podermos responder com sucesso a eles.

\subsection{Os desafios sociais atuais}

Definir a sociedade atual por si só já representa um enorme desafio. Nos autores em que nos baseamos para caracterizar o contexto, encontramos um sem-fim de análises e posições, entre as quais podemos destacar: a degradação da natureza (UICN, PNUD, OMM, FAO, UNICEF e UICN) e a degradação da qualidade de vida, visualizada na pobreza, no desemprego, na violência, na saúde física (PNUD, UNICEF, OMS, ONU) e na crise do ser no mundo; o individualismo (TAYLOR, 1994), o consumismo (DE LA GÁNDARA) e o estresse social e ocupacional (CODO, 1993), configurando uma sociedade de risco (BECK, 1986; GIDDENS, 1991), em meio a uma revolução tecnológica que dá forma uma sociedade da informação em rede (CASTELLS, 2000) e uma sociedade da aprendizagem, da informação e do conhecimento (POZO, 1996; 
UNESCO, 2005), potencializando a construção de uma nova cultura, da cibercultura (LEVY, 1999), descobrindo as abordagens da complexidade (MORIN, 1998).

\subsubsection{Degradação da Natureza}

A natureza pode satisfazer todas as necessidades básicas do homem, porém não todas as suas ambições.

Mahatma Gandhi

A degradação da natureza tem expressão clara em fatores como a mudança climática, as precipitações ácidas, o desmatamento, a erosão e a desertificação, a contaminação hídrica, atmosférica e dos solos, bem como a perda da diversidade biológica, entre outros.

Existem numerosos indicadores que ilustram esta emergência. $\mathrm{O}$ ano de 2005, por exemplo, foi um ano tristemente célebre, no qual se quebraram numerosos recordes: foi o mais quente dos últimos 100 anos (seguido pelos anos de 1998, 2002, 2003 e 2004). ${ }^{32}$ Também foi um dos anos mais destrutivos em relação a desastres naturais e meteorológicos, quebrando o recorde de tormentas tropicais, com um total de 27 , o que superou o ano de 1933, em que ocorreram 23 tempestades. Em 2005 houve 14 furacões, o que também supera o recorde de 12, registrado em 1969, segundo os dados da $\mathrm{OMM}^{33}$, que destaca que 3 deles foram de categoria 5, quatro de categoria 4 e sete de categoria 3 na escala de Saffir-Simpson.

Do ponto de vista dos recursos naturais, a visão não é menos preocupante. Em 2005, segundo a Avaliação dos Recursos Florestais Mundiais da FAO (2005) ${ }^{34}$, a perda líquida de área florestal no mundo (2000-2005) prosseguia a um ritmo alarmante - 13 milhões de hectares ao ano -, sem considerar os entre cinco e sete milhões de hectares de terra fértil perdidas pela erosão; a desertificação, que já tinha alcançado $30 \%$ da superfície da Terra, e a salinização, que tem causado danos a aproximadamente 30 milhões dos 237 milhões de hectares irrigados da superfície agrícola, além de uns 80 milhões de hectares que já estavam afetados em certo grau.

\footnotetext{
${ }^{32}$ Disponível em: <http://www.giss.nasa.gov>. Acesso em: 20 jan 2006.

${ }^{33}$ Disponível em: $<$ http://www.wmo.ch/index-sp.html>. Acesso em: 21/1/2006.

${ }^{34}$ Disponível em: $<$ http://www.fao.org $>$ Acesso em: 12 maio 2005.
} 
A biodiversidade também se encontra ameaçada como nunca. Para se ter uma clara noção da tendência, em 1996, no Livro Vermelho do IUCN, ${ }^{35}$ as espécies consideradas ameaçadas de extinção eram 10.533; em 2006, já alcançavam 16.118. As espécies silvestres estão sendo extintas 50 a 100 vezes mais rápido do que o seriam de forma natural.

Esses indicadores ilustram uma sociedade ameaçada já não só pelas lutas de classes, ou pela guerra, mas pela luta pela sobrevivência, em um mundo que tem se mostrado finito, referindo-nos aos recursos naturais; frágil, devido ao fato de que o equilíbrio global depender de inúmeras e desconhecidas relações entre os seus elementos constituintes mais imperceptíveis; inconquistável, já que o velho sonho de controlar a natureza por meio da ciência e da tecnologia da modernidade tem se transformado no pesadelo de uma crise global de magnitudes desconhecidas; e poderoso, já que, uma vez quebrado o equilíbrio ambiental, o mundo reage de formas assustadoras: deslizamentos de terra e furacões que engolem cidades, tormentas violentas que deixam milhares de refugiados, secas históricas que geram mais fome e vulnerabilidade social, entre outros.

No entanto, o problema atual não se restringe à natureza: o modelo de desenvolvimento predominante, além de impactar fortemente no ambiente natural, tem trazido problemas para a vida de grande número de habitantes do planeta.

\subsubsection{A degradação da qualidade de vida}

Não só a natureza está sendo degradada, também a qualidade de vida de enormes setores da população mundial, o que pode ser evidenciado não só na pobreza extrema, no empobrecimento gradual e na exclusão social, na saúde física ou na falta dela, nas mortes evitáveis, na esperança de vida ao nascer, mas também na saúde psicológica, no sentimento de perda da dignidade, na violência social, na angústia, na depressão e no suicídio, no isolamento individual e no enfraquecimento das redes solidárias, entre outros.

\footnotetext{
${ }^{35}$ Disponível em: $<$ http://www.redlist.org $>$. Acesso em: 7 Outubro 2006.
} 


\section{a) Pobreza, desigualdade extrema e fome ${ }^{36}$}

El hambre es un crimen que aniquila el prodigio de la vida. Debe ser detenido. Si o si. Porque no faltan riquezas, ni alimentos, ni platos, ni madres, ni médicos, ni maestros; faltan en cambio la voluntad política, la imaginación institucional, la comprensión cultural y las ganas de construir una sociedad de semejantes donde broten los panes en la mesa en una mirada de manteles, para vestirse de guardapolvo blanco, para decir trabajo, para cantar infancia, para besar familia. $(\mathrm{UNICEF}, 2005)^{37}$

A análise de situação da pobreza revela um panorama sombrio. $O$ ano de 2005 não apresentou apenas recordes nos indicadores de degradação da natureza, do ponto de vista da qualidade de vida das pessoas: como significou também um ano no qual se continuou a observar níveis inadmissíveis de privação humana - uma crise social que também está começando a entrar em eclosão, como poderemos corroborar no percurso da análise.

No século XXI, mais de 1 bilhão de pessoas sobrevivem com menos de 1 dólar por dia, e 1,5 bilhões de pessoas com 2 dólares ${ }^{38}$. Isso significa que $40 \%$ das pessoas que habitam este mundo lutam cotidianamente pela sua sobrevivência, defendendo-se da extinção como mais uma espécie natural. Esta pobreza terá um enorme impacto nas pessoas e no futuro dos países: a pobreza e a indigência impõem que $40 \%$ da população do mundo careça de acesso a água potável, saneamento e educação: "1.1 bilhão de pessoas sem acesso a fontes de água potável, 2,6 bilhões sem acesso a saneamento melhorado, e mais de 115 milhões de crianças sem acesso ao ensino primário mais básico”. (PNUD, 2006)

Em meio à abundância, milhões de pessoas ficam todos os dias com fome, mais de 830 milhões de pessoas, incluindo uma em cada três crianças em idade pré-escolar que ainda estão presas em um círculo vicioso de desnutrição e seus efeitos. Sem retóricas, "75 milhões de pessoas estão, neste momento, necessitando ajuda alimentar urgente para

\footnotetext{
36 "la pobreza puede definirse como una condición humana que se caracteriza por la privación continua o crónica de los recursos, la capacidad, las opciones, la seguridad y el poder necesarios para disfrutar de un nivel de vida adecuado y de otros derechos civiles, culturales, económicos, políticos y sociales" (Comité de Derechos Económicos, Sociales y Culturales de las Naciones Unidas, 2001). Em: Panorama social de América Latina • 2005. CEPAL. Página 76. Disponível em:

http://www.cepal.org/publicaciones/xml/4/23024/PSE2005 Cap1 Pobreza.pdf. Acesso em: 12/10/2006

${ }^{37}$ Disponível em: http://www.pelotadetrapo.org.ar/. Acesso em: 10/10/2006.

38 População atual: 6 bilhões e 540 milhões de habitantes. State of World Population 2006. United Nations Population Fund. New York, U.S.A. 2006.2 Disponível em: http://www.globalaging.org/elderrights/world/2006/unfpa.pdf. Acesso em: 10/10/2006.
} 
salvar a sua vida" (NAÇÕES UNIDAS, 2006, p. 18) ${ }^{39}$ e, quando este documento estiver finalizado, possivelmente já estarão mortas.

Como podemos observar no mapa da fome elaborado pela FAO em 2003, 15\% da população do Brasil, México, Peru, Colômbia, Equador, alguns países da África, China, entre outros, passa fome todos os dias. Alguns países da América Latina e da África, a Índia e o Paquistão ficam ainda em uma situação pior, já que $25 \%$ da sua população vive com fome. A África concentra ainda países nos quais $50 \%$ ou mais da sua população vai dormir todos os dias com fome.

As que sobreviverem à fome ainda terão que enfrentar muitas dificuldades: a UNICEF (2004) adverte que sofrer fome durante o período da infância pode provocar um retardo mental irreversível, com uma diminuição do QI (coeficiente de inteligência) e da capacidade de aprendizagem. Os efeitos podem ser trágicos para as pessoas e muito importantes para o futuro dos países - estima-se que o QI médio da população de mais de 60 países, devido às carências de iodo na infância, é entre 10 e 15 pontos inferior à pontuação que as pessoas deveriam ter em situações normais,.

A situação fica insustentável se consideramos que, segundo a UNICEF (2004), 32\% das crianças menores de cinco anos, no mundo em desenvolvimento, sofrem retardo moderado ou severo do crescimento e nunca desenvolveram o seu potencial genético ou intelectual, e que 135,5 milhões de crianças em idade pré-escolar sofrem com "insuficiência ponderal" "40, que poderá gerar danos mentais irreversíveis. A fome dificulta a aprendizagem, porém a aprendizagem é um meio eficaz para fazer frente à fome. Cria-se, dessa forma, um círculo vicioso no qual as crianças passam fome e chegam a ser adultos com capacidades muito limitadas, o que acaba por fazer com que seus filhos também passem fome. A fome rouba o futuro das crianças e dos países. "A pobreza é a principal causa de milhões de mortes evitáveis e a razão de as crianças estarem desnutridas, não freqüentarem a escola e serem vítimas de abusos e exploração". (UNICEF, 1999) ${ }^{41}$

\footnotetext{
${ }^{39}$ Disponível em: http://www.lpp-uerj.net/olped/documentos/1754.pdf. Acesso em: 17/10/2006.

${ }^{40}$ Medida composta do peso de uma pessoa para a sua idade, comparada com a população de referência. Reflete tanto a fome crônica como a fome aguda. Op. Cit., 2006, p. 167.

${ }^{41}$ Disponível em: <http://www.unicef.cl/centrodoc/ficha.php? id=74>. Acesso em: 12 maio 2005.
} 
Isso sem falar das desigualdades de acesso à educação: em média, para uma criança nascida hoje em Moçambique, podem-se prever quatro anos de ensino formal; para uma nascida na França, 15 anos e níveis muito mais elevados de preparação. Essas desigualdades educativas gerarão as desigualdades sociais e econômicas globais de amanhã.

Uma sociedade de grandes contrastes, já que a pobreza, a fome e o analfabetismo existem não por escassez de recursos, mas por desigualdade na sua distribuição. $O$ século $\mathrm{XX}$ tem testemunhado o aumento do consumo em um ritmo vertiginoso, chegando a 24 trilhões de dólares em 1998, o dobro do nível de 1975 e seis vezes o de 1950, refletindo o crescimento de mais de $40 \%$ do PIB mundial. Contudo, a pobreza cresceu 17\% nesse mesmo período. Segundo o PNUD (1998), o mundo se encontrava cada vez mais polarizado no final dos anos 90. A quinta parte da população mundial, que vivia nos países de maior renda, detinha $86 \%$ do PIB mundial e $82 \%$ do mercado mundial de exportação; já a quinta parte que vivia nos países de menor renda detinha somente $1 \%$ do PIB mundial e $1 \%$ do mercado mundial de exportação.

No entanto, o mais preocupante são as tendências à concentração da riqueza. Nos últimos 30 anos, a participação na renda mundial dos $20 \%$ mais pobres da população mundial se reduziu de $2,3 \%$ a $1,4 \%$, enquanto a participação dos $20 \%$ mais ricos aumentou de $70 \%$ a $85 \%$. As desigualdades mundiais aumentaram constantemente durante os dois últimos séculos. Uma análise das tendências de longo prazo na distribuição da receita mundial (entre países) indica que a distância entre o país mais rico e o país mais pobre tem aumentado escandalosamente: de 3 a 1 em 1820 a 72 a 1 em 1992 (PNUD, 1999).

A concentração da riqueza atual mostra uma civilização irracional, como o PNUD aponta claramente: os 225 habitantes mais ricos do mundo têm uma riqueza combinada superior a um trilhão de dólares, o equivalente à receita dos $47 \%$ mais pobres da população mundial ( 3 bilhões de habitantes). A grandiosidade da riqueza dos ultra-ricos é um contraste chocante com os baixos recursos do mundo em desenvolvimento. As três pessoas mais ricas têm ativos que superam o PIB total da África ao sul do Saara. A riqueza das 32 pessoas mais ricas supera o PIB total da Ásia meridional. Os ativos das 84 pessoas mais ricas superam o PIB da China, o país mais povoado do mundo, com 1,2 bilhão de habitantes. 
Outro contraste surpreendente é a riqueza das 225 pessoas mais ricas em comparação com os recursos necessários para conseguir o acesso universal aos serviços sociais básicos para todos. O PNUD (1999)

estima que o custo de prover acesso universal ao ensino básico para todos, assistência básica de saúde para todos, assistência de saúde reprodutiva para todas as mulheres, alimentação suficiente para todos e água limpa e saneamento para todos, é de aproximadamente 44 bilhões de dólares ao ano. Isto é inferior a $4 \%$ da riqueza combinada das 225 pessoas mais ricas do mundo.

Vivemos em uma sociedade dividida em duas dimensões paralelas: uma realidade é possível ser vista na forma de vida dos setores privilegiados da sociedade, descrita nos documentos oficiais e nos discursos, nos quais os direitos universais proclamam que todas as pessoas têm o mesmo valor e os mesmos direitos. A outra realidade, que resulta da anterior e a contradiz, pode ser caracterizada na vida dos excluídos, que já somam $40 \%$ da população do mundo, em que as pessoas não têm acesso seguro a água, educação, serviços de saúde decentes ou proteção ante a lei.

$\mathrm{Na}$ América Latina a situação é ainda mais preocupante, já que, segundo a $\mathrm{Cepal}^{42}$, em 2005, 41,7\% da população já se encontrava em situação de pobreza (211 milhões de pessoas) e 17,4\% (90 milhões de pessoas) já tinham atingido a pobreza extrema ou a indigência (DEL GROSSI, SILVA e TAKAGI, 2001) ${ }^{43}$.

Evidentemente, o local do mundo onde se nasce contribui para determinar as possibilidades da vida.

A desigualdade, a pobreza, a qualidade de vida e a qualidade ambiental estão intimamente atreladas. A degradação do passado aprofunda a pobreza do presente, enquanto a pobreza do hoje dificulta a resolução de problemas como o acesso à educação de qualidade, a serviços de saúde, alimentação adequada, proteção da biodiversidade e dos recursos agrícolas, controle do desmatamento, prevenção da desertificação, capacidades cognitivas iguais, entre outros. Os pobres se vêem obrigados

\footnotetext{
42 Panorama social de América Latina - 2005. CEPAL. Pagina 3. Disponível em: http://www.cepal.org/publicaciones/xml/4/23024/PSE2005 Cap1 Pobreza.pdf. Consultado em: 12/10/2006.

${ }^{43}$ A linha de indigência refere-se à renda mínima necessária para adquirir o valor de uma cesta de alimentos com quantidades energéticas mínimas ou recomendadas. A linha de pobreza é superior à linha de indigência, pois inclui, além do valor da cesta de alimentos, todas as outras despesas não-alimentares, como vestuário, moradia, transportes, etc. Fonte: Evolução da Pobreza no Brasil, 1995/99. Mauro Eduardo Del Grossi, José Graziano da Silva e Maya Takagi. Texto para Discussão. IE/UNICAMP. n. 104, nov. 2001. Disponível em:

http://www.eco.unicamp.br/publicacoes/textos/download/texto104.pdf. Acessado em: 16/10/2006.
} 
a esgotar os recursos naturais para sobreviver, empobrecendo-se ainda mais. Este é o principal obstáculo para transitar rumo a um mundo sustentável.

\section{b) Desemprego de jovens e violência urbana}

Nós colocamos uma panela de pressão em fogo alto e agora estamos esperando para ver quanto tempo levará para explodir.

Thurow $^{44}$

Como se este panorama não fosse por si só pouco alentador, há o fato de que os mais ameaçados são os jovens, a força motriz da sociedade.

Segundo reconhece a Organização Mundial do Trabalho no seu relatório de 2006, o mundo enfrenta uma crise do emprego juvenil. "Um de cada três integrantes da população juvenil mundial de 1,1 bilhão de pessoas entre 15 e 24 anos está buscando trabalho sem sucesso, tem abandonado essa busca por completo ou está empregado mas vive com menos de 2 dólares diários" (OIT, 2006, p.9) ${ }^{45}$. O relatório informa que, na última década, o número de jovens desempregados aumentou de 74 para 85 milhões, um incremento de $14,8 \%$, e ratifica que a juventude de hoje enfrenta um déficit de oportunidades muito maior que dos adultos: os jovens representam $44 \%$ dos desempregados, sendo a sua participação na população economicamente ativa só de $25 \%$.

Mas o desemprego não é o único problema que têm de enfrentar, já que a maioria dos jovens que trabalha continua sendo pobre: $56 \%$ dos jovens trabalhadores têm longas jornadas de trabalho, contratos temporários, salários baixos e escassos ou nulos sistemas de proteção social. Este modelo desencoraja outros jovens a buscar trabalho, já que vêem nele uma garantia de pobreza.

A violência ${ }^{46}$, em parte, é resultado deste processo, e uma das principais causas de óbito em todo o mundo para a população de 14 a 44 anos de idade. A cada ano, 1,6 milhão de

\footnotetext{
${ }^{44}$ In: Musetti, 1999. Disponível em: http://www.infojus.com.br/area15/rodrigo3.html, Acesso em: 16/10/2006.

${ }^{45}$ Disponível em: www.ilo.org/trends. Acesso em: 16/10/2006.

46 Assumimos a definição de violência da OMS: "O uso intencional da força ou poder físico, de fato ou como ameaça, contra si mesmo, outra pessoa ou um grupo ou comunidade, que cause ou tenha muitas possibilidades de causar lesões, morte, danos psicológicos, transtornos do desenvolvimento ou privações". Informe mundial sobre la violencia y la salud. Organización Mundial de la Salud 2002. Ginebra. Disponível em: http://www.who.int/violence injury prevention/violence/world report/en/index.html.
} 
pessoas perdem a vida e muitos milhões mais sofrem lesões não mortais como resultado da violência auto-infligida, interpessoal ou coletiva, segundo a Organização Mundial da Saúde (OMS) ${ }^{47}$.

$\mathrm{Na}$ região latino-americana, a violência urbana tem experimentado um significativo crescimento nas últimas décadas, segundo dados do programa das Nações Unidas para Assentamentos Urbanos $^{48}$. A média latino-americana de criminalidade é três vezes maior que a média mundial, como resultado de fortes iniqüidades sociais e territoriais, da insuficiência de políticas públicas e da natureza cada vez mais organizada da criminalidade, conclui o relatório. A própria Organização Pan-Americana da Saúde (OPAS) declara que "a violência, pelo número de vítimas e a magnitude de seqüelas emocionais que produz, adquiriu um caráter endêmico e se converteu num problema de saúde pública em vários países" (BALLONE, 2003) ${ }^{49}$.

A violência tem como origem complexos fatores psicológicos, sociais e culturais, e não se restringe à pobreza: a sociedade torna-se mais violenta no trânsito, no futebol, na família, no aumento indiscriminado de detenções policiais, nas condições do serviço penitenciário. Assim como tem aumentado a violência simbólica, ou seja, o abuso de poder das autoridades, a violência institucional, a violência exercida por meio da discriminação, da pobreza, da fome, da segregação e da exclusão quase completa dos jovens aos mais mínimos direitos, além de uma forte cultura da ilegalidade, que reconhece que certas leis podem ser quebradas em diversos momentos.

Esses últimos anos também têm se caracterizado por uma forte perda de legitimidade do Estado, das instituições, dos políticos e de líderes sociais; por uma forte corrupção e pela coroação do consumo como característica principal da identidade, um contexto no qual as pessoas se definem em função do que consomem e do que possuem, e não pelo que são.

\footnotetext{
Acessado em 16/10/2006.

${ }^{47}$ Informe mundial sobre la violencia y la salud. Organización Mundial de la Salud 2002. Ginebra. Disponível em: http://www.who.int/violence_injury_prevention/violence/world_report/en/index.html. Acessado em 16/10/2006.

${ }^{48}$ Ciudades Más Seguras. Programa de las Naciones Unidas para Asentamientos Urbanos. UN-Habitat. Disponível em:

http://www.unhabitat-rolac.org/default.asp?pag=areas_programaticas.asp\&id_secao=12\&id_idioma=2. Acessado em: 15/10/2006.

49 Ballone GJ - Violência e Saúde, in. PsiqWeb, Internet, disponível em $<$ http://gballone.sites.uol.com.br/temas/violen_inde.html $>2003$
} 
É neste contexto que muitos jovens encontram na violência uma forma de construção da sua identidade no meio social: o pertencimento a diversos bandos resulta em uma espécie de socialização, de rede de contenção emocional, um lugar onde podem expressar a sua frustração, o seu ressentimento e, ao mesmo tempo, satisfazer as suas aspirações de consumo impulsionadas pela cultura. Um fenômeno que, segundo o programa "UN-Habitat", é relativamente novo, já que, na história, a violência sempre esteve associada a movimentos políticos. Neste momento, ela é de origem social, enraizada no empobrecimento da população dos últimos 30 anos, na perda de ideais políticos, de canais de expressão e na ausência de alternativas de mudança.

Esta situação gera um alto nível de incerteza econômica e social, já que os jovens representam a força motriz de uma sociedade, o seu futuro. A incapacidade de encontrar emprego gera uma sensação de vulnerabilidade e inutilidade, fortalecendo a relação intrínseca entre desemprego juvenil, exclusão social e violência urbana. Por outro lado, ocasiona uma intensa sensação de insegurança, aumento de casos de estresse póstraumático, de ataques de pânico e outras seqüelas econômicas, sociais e psicológicas.

\section{c) Saúde física e mortalidade evitável}

A vulnerabilidade da população na modernidade tardia também resulta em um indicador da crise deste começo de século. A saúde física encontra-se ameaçada por vários fatores anunciados. Por um lado, pela crescente contaminação do ambiente, tanto é assim que a Organização Mundial da Saúde (OMS, 2006) ${ }^{50}$ solicitou que os governos melhorem a qualidade do ar nas cidades. A poluição atmosférica mata 2 milhões de pessoas anualmente, e reduzir o tipo de poluição conhecido como PM10 - matéria particulada menor que 10 micrômetros - poderia salvar até 300.000 vidas a cada ano.

Por outro lado, pela pobreza, que não possibilita acesso a água potável, a serviços sanitários, a educação de qualidade e a sistema de saúde eficientes; condições que, combinadas entre si, geram, por exemplo, a morte de quatro pessoas a cada dois minutos - três das quais são crianças -, por causa da malária:

Milhões de crianças caminham pela vida em situação de pobreza, abandono, sem acesso à educação, desnutridas, discriminadas, negligenciadas e vulneráveis. Para elas, a vida é uma luta diária pela sobrevivência. Vivendo em centros urbanos ou

\footnotetext{
${ }^{50}$ Disponível em: $<$ http://www.who.int/phe/health_topics/outdoorair_aqg/en/index.html>. Acesso em: 8 out 2006.
} 
em povoados rurais remotos, correm o risco de perder sua infância - sem acesso a serviços essenciais, como hospitais e escolas, sem a proteção da família e da comunidade, freqüentemente expostas a exploração e abusos. Para essas crianças, a infância como o tempo de crescer, aprender, brincar e sentir segurança não tem, na realidade, nenhum significado (UNICEF, 2005, p. 6). ${ }^{51}$

No relatório A Saúde do Mundo, de 2005, a $\mathrm{OMS}^{52}$ faz um alerta sobre os quase 10,6 milhões de crianças menores de 5 anos que morreram, em grande maioria, de doenças possíveis de prevenir. Delas, 4 milhões não viveram mais de um mês. As doenças transmitidas pela água, ou por detritos humanos, são a segunda principal causa de óbito de crianças em todo o mundo, depois das infecções do trato respiratório.

Registram-se todos os anos 5 milhões de casos de diarréia em crianças oriundas de países em desenvolvimento. Trata-se de uma doença que mata anualmente 1,8 milhões de crianças com idade inferior a cinco anos, o que equivale a uma taxa de mortalidade de 4.400 crianças por dia (PNUD, 2006, p. 42).

As doenças e as mortes, que poderiam ser evitadas por vacinas e educação, são outro claro indicador de abandono social, de exclusão, da invisibilidade dos pobres, deixando a população carente à própria sorte: o sarampo, a difteria e o tétano representam outros 2 a 3 milhões de óbitos de crianças. As crianças encontram-se tão vulneráveis, que dos 60 milhões de mortes em todo o mundo em 2004, 10,6 milhões eram crianças com menos de cinco anos - grosso modo, morreu uma criança a cada três segundos.

Outro indicador da desigualdade mundial é constituído pelo hiato da esperança média de vida entre um país de rendimento baixo e um país de rendimento elevado, que ainda é de 19 anos. Uma pessoa nascida em Burkina Faso tem por expectativa de vida 35 anos menos do que uma nascida no Japão, e uma pessoa da Índia pode ter como expectativa de vida 14 anos menos do que uma nascida nos Estados Unidos. Segundo os indicadores atuais, uma criança nascida hoje na Zâmbia tem menos possibilidades de viver mais do que 30 anos do que tinha uma criança nascida em 1840 na Inglaterra.

Mas esta aguda problemática social não termina aí, já que os sobreviventes desta luta pela vida ainda devem lutar com a fome, a violência, a exclusão; sem falar das seqüelas psicológicas, que geram toda uma cadeia de eventos sociais, constituindo um enorme sofrimento.

\footnotetext{
${ }^{51}$ Disponível em: <http://www.unicef.org/brazil/cap1_sowc06.pdf > . Acesso em: 9 out 2006.

${ }^{52}$ Informe sobre la salud en el mundo 2005. Organización Mundial de la Salud. Disponível em:

$<$ http://www.who.int/whr/2005/es/>. Acesso em: 8 out 2006
} 


\section{d) Saúde psicológica}

Numerosos pensadores - Marx, Durkheim e Max Weber -, entre outros, tinham alertado sobre os efeitos indesejados da modernidade, já que enxergavam no trabalho industrial moderno conseqüências degradantes, nas quais as pessoas se submetiam à disciplina de labores maçantes e repetitivos. Na modernidade tardia, além dos impactos já anunciados por estes autores, somaram-se outros relacionados à pobreza, à exclusão, ao estilo de vida individualista e consumista, à insegurança social, entre outros.

\section{- A degradação da dignidade humana ${ }^{53}$}

Um dos primeiros elementos que podemos analisar é o impacto psicológico que geram a pobreza, o desemprego e os valores da modernidade baseados na discriminação de raça, sexo, religião e classe social; a exclusão como valor social e cultural e, em decorrência, a degradação da dignidade humana:

"No verão sentimo-nos tão sujas. Passam-se semanas que não lavamos as nossas roupas. As pessoas dizem que nós estamos sujas e cheiramos mal. Mas como podemos estar limpas sem água?” (PNUD, 2006, p. 64)

Estas palavras de uma mulher indiana de classe baixa mostram a relação entre os sentimentos íntimos e a exclusão social no que se refere ao acesso a um recurso básico, a água:

"Fue como salir de un túnel hacia la luz", exclamó la Señora Eugenia, quien aprendió a leer y escribir a los 65 años.

"Yo no sabía hacer ni una raya, nunca había ido a la escuela. Hoy le escribí una carta a mi mamá. Ahora que he aprendido a leer y escribir me siento realmente gente, antes no me sentía gente". Héctor (52 años).

"No saber leer y escribir es como tener una discapacidad, es como no tener visión, es como estar ciego. Tengo una hija de seis años que comenzó la escuela y quiero ayudarla en las tareas... ésa es mi angustia". Marta (34 años). (CEAAL, carta $\mathrm{n}^{\mathrm{o}}$ $179,2004)^{54}$

\footnotetext{
53 "Dignidade vem do latim dignitate e pode ser definida como honradez, honra, nobreza, decência, respeito a si próprio, conforme O NOVO DICIONÁRIO AURÉLIO E O MINIDICIONÁRIO AURÉLIO, e está ligada ao ser humano por uma abstração intelectual representativa de um estado de espírito". No Brasil, a Constituinte de 1988 "traduz a repulsa constitucional às práticas, imputáveis aos poderes públicos ou aos particulares, que visem a expor o ser humano, enquanto tal, em posição de desigualdade perante os demais, a desconsiderá-lo como pessoa, reduzindoo à condição de coisa, ou ainda a privá-lo dos meios necessários à sua manutenção". (NOBRE JÚNIOR). Disponível em: http://www.infojus.com.br/area3/edilsonnobre.htm. Acesso em: 10 out 2006.

${ }^{54}$ Disponível em: <http://www.lpp-uerj.net/olped/documentos/1766.pdf>. Acesso em: 18 out 2006.
} 
Estas outras palavras de cidadãos latino-americanos expressam o que se sente ao sair da exclusão social mais profunda que representa o analfabetismo. A dignidade não é mensurável, contudo é o cerne do desenvolvimento humano e do nosso sentido de bemestar, do nosso amor próprio, da nossa auto-estima - o que nos impulsiona a atuar.

A auto-estima é algo vital para o ser humano e para a evolução da sociedade. Graças a ela as pessoas podem enfrentar todas as dificuldades que se apresentam cotidianamente. Passam a ter confiança em si mesmas, vontade de melhorar: sentem-se capazes de tudo e não se resignam com seu destino ou com a ordem estabelecida. É o que tem movido o mundo através dos séculos e tem feito as pessoas superar os momentos mais difíceis na história da humanidade.

Agora, quando toda uma indústria cultural está determinada a degradar a dignidade das pessoas, a realidade muda, e aí sim se pode fazer com que um homem se sinta miserável e dominá-lo por muitas tiranias, fazendo com que abandone a luta social por uma melhora na qualidade de vida e garantindo a reprodução da estrutura social.

Assim se sentem os pais no pronto-socorro, com seu filho nos braços morrendo sem assistência médica. Assim se sente o trabalhador que pega 4 ônibus e viaja 6 horas por dia para trabalhar outras 10, só para botar um prato de comida na mesa. Assim se sente a mãe que tem que escolher quem de seus quatro filhos terá o privilégio de ir à escola, condenando o resto à pobreza e à ignorância. Assim se sente quem não pode mais sustentar seus filhos, porque foi pego pelo desemprego. Assim se sente quem não tem ninguém que o proteja da violência das ruas, ou mesmo da polícia. Assim se sente a criança que vai à escola com os sapatos rotos, sentindo o olhar de seus colegas, suportando a "vergonha de ser pobre".

Perde-se a auto-estima, a confiança em si mesmo, o que gera, às vezes, até um fenômeno de auto-exclusão. Nesse contexto, a violência pode funcionar como contrapeso, como forma de canalizar a angústia reprimida; como jeito de recuperar a dignidade perdida, gerando respeito não só do seu grupo de pares, mas também das suas vítimas. 


\section{- Individualismo e a crise do ser no mundo}

Fica evidente que a crise que vivemos não se limita à natureza: encontra-se profundamente arraigada na sociedade e na cultura. A modernidade significou uma cosmovisão na qual o sujeito se libertava da magia e da religião, erigindo-se como dono de seu destino, por intermédio da ciência e da tecnologia. Assim, o homem acreditou que lograria a felicidade e o eterno bem-estar. A cosmovisão de uma época foi trocada por uma mentalidade imediatista: a boa indicação agora é aproveitarmos o máximo possível o momento presente, sem nos preocuparmos com o que vem depois. Por isso um dos traços da humanidade atual é a ditadura da utilidade, entendida esta no sentido material, com exclusão de toda consideração ao espírito.

Como mostra Taylor (1994, p.40), "foi trocado assim um fim objetivo para a vida, como o que oferece a religião, por apenas um propósito subjetivo: experimentar sentimentos de prazer, e evitar o desprazer". O hedonismo, o narcisismo, o conformismo e o consumismo são os valores fundantes da 'nova' cultura mundializada, que atraem todos para o consumo de mercadorias, oferecidas como chaves do sucesso, do prazer e da felicidade.

O desencanto não tardou a chegar. Na modernidade tardia, o sentimento de vazio, de solidão, de falta de propósitos ou objetivos na vida apoderou-se da sociedade. Taylor (1994, p. 40) caracteriza o chamado mal-estar da modernidade segundo três formas.

À primeira, ele denomina o lado obscuro do individualismo. Em verdade, Taylor não critica o individualismo, já que o reconhece como uma conquista da modernidade, mas critica essa força narcisista e egoísta de entender-se a si mesmo como átomo independente de um mundo circundante. Segundo ele, esta é uma das conseqüências do desencantamento do mundo, a partir do qual se faz difícil encontrar horizontes de ação e de sentido para uma vida mais plena.

A segunda forma resulta na primazia do pensamento instrumental, tendo a racionalidade como seu propósito essencial (meios-fins e custo-benefício), e parece ter-se apoderado da vida da população.

A terceira é o consentimento do individualismo, que conduz ao atomismo social, no qual cada um se ocupa de si mesmo, e a coisa pública perde interesse. $\mathrm{O}$ individualismo 
ou a mentalidade do "salve-se quem puder" têm correlatos destrutivos, fincados na profunda desconfiança nos outros e na escassa capacidade de nos associarmos para cooperar em objetivos comunitários.

O resultado evidente deste cenário é que esta é a época na qual proliferam as doenças da alma - síndrome do pânico, sociofobia, tédio, depressão - e diversas patologias relacionadas com a questão do contato com os outros.

\section{- Consumismo como valor e indústria cultural como veículo}

Nuestra recompensa se encuentra en el esfuerzo y no en el resultado. Un esfuerzo total es una victoria completa.

Mahatma Gandhi

Assim, na falta de um propósito na vida, o consumo tem se convertido no objetivo da vida de muitas pessoas que, em verdade, não sabem o que fazer com a sua liberdade, o que buscar, como ser felizes. Em uma sociedade de mercado, tudo é considerado mercadoria, a publicidade "em cada anúncio vende um estilo de vida, sensações, visões de mundo, relações humanas, sistemas de classificação, hierarquias, etc., em quantidades significativamente maiores que geladeiras, roupas ou cigarros" (REIS, 2004)..$^{55}$

O consumo tem se convertido em um símbolo de status social. Sua importância na vida cotidiana das pessoas fica em evidência à luz da doença do status, como se costuma chamar, para representar as doenças mentais relacionadas com a luta por estar a par dos outros, ou sobressair-se em relação aos demais.

Este modelo de desenvolvimento, baseado no consumo extremo, além de causar um forte impacto na vida individual das pessoas, tem sido o responsável pela degradação ambiental:

[...] el consumo es un medio esencial para el desarrollo humano sólo cuando enriquece la vida de las personas sin afectar negativamente el bienestar de los otros. Sin embargo, las pautas de consumo actuales, son hostiles al desarrollo humano, ya que van en desmedro de la base ambiental de los recursos, exacerban las

\footnotetext{
${ }^{55}$ Disponível em: <http://www.rieoei.org/rie36a04.htm>. Acesso em 22 out 2006.
} 
desigualdades, y están acelerando la dinámica del nexo pobreza - desigualdad degradación ambiental (PNUD, 1998, p. 1).

Vivemos em um contexto social no qual o sonho de todo cidadão é consumir como o fazem os setores opulentos das sociedades desenvolvidas, um sonho alimentado pelas promessas eleitorais, como apresenta Galeano (1999, p. 45):

[...] Os presidentes dos países do sul que prometem o ingresso ao primeiro mundo um passe de mágica que nos transformara em prósperos membros do descarte deveriam ser processados por fraude e apologia do crime. Por fraude porque prometem o impossível. Se todos consumíssemos como consomem os depredadores do mundo, ficaríamos sem mundo. E por apologia do crime: este modelo de vida que nos é oferecido como um grande orgasmo de vida, estes delírios de consumo que dizem ser a chave da felicidade, estão enfermando o nosso corpo, envenenando a nossa alma e nos deixando sem casa: aquela casa que o mundo quis ser quando ainda não era $[\ldots]$.

$\mathrm{Na}$ sociedade de consumo atual, as pessoas são reconhecidas e valorizadas pelo que possuem: as marcas comerciais que consomem as classificam, além de hierarquizá-las. Quando compra um produto de marca, a pessoa é identificada pela marca, passando a fazer parte do grupo de seus consumidores, ocupando assim um determinado estrato social. Uma sociedade que, como diz Leff (1994, p. 87), gera um processo de produção ideológica de necessidades, que desencadeia o desejo a uma demanda inesgotável de mercadorias, uma verdadeira manipulação publicitária do desejo.

A roupa de marca ou outros objetos podem ser o sonho de milhões de pessoas, porém ansiar por objetos materiais pode gerar depressão e angústia. Uma das possíveis causas de depressão entre os consumidores é o fato de que o que compram tende a perder valor rapidamente, e como eles se valorizam e são valorizados pelas posses, acabam por entrar numa correria louca, que não tem fim.

Neste ponto, chegamos a nos associar ao proposto por Gándara (1996, p.130), quando alerta:

Las emociones negativas, especialmente la tristeza, aumentaban la propensión a comprar. La soledad, el enfado, la irritación, la baja autoestima y la frustración también desembocaban con frecuencia en episodios de compra compulsiva.

Esse constitui um outro desafio da educação atual, intrinsecamente relacionado com a sociedade de risco e a crise ambiental, uma vez que, segundo o Manifesto por uma Ética 
para a Sustentabilidade $(2002)^{56}$, esta só será possível quando a vida se sobrepuser aos demais valores criados pelas pessoas; quando formos capazes de questionar os estilos de vida e de consumo que geram a insustentabilidade.

\section{- Suicídio e estresse ocupacional}

A era moderna parece ser a Idade da Ansiedade, pela agitada dinâmica existencial da modernidade, sociedade industrial, competitividade, consumismo desenfreado, solidão, crise do ser no mundo, insegurança.

A simples participação do indivíduo na sociedade contemporânea já preenche, por si só, um requisito suficiente para o surgimento da Ansiedade. Portanto, viver ansiosamente passou a ser considerado uma condição do homem moderno ou um destino comum ao qual todos estamos, de alguma maneira, atrelados (BALLONE, 2002) $)^{57}$.

A África e a América Latina, no contexto mundial, destacam-se pela violência, pela criminalidade e pelos homicídios. Os países europeus e do Pacífico Ocidental (China, Austrália, Japão, Coréia) se destacam pela violência auto-infligida, pelos suicídios, como pode se observar na tabela 2 .

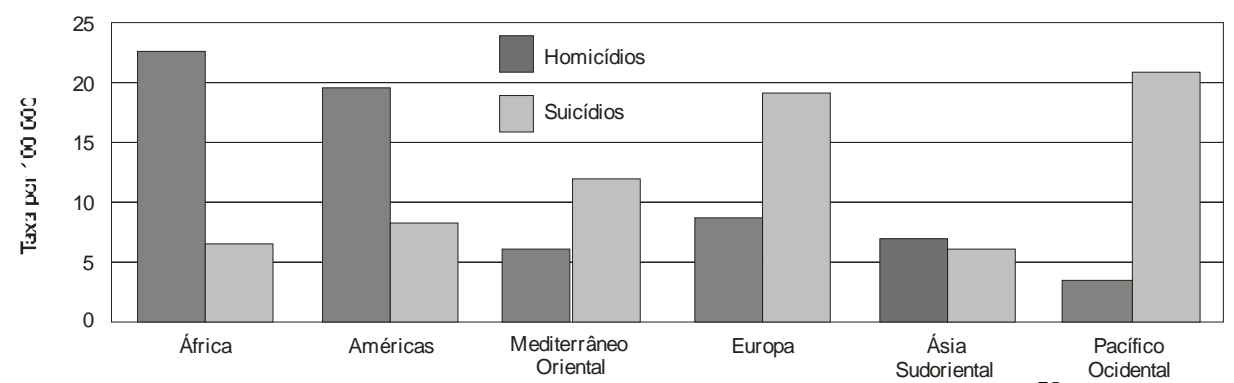

Gráfico 1: Taxa de homicídios e suicídios por regiões da OMS. 2000. ${ }^{58}$

O certo é que este estado de violência social está manifestando um profundo mal-estar da cultura, um vazio existencial que termina na eclosão da violência.

O suicídio, por exemplo, provoca a metade de todas as mortes violentas do mundo e se traduz em:

1 milhão de vítimas ao ano; a situação chegou a ser gravíssima na Europa, onde o número anual de suicídios supera o de vítimas de acidentes de trânsito; e também a

\footnotetext{
${ }^{56}$ Disponível em: <www.pnuma.org/educamb/esp/mantexto.php>. Acesso em: 13 mai 2005.

${ }^{57}$ Disponível em: <http://www.psiqweb.med.br/cursos/stress1.html $>$. Acesso em: 14 out 2006.

58 Disponível em: <http://www.who.int/violence_injury_prevention/violence/world_report/en/index.html $>$. Acesso em: 16 out 2006.
} 
nível mundial, já que no ano de 2001, os suicídios registrados em todo o mundo superaram a cifra de mortes por homicídio (500 mil) e pelas guerras $(230 \mathrm{mil}) .{ }^{59}$

Se a esse fato acrescentamos o de que, a cada suicídio, produzem-se no mundo 10 ou 20 tentativas, segundo a OMS (2002), temos um quadro gravíssimo, com até 20 milhões de pessoas ao ano que poderiam estar tentando pôr fim a sua vida, tentativas que se traduzem em lesões, hospitalizações e traumas emocionais e mentais. Porém o fato mais grave ainda - se é que pode haver algum - consiste no número cada vez maior de jovens de 15 a 25 anos que apresentam comportamentos suicidas.

Mas o comportamento suicida, que representa o mais alto escalão da autodestruição, não é a única dinâmica que encontramos na sociedade atual. As pessoas se autodestroem de muitas maneiras diferentes. Com o fumo, por exemplo. Dados do Banco Mundial permitem afirmar que o tabagismo agrava a pobreza e dificulta o desenvolvimento dos países subdesenvolvidos.

O estresse é outro fenômeno universal que devemos ao modo de vida moderna. É resultado de uma postura de alerta que as pessoas, de forma natural, possuem para enfrentar situações de grande risco. Na sociedade atual, as pessoas se vêem submetidas a uma enorme tensão, já que a postura de alerta se faz cada vez mais necessária diante da insegurança, da violência, da competição desenfreada no trabalho, no trânsito, entre outros fatores.

Quando a urgência se torna permanente, quando a tensão é vivida todos os dias e não há um período de calma para recuperação, pode haver um esgotamento do organismo, afetando seriamente a qualidade de vida.

Um dos problemas que mais afetam a educação de hoje em dia é a chamada Síndrome de Burnout (CODO; SAMPAIO e HITOMI, 1993, p. 280), definida como uma das conseqüências mais marcantes do estresse profissional da sociedade atual.

Podemos entender a Síndrome de Burnout como o produto de uma interação negativa entre a pessoa, o local e a equipe de trabalho, como afirmam Gallego e Rios (1991, p. 257-265).

\footnotetext{
${ }^{59}$ Disponível em: <http://www.who.int/mediacentre/news/releases/2004/pr61/es/>. Acesso em: 25 out 2006.
} 
A Organização Internacional do Trabalho reconhece que o estresse e a síndrome de Burnout não são fenômenos isolados: ambos foram convertidos em um risco ocupacional significativo. De fato, tanto Barona (1991, p. 63-76) como Aluja (1997, p.47-61) confirmaram, por intermédio de pesquisas, a relação existente entre saúde mental, psicopatologia e Burnout.

\subsubsection{Sociedade de risco}

Os indicadores socioambientais apresentados são traduzidos, em parte, por intermédio do conceito "Sociedade de Risco" "60. Um conceito fortemente associado às obras de dois sociólogos, o alemão Ulrich Beck e o inglês Anthony Giddens ${ }^{61}$.

Para Beck (1986, p. 16), o processo de produção de riquezas da modernidade ${ }^{62}$ foi sistematicamente acompanhado por um processo de produção de riscos globais, trazendo a ameaça de destruição da vida no planeta, como o risco nuclear, o lixo radioativo e as guerras.

E como o mesmo Beck (1995) aponta:

Os perigos na Sociedade de Risco não são calculáveis, nem em termos espaciais, nem em termos temporais. Por exemplo, em Chernobyl a questão espacial e temporal não pode ser totalmente delimitada: a totalidade das pessoas afetadas ainda não pode ser prevista, pois muitos indivíduos potencialmente afetados ainda estão por nascer. ${ }^{63}$

Dito de um modo mais sintético: a Sociedade do Risco caracteriza-se por ser a primeira época histórica na qual as sociedades têm de se enfrentar para o desafio que representam

\footnotetext{
${ }^{60}$ Risco: entendido como a compreensão dos resultados inesperados que podem ser uma conseqüência de nossas próprias atividades ou decisões. (GIDDENS, 1991, p. 38).

${ }^{61}$ Em 1986, Beck lança sua obra Risikogesellschaft (Sociedade de Risco), e são lançadas as obras The Consequences of Modernity (1990) e Modernity and Self Identity (1991), de Giddens.

${ }^{62}$ Modernidade: Aparece ao final de século XVII e se cristaliza ao final do século XVIII. Caracteriza-se pelo auge da ciência, as mudanças nas formas de conhecer o mundo (positivismo), o desenvolvimento da indústria; do Estado como principal ator político; da organização capitalista da produção; baseado em uma racionalidade pragmática, individualista e instrumental; pela fé no sistema social e por fazer amplo uso e desenvolvimento da ciência e da tecnologia.

Outras caracterizações, como a de Perez Gomez, a descrevem assim: "A modernidade, a idéia de progresso linear e indefinido, e a [?] produtividade racionalista, a concepção positivista, a tendência etnocêntrica e colonial de impor o modelo de verdade, bondade e beleza próprio do Ocidente como um modelo superior e a concepção homogênea de desenvolvimento humano, que discrimina e despreza as diferenças de raça, sexo e de cultura, se desmorona ante as evidências da história da humanidade no século XX, coalhada de catástrofes e hostilidades". (PÉREZ GÓMEZ, 1998, p. 19).

${ }^{63}$ Conferência RISK SOCIETY, realizada na Escola Nacional de Saúde Pública, FIOCRUZ, em 21 nov 95.

Disponível em: <www.ensp.fiocruz.br/projetos/esterisco/maryfim5.htm>. Acesso em: 14 jun 2005.
} 
os sistemas de produção e consumo, pela capacidade que eles têm para destruir todo tipo de vida na terra.

Atualmente podemos identificar inúmeros riscos além daqueles identificados por Beck (1986): a mudança climática, a falta de água doce, a perda de biodiversidade e de florestas, a poluição, a pobreza crescente. E até, como a UNICEF (2001) tem mostrado, um novo conceito que mede a fragilidade da vida das crianças: o mero risco de nascer ${ }^{64}$.

A modernidade, ainda que tenha trazido aumento de oportunidades de vida, é uma faca de dois gumes, já que o preço cobrado para que uma pequena parte da população tenha uma vida mais segura e gratificante está sendo alto demais para a geração do risco global. Isso pode ser observado de forma mais clara nos problemas socioambientais, o "lado sombrio, $[\ldots]$ da modernidade $[\ldots]$ que se tornou muito evidente no século atual" (GIDDENS, 1991, p. 16).

Uma sociedade desigual, na qual, como diz Beck (1998, p. 31), “[...] em uma parte da terra a gente morre de fome, enquanto na outra os problemas causados pela sobrealimentação têm se convertido em um problema de primeira ordem". Ou, como coloca Bifani (1997, p.35), um modelo de desenvolvimento no qual “[...] a sociedade rica explora ao máximo a natureza para satisfazer necessidades supérfluas, enquanto os mais necessitados a degradam em seu afã de prover-se do mínimo necessário para sobreviver".

Uma sociedade que, segundo Beck (1998), apresenta inúmeros desafios: os relativos ao esgotamento de recursos naturais, os relativos à crise institucional e os relativos à perda de credibilidade das pessoas, ou à capacidade de acreditar em algo.

\footnotetext{
${ }^{64} \mathrm{O}$ mero fato de nascer gera riscos para todas as crianças. As possibilidades de que uma criança consiga um desenvolvimento pleno e saudável depende de uma vasta gama de fatores, "e em alguns casos, da sorte. O certo é que as crianças hoje já nascem com uma dívida. Cada recém-nascido na Mauritânia chega ao mundo com uma dívida de 997 dólares; na Nicarágua, de 1.213 dólares, e no Congo, de 1.872 dólares". A UNICEF colocou em debate um novo conceito que mede o risco das crianças, um índice complexo composto por três componentes; o primeiro relacionado com o desenvolvimento, que integra a mortalidade de crianças menores de cinco anos, o peso inferior ao normal em moderado ou estado grave, e a escolaridade primária. O segundo componente ressalta o risco dos conflitos armados; e o terceiro é o risco de se contrair AIDS. Disponível em: http://www.unicef.cl/centrodoc/ficha.php?id=74. Acesso em: 12 mai 2005.

O índice que mede o risco aparece em uma escala que vai de zero a cem, existindo continentes com uma média regional de 61, como África ao sul do Saara: regiões com uma média de 24, como Oriente Médio e África Setentrional; regiões com uma média de 41, como a Ásia Central; regiões com uma média de 31, como a Ásia Sul Oriental e o Pacífico; regiões com uma média de 10, como a América; e regiões com uma média de 6, como a Europa. (UNICEF, 2001).
} 
Três eixos configuram, segundo esse autor, a sociedade de risco. O primeiro, $a$ depreciação da natureza e a cultura por parte da sociedade industrial, com os recursos, dilapidados em virtude da própria modernização, sendo consumidos até o esgotamento. O segundo, a crise das normas sociais, que diz respeito ao fracasso da segurança prometida, diante dos perigos desencadeados pela tomada de decisões muitas vezes errôneas. E o terceiro, o deterioramento e o desencanto com os preceitos da modernidade, com a fé no progresso, na consciência de classe, nos partidos políticos e nas instituições em geral, tendo perdido relevância e credibilidade.

Problemas muito graves para o normal funcionamento social, se considerarmos que, na base do sistema moderno, se encontra o processo de "desencaixe" ${ }^{\text {"65 }}$ e dos sistemas peritos $^{66}$ que, por sua vez, se baseiam na confiança da população. Uma sociedade que tem chegado a um momento de inflexão na sua história, no qual se descobre que nada pode ser conhecido com certeza, nenhuma visão de progresso já é possível, tendo emergido uma nova agenda mundial com predominância nas questões ecológicas e de novos movimentos sociais.

O conceito de sociedade de risco, mais que nenhum outro, identifica um dos grandes desafios que a educação desta era tem de enfrentar, ou seja, ajudar a humanidade a sobreviver a si mesma, às suas condutas destrutivas e às suas tendências de domínio e controle.

\footnotetext{
${ }^{65}$ Desencaixe. Este conceito faz parte das três fontes dominantes do dinamismo da modernidade. Segundo Giddens: a separação entre tempo e espaço, a apropriação reflexiva do conhecimento e os mecanismos de desencaixe, que retiram a atividade social dos contextos localizados, reorganizando as relações sociais através de grandes distâncias tempo-espaciais (GIDDENS,1991, p. 58).

${ }^{66}$ Giddens (1991) denomina sistemas abstratos o "conjunto de sistemas peritos e de fichas simbólicas" (p. 84) definidos pelo autor como "mecanismos de desencaixe, pois removem as relações sociais das imediações do contexto" (p. 36). Os sistemas peritos são "sistemas de excelência técnica ou competência profissional, que organizam grandes áreas dos ambientes material e social em que vivemos hoje" (p. 35). Fichas simbólicas: "meios de intercâmbio que podem ser circulados sem ter em vista as características específicas dos indivíduos ou grupos que lidam com eles em qualquer conjuntura em particular" (p. 36). Os sistemas peritos são "sistemas de excelência técnica ou competência profissional que organizam grandes áreas dos ambientes material e social em que vivemos hoje" (GIDDENS,1991, p. 35-36, 84).
} 


\subsection{As características da sociedade atual}

O papel que a educação deve ocupar na sociedade pode, em parte, ser respondido pelos desafios sociais, mas, por outro lado, encontra-se profundamente influenciado pelas características que apresenta a sociedade, o avanço da ciência e a tecnologia, bem como as demandas relacionadas ao funcionamento democrático e ao mercado, as características culturais, as linguagens, entre outras.

\subsubsection{Sociedade da informação, sociedade em rede}

De acordo com Castells (2000), se definíssemos a ação social como o resultado das relações entre a natureza e a cultura, poderíamos dizer que nos encontramos em um momento de profunda transformação.

O primeiro modelo de relação entre esses dois pólos foi caracterizado pela dominação da natureza sobre a cultura. Os homens e as mulheres da Idade Média sofriam duramente as conseqüências do angustiante peso do meio físico, uma época na qual a relação entre as pessoas e a terra era muito estreita. O clima tinha conseqüências dramáticas de vida ou morte, tanto é assim que, na Europa, em 1033, a fome fez temer pelo desaparecimento do gênero humano. "Os códigos de organização social expressavam a luta pela sobrevivência diante dos rigores incontroláveis da natureza" (CASTELLS, 2000, p. 505). Um modelo que Toffler (1995, p. 20) identifica como a primeira onda, na qual os homens teriam se organizado em torno das sociedades agrárias como fonte de riqueza.

O segundo modelo de relação entre natureza e cultura foi estabelecido nos princípios da era moderna, e associado à Revolução Industrial, ao triunfo da razão, resultando na tentativa de dominação da natureza pela cultura. Todo o pensamento de uma época se volta ao intento de controlar essas forças destrutivas da natureza para benefício próprio. Nesse sentido, e completando com a visão de Toffler, se, na primeira onda, o foco era a agricultura, na segunda a forma de criar riqueza passou a ser a manufatura industrial e o comércio de bens. Os meios de produção de riqueza se alteraram, ou seja, houve a passagem da sociedade agrária para uma sociedade industrial. 
No terceiro modelo, a característica principal é a de que, na sociedade atual, os serviços culturais têm suplantado os bens materiais como núcleo da produção. Entramos em um modelo genuinamente cultural de interação e organização social. Por isso é que a informação representa o principal ingrediente de nossa organização social, e os fluxos de mensagens e imagens entre as redes constituem o encadeamento básico de nossa estrutura social.

Toffler (1995) reafirma que a terceira onda começou a se desenhar com a Revolução do Conhecimento. Nesse modelo social, completa Schaff (1992, p. 43), a individualidade é estimulada, fazendo surgir uma nova civilização centrada na informação e simbolizada pelo computador, pela informática. Na terceira onda, a principal inovação está no fato de que o conhecimento passou a ser não um meio adicional de produção de riquezas, mas o meio principal. O conhecimento humano está se tornando o principal fator de produção de riquezas, os serviços e as informações gerados por ele tendem a se materializar nos bens negociados no mercado. Hoje os fatores clássicos de produção não são mais os principais responsáveis pela criação do valor de mercado.

Neste contexto, segundo Davis (1999, p. 56), a tendência do mercado é clara: uso cada vez mais intensivo do conhecimento na produção de bens e serviços. $\mathrm{Na}$ era industrial, o predominante era a utilização de capital. Agora a tecnologia e a velocidade de transmissão de informação nivelam a competitividade, por isso o crescimento das empresas só pode vir da inovação em produtos e serviços; há obsolescência do conhecimento, o conhecimento se cria a um ritmo muito rápido, o que acelera também a sua obsolescência, gerando uma necessidade de atualização permanente, preferência por "smart products". Os produtos concentram cada vez mais conhecimento e devem ser mais inteligentes. Produtos que podem se autodiagnosticar, se adaptar a diferentes usuários, etc.

A revolução tecnológica, centrada nas tecnologias de informação e comunicação, está mudando a sociedade a um ritmo acelerado. "Este processo reflete os primeiros passos do homo culturalis, em contraposição ao homo economicus dos séculos XIX e XX" (DOWBOR, 1994, p. 20) ${ }^{67}$.

\footnotetext{
${ }^{67}$ Disponível em: <http://ppbr.com/ld/conhec.asp>. Acesso em: 17 mai 2005.
} 
O conceito de sociedade da informação faz referência a este novo modelo, a esta terceira onda, que está produzindo profundas mudanças neste começo do milênio. Esta transformação está sendo impulsionada principalmente pelos novos meios disponíveis para criar e divulgar informação mediante tecnologias digitais. Processo que está mudando a base material da sociedade a um ritmo cada vez mais acelerado: as economias e as culturas em todo o mundo se fizeram interdependentes em escala global - globalização econômica e cultural -, introduzindo uma nova forma de relação entre Economia, Estado e Sociedade.

Uma mudança caracterizada por Castells (2000) por meio do conceito "espaço de fluxo" ${ }^{68}$, e por Giddens (1991, p. 16) por meio do conceito de desencaixe, indicando um mesmo fenômeno no qual as relações sociais se retiram dos contextos localizados, possibilitando sua reorganização em grandes distâncias espaço-temporais, abrindo caminho para uma nova realidade em geral e para uma realidade educativa em particular.

Esta transformação está tendo um profundo impacto na educação. Por um lado, pela exigência que produz a rápida obsolescência dos conteúdos - hoje até planetas novos aparecem diante dos nossos olhos, o que gera a necessidade de criar sistemas mais flexíveis, que possam rapidamente adaptar seus currículos às novidades cotidianas da ciência e da tecnologia. Por outro lado, a educação começa a deixar seu lugar de guardiã universal do conhecimento e passa a ocupar o papel de ajudar as pessoas a interpretar e compreender a informação: já não basta apenas transmitir.

O certo é que os espaços estão sendo transformados pelos fluxos de informação, afetando diretamente a forma de socialização dos seus ocupantes, mudando radicalmente as formas de organização social, incluindo a educação.

\footnotetext{
68 "Proponho a idéia de que há uma nova forma espacial característica das práticas sociais que dominam e moldam a sociedade em rede: o espaço de fluxos. O espaço de fluxos é a organização material das práticas sociais de tempo compartilhado que funcionam por meio de fluxos. Por fluxos, entendo as seqüências intencionais, repetitivas e programáveis de intercâmbio e interação entre posições fisicamente desarticuladas, mantidas por atores sociais nas estruturas econômica, política e simbólica da sociedade." (CASTELLS, 2000, p. 505).
} 


\subsubsection{Cibercultura e tecnologias aplicadas à educação}

Essas novas formas de comunicação e de relacionamento social, que emergem da interação entre a sociedade da informação, as novas tecnologias e a cultura, geram uma nova forma de manifestação cultural: a cibercultura. Esta nova cultura, em gestação, envolve numerosas modalidades de comunicação: e-mails, blogs, chats, listas de discussão, videoconferências, podcasts, jornalismo on-line, comunidades virtuais eletrônicas, tecnologias móveis, cibercidades, cibercafés, bankline, cultura napster, skype, que se caracterizam pela liberação do pólo emissor.

A cibercultura está revolucionando as práticas de comunicação com o surgimento de novas formas de jornalismo on-line, como TV on-line, rádio on-line; troca de informações entre cientistas através dos mecanismos de busca especializados, como Scirus, SciELO, entre outros; novas formas de construção de conhecimento, como a enciclopédia Wikipédia ${ }^{69}$; novas formas de comércio por meio do comércio eletrônico; novas relações sociais criadas e mantidas a distância, sem presença física, por intermédio dos mecanismos de comunicação (chat, messenger, Skype); novas formas de participação política da comunidade, protestos organizados e realizados com a participação de diferentes culturas, unidas por uma causa; novas formas de produção de softwares livres (moddle); novas formas de organizar grupos temáticos através de redes (Rebea, Repea, CUEDISTANCIA, entre outras).

De uma cultura de massa centralizadora, massiva e fechada, estamos nos encaminhando para a cultura "copyleft" ${ }^{, 70}$, personalizada, colaborativa e aberta (LEMOS, 2004) ${ }^{71}$. Como meio, a internet está problematizando as formas das mídias massivas tradicionais de divulgação cultural; ela é o foco de irradiação de informação, conhecimento e troca de mensagens entre pessoas ao redor do mundo, abrindo o pólo da emissão.

Por isso, a cibercultura é a emergência da inteligência coletiva, o que significa a formação de uma nova sociedade, já que, como diz Levy (1999, p. 166), “esse ideal da

\footnotetext{
${ }^{69}$ A Wikipédia é uma enciclopédia livre que está sendo construída por milhares de colaboradores de todo o mundo. Trata-se de um site baseado no conceito de Wiki Wiki, o que significa que qualquer internauta, inclusive você, pode editar o conteúdo de quase TODOS os artigos acionando o link "Editar" (nas abas de conteúdo) que é mostrado em quase todas as páginas do site. O projeto Wikipédia foi iniciado em 15 de janeiro de 2001, na versão em língua inglesa (http://pt.wikipedia.org).

${ }^{70}$ Copyleft pode ser definido como os processos de transformação de obras nas quais o usuário pode adicionar informações e transformações desde que a obra continue livre para novas transformações. A essa apropriação criativa e coletiva de trabalhos chama-se de copyleft, termo surgido como uma oposição ao termo copyright.

71 Disponível em: <http://twiki.im.ufba.br/bin/view/GEC/SociCibercon>. Acesso em: 19 jun 2005.
} 
inteligência coletiva passa evidentemente pela colocação em comum da memória, da imaginação e da experiência, por uma prática banalizada do intercâmbio de conhecimentos, por novas formas, flexíveis e, em tempo real, de organização e coordenação".

Em suma, espera-se que daqui a algumas décadas o ciberespaço seja o mediador essencial da inteligência coletiva da humanidade, gerando toda uma gama de novos gêneros, conhecimentos, comportamentos, espaços de trabalho, novos autores, entre outras mudanças significativas.

Mas a cibercultura, como Levy bem já assinalou, significa também uma nova linguagem e numerosas formas que ampliam, potencializam e mudam muitas funções cognitivas, tanto no que se refere à memória, por meio de bancos de dados, hipertextos, como no que se refere à imaginação, na utilização de simulações $^{72}$, na percepção, nas realidades virtuais, na telepresença; ou ao raciocínio, com o uso de modelizações de fenômenos complexos, entre outros.

Heidegger (2000) ${ }^{73}$ dizia que “a linguagem é a casa do ser”. Se for certa esta afirmação, então temos que considerar as novas linguagens emergentes no ciberespaço, para tentar compreender as características que o ser está assumindo nesta nova era que se inicia.

Parece ficção científica, mas, em verdade, no futuro próximo nos depararemos com numerosas aproximações que, sem dúvida, irão revolucionar a educação tal como a conhecemos. Já começam a ser vistos ambientes que propiciam interagir, explorar, construir, regular o próprio ritmo de aprendizagem, escolher em função dos próprios interesses, em suma: assumir a gestão dos próprios processos de aprendizagem. Esses ecossistemas cognitivos podem vir a representar a concretização dos ideais construtivistas, criando uma enorme área de desenvolvimento potencial para os $\operatorname{alunos}^{74}$.

\footnotetext{
72 "As técnicas de simulação, em particular as que envolvem imagens interativas, não substituem os raciocínios humanos, mas prolongam e transformam as capacidades de imaginação e pensamento. Com efeito, nossa memória de longo prazo tem a capacidade para armazenar uma quantidade muito grande de informações e conhecimentos. Nossa memória de curto prazo, que contém as representações mentais às quais prestamos deliberadamente nossa atenção, possui, ao contrário, capacidades muito limitadas. Para nós é impossível, por exemplo, representarmos clara e distintamente mais de uma dezena de objetos em interações.” (LEVY, 1999, p. 165).

${ }^{73}$ Disponível em: <http://personales.ciudad.com.ar/M_Heidegger/carta_humanismo.htm>. Acesso em: 20 jun 2005

${ }^{74}$ Vygotsky postula que a educação, a cultura e o desenvolvimento cognitivo entrelaçam-se para potenciar os processos de aprendizagem que precedem o desenvolvimento, através da Zona de Desenvolvimento Proximal (ZDP), entendida como a distância entre o nível alcançado pelo aluno sozinho e o nível de desenvolvimento potencial que se
} 
Um exemplo desse tipo de ambiente é a cave (caverna) desenvolvida no Laboratório de Visualização Eletrônica da Universidade de Illinois, nos Estados Unidos, em 1992: um cubo com $3 \mathrm{~m}^{3}$ e projeções em todas as paredes, que permite a criação de realidade virtual, a manipulação do ambiente por meio de joysticks e óculos semitransparentes, que dão ao usuário a capacidade de enxergar simultaneamente o ambiente físico e o virtual. Até seis pessoas podem compartilhar o uso simultâneo da cave, podendo uma cave ser interconectada a outra, não importa onde estejam.

Como Bruner (1991, p. 48) já tinha analisado, são as culturas que criam "próteses culturais" que nos permitem transcender as nossas limitações biológicas, como, por exemplo, os limites da nossa capacidade de memória ou de audição. É a cultura que molda a vida e a mente humanas, que confere significado à ação situando os seus estados intencionais subjacentes nos sistemas interpretativos. A cultura atual está começando a gerar um sistema de "próteses culturais" como nunca antes visto, e elas certamente mudarão as modalidades de linguagem e do discurso, as formas de explicação lógica e narrativa e os padrões de vida comunitária.

Sistemas como a caverna podem ser identificados como verdadeiros ecossistemas cognitivos, os quais começam a virtualizar a realidade, produzindo duas quebras. A primeira faz referência à troca da categoria lugar pela linguagem para dar conta da realidade, como já tínhamos assinalado; a segunda faz referência à troca da palavra, como signo lingüístico preponderante, pela imagem.

Estamos no limiar de uma mudança em ambos os sentidos, em cujos sistemas de representação simbólica aparecem novas linguagens, inclusive mais universais que o alfabeto, como a linguagem digital, começando a imagem a ocupar um papel mais preponderante que a escrita. O desejo de ver o mundo através das palavras, característico dos séculos XIX e XX, parece que está dando lugar ao desejo de ver o mundo mediante tecnologias de ilusão perceptual.

Sem dúvida a utilização de mídias audiovisuais em educação apresenta elementos muito positivos: permite ilustrar e simular processos reais, demonstrar experiências, apresentar posições de profissionais destacados, ilustrar princípios tridimensionais ou abstratos, condensar ou sintetizar num todo coerente toda uma gama de informações e processos,

cria com a ajuda da mediação instrumental, ou seja, através de outras pessoas, as quais se valem de instrumentos para ordenar a informação e operar com estímulos representados, sendo o mais importante deles a linguagem. 
mostrar processos de tomada de decisão, bem como o funcionamento de máquinas e processos. A imagem é um importante meio de comunicação com o qual se podem transmitir idéias, conceitos, relações, etc. A imagem promove a atenção, a descoberta e a compreensão. A imagem é um recurso com elevado poder pedagógico: através dela pode-se captar a atenção do aluno, rompendo com a monotonia do texto e da lousa, despertando seu interesse (TERRY, 1994). Além disso, as pesquisas de Yuill y Joscelyne (2000) mostram sua importância como organizadores prévios: "um poderoso motivador inicial, a linguagem do vídeo entra no mundo dos sentimentos, permitindonos projetar-nos nele",75.

Porém a utilização de mídias pode apresentar certas dificuldades. A pergunta que surge imediatamente quando falamos da utilização das mídias em educação é: como conciliar o fato conhecido de que o único elemento que diferencia o homem dos primatas é a sua capacidade simbólica, de que o nosso pensamento e a nossa linguagem estão intimamente unidos e são a chave para compreender a consciência humana (VYGOTSKY, 1993, p. 346), com as posturas que apresentam a cultura da imagem como anuladora dos conceitos e, desse modo, atrofiadora da nossa capacidade de abstração e, com ela, de toda a nossa capacidade de entender, suplantando o homo sapiens pelo homo videns (GUTIÉRREZ, 2000) ${ }^{76}$.

Por outro lado, temos que considerar que as palavras articulam a linguagem humana, são símbolos que evocam representações e levam à nossa mente figuras, imagens de coisas visíveis que temos visto. Mas isso só acontece com algumas palavras. Ocorre que o nosso vocabulário é formado não só de palavras concretas, que denominam objetos reais, como de palavras que denominam abstrações - como o conceito de liberdade -, que são de difícil ilustração com uma imagem, a qual pode empobrecer a riqueza do próprio significado do conceito.

Mas também entendemos que a dimensão lingüística baseada na linguagem escrita tem chegado a um ponto de abstração em que tem se afastado da realidade, do valor das coisas - e quem sabe de algo mais vital: a necessidade de experimentar, explorar, viajar; a maravilha de contemplar em forma direta a realidade, a emoção que produz a experiência própria, não relatada por ninguém, sem mediações, direta.

\footnotetext{
${ }^{75}$ Disponível em: $<$ http://www.sav.us.es/pixelbit/articulos/n15/n15art/art159.htm>. Acesso em: 2 nov 2006.

${ }^{76}$ Disponível em: <www.utem.cl/deptogestinfo/haydeepubli.doc>. Acesso em: 2 nov 2006.
} 
Acreditamos que a imagem constitui um meio de enriquecimento didático quando seu uso se complementa com a linguagem verbal ou escrita, com a reflexão.

A prática continuada das linguagens audiovisuais favorece o desenvolvimento de capacidades (pensamento associativo, percepção visual, emotividade...) complementares às que promove a linguagem escrita (pensamento lógico, capacidade de abstração, análises e reflexão) (RUIZ, 1999, p. 8).

O que não podemos perder de vista é que os instrumentos ou mediadores utilizados na educação devem servir não só como mediadores para ordenar e posicionar a informação, de modo que o aluno não fique petrificado na percepção do aqui e agora, mas também como facilitadores do desenvolvimento da linguagem simbólica, sobre a qual se constroem o pensamento e o conhecimento científico. Por isso, a utilização dos meios audiovisuais deveria ser acompanhada de conceitos, procedimentos e atitudes que capacitassem o aluno para selecionar, processar, tirar conclusões e comunicá-las, ante qualquer tipo de informação que receba por qualquer meio ou canal, consolidando o papel de receptor crítico de informação.

Como o próprio Bruner (1991) tem alertado, a psicologia cognitiva, mais do que se preocupar com as características de processamento da informação do cérebro humano, deveria estar se preocupando em como as pessoas atribuem significados às coisas, não só da perspectiva biológica, mas também da cultural, outorgando às próteses culturais um papel na construção de andaimes que assegurem um pleno desenvolvimento dos potenciais humanos.

\subsubsection{Sociedade da Aprendizagem: da sociedade da informação às sociedades do conhecimento}

Numa sociedade na qual o avanço tecnológico, que muda os rituais e as formas de organização, é cada vez mais vertiginoso; na emergência de uma sociedade em rede, na qual se encontram em formação mutações culturais transcendentes, como o espaço do fluxo, e na qual o conhecimento ascende à categoria de fundamento que dota de sentido o desenvolvimento da sociedade, emerge uma outra característica crucial para a educação: a chamada Sociedade da Aprendizagem.

Segundo Levy (1999, p.165), esta sociedade se caracteriza por dois elementos principais: por um lado, pela primeira vez na história da humanidade, a maioria das 
competências adquiridas por uma pessoa no começo de seu percurso profissional será obsoleta no fim de sua carreira. Por outro, a natureza do trabalho na sociedade da informação produz uma transação de conhecimentos que não pára de crescer. Trabalhar equivale cada vez mais a aprender, transmitir saberes e produzir conhecimentos.

Por isso, Pozo (1998, p. 38) afirma que a cultura atual demanda formação permanente e reciclagem profissional em todas as áreas produtivas, considerando a dinâmica complexa do mercado de trabalho e o acelerado ritmo de produção de conhecimento, de mudança tecnológica e de transmissão da informação. Nesse cenário, o indivíduo se vê diante da necessidade de aprender coisas novas diariamente e, mais do que isso, de aprender a aprender. A necessidade de aprendizado contínuo é uma das características que definem a sociedade atual. No entanto, não se trata apenas de aprender muitas coisas, mas de estudar coisas diferentes em um tempo escasso, dado o grande volume de informação que precisamos processar e a velocidade das mudanças e inovações que nos exigem aperfeiçoamento constante ao longo de toda a vida. Por essa razão, a necessidade de "aprender a aprender" é uma das características que definem essa cultura, pois temos que estudar temas variados e complexos e aplicá-los a contextos diversos, que se mantêm em evolução permanente.

Porém, de acordo com Pozo (1996, p.37), a sociedade atual vive um momento paradoxal. Por um lado, há cada vez mais pessoas com dificuldades para aprender aquilo que a sociedade exige delas, o que, em termos educacionais, costuma ser interpretado como um crescente fracasso escolar. Mas, por outro lado, também podemos afirmar que o tempo dedicado a aprender estende-se e prolonga-se cada vez mais na história pessoal e social, ampliando a educação obrigatória, impondo uma aprendizagem ao longo de toda a vida e, inclusive, levando a que muitos espaços de ócio sejam dedicados a organizar sistemas de aprendizagem informais. No entanto, essa demanda de formação crescente acaba por saturar as nossas capacidades de aprendizagem. A necessidade de uma aprendizagem contínua "nos obriga a um ritmo acelerado, quase neurótico, no qual não se tem prática suficiente, com o que apenas consolidamos o aprendido e o esquecemos com facilidade" (POZO, 1996, p. 40).

Saturar a capacidade de recepção informativa dos alunos não gera as condições para desenvolver uma cidadania transformadora. Por esse motivo se faz necessária uma reflexão sobre a organização escolar baseada na transmissão de informação e no 
currículo. Para elaborar estratégias que permitam produzir um diálogo com o conhecimento, dialogar com ele e não se deixar invadir ou inundar pelo fluxo informativo, tornam-se necessárias capacidades ou competências cognitivas dos leitores dessas novas fontes de informação. Muito mais se consideramos que, na atualidade, os sistemas educativos não são mais a principal fonte de informação social.

A sociedade da informação tem gerado certos problemas às pessoas, de ter dificuldade para conseguir uma determinada informação para fortalecer a sua tomada de decisão; elas passaram a ter de lidar com o desafio de analisar pilhas de informações irrelevantes para obter aquela que é indispensável às suas necessidades.

Essa é uma espécie de intoxicação informativa: bombardeadas com tanta informação, em vez de verem reduzir a incerteza, de poderem predizer o ambiente e tomar decisões com facilidade, as pessoas vêem aumentar significativamente a incerteza, a sensação de perda do controle do tempo em relação às atividades a cumprir. Diante de um oceano de informação fragmentada, às vezes pouco coerente e contraditória, ou simplesmente inútil, fica muito difícil desenvolver o poder de decisão:

La información es efectivamente un instrumento del conocimiento, pero no es el conocimiento en sí. [...] La excesiva importancia concedida a las informaciones con respecto a los conocimientos pone de manifiesto hasta qué punto nuestra relación con el saber se ha visto considerablemente modificada por la difusión de los modelos de economía del conocimiento (UNESCO, 2005, p.19) ${ }^{77}$.

Formar cidadãos para uma sociedade democrática e, mais ainda, formá-los para democratizar a sociedade, requer dotá-los de capacidades de aprendizagem que possibilitem diferenciar a informação valiosa da informação fraudulenta, assim como para decodificar as mensagens publicitárias, ou para interpretar os recortes da realidade que a informação dos meios massivos de comunicação transmitem; desenvolver capacidades de pensamento que lhes permitam utilizar estrategicamente a informação que recebem, para que possam converter essa informação em conhecimento verdadeiro.

Por isso diversos autores concordam em definir este século como o século da cidadania reflexiva, com profissionais reflexivos, docentes reflexivos e consumidores reflexivos. A reflexão parece ser a característica mais marcante da nova cidadania.

\footnotetext{
${ }^{77}$ Disponível em: $<$ http://portal.unesco.org/culture/es/ev.phpURL_ID=29619\&URL_DO=DO_TOPIC\&URL_SECTION=201.html> Acesso em: 13 fev 2006.
} 
No entanto, a reflexividade não poderá evitar outros grandes riscos da sociedade do conhecimento: a brecha digital, o determinismo tecnológico e a crença de que a sociedade do conhecimento implica a imposição de um modelo cultural único como modelo a ser consumido, em detrimento da diversidade cultural e lingüística. Por isso a UNESCO (2005) incorpora o conceito de sociedades do conhecimento, conotando com o plural a diversidade cultural mundial e a importância de preservar a multiculturalidade.

\title{
1.3.4 Epistemologia do conhecimento: $O$ olvido do ser, a complexidade e o pensamento instrumental
}

\begin{abstract}
¡Ah, la razón, la seriedad, el dominio sobre los afectos, toda esa cosa siniestra que se llama recapacitar, todos estos privilegios y suntuosos ornatos del hombre: qué caros se han hecho pagar, cuánta sangre y crueldad hay a la base de todas las $<$ cosas buenas $>$ ! (NIETZSCHE, 2003, p. 103).
\end{abstract}

A crise ambiental está mostrando não só os limites da natureza, do modelo de desenvolvimento baseado no crescimento econômico, dos desequilíbrios ecológicos, da capacidade de sustentação da vida, do crescimento populacional, da pobreza, da desigualdade social, da crise de identidade, do ocaso do ser; mas também, como numerosos autores já têm assinalado (CAPRA, 1982; MORIN, 1998; LEFF, 2003), dos limites do modelo de pensamento ocidental.

Por isso, Leff (2003) mostra insistentemente que a problemática ambiental, mais que uma crise ecológica, é um profundo questionamento sobre as formas de pensamento e de entendimento sobre o qual a civilização ocidental tem se construído, tem compreendido o ser, o ente e as coisas.

Essa crise é produto da intervenção do pensamento no mundo, uma forma de pensamento que tem se baseado em três erros históricos. O primeiro, ontológico, no olvido do ser na modernidade, que Kant, primeiro, e Heidegger, depois, têm denunciado. $\mathrm{O}$ segundo refere-se à inteligência cega, que não tem podido capturar a complexidade da realidade por meio do método analítico; já o terceiro consiste na redução da inteligência à sua dimensão intelectual, e a razão a pensamento instrumental, gerando assim o homem unidimensional (MARCUSE, 1985). 


\section{a) O olvido do ser na modernidade}

O movimento da modernidade, embora tenha significado o rompimento com a mentalidade mística da escolástica, gerou outros problemas. O paradoxo é que a modernidade é uma época na qual, ao mesmo tempo em que o sujeito se fez o centro do mundo, tem sido ele "coisificado",78. Uma época na qual, como aponta Heidegger (1995, p.13), ao pensar o ser como ente, abriu-se a via da racionalidade científica que produziu a modernidade como uma ordem coisificada e fragmentada, como forma de domínio e controle sobre o mundo.

Cada época histórica constrói o sentido da sua existência sobre a base de certas certezas, que são as que ajudam as pessoas a viver compreendendo o mundo e seu lugar nele. Assim a humanidade tem contado com diversas certezas ao longo da sua história cosmologia, teogonia $^{79}$, magia, religião, sistema de valores, entre outros. Ocorre que o sentido da nossa existência tem se perdido nesses últimos decênios. A perda da certeza é o que tem gerado a crise da existência, a crise do ser na modernidade tardia, já que sem certezas, perdemos a possibilidade de viver uma vida organizada e dotada de sentido. No passado as pessoas viam o futuro com esperança, agora só o vemos com desconfiança, confusão e insegurança.

Na modernidade a racionalização tem sido a característica por excelência, não só da ciência e da técnica, mas também da vida dos indivíduos e das coisas. A dúvida metódica de Descartes, que se pratica faz três séculos, tem calado fundo na alma do homem moderno, a tal ponto que já não temos mais nada ou ninguém em que ou em quem acreditar, às vezes nem em nós mesmos.

En suma, el trayecto que recorre la temática teórica que fija su atención sobre las consecuencias sociales derivadas de la modernidad acepta como denominador común una desestructuración y fragmentación de los plexos en los que se construyen las subjetividades sociales. Desde Simmel y Lukács, e incluyendo también a Heidegger, Ortega, Benjamin o los primeros frankfurtianos, hasta Habermas, Giddens y Bauman se manifiesta, con diferentes matices en cada caso, una constante preocupación por mostrar las dislocaciones que afectan al orden simbólico-cultural del mundo social como resultado del constreñimiento de la vida

\footnotetext{
${ }^{78}$ Coisificar: reduzir o homem e sua consciência a coisa, objeto ou valores materiais. Dicionário Aurélio, Século XXI.

${ }^{79}$ Teogonia: Doutrina mística relativa ao nascimento dos deuses, e que freqüentemente se relaciona com a formação do mundo. Dicionário Aurélio, Século XXI.
} 
a una perversa racionalidad que le sirve como unidimensional directriz $\left(\right.$ CARRETERO, 2003) ${ }^{80}$.

Por isso o principal desafio da atualidade consiste em realizar uma profunda reflexão acerca do que significa "ser humano", na busca pela identidade perdida, para não continuar promovendo uma vida sem sentido e sem esperanças.

\section{b) Complexidade}

A modernidade tem construído o mundo em que vivemos a partir do enorme sucesso da ciência moderna, a qual, baseada na tradição galileana do conhecimento, tentou dissipar a aparente complexidade dos fenômenos a fim de revelar a ordem simples a que eles obedecem. Essa tradição constituiu uma nova imagem do mundo, que podemos perceber em Galileu e em Bacon: um enfoque funcional e mecanicista.

Os novos olhos da ciência moderna, dirá Mardones (1991, p. 24), “estão petrificados de ânsias de poder e controle da natureza. O centro já não é o mundo, mas sim o homem. Por esta razão, seu olhar converte e reduz a natureza em objeto para as suas necessidades e utilidades". Esse novo interesse - pragmático, mecânico e causalista não colabora para que a ciência possa perguntar o porquê e o para quê dos fenômenos; mas o como mais imediato e mais prático dos fenômenos e as suas conseqüências.

Descartes inaugurou definitivamente o pensamento moderno ao propor o uso disciplinado da razão como caminho para o conhecimento verdadeiro, formulando os princípios dessa nova forma de produção de saberes; um método baseado em uma série de operações de decomposição da coisa a conhecer e na redução às suas partes mais simples - o método analítico.

Uma forma de raciocinar que, na sua busca de uma verdade objetiva, distinguiu objetos "claros e definidos" e retirou o sujeito da relação de conhecimento. Assim, pelo método científico, isto é, racional e objetivo, desvendar-se-iam os mistérios da natureza para dominá-la. Desta forma ergueu-se todo um conjunto de categorias dicotômicas características do pensamento moderno: natureza e cultura; sujeito e objeto; matéria e espírito; corpo e mente; razão e emoção; indivíduo e sociedade; ser e pensamento.

\footnotetext{
${ }^{80}$ Disponível em: <http://www.ucm.es/info/nomadas/7/ecarretero.htm>. Acesso em: 23 nov 2006.
} 
Esse modelo de ciência, baseado nos modos simplificadores do conhecimento, tem demonstrado que mutila mais do que expressa as realidades e os fenômenos que tenta analisar. "É evidente que produz mais cegueiras que elucidação" (MORIN, 1998, p.21).

Vivemos atualmente sob o império dos princípios da "disjunção, redução e abstração", unidos em um paradigma de simplificação, uma perspectiva que, segundo Morin (1990, p. 21), gerou a inteligência cega, que destrói os conjuntos e as totalidades, isola e separa os objetos de seus ambientes.

No entanto, esta visão analítica e a divisão do trabalho científico entre as ciências naturais e as ciências humanas começam a ficar em segundo plano quando a mudança climática global deixa de ser um tema exclusivo de físicos, químicos, geógrafos e meteorologistas e se torna objeto de debate político e social, questionando a matriz energética que está pondo em risco o mundo, os valores, a cultura e as formas de organização social.

Por isso, assistimos, nas últimas duas décadas, à ênfase na complexidade. Este seria um traço geral que percorre a realidade, do objeto inanimado ao ser vivo, do humano ao social. A ciência, como repete continuamente Luhmann, não é mais que uma estratégia de redução da complexidade; não se pode perder de vista o sistema, nem o singular, nem o temporal, muito menos o local. Temos que atuar de forma conciliatória entre a visão totalizadora e a contextual. Uma metodologia que, como diz Morin, "não pode ter método próprio".

Uma perspectiva na qual predominam as visões gerais, os rascunhos, a ruptura de compartimentos, a integração do sujeito na observação; que, além do conhecimento científico, percebe que existem outras formas de conhecimento; que, além das "leis da natureza", ordem e causalidade, constata que há, também, indeterminação, acaso e caos; que, além do pensamento, existe o sentimento associado a este e os valores com os quais interpretamos os fatos empíricos. $\mathrm{O}$ tema da interdisciplinaridade, da centralidade do sujeito, da compreensão, e até do cânone do conhecimento das ciências sociais, volta a estar presente através da epistemologia da complexidade.

Avançamos decididamente a uma complementaridade metodológica. Como Habermas dizia: 
Se os positivistas compreenderam que nas ciências sociais o verdadeiro interesse é entender os fins e motivos pelos quais acontece um fato, o qual é diferente de uma explicação causal, estaríamos no caminho da complementaridade de métodos. Isto é, do reconhecimento da peculiaridade do Erklären (descrição) e do Verstehen (compreensão) de sua significatividade e razão de ser em cada caso. E da possibilidade da aplicação da explicação causal (Erklären), ou quase-explicativa, no serviço da emancipação mediante a auto-reflexão. [...] Uma ciência social críticohermenêutica com um método que necessariamente utilize a interpretação (Verstehen) como a explicação por causas (Erklären), orientada pelo interesse de emancipação e dirigida a fazer uma sociedade boa, humana e racional (In: MARDONES, 1991, p. 48).

Isso requer uma transformação dos paradigmas do conhecimento, a sua ambientação, segundo Leff (1994, p.56), para quem o saber ambiental emerge de uma problemática que transborda o campo da racionalidade do conhecimento, "gerando uma verdadeira revolução ideológica e cultural que problematiza e transforma todo um conjunto de paradigmas do conhecimento teórico e de saberes práticos [...] em três níveis": 1) a orientação da investigação e aplicação dos conhecimentos científicos e técnicos através das políticas científico-tecnológicas; 2) a integração interdisciplinar de especialidades diversas e de um conjunto de saber existente em torno de um objeto de estudo e de uma problemática comum à elaboração de um conhecimento integrado através de um método de análises de sistemas complexos (GARCÍA, 1986); e 3) a problematização dos paradigmas teóricos de diferentes ciências, a reelaboração de seus conceitos, a emergência de novas áreas temáticas e a constituição de novas disciplinas ambientais que transbordam os objetos de conhecimento e os campos de experimentação dos atuais paradigmas teóricos (LEFF, 1994).

Atualmente nos encontramos num processo que rechaça os exclusivismos, em que a concepção da ciência se flexibiliza, a explicação científica já não pode ser apenas de uma perspectiva causalista, nem só teleológica ou hermenêutica. O postulado da complementaridade anda lentamente, numa trilha incerta, na construção de uma nova racionalidade que olha para o milênio que começa.

\section{c) A redução do pensamento ao pensamento instrumental, a razão objetiva e a razão subjetiva}

Horkheimer, no seu intento por interpretar o conceito de racionalidade ou razão que se encontra por trás da cultura industrial, distingue entre razão objetiva e razão subjetiva. A primeira é a razão que se ocupa em encontrar os fins que o homem se coloca ao longo 
da vida, para fazê-la mais humana; a segunda é a razão que se ocupa em resolver os problemas práticos, técnicos, da relação entre fins e meios, sem examinar a sua racionalidade. O positivismo para o autor constitui a base teórica dessa razão instrumental. Uma razão questionada também por Marcuse (1985), na sua análise sobre o homem unidimensional, que só conhece a razão técnica eliminando todo tipo de valoração moral.

O que fica em evidência é que a razão instrumental inibe a reflexão sobre os objetivos para os quais a sociedade aponta. Então, não podendo ser discutidos racionalmente, os fins e os valores ficam reféns da arbitrariedade e de decisões irracionais, produtos de desejos e interesses de grupos de poder.

Ou seja, o paradoxo consiste em fazer esforços por construir um edifício racional, objetivo e estável do conhecimento humano, e posteriormente deixá-lo a serviço da irracionalidade, da destruição, do medo e da eventual destruição total do ambiente no qual prosperamos. No passado o conhecimento foi utilizado para a destruição. O exemplo mais representativo pode ser o levantado por Dowbor (2001) na sua análise sobre as tecnologias do conhecimento e os desafios da educação.

"Terminada a última guerra mundial foi encontrada, num campo de concentração nazista, a seguinte mensagem dirigida aos professores:

Prezado Professor,

Sou sobrevivente de um campo de concentração. Meus olhos viram o que nenhum homem deveria ver.

Câmaras de gás construídas por engenheiros formados.

Crianças envenenadas por médicos diplomados.

Recém-nascidos mortos por enfermeiras treinadas.

Mulheres e bebês fuzilados e queimados por graduados de colégios e universidades.

Assim, tenho minhas suspeitas sobre a Educação.

Meu pedido é: ajude seus alunos a tornarem-se humanos.

Seus esforços nunca deverão produzir monstros treinados ou psicopatas hábeis.

Ler, escrever e aritmética só são importantes para fazer nossas crianças mais humanas.

As tecnologias são importantes, mas apenas se soubermos utilizá-las. E saber utilizá-las não é apenas um problema técnico" ${ }^{\text {. }}$.

E precisamente como reação a esta barbárie do nazismo é que emerge a teoria crítica da primeira escola de Frankfurt, a que postula que o positivismo nega a

\footnotetext{
${ }^{81}$ Disponível em: <http://dowbor.org/tecnconhec.asp>. Acesso em 13 nov 2006.
} 
faculdade crítica da razão, permitindo-lhe operar só no campo dos fatos. O conhecimento é reduzido ao domínio exclusivo da ciência, e a ciência dentro de uma metodologia que a limita a descrição, classificação e generalização de fenômenos, ficando fora de seus confins a análise valorativa do que é importante e do que não é, da análise de prioridades valorativas, da ética das ações.

Assim, chegamos ao descontrole do homem sobre os influxos da racionalidade instrumental, a irracionalidade denunciada por Horkheimer e Adorno, na sua análise de indústria cultural.

A crise da razão se manifesta na crise do indivíduo, por meio da qual se desenvolveu.

A ilusão acalentada pela filosofia tradicional sobre os indivíduos e sobre a razão - a ilusão de sua eternidade - está se dissipando. O indivíduo outrora concebia a razão como um instrumento do eu, exclusivamente. Hoje, ele experimenta o reverso dessa autodeificação. A máquina expeliu o maquinista: está correndo cegamente no espaço. No momento da consumação, a razão tornou-se irracional e embrutecida (HORKHEIMER, 1976, p. 19).

Mais ainda: a razão crítica necessária é a que impulsiona a mudança social, como Adorno (1973, p. 123) tem mostrado, sem um momento hermenêutico de antecipação. Sem se antecipar um modelo de sociedade que expresse a busca de um mundo bom, não se tem possibilidades de fugir do anel mágico da repetição do dado.

A inteligência não pode ser reduzida à dimensão lógico-matemática, os seres humanos têm um potencial de desenvolvimento que abrange o que Gardner (1997), da universidade de Harvard, tem chamado as inteligências múltiplas, incorporando uma inteligência naturalista, uma existencial, uma lingüística, uma lógico-matemática, uma espacial, uma físico e sinestésica, uma musical, uma interpessoal e uma intrapessoal.

Além dos debates acerca de quais são estas dimensões do ser, fica em evidência que os seres humanos não são só uma razão lógico-matemática que anda: somos muito mais do que isso, o que nos leva à busca dos elementos do ser perdidos na era do utilitarismo. 


\subsubsection{A educação no cenário atual}

Educação é o que fica depois de se esquecer o que se aprendeu na escola.

Albert Einstein (1879-1955)

A educação, filha de um modelo sociocultural, resulta de um reflexo de todos os problemas identificados, já que a escola é uma microssociedade onde se reproduzem, em escala menor, os mesmos padecimentos e conflitos da sua mãe: as desigualdades, os problemas do ser, os problemas de saúde e meio ambiente, de violência, uso de drogas, depressão, entre outros.

\section{a) Expansão da matrícula e baixa qualidade educativa}

Uma parte da história da educação do último século é de sucesso. As estatísticas mostram um crescente aumento mundial da matrícula no ensino fundamental, no médio e no superior. No entanto, a outra parte da história é uma história de baixa qualidade educativa, desigualdade e fracasso escolar.

O relatório do "Programa de Promoción de la Reforma Educativa en América Latina y el Caribe (PREAL) ${ }^{\prime 82}$ de 2006 relata os péssimos resultados dos exames globais de aproveitamento dos alunos, nos quais a região teve os resultados mais baixos de todos:

Apesar dos sinceros e impressionantes esforços, a maioria das escolas continua fracassando no que se relaciona a dar às crianças as habilidades e competências necessárias para o seu sucesso pessoal, econômico e a prática da cidadania. [...] Nas medidas-chave de sucesso - qualidade, igualdade e eficiência -, os níveis permanecem baixos e os avanços são poucos ou inexistentes. Baixos níveis de aprendizagem, ausência de sistemas baseados no desempenho, pouca responsabilidade e a crise do magistério conspiram no sentido de privar a maioria das crianças latino-americanas do conhecimento e das habilidades necessárias para progredir nas sociedades modernas (BOLETIM DA EDUCAÇÃO NA AMÉRICA LATINA, 2006) $)^{83}$.

\footnotetext{
82 O Programa de Promoção da Reforma Educativa na América Latina e Caribe (PREAL) é um projeto conjunto do Diálogo Interamericano em Washington, D.C. e a Corporación de Investigaciones para el Desarrollo (CINDE) em Santiago do Chile. A PREAL é financiada pela United States Agency for International Development (USAID), o Banco Interamericano de Desenvolvimento (BID), a Avina Foundation, a Tinker Foundation, o Banco Mundial, a GE Foundation e outros.

${ }^{83}$ Disponível em: <www.preal.org>. Acesso em: 17 nov 2006.
} 
A tabela abaixo, extraída do relatório de 2006, "Quantidade sem Qualidade" 84 , fornece um raio $\mathrm{X}$ da situação da educação na região, utilizando uma escala que vai de "A" (excelente) a "F" (muito ruim).

\section{Boletim sobre a Educação na América Latina}

\begin{tabular}{|c|c|c|c|}
\hline Matéria & Nota & Tendência & Comentários \\
\hline Resultados nas provas & D & & $\begin{array}{l}\text { As notas nos exames nacionais e intemacionais permanecem } \\
\text { abaixo dos niveis aceitáveis } \theta \text {, de modo geral, nâo estāo } \\
\text { melhorando. }\end{array}$ \\
\hline Matriculas & B & & $\begin{array}{l}\text { O número de alunos matriculados está aumentando } \\
\text { rapidamente, especialmente na pré-escola eno ensino } \\
\text { médio, porém muitas crianças ainda não estāo na escola. }\end{array}$ \\
\hline Permanência na escola & $\mathrm{c}$ & & $\begin{array}{l}\text { Os alunos estāo permanecendo por mais tempo na escola, } \\
\text { porém as taxas de conclusāo ainda não são boas e as } \\
\text { reprovaçōes sāo muito majores que em outras regiōes. }\end{array}$ \\
\hline Eqüidade & D & $\leftrightarrow$ & $\begin{array}{l}\text { Um número maior de crianças pobres, das zonas rưais e de } \\
\text { grupos indigenas estão na escola, porém aprendem menos } \theta \\
\text { evadem prematuramente. }\end{array}$ \\
\hline Pacrōes & D & & $\begin{array}{l}\text { Apesar de que vários paises estão trabalhando risso, } \\
\text { nenhum deles conseguiu ainda estabelecer e implementar } \\
\text { plenamente parâmetros nacionais abrangentes, nem } \\
\text { incorporá-los na formaçāo dos professores, nos livros } \\
\text { didáticos e nos exames. }\end{array}$ \\
\hline Avaliaçāo & $\mathrm{C}$ & & $\begin{array}{l}\text { São cada vez mais comuns os exames nacionais de } \\
\text { aproveitamento, porém eles anda sāo precários. Além do mais, } \\
\text { os resultados destes exames raramente influenciam as politicas. }\end{array}$ \\
\hline $\begin{array}{l}\text { Autoridade } e \\
\text { responsablidade } \\
\text { na escola }\end{array}$ & C & & $\begin{array}{l}\text { Vários paises transferiram processos decisórios para os } \\
\text { niveis estaduais e municipais, porém a gestäo } \theta \text { a supervisāo } \\
\text { continuam sendo inadequadas. }\end{array}$ \\
\hline $\begin{array}{l}\text { Fortalecimento do } \\
\text { magistério }\end{array}$ & D & $\leftrightarrow$ & $\begin{array}{l}\text { Os esforços para melhorar a qualidade e a responsabilidade } \\
\text { dos professores ainda nāo mostram mudanças mensuráveis } \\
\text { nos processos de sala de aula. }\end{array}$ \\
\hline $\begin{array}{l}\text { Investimento no ensino } \\
\text { fundamental e médo }\end{array}$ & C & 1 & $\begin{array}{l}\text { Os investimentos estāo aumentando, porém o gasto por } \\
\text { aluno é insuficiente para que todos os alunos recebam } \\
\text { educaçāo de qualidade. }\end{array}$ \\
\hline NOTAS: & $\begin{array}{l}\text { A } \\
\text { B } \\
\text { C } \\
\text { D } \\
\text { F }\end{array}$ & $\begin{array}{l}\text { Excelente } \\
\text { Bom } \\
\text { Satisfatório } \\
\text { Ruim } \\
\text { Muito rum }\end{array}$ & $\begin{array}{l}\uparrow \text { Melhorando } \\
\downarrow \text { Em declirio }\end{array}$ \\
\hline
\end{tabular}

Tabela 2 - Boletim sobre a Educação na América Latina

Evidentemente não podemos tomar estes dados como exatos, já que envolvem numerosas dimensões subjetivas na sua formulação, porém eles ilustram os pontos negativos do sistema educativo, ainda com seriíssimas dificuldades: tantas que, em muitos países, as crianças passam de ano compulsivamente, por ordem do Estado.

${ }^{84} \mathrm{O}$ boletim reflete os esforços combinados dos integrantes do Conselho Consultivo e da equipe do PREAL na Corporación de Investigaciones para el Desarrollo (CINDE) em Santiago, Chile, e do Diálogo Interamericano em Washington, D.C. 
Assim, as três categorias mais importantes - eqüidade, qualidade e formação de professores - encontram-se estancadas.

O relatório apresenta alguns dados interessantes, que possibilitam ilustrar o estado de situação da educação na região.

Em 2003, jovens de 15 anos de três países da América Latina (Brasil, México e Uruguai) que participaram na prova do Programme for International Student Assessment (PISA) tiveram notas próximas da mínima em leitura, matemática e ciências, sendo estes resultados os mais baixos entre os 41 países avaliados. Quase a metade dos alunos da América Latina apresentou graves dificuldades no uso da leitura para ampliar seus conhecimentos e habilidades. A maioria (três quartos no Brasil, dois terços no México e quase a metade no Uruguai) não conseguiu aplicar de forma consistente as habilidades básicas de matemáticas para explorar e compreender uma situação cotidiana (BOLETIM DA EDUCAÇÃO NA AMÉRICA LATINA, 2006) ${ }^{85}$.

No Brasil a situação não é diferente. Segundo dados do Relatório do MEC Qualidade na Educação Básica do ano $2005^{86}$, só $10 \%$ das crianças matriculadas na escola atingem o desempenho adequado em Língua Portuguesa e Matemática para seu nível de ensino.

O mais grave possivelmente signifique a desigualdade oculta nestas porcentagens, já que as crianças que se encontram entre os $20 \%$ mais ricos da população estão classificadas 50 a 70 pontos acima da média em relação às crianças contidas nos $20 \%$ da população mais pobre. No Chile, segundo o relatório, esta diferença alcançou os 70 pontos em línguas e os 100 pontos em matemática.

\section{b) Enfoque centrado em competências e mercantilização educativa}

As reformas educacionais realizadas em alguns países europeus e latino-americanos têm adequado cada vez mais a educação às demandas do mundo contemporâneo, especialmente no que diz respeito à formação de trabalhadores. O enfoque centrado em competências - que tão fora de moda tem ficado nos últimos anos, especialmente a apropriação socioeconômica deste conceito originário da psicologia - parece corroborar as teses de que a educação, além de formar tecnicamente os trabalhadores, agora tem também o papel de adequá-los psicologicamente para enfrentar as relações de produção.

\footnotetext{
${ }^{85}$ Disponível em: <www.preal.org>. Acesso em: 17 nov 2006.

${ }^{86}$ Disponível em: <http://portal.mec.gov.br/arquivos/pdf/progr_qualidadenaeducacao.pdf $>$. Acesso em: 12 nov 2006.
} 
Um sistema educativo em que, com o objetivo de encurtar as distâncias entre a escola e o mercado de trabalho, transita uma reforma que parece estar mudando os currículos baseados em disciplinas para currículos baseados em competências, na busca da eficácia e da eficiência dos trabalhadores.

Não podemos esquecer que a origem do conceito se baseia na necessidade de expressar os objetivos de ensino em termos de condutas e práticas observáveis. Objetivos operacionais de formação e produção, baseados no behaviorismo de B. F. Skinner, de que se apropriou pedagogicamente B. S. Bloom, e que, segundo Nogueira Ramos $(2001)^{87}$, reduzem os comportamentos humanos às suas aparências observáveis, reduzem a natureza do conhecimento ao próprio comportamento, consideram a atividade humana como uma justaposição de comportamentos elementares, cuja aquisição obedeceria a um processo cumulativo, e não colocam a efetiva questão sobre os processos de aprendizagem.

É por isso que falamos que a educação se encontra focada na preparação de mão-deobra para o mercado, baseada em raciocínio dirigido a resolver problemas imediatos, com um conceito de conhecimento que resulta em sinônimo de conteúdos, um currículo organizado em competências instrumentais e estandardizadas a partir dos manuais e dos livros de texto.

Por razões semelhantes, muitas vezes a ênfase na pedagogia por projetos ou baseada na resolução de problemas acaba sem conseguir distinguir os diferentes tipos de resultados existentes, tentando reduzir tudo à medição de sucesso.

Desta forma, tratam-se indistintamente os problemas cotidianos, o científico e o escolar, promovendo-se equívocos bastante delicados:

Enquanto nos problemas cotidianos o conhecimento costuma estar mais orientado para o resultado do que para a explicação, a resolução de problemas científicos tem por finalidade não tanto a obtenção de sucesso mas a compreensão das razões de sua ocorrência. Em síntese, o problema científico não tem como objetivo estrito alcançar um resultado prático, mas atribuir-lhe significado teórico que possa ser generalizado na forma de princípios aplicáveis a novas situações (NOGUEIRA RAMOS, 2001, p. 26).

\footnotetext{
${ }^{87}$ Disponível em: <http://www.senac.br/informativo/BTS/>. Acesso em: 12 nov 2006
} 
O grande paradoxo reside no fato de que a maioria das reformas educativas da América Latina apresenta concepções epistemológicas interdisciplinares e enfoques psicossociais, mas em seus objetivos se observam intenções funcionalistas. Já nas salas de aula, persistem as velhas atitudes, as rotinas autoritárias e as pedagogias repetitivas. Muitos mundos coexistindo ao mesmo tempo: a clássica diferença entre o que se diz e o que se faz, entre a retórica e a realidade.

A este problema soma-se a mercantilização do mercado educacional. Segundo a UNESCO (2005), em muitos países está ocorrendo o que muitos têm chamado de "macdonaldização" do conhecimento: o forte crescimento experimentado pelas universidades privadas gera grande preocupação, não só relacionada à qualidade do que se aprende, mas também sobre o que se aprende. Assim, a UNESCO destaca as diferenças substantivas que existem entre uma universidade criada com o objetivo de fazer dinheiro e uma universidade cuja motivação principal é gerar prestígio acadêmico.

Outro problema associado à proliferação de ensino superior privado encontra-se na definição de Instituição de Ensino Superior (IES) assumida. Com o objetivo de flexibilizar as condições de credenciamento de IES, muitos países utilizaram a categoria faculdade para descrever uma instituição de ensino superior que não pesquisa, que não produz conhecimento, que não gera inovação, reduzindo assim as instituições de ensino superior a centros de ensino terciários, processo a que a UNESCO tem chamado terceirização do ensino superior.

Esse processo está degradando a qualidade do ensino e deixando os países sem produção de conhecimento, transformando-os em consumidores de conhecimentos gerados em outros países, criando um ensino superior de segunda categoria para países pobres, especialistas em copiar e imitar.

Isso sem falar do total esquecimento dos conhecimentos locais, em detrimento de conteúdos cada vez mais internacionalistas, e a acentuação da brecha cognitiva entre os países industrializados e os países em vias de industrialização.

A mercantilização da educação reproduz as condições sociais, culturais e valorativas da sociedade depredadora atual e, de forma semelhante aos processos produtivos insustentáveis da indústria, degrada a matéria-prima natural do processo, as pessoas, 
freando o desenvolvimento cognitivo dos países, empobrecendo mais a população e fazendo-a mais dependente dos centros de produção mundial.

\section{c) Educação a distância}

Uma outra característica da educação atual é o expressivo aumento da educação a distância. Podemos observar uma tendência de crescimento quantitativo desta modalidade de estudo por dois motivos principais. O primeiro deles é atender ao aumento de demanda de formação gerada pela sociedade da informação; o segundo é poder fazê-lo a baixo custo:

El objetivo principal de estas universidades es atender un gran número de estudiantes a un bajo costo. Sin duda estos datos indican claramente que existe una nueva estrategia educacional que será una parte importante en el futuro de la educação, contribuyendo a diversificar el concepto tradicional de enseñanzaaprendizaje (CERDA-GONZÁLEZ, 2002, p. 11).

Este crescimento tem contado com o amplo apoio da UNESCO, que, desde o princípio, tem acreditado que a educação a distância poderá colaborar fortemente com os ideais de ampliação da oferta educativa, impulsionando o desenvolvimento dos países pobres que não possuem fontes de recursos para financiar a ampliação dos sistemas presenciais.

O Brasil encontra-se numa fase de expansão da $\mathrm{EaD}$, principalmente no ensino superior. Mais de 217 instituições deste nível de ensino estão autorizadas e credenciadas pelo MEC a desenvolver ações de educação a distância, com 500 mil alunos fazendo cursos de graduação e pós-graduação.

Além disso, existem as experiências fora do âmbito acadêmico, como as universidades corporativas, projetos da Secretaria de Educação do Estado de São Paulo, de fundações como a Roberto Marinho, entre outras, somando um número de alunos que chegou, em 2005, a 1.278.022 (ABRAEAD/ABED, 2006, p. 118) .

Mas a pergunta que merece ainda ser formulada é: em que sentido está crescendo a educação a distância? 
Moran $(2005)^{88}$, na sua avaliação do ensino superior a distância no Brasil, expressa sua preocupação com algumas das tendências que esta modalidade está apresentando: a sua definição como ação supletiva, destinada àquelas pessoas que se encontram com dificuldades de acesso a uma educação tradicional, baseada em modelos simplificadores, com foco em avaliações somativas, estandardizadas e quantitativas, com cursos focados mais no conteúdo que na pesquisa, na leitura pronta mais do que na realização de projetos.

A educação a distância está sendo desenvolvida como uma alternativa compensatória à educação presencial, apresentando, ainda, outras dificuldades, como a tomada de decisões em função da análise custo-benefício, sem considerar as necessidades pedagógicas dos alunos; estudos fragmentados e centrados na dimensão tecnológica e uma visão de curto prazo, como afirma a UNESCO $(2005)^{89}$.

A educação a distância está reproduzindo o ensino presencial por meio de novas tecnologias, focando-se na transmissão de informação, como observam Catapan e Fialho:

Raramente, as propostas de trabalho pedagógico que exploram as novas tecnologias superam o modelo tradicional do ensino. Coloca-se em um sistema avançado de comunicação a forma tradicional do professor ministrar aulas expositivas. A diferença se limita ao veículo de mediação. [...] Os alunos fazem suas leituras e exercícios na Internet, e quando estabelecem uma interlocução (e-mail, fóruns etc.), na maioria das vezes não é para aprofundar o assunto e sim para suprir as necessidades básicas de interação humana, como trocar informações e reconhecerse (CATAPAN e FIALHO, 2001, p. 3) ${ }^{90}$.

Como afirma David Carvalho, do Media Lab do Instituto de Tecnologia de Massachusetts (MIT), os projetos de EaD combinam o pior dos dois mundos: o pior da educação e o pior da distância. O que eles fazem, em sua maioria, é meramente despejar informações sobre os alunos (GUIMARÃES, 2002) ${ }^{91}$.

$\mathrm{Na}$ sociedade das novas tecnologias, confunde-se informação com conhecimento, e continua se perpetuando, agora com tecnologia de vanguarda, o modelo enciclopedista

\footnotetext{
${ }^{88}$ Disponível em: <http://www.eca.usp.br/prof/moran/avaliacao.htm>. Acesso em: 17 jun 2005.

${ }^{89}$ Disponível em: < http://firgoa.usc.es/drupal/node/23044>. Acesso em: 9 mar 2006.

${ }^{90}$ Disponível em: <http://www.abed.org.br/antiga/htdocs/paper_visem/araci hack_catapan.htm>. Acesso em: $1 \mathrm{fev}$ 2005.

${ }^{91}$ Disponível em:

$<$ http://www.abed.org.br/publique/cgi/cgilua.exe/sys/start.htm?UserActiveTemplate=1 por\&infoid=25\&sid=69>.

Acesso em: 18 nov 2005.
} 
do Iluminismo francês. Os cidadãos, paradoxalmente, estão cada vez mais informados e cada vez têm maior dificuldade para expressar um ponto de vista sobre a informação recebida.

\section{4 À guisa de conclusão}

Neste capítulo pudemos levantar uma série de elementos que nos permitem aproximar a reflexão acerca da função social da educação neste período histórico, para poder assim começar a dar respostas a alguns dos principais desafios da atualidade, tanto no que se refere às emergências contemporâneas como também às características que essa nova demanda social apresenta: novas formas de comunicação, linguagens, tempo e espaço das interações; novas formas de pensar e sentir o mundo.

Também pudemos observar as limitações da educação atual, não só no que tem a ver com a crise da qualidade, mas também para dar respostas às novas características da sociedade da informação e do conhecimento, ou seja, a possibilidade real de uma educação permanente de qualidade para todos.

Acreditamos que as tecnologias educativas têm o potencial de revolucionar a educação, assim como o foram, em seu momento, o livro impresso, o rádio e a televisão. Mas não só em referência ao possível aumento de matrícula e sim à possibilidade de fazer da educação permanente uma realidade: também no que diz respeito às possibilidades de desenvolver a capacidade de aprender a aprender, por meio de metodologias exploratórias, ativas, cognitivas, significativas e reflexivas, entre outras.

Poderíamos dizer que a tecnologia educativa, em geral, e a chamada educação a distância, em particular, poderiam se converter em alternativas reais para uma transformação da educação como um todo, respondendo às demandas da sociedade atual.

Neste sentido, o seguinte capítulo analisa as diferentes visões existentes sobre a educação a distância. A proposta apresentada busca correlacionar as visões com os marcos explicativos de cada período, produzindo significados à luz dos pontos de vista históricos, mostrando suas mutações semânticas a partir das mudanças contextuais da sociedade atual. 
Tal abordagem possibilitará avançar no círculo reflexivo, passando da análise do papel da educação no contexto atual (capítulo 1) ao marco teórico que fundamenta a ação de educação a distância (capítulo 2), para logo analisar as experiências concretas de educação aberta e a distância mundial (capítulo 3), com o objetivo de analisar o papel da educação a distância na mudança de paradigma educativo (capítulos 4 e 5). 


\section{Capítulo 2}

\section{Educação a distância - da visão dicotômica ao continuum educativo}

\subsection{Aproximação histórica da educação a distância}

O rápido crescimento experimentado pela Educação a Distância $(\mathrm{EaD})$ nos últimos anos, impulsionado principalmente pelo desenvolvimento tecnológico, pode erroneamente fazer pensar que esta modalidade trata de uma nova estratégia de educação.

Na verdade, a EaD tem uma longa história (GARCIA ARETIO, 1994, p. 24). Em 1728, a Gazeta de Boston publicava o anúncio de Caleb Philipps, professor de taquigrafia:

Toda pessoa da região, desejosa de aprender esta arte, pode receber em sua casa várias lições semanalmente e ser perfeitamente instruída, como as pessoas que vivem em Boston. (In: GARCIA ARETIO, 1994, p. 24).

Primeiramente vinculada à iniciativa de alguns professores, a $\mathrm{EaD}$ começa, já na segunda metade do século XIX, a existir institucionalmente. Assim, em 1840, Isaac Pitman organiza na Inglaterra a primeira escola de educação por correspondência; em 1856, Charles Toussaint e Gustav Langenscheidt criam a escola de línguas por correspondência, em Berlim; Thomas J. Foster inicia, em 1891, em Scranton (Pensilvânia), o International Correspondence Institute; em 1892, o Reitor William R Harper, que já experimentara o ensino por correspondência na formação de professores para escolas paroquiais, cria a Divisão de Ensino por Correspondência no Departamento de Extensão da Universidade de Chicago; em Oxford, em 1894/1895, Joseph Knipe inicia os cursos de Wolsey Hall; em 1898, Hans Hermod dá início ao famoso Instituto Hermod, da Suécia.

Após a Segunda Guerra Mundial, com a intensa preocupação de formar recursos humanos para a carreira armamentista e para o desenvolvimento industrial, produz-se uma forte expansão da educação e, com ela, a da educação a distância, para facilitar o acesso educativo em todos os níveis. 
Nas décadas de 60 e 70, a educação a distância apresenta uma marcada expansão, tanto no terreno prático como no teórico. Entre 1960 e 1975, criam-se na África mais de 20 instituições de educação a distância. De 1972 a 1980, na Austrália, o número de instituições passa de 15 a 48. Também se criam universidades a distância no Paquistão, na China, nos Estados Unidos, no Canadá, na Coréia do Sul, na Tailândia, na Espanha, na Inglaterra, no Japão, entre outros. Entre os exemplos latino-americanos, destacam-se: o Programa Universidade Aberta, da Universidade Nacional Autônoma do México, implantado em 1972; a Universidade Estatal a Distância da Costa Rica, criada em 1977; a Universidade Nacional Aberta da Venezuela, também criada em 1977, e a Universidade Estatal Aberta e a Distância da Colômbia, criada em 1983.

$\mathrm{Na}$ sua evolução histórica, a educação a distância tem estado sempre intimamente relacionada à revolução na transmissão de mensagens: a escrita, a impressora, a possibilidade de envio de correspondência, o telefone, o rádio, a televisão, o vídeo e, agora, a internet.

Nesse sentido, na literatura existente na área, podem se identificar as chamadas gerações de ensino a distância.

\subsection{As cinco gerações da educação a distância}

No século XX e no início do XXI, o que se observa é um contínuo movimento de consolidação e expansão da educação a distância, podendo-se identificar uma evolução que não só tem a ver com o aumento do número de alunos e de matrículas, mas também com a introdução de novas tecnologias (meios), que têm facilitando a interação entre professor e aluno, entre os próprios alunos e entre alunos e conteúdos (mediadores).

Taylor $(2001)^{92}$ identifica quatro gerações na história da educação a distância: o "modelo por correspondência", o "modelo multimídia", o "modelo de teleaprendizagem" e o "modelo flexível de aprendizagem", e aponta que já há uma quinta se configurando: o "modelo inteligente e flexível de aprendizagem".

A primeira geração, o chamado "modelo por correspondência", no qual se identificam as primeiras manifestações desta modalidade de estudo, baseia-se fundamentalmente na

\footnotetext{
${ }^{92}$ Disponível em: <http://www.usq.edu.au/users/taylorj/>. Acesso em: 12 jan 2006.
} 
produção e na distribuição de materiais educativos impressos, entregues aos alunos pelo correio. Um modelo de alta flexibilidade de estudo, considerando o tempo, o lugar e o ritmo de estudo de cada pessoa, mas com escassa ou nula comunicação entre alunos e entre alunos e professores.

A segunda geração, o chamado "modelo multimídia", soma aos materiais impressos outras tecnologias, como, por exemplo: áudio e vídeo, que melhoram a apresentação dos conteúdos. Um modelo com alta flexibilidade, mas com escassa ou quase nenhuma interatividade. Na terceira geração, identifica-se o "modelo de teleaprendizagem", incorporando recursos tecnológicos como a audioconferência, a videoconferência e a transmissão audiográfica, que, segundo Taylor, perdem flexibilidade e, às vezes, qualidade na preparação dos materiais de estudo, mas ganham em interatividade. Uma quarta geração, que o autor identifica como o "modelo flexível de aprendizagem", na qual todos os recursos anteriores se somam à multimídia interativa, é caracterizada pelo acesso a recursos por meio da internet e às tecnologias de comunicação. Trata-se, segundo o autor, de um modelo que apresenta alta flexibilidade, boa qualidade e interação.

Essa geração de educação a distância se distingue pela sua interatividade nos processos de comunicação, o que possibilita o acesso aos recursos universitários, a recursos de outras instituições educacionais ou não educacionais e a comunicação entre estudantes, entre estudantes e tutores e ainda entre estudantes e especialistas, sem dúvida uma das mais usadas hoje em dia.

Segundo o autor, uma quinta geração está se configurando na atualidade. O "modelo inteligente e flexível de aprendizagem", uma aproximação na qual começam a se utilizar os sistemas multimídias on-line, acesso a recursos pela internet, uso de sistemas de auto-resposta por meio de tecnologia de comunicações e acesso a serviços a partir de portais institucionais.

A velocidade de desenvolvimento tecnológico indica que uma sexta geração - integrada pelos "Automatic Virtual Environments", sistemas de realidade virtual de múltiplas projeções que articulam som e imagem em três dimensões, para levar os grupos de alunos a mergulhar em um mundo virtual, gerado por computadores em tempo real está sendo desenvolvida. 
No futuro poderemos falar da sétima geração, formada pelos sistemas holográficos, que possibilitarão expandir os sistemas educacionais a fronteiras nunca vistas.

Portanto, fica claro que a ciência e a tecnologia estão profundamente imbricadas na educação, apresentando uma tendência histórica de permanente transformação.

\subsection{Conceituação da educação a distância}

A educação a distância não é um fenômeno recente, apresenta uma história prolífica. No entanto, cabe perguntar: o que é educação a distância? uma modalidade de estudo? uma técnica? um novo paradigma educativo que vem se impor?

O conceito de educação a distância apresenta dificuldades particulares para sua definição em razão da diversidade de características que os sistemas possuem denominações, estruturas, metodologias, organização -, que acabam por configurar não só diferentes definições, mas também realidades educativas que correspondem às visões de mundo que elas adotam.

As definições de educação a distância, por outro lado, apresentam na sua estrutura muitos conceitos não definidos, com semânticas contrapostas, significando coisas diferentes, inclusive contrárias. Por exemplo, o conceito de meio de comunicação, para algumas teorias, pode significar comunicação bidirecional; para outras, transmissão maciça de informação.

A seguir apresentamos 43 definições e visões sobre a educação a distância de diversos autores reconhecidos da área e instituições internacionais representativas, tentando analisar, de forma comparativa, quais são os eixos gerais que definem a educação a distância e que novas perspectivas se anunciam. 


\subsubsection{Definições de Educação a Distância de 1960 a 2006}

- C. Wedemeyer (1960):

A principal característica da Educação a Distância está em possibilitar autonomia e independência de aprendizagem do aluno adulto. O surgimento e o desenvolvimento de uma série de elementos têm facilitado a irrupção do fenômeno da educação não presencial. Utilizando-se racionalmente a escrita, a imprensa, a correspondência, a telecomunicação e os textos programados, supõe Wedemeyer, pode-se vencer plenamente o problema da distância ou a separação entre professor e aluno.

- G. Dohmem (1967):

Educação a distância (Ferstudium) é uma forma sistematicamente organizada de autoestudo em que o aluno se instrui a partir do material que lhe é apresentado, em que o acompanhamento e a supervisão do sucesso do estudante são levados a cabo por um grupo de professores. Isso é possível de ser feito a distância através da aplicação de meios de comunicação capazes de vencer longas distâncias. $\mathrm{O}$ oposto de "educação a distância" é a "educação direta", ou "educação face-a-face", um tipo de educação que tem lugar com o contato direto entre professores e estudantes. ${ }^{93}$

- O. Peters (1973):

Educação/ensino a distância (Fernunterricht) é um método racional de partilhar conhecimento, habilidades e atitudes, através da aplicação da divisão do trabalho e de princípios organizacionais pelo uso extensivo de meios de comunicação, especialmente com o propósito de reproduzir materiais técnicos de alta qualidade, que tornam possível instruir um grande número de estudantes ao mesmo tempo, enquanto esses materiais durarem. É uma forma industrializada de ensinar e aprender. (Op. Cit.).

- M. Moore (1973):

Ensino a distância pode ser definido como a família de métodos instrucionais em que as ações dos professores são executadas à parte das ações dos alunos, incluindo aquelas situações continuadas que podem ser feitas na presença dos estudantes. Porém a comunicação entre o professor e o aluno deve ser facilitada por meios impressos, eletrônicos, mecânicos ou outros. (Op. Cit.).

\footnotetext{
${ }^{93}$ NUNES, in BARRETO, s/d, p. 2-23.
} 
- B. Holmberg (1977):

O termo "educação a distância" esconde-se sob várias formas de estudo, nos vários níveis que não estão sob a contínua e imediata supervisão de tutores presentes com seus alunos nas salas de leitura ou no mesmo local. A educação a distância se beneficia do planejamento, da direção e da instrução da organização do ensino. (Op. Cit.).

- N. Mackenzie e outros (1979):

O sistema deve facilitar a participação de todos os que queiram aprender sem importarlhes os requisitos tradicionais de ingresso e sem que a obtenção de um título acadêmico ou qualquer outro certificado seja a única recompensa. Com o objetivo de obter a flexibilidade que se requer para satisfazer uma ampla gama de necessidades individuais, o sistema deveria permitir o emprego efetivo, a opção dos meios sonoros, televisivos, cinematográficos ou impressos como veículos de aprendizagem. O sistema deve estar em condições de superar a distância entre seu pessoal docente e os alunos, utilizando esta distância como elemento positivo para o desenvolvimento de autonomia na aprendizagem. (GARCIA ARETIO, 1987, p. 4).

- J. Sarramona (1979):

Ensino a distância é aquele sistema didático em que as condutas docentes têm lugar à parte das condutas discentes, de modo que a comunicação professor-aluno fica distinta no tempo, no espaço ou em ambos. Trata-se de um processo de ensino-aprendizagem que requer todas as condições generais dos sistemas de instrução: planificação prévia, orientação do processo, avaliação e retroalimentação. (Op. Cit.).

- P. Navarro Alcalá (1980):

São aquelas formas de estudo que são guiadas ou controladas diretamente pela presença de um professor na sala de aula, mas se beneficia da planificação e guia dos tutores através de um meio de comunicação que permita a inter-relação professor-aluno. $(\mathrm{UNAM})^{94}$

- M. L. Ochoa (1981):

Um sistema baseado no uso seletivo de meios instrucionais, tanto tradicionais quanto inovadores, que promovem o processo de auto-aprendizagem, para obter objetivos educacionais específicos, com um potencial de maior cobertura geográfica que a dos sistemas educativos tradicionais (presenciais) (SOUZA, 2000, p. 75) ${ }^{95}$.

\footnotetext{
94 Disponível em: <http://www.filos.unam.mx/POSGRADO/seminarios/pag_robertp/paginas/educ_distancia.htm>. Acesso em: 25 nov 2006.

${ }^{95}$ Disponível em: $<$ http://das-rheingold.rnagardas.info/a-reinveno-das-organizaes-educacionais-na-sociedade-doconheci>. Acesso em: 25 nov 2006.
} 
- M. Casas Armengol (1982):

Educação a distância cobre um amplo espectro de diversas formas de estudo a distância e estratégias educativas que têm em comum o fato de que não se cumprem mediante a tradicional contigüidade física, de professores e alunos em locais especiais para fins educativos. Esta nova forma educativa inclui todos os métodos de ensino nos quais, devido à separação existente entre estudantes e professores, as fases interativa e pré-ativa do ensino são conduzidas mediante a palavra impressa e elementos mecânicos ou eletrônicos. (GARCIA ARETIO, 1987, p. 4) ${ }^{96}$.

- G. Cirigliano (1983):

Educação Distância é um ponto intermediário de uma linha contínua entre dois extremos. Em um situa-se a relação presencial professor-aluno; no outro, a educação autodidática, aberta, em que o aluno não necessita a ajuda do professor. Neste contexto, a Educação a Distância, ao não apresentar contato direto entre educador e educando, necessita que os conteúdos estejam tratados de um modo especial, isto é, que tenham uma estrutura ou organização que os façam possíveis de aprender a distância. Essa necessidade de tratamento especial exigida pela "distância" é a que valoriza o "desenho de instrução", tanto que é um modo de tratar e estruturar os conteúdos para fazê-los possíveis de aprender. Na educação a distância, ao colocar em contato ao estudante com o "material estruturado", isto é, os conteúdos organizados segundo um desenho, é como se, no texto, graças ao desenho, estivesse presente o próprio professor (Op. Cit.).

- R. Marín Ibáñez (1984):

Definir o ensino a distância porque não é imprescindível que o professor esteja junto ao aluno, não é exato, além de ser um traço meramente negativo. No ensino a distância, a relação didática tem um caráter múltiplo. É necessário recorrer a una pluralidade de vias. É um sistema multimídia. (Op. Cit.).

- V. Guedez (1984):

Educação a distância é uma modalidade mediante a qual se transferem informações cognoscitivas e mensagens formativas através de vias que não requerem uma relação de contigüidade presencial em recintos determinados. (Op. Cit.) $)^{97}$.

\footnotetext{
${ }^{96}$ Disponível em: $<$ http://www.uned.es/catedraunesco-

ead/articulos/1987/hacia\%20una\%20definicion\%20de\%20educacion\%20a\%20distancia.pdf $>$. Acesso em: 20 nov 2006.

${ }^{97}$ Disponível em: $<$ http://www.uned.es/catedraunescoead/articulos/1987/hacia\%20una\%20definicion\%20de\%20educacion\%20a\%20distancia.pdf $>$. Acesso em: 20 nov 2006.
} 
- F. Henri (1985):

A formação a distância é o produto da organização de atividades e de recursos pedagógicos dos quais se serve o aluno, de forma autônoma e seguindo seus próprios desejos, sem que lhe seja imposto submeter-se às limitações espaço-temporais nem às relações de autoridade da formação tradicional. (Op. Cit.).

- M. Ramón Martinez (1985):

A Educação a Distância é uma estratégia para operacionalizar os princípios e os fins da educação permanente e aberta, de tal maneira que qualquer pessoa, independentemente do tempo e do espaço, possa converter-se em sujeito protagonista de sua própria aprendizagem graças ao uso sistemático de materiais educativos, reforçado por diferentes meios e formas de comunicação. (Op. Cit.).

- B. Holmberg (1985):

A característica geral mais importante da educação a distância é que ela se baseia na comunicação não direta As conseqüências desta característica geral do estudo a distância podem ser agrupadas em seis categorias [...] A base do estudo a distância é normalmente um curso pré-produzido, que, em geral, encontra-se impresso, mas que também pode ser apresentado por outros meios diferentes da palavra escrita, como por exemplo as fitas de áudio ou vídeo, os programas de rádio e televisão ou os jogos experimentais... O curso deve ser auto-instrutivo, isto é, ser acessível para o estudo individual sem o apoio de um professor [...] a comunicação organizada de ida e volta tem lugar entre os estudantes e uma organização de apoio... O meio mais utilizado é a palavra escrita, mas o telefone está se convertendo em um instrumento de importância [...] A educação a distância leva em conta o estudo individual [...] dado que o curso produzido é utilizado facilmente por um grande número de estudantes e com um mínimo de gastos, a educação a distância pode ser, e é, muitas vezes, uma forma de comunicação massiva. [...] Quando se prepara um programa de comunicação massiva é pratico aplicar os métodos de trabalho industrial. Estes métodos incluem: planejamento, procedimentos de nacionalização, tais como divisão do trabalho, mecanização, automação e controle e verificação. [...] os enfoques tecnológicos implicados não impedem que a comunicação pessoal em forma de diálogo seja modular no estudo a distância. Isto se dá inclusive quando se apresenta a comunicação computadorizada. O estudo a distância está organizado como uma forma mediatizada de conversação didática guiada. (Op. Cit.) ${ }^{98}$.

- J. García Llamas (1986):

A Educação a Distância é uma estratégia educativa baseada na aplicação da tecnologia de aprendizagem, sem limitação de lugar, tempo, ocupação ou idade dos alunos. Implica novos papéis para os alunos e para os professores, novas atitudes e novos enfoques metodológicos. (Op. Cit.).

\footnotetext{
${ }^{98}$ Disponível em: $<$ http://www.uned.es/catedraunescoead/articulos/1987/hacia\%20una\%20definicion\%20de\%20educacion\%20a\%20distancia.pdf $>$. Acesso em: 20 nov 2006.
} 
- Ibanês (1986):

Educação a Distância é um sistema multimídia de comunicação bidirecional com o aluno alijado do centro docente (escola) e facilitado por uma organização de apoio, para atender de um modo flexível o aprendizado independentemente de uma grande população dispersa. O sistema pode configurar-se com desenhos tecnológicos que permitam economias de escala. (Op. Cit.) ${ }^{99}$.

- D. Rowntree (1986):

Por Educação a Distância entendemos aquele sistema de ensino em que o aluno realiza a maior parte de sua aprendizagem por meio de materiais didáticos previamente preparados, com um escasso contato direto com os professores. Ainda assim, pode ter ou não um contato ocasional com outros alunos. (Op. Cit.) ${ }^{100}$.

- W. Perry \& G.Rumble (1987):

A característica básica do Ensino a Distância é o estabelecimento de uma comunicação de dupla via, na medida em que professor e aluno não se encontram juntos na mesma sala.

- J. S. Pomenta (CRESALC-UNESCO, 1990):

A educação a distância é uma forma de ensinar e aprender mais motivante e participativa, que estimula o auto-ensino, permitindo assim redefinir os papéis que educadores e educandos jogam no processo educativo (...) A educação a distância pode ser um fator importante de inovação em nossos pesados e lentos sistemas educativos, que poderia contribuir para romper muitas barreiras e abrir novos caminhos. Mas sua colaboração mais significativa é talvez a de assentar as bases para conhecer, de maneira mais profunda, adequada e sistemática, as particularidades do processo de ensino e aprendizagem no nível superior. ${ }^{101}$

- D. Keegan (1991):

A EaD é definida a partir de suas características, Separação entre professor e aluno, influência de uma organização educacional, especialmente no planejamento e na preparação de materiais, utilização de meios técnicos de comunicação para unir o professor ao aluno e transmitir os conteúdos educativos; mecanismos que assegurem feedback ao aluno e ao professor, orientação pedagógica direcionada ao indivíduo, com

\footnotetext{
99 Disponível em: <http://vitoria.upf.tche.br/ teixeira/2002-2/material/Aula-20-8-2002.pdf $>$. Acesso em: 22 nov 2006.

${ }^{100}$ Disponível em: $<$ http://www.uned.es/catedraunescoead/articulos/1987/hacia\%20una\%20definicion\%20de\%20educacion\%20a\%20distancia.pdf $>$. Acesso em: 20 nov 2006.

${ }^{101}$ Qué es la Educación a Distancia. Faculdade de Sociología. Universidad de Buenos Aires. Disponível em: $<\mathrm{http}$ ://www.catedras.fsoc.uba.ar/edudist/brevead.htm>. Acesso em: 24 nov 2006.
} 
a possibilidade de encontros com propósitos pedagógicos e socializantes, uso de técnicas industriais de educação. (NUNES, s/d., p. 2-23)

- Comunidade Européia (1991):

Educação a distância é definida como qualquer forma de estudo que não se encontre sob a contínua e imediata supervisão de um tutor, não entanto, mas que se beneficia do planejamento, da condução e do ensino da organização do curso. Educação a distância é um grande componente da aprendizagem independente e autônoma, e é então dependente do desenho didático dos materiais que substitui a interatividade encontrada entre os professores e alunos nas aulas convencionais nas instituições presenciais. A autonomia é suportada por sistemas de tutores e conselheiros que idealmente estão presentes nos centros de estudo da mesma região ou local de estudo, e para uma extensão crescente de alunos através de sistemas de comunicação modernos. ${ }^{102}$

- Holmberg (1995):

O sistema a distância implica estudar por si mesmo, mas o estudante não está só, se vale do curso e da interação com os tutores e com a organização de apoio. (MARTINS e POLAK, 2001) ${ }^{103}$.

- T. Bates (1995):

A educação a distância é um meio para esse fim, é um caminho pelo qual o aprendiz pode estudar de maneira flexível, com ajuda de material instrucional; o aluno pode estudar no seu tempo e no lugar que escolher (em casa, no trabalho ou no centro de aprendizagem), sem contacto face a face com o professor. (GARCIA ARETIO, 1987, p. 4) ${ }^{104}$.

- M. Mena (1995):

Modalidade educativa que, através de meios e estratégias distintos, permite estabelecer uma forma particular de relação entre quem ensina e quem aprende, constituindo-se em uma singular forma de presença que ajuda a superar problemas de tempo e distância. (Op. Cit.).

\footnotetext{
102 The European Commission's Memorandum on Open Distance Learning in the European Community (1991), Disponivel em: <http://www.city.ac.uk/ictop/distance.html>. Acesso em: 20 nov 2006.

103 Disponível em: <http://vitoria.upf.tche.br/ teixeira/2002-2/material/Aula-20-8-2002.pdf>. Acesso em: 22 nov 2006.

${ }^{104}$ Disponível em: $<$ http://www.uned.es/catedraunescoead/articulos/1987/hacia\%20una\%20definicion\%20de\%20educacion\%20a\%20distancia.pdf $>$. Acesso em: 20 nov 2006.
} 
- O. Pretti (1996):

A Educação a Distância (...) não deve ser simplesmente confundida com o instrumental, com tecnologias a que recorre. Deve ser compreendida como uma prática educativa situada e mediatizada, uma modalidade de se fazer educação, de se democratizar o conhecimento. É, portanto, uma alternativa pedagógica que se coloca hoje ao educador que tem uma prática fundamentada em uma racionalidade ética, solidária e comprometida com as mudanças sociais. (Op. Cit.).

- Moore e Kearsley (1996):

Educação a Distância é o aprendizado planejado que normalmente ocorre em lugar diverso do professor e como conseqüência requer técnicas especiais de planejamento de curso, técnicas instrucionais especiais, métodos especiais de comunicação, eletrônicos ou outros, bem como estrutura organizacional e administrativa específica (RODRIGUES, 1998). ${ }^{105}$

- Daniel (1996):

Educação a distância é a oferta de programas educacionais projetados para facilitar a implementação de estratégias de aprendizagem que não dependem do contato cotidiano com o professor, mas utiliza o potencial dos alunos para estudar por eles próprios. Provê material de estudo interativo e instalações de aprendizagem descentralizadas onde os estudantes podem buscar assistência acadêmica ou outras formas de ajuda educacional quando eles precisarem. ${ }^{106}$

- Associação de Aprendizagem a Distancia de USA (USDLA) (1997):

Distribuição de educação ou treinamento através de uma instrução eletronicamente transmitida. ${ }^{107}$

- $\operatorname{arcia}$ Aretio (1998):

A educação a distância é um "sistema tecnológico de comunicação bidirecional, que substitui a interação pessoal, em sala de aula, de professor e aluno como meio preferencial de ensino, pela ação sistemática e conjunta de diversos recursos didáticos e pelo apoio de uma organização tutorial, que propiciam a aprendizagem autônoma dos estudantes". ${ }^{108}$

\footnotetext{
${ }^{105}$ Rosângela Schwarz Rodrigues. Modelo de avaliação para cursos no ensino a distância. Universidade federal de santa catarina departamento de engenharia de produção programa de pós-graduação em engenharia de produção. 1998. Disponivel em: http://www.deps.ufsc.br/disserta98/roser/. Acessado em 22/11/2006.

106 Mega-Universities \& Knowledge Media, Technology Strategies for Higher Education. London: Kogan Page. Disponivel em: http://www.columbia.edu/ mar178/def.htm. Acessado em 18/11/2006.

107 Qué es la Educación a Distancia. Faculdade de Sociología. Universidad de Buenos Aires. Disponivel em: http://www.catedras.fsoc.uba.ar/edudist/brevead.htm. Acessado em 24/11/2006.

${ }^{108}$ Flávio Castro. Educação a Distância e Políticas Públicas no Brasil. Uma Experiência do Núcleo de Educação a Distância da Universidade de Brasília. 2001. Disponível em:
} 
- Brasil - Decreto n. ${ }^{\circ}$ 2.494/98:

Art.1. Educação a distância é uma forma de ensino que possibilita a auto-aprendizagem, com a mediação de recursos didáticos sistematicamente organizados, apresentados em diferentes suportes de informação, utilizados isoladamente ou combinados, e veiculados pelos diversos meios de comunicação. ${ }^{109}$

- Associação de Aprendizagem a Distancia de USA (USDLA) (1999):

Aquisição de conhecimentos e habilidades através da instrução e informação mediada, cobrindo todas as tecnologias e outras formas de aprendizagem a distancia (RIVERAPORTO, 1999) ${ }^{110}$.

- D. Garrison, D. Shale (1999):

A característica mais importante para poder caracterizar a educação a distancia não é a sua morfologia, mas o modo como facilita a comunicação entre o professor e o aluno. Devido ao fato de estes estarem fisicamente separados, a educação a distância tem que depender da tecnologia para que atue como mediadora no processo de comunicação. Mas, ainda que se tenha prestado uma grande atenção ao uso dos meios tecnológicos, tem havido pouco foco na natureza do processo de comunicação e no papel da tecnologia que lhe serve de apoio. (op. cit.)

- E. Chaves $(1999)^{111}$ :

A educação e a aprendizagem, embora aconteçam dentro do indivíduo, e, portanto, não possam, literalmente, ser feitas a distância, podem, e devem, ser mediadas através dos contatos do indivíduo com o mundo que o cerca, em especial, através de seu contato com outras pessoas, seja esse contato "cara a cara" ou "remoto" ("virtual", no sentido de que não envolve a "contigüidade espaço-temporal" das duas pessoas). Se for só isso que se quer dizer com as expressões "educação a distância" e "aprendizagem a distância", então não há porque não utilizá-las. (CHAVES, 1999)

\footnotetext{
http://www.abed.org.br/publique/cgi/cgilua.exe/sys/start.htm?UserActiveTemplate=4abed\&infoid=165\&sid=106. Acessado em17/11/2006.

${ }^{109}$ MARCOS LEGAIS. MINISTÉRIO DA EDUCAÇÃO FUNDESCOLA. BRASÍLIA 2000. Disponivel em:

http://www.fnde.gov.br/home/fundescola/manuais_tecnicos_operacionais/marcos_legais.pdf. Acessado em 18/11/2006. p 189.

${ }^{110}$ Disponivel em: http://www.quadernsdigitals.net/datos_web/hemeroteca/r_1/nr 10/a 121/121.html. Acessado em 26/11/2006.

${ }^{111}$ Disponível em: http://www.edutecnet.com.br/. Acessado em 17/11/2005.
} 
- C. Landim (1999):

EaD pressupõe a combinação de tecnologias convencionais e modernas que possibilitam o estudo individual ou em grupo, nos locais de trabalho ou fora, por meio de métodos de orientação e tutoria a distância, contando com atividades presenciais específicas, como reuniões de grupo para estudo e avaliação. ${ }^{112}$ (ABED, 1999)

- Associação de Comunicação e Tecnologia Educativa (ACTE) (1999):

Experiência planificada de ensino-aprendizagem que utiliza una ampla gama de tecnologias para chamar a atenção do estudante a distância. Desenhado para estimular a interação e a verificação da aprendizagem sem mediar um contato físico. ${ }^{113}$

- E. Rodríguez Galindo (2000):

Entendemos por educação a distância todos aqueles processos de ensino-aprendizagem nos quais o aluno não está no mesmo espaço físico que o professor; em que há uma distância espaço-temporal entre os dois, pelo que o aluno e o professor não estão em contato direto ou presencial, mas se comunicam através de algum meio que salve esta distância. (ABED, 1999)

- The Commonwealth of Learning $(2000)^{114}$ :

Não existe uma definição de educação aberta e a distância; existem muitas aproximações que definem o termo. Muitas definições, no entanto, focam a sua atenção nas suas características: separação entre professor e aluno, no tempo e no espaço, ou em ambos; credenciamento institucional, isto é, estudo acreditado ou certificado por alguma instituição ou agência. Este tipo de aprendizagem é distinto da aprendizagem com o próprio esforço sem o reconhecimento oficial de uma instituição de ensino; Uso do diversos meios incluindo impressos, transmissões de rádio e televisão, ou vídeo e gravações de áudio, aprendizagem por computador e telecomunicações; comunicação bidirecional que permite que estudantes e tutores interajam, diferenciando-se da recepção passiva de sinais da transmissão (uma comunicação pode ser síncrona ou assíncrona); possibilidade de reuniões presenciais para tutorias, interação de estudantes entre sim, consulta de biblioteca e laboratórios ou sessões de prática; uso de processos industrializados (isto é, em grande escala, o trabalho é dividido e as tarefas são atribuídas a várias equipes de funcionários que trabalham juntos em equipes de desenvolvimento dos cursos).

- The Commission on Colleges Southern Association of Colleges and Schools (2000):

\footnotetext{
112 Educação a Distância e seu Emprego no Ensino Contábil no Brasil. ABED. 1997 Disponível em: http://www2.abed.org.br/visualizaDocumento.asp?Documento_ID=42. Acessado em 18/11/2006.

113 Op.Cit.

${ }^{114}$ Disponível em: http://www.col.org/colweb/site. Acesso em: 17 out. 2006.

${ }^{115}$ The Commonwealth of Learning (COL). Disponível em: http://www.col.org/colweb/site/pid/3095. Acessado em: 23/11/2006.
} 
A educação a distância é definida como um processo educacional formal em que a maioria da instrução ocorre quando o estudante e o instrutor não estão no mesmo lugar. A instrução pode ser síncrona ou assíncrona. A educação a distância pode empregar o estudo por correspondência, ou o áudio, ou vídeo, ou tecnologia informática. ${ }^{116}$

- Holmberg, B. (2000):

O estudo a distância é essencialmente auto-estudo, mas o estudante não está só: ele se beneficia do curso e da interação com os tutores (assessores) e da organização que o apóia. Um certo tipo de conversação de dois sentidos, que, mediante a palavra escrita ou por telefone ocorre entre o estudante e os assessores. ${ }^{117}$

- Brasil, Decreto $\mathrm{n}^{\mathrm{o}} 5.622$ de 19 de dezembro de (2005):

Art. $1^{\circ}$. Para os fins deste Decreto, caracteriza-se a educação a distância como modalidade educacional na qual a mediação didático pedagógica nos processos de ensino e aprendizagem ocorre com a utilização de meios e tecnologias de informação e comunicação, com estudantes e professores desenvolvendo atividades educativas em lugares ou tempos diversos. (ABRAED/ABED, p. 138)

- UNESCO (2006):

A educação a distância consiste no uso de técnicas, de recursos e de meios instrutivos específicos para facilitar a aprendizagem e o ensino entre alunos e professores que estão separados por tempo ou espaço. As técnicas, os recursos e os meios são dependentes de fatores como: conteúdo, necessidades e contexto do estudante, habilidades e experiência do professor, objetivos, tecnologias disponíveis e capacidade institucional. ${ }^{118}$

\footnotetext{
116 The Commission on Colleges Southern Association of Colleges and Schools (SACS). "DISTANCE EDUCATION: DEFINITION AND PRINCIPLES - A POLICY STATEMENT", May 2000. Disponível em: http://www.sacscoc.org/pdf/081705/distance\%20education.pdf. Acessado em 22/11/2006.

${ }_{117}$ Qué es la Educación a Distancia. Faculdade de Sociología. Universidad de Buenos Aires. Disponível em: http://www.catedras.fsoc.uba.ar/edudist/brevead.htm. Acessado em 24/11/2006.

${ }^{118}$ UNESCO. Distance Learning Resource Network. Disponível em: http://portal.unesco.org/education/en/ev.phpURL_ID=18649\&URL_DO=DO_TOPIC\&URL_SECTION=201.html. Acessado em 18/11/2006.
} 


\subsubsection{Estudo comparativo das definições de educação a distância}

Para efetuar o estudo comparativo das definições de educação a distância, foram elaboradas dimensões e categorias de análise com base, por um lado, no exame preliminar das definições e dos elementos com maior percentual de incidência; por outro, na análise de estudos comparativos similares, tentando facilitar as comparações com estes; no entanto, algumas categorias foram excluídas, como a categoria enfoque tecnológico, já que, definindo tecnologia como processo, resulta uma categoria pouco distintiva.

Assim sendo, o estudo comparativo foi organizado em quatro dimensões de análise:

1) a dimensão pedagógica, integrada pelas categorias autonomia do estudante, metodologias didáticas, estratégias, planejamento e organização e tutoria (ou supervisão) educativa;

2) a relação professor-aluno, no tempo e no espaço, integrada por três categorias - separação, continuidade e presencialidade;

3) a comunicação, estruturada com base nas categorias meios - integradas por sua vez por meios impresso, mecânico, eletrônico, cinematográfico, som, TV, multimídia, bidirecionalidade e interatividade nas comunicações - e comunicação massiva.

4) Esta última dimensão expressa como é vista a produção dos sistemas a distância com a dimensão industrial, que faz referência à divisão do trabalho, à mecanização, à linha de montagem, à produção de massa, ao modelo fordista.

Foram analisadas 43 definições e caracterizações de educação a distância, desde 1960 até 2006, integrando tanto as elaboradas por teóricos renomados como por instituições representativas - européias, norte-americanas e latino-americanas.

Destacamos ainda que esta análise se reporta à dimensão sintática, considerando os elementos expressados explicitamente nas definições, e à dimensão semântica, no que se refere aos elementos implícitos em cada uma. 


\begin{tabular}{|c|c|c|c|c|c|c|c|c|c|c|c|c|}
\hline & \multirow[b]{2}{*}{ Autores } & \multicolumn{4}{|c|}{$\begin{array}{c}\text { Pedagógico } \\
\text { Didático ou Didático-pedagógico? }\end{array}$} & \multicolumn{3}{|c|}{$\begin{array}{c}\text { Relação professor-aluno } \\
\text { Tempo e espaço }\end{array}$} & \multicolumn{3}{|c|}{ Tecnologia e Meios de Comunicação } & \multirow{2}{*}{$\begin{array}{c}\text { Forma } \\
\text { Industrial } \\
119\end{array}$} \\
\hline & & $\begin{array}{c}\text { Autonomia } \\
\text { Aprendizagem } \\
\text { independente }\end{array}$ & $\begin{array}{l}\text { Métodos } \\
\text { didáticos }\end{array}$ & $\begin{array}{l}\text { Estratégias, } \\
\text { planejamento, } \\
\text { organização. }\end{array}$ & $\begin{array}{l}\text { Tutoria ou } \\
\text { supervisão }\end{array}$ & $\begin{array}{l}\text { Separação } \\
\text { Distância }\end{array}$ & $\begin{array}{c}\text { Contínuo com } \\
\text { graus }\end{array}$ & $\begin{array}{l}\text { Reunião } \\
\text { presencial }\end{array}$ & Meios $^{120}$ & $\begin{array}{c}\text { bidirecional } \\
\text { interatividade }\end{array}$ & massiva & \\
\hline (1960) & Charles Wedemeyer & & & & & & & & & & & \\
\hline (1967) & G. Dohmem & & & & & 121 & & & & & & \\
\hline (1973) & O. Peters & & & & & & & & 122 & & & \\
\hline (1973) & Michael Moore & & & & & & & & $1-2-3$ & & & \\
\hline (1977) & B. Holmberg & & & & & & & & & & & \\
\hline (1979) & Norman Mackenzie & & & & & & & & $1-4$ & & & \\
\hline (1979) & Jaume Sarramona & & & & & & & & & & & \\
\hline (1980) & Pío Navarro Alcalá & & & & & & & & & & & \\
\hline (1981) & M.L. Ochoa & & & & & & & & & & & \\
\hline (1982) & Miguel Casas Armengol & & & & & & & & $1-2-3$ & & & \\
\hline (1983) & Gustavo Cirigliano & & & & & & & & & & & \\
\hline (1984) & Ricardo Marín Ibáñez & & & & & & & & 5 & & & \\
\hline (1984) & Victor Guedez & & & & & & & & ${ }^{123}$ & & & \\
\hline (1985) & France Henri & & & & & 124 & & & & & & \\
\hline (1985) & Miguel Ramón Martinez & & & & & & & & & & & \\
\hline (1985) & Holmberg & & & & & & & & & & & \\
\hline (1986) & José Luís García Llamas & & & & & & & & & & & \\
\hline (1986) & Ibanês & & & & & & & & 5 & & 125 & \\
\hline
\end{tabular}

${ }^{119}$ Expressa formas de produção nas quais se utilizam: divisão do trabalho, mecanização, linha de montagem, produção de massa, modelo fordista.

120 1: Impresso // 2: Mecânico // 3: Eletrônico // 4: Cinematográfico, som, TV // 5: Multimídia

${ }^{121}$ Oposto ao Presencial

${ }^{122}$ Especialmente para o propósito de reproduzir materiais técnicos de alta qualidade

${ }^{123}$ Transferem-se informações cognitivas e mensagens formativas.

${ }^{124}$ Referem-se às relações de autoridade da formação tradicional 


\begin{tabular}{|c|c|c|c|c|c|c|c|c|c|c|c|c|}
\hline & \multirow[b]{2}{*}{ Autores } & \multicolumn{4}{|c|}{$\begin{array}{c}\text { Pedagógico } \\
\text { Didático ou Didático-pedagógico? }\end{array}$} & \multicolumn{3}{|c|}{$\begin{array}{c}\text { Relação professor-aluno } \\
\text { Tempo e espaço }\end{array}$} & \multicolumn{3}{|c|}{ Comunicação } & \multirow{2}{*}{$\begin{array}{c}\text { Forma } \\
\text { Industrial } \\
\quad 126\end{array}$} \\
\hline & & $\begin{array}{c}\text { Autonomia } \\
\text { Aprendizagem } \\
\text { independente }\end{array}$ & $\begin{array}{l}\text { Métodos } \\
\text { didáticos e } \\
\text { instrução }\end{array}$ & $\begin{array}{c}\text { Estratégias, } \\
\text { planejamento, } \\
\text { organização. }\end{array}$ & $\begin{array}{l}\text { Tutoria ou } \\
\text { supervisão }\end{array}$ & $\begin{array}{l}\text { Separação } \\
\text { Distância }\end{array}$ & $\begin{array}{c}\text { Contínuo com } \\
\text { graus }\end{array}$ & $\begin{array}{c}\text { Reunião } \\
\text { presencial }\end{array}$ & Meios $^{127}$ & $\begin{array}{c}\text { bidirecional } \\
\text { interatividade }\end{array}$ & massiva & \\
\hline (1986) & Dereck Rowntree & & & & & & & & & & & \\
\hline (1987) & Perry \& Rumble & & & & & & & & & & & \\
\hline (1990) & Pomenta, José Silvio. ${ }^{128}$ & 129 & & & & & & & & & & \\
\hline (1991) & D. Keegan & & & & & & & & 130 & & & \\
\hline (1991) & European Community & & & & & & & & & & & \\
\hline (1995) & Holmberg & & & & & & & & & & & \\
\hline (1995) & Tony Bates & & & & & & & & & & & \\
\hline (1995) & Marta Mena & & & & & & & & & & & \\
\hline (1996). & Pretti & & & & & & & & & & & \\
\hline (1996) & Michael Moore e Kearsley & & & & & & & & 3 & & & \\
\hline (1996). & Daniel. & & & & & & & & & & & \\
\hline (1997) & (USDLA) $^{131}$ & & & & & & & & 3 & & & \\
\hline (1998) & Garcia Aretio & & & & & & & & & & & \\
\hline (1998) & Decreto n. ${ }^{\circ} 2.494$ (Brasil) & & & & & & & & & & & \\
\hline (1999) & (USDLA) & & & & & & & & & & & \\
\hline (1999) & Garrison, D., Shale, D & & & & & & & & & & & \\
\hline (1999) & Chaves & & & & & & & & & & & \\
\hline (1999) & Landim & & & & & & & & & & & \\
\hline
\end{tabular}

\footnotetext{
${ }^{125}$ Economia de escala

${ }^{126}$ Expressa formas de produção nas quais se utilizam: divisão do trabalho, mecanização, linha de montagem, produção de massa, modelo fordista.

${ }^{127}$ 1: Impresso // 2: Mecânico // 3: Eletrônico // 4: Cinematográfico, som, TV // 5: Multimídia

${ }^{128}$ CRESALC-UNESCO

${ }^{129}$ Uma forma de ensinar e aprender mais motivante e participativa.

${ }^{130}$ Transmitir os conteúdos educativos

${ }^{131}$ Associação de Aprendizagem a Distância de Estados Unidos de Norte América.
} 


\begin{tabular}{|c|c|c|c|c|c|c|c|c|c|c|c|c|}
\hline & \multirow[b]{2}{*}{ Autores } & \multicolumn{4}{|c|}{$\begin{array}{c}\text { Pedagógico } \\
\text { Didático ou Didático-pedagógico? }\end{array}$} & \multicolumn{3}{|c|}{$\begin{array}{c}\text { Relação professor-aluno } \\
\text { Tempo e espaço }\end{array}$} & \multicolumn{3}{|c|}{ Comunicação } & \multirow{2}{*}{$\begin{array}{c}\text { Forma } \\
\text { Industrial } \\
132\end{array}$} \\
\hline & & $\begin{array}{l}\text { Autonomia } \\
\text { Aprendizagem } \\
\text { independente }\end{array}$ & $\begin{array}{l}\text { Métodos } \\
\text { didáticos e } \\
\text { instrução }\end{array}$ & $\begin{array}{l}\text { Estratégias, } \\
\text { planejamento, } \\
\text { organização. }\end{array}$ & $\begin{array}{l}\text { Tutoria ou } \\
\text { supervisão }\end{array}$ & $\begin{array}{l}\text { Separação } \\
\text { Distância }\end{array}$ & $\begin{array}{c}\text { Contínuo com } \\
\text { graus }\end{array}$ & $\begin{array}{c}\text { Reunião } \\
\text { presencial }\end{array}$ & Meios $^{133}$ & $\begin{array}{c}\text { bidirecional } \\
\text { interatividade }\end{array}$ & massiva & \\
\hline (1999) & ACTE $^{134}$ & & & & & & & & & & & \\
\hline (2000) & Rodríguez Galindo & & & & & & & & & & & \\
\hline (2000) & Commonwealth of learning & & & & & & & & $1-2-3-4-5$ & & & \\
\hline (2000) & $\begin{array}{l}\text { The Commission on } \\
\text { Colleges Southern } \\
\text { Association of Colleges and } \\
\text { Schools }\end{array}$ & & & & & & & & & & & \\
\hline (2000) & Holmberg, B. & & & & & & & & & & & \\
\hline (2005) & Decreto no 5.622 (Brasil) & & & & & & & & & & & \\
\hline (2006) & UNESCO & & & & & & & & & & & \\
\hline
\end{tabular}

Tabela 3 - Tabela comparativa dos conceitos de Educação a Distância, de autores e instituições representativos

Tabela elaborada pelo autor.

\footnotetext{
${ }^{132}$ Expressa formas de produção nas quais se utilizam: divisão do trabalho, mecanização, linha de montagem, produção de massa, modelo fordista.

133 1: Impresso // 2: Mecânico // 3: Eletrônico // 4: Cinematográfico, som, TV // 5: Multimídia
}

${ }^{134}$ Associação de comunicação e tecnologia educativa 


\subsubsection{Análise histórica das tendências teóricas}

A análise dos dados comparados reflete não só o estado de situação da produção teórica da educação a distância mas também as tendências de cada período histórico.

Na década de 1960, o foco das propostas esteve mais centrado na autonomia e na independência dos alunos - a educação a distância começa a se definir através do conceito de separação física, chegando a posições extremas como a de Dohmem, que a define como o oposto à educação presencial.

Nos anos 70, poder-se-ia vislumbrar o surgimento do modelo fordista de educação a distância, caracterizado pela racionalização, divisão do trabalho, mecanização, linha de montagem, produção de massa, planejamento, formalização, estandardização, mudança funcional, objetivação, concentração e centralização (KEEGAN, 1986). Tanto é assim que Peters considera que a educação a distância "sólo puede ser rentable si el número de alumnos matriculados es alto. El principio de economía a escala humana es utilizado desde esta perspectiva para justificar los costos involucrados". (In: CERDA GONZALEZ, 2002) $)^{135}$

Peters enfatiza que qualquer pessoa envolvida profissionalmente na educação deve compreender que existem duas formas de ensino: o ensino tradicional, baseado na comunicação interpessoal, e o ensino industrializado, baseado nas formas técnicas e préfabricadas de comunicação. (In: ARETIO, 1994) ${ }^{136}$

Nos anos de 1980, coexistem três orientações teóricas. De um lado, o modelo industrial, fordista. De outro, a emergência de um modelo mais centrado na comunicação, mais flexível, que começa a considerar a comunicação bidirecional como um dos elementos centrais do processo de aprendizagem. E ainda uma terceira orientação, que tem passado despercebida na maioria das análises teóricas destacadas, que supera o pensamento dicotômico: aquela que define a educação a distância como um ponto de um "continuum"137 chamado educação, levantando ainda outro elemento que, nas posições

\footnotetext{
${ }^{135}$ CERDA GONZÁlEZ, C. EDUCACIÓN A DISTÂNCIA: PRINCIPIOS Y TENDENCIAS. Rev. Perspectiva Educacional, Instituto de Educación UCV, No 39-40, I y II Semestres 2002 - Págs. 11-30. Disponivel em: < euv.cl/archivos_pdf/.../perspectiva_articulo_39-40.pdf >. Acessado em: 26/05/2005.

136 GARCIA ARETIO, L. Educación a distância hoy, serie educación permanente. Universidad Nacional de Educación a Distância. Madrid. 1994. p 70.

137 Série longa de elementos numa determinada seqüência, em que cada um difere minimamente do elemento subseqüente, daí resultando diferença acentuada entre os elementos iniciais e finais da seqüência.
} 
dos anos 60, 70 e 80, encontra-se quase inexistente: a importância do processamento didático dos materiais de estudo.

Os anos 90 representam uma década de amadurecimento conceitual da educação a distância, consolidando-se um modelo centrado na comunicação e na comunicação bidirecional. Holmberg (1995), baseado na teoria da interação e da comunicação, define educação a distância como uma variada gama de formas de estudo, baseada na teoria didática da conversação, utilizando o conceito de comunicação não imediata. A teoria da didática da conversação proposta por Holmberg fundamenta-se em processos de comunicação, os quais são reforçados mediante a elaboração de materiais de apoio.

Keegam (1991), por sua vez, define EaD a partir de suas características - a separação física entre professor e aluno, que a distingue do ensino presencial; a influência da organização educacional (planejamento, sistematização, plano, projeto, organização dirigida, etc.), que a diferencia da educação individual; a utilização dos meios técnicos de comunicação, usualmente impressos, para unir o professor ao aluno e transmitir os conteúdos educativos; a previsão de uma comunicação de via dupla, na qual o estudante se beneficia de um diálogo, e a possibilidade de iniciativas de via dupla, bem como de encontros ocasionais com propósitos didáticos e de socialização -, considerando-a como uma forma industrializada de educação.

Garrison (1993) e Verduin e Clark (1999) possuem interessantes colaborações. Garrison (1993) analisa que a única forma de superar a separação entre aluno e professor é a elaboração de uma comunicação bidirecional que possibilite o diálogo e a colaboração: as ferramentas de comunicação eletrônica são utilizadas para obter conhecimento por meio do diálogo e do debate.

Por último, Michael Moore (1996) tem uma interessante teoria de educação a distância, com duas dimensões: comunicação transacional e autonomia do estudante. Entende-se por comunicação transacional o espaço gerado pela separação entre o aluno e o professor, que pode levar à perda de compreensão. De acordo com Moore (1996), esta separação, que afeta o processo de ensino/aprendizagem, gera condutas especiais para o professor e o aluno. A distância transacional tem duas dimensões: diálogo e estrutura. O diálogo é produzido entre o professor e o aluno por intermédio dos meios de comunicação. A estrutura é uma dimensão associada ao desenho dos cursos e representa 
a capacidade de cada programa de $\mathrm{EaD}$ de atender às necessidades particulares de cada grupo e aluno. A autonomia dos alunos está relacionada com o grau de distância transacional. Se o programa é altamente estruturado, com um detalhamento de conteúdos organizados em seqüências didáticas, atividades, com freqüentes espaços de diálogo, os alunos necessitarão de menor autonomia; se o programa for pouco estruturado, os alunos necessitarão de maior autonomia.

\subsubsection{Análise das principais características presentes nas definições de educação a distância}

A análise comparativa de definições de educação a distância permite visualizar os elementos presentes nas visões de cada grupo e cada época histórica. A primeira conclusão derivada da análise comparativa consiste em assinalar os elementos que fazem parte do universo conceitual da educação a distância. Separação física; meios de comunicação; autonomia e independência; tutoria ou supervisão; comunicação bidirecional e interatividade; estratégias, organização e planejamento; métodos didáticos; reuniões presenciais; comunicação massiva e forma industrial.

\begin{tabular}{|l|l|}
\hline Características & Percentual de incidência (\%) \\
\hline Separação física & $97 \%$ \\
\hline Meios de comunicação & $86 \%$ \\
\hline Autonomia & $46 \%$ \\
\hline Tutoria ou supervisão & $41 \%$ \\
\hline Comunicação bidirecional e interatividade & $37 \%$ \\
\hline Estratégias, organização e planejamento & $34 \%$ \\
\hline Métodos didáticos & $23 \%$ \\
\hline Reuniões presenciais & $11 \%$ \\
\hline Comunicação massiva & $11 \%$ \\
\hline Forma industrial & $11 \%$ \\
\hline Educação como um continuum & $2 \%$ \\
\hline
\end{tabular}

Tabela 4: Análise de 43 definições de EaD, de 1960 a 2006. Tabela elaborada pelo autor

A tabulação dos dados das conceitualizações do período 1960-2006 permite observar que só dois elementos caracterizam fortemente a $\mathrm{EaD}$ : a separação física e o uso de meios de comunicação para superar a separação física. Porém não estamos falando da geração de um diálogo entre professor e aluno através de meios de comunicação, já que, se olharmos os percentuais das categorias tutoria e comunicação bidirecional, nós as 
encontraremos com 41 e 37\%, respectivamente. Isso nos permite inferir que, quando se fala de meios de comunicação, está-se falando, em pelo menos uns $60 \%$ dos casos, de modelos de transmissão de conteúdos.

A segunda constatação resulta em observar que as principais categorias que expressam a dimensão didático-pedagógica do processo educativo encontram-se abaixo dos $40 \%$ de freqüência, ou seja, tutoria, comunicação bidirecional, planejamento e organização, métodos didáticos e reuniões presenciais são aspectos relegados a um segundo plano, que sequer chegam à metade da amostra. Evidentemente, isso denota uma clara tendência tecnológica, que parte de uma visão na qual o professor é o centro do processo educativo, e a sua presença física se torna fundamental para a aprendizagem do aluno. Portanto, buscar os meios mais adequados para trasladar o papel do professor na educação presencial tradicional para a educação a distância significa transmitir informação.

Esta análise corrobora, em termos gerais, as conclusões da análise de Landim (1997) de 21 definições de EaD, já que, como podemos observar na tabela abaixo, a posição dos elementos se mantêm na mesma ordem, mudando apenas na sua magnitude: as mudanças mais significativas entre ambas resultam na diferença de quase 20 pontos percentuais entre a importância da tutoria, a da aprendizagem independente e a da comunicação massiva.

\begin{tabular}{|l|c|}
\hline Características & Percentual de incidência (\%) \\
\hline Separação professor/aluno & 95 \\
\hline Meios técnicos & 80 \\
\hline Organização (apoio - tutoria) & 62 \\
\hline Aprendizagem independente & 62 \\
\hline Comunicação bidirecional & 35 \\
\hline Enfoque tecnológico & 38 \\
\hline Comunicação massiva & 30 \\
Procedimentos industriais & 15 \\
\hline
\end{tabular}

Tabela 5: Características Conceituais da Educação a Distância.

Fonte: Landim (1997, p. 30)

Com o objetivo de analisar as mudanças nos conceitos dos últimos 20 anos, fizemos um recorte da tabela geral, comparando só as definições do período 1991-2006, alcançando os seguintes resultados: a categoria distância obteve 100\% de incidência nas definições; 
denotando um completo triunfo da visão dicotômica da educação, que, em alguns casos, chega a considerar a educação a distância como o oposto da educação presencial.

\begin{tabular}{|l|c|}
\hline Características & Percentual de incidência (\%) \\
\hline Separação física & $100 \%$ \\
\hline Meios de comunicação & $95 \%$ \\
\hline Tutoria ou supervisão & $50 \%$ \\
\hline Comunicação bidirecional e interatividade & $50 \%$ \\
\hline Estratégias, organização e planejamento & $40 \%$ \\
\hline Autonomia & $36 \%$ \\
\hline Métodos didáticos & $31 \%$ \\
\hline Reuniões presenciais & $18 \%$ \\
\hline Forma industrial & $9 \%$ \\
\hline Massiva & $4 \%$ \\
\hline Educação como um continuum & $0 \%$ \\
\hline
\end{tabular}

Tabela 6: Análise de 23 definições de EaD, de 1991 a 2006.

Tabela elaborada pelo autor

Os meios de comunicação se consolidam na segunda posição, com $95 \%$ de incidência; a tutoria se mantém na terceira posição, com um leve crescimento, que alcança a metade da amostra, assim como a comunicação bidirecional.

Apesar das melhoras visíveis no percentual de incidência das categorias da dimensão pedagógica, mesmo assim a maioria se encontra abaixo da linha dos $40 \%$. Por outro lado, é interessante observar que, enquanto quase $95 \%$ da amostra faz referência aos meios de comunicação, só 50\% fazem referência à tutoria e à comunicação bidirecional, o que nos permite inferir que os outros $50 \%$ da amostra utilizam os meios de comunicação simplesmente para transmissão de informação.

Isso indica que, apesar de se basear fortemente na transmissão de informação a partir de textos impressos, ainda não se dá a importância necessária ao processamento didático (31\%), ao planejamento pedagógico das experiências educacionais $(40 \%)$, às reuniões presenciais $(18 \%)$, à tutoria $(50 \%)$ e à comunicação bidirecional $(50 \%)$. Observa-se, portanto, o predomínio de uma modalidade educativa profundamente tecnológica e afastada da pedagogia e da didática.

Prevalece, assim, uma tendência tecnológica que parece definir a visão que enfatiza a concepção de distância como eixo central da teoria de EaD, configurando-se os meios de comunicação como elemento central da ação educativa, para encurtar as distâncias. 
Agora, com a incorporação das tecnologias eletrônicas, e também pela influência da pedagogia vigotskiana e pela influência dos estudos de Garrison, Holmberg, Moore e Rowntree, começa a se ter foco na tutoria e na interatividade, lenta e vagarosamente.

\subsection{Definição de Educação Aberta}

Hoje, além do conceito de educação a distância, encontra-se em desenvolvimento outro conceito inovador na organização universitária, a chamada educação aberta.

Wedemeyer (1975), um dos primeiros teóricos da educação aberta, diz que, quando se soma o adjetivo aberto à palavra aprendizagem, caracteriza-se uma aprendizagem que não encontra impedimento, um conhecimento que não se encontra confinado, encerrado ou escondido da sociedade; um conhecimento que está disponível a qualquer interessado.

Essa idéia apresenta a possibilidade de um contínuo acesso e uma boa oportunidade para dar continuidade aos estudos. Por isso, o ideal do conceito de educação aberta pode tomar a forma de educação permanente, para as pessoas de todos os níveis, desde o nascimento até a morte.

Segundo Shale $(1987)^{138}$, em uma universidade aberta:

- as exigências usuais da entrada para a admissão à universidade podem ser facilitadas ou mesmo eliminadas completamente;

- as restrições de estar em um determinado lugar, em um determinado tempo, podem ser reduzidas ou canceladas completamente;

- os créditos podem ser concedidos na mesma universidade ou em outra parte;

- algum crédito pode ser concedido para a aprendizagem não formal (considerando-o como aprendizagem - experiência);

\footnotetext{
${ }^{138}$ Disponível em: $<$ http://cade.athabascau.ca/vol2.1/shale.html $>$. Acesso em: 30 nov. 2004.
} 
- os créditos ganhos com o estudo em outra parte podem "ser depositados" e talvez possam ser combinados com os créditos não formais ou com os créditos da universidade que estão sendo adquiridos atualmente;

- os estudantes podem estudar independentemente e no ritmo que desejarem.

Podemos concluir que a educação é mais aberta na medida em que tem menos das características da educação tradicional. Isto é, na medida em que são mais flexíveis os períodos escolares e a sua duração (desde o ato da matrícula, início e término de cursos, assistência, ritmo de estudos e transferência de uma universidade a outra, entre outras).

Porém emergem algumas dúvidas a respeito da relação entre educação aberta e educação a distância. Segundo Trindade, criador e reitor da Universidade Aberta de Portugal,

[...] a relação entre os conceitos de aprendizagem aberta e aprendizagem a distância é mais complexa. Aprendizagem aberta tem essencialmente dois significados: de um lado refere-se aos critérios de acesso aos sistemas educacionais (abertura como equivalente da idéia de remover barreiras ao livre acesso à educação e ao treinamento); de outro lado, significa que o processo de aprendizagem deve ser, do ponto de vista do estudante, livre no tempo, no espaço e no ritmo ("time-free", "place-free" e "pace-free"). Ambos os significados estão ligados a uma filosofia educacional que identifica abertura com aprendizagem centrada no estudante (TRINDADE, 1992, p. 30) ${ }^{139}$.

A educação aberta simboliza uma mudança fundamental na rígida estrutura das instituições atuais, flexibilizando o conceito de educação, uma educação que liberta as possibilidades das pessoas, em qualquer momento das suas vidas, permitindo o pleno desenvolvimento dos potenciais humanos, sem barreiras de nenhum tipo.

\section{5 À guisa de conclusão}

Como se pode observar, existem definições que focam a educação a distância sob a perspectiva da função social que assume, colaborando com a democratização da educação: a ampliação da matrícula educativa e a oferta de cursos que possibilitem a formação permanente. Outras definições que enumeram as características que os sistemas possuem: uso dos meios tecnológicos, materiais instrucionais. Há ainda outras

\footnotetext{
139 BELLONI, M. Educação a distância mais aprendizagem aberta GT 16. Educação e comunicação. 2001. Disponível em: <http://www.educacaoonline.pro.br/art_educacao_a_distância.asp?f_id_artigo=42. $>$ Acesso em: 12 fev 2006
} 
definições que se baseiam em uma análise comparativa com a educação presencial, contrastando suas diferenças, como o nível de separação física entre professor e aluno, o uso de tecnologia educacional e outras que misturam esses elementos na sua definição.

A análise das definições apresentadas pode nos ajudar a determinar qual é a direção do pensamento educativo oculto nas diversas aproximações, e a repensar o já pensado à luz de um contexto em mudança permanente, que começa a definir na prática o que é a sociedade do conhecimento, considerando que, na história, toda definição envolve a significação da cultura na qual está inserida.

Por isso, no próximo capítulo iniciaremos o último estágio exploratório da tese, tentando caracterizar o momento histórico que vivemos em relação à inserção da educação a distância no ensino superior mundial, que realizaremos não só pela análise de algumas das principais megauniversidades da Ásia, da África, da Europa e da América como também da análise das experiências que nesses continentes estão começando a surgir como referências para o desenvolvimento futuro desta modalidade educativa.

$\mathrm{Na}$ análise temos trabalhado com um amplo conjunto de categorias, que abrangem o contexto nacional e o desenvolvimento que a EAD tem apresentado em cada país; as universidades e as experiências mais importantes; o endereço, o contexto histórico, os objetivos, o público-alvo, os recursos humanos e os materiais; os cursos oferecidos, os sistemas de estudo adotados, os materiais de estudo e as estratégias instrucionais; as pesquisas e as experiências desenvolvidas; os métodos de desenvolvimento de materiais, os sistemas de avaliação, os centros de estudo, os valores dos cursos e, às vezes, até a análise de custos e orçamento.

Este estudo exploratório, ainda que incompleto, apresenta uma série de elementos que podem contribuir para o desenvolvimento de políticas educativas na educação em geral, e na educação superior a distância (nacional e regional), em particular. 
2.6) Tabulação de dados de 43 definições de $\mathrm{EaD}$, de 1960 a 2006

\begin{tabular}{|c|c|c|c|c|c|c|c|c|c|c|c|}
\hline \multirow[b]{2}{*}{ Autores } & \multirow[b]{2}{*}{$\begin{array}{c}\text { Autonomia } \\
\text { Aprendizagem } \\
\text { independente } \\
\end{array}$} & \multicolumn{2}{|c|}{$\begin{array}{l}\text { Pedagógico } \\
\text { Didático }\end{array}$} & \multirow[b]{2}{*}{$\begin{array}{l}\text { Tutoria ou } \\
\text { supervisão }\end{array}$} & \multicolumn{3}{|c|}{$\begin{array}{l}\text { Relação professor-aluno } \\
\text { Tempo e espaço }\end{array}$} & \multicolumn{3}{|c|}{ Tecnologia e Meios de Comunicação } & \multirow{2}{*}{$\begin{array}{c}\text { Forma } \\
\text { Industrial }\end{array}$} \\
\hline & & $\begin{array}{l}\text { Métodos } \\
\text { didáticos }\end{array}$ & \begin{tabular}{|} 
Estratégias, \\
planejamento, \\
organização. \\
\end{tabular} & & $\begin{array}{l}\text { Separação } \\
\text { Distância }\end{array}$ & $\begin{array}{c}\text { Contínuo } \\
\text { com graus }\end{array}$ & $\begin{array}{c}\text { Reunião } \\
\text { presencial }\end{array}$ & Meios & $\begin{array}{l}\text { bidirecional } \\
\text { interatividade }\end{array}$ & massiva & \\
\hline-1960 Charles Wedemeyer & 1 & & & 1 & 1 & & & 1 & & & \\
\hline -1967 G. Dohmem & 1 & & 1 & 1 & 1 & & & 1 & & & \\
\hline \begin{tabular}{|l|l|}
-1973 & O. Peters \\
\end{tabular} & & & & & 1 & & & 1 & & 1 & 1 \\
\hline -1973 Michael Moore & 1 & & & 1 & 1 & & & 1 & & & \\
\hline \begin{tabular}{ll|l|}
-1977 & B. Holmberg \\
\end{tabular} & 1 & & 1 & & 1 & & & & & & \\
\hline -1979 Norman Mackenzie & 1 & & & & 1 & & & 1 & & & \\
\hline -1979 Jaume Sarramona & & & 1 & 1 & 1 & & & & & & \\
\hline -1980 Pío Navarro Alcalá & & & 1 & 1 & 1 & & & 1 & 1 & & \\
\hline -1981 M.L. OCHOA & 1 & & & & 1 & & & 1 & & 1 & \\
\hline -1982 Miguel Casas Armengol & & & & & 1 & & & 1 & 1 & & \\
\hline $\begin{array}{l}-1983 \text { Gustavo Cirigliano } \\
\end{array}$ & 1 & 1 & & & 1 & 1 & 1 & 1 & & & \\
\hline -1984 Ricardo Marín Ibáñez & & & & & 1 & & & 1 & & & \\
\hline -1984 Victor Guedez & & & & & 1 & & & 1 & & & \\
\hline \begin{tabular}{l|l|}
-1985 & France Henri \\
\end{tabular} & 1 & & & & 1 & & & & & & \\
\hline -1985 Miguel Ramón Martinez & 1 & & & & 1 & & & 1 & & & \\
\hline-1985 Holmberg & 1 & 1 & 1 & 1 & 1 & & & 1 & 1 & 1 & 1 \\
\hline -1986 José Luís García Llamas & & & & & 1 & & & 1 & & & \\
\hline-1986 Ibanês & 1 & & 1 & & 1 & & & 1 & 1 & 1 & 1 \\
\hline -1986 Dereck Rowntree & & 1 & & & 1 & & & & & & \\
\hline -1987 Perry \& Rumble & & & & 1 & 1 & & & 1 & 1 & & \\
\hline -1990 Pomenta, José Silvio. & 1 & & & & & & & & & & \\
\hline -1991 D. Keegan & & 1 & 1 & 1 & 1 & & 1 & 1 & 1 & & 1 \\
\hline -1991 European Community & 1 & 1 & 1 & 1 & 1 & & 1 & 1 & 1 & & \\
\hline -1995 Holmberg & 1 & & 1 & 1 & 1 & & & 1 & 1 & & \\
\hline -1995 Tony Bates & 1 & & & & 1 & & & & & & \\
\hline -1995 Marta Mena & & & 1 & & 1 & & & 1 & & & \\
\hline-1996 Pretti & & & & & 1 & & & 1 & & & \\
\hline \begin{tabular}{|l|l|}
-1996 & Michael Moore earsley \\
\end{tabular} & & 1 & 1 & & 1 & & & 1 & & & \\
\hline -1996 Daniel. & 1 & & & 1 & 1 & & & 1 & 1 & & \\
\hline-1997 (USDLA) & & & & & 1 & & & 1 & & & \\
\hline
\end{tabular}




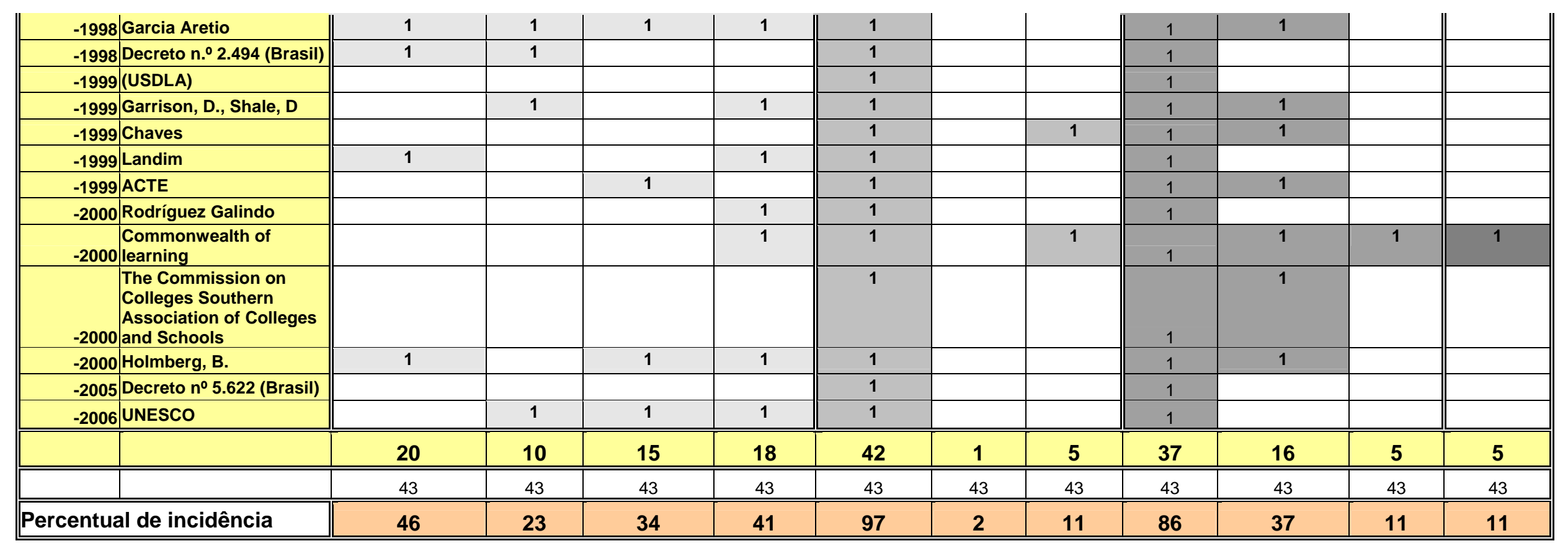

Tabela 7: Tabulação de dados de 43 definições de EaD, de 1960 A 2006 
2.7) Tabulação de dados de 22 definições de EaD, de 1991 A 2006

\begin{tabular}{|c|c|c|c|c|c|c|c|c|c|c|c|c|}
\hline & \multirow[t]{2}{*}{ Categorias } & \multicolumn{4}{|c|}{$\begin{array}{l}\text { Pedagógico } \\
\text { Didático }\end{array}$} & \multicolumn{3}{|c|}{$\begin{array}{l}\text { Relação professor-aluno } \\
\text { Tempo e espaço }\end{array}$} & \multicolumn{3}{|c|}{ Tecnologia e Meios de Comunicação } & \multirow{2}{*}{$\begin{array}{c}\text { Forma } \\
\text { Industrial }\end{array}$} \\
\hline & & $\begin{array}{c}\text { Autonomia } \\
\text { Aprendizagem } \\
\text { independente }\end{array}$ & $\begin{array}{l}\text { Métodos } \\
\text { didáticos }\end{array}$ & $\begin{array}{c}\text { Estratégias, } \\
\text { planejamento, } \\
\text { organização. }\end{array}$ & $\begin{array}{l}\text { Tutoria ou } \\
\text { supervisão }\end{array}$ & \begin{tabular}{|l} 
Separação \\
Distância
\end{tabular} & $\begin{array}{c}\text { Contínuo } \\
\text { com } \\
\text { graus }\end{array}$ & $\begin{array}{c}\text { Reunião } \\
\text { presencial }\end{array}$ & Meios & $\begin{array}{c}\text { bidirecional } \\
\text { interatividade }\end{array}$ & massiva & \\
\hline-1991 & D. Keegan & & 1 & 1 & 1 & 1 & & 1 & 1 & 1 & & 1 \\
\hline-1991 & European Community & 1 & 1 & 1 & 1 & 1 & & 1 & 1 & 1 & & \\
\hline-1995 & Holmberg & 1 & & 1 & 1 & 1 & & & 1 & 1 & & \\
\hline-1995 & Tony Bates & 1 & & & & 1 & & & & & & \\
\hline-1995 & Marta Mena & & & 1 & & 1 & & & 1 & & & \\
\hline-1996 & Pretti & & & & & 1 & & & 1 & & & \\
\hline-1996 & \begin{tabular}{|l|}
$\begin{array}{l}\text { Michael Moore e } \\
\text { Kearsley }\end{array}$ \\
\end{tabular} & & 1 & 1 & & 1 & & & 1 & & & \\
\hline-1996 & Daniel. & 1 & & & 1 & 1 & & & 1 & 1 & & \\
\hline-1997 & (USDLA) & & & & & 1 & & & 1 & & & \\
\hline-1998 & Garcia Aretio & 1 & 1 & 1 & 1 & 1 & & & 1 & 1 & & \\
\hline-1998 & Decreto n. ${ }^{\circ} 2.494$ (Brasil) & 1 & 1 & & & 1 & & & 1 & & & \\
\hline-1999 & (USDLA) & & & & & 1 & & & 1 & & & \\
\hline-1999 & Garrison, D., Shale, D & & 1 & & 1 & 1 & & & 1 & 1 & & \\
\hline-1999 & Chaves & & & & & 1 & & 1 & 1 & 1 & & \\
\hline-1999 & Landim & 1 & & & 1 & 1 & & & 1 & & & \\
\hline-1999 & ACTE & & & 1 & & 1 & & & 1 & 1 & & \\
\hline-2000 & Rodríguez Galindo & & & & 1 & 1 & & & 1 & & & \\
\hline-2000 & $\begin{array}{l}\text { Commonwealth of } \\
\text { learning }\end{array}$ & & & & 1 & 1 & & 1 & 1 & 1 & 1 & 1 \\
\hline-2000 & $\begin{array}{l}\text { The Commission on } \\
\text { Colleges Southern } \\
\text { Association of Colleges } \\
\text { and Schools } \\
\end{array}$ & & & & & 1 & & & 1 & 1 & & \\
\hline-2000 & Holmberg, B. & 1 & & 1 & 1 & 1 & & & 1 & 1 & & \\
\hline-2005 & Decreto $n^{\circ} 5.622$ (Brasil) & & & & & 1 & & & 1 & & & \\
\hline-2006 & UNESCO & & 1 & 1 & 1 & 1 & & & 1 & & & \\
\hline & & 8 & 7 & 9 & 11 & 22 & 0 & 4 & 21 & 11 & 1 & 2 \\
\hline & & 22 & 22 & 22 & 22 & 22 & 22 & 22 & 22 & 22 & 22 & 22 \\
\hline Percentua & al de incidência & 36 & 31 & 40 & 50 & 100 & 0 & 18 & 95 & 50 & 4 & 9 \\
\hline
\end{tabular}

Tabela 8: Tabulação de dados de 22 definições de EaD, de 1991 A 2006 


\section{Capítulo 3}

\section{Educação a distância no ensino superior global -}

\section{Mega Open-Universities}

\section{1) Panorama Geral}

Nos últimos 10 anos, 106 países têm oferecido cursos de educação a distância. Esses cursos estão distribuídos nos diferentes continentes da seguinte forma: 28 países na América Latina e no Caribe; 29 na África; 5 no Oriente Médio; 21 na Ásia e 23 na Europa. ${ }^{140}$ (UNESCO, 2004)

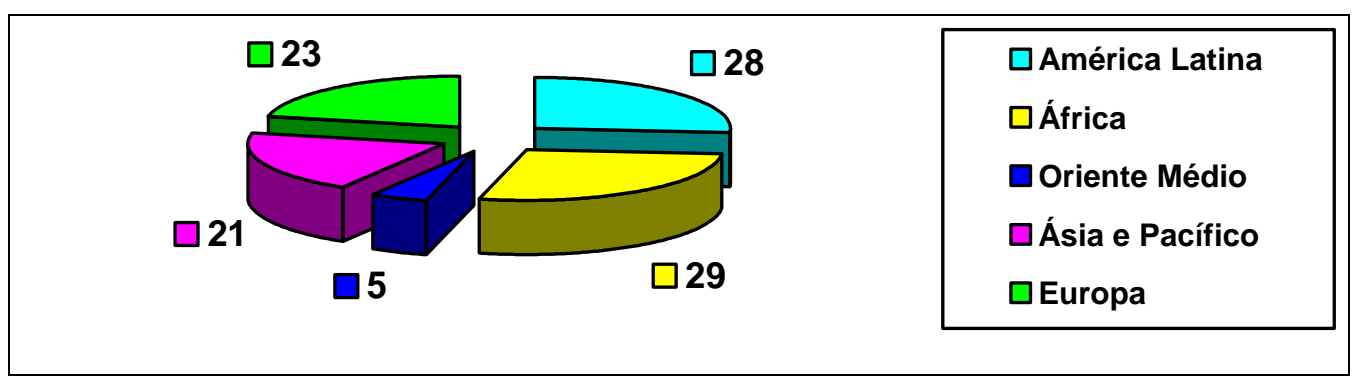

Gráfico 2: 106 países e territórios que ofereceram cursos de EaD nos últimos 10 anos $^{141}$

Segundo o CNED, no mundo, aproximadamente "80 milhões de pessoas estudam na modalidade de educação a distância" ${ }^{142}$, considerando-se os diversos formatos e suportes (material impresso, TV, rádio, on-line ou as formas híbridas), bem como todos

\footnotetext{
${ }^{140}$. Em: $<$ http://www.unesco.org/iiep/eng/training/virtual/distance.htm>. Acesso em: 30 nov. 2004.

141 Fonte UNESCO. Instituto para o planejamento educacional (IIEP). Distance Education Courses. 2004. Na América Latina: Argentina, Aruba, Bahamas, Barbados, Belize, Bolívia, Brasil, British Virgin Islands, Ilhas Caiman, Chile, Colômbia, Costa Rica, Dominica, Republica Dominicana, Equador, Granada, Haiti, Honduras, Jamaica, Netherlands Antilles, Panamá, Peru, Saint Kitts and Nevis, Saint Lucia, Saint Vincent and the Grenadines, Suriname, Trinidad and Tobago, Uruguai.

Na África: Burkina Faso, Burundi, Cameron, Central African Republic, Congo, Djibouti, Eritrea, Ethiopia, Gâmbia, Ghana, Guinea, Guinea-Bissau, Kenya, Lesotho, Madagascar, Malawi, Mauritius, Mozambique, Namíbia, Niger, Nigéria, Rwanda, Seychelles, South África, Swaziland, United Republic Of Tanzânia, Togo, Zâmbia, Zimbabwe. No Oriente Médio: Egypt, Jordan, Morocco, Palestinian Authority, Sudan

Na Ásia e o Pacifico: Bangladesh, Cambodia, China, Democratic People's Republic Of Korea, India, Indonesia, Iran, Lao People's Democratic Republic, Malaysia, Maldives, Mongolia, Nepal, Pakistan, Palau, Philippines, Samoa, Solomon Islands, Sri Lanka, Thailand, Tonga, Viet Nam

Na Europa: Andorra, Belgium, Croatia, Estonia, France, Germany, Hungary, Iceland, Israel, Italy, Latvia, Lithuania, Netherlands, Poland, România, Russian Federation, Slovakia, Slovenia, Spain, Sweden, Turkey, Ukraine, United Kingdom

${ }^{142}$ Disponível em: <//www.cned.fr> Acesso em: 17 set. 2004.
} 
os propósitos educacionais: formações universitária, não universitária, formal, não formal, etc.

\subsection{Panorama no Ensino Superior}

O crescimento da educação a distância tem sido tal que, já nos anos 90, existiam as denominadas "megauniversidades", conceito cunhado por Daniel em 1996, que utilizou como critério para assim classificá-las a matrícula de 100 mil alunos anuais. Já em 1995, Daniel identificou onze $\operatorname{casos}^{143}$, descritos na tabela abaixo:

\begin{tabular}{|c|c|c|c|c|}
\hline País & Nome da Instituição & $\begin{array}{l}\text { Fundada } \\
\text { em }\end{array}$ & $\begin{array}{l}\text { Estudantes em } \\
\text { programas de } \\
\text { graduação } 1995\end{array}$ & $\begin{array}{l}\text { Graduados por ano } \\
1995\end{array}$ \\
\hline China & China TV University System & 1979 & 530.000 & 101.000 \\
\hline France & $\begin{array}{l}\text { Centre national } \\
\text { d'enseignement à distance }\end{array}$ & 1939 & 184.614 & 28.000 \\
\hline Índia & $\begin{array}{l}\text { Indira Gandhi National Open } \\
\text { University }\end{array}$ & 1985 & 242.000 & 9.250 \\
\hline Indonesia & Universitas Terbuka & 1984 & 353.000 & 28.000 \\
\hline Iran & Payame Noor University & 1987 & 117.000 & 7.563 \\
\hline Korea & $\begin{array}{l}\text { Korea National Open } \\
\text { University }\end{array}$ & 1982 & 210.578 & 11.000 \\
\hline $\begin{array}{l}\text { South } \\
\text { Africa }\end{array}$ & University of South Africa & 1873 & 130.000 & 10.000 \\
\hline Spain & $\begin{array}{l}\text { Universidad Nacional de } \\
\text { Educación a Distância }\end{array}$ & 1972 & 110.000 & 2.753 \\
\hline Thailand & $\begin{array}{l}\text { Sukhothai Thammathirat Open } \\
\text { University }\end{array}$ & 1978 & 216.800 & 12.583 \\
\hline Turkey & Anadolu University & 1982 & 577.804 & 26.321 \\
\hline $\begin{array}{l}\text { United } \\
\text { Kingdom }\end{array}$ & Open University & 1969 & 157.450 & 18.359 \\
\hline
\end{tabular}

Tabela 9: Estudos de Casos descritos por Daniel. Fonte: Adaptada de J.S. Daniel, 1996, Mega Universities and Knowledge Media: Technology Strategies for Higher Education (London: Kogan Page)

Porém, desde então, muito mudou na educação superior mundial. Em primeira instância, podemos citar o forte crescimento dessas universidades; a seguir, o surgimento de novas categorias dentro do conceito de megauniversidade, como resultam ser as universidades digitais; e, em terceiro lugar, o surgimento de novos papéis das

\footnotetext{
${ }^{143}$ Daniel, John. Mega-universities = Mega-impact on Access, Cost and Quality. UNESCO. First Summit of Megauniversities, Shanghai, China, 7-9 November 2003. In: UNESCO. Disponível em: <

http://portal.unesco.org/education/en/ev.php-URL ID=26277\&URL DO=DO TOPIC\&URL SECTION=201.html > Acesso em: 12 fev. 2006
} 
instituições de educação superior na sociedade do conhecimento e na construção de uma nova estrutura educativa que dê conta das novas demandas da sociedade do conhecimento.

\subsection{Megauniversidades}

Para identificar o estado da arte da educação a distância no mundo, realizamos uma análise das principais megauniversidades dos continentes asiático, africano, europeu e americano, buscando entender a verdadeira dimensão que esta modalidade tem alcançado, suas características mais importantes, suas funções sociais, suas melhores práticas e idéias para enriquecer o acervo de estratégias para a educação a distância latino-americana. Dentro desta perspectiva, a presente tese busca apresentar uma atualização da tabela das megauniversidades, conforme o proposto por Daniel, incorporando algumas universidades consideradas na categoria de 20 a 50 mil alunos e outras na categoria de 50 a 100 mil, que se configuram como modelos pelas estratégias adotadas para resolver as necessidades educativas da população.

\section{4 ÁSIA}

\subsection{1 Índia}

\section{Contexto Nacional}

A Índia possui uma enorme demanda não atendida de educação, que é certamente monumental, quando se considera que o continente indiano cobre quase $2,4 \%$ da área total do mundo e abriga uma população de mais de 1 bilhão de pessoas $(17 \%$ da população mundial). A tarefa é por si só complicada, porém, o cenário é ainda mais complicado se considerarmos que quase $40 \%$ da população tem 15 anos de idade e $75 \%$ dela vive em áreas rurais. A taxa total do analfabetismo estimada em 2001 era de aproximadamente $65 \%$ entre os falantes das 22 línguas oficiais reconhecidas, incluindo o hindi e o inglês.

O crescimento acelerado da população colocou mais pressão sobre o governo para aumentar seus esforços na busca de soluções para o problema. Os intentos por fornecer 
educação universal através dos sistemas convencionais fracassaram e forçaram o governo a procurar formas mais eficientes para fornecer acesso justo e eqüitativo à educação. Por isso não é surpresa que o país tenha investido tão seriamente na educação aberta e a distância.

Até o presente momento, 12 Universidades Estatais Abertas (Open University) ${ }^{144}$ e 70 Institutos de Estudo por Correspondência funcionam na Índia, atendendo a um contingente de 20 milhões de alunos ${ }^{145}$. Esses institutos, em geral, fazem parte de universidades convencionais, que têm procurado incorporar a educação a distância às suas estruturas. Os estudantes desta modalidade estudam os mesmos conteúdos e recebem os mesmos diplomas que os alunos convencionais.

Mas isso não é tudo. Também existem enormes esforços do governo indiano para fornecer educação geral à população através de sistemas abertos e a distância. A Índia estabeleceu em 1989 o Instituto Nacional de Educação Aberta (NIOS), para prover continuidade ao desenvolvimento da educação a todas as pessoas com cursos de educação geral, educação para a vida, vocacionais de nível escolar, entre outros, tendo como alguns de seus objetivos fornecer educação para todos, oferecer oportunidades educativas em consonância com valores de igualdade e eqüidade e, ainda, colaborar com o desenvolvimento da sociedade da aprendizagem.

\footnotetext{
${ }^{144}$ Dr. B.r. ambedkar open university (braou), hyderabad, a.p.; vardhman mahaveer open university (vmou), kota, rajasthan; nalanda open university (nou). Patna, bihar; yashwantrao chavan maharahstra open university (ycmou), nashik, maharashtra; madhya pradesh bhoj open university (mpbou), bhopal, m.p.; dr. Babasaheb ambedkar open university (baou), ahmedabad, u.p; karnataka state open university (ksou), mysore, karnataka; netaji subhas open university (nsou), kolkata, w.b; u.p. rajarshi tandon open university (uprtou), allahabad, u.p; tamil nadu open university (tnou), chennai, tamil nadu; pt. Sunderlal sharma open university (pssou), bilaspur, chhattisgarh; uttaranchal open university, haldwani-263141, nainital.

${ }^{145}$ STRIDE, Handbook 2, Effective Learning, A Practical Guide for Open and Distance Learners. How to Study prepared by B. N. Koul and K. Murugan (1989). The present version was published in 2002 under the coordination of Sanjaya Mishra, who has also prepared the web version of this Handbook. Section 2: Open and Distance Learning in Índia.
} 


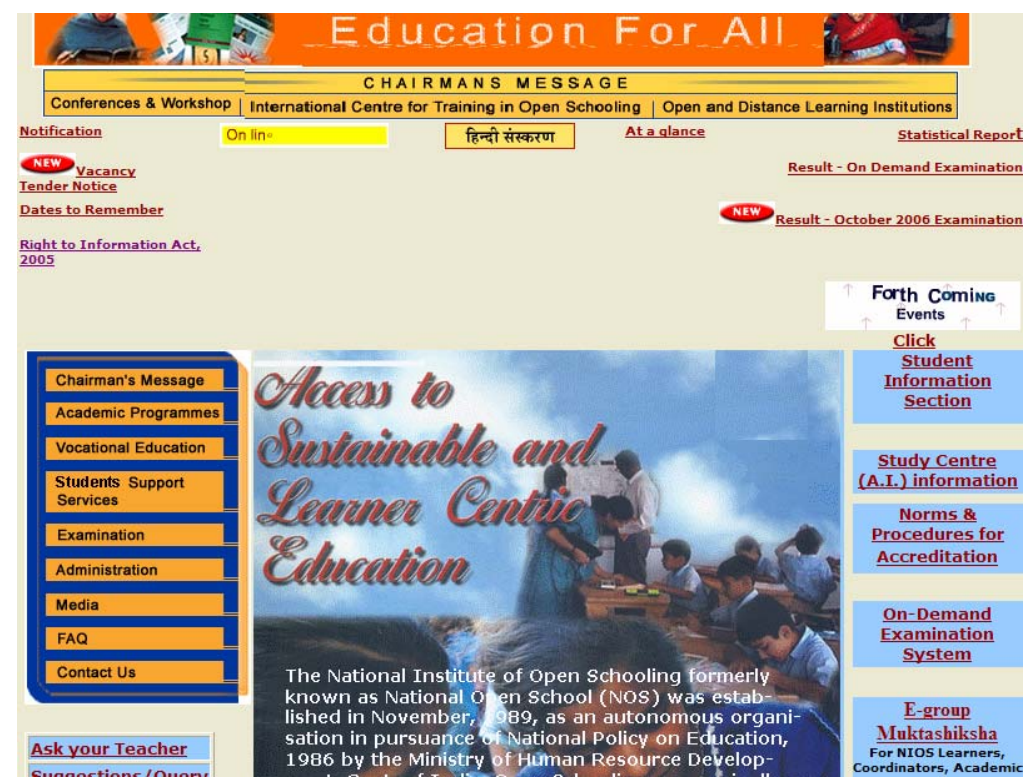

Figura 1: Web site do Instituto Nacional de Educação Aberta (NIOS). Fonte: NIOS. Disponível em: http://www.nios.ac.in/\#

Atualmente o Instituto Nacional de Educação Aberta possui aproximadamente 1,3 milhão de estudantes ${ }^{146}$ matriculados (KUMAR,2005).

\section{a) Indira Gandhi National Open University (IGNOU)}

\section{Endereço}

Maidan Garhi

New Delhi

Índia

Telefono: 91-11- 29535115

Fax: 91-11-29533062

\section{Contexto Histórico}

Fundada em 1985 com estatuto de universidade nacional, é considerada a segunda universidade a distância criada na Índia para atender à enorme demanda educativa do país.

\footnotetext{
${ }^{146}$ Disponível em: http://www.ignou.ac.in/icde2005/PDFs/contents.htm. Acessado em 25/03/2006.
} 


\section{Objetivos}

O principal de seus objetivos é democratizar o acesso à educação na Índia, principalmente das populações que tradicionalmente estiveram sem acesso à educação superior: população de baixos recursos e outras que vivem em lugares afastados geograficamente.

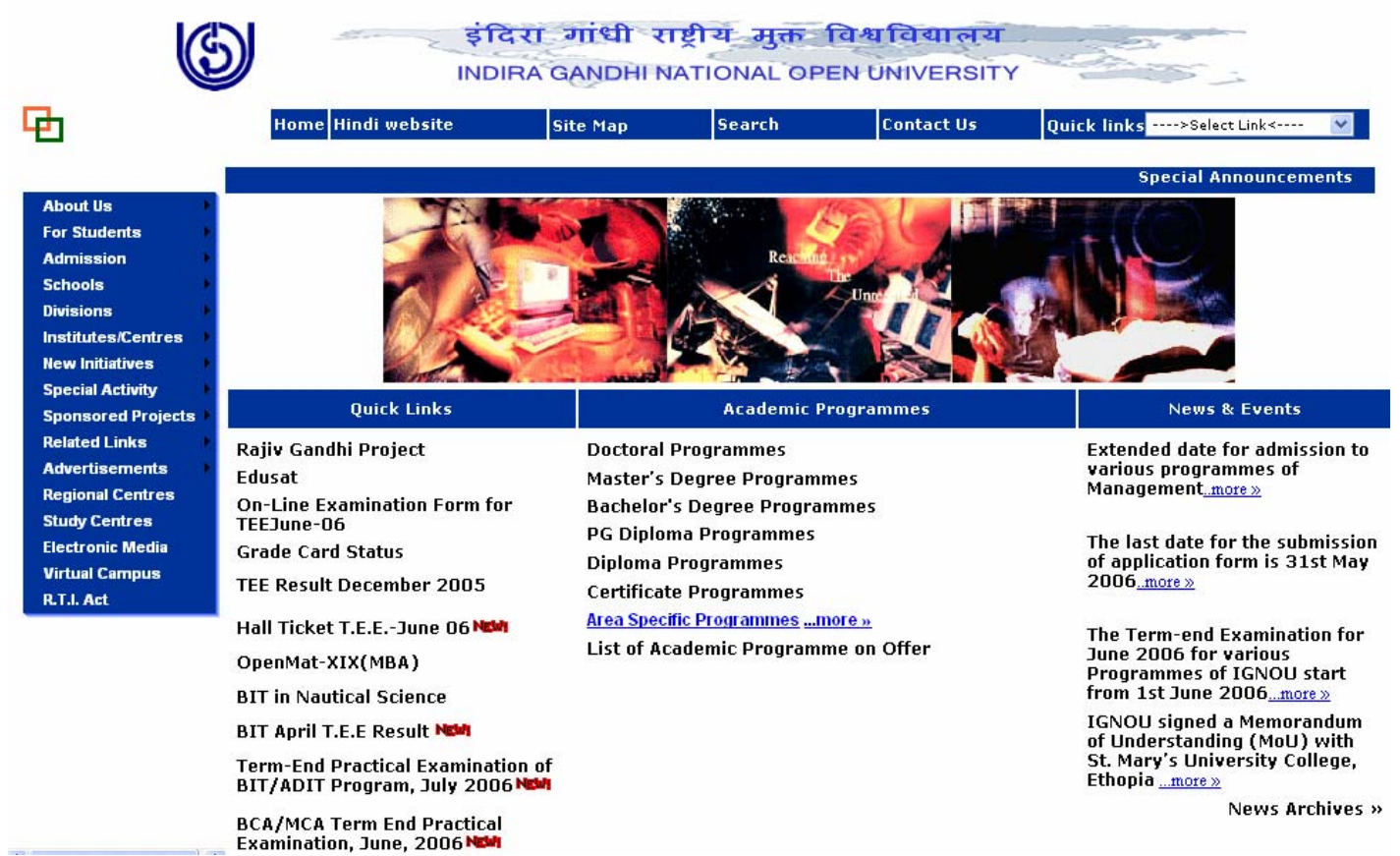

Figura 2: Portal da Indira Gandhi National Open University (IGNOU.

Fonte: Indira Gandhi National Open University. Disponível em:< http://www.ignou.ac.in/>. Acesso em: 27. Junho 2006

\section{Público-alvo}

A Indira Gandhi National Open University é hoje considerada como uma das maiores universidades abertas do mundo, com uma matrícula acumulada, desde a sua fundação, de mais de 1.5 milhão de alunos, em mais de 30 países. Atende a 13\% dos alunos do sistema de educação superior da Índia e a mais de 50\% dos alunos que estudam na modalidade a distância, fato que nos dá uma referência da sua magnitude.

A análise realizada sobre a evolução da inscrição anual de alunos ${ }^{147}$ revela um forte crescimento. Nos seus primeiros nove anos a faculdade cresceu em um ritmo assombroso, passando de 4.528 alunos anuais, em 1987, a 91.398, em 1995, o que

\footnotetext{
${ }^{147}$ A tradução da palavra enrolment pode ser entendida tanto como inscrição como matrícula, porém depreendemos que existe uma diferença entre ambos conceitos. Inscrição, neste estudo, será entendida como a quantidade de alunos que ingressam ano a ano na universidade; já matrícula terá como sentido privilegiado a quantidade de alunos ativos existentes nesse período.
} 
resulta em um percentual de crescimento de $884 \%$, com uma média de crescimento anual de $28,92 \%$. Nos últimos nove anos de existência, a tendência de crescimento continua em aumento, mas a um ritmo menor, passando de 91.398 alunos, em 1995, a 492.542 estudantes em 2006, refletindo um percentual de crescimento de $439 \%$ e uma média de crescimento anual de $16,55 \%$.

É importante assinalar que, desde a sua fundação até 2006, a faculdade cresceu 10.778\%, em 19 anos de existência, com uma média de crescimento anual de 27,99\%, conforme mostra a tabela 4 .

\section{$\square$ Inscrição anual de alunos}

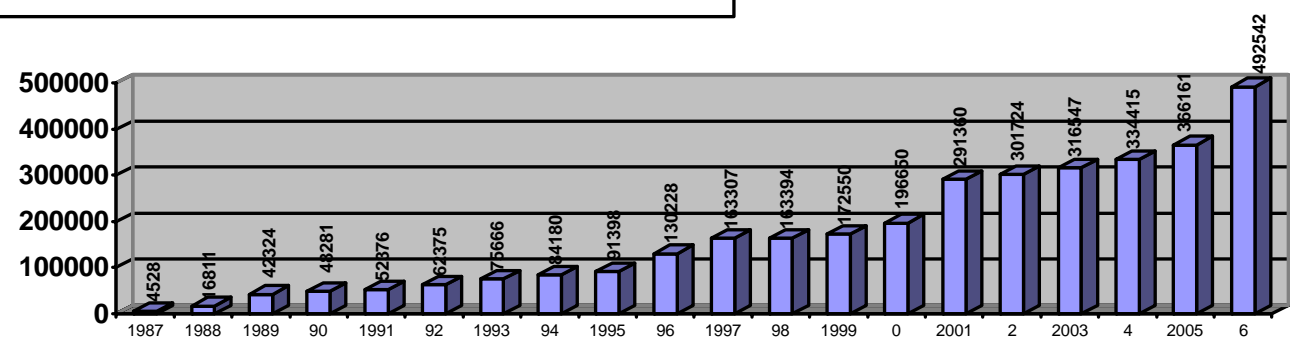

Gráfico 3: Growth of IGNOU Fresh Enrolment of Students over the year. Fonte: Indira Gandhi National Open University. Profile 2006.

Seu número de graduados anuais também reflete um crescimento de mais de $6.320 \%$, desde seus 1.171 da primeira promoção, em 1990 , aos 75.174 na sua $17^{\mathrm{a}}$ promoção, em 2005, com uma média de crescimento anual de 27,74\%. Desde a sua criação até 2006 , já formou 614.668 alunos, como pode ser observado na tabela 5. 


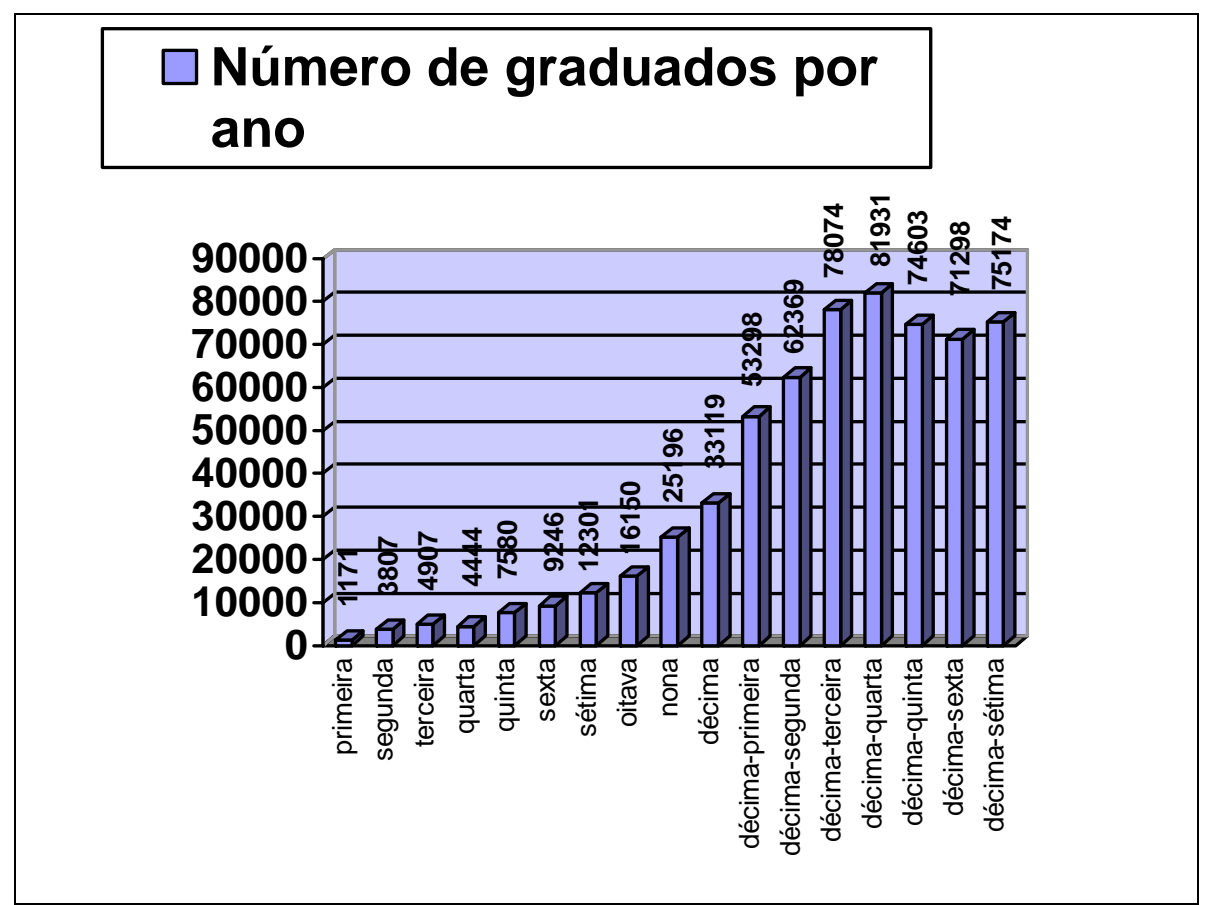

Gráfico 4: Crescimento das graduações outorgadas pela IGNOU. Fonte: Indira Gandhi National Open University. Profile 2006.

A evasão da universidade é sumamente alta, segundo estudos de Fozdar e Kumar $(2006)^{148}$. O índice de evasão do primeiro ao segundo ano é o maior, alcançando 51,7\%, em média; destes, aproximadamente $73 \%$ se matricularam no terceiro ano, o que significa que, após o primeiro ano, apenas $37,1 \%$ do total dos estudantes matricularamse no terceiro ano do programa, ou seja, um grande número de estudantes $(62,9 \%)$ não está terminando seus estudos.

\section{$\square 1^{\circ}$ ano $\square 2^{\circ}$ ano $\quad \square 3^{\circ}$ ano}

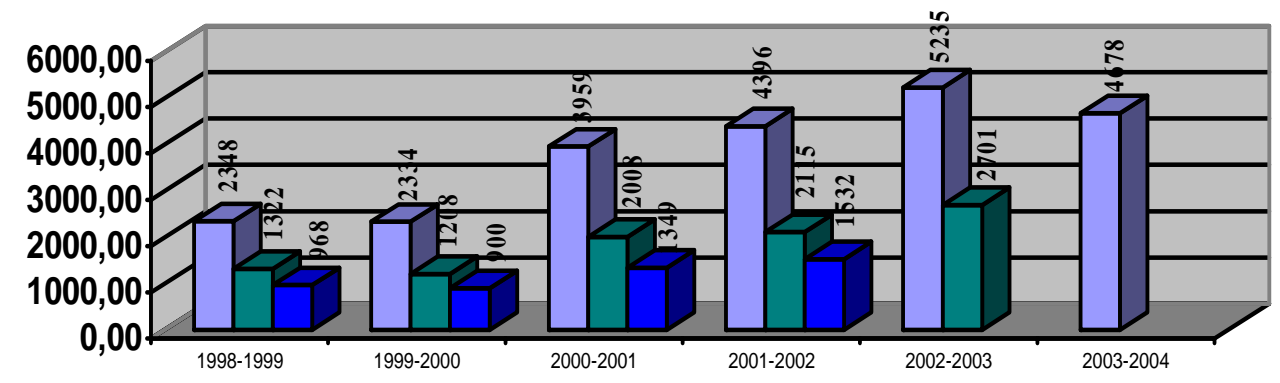

Gráfico 5: Registro de admissão e teste padrão dos últimos seis anos (Fonte Fozdar e Kumar, 2006).

\footnotetext{
${ }^{148}$ Disponível em: www.irrodl.org/index.php/irrodl/article/viewPDFInterstitial/291/755. Acesso em: Acesso em: 21 out. 2006.
} 
As pesquisas destes autores, feita sob a forma de entrevista com uma mostra de alunos que não terminaram seus estudos, indicam que as razões expostas para justificar sua desistência são:

- o centro de estudo fica longe demais $(64,70 \%)$

- insuficiente suporte acadêmico do centro de estudos $(58,82 \%)$

- o tempo consomido para estudar todas as disciplinas (55,88 \%)

- dificuldade em assistir às sessões de laboratório devido à distância geográfíca $(52,94 \%)$

- ausência de interação com outros estudantes, dificuldade em estudar ciência a distância, dificuldades sentidas com os exames finais, número insuficiente de encontros presenciais e falta de responsabilidade do centro de estudos $(47,06 \%)$

\section{Recursos Humanos e Materiais}

A IGNOU conta com uma equipe que totaliza mais de 48.000 conselheiros acadêmicos, que trabalham em serviços de tutoria para dar suporte às atividades de ensino e aprendizagem dos alunos, o que significa uma média de 20 alunos por professor, demonstrando a importância dada à tutoria no processo de aprendizagem.

Além disso, em termos de infra-estrutura, a IGNOU desenvolveu um portal de apoio às suas atividades de comunicação entre professores, alunos e instituição. Por meio deste portal de serviços, é possível ter acesso a informações administrativas. Os arquivos acadêmicos trazem geralmente a relação de materiais educacionais que podem ser utilizados via computador, o guia acadêmico relativo às matérias ministradas, a relação de grupos de discussão, um boletim informativo, diretório de empregos e bolsas de estudos, relação de centros de apoio à aprendizagem, além de livros recomendados para estudos complementares, como aponta o acesso ao endereço eletrônico: http://www.ignou.ac.in/ . 


\section{Cursos oferecidos}

A oferta de cursos da Universidade é variada. Abrange desde os clássicos cursos de graduação, mestrado e doutorado, atá cursos vocacionais e de extensão universitária dirigidos a treinamento profissional, com o objetivo de colaborar com $\mathrm{o}$ desenvolvimento socioeconômico das populações de baixa renda. Os cursos da Universidade são organizados em escolas:

- Escola de Computação - graduação e mestrado em computação; graduação em tecnologia da informação; diploma avançado em informática e certificado em computação.

- Escola de Educação - os cursos de doutorado em filosofia, graduação em educação, diploma em educação primária e graduação em educação superior, entre outros.

- Escola de Educação Continuada - os cursos de graduação, pós-graduação e certificação em desenvolvimento rural e trabalho social; diploma avançado e certificação em AIDS e educação familiar; diploma em nutrição e educação para a saúde, diploma em cuidados de crianças pequenas e educação, certificado em alimentação e nutrição, certificado de assistência na infância, certificado de facilitadoras de grupos de auto-ajuda para a mulher, pós-graduação em jornalismo e meios de comunicação, produção de rádio, segurança alimentar, entre outros.

- Escola de Engenharia - cursos de graduação, diplomas avançados e diplomas em engenharia civil, náutica, de construções, de água, mecânica, elétrica.

- Escola de Ciências da Saúde - graduações em enfermagem, cuidados maternoinfantis, administração hospitalar, medicina geriátrica, saúde e meio ambiente, em cuidados da saúde e lixo, cardiologia, entre outros.

- Escola de Humanidades - graduações e pós-graduações em inglês, hindi, cursos de tradutor, roteirista de $\mathrm{TV}$, roteirista de rádio, entre outros. 
- Escola de Administração - cursos de graduação e pós-graduação em administração de empresas, recursos humanos, administração financeira, administração de operações, administração em marketing, entre outros.

- Escola de Ciências - graduação em ciência, pós-graduação em desenvolvimento sustentável, doutorado em física, doutorado em matemática; certificados em professorado de matemáticas para ensino primário, técnicas de laboratório e propriedade intelectual, entre outros.

- Escola de Ciências Sociais - doutorados em filosofia, ciência política, economia, sociologia e administração pública, entre outros.

O número de cursos tem crescido paralelamente ao crescimento da universidade, passando de 2 programas e 13 cursos no biênio 1986-87 a 88 programas e 820 cursos em 2004 (ver anexo 1), alcançando um percentual de crescimento de $4.300 \%$ em programas e de $6.210 \%$ em cursos.

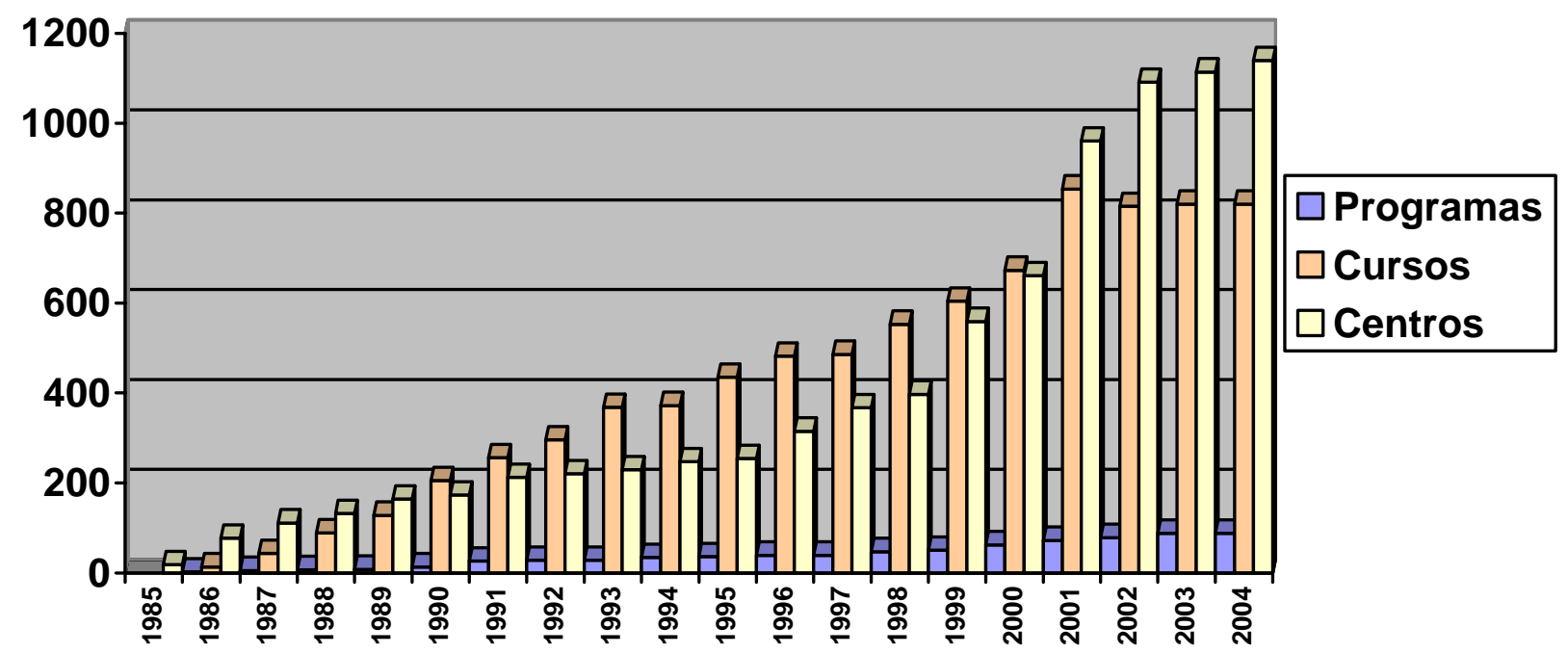

Gráfico 6: Crescimento anual, programas, cursos e centros da IGNOU. Fonte: IGNOU 2004. Tabela adaptada

\section{Sistema de estudo}

O sistema de estudo é flexível, tanto no que se refere ao ingresso como à duração dos estudos. A licenciatura, por exemplo, pode ser cursada em um mínimo de três anos e em um máximo de oito. O sistema de credenciamento se baseia no fator horas de estudo: 1 crédito equivale a $30 \mathrm{~h}$ de estudos, incluindo todas as atividades de aprendizagem. Os 
estudantes podem concluir seus créditos, que podem ser transferidos para qualquer outra universidade, em qualquer momento de seus estudos, da forma e no tempo mais adequado às suas necessidades e capacidades (PORTAL IGNOU) ${ }^{149}$.

\section{Materiais de estudos e estratégia instrucional}

Do ponto de vista instrucional, a universidade tem evoluindo muito, passando por todas as gerações de ensino a distância. Esta evolução das gerações tem sido integrada de acordo com o crescimento da universidade, como se observa na tabela 7. De 1987 a 1989, a universidade trabalhou com a primeira e a segunda gerações; entre os anos de 1990 a 1992, somou às primeiras gerações a terceira, com a utilização do rádio, bem como, entre os anos de 1993 a 1995, adotou o uso da teleconferência; por fim, entre os anos de 1996 e 2001, começou a trabalhar já com um modelo multimídia, integrando, posteriormente, nesta internet, CDs e plataformas de ensino a distância.

\begin{tabular}{|c|c|c|c|c|c|c|c|}
\hline \multicolumn{2}{|c|}{$\begin{array}{l}\text { Primeira fase } \\
\text { (1987 a 1989) }\end{array}$} & \multicolumn{2}{|c|}{$\begin{array}{l}\text { Segunda fase } \\
\text { (1990 to 1992) }\end{array}$} & \multicolumn{2}{|c|}{$\begin{array}{c}\text { Terceira fase } \\
\text { (1993 to 1995) }\end{array}$} & \multicolumn{2}{|c|}{$\begin{array}{c}\text { Quarta fase } \\
\text { (1996 to 2001) }\end{array}$} \\
\hline impressa & $\begin{array}{l}\text { Primeira } \\
\text { geração }\end{array}$ & $\begin{array}{c}\text { Mídia } \\
\text { eletrônica } \\
\text { de massas } \\
\text { Rádio }\end{array}$ & $\begin{array}{l}\text { Terceira } \\
\text { geração } \\
\text { (Modelo } \\
\text { de Tele- } \\
\text { educação }\end{array}$ & $\begin{array}{l}\text { Mídia Satelital } \\
\text { Conferências. } \\
\text { Telecursos }\end{array}$ & $\begin{array}{c}\text { Terceira } \\
\text { geração } \\
\text { Modelo de } \\
\text { Tele- } \\
\text { educação }\end{array}$ & $\begin{array}{l}\text { Internet, } \\
\text { CDs, } \\
\text { e-mail, } \\
\text { website }\end{array}$ & $\begin{array}{l}\text { Quarta } \\
\text { geração } \\
\text { (Modelo } \\
\text { flexível ) }\end{array}$ \\
\hline $\begin{array}{l}\text { Mídia } \\
\text { eletrônica: } \\
\text { áudio, vídeo, }\end{array}$ & $\begin{array}{l}\text { Segunda } \\
\text { geração } \\
\text { modelo } \\
\text { multimídia }\end{array}$ & \multicolumn{2}{|c|}{$\begin{array}{l}\text { Experiências Práticas } \\
\text { Laboratórios } \\
\text { Programa de contatos }\end{array}$} & \multicolumn{2}{|c|}{ Atividades em campo } & \multicolumn{2}{|c|}{$\begin{array}{c}\text { Tutoria interativa pelo } \\
\text { rádio }\end{array}$} \\
\hline $\begin{array}{c}\text { Ensino } \\
\text { baseado no } \\
\text { computador. }\end{array}$ & & \multicolumn{2}{|c|}{$\begin{array}{l}\text { Mídias da fase } 1 \text { ainda } \\
\text { continuam sendo } \\
\text { utilizadas }\end{array}$} & \multicolumn{2}{|c|}{$\begin{array}{l}\text { Mídias das fases } 1 \text { e } 2 \text { ainda } \\
\text { continuam sendo utilizadas }\end{array}$} & \multicolumn{2}{|c|}{$\begin{array}{c}\text { Mídias das fases } 1,2 \text { e } \\
3 \text { ainda continuam } \\
\text { sendo utilizadas }\end{array}$} \\
\hline
\end{tabular}

Tabela 10: Shift in the instructional media. In IGNOU 1987-2001.

Fonte: IGNOU 2004.

Atualmente, como pode se ver na figura 1, encontram-se todas as gerações integradas, utilizando-se um sistema multimídia flexível que incorpora tanto material impresso, como rádio, vídeo-cassete, $\mathrm{TV}$, práticas em laboratórios, encontros presenciais, sessões de aconselhamento tutorial, teleconferências, entre outros.

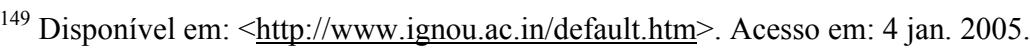


Material impresso e fitas de áudio são entregues entre 2 e 4 por curso, mas, além disso, os cursos contam com rádio interativa com tutores, videocassetes, audiocassetes, teleconferências, aulas por televisão, CD-ROMs e material baseado na web.

$\mathrm{Na}$ universidade o material impresso tem sido a base do desenvolvimento instrucional, para o trabalho teórico e prático das diversas disciplinas de estudo. Cada bloco de material de estudo corresponde a um crédito acadêmico, ou seja a $30 \mathrm{~h}$ de estudo. Os blocos são auto-instrucionais, com uma média de 40 a 80 páginas cada um. O material é preparado por uma equipe de especialistas em nível nacional, de forma muito rigorosa, apresentando não só informação, mas motivação, guia, feedback, etc.

O áudio e o videocassete têm sido parte integral da estratégia instrucional da universidade, buscando as formas de fazer o melhor uso destes recursos. Para isso, cada centro de estudo possui uma lista que os tutores apresentam aos alunos nas reuniões presenciais de discussão de temas. Também há espaços onde os alunos podem ver os materiais, inclusive de forma individual. Além disso, são transmitidos por TV vídeos educativos em horários determinados para o estudo dos alunos que não podem se dirigir ao centro de estudo. Como podemos ver na tabela abaixo, a produção de áudio e vídeocassete tem estado em constante crescimento:

\begin{tabular}{lcc}
\multicolumn{1}{c}{ Ano } & Vídeo & Áudio \\
$1994-1995$ & 512 & 605 \\
$1995-1996$ & 554 & 645 \\
$1996-1997$ & 606 & 659 \\
$1997-1998$ & 729 & 768 \\
$1998-1999$ & 863 & 834 \\
$1999-2000$ & 941 & 984 \\
$2000-01$ & 1102 & 1051 \\
$2001-02$ & 1246 & 1109 \\
$2002-03$ & 1520 & 1235
\end{tabular}

Tabela 11: Crescimento da produção acumulativa de áudio e vídeo-cassete na IGNOU Fonte: Commonwealth of Learning. Perspectives on Distance Education.Educational Media in Asia. Vancouver, 2005, p. 131.

As tutorias por rádio interativa começaram em 1998, com a realização de "pilotos" para avaliar a efetividade da estratégia. Na “All India Radio", estação localizada em Bhopal, em razão do sucesso alcançando, a universidade planejou o crescimento do ano seguinte com 9 estações adicionais. Atualmente o programa abrange 186 estações de rádio em todo o país, principalmente aos domingos. 
Para os programas são convidados especialistas em diversos temas relacionados aos conteúdos programados, os quais, junto aos tutores, atendem às ligações dos alunos no ar, o que gera debate sobre os diversos temas. Essas ligações telefônicas são realizadas por um número de telefone gratuito, à disposição em 80 cidades do país. Assim mesmo, atualmente está em desenvolvimento o plano de concluir a instalação de 40 estações de rádio FM adicionais, estratégia que aproximará ainda mais professores e alunos, tirando ambos do isolamento.

Outra estratégia utilizada pela universidade é a televisão, que tem resultado, na avaliação da universidade, como mais efetiva que o rádio, apesar de seu alcance ser comparativamente mais curto e de pouca disponibilidade do que o rádio. A IGNOUDoordarshan telecast começou a operar em 1991, através da rede nacional de Doordarshan, que também provê teletutoria para estudantes nas áreas mais remotas do país. Em janeiro de 2000, o canal de TV educativa exclusivo da Índia foi lançado conjuntamente pelo Ministério do Desenvolvimento e Recursos Humanos, a Prasar Bharti (corporação boadcasting da Índia) e a IGNOU, responsável pela iniciativa.

A TV educacional transmite aproximadamente 8.760 horas anualmente, cobrindo a maior parte dos conteúdos e programas da IGNOU. O Gyan Darshan tem hoje a capacidade para que três canais desenvolvam programas educacionais. O sucesso da experiência realizada até agora está fazendo com que se analisem ampliações a áreas como agricultura, educação primária e secundária, aproveitando ao máximo os benefícios da tecnologia digital.

Como se fosse pouco, a Índia está em processo de desenvolvimento de um satélite educacional EduSAT, que, quando concluído, possibilitará a implementação de até 70 canais de TV educativa. Como um elemento adicional a esta estratégia, desenvolveu-se uma rede de teleconferência, também em 1991, que foi usada como um elemento adicional de interatividade, para motivar aos alunos, treinar tutores, facilitar o contato com os centros regionais e para trabalhos administrativos.

O sistema funciona disponibilizando materiais pré-elaborados, como vídeos e leituras ou tópicos. Os participantes nas salas de aula espalhadas pelo país possuem capacidade de recepção e de emissão de perguntas gerando um debate. Essa modalidade de interação simula essencialmente um ambiente, como se o processo de aprendizagem 
inteiro estivesse sendo realizado em uma sala de aula prolongada. A universidade pretende promover consideravelmente o uso deste meio, a fim de alcançar os cantos mais remotos do país.

Uma rede muito forte de aproximadamente 500 pontos foi criada nos centros regionais e em centros de estudo da IGNOU, em suas matrizes, nos centros regionais e nos centros de estudo de universidades abertas do estado. A IGNOU pretende trazer os benefícios do melhor professor aos estudantes nos mais obscuros e remotos lugares, criando 1.000 pontos adicionais nos dois próximos anos.

A IGNOU também está se desenvolvendo na área de educação digital via web, com a iniciativa virtual do campus (VCI), que começou a operar em 1999, quando foram lançados dois programas importantes: o BIT (graduação em tecnologia de informação) e o ADIT (diploma avançado em tecnologia de informação).

Basicamente podemos ilustrar o processo instrucional da IGNOU da seguinte forma:

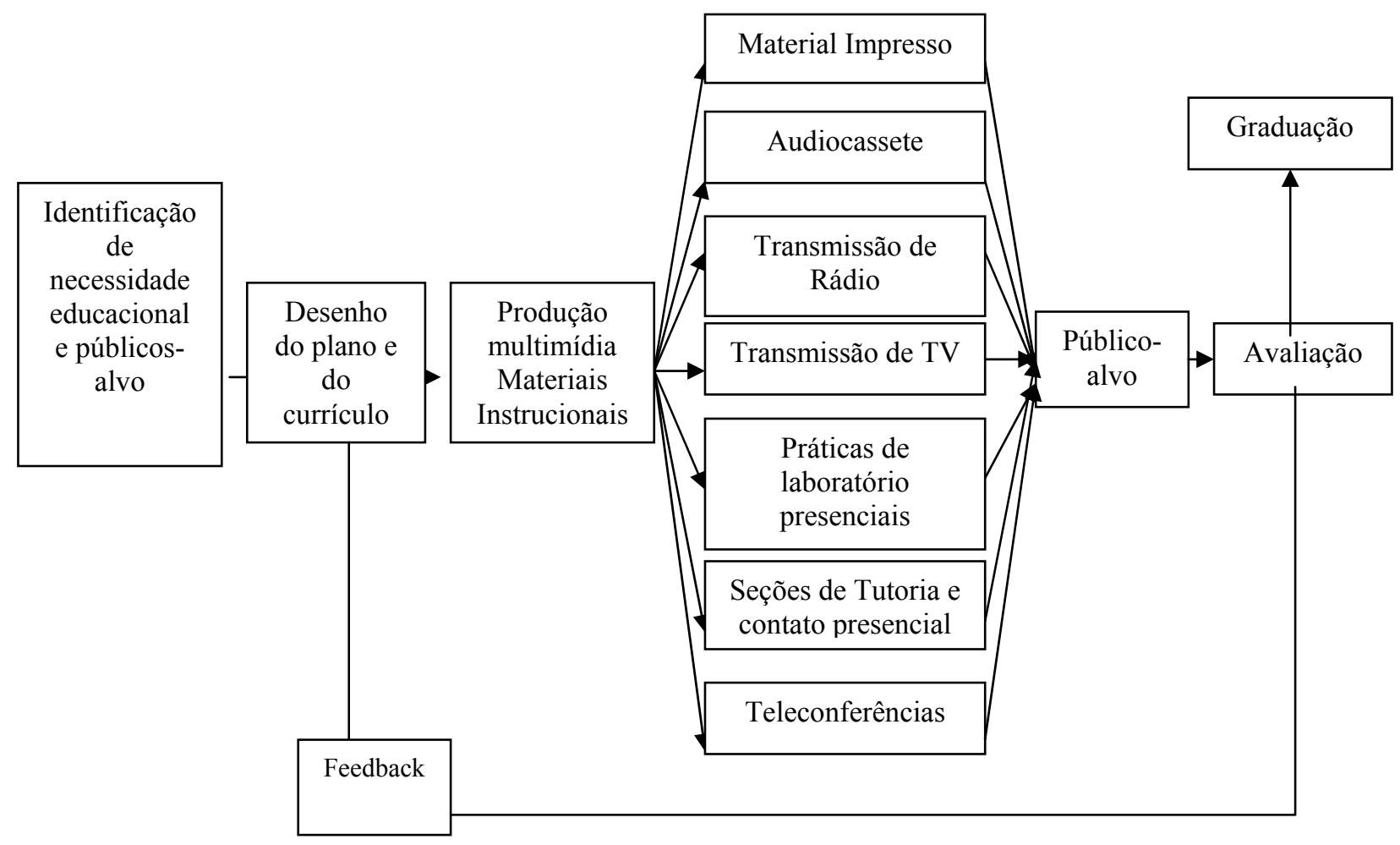

Figura 3: Sistema Instrucional na IGNOU. Fonte: IGNOU 2004.

A Universidade faz uso de rádio interativa e comunicação via satélite e fibra óptica há mais de 10 anos. Atualmente tem em construção um repositório nacional de recursos 
didáticos digitais que suporta a integração de recursos de aprendizagem em formatos diferentes, programas de áudio, vídeo, arquivos de cessões ao vivo, entre outros. Esse repositório estará disponível 24 horas nos 7 dias da semana, 365 ao ano, procurando facilitar o acesso dos alunos. A coleção poderá ser utilizada com sistemas de busca flexíveis, por assunto, por título, por autor, etc. Na primeira fase, todos os recursos de aprendizagem digital disponíveis na IGNOU serão incorporados. Na segunda, será realizada uma pesquisa de todos os materiais que não se encontram em formato digital, mas que, pela sua qualidade, merecem ser digitalizados para ser incorporados ao repositório. Posteriormente a universidade realizará uma pesquisa de todos os materiais desenvolvidos no país por outras instituições para ser incorporados a ele.

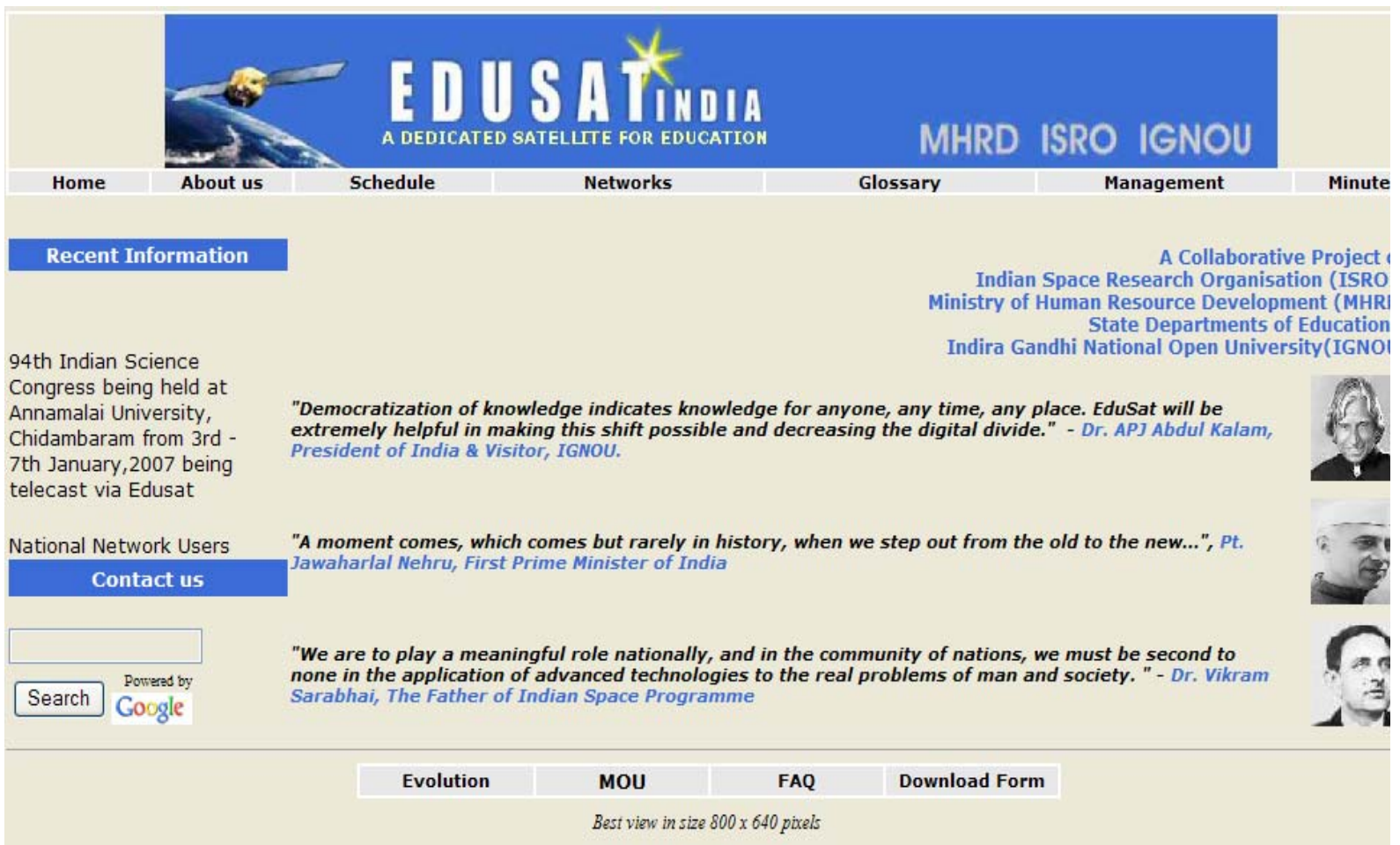

Figura 4: EDUSAT. Disponível em: http://www.edusatindia.org/

\section{Pesquisa}

Em relação à efetividade das estratégias e às práticas da universidade, existe uma série de pesquisas relacionadas aos diferentes suportes de mídia utilizados pela universidade. Os estudos de Basu (2005) ${ }^{150}$, que faz uma análise sobre o grau de satisfação dos alunos sobre os programas da TV educativa através do canal de Doordarshan, permitem ter uma idéia dos problemas mais significativos encontrados, a saber: falta de informação

${ }^{150}$ In:Commonwealth of Learning. Perspectives on Distance Education. Educational Media in Ásia. Vancouver, 2005, p. 131. 
nos alunos sobre a programação do canal, falta de sincronismo na transmissão, inacessibilidade de muitos alunos que possuem TV, e, às vezes, até falta de relevância dos programas em relação aos conteúdos.

Com pesquisas realizadas sobre os programas emitidos por TV a cabo em Modasa, cidade do estado de Gujarat, Chaudhary e Behari (1994) ${ }^{151}$ chegaram à conclusão de que os 20 minutos de duração padrão dos programas eram suficientes para a transmissão dos conteúdos com a qualidade desejada, porém não eram suficientes para gerar os debates com os tutores.

Em suas pesquisas sobre o uso do rádio, Sharma (2002) ${ }^{152}$ analisa a tutoria interativa através desta mídia para analisar a sua efetividade. Em função do grau de satisfação que encontrou nos alunos em relação ao nível dos conteúdos e da sua clareza, recomenda o autor que todos os programas de educação a distância adotem a tutoria por rádio interativa. Na mesma linha de pesquisa, Sukumar $(2001)^{153}$, que estudou a utilização de tutoria por rádio interativa nos programas da IGNOU na jurisdição de Cochin, ratifica, em função dos resultados por ele encontrados, que o uso de tutoria interativa por rádio se mostrou um meio eletrônico mais atrativo para os estudantes do que o áudio, o vídeo e as teleconferências. A razão mais apresentada pelos alunos faz referência à facilidade na recepção, já que qualquer um pode receber o sinal em sua casa. O pesquisador ressalta que, para a estratégia funcionar corretamente, é necessária uma quantidade de números telefônicos gratuitos para que os alunos se comuniquem com os tutores. Satyanarayana e Sesharatnam (2000) ${ }^{154}$ indicam que o rádio também é importante para realizar atualizações em relação ao conteúdo - quando se faz difícil atualizar os materiais impressos -, ou para realizar uma tutoria corretiva.

Em relação à teleconferência, são diversas as pesquisas. Sahoo (1994) e Sinha (1994) realizaram estudos com diferentes experiências desenvolvidas com diversos públicosalvo, desde alunos de pós-graduação até diretores regionais, diretores assistentes e tutores. A recepção dos públicos foi muito positiva, e esta estratégia pode se constituir em uma proposta viável para a educação a distância. É importante destacar que estas

\footnotetext{
151 . Op. Cit.

152 Op. Cit.

${ }^{153}$ Op. Cit

${ }^{154}$ Op. Cit
} 
experiências contavam com outros espaços de trabalho, grupos de discussão, elaboração de projetos em grupos, "tempestade cerebral", projetos individuais, entre outros.

Já as pesquisas de Subhayamma (1998), que desenvolveu um estudo avaliativo no sistema de teleconferência da IGNOU, indica que os estudantes ficavam apreensivos sobre determinados aspectos relacionados a sua participação em sessões de perguntas e de respostas. Outro problema advém do tempo outorgado para interação, o que impacta negativamente na eficácia de tais sessões. Mishra (1999), que conduziu um estudo sobre a interatividade durante sessões de teleconferência, destaca a necessidade de treinar adequadamente as pessoas para o uso deste recurso, orientando os alunos antes das sessões sobre como colocar corretamente suas perguntas pelo telefone sem excesso de comentários.

\section{Desenvolvimento de cursos}

A universidade contrata especialistas de todo o país para o desenho e o desenvolvimento de seus cursos e programas, garantindo com isso a qualidade e a eficácia de todos os materiais por intermédio de variados testes, incluindo aqules de usabilidade com alunos em potencial. O gráfico 2 apresenta como é o processo de desenvolvimento de cursos.

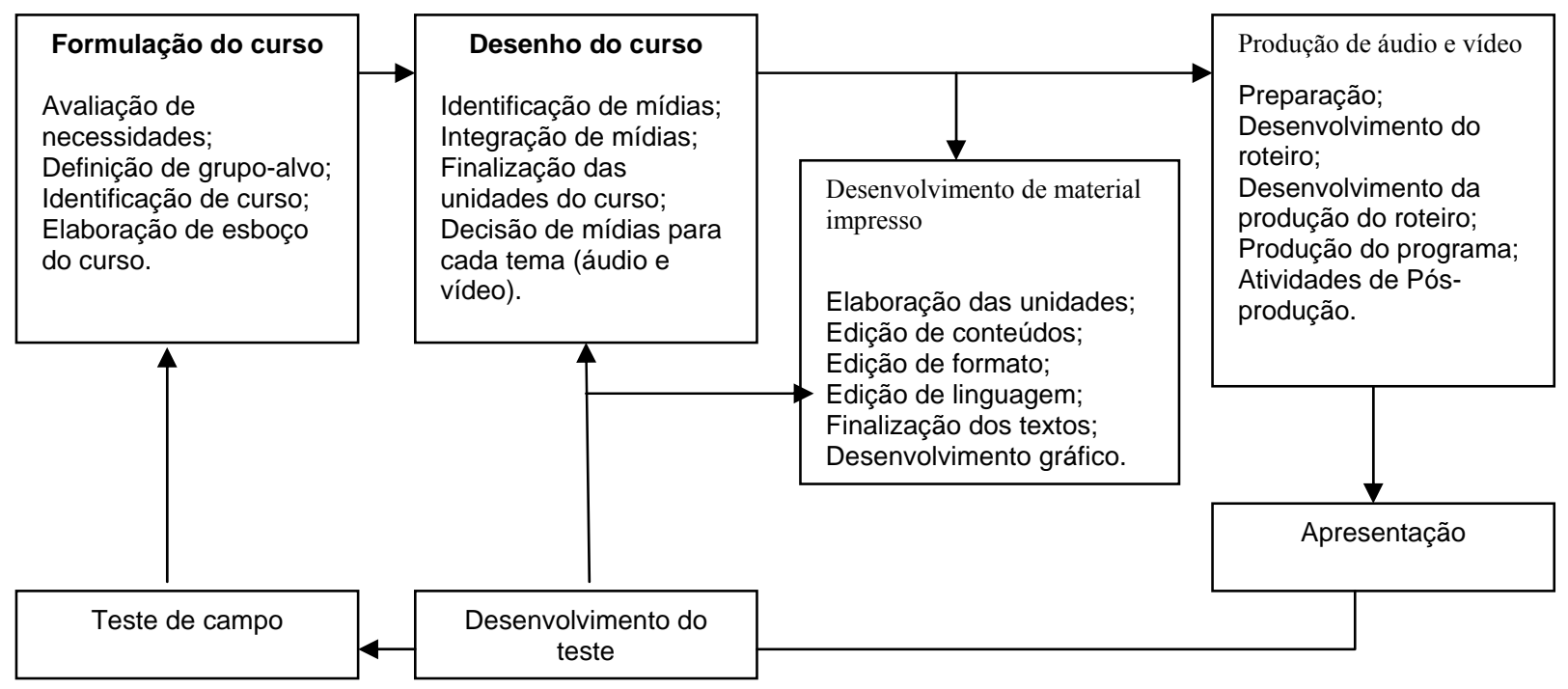

Figura 5: Modelo de desenvolvimento de cursos. Fonte: IGNOU 2004. 
A estrutura do material impresso de auto-instrução segue uma formatação que facilita o seu estudo. Assim, cada apostila está constituída por blocos; cada bloco tem lições que são chamadas de unidades, e cada unidade está estruturada da seguinte forma ${ }^{155}$ :

Título da Unidade

Estrutura

1.1 Introdução

Objetivos

1.2 Seção 1: Conceito 1

1.2.1 Subseção 1.1

1.2.2 Subseção 1.2

1.2.n Subseção 1.n (Auto-avaliação)

1.3 Seção 2: Conceito 2

1.3.1 Subseção 2.1

1.3.2 Subseção 2.2

1.3.n Subseção 2.n (Auto-avaliação)

$1 . \mathrm{m}$ Seção $\mathrm{m}$

$1 . \mathrm{m}+1$ Sumário

1.m+2 Glossário

$1 . m+3$ Bibliografia

$1 . m+4$ Respostas para as atividades de auto-avaliação

\section{Avaliação}

A universidade segue um sistema flexível de avaliação, com dois componentes: avaliação em processo e avaliação final. A avaliação contínua é feita com tarefas indicadas pelo tutor. A experiência da IGNOU mostra que as tarefas servem como uma ferramenta útil para avançar nos estudos e desenvolver um diálogo entre professor e aluno.

Em 2005 mais de 2.5 milhões de tarefas foram avaliadas pelos conselheiros nos centros de estudo. A universidade aplica uma avaliação presencial duas vezes por ano, permitindo que os alunos a realizem em um lugar de sua escolha, mas não há nenhum acordo nos padrões de avaliação de desempenho. Para manter a credibilidade do sistema, a universidade envolve um grande número de professores de diversas universidades do país, como avaliadores, revisores e moderadores. Isso ajuda os estudantes a estar a par com os padrões da avaliação de desempenho seguidos em instituições convencionais do país.

\footnotetext{
${ }^{155}$ Disponível em:

$<$ http://www.ignou.ac.in/schools/soet/nautical\%20science/prospectus'06/Prospectus_Aug06_new.doc>.
} 
Em 2005 mais de 562 mil estudantes foram registrados para os exames, e 735.448 livros de resposta foram avaliados em 1384 centros.

\section{Centros de estudo}

A IGNOU possui um network de mais de 1400 centros de estudos e práticas de laboratório por meio dos quais alcança todos os estudantes localizados em diferentes partes do país. Cada centro possui conselheiros acadêmicos trabalhando em período parcial, especialistas em diversos conteúdos, equipamentos para utilizar áudio e vídeo, biblioteca, espaços para a visualização de videoconferências e teleconferências, informações relacionadas a regras, regulamentos, procedimentos, calendários, etc., além de realizar avaliações acadêmicas.

O aumento na quantidade de centros de estudo, centros regionais e sub-regionais passando de 18 em 1985-86 a 1139 em 2004/05 e 1400 em 2006 - e o aumento de conselheiros acadêmicos para dar suporte e atendimento a todos esses estudantes - que já são mais de 48.000 - demonstram o crescimento da universidade, como pode ser observado na tabela abaixo.

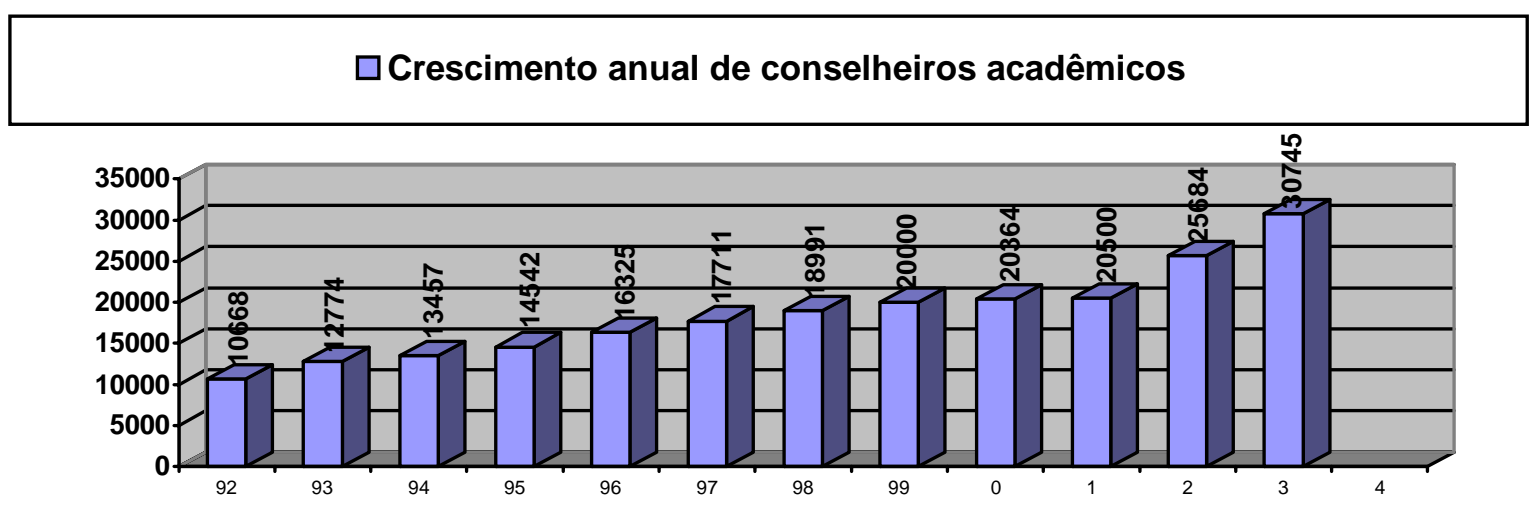

Gráfico 7: Crescimento anual de conselheiros acadêmicos da IGNOU. Fonte: IGNOU 2004. Tabela adaptada. 


\section{Valor dos cursos}

Segundo o Ministério da Educação da Índia ${ }^{156}$, a IGNOU recebe dois tipos de subsídios: um proveniente do governo central, da Comissão Universitária de Doações, e uma ajuda para o desenvolvimento, isto é, para a construção de laboratórios, aquisição de equipamentos; e para ajudar no pagamento das despesas que geram a sua manutenção. O governo subsidia aproximadamente $20 \%$ dos custos anuais da universidade.

O valor dos doutorados, com uma duração mínima de 2 anos e máxima de 5 anos, fica na faixa de 10.000 rúpias (US\$ 266,00) ${ }^{157}$; os MBAs em administração, com uma duração mínima de 5 semestres, estão na ordem de 14.700 rúpias (US\$ 333,20); o Mestrado em Computação, entre 3 e 6 anos, 16.000 rúpias (US\$ 362,67); o Mestrado em Artes, 5.400 rúpias (US\$ 122,40). Algumas das graduações ficam na faixa de $1300 \mathrm{a}$ 2000 rúpias (US\$29,46 a US\$ 45,33) por ano, com a duração de 3 a 6 anos.

Apesar de pagos, os programas são oferecidos a um preço menor do que o custo real da universidade. Assim, a pós-graduação com diploma em saúde maternal e infantil, por exemplo, tem um preço para os alunos de 15.400 rúpias, mas um custo para a faculdade de 16.177 rúpias.

\section{b) Dr. B.R. Ambedkar Open University (BRAOU) ${ }^{158}$}

\section{Endereço}

Prof. G. Ram Reddy Marg, Road, 46

Jubilee Hills

Hyderabad - 500 033. A.P.

+9104023680000

Informação General: +91 04023544734

\footnotetext{
156 Ministério de Educação da Índia. Relatório anual, 2004-2005. P 1. Disponível em: www.education.nic.in/htmlweb/Annualreport2004-05/EduDev.pdf. Consultado em 27/07/2006

157 Conversor de moedas. Yahoo Finanças. Taxa de câmbio: 0.0002376. Disponível em: http://br.finance.yahoo.com/currency/convert?amt=2000\&from=IDR\&to=BRL. Acessado em 16/12/2006.

${ }^{158}$ Disponível em: < http://www.braou.ac.in/profile.htm> . Acesso em: 2 jan. 2005.
} 


\section{Contexto histórico}

Fundada na cidade de Hyderabad (Índia), em agosto de 1982, pela legislação estadual de Andhra Pradesh, é comumente conhecida como Andhra Pradesh Open University.

\section{Objetivos}

Primeira de seu gênero na Índia, assumindo-se como uma ação do governo para prover oportunidades de educação superior para todos, tem como foco especial as populações pobres e isoladas que nunca tiveram acesso à educação superior.

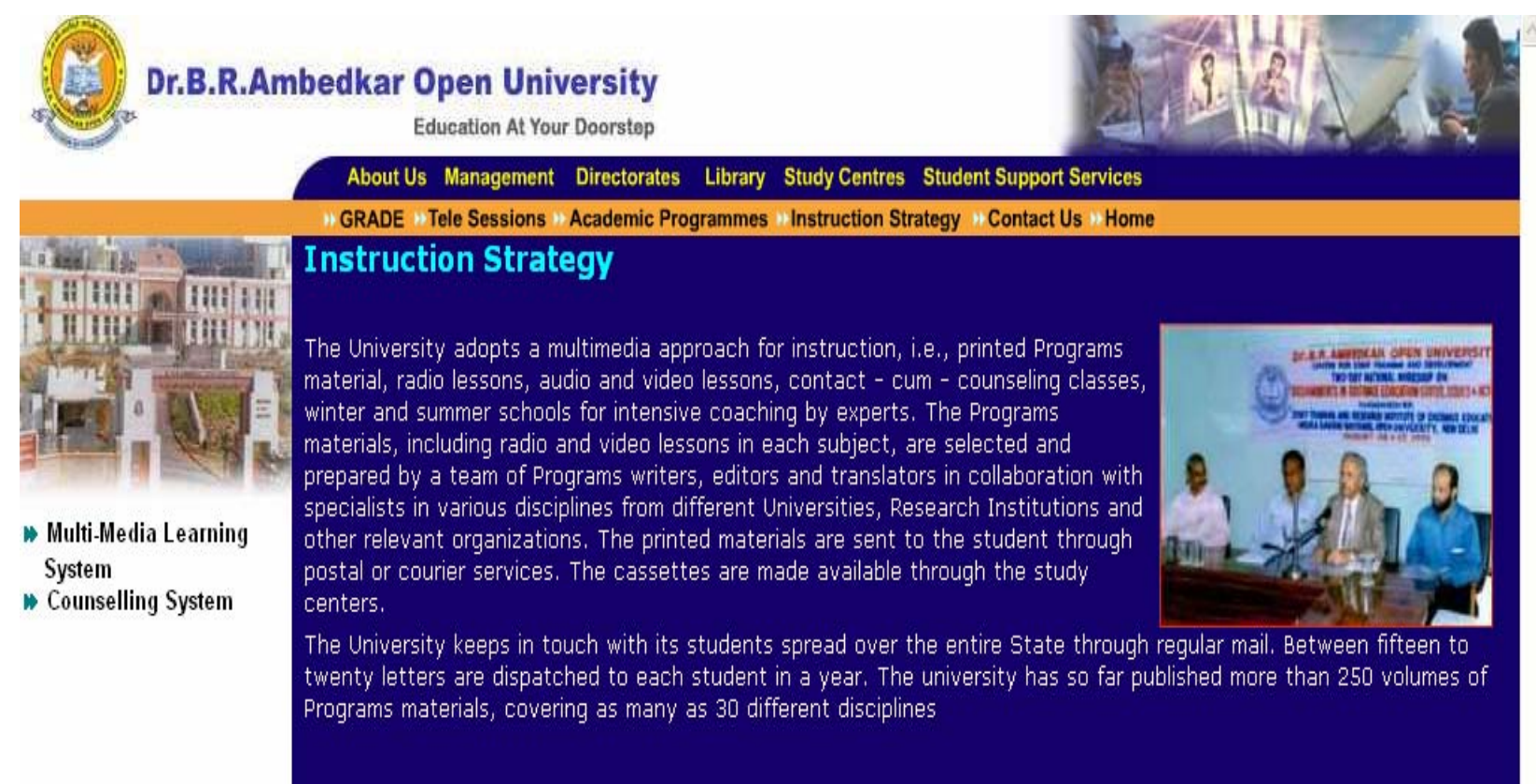

Figura 6: Portal da Dr. B.R. Ambedkar Open University (BRAOU).

Fonte: Dr. B.R. Ambedkar Open University. Disponível em: <http://www.braou.ac.in/profile.htm> . Acesso em: 2 jan. 2005. 


\section{Público-alvo}

O público-alvo é formado em média por jovens de 26 anos de idade, $60 \%$ dos quais são de origem rural, das castas mais baixas da sociedade, a maioria desempregada.

A universidade é considerada uma das maiores da Índia, com uma matrícula de quase 500 mil alunos e mais de 125 mil inscrições anuais. Na análise realizada, detectamos que esta universidade também apresentou um forte crescimento nos últimos decênios, passando de uma inscrição de 6.231 alunos anuais no período de 1983-1984 a 79.825 alunos em 1995, o que significa um percentual de crescimento de $1181 \%$, com uma média de crescimento anual de 21,67\%. De 1995 até 2000, a universidade passou de 79.825 alunos a 102.317 estudantes, refletindo um percentual de crescimento de $28 \%$ em 9 anos, com uma média de crescimento anual de 2,88\%, conforme indicado na tabela 8 .

Desde a sua fundação até o ano 2000, a universidade cresceu 1542\% em 17 anos de vida, com uma média de crescimento anual de 19,11\%. "As matrículas para o ano de 2001 foram de 450 mil alunos"159, e as matrículas acumuladas chegaram a aproximadamente 1 milhão para o período de 1983-2001.

\section{$\square$ Número de estudantes ativos}

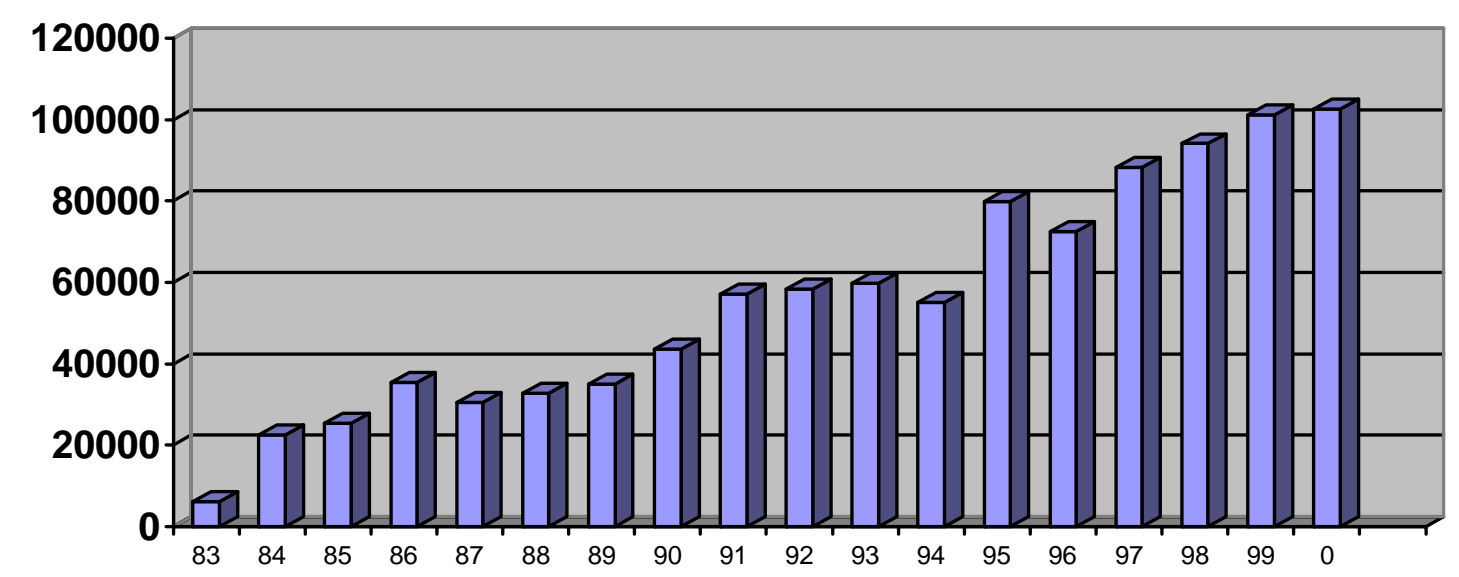

Gráfico 7: Concentração de estudantes ativos por ano na BRAOU.

Fonte: Dr. B.R. Ambedkar Open University. Annual graphical representation of BRAOU's Growth. Disponível em: <http://www.braou.ac.in/profile.htm. Acesso em: 21 jan. 2005.

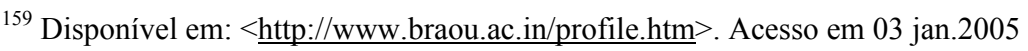


Seu número de graduados anuais reflete um crescimento de mais de $1.079 \%$, passando de 1492 em 1987 para 17.591 em 2001, com uma média anual de crescimento de $19,27 \%$, tendo formado, desde a sua criação até o ano 2001, 47.134 graduados.
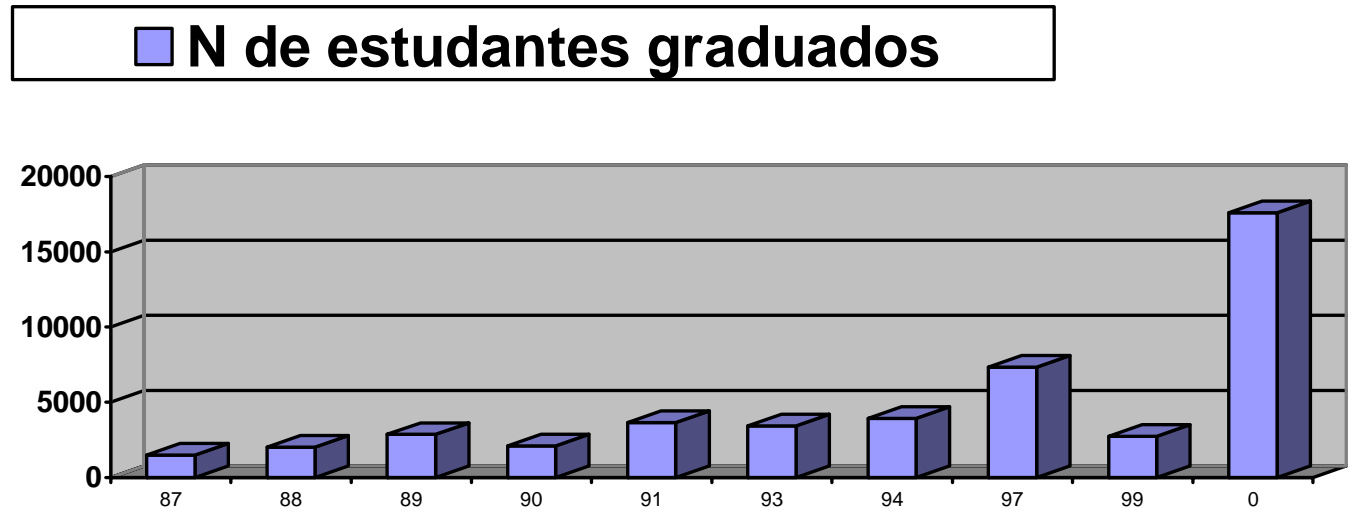

Gráfico 9: Número de estudantes que obtiveram diploma por ano na BRAOU.

Fonte: Dr. B.R. Ambedkar Open University.Annual graphical representation of BRAOU's Growth. Disponível em: http://www.braou.ac.in/profile.htm. Acesso em: 2/1/2005.

\section{Recursos humanos e materiais}

Em termos de infra-estrutura, a BRAOU desenvolveu um portal de apoio às suas atividades de comunicação entre professores, alunos e instituição. Por meio deste portal de serviços, é possível ter acesso a várias informações administrativas: dados biográficos, arquivos acadêmicos, resultados de exames, calendário de atividades e dados sobre financiamento institucional, como se verifica no endereço eletrônico http://www.braou.ac.in

\section{Cursos oferecidos}

A oferta de cursos da Universidade é variada, abrangendo os cursos de graduação em Artes; Comércio; Ciências; Biblioteca, Ciências da Informação e Relações Públicas. E também mestrados em Estudos do Desenvolvimento; História, Ciências Econômicas, Administração Pública, Ciências políticas, Matemáticas, Administração de Empresas, Biblioteca, além de pós-graduações em Estudos de Meio Ambiente, Finanças, Marketing, Roteirista para jornal, Certificados em Alimentação e Nutrição, Computação, entre outros. 


\section{Sistema de estudos}

A universidade possui um sistema aberto e flexível em termos da admissão, da escolha dos programas, das exigências de duração e da idade, dos métodos de ensino e dos procedimentos de avaliação, oferecendo assim um canal alternativo àqueles que não tiveram oportunidades de educação superior, especialmente as mulheres, os trabalhadores e as populações social e geograficamente desfavorecidas.

A universidade já possui um sistema de atendimento nas prisões, com centros de estudos para fornecer aos presos alternativas de continuidade dos estudos.

\section{Materiais para Estudos e Estratégia Instrucional}

A universidade adotou uma metodologia multimídia, integrada por apostilas impressas, audiovisuais, programas de TV e rádio e encontros presenciais intensivos com especialistas da área, como pode ser observado na figura a seguir:

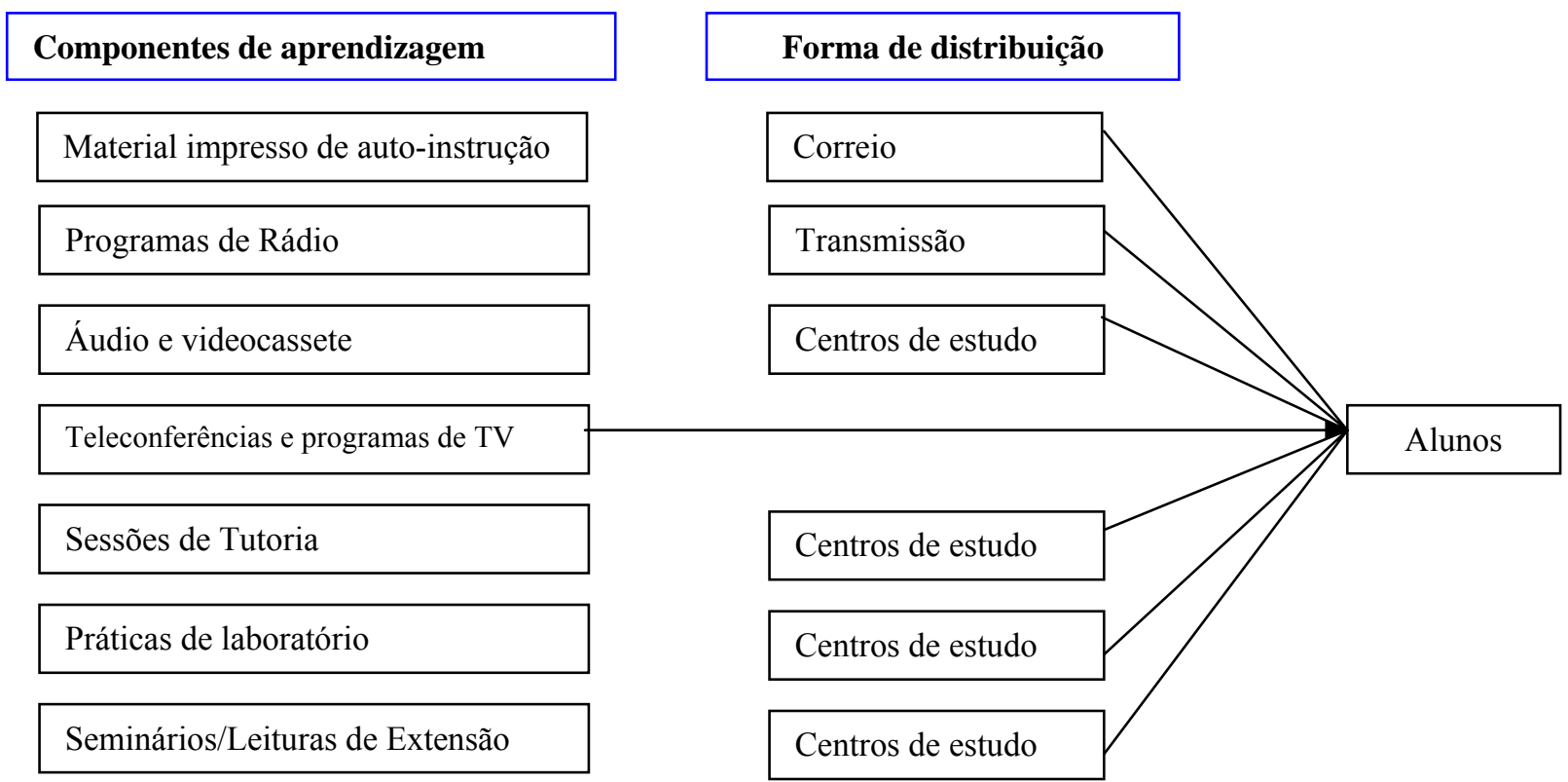

Figura 7: Estratégia Instrucional. Fonte: Dr. B.R. Ambedkar Open University. Annual graphical representation of Instruction Strategy . Disponível em http://www.braou.ac.in/mulmedl.htm Acesso em: 8/1/2005.

O material impresso é o suporte básico de todas as disciplinas. É preparado por uma equipe de especialistas com um formato pedagógico auto-instrucional. A universidade até agora já desenvolveu 399 cursos. 
Ao mesmo tempo, este recurso se vê complementado com aulas por rádio, que são transmitidas todos os dias em 4 blocos de 15 minutos cada. $O$ primeiro vai das 7 h 15 às $7 \mathrm{~h} 30$; o segundo das $7 \mathrm{~h} 30$ às $7 \mathrm{~h} 45$; o terceiro das $22 \mathrm{~h} 30$ às $22 \mathrm{~h} 45$, e o último das $22 \mathrm{~h} 45$ às $23 \mathrm{~h} 00$. Aos domingos, quando não se tem programação, das 16 às $17 \mathrm{~h}$ são realizadas atividades da rádio interativa com uso de telefone de números gratuitos para consultas aos tutores.

Os estudantes também contam com áudio e vídeocassetes, produzidos pelo centro de produção e pesquisa audiovisual da universidade e podem ser tanto retirados como vistos nos centros de estudo, já que todos contam com este material e com suficientes equipamentos de vídeo, televisores e áudio para as pessoas que queiram acessar no mesmo lugar.

$\begin{array}{lccc}\text { Ano } & \text { Rádio } & \text { Áudio } & \text { Vídeo } \\ \mathbf{1 9 8 3 - 8 4} & 127 & & 03 \\ \mathbf{1 9 8 4 - 8 5} & 228 & 22 & 24 \\ \mathbf{1 9 8 5 - 8 6} & 368 & 24 & 36 \\ \mathbf{1 9 8 6 - 8 7} & 221 & 54 & 24 \\ \mathbf{1 9 8 7 - 8 8} & 129 & 55 & 11 \\ \mathbf{1 9 8 8 - 8 9} & 59 & 43 & 09 \\ \mathbf{1 9 8 9 - 9 0} & 32 & 22 & 08 \\ \mathbf{1 9 9 0 - 9 1} & 29 & 08 & 07 \\ \mathbf{1 9 9 1 - 9 2} & 22 & 04 & 10 \\ \mathbf{1 9 9 2 - 9 3} & 25 & & 18 \\ \mathbf{1 9 9 3 - 9 4} & 144 & & 42 \\ \mathbf{1 9 9 4 - 9 5} & 18 & 02 & \\ \mathbf{1 9 9 5 - 9 6} & 12 & 07 & \\ \mathbf{1 9 9 6 - 9 7} & 66 & 01 & 19 \\ \mathbf{1 9 9 7 - 9 8} & 71 & 02 & 12 \\ \mathbf{1 9 9 8 - 9 9} & 51 & & 72 \\ \mathbf{1 9 9 9 - 0 0} & 17 & & 506 \\ \mathbf{2 0 0 0 - 0 1} & 29 & & \end{array}$

Tabela 12 - Produção de lições em radio, áudio e vídeos BRAOU

Fonte: Commonwealth of Learning. Perspectives on Distance Education. Educational Media in Ásia. Vancouver, 2005. Página 167.

Até 2003, a universidade tinha produzido 1805 programas de rádio, 244 fitas de áudio e 506 programas de televisão. Com a abertura da MANA TV, foram transmitidos 972 programas, entre março de 2001 e março de 2003. 
As transmissões se realizam através da MANA TV, uma iniciativa do governo de Andhra Pradesh, que possui 5 canais com o propósito de promover educação a distância, cursos de extensão para agricultura, desenvolvimento rural, telemedicina e governo eletrônico.

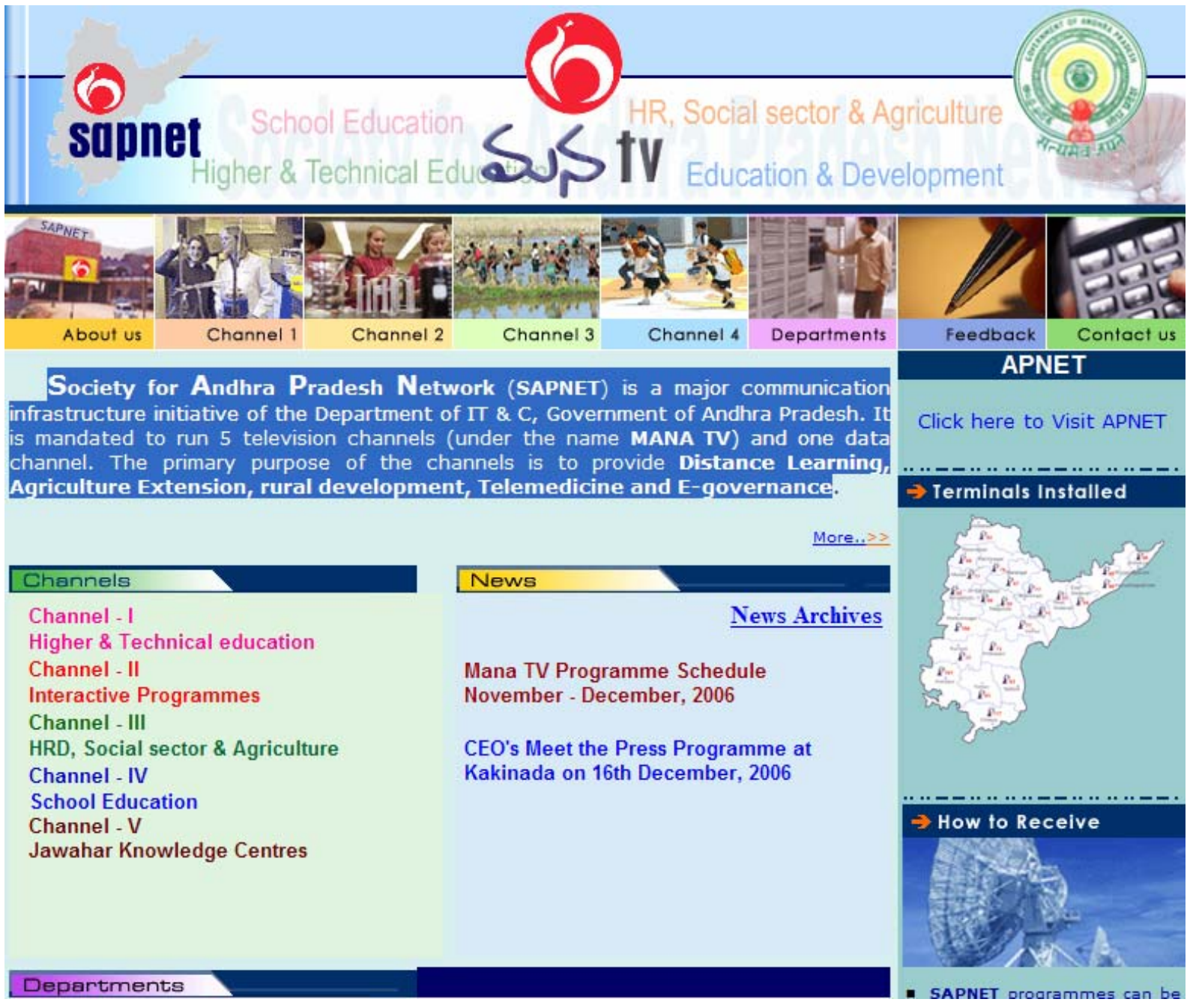

Figura 8: MANA TV. Disponível em http://www.manatv.net/default.asp

O canal 1 tem por finalidade transmitir programas pré-gravados de educação superior e técnica, transmitindo para a universidade BRAOU. O canal 2 é um canal interativo que promove palestras ao vivo: os alunos podem ligar para fazer perguntas durante a sessão. Neste canal são desenvolvidas atividades da universidade BRAOU de instrução médica, escolas primárias, secundárias, agricultura, política, entre outras. O canal 3 é dedicado ao treinamento a distância para agricultura e à educação de adultos. Por útimo, o canal 4, que é dedicado a escolas primárias e secundárias. Já o canal 5 se destina a programas de treinamento para funcionários públicos. 
Esta rede conecta 582 escolas, 163 universidades do governo, 567 faculdades, 9 faculdades médicas, 64 institutos politécnicos, 24 centros da universidade aberta do Dr. B. R. Ambedker, 330 centros de aprendizado de MPDOs e 5 das polícias.

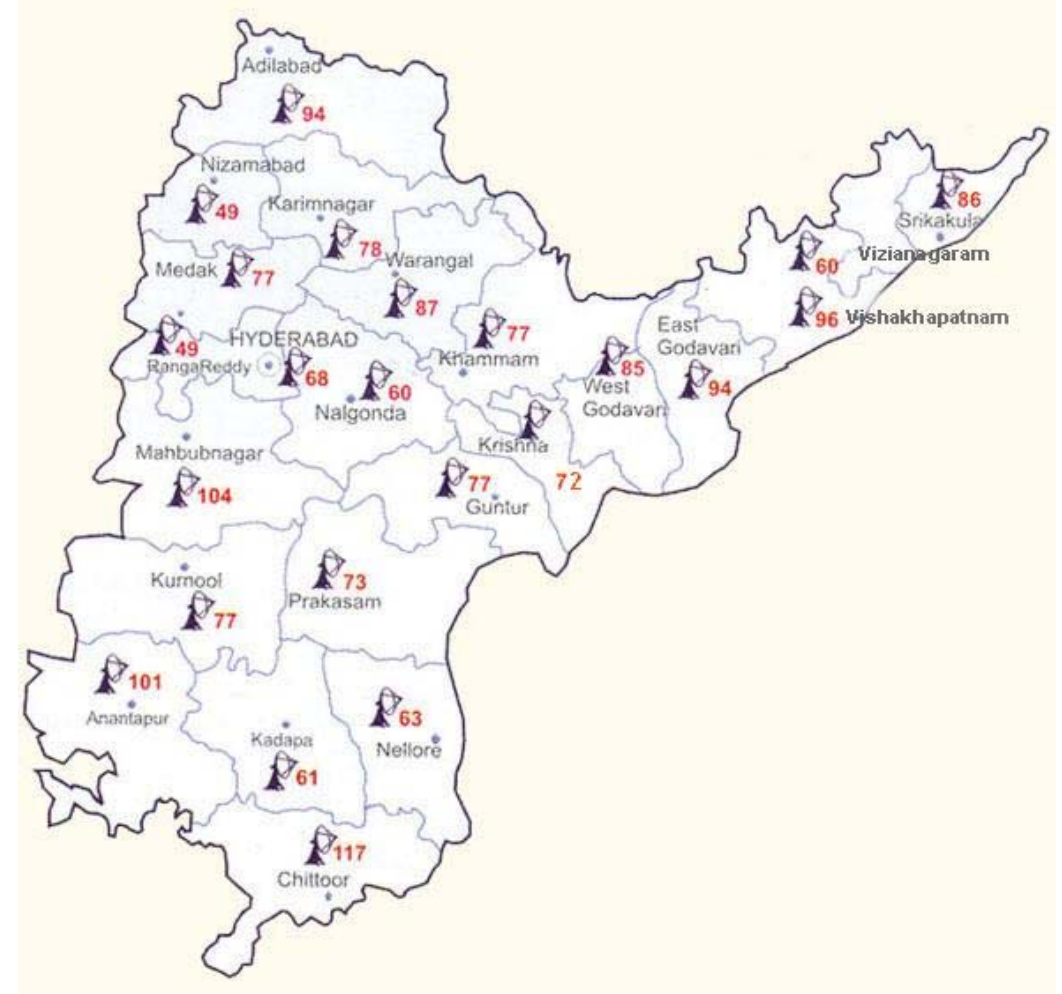

Figura 9: Terminais de recepção instalados para a MANA TV. Disponível em: http://www.manatv.net/terchart.asp.

O interessante desta rede é a flexibilidade nas possibilidades de recepção: a clássica via sinal de TV; via de sinal de TV somada à capacidade telefônica para realizar as interações com os alunos; recebimento do sinal pelo computador pessoal; possibilidade de voz sobre IP, facilitando as interações, entre outras.

Algumas das dificuldades mais importantes deste empreendimento resultam da escassez de fundos para desenvolver os conteúdos de qualidade, realizar a manutenção dos terminais ou realizar a segurança dos equipamentos.

Os contatos entre professor e aluno são realizados a partir de múltiplos meios. Por um lado, encontros presenciais agendados, nos quais os professores apresentam, de forma sucinta, os tópicos mais importantes e difíceis dos conteúdos. Além disso, os alunos contam com tutorias, tanto presenciais como através de diversas mídias, vídeo, áudio e correio, organizadas em função de unidades de estudo, tarefas acadêmicas, avaliações e 
escolhas de disciplinas e planejamento da carreira profissional, como pode ser observado no gráfico abaixo.

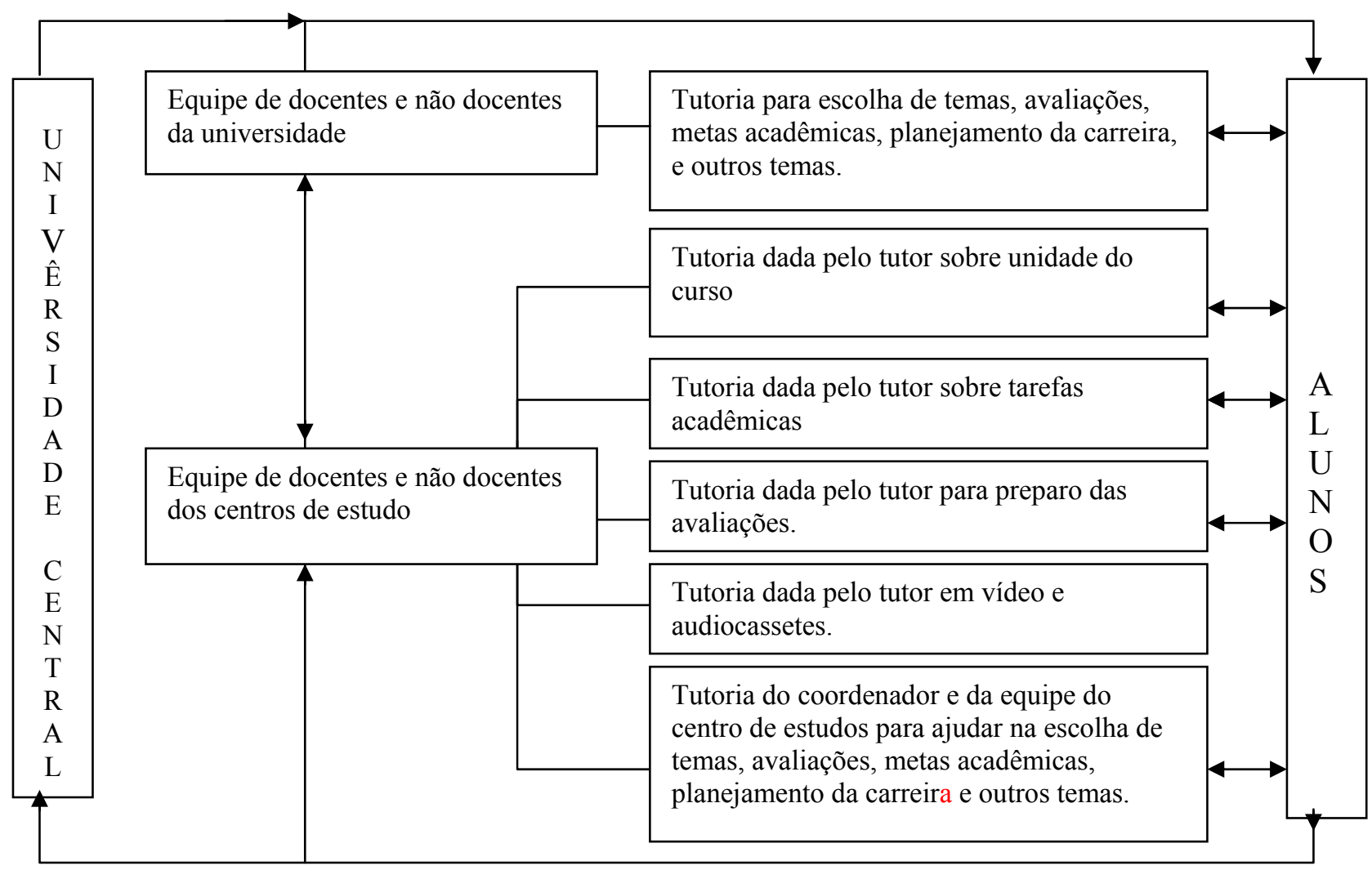

Figura 10: Sistema de Tutoria da BRAOU. Fonte: Dr. B.R. Ambedkar Open University. Annual graphical representation of Instruction Strategy. Disponível em: http://www.braou.ac.in/mulmedl.htm. Acesso em: 8 jan. 2005.

\section{Pesquisa}

De acordo com um estudo conduzido pelo centro de avaliação da universidade (Subba Rao 1989)160, as lições de rádio e de áudio à disposição dos alunos nos centros de estudo quase não foram usadas. Parece que, embora os estudantes tenham interesse nos recursos, não os usam por diversos motivos: falta de instalações físicas e falta das habilidades necessárias dos coordenadores e dos tutores para usar os recursos eficazmente. Esta pesquisa é reafirmada por Sesharatnam (1994)161, que observou que um percentual insignificante $(3,78 \%)$ dos estudantes escutou as lições de rádio regularmente. Enquanto $25 \%$ deles escutaram ocasionalmente, a maioria dos estudantes (71.22\%) não as escutou nunca. O mesmo ocorre com os vídeos educativos, disponíveis

${ }^{160}$ In: Commonwealth of Learning. Perspectives on Distance Education. Educational Media in Ásia. Vancouver, 2005. Pagina 173

161 Op. Cit 
nos centros do estudo: 3,78\% dos estudantes usaram as fitas regularmente, $21,28 \%$ ocasionalmente e $71,34 \%$ não as usaram.

É muito interessante observar a experiência desenvolvida por Srinivasacharyulu (1996). Ele conduziu um estudo experimental para examinar a efetividade de prover informação com antecedência sobre os horários de rádio para os estudantes, fornecendo cópias para serem levadas para casa em um sistema de préstimos estendidos. Os resultados foram completamente distintos das experiências anteriores em relação ao rádio. Quando a programação das disciplinas no rádio foi entregue a tempo, a participação passou de $32 \%$ para $71 \%$; $95 \%$ dos alunos escutaram as fitas de áudio e todos viram as fitas de vídeo. A pesquisa, que foi realizada com um grupo de controle, indicou também que os alunos que utilizaram os recursos didáticos multimídia tiveram um significativo melhor desempenho em relação ao grupo de controle, sendo que $62 \%$ dos alunos que escutaram as fitas de áudio reconheceram que elas os ajudaram na leitura das apostilas no início do ano.

O problema principal que está sendo examinado se refere à ausência de informação a respeito da programação, tanto do rádio como da TV, ou quando ela ocorreu com atraso.

No que diz respeito aos programas de TV, segundo V. Venkaiah (2005, p. 175), depois de fazer o investimento de equipamentos necessários para criar o estudo na universidade, o problema principal foi como produzir programas educativos de qualidade. A solução foi ensinar os professores a desenvolver os programas.

Alguns problemas detectados pelo autor têm a ver com os horários de transmissão (5h30 às $6 \mathrm{~h}$ da manhã), com o sincronismo entre os tópicos e os assuntos a ser tratados (que não são informados com adequada antecedência aos alunos), com a baixa qualidade dos programas (no que se refere a estilos de apresentação para TV educacional), com a escassez de tempo e com os escassos recursos humanos e financeiros.

Uma outra observação é que os programas produzidos pela universidade não são de qualidade elevada nem em termos de conteúdo e de planejamento visual nem no que diz respeito aos programas para a televisão educacional. 


\section{Avaliação}

A universidade possui um centro de avaliação que desenvolve estudos exploratórios sobre as avaliações dos alunos, as necessidades sociais, os aspectos acadêmicos e organizacionais dos cursos e os padrões de inscrição, entre outros. $\mathrm{O}$ centro monitora todas as variáveis que fazem a qualidade educativa da instituição. A universidade realiza um teste para a admissão dos novos alunos, que é aplicado em 200 centros de estudos em todo o estado a cada ano, para o qual se inscrevem entre 70 e 80 mil candidatos. Como critério de qualidade do sistema, a universidade avalia o tempo de envio dos materiais pelo correio, como um elemento central do sucesso do programa de estudos.

\section{Centros de estudo}

O aumento da sua rede de centros em todo o país constitui-se em um outro indicador de crescimento, passando de 26 na sua criação a 137 em 2001, sendo 5 deles só para mulheres e 2 funcionando em prisões.

\section{$\square$ Número de centros de estudos}

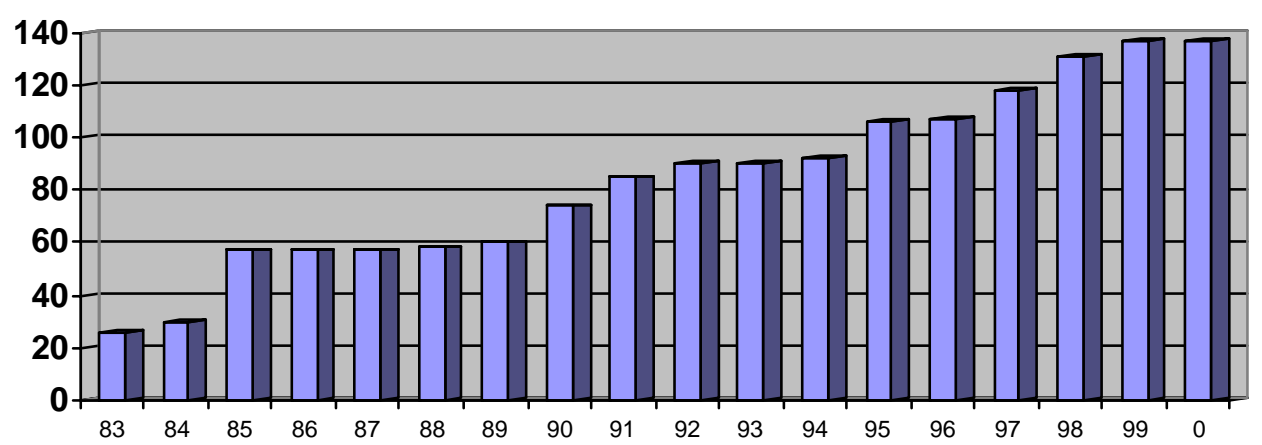

Gráfico 9: Número de Centros de Estudo por ano da BRAOU’s.

Fonte: Dr. B.R. Ambedkar Open University. Annual graphical representation of BRAOU's Growth. Disponível em: http://www.braou.ac.in/profile.htm. Acesso em: 2 jan. 2005. 


\section{Valor dos cursos}

Segundo o Ministério da Educação da Índia ${ }^{162}$, a BRAOU recebe subsídio do governo central, que cobre $30 \%$ de seus gastos de operação.

O mestrado em estudos do desenvolvimento, comércio, estatística, economia, administração pública, ciência política, geografia e sociologia, com duração de um ano e meio, tem um custo de 1.500 rúpias por ano (US\$ 34,00). Os doutorados nas mesmas áreas, com duração entre 2 e 6 anos, 500 rúpias por ano (US\$11,33). Os mestrados em história, arte, matemática, com duração entre 2 e 6 anos, 2.500 rúpias ao ano (US\$ 56,66). Os diplomas em marketing, finanças, estudos ambientais, roteirista de mídias, os mestrados em administração de empresas e de biblioteca e ciências da informação, com duração entre 3 e 9 anos o primeiro, e de 1 a 4 o segundo, 4.500 rúpias ao ano (US\$ $102,00)$.

As graduações em ciências da informação, relações públicas e ciências, com duração de entre 1 a 5 anos, 2.000 rúpias ao ano (US\$ 45,33). As graduações em artes e comércio, com duração entre 3 a 9 anos, entre 900 e 1.100 rúpias ao ano (US\$ 20,40 e 24,93).

Os certificados em nutrição, alimentação e computação, com uma duração de 6 meses a 18 meses, 500 rúpias (US\$ 11,33).

\footnotetext{
162 Ministério de Educação da Índia. Relatório anual, 2004-2005. P 1. Disponível em:
} www.education.nic.in/htmlweb/Annualreport2004-05/EduDev.pdf. Acesso em 27/07/2006. 


\subsection{2) China}

\section{Contexto Nacional}

$\mathrm{Na}$ China, o sistema educacional se divide em três categorias: educação básica, educação superior e educação para adultos. A Lei de Educação Compulsória estipula que toda criança tenha, pelo menos, nove anos de educação formal. Todo o sistema educacional da China é gratuito e estatal, não acarretando nenhum custo para os alunos chineses, embora alunos estrangeiros estejam sujeitos a pagar por seus estudos.

O ciclo de educação básica na China compreende pré-escola e primeiro e segundo graus, com o ano acadêmico dividido em dois semestres.

A pré-escola, diferentemente do Brasil, pode durar até 3 anos. As crianças entre três e seis anos podem ser matriculadas. A partir dos sete anos, elas geralmente são admitidas no primeiro ano do primeiro grau (também chamado escola primária). A educação secundária (ou segundo grau) é dividida em "acadêmica" (nosso antigo "normal" e atual segundo grau comum) ou técnica/especializada/vocacional. Os alunos que deixam o primeiro grau geralmente prestam algum tipo de exame vestibular ou classificatório, de acordo com o qual lhes será dada a opção de ingressar no segundo grau normal, cujo objetivo é prepará-los para algum curso universitário, ou então para entrar em uma escola vocacional, que lhes capacitará a exercer algum tipo de ofício ou profissão. As escolas vocacionais oferecem programas cuja duração varia de dois a quatro anos e treinam os alunos para o mercado de trabalho, para o setor rural ou para prestar serviços técnicos. As escolas técnicas, por outro lado, tipicamente oferecem cursos de quatro anos. Existem ainda as "Escolas de Capacitação Profissional", que treinam trabalhadores e técnicos para a produção industrial. A duração desses cursos é, geralmente, de apenas três anos.

A educação de nível superior inclui desde cursos de curta duração (com duração de dois a três anos), faculdades com cursos de quatro anos e universidades que oferecem programas que combinam assuntos acadêmicos e vocacionais (ou seja, que visam a inserção no mercado de trabalho). Muitas faculdades e universidades oferecem ainda programas de pós-graduação, que capacitam o aluno a obter o grau de Mestre ou Doutor (Ph.D). Muitos cursos de graduação encaixam-se, ainda, na categoria de "educação para 
adultos", já que seu objetivo é preparar trabalhadores para o mercado de trabalho, ou capacitá-los para operar novas tecnologias de produção, que são inseridas na economia chinesa.

A categoria de educação para adultos engloba os outros três tipos mencionados. A educação primária para adultos geralmente é realizada pelas "Escolas Primárias dos Trabalhadores", "Escolas Primárias dos Agricultores”, etc. Há aulas diferenciadas para promover a alfabetização desses grupos, uma tarefa bastante difícil, dada a complexidade da escrita chinesa. A educação secundária para adultos geralmente é de caráter técnico e inclui cursos por correspondência e a distância. $\mathrm{O}$ ensino superior é normalmente de curta duração, havendo poucas universidades que fornecem cursos regulares com duração superior a quatro anos.

De um modo geral, a educação na China, o país mais populoso da Terra e com os maiores contrastes econômicos, ainda precisa se desenvolver de modo mais abrangente e inclusivo. A proporção de alunos egressos do primeiro, segundo e terceiro graus do ensino é considerada um importante índice para medir o nível educacional da nação. De acordo com uma pesquisa demográfica nacional (cuja amostra representava 1\% de toda a população) realizada em 1995, entre cerca de 100.000 pessoas, apenas 2.065 completaram programas de pós-graduação; 8.282 graduaram-se em escolas secundárias e apenas 27.283 terminaram o primeiro grau, o que é bastante insatisfatório, se formos pensar na necessidade premente tanto de trabalhadores quanto de cientistas e pessoal acadêmico necessários para continuar impulsionando de modo produtivo e autosustentável a economia chinesa.

A EaD talvez possa ser o meio mais barato e eficiente de maximizar a educação e a capacitação de jovens e adultos no país. No último $\left(11^{\circ}\right)$ Plano Qüinqüenal para o Desenvolvimento Socioeconômico, em 2006, o governo chinês anunciou que pretende aumentar gradualmente o investimento em educação e capacitação em até $4 \%$ do PIB nacional (cerca de 27,27 bilhões de dólares), o que pode representar um grande influxo de capital para o desenvolvimento de soluções de educação a distância.

A EaD na China evoluiu através de três gerações: (1) EaD baseada principalmente em cursos por correspondência; (2) Educação através de transmissão de rádio/TV, a partir 
de 1980, e (3) Educação eletrônica a distância (e-learning), baseada nas tecnologias de informação e internet, a partir de 1990, o que parece ser o futuro da $\mathrm{EaD}$ no país.

Após a revolução de 1949, a educação por correspondência e por rádio foram as estratégias escolhidas pelo governo para a ampliação da matrícula educativa e a solução para o analfabetismo. Já nos anos 60, foram estabelecidas as primeiras televisões educativas e, em 1980, foi criada a Central Chinesa de Rádio e Televisão Universitária (CCRTVU), que abrange todo o país - uma rede que, como veremos, articula mais de 44 escolas estaduais, 841 escolas municipais, 1.780 estações de trabalho e 13.000 escolas distritais.

Assim, em 1980 foi criada a "China Agricultural Broadcast and Television School" (CABTS), uma rede dedicada a desenvolver programas educativos para agricultores em áreas rurais. O sistema é formado por 1 escola central, 38 escolas provinciais, 330 escolas distritais, 2.408 escolas municipais e 23.000 estações de ensino municipais, empregando 46.000 pessoas, entre pessoal de administração, professores e tutores. $\mathrm{O}$ sistema tem graduado mais de 1,6 milhão de pessoas em educação secundária; 62 mil em educação pós-secundária; 278 mil em nível superior; mais de 112 milhões em cursos curtos de tecnologia agrária; 3,9 milhões de pessoas com certificado verde e mais de 130 milhões com Certificado de Avaliação de Habilidade Profissional.

No final de 1994, graças ao apoio da Comissão de Educação da República Popular da China (abreviado RPC de agora em diante), da Universidade de Tsinghua e de outras nove universidades, foi completado o projeto piloto da "Rede Nacional Chinesa de Educação e Pesquisa" (CERNET), a primeira rede pública de TCP/IP na China. Em 1996, Wang Dazhong, presidente da Universidade de Tsinghua, foi o pioneiro a advogar pelo desenvolvimento da educação a distância no país. Em 1997, a Universidade de Hunan, em associação com a Hunan Telecom, deu início às atividades da primeira universidade on-line da China.

Em julho, as 31 universidades reconhecidas pelo governo uniram-se em um consórcio chamado “Associação para o Avanço da Educação a Distância em Educação de Nível Superior", com o intuito de fortalecer e facilitar a cooperação e o intercâmbio de tecnologias de educação entre essas universidades. 
Em outubro, a Plataforma de Transmissão de Multimídia de Banda Larga por Satélite da China entrou em operação, permitindo a transmissão simultânea de canais de vídeo e conteúdo multimídia. Além disso, o acesso à internet através da nova plataforma permite uma maior taxa de troca de bits de informação com o CERNET, formando, assim, uma rede consolidada e bidirecional terra-satélite de educação, o que muda completamente o cenário da transmissão de TV via satélite na China, que até então era apenas unidirecional. De acordo com as últimas estatísticas feitas pelo Ministério da Educação até o presente, as 31 universidades pioneiras ofereceram vagas para quase 190.000 alunos, a maioria das quais destina-se a programas de graduação. Ao mesmo tempo, uma bolha de sites educacionais tem surgido e muitas empresas globais estão envolvidas em $\mathrm{EaD}$ na China, instalando suas próprias plataformas de rede educacionais.

De acordo com o novo plano educacional da China elaborado para o período 20032007, chamado "moderno sistema educativo", o sistema de educação permanente foi combinado com o sistema de educação formal, e o sistema presencial com o sistema a distância. Isso significa que as instituições de educação formal (escolas, faculdades e universidades) estão se articulando para responder às demandas da sociedade de aprendizagem e ao crescimento de demanda por educação permanente, atendendo, por sua vez, às diversas necessidades educativas da sociedade - educação superior, educação permanente, educação corporativa e educação governamental.

$\mathrm{Na}$ sociedade da informação e do conhecimento, as autoridades educativas da China entendem que existe um novo papel para as universidades: participar ativamente do desenvolvimento do país como unidades de produção do conhecimento. 


\section{a) Central Broadcast Television University - China TV University}

\section{Endereço}

160 Funei Dajie, Pequim

China (PRC)

Telefone: +86 (10) $66039048 / /$

Site: http://www.crtvu.edu.cn/

\section{Contexto histórico}

A Central Chinesa de Rádio e Televisão Universitária (CCRTVU) é uma rede nacional que constitui o sistema nacional de educação aberta e a distância da China. Esta rede está integrada por 44 rádios provinciais e TVs universitárias (RTVUs), 841 escolas de nível municipal e prefeituras e 1.768 emissoras, que operam em diferentes níveis: nacional, provincial, municipal e distrital, assim como o sistema educativo da China.

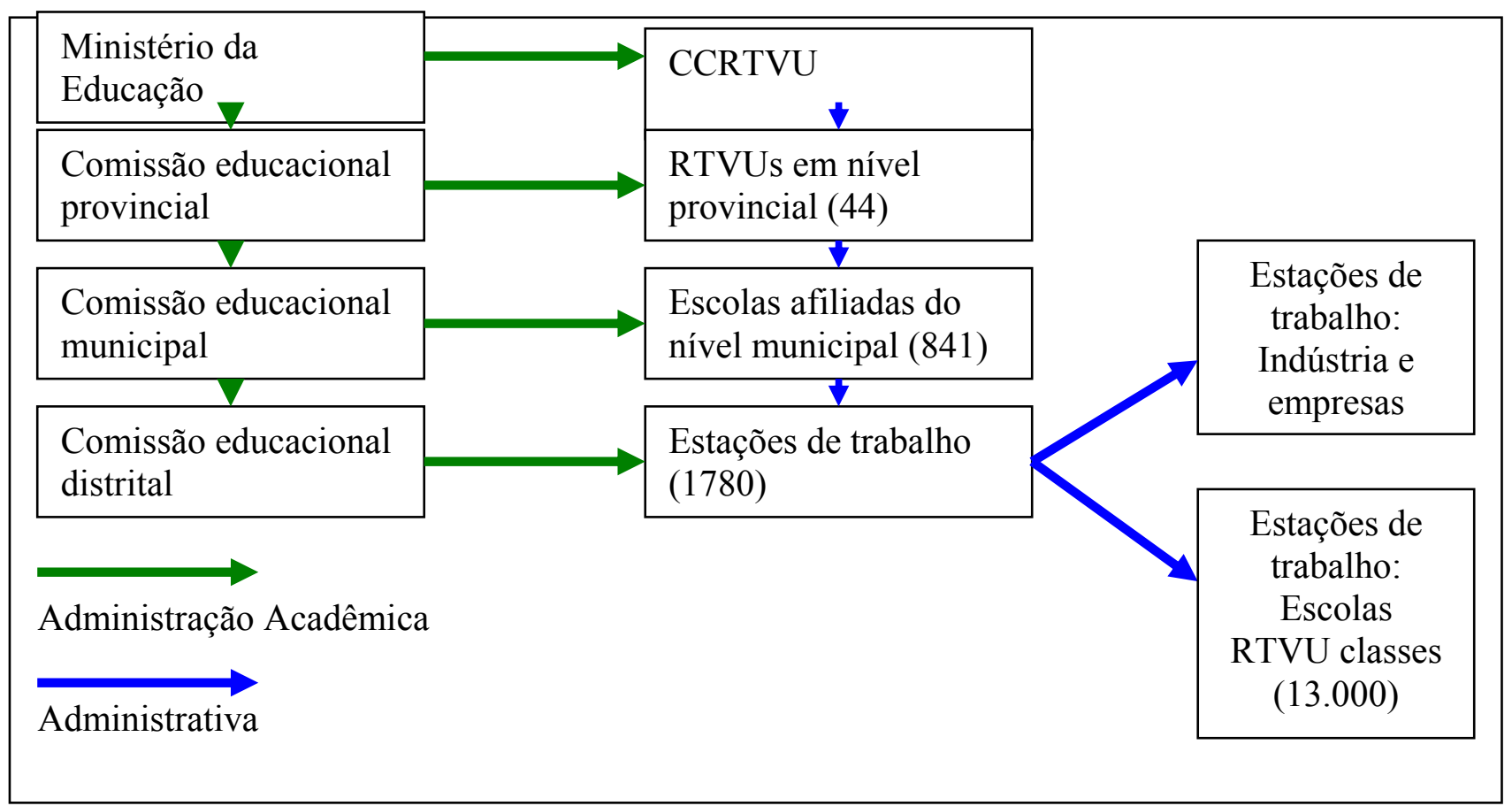

Figura 11: Sistema educativo da China

Localizada na cidade de Pequim, a CCRTVU foi fundada em 1979 e atua como uma instituição subordinada diretamente ao Ministério de Educação, com status de 
universidade nacional. É responsável pelo planejamento de todo o sistema de educação a distância.

A CCRTVU compreende:

$\checkmark$ China TV Teacher College

$\checkmark$ Central Radio \& TV Specialized Secondary School

$\checkmark$ China Liaoyuan Radio \& TV School

$\checkmark$ Distance Education Research and Information Institute

$\checkmark$ Library

$\checkmark$ Press

$\checkmark$ The Publishing House for Audio-Visual Materials

$\checkmark$ China TVU Education Management Departments

\section{Objetivos}

A universidade tem como missão primária o desenvolvimento de cursos de educação superior destinados a profissionais, trabalhadores de empresas, funcionários das forças armadas e outros membros de diversas classes sociais que visualizam a educação superior como uma oportunidade de crescimento ${ }^{163}$.

Suas principais responsabilidades são: oferecer educação média e superior; elaborar os programas unificados de educação; promover as reformas na modalidade de educação a distância; estabelecer os critérios de avaliação; responder pela administração centralizada da rede de informação.

\footnotetext{
163 China Education and Research Network. Distance education. 2001. Disponível em:
}

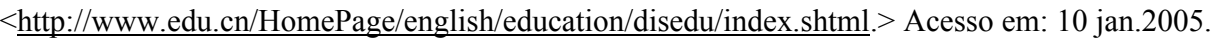




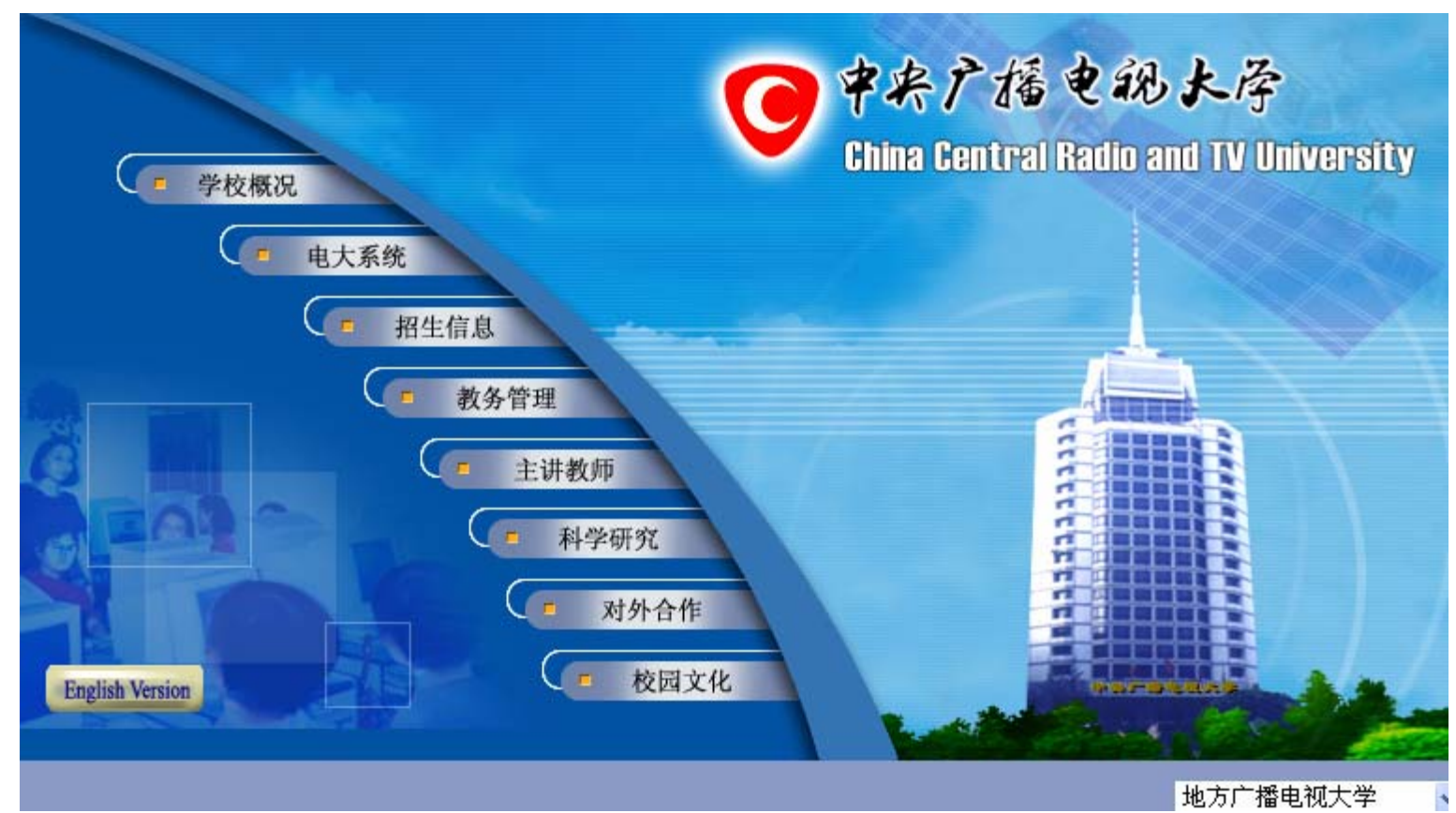

Figura 22: Portal da Central Broadcast Television University - China TV University.

Fonte: Central Broadcast Television University - China TV University. Disponível em: $<$ http://www.crtvu.edu.cn/. $>$ Acesso em: 3 jan. 2005.

\section{Público-alvo}

O público-alvo dos cursos de graduação da CCRTVU são cidadãos chineses com educação secundária e com exame nacional de ingresso aprovado pela comissão educativa estatal. Os estudantes que se inscrevem para aperfeiçoar suas habilidades profissionais não precisam fazer o exame de ingresso.

A universidade apresenta um forte crescimento, passando de 97.502 alunos anuais em 1979 a 1,5 milhão de alunos até o final de $2002^{164}$; e 2,3 milhão de alunos para 2004, o que reflete um percentual de crescimento de aproximadamente $2.259 \%$ em 28 anos de existência, com uma média de crescimento anual de $11,95 \%$.

\footnotetext{
${ }^{164}$ Central Broadcast Television University - China TV University. Disponível em: < $\underline{\text { http://www.crtvu.edu.cn/.> }}$ Acesso em: 3 jan. 2005. Traduzido por Tu Ling. Tradutor de chinês-português.
} 


\section{$\square \mathrm{N}^{\circ}$ de estudantes ativos}

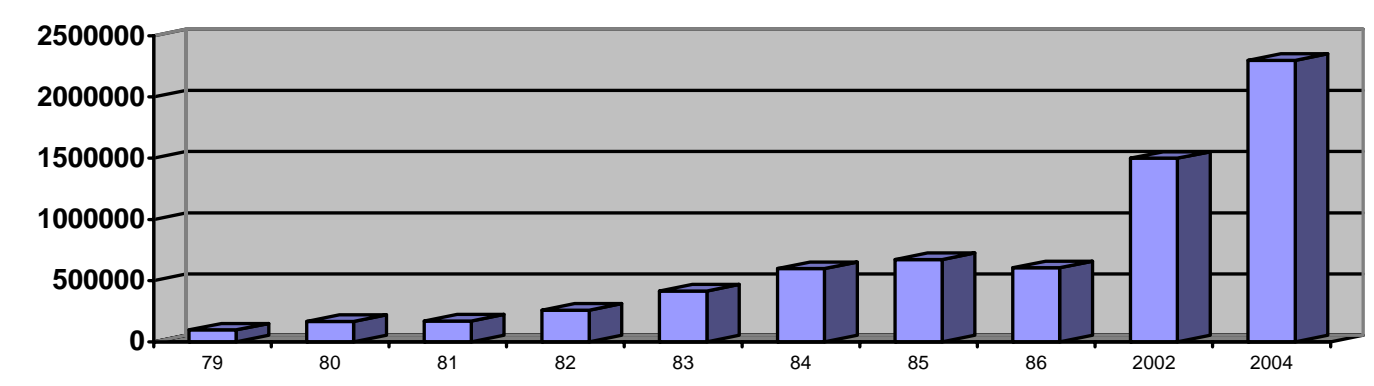

Gráfico 11: Fluxo de estudantes da CCRTVU

Fonte: Gráfico construído pelo autor com dados:

De: Yuhui, Zhao. China: Its Distance Higher-Education System. Prospects. 1988. Em The World Bank Site. Global Distance em Educationet.

Disponível em: $<$ http://www1.worldbank.org/disted/Technology/broadcast/tv-02.html >.

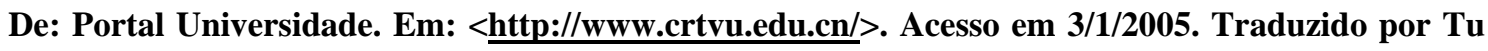
Ling. Tradutor de chinês-português.

De: UNESCO, Perspectives on distance education: Lifelong Learning and Distance Higher Education. 2005.

Seu número de graduados anual reflete um crescimento de mais de $170 \%$, passando de 92.022 alunos em 1982 para mais de 248.778 em 1986.

Até o final de 2002, o sistema de ensino a distância formou 3.337.000 graduados, o que corresponde a $12,7 \%$ dos alunos com nível superior no mesmo período e $26,6 \%$ dos alunos adultos. Também passaram pelos treinamentos profissionais 40 milhões de pessoas, das quais se formaram 1.280.000 professores. A China conta atualmente com 2 milhões de alunos no ensino superior a distância, dos quais 1,5 milhão são da CCRTVU ${ }^{165}$.

\section{Recursos humanos e materiais}

A CCRTVU possui uma equipe acadêmica de 52.600 pessoas em período integral, mais de 31.500 tutores em meio-período e uma equipe administrativa de 16.500 pessoas ${ }^{166}$. Nos últimos anos, a CCRTVU convidou mais de 1.300 professores, especialistas e acadêmicos eminentes das 100 melhores universidades e instituições de pesquisa da China e do exterior para elaborar os materiais didáticos e ministrar aulas.

\footnotetext{
${ }^{165}$ Op. Cit.

${ }^{166}$ UNESCO, COL. Perspectives on distance education: Lifelong Learning and Distance Higher Education. 2005. P. 81.
} 
A universidade dispõe de um portal com informações de inscrição, avaliações, recursos didáticos, programação, entre outros. Para prover um adequado suporte aos alunos, a rede tem introduzido, além do atendimento nos centros de estudo, uma plataforma tecnológica que provê acesso on-line aos recursos de aprendizagem e consulta a tutores, grupos de estudo, recursos didáticos digitais, entre outros. ${ }^{167}$

\section{Cursos oferecidos}

A CCRTVU disponibiliza nacionalmente mais de 580 cursos, provenientes de 9 campos do conhecimento (agricultura, engenharia, medicina, letras, direito, economia, administração, pedagogia, história). As RTVUs disponibilizam os cursos padrão e os derivados (os derivados adotam $60 \%$ ou mais do conteúdo obrigatório das disciplinas obrigatórias do CCRTVU) e conteúdos específicos elaborados para cada curso.

A rede está orientada principalmente à oferta de cursos de faculdade de dois e três anos, dirigidos ao treinamento profissional da área rural do país, os quais têm em conta não só o conhecimento técnico, mas também o conhecimento moral e físico que o país necessita para a construção socialista.

Desde 1986 a rede tem cooperado com mais de 40 instituições, incluindo departamentos de governo, organizações não governamentais, corpos acadêmicos, universidades e faculdades, desenvolvendo mais de 60 projetos de educação profissional, alcançando aproximadamente 4 milhões de estudantes. As RVTUs têm oferecido cursos profissionalizantes, alcançando quase 30 milhões de estudantes. Dois milhões de estudantes de escolas primárias e secundárias também têm recebido cursos através da rede.

\section{Sistema de estudos}

O ano acadêmico está dividido em dois semestres, com 18 semanas de ensino cada um. Os créditos são calculados em termos de horas de estudo, e cada um equivale a 18 horas, incluindo créditos outorgados para estudos de campo. O número mínimo de

${ }^{167}$ Innovative and Good Practices of Open and Distance Learning in Asia and the Pacific. (A study commissioned by UNESCO, Bangkok). October 1, 2005. Dr. Insung Jung, Professor International [da?] Christian University Tokyo, Japan. 
créditos requerido para concluir os estudos é de 76. O estudante pode integralizar os créditos com não menos de $60 \%$ deles obtidos na rede, e pode ter como máximo $40 \%$ dos créditos de outras universidades ou faculdades.

O programa piloto de ingresso de estudantes sem exame (open students) adota um sistema de crédito flexível no qual o período de validade de qualquer crédito obtido é de 8 anos. Quando o estudante obtiver os créditos totais especificados no currículo, qualificado para experiência prática ou estudo de campo e avaliação moral, será concedido um certificado de graduação que também é reconhecido pelo governo.

\section{Materiais para estudos e estratégia instrucional}

A CCRTVU, associada a outras instituições de ensino a distância, incluindo as de nível estadual, municipal e distrital, forma um sistema de ensino com planejamento unificado e administração descentralizada. A CCRTVU tem produzido mais de mil títulos de audiovisual e materiais de ensino, incluindo guias para professores e alunos, bem como mais de 300 títulos de audiovisual para professores.

O sistema funciona com base na combinação entre internet, comunicação por satélite, TV a cabo e TV sobre IP, em formato digital. Desta forma, segundo a universidade, o uso de satélite beneficia aqueles alunos que se encontram afastados em áreas rurais, mas que podem ter fácil acesso à televisão. Ao mesmo tempo, além do uso do satélite, do material audiovisual e do material impresso, o sistema oferece aos alunos ajuda direta (pessoal) e biblioteca, bem como outros serviços de suporte, como a internet através da rede CERNET. 


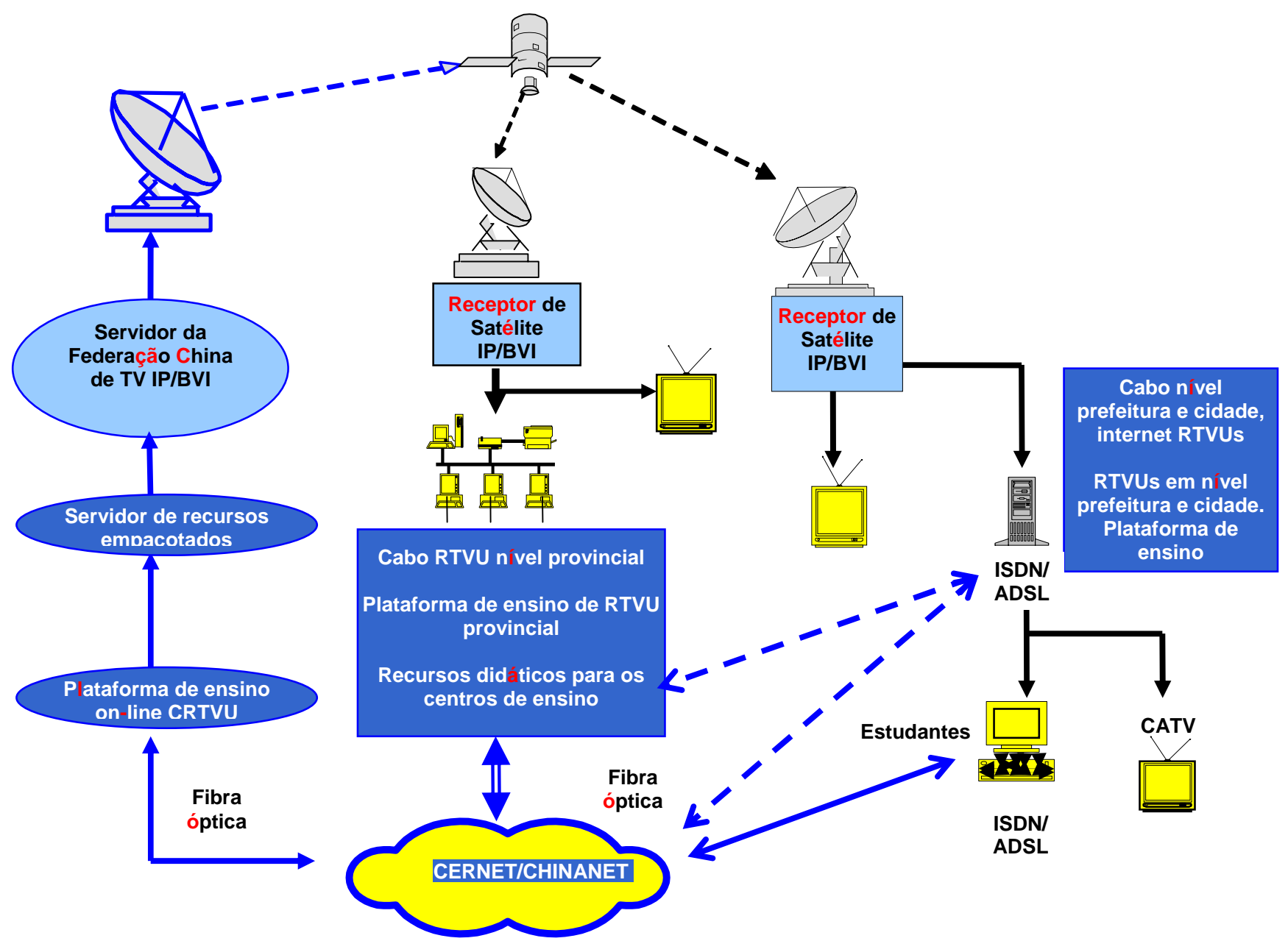

Figura 13: Sistema de transmissão de satélite e rede baseada em computadores Fonte: Portal Universidade.

Os alunos podem, a qualquer hora, escolher e gravar seus materiais de ensino, utilizar transmissão ao vivo via internet, conversar diretamente com o professor e os colegas, montar grupos de estudo, entre outros.

As classes por televisão apresentam 4 diferentes formatos: (a) as que funcionam nos departamentos do governo local (uma secretaria de educação, ou de indústria ou similar); (b) as que funcionam nas grandes fábricas e minas; (c) as que funcionam conjuntamente nas unidades de trabalho médias ou pequenas e (d) as que funcionam nas TVUs das localidades. 
Cada nível tem uma responsabilidade diferente no sistema: a CCRTVU é responsável pela produção e envio de material impresso e pela produção e transmissão de programas de rádio e televisão de nível nacional. Também é responsável pelo treinamento de professores, técnicos e equipe administrativa de funcionários das RTVUs, conduzindo as pesquisas para elevar a qualidade do sistema de educação a distância nacional. As RTVUs são responsáveis pela produção de impressos, programas de TV e rádio relacionados a cursos de interesse local ou regional. Também desenvolvem, programam e supervisionam as avaliações e os procedimentos destes cursos. Além disso, são responsáveis pelo registro de alunos, avaliação, edição de diplomas e certificados, entre outros. As escolas afiliadas administram todos os aspectos das atividades de ensino e aprendizagem, como programação, elaboração de tutoriais, trabalho do laboratório, testes e avaliações, bem como estudos de campo estipulados pela CCRTVU e pelas RTVUs.

Os materiais impressos utilizados são divididos em três tipos: livros dos cursos, livros de referências e guias de estudos. Os livros de texto são em geral os mesmos das faculdades convencionais. Nos últimos 8 anos mais de 400 livros e 40 milhões de cópias foram publicados.

Além dos materiais impressos e em vídeo, o sistema possui materiais on-line em vários formatos, distribuídos através de uma plataforma de aprendizagem. Esses conteúdos são publicados no servidor pelo centro de produção da CCTV em formato digital e transmitidos ao canal educativo da estação de TV (CETV), que os transmite através do Satélite Ásia II (canal de IP). Depois de desempacotar os conteúdos, eles são publicados ou na plataforma de educação instalada na rede de internet ou transmitidos pelas RTVUs.

Os estudantes podem consultar os conteúdos da internet tanto em casa como nos centros de estudo, assim como têm a alternativa de receber a transmissão através de TV a cabo. As interações entre o professor e o estudante são realizadas na plataforma on-line de educação aberta através da internet. Todos os centros de estudos contam com acesso à internet banda larga. A plataforma conta com bate-papo, fórum, auto-avaliações, entre outros recursos. Além do suporte virtual, os estudantes são incentivados a se comunicar com seus colegas e colaborar nas reuniões presenciais. 
Todos os currículos são elaborados por especialistas e professores de diversas universidades de prestígio do país. Desde o outono de 1999, o projeto de reforma de treinamento e ensino aprovado pelo Ministério da Educação ${ }^{168}$ conta com 44 RTVUs estaduais e algumas escolas da CCRTVU. O projeto se baseia em uma plataforma digital, multimídia e interativa para aprendizagem a distância. Até o outono de 2004, estavam inscritos 2.109.000 estudantes, dos quais 361.000 concluíram suas formações.

Os encontros presenciais com tutores são importantes no sistema. Os alunos se reúnem e assistem aos programas de TV junto aos tutores. Estes são também responsáveis por avaliar os trabalhos dos estudantes e guiar o seu estudo individual. Em algumas especialidades, os tutores ajudam a organizar o trabalho prático de laboratório e outras atividades visando a aplicação da teoria na prática. Os trabalhos práticos são feitos ou nos centros de estudos da RTVU ou em universidades ou institutos de pesquisa convencionais durante os feriados.

\section{Desenvolvimento de cursos}

A CCRTVU oferece cursos nos assuntos reconhecidos como sendo de interesse nacional, e conta com equipes que produzem o material impresso, de rádio e de televisão para todo o país. As RTVUs são responsáveis pela produção dos materiais impressos, de rádio e televisão, com conteúdos de interesse local ou regional. Existem na atualidade mais de 40 centros de produção de materiais educativos, sendo os da CCRTVU localizados nas principais cidades e os mais bem equipados de toda a rede.

As RTVUs colaboram na produção conjunta de conteúdos relacionados aos seus interesses, com o objetivo de partilhar os custos e poder desenvolver cursos nas áreas de teoria básica da medicina, enfermagem, tecnologia para o processamento de alimentos, reforma criminal, administração de indústria rural, inglês para professores de ensino secundário, entre outros.

\footnotetext{
1682003 World Summit of Mega Universities. Innovation and Collaboration - Joint Action for the Future of Distance Education. Date: 6-7 November 2003. Shanghai, China. Disponível em: $<$ http://03summit.shtvu.edu.cn/web/MegaUniversities/ctvu.htm>. Acesso em: 31 jan. 2005.
} 


\section{Avaliação educacional}

As avaliações em processo são elaboradas pelas RTVUs, porém as avaliações finais sempre são elaboradas pela CCRTVU para todo o país.

Nas avaliações em processo, consideram-se a participação dos alunos nas oficinas, nos laboratórios e nos seminários, contatos com o tutor e trabalhos de pesquisa. Nunca se concedem os créditos correspondentes sem aprovação na parte prática. A avaliação final sempre é realizada por escrito. Os estudantes devem completar 114 créditos para um grau equivalente ao de três anos em tempo integral, e 76 créditos para um grau equivalente ao de dois anos em tempo integral. Um crédito é concedido para um conjunto de 18 horas de estudo.

\section{Centros de estudo}

Os centros de estudo possuem uma pequena biblioteca, sala audiovisual, sala de teleconferência e laboratórios, como podemos observar nas imagens abaixo. $\mathrm{O}$ crescimento dos centros de estudo tem sido muito importante, passando de 966 a 1.968 em 1 ano, entre 2001 e 2002. O que temos podido detectar é a desigualdade na distribuição de recursos nos centros de estudo: os centros são bem equipados nas regiões ricas e mal equipados nas regiões pobres.
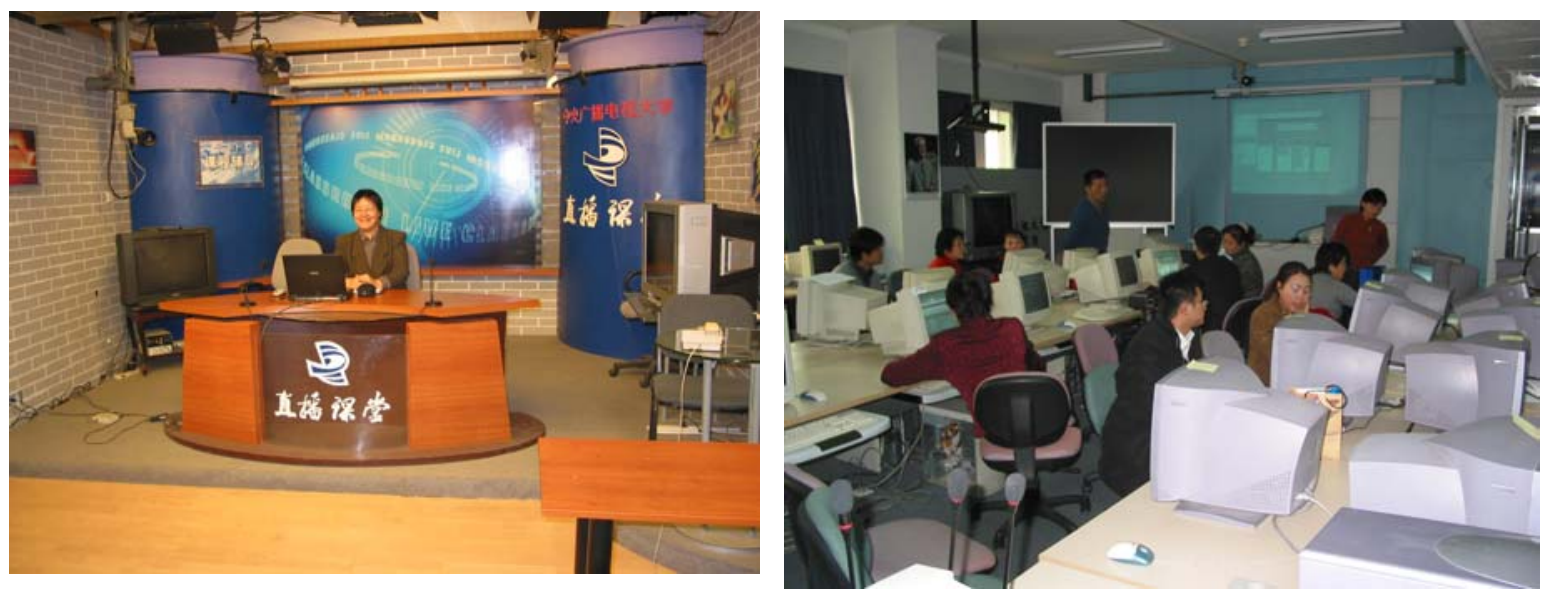

Figura 14: Estúdio de transmissão ${ }^{169}$ Salas de aula de transmissão ao vivo

\footnotetext{
169 George Bagwell, Prof., Colorado Mountain College, LBagwell@coloradomtn.edu, $<\underline{\text { http://faculty.coloradomtn.edu/bagwell/>. }}$. 15th Annual WCET Conference. China Distance Learning Study Award.
} 


\section{Valor dos cursos e financiamento do sistema}

Os recursos financeiros do sistema vêm de uma variedade de fontes. A CCRTVU é administrada e financiada pelo Ministério da Educação e pela CCTV e CETV, que são responsáveis pelos custos de transmissão da televisão. Recebe também apoio financeiro dos ministros que pedem ao CCRTVU ajuda para treinar o pessoal.

As RTVUs estão sob os auspícios dos governos provinciais, e suas escolas afiliadas recebem financiamento dos governos municipais. Os fundos para RTVUs são parte do orçamento educacional dos governos em todos os níveis. As estações de trabalho são financiadas, por sua vez, pelos diversos usuários: as secretarias de educação distritais, as indústrias, as empresas, comércios e agências do governo, como se pode observar no gráfico.

\section{Financiamento do sistema ${ }^{170}$}

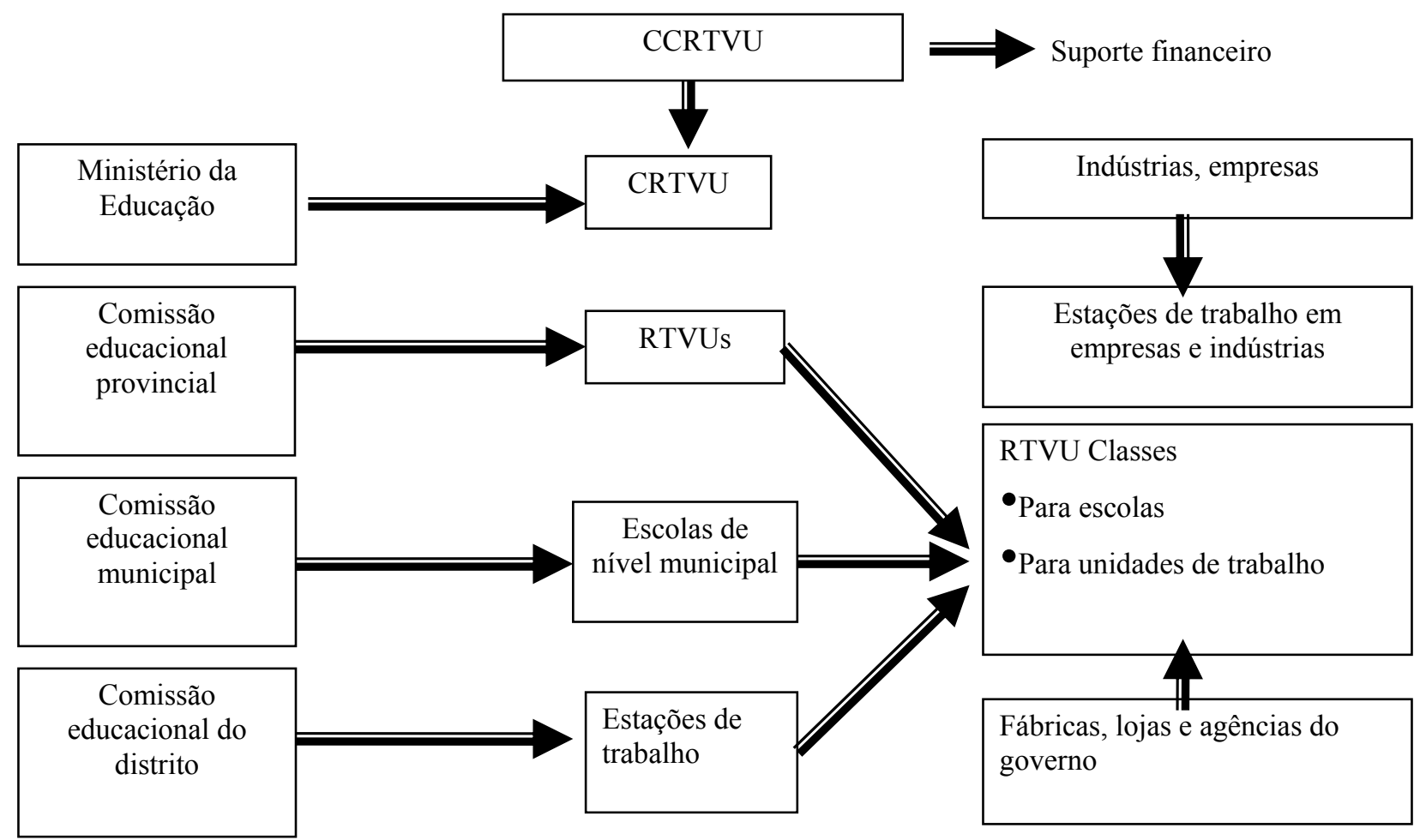

Figura 15: Esquema de financiamento do sistema

\footnotetext{
${ }^{170}$ Distance Education in China. James Willcox; Joanne Kline; Universidade de Stanford. Yoko Nagashima. Disponível em: $<$ http://ldt.stanford.edu/ jkline/China-final.ppt $>$.
} 
Segundo Yuhui (1988), ${ }^{171}$ os estudantes estão livres de taxas de matrícula, exceto os ouvintes, que têm que pagar pelo registro e pelos exames. Entretanto, todos os estudantes devem pagar por suas próprias despesas de estudo (materiais de ensino e artigos de papelaria, impressos). Existem sistemas de bolsas de estudos doadas pelo Ministério da Educação para o pagamento de despesas de materiais de estudo.

\section{b) Universidade de Tsinghua}

\section{Endereço}

Tsinghua University

Beijing, P.R.

China

Telefone: 8610-62785001

Fax: 8610-62770349

Site: http://www.tsinghua.edu.cn

\section{Contexto histórico}

A Universidade de Tsinghua lidera o ranking das trinta melhores universidades da China e foi a primeira a ter seu programa de educação a distância reconhecido pelo governo chinês. A construção do sistema de educação a distância na universidade começou em junho de 1997 e terminou a fase preliminar em setembro do mesmo ano. O orçamento inicial foi uma doação de 150 milhões de dólares por uma corporação.

No início eram apenas 10 cursos, mas já em 1998 esse número havia crescido para 137 e, em março de 1999, foi inaugurado um sistema on-line de cursos por demanda (courses on demand). Em julho do mesmo ano foi inaugurado o Centro de Testes online, que permite aos alunos poder realizar suas provas em um ambiente virtual. Também em 99 foi inaugurada a "Tsinghua Web School”, que, posteriormente, em outubro de 2001, teve sua infra-estrutura totalmente reformulada e aberta ao público interessado.

\footnotetext{
${ }^{171}$ Yuhui, Zhao. 1988. "China: Its Distance Higher-Education System." Prospects 18(2): 217-28. Disponível em: $<$ http://www1.worldbank.org/disted/Technology/broadcast/tv-02.html>. Acesso em 12/8/2005.
} 
A Universidade de Tsinghua foi eleita em julho de 2000 como a unidade supervisora da Organização Nacional de Cooperação em Educação a Distância Moderna de faculdades e universidades. Foi ela que construiu e administra a rede CERNET $^{172}$, do Ministério de Educação da China.

A universidade mantém, desde a sua fundação, uma estreita relação de cooperação com as empresas, estabelecendo parcerias que têm possibilitado aquisição de tecnologia e infra-estrutura e prestado serviços de treinamento de recursos humanos.

A partir de 2003 a universidade começou a inovar em duas direções: o programa de educação a distância para treinamento corporativo e o programa de educação a distância para ajudar a superar a pobreza.

Desta forma, a universidade se aproxima da comunidade e das empresas e possibilita a socialização de conhecimento e educação para todas as pessoas, "atualizando" a sua função de serviço educativo.

\section{Objetivos}

Além de sua função de formar profissionais e pessoal acadêmico qualificado para responder às necessidades do mercado, a universidade fornece serviços a outras universidades nas suas atividades de e-learning, como autorizações e certificados, equipamentos e materiais multimídia para diferentes cursos, materiais de cursos on-line - como CD-ROM -, supervisão e treinamento de professores para outros centros de aprendizagem, etc.

Abaixo podemos ver o portal de acesso da "Escola On-line" da Universidade de Tsinghua:

\footnotetext{
${ }^{172}$ China Education and Research Network. O objetivo principal do projeto da CERNET é estabelecer uma infraestrutura nacional de telecomunicação, internet e microcomputador,além de e coordenar a pesquisa entre universidades, institutos e escolas usuárias.
} 


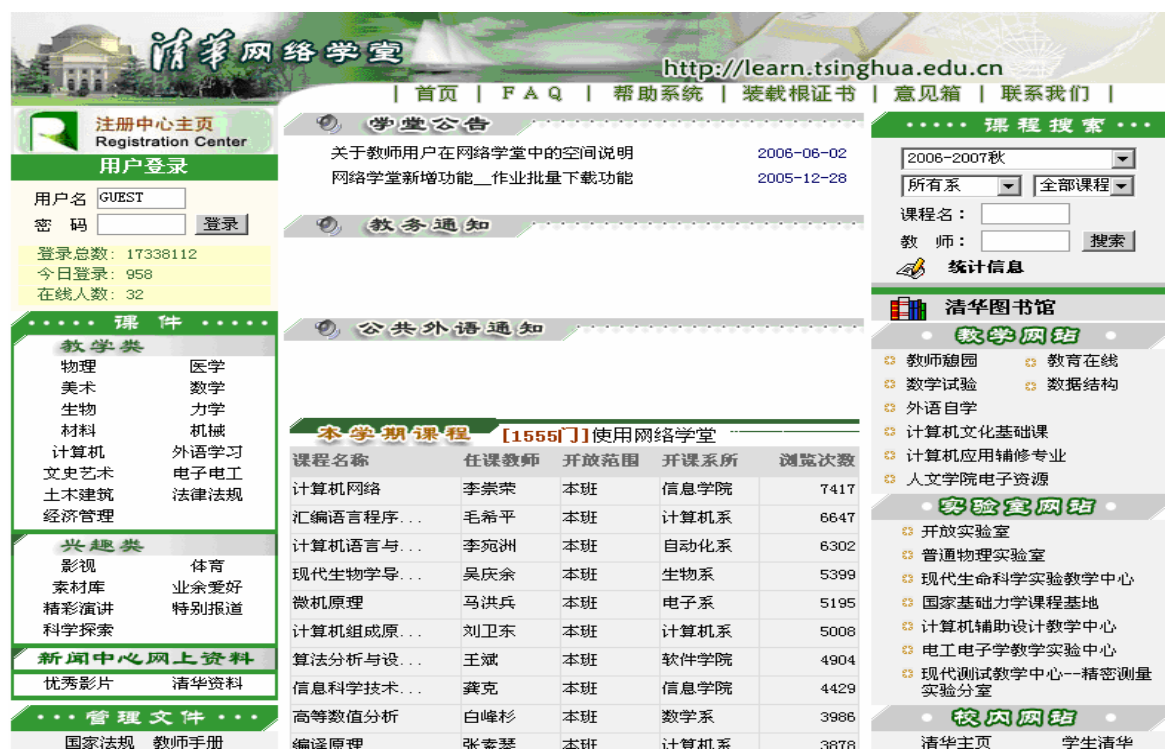

Figura 1: Portal da Universidade de Tsinghua na China

\section{Público-alvo}

As estatísticas de 2002 mostram que a universidade, através da escola na internet, com 1.014 cursos, contava com mais de 25.734 usuários, dentre os quais 2.034 eram professores. O acesso semestral chegou a 1.080.000, descontando-se disso os visitantes não registrados (“convidados"), o que contabilizaria 180.000 horas/aula ininterruptas e totalmente on-line. Através do Centro de Testes da internet, cerca de 2.000 estudantes do curso de engenharia realizaram suas provas finais de inglês e de linguagem de programação em linguagem $\mathrm{C}$.

\begin{tabular}{|c|c|c|}
\hline Mês & Número de Visitantes/dia & Acesso aos cursos por dia \\
\hline Jan.- Março & 4,445 & 300 \\
\hline Abril & 7,192 & 660 \\
\hline Maio & 8,565 & 720 \\
\hline \hline Junho & 8,587 & 1,050 \\
\hline
\end{tabular}

Tabela 13 - Estatísticas de e-learning no $1^{\circ}$ semestre de 2002 na Universidade de Tsinghua. 


\section{Recursos humanos e materiais}

A Universidade de Tsinghua construiu um sistema de transmissão que cobre o país inteiro, combinando a internet, a rede digital por satélite e a rede de transmissão de TV a cabo.

A instituição também tem desenvolvido um software chamado lyceum online, que é uma plataforma de ensino e de administração de educação a distância em que os estudantes podem se registrar, selecionar cursos, fazer perguntas, downloads, atividades, pagar matrículas e participar de fórum de discussão através do sistema. Atualmente, mais de 10.000 estudantes usam o lyceum, e o seu site registrou mais de 2.050.000 entradas desde que o programa começou em 2002.

Todos os anos mais de 10 mil pessoas participam dos treinamentos no trabalho, tanto em agências do governo como em empresas e em comunidades, para líderes de serviço comunitário. Para atender a essa demanda, a escola contratou um corpo de 1.435 professores de tempo parcial ao final de 2005.

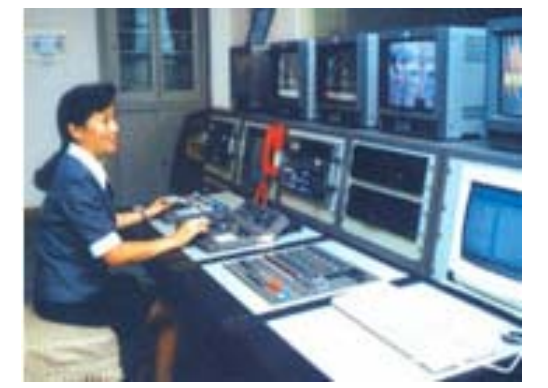

Figura 17: Tsinghua On-line Lyceum ${ }^{173}$

Os recursos do repositório de objetos desenvolvido até a atualidade incluem 300 tipos de cursos, 6 mil videotapes digitais, 8 mil CD-ROMs e 240 cursos on-line.

\section{Cursos oferecidos}

Os principais cursos inicialmente previstos no projeto e suas principais características foram: Direito Civil e Comercial - ensino através de um Tribunal Simulado ("Mootcourt"); Inglês Oral - através de Prática de "listening" e conversação; Informática - por meio de experimentos on-line; Arte e Design - com um software de

\begin{tabular}{l}
\hline $173 \quad$ Tsinghua $\quad$ University. \\
$<\underline{\text { http://www.sce.tsinghua.edu.cn/e_edition/long_distance/long_distance.htm }>\text {. }}$ Modern
\end{tabular}


estúdio de desenho on-line; Teoria e Metodologia do Design - com aulas on-line e atividades interativas.

Além dos seus cursos regulares, a universidade fundou a primeira escola de educação contínua aprovada pelo Ministério da Educação. Os programas de treinamento para administradores sênior oferecem cursos em vários campos, incluindo administração pública, gerência de empresa, gerência de engenharia, gerência de serviço financeiro, gerência da saúde e do serviço público; propaganda e mídia; cultura e arte; bens imobiliários; indústria automotiva; agricultura; etc.

\section{Materiais de estudo e estratégia instrucional}

O sistema opera tanto através da internet quanto via satélite e/ou CD-ROM. Suas principais características são: Internet - opera através do CERNET; Satélite - Asia SatII: C-Band, operando a 6.5 megabytes; Cable TV e Videoconferência - através do sistema ISDN; CD-ROM; Tutoriais e seminários "presenciais" - através de teleconferência multi-point MCU.

Abaixo podemos ver a estrutura do servidor da universidade e o fluxograma que permite que diferentes alunos criem sessões de aulas no servidor:

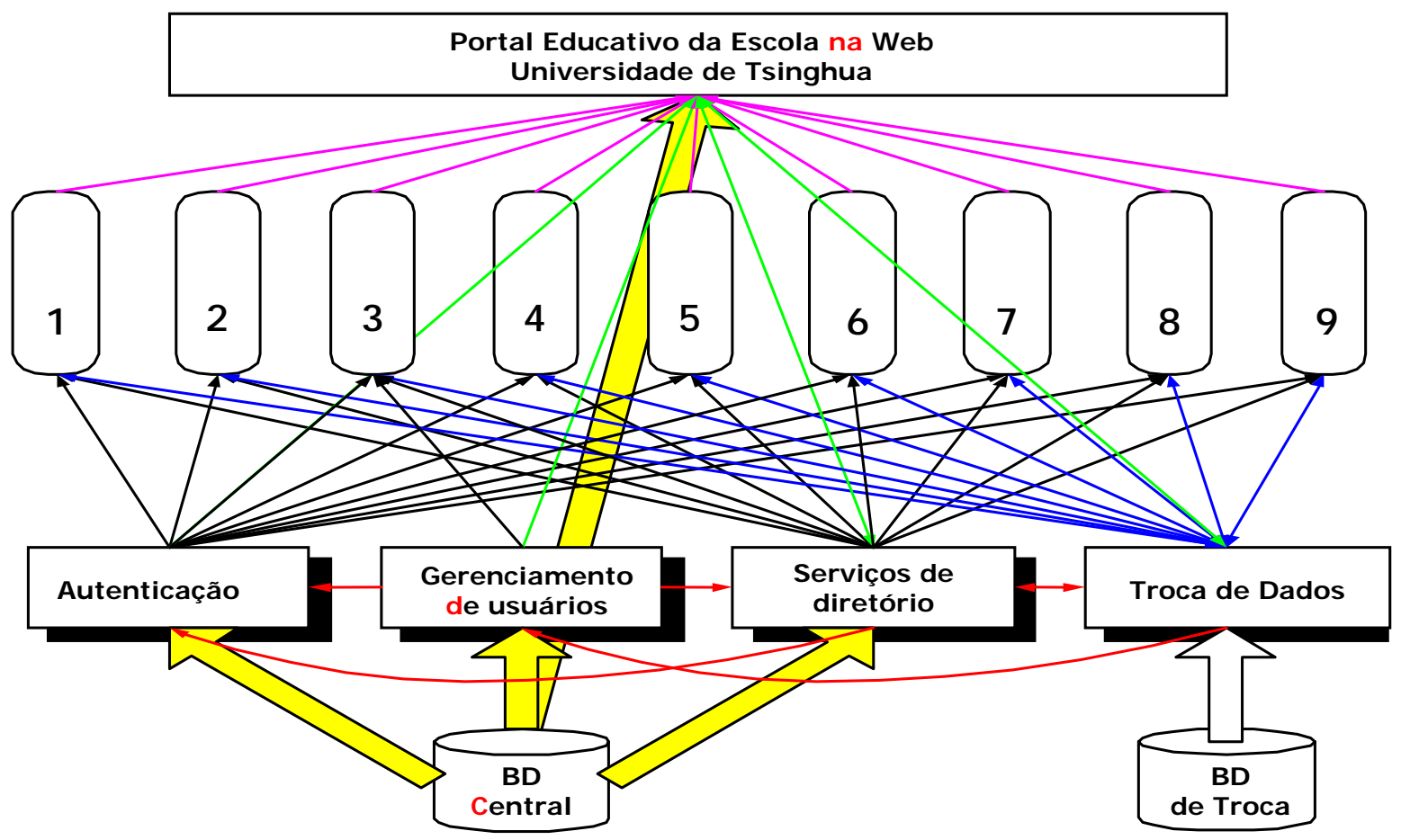

Figura 18 - Sistema do "mainframe” da escola na web da Universidade de Tsinghua. 
O sistema compreende:

1 - Aula síncrona virtual

2 - Sistema de Cursos por Demanda

3 - Administração

4 - Contabilidade

5 - Questões e Respostas

6 - Tarefas

7 - "Quizes" e testes

8 - Gerenciamento de Recursos

9 - Avaliação da Qualidade

Ou seja, um sistema que articula encontros presenciais, material on-line e multimídia educativa.

Na seqüência podemos ver o organograma funcional da escola on-line:

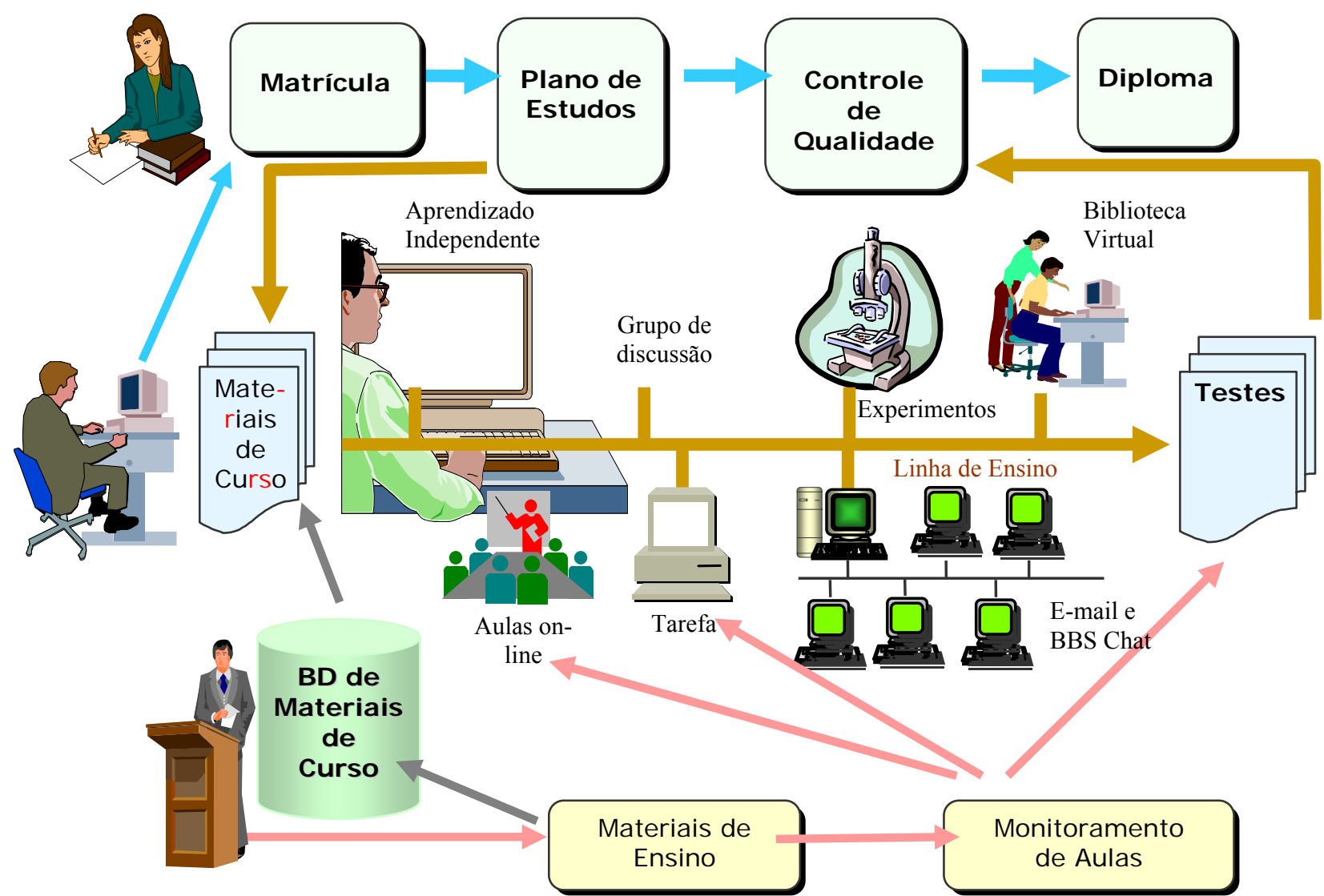

Figura 19 - Organograma funcional da escola on-line da Universidade de Tsinghua.

O sistema da universidade articula diversas mídias em busca de um processo educativo bidirecional que possibilite uma ampla interação entre professores e alunos. Assim, o sistema possibilita a transmissão em tempo real para mais de 150 centros em todo o país e se articula com outras redes de ensino a distância, excetuando o Tibete. 
Como podemos observar, a metodologia envolve um sistema multicanal, para assegurar o diálogo entre estudantes e professores, que inclui salas de trabalho, onde os alunos apresentam seus trabalhos individuais e os tutores os avaliam, fazendo comentários, chat síncrono, fórum de discussão, e-mail, encontros presenciais e telefone.

Isso possibilita a construção de um ambiente multicanal, com sistemas baseados na web (novidades, introdução dos cursos, introdução dos tutores, ajuda, planos de estudo, cursos, fórum, chat, atividades e diversos recursos de estudo), canais on-line (e-mail, softwares de chat) e canais off-line (telefone e encontros presenciais).

As pesquisas desenvolvidas pela universidade mostram que os meios mais populares de comunicação com o tutor são o fórum e o e-mail, seguidos pelo chat e, por último, os encontros presenciais, como pode se ver na figura:

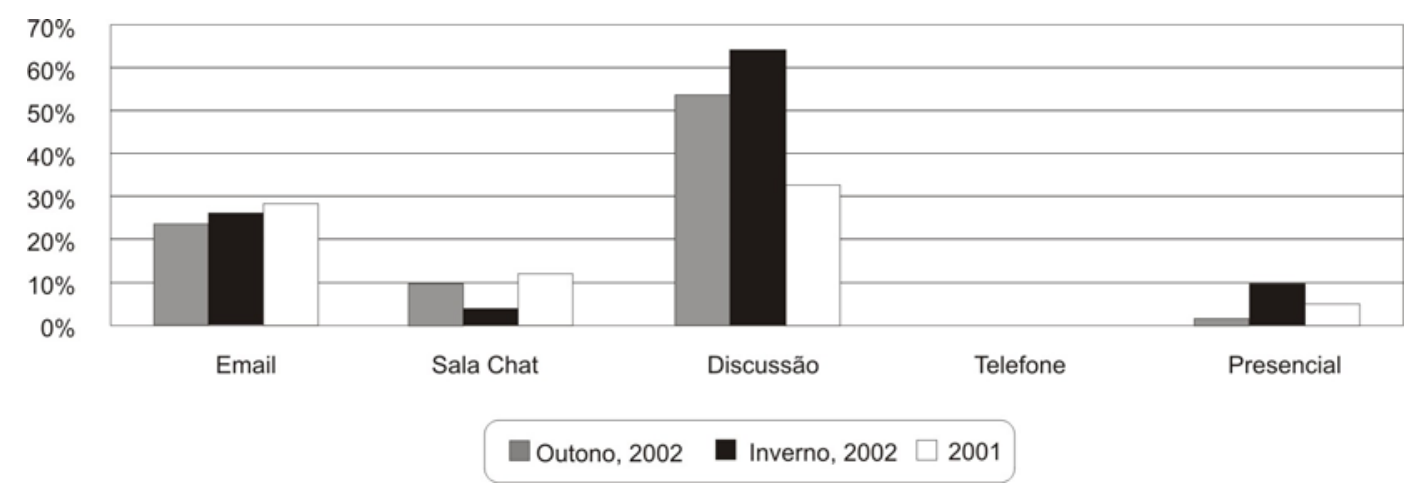

Gráfico 12 - Meios mais populares de comunicação com o tutor na Universidade de Tsinghua. 
Já quando se trata de comunicação entre alunos, vemos cair a freqüência do e-mail, aparecer o telefone e crescer significativamente os encontros presenciais:

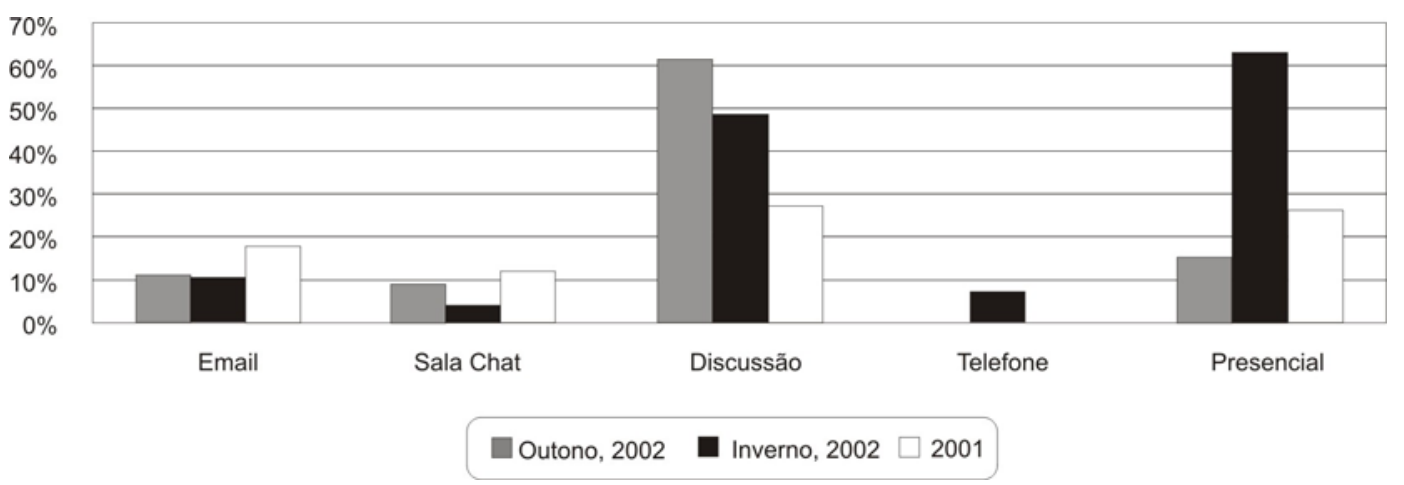

Gráfico 13: Strategies for enhancing instructor immediacy in e learning, Liu Huifen, He Ling. Tsinghua University. School of Journalism and Communication, Tsinghua University, Beijing, P. R. China. 2004. Disponível em: < www.ice.upc.edu/butlleti/innsbruck/416-032.pdf>.

Os tutores da universidade publicam homepages próprias com suas fotos, das suas famílias, seu currículo, suas pesquisas e experiências, rompendo com a imagem fria e distante e trazendo a imagem de um pai, uma mãe carinhosa, o que gera maior aproximação entre os professores e os estudantes.

Os tutores, na comunicação on-line, se apresentam mais como amigos do conhecimento e de seus estudantes, não como uma autoridade. O tutor incentiva os alunos a discutir com outros alunos, de forma a aprenderem que a colaboração ajuda a resolver problemas. Os tutores incentivam quando um aluno fica para trás ou se sente mal por não compreender. $\mathrm{O}$ tutor desenvolve um relacionamento com cada aluno, tratando-o como um indivíduo e respeitando-o. Às vezes alguns alunos têm dificuldades para se expressar no grupo, por isso preferem um relacionamento por meio de e-mail com o tutor. Os tutores vêem suas caixas postais duas vezes ao dia, uma pela manhã e outra pela noite. Havendo requerimentos, o tutor os atende imediatamente.

Muitas vezes os alunos continuam o relacionamento com o tutor por meio de e-mail muito tempo depois de terem concluído o curso.

Os tutores contam com a ajuda de assistentes, estudantes avançados que ajudam o instrutor a controlar o curso. Isso colabora muito para a aproximação com os alunos, já que eles o sentem mais próximo, dada a sua idade e linguagem. 
As estatísticas da universidade mostram que, ano a ano, os cursos e os tutores ganham reconhecimento dos estudantes. Desde 2001, mais e mais estudantes (93,5\% em 2002 contra $89 \%$ em 2001) expressaram que gostariam de fazer outros cursos no futuro. A maioria dos estudantes $(88,1 \%$ no outono de 2002$)$ expressou que tinha conseguido seus objetivos de aprendizagem e tinha ganhado muito com a aprendizagem on-line. As estatísticas mostram também que a maioria dos estudantes considera o instrutor bom $(20,8 \%)$ ou excelente $(77,2 \%)$.

\section{Pesquisa}

A universidade desenvolve numerosas pesquisas. Na avaliação dos alunos on-line, têm sido desenvolvidos métodos, com base em pesquisas realizadas pelo laboratório de tecnologia e sistemas do departamento de ciências da computação da universidade, com o objetivo de utilizar os weblogs ${ }^{174}$ para avaliar a performance dos alunos através da sua navegação no sistema. Assim, tanto na avaliação em processo como na avaliação final pode-se interpretar o histórico de aprendizagem de cada aluno através da leitura dos relatórios do software educacional da universidade. Nesse sentido, de acordo com o comportamento de cada aluno na navegação do sistema, tem sido construída uma série de modelos. Por exemplo, o fato de um aluno ficar muito tempo em uma página, ou muito menos tempo do que o modelo pedagógico indica, provavelmente signifique que ele não está concentrado. ${ }^{175}$

A universidade está desenvolvendo experiências comparando os tempos médios calculados nos modelos pedagógicos com os tempos reais usados pelos alunos, tentando determinar o comportamento assumido pelos alunos no sistema. Para isso, para cada tipo de página tem sido estabelecida uma carga horária mínima. Nas páginas de conteúdo, uma análise de tempo de leitura; nas páginas de recursos, como vídeos, a análise de tempo para ver os vídeos; nas páginas de atividades ou leituras, outra análise de carga horária diferente.

\footnotetext{
${ }^{174}$ Um weblog ou blog é uma página da web cujas atualizações (chamadas posts) são organizadas cronologicamente (como um histórico ou diário).

${ }^{175}$ Ling Guo, Xin Xiang, YuanChun Shi. Use Web Usage Mining to Assist Online E-Learning Assessment. State Key Lab of Intelligent Technology and Systems, Computer Science Department, Tsinghua University, Beijing, China. 2004.
} 
Desde 2000 a universidade empreende uma pesquisa sobre o desenvolvimento de salas de aulas inteligentes - as smart classrooms - um sistema de transmissão simultânea, em tempo real, que possibilita a interação bidirecional entre o professor e os alunos dispersos por todo o país. O sistema funciona da seguinte forma: em uma parede da sala de aula há a projeção de estudantes que se encontram on-line em outras universidades espalhadas pela China ou em suas casas, já que o sistema opera com webcam, caixas de som e microfone no microcomputador de cada aluno; na outra parede o professor conta com uma lousa eletrônica na qual pode escrever, passar uma apresentação, um vídeo, uma animação ou qualquer outro recurso, que é transmitido aos computadores dos alunos em tempo real.

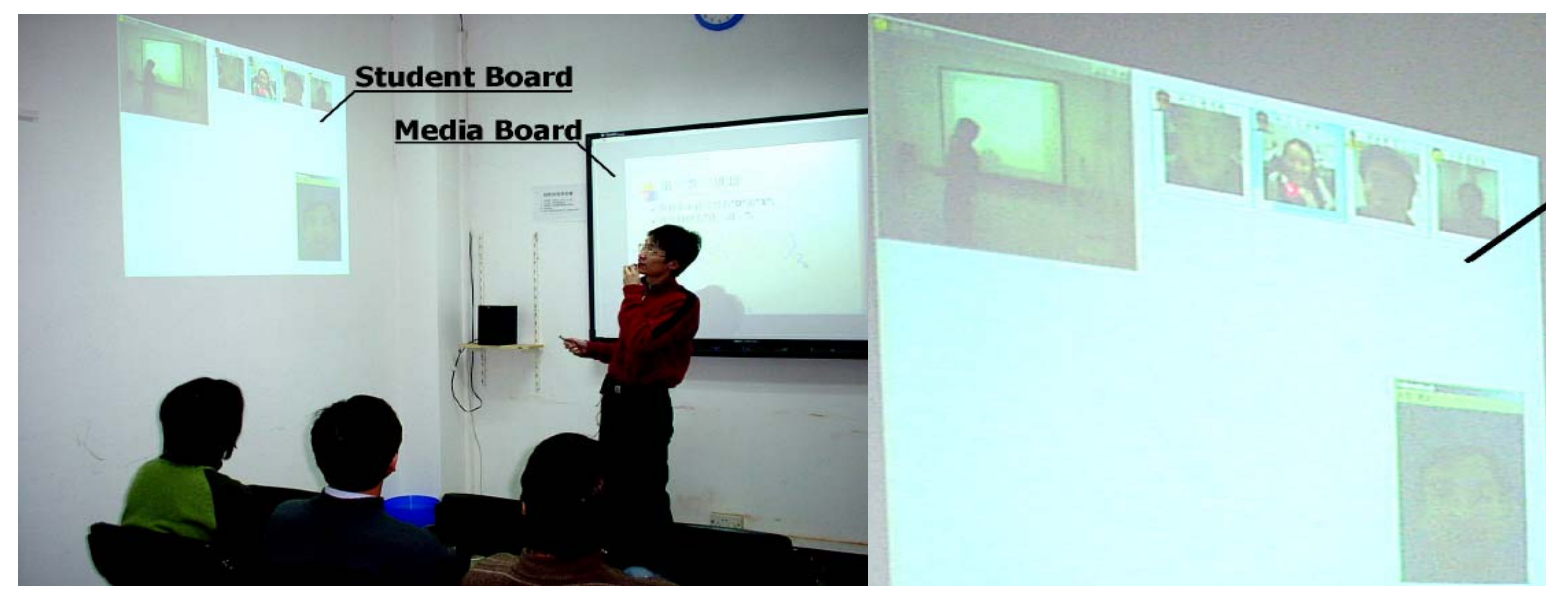

Figura 20: Uso da ponteira laser para dar permissão para usar a palavra para estudantes remotos apontando para suas imagens no quadro de estudantes ${ }^{176}$

O professor possui um ponteiro laser com o qual, simplesmente apontando a foto de um aluno, o sistema comuta automaticamente, ampliando a imagem do aluno e dando áudio para a sua apresentação; também o ponteiro possibilita acessar a lousa eletrônica, passando as páginas. Outras funcionalidades são realizadas com os movimentos das mãos. Eles têm um significado para o sistema, que opera as câmeras de acordo com os movimentos da mão do professor.

Nos fundos da sala, atrás de uma cortina, ficam 7 microcomputadores que coordenam as 8 câmeras que seguem os movimentos do professor pela sala, de forma automática, trocando de foco a partir do ponteiro laser e de simples instruções faladas.

\footnotetext{
${ }^{176}$ Streaming Support for Multimodal Data in Smart Spaces. Multimedia Lab of Tsinghua University, 2003. Disponível em: <www.cse.ucsd.edu/ yamao/publications/Stream_MYH.pdf>.
} 
Esse sistema, além de permitir uma interação mais natural entre professor e alunos, incorporando a comunicação gestual, também vem sendo testado como uma ferramenta de avaliação, já que possibilita um controle remoto dos alunos fazendo a prova.

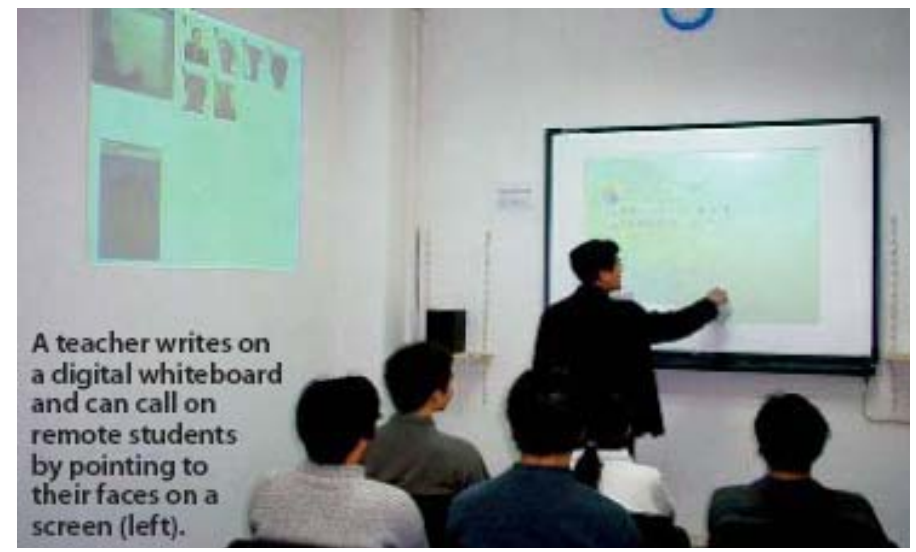

Figura 21: Uso da ponteira laser para dar permissão para usar a palavra para estudantes remotos apontando para suas imagens no quadro de estudantes ${ }^{177}$

O sistema conta com um identificador visual e de reconhecimento de voz na porta de entrada da sala de aula. Cada pessoa que entra na sala é identificada imediatamente, e sua imagem aparece na tela de alunos locais. Quando a sala identifica o professor, concede-lhe o controle da sala.

\section{Centros de estudo}

A universidade conta hoje com 150 centros de estudo fora do campus, em 31 províncias, em regiões autônomas e em municipalidades.

Além disso, a universidade criou o programa "Tsinghua Education Aiding Poverty Modern Long Distance Teaching Centers", que conta com mais de 100 centros de ensino em regiões pobres do país.

\footnotetext{
177 Streaming Support for Multimodal Data in Smart Spaces. Multimedia Lab of Tsinghua University, 2003. Disponível em: <www.cse.ucsd.edu/ yamao/publications/Stream_MYH.pdf>.
} 
Estes centros se apresentam em três níveis, como se pode observar na figura:

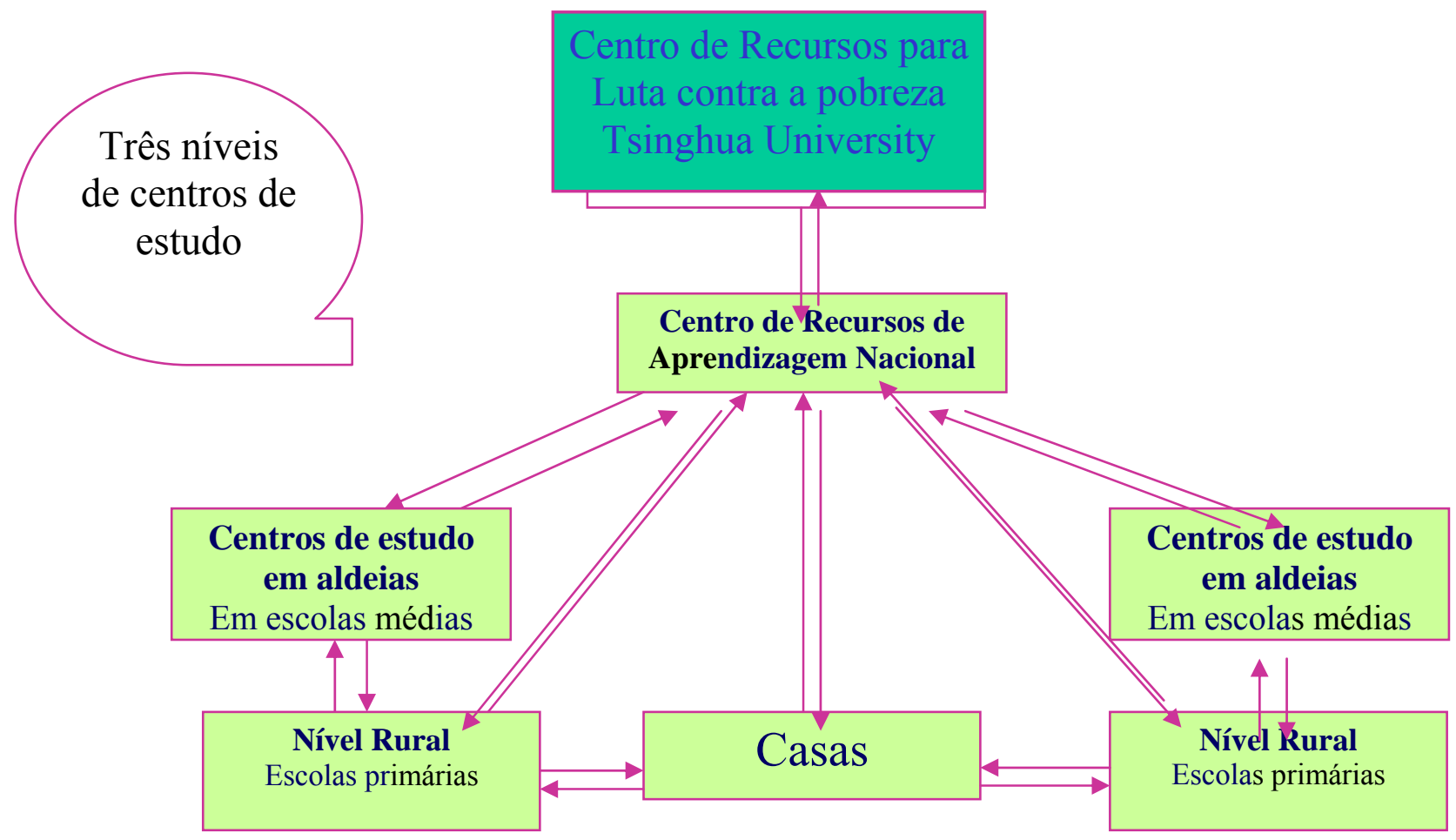

Figura 22: Centros de Estudo da Universidade de Tsinghua.

Objetivos dos centros: administrar os recursos educativos na comunidade e organizar atividades e recursos educacionais para ajudar a treinar os membros da comunidade. $\mathrm{O}$ centro também planeja e organiza diferentes tipos de grupos de aprendizagem com atividades e cursos variados para a comunidade.

Os centros de treinamento e os centros de aprendizagem oferecem à população em idade escolar educação e treinamento flexível, desenvolvendo habilidades vocacionais, sociais e culturais, possibilitando treinamento em serviço e educação continuada.

Para a execução dos programas de combate à pobreza, a Universidade de Tsinghua, o comitê de Yuanzhou e o governo local são obrigados a fornecer regulamentos, padrões de avaliação e mecanismos da competição.

O programa oferece cursos variados, como treinamento de professores, agricultura, saúde pública e enfermagem, administração de negócios, inglês e computação, entre outros. 


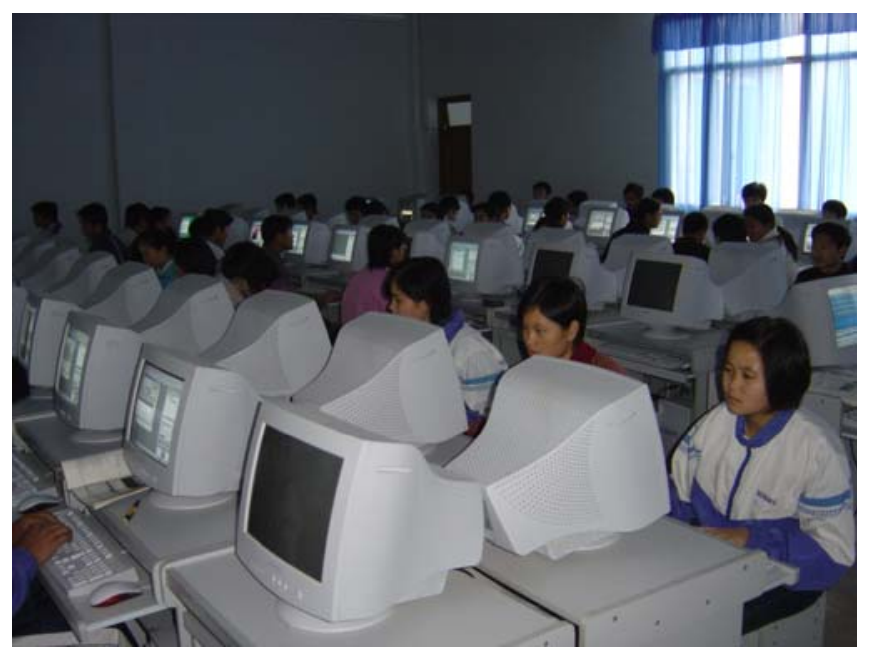

Figura 23: Centro municipal de educação a distância de Guizhou Nawei

Fonte: Distance Learning in the Knowledge Age: Beyond the Digital Gap. A Perspective from Tsinghua University. The School of Continuing Education, Tsinghua University. Dr. Song Gilsun (Sunny). October 5th, 2005.

Disponível em: $<$ http://www.fenu.ru/?a=page\&id=524 $>$.

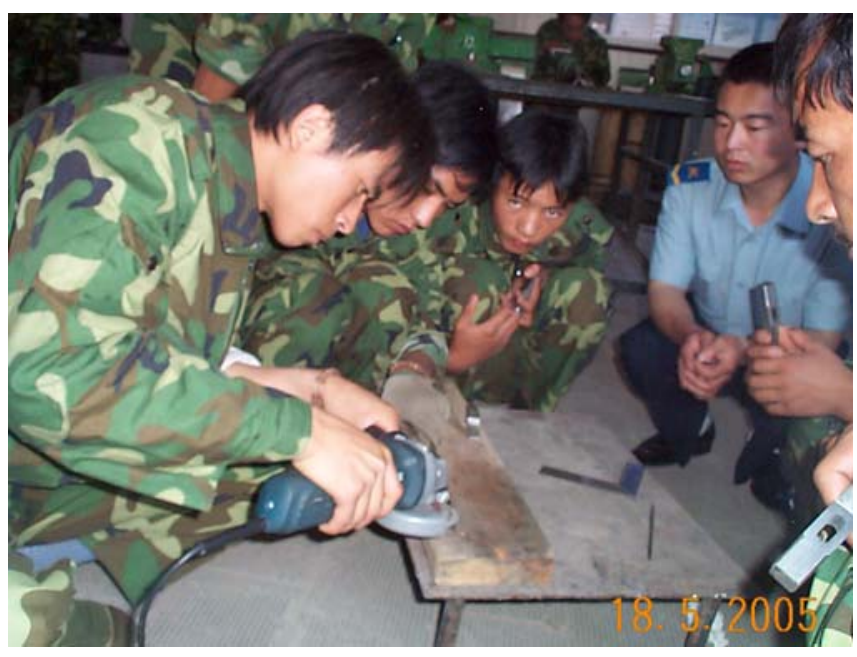

Figura 24: Estudantes no centro de ensino do município de Shanggelila aprendendo a reparar motores em Beijing (18.5.2005)

Fonte: Distance Learning in the Knowledge Age: Beyond the Digital Gap. A Perspective from Tsinghua University. The School of Continuing Education, Tsinghua University. Dr. Song Gilsun (Sunny). October. 5th, 2005. Disponível em: <http://www.fenu.ru/?a=page\&id=524>. 


\subsubsection{Japão}

\section{Contexto Nacional}

O sistema de educação superior japonês é muito bem-sucedido, com 50\% da população que deixa a escola secundária seguindo para algum curso de graduação (Daigaku). É comum dividi-lo em dois setores principais: o público $(23,8 \%)$ e o de iniciativa privada $(76,2 \%)$, sendo que aquele possui instituições mais bem conceituadas (exceção feita às universidades de Keio e Waseda, ambas privadas). Estima-se que 73\% dos estudantes universitários (Daigaku-sei) freqüentem algum tipo de universidade particular, enquanto nos Estados Unidos, por exemplo, este número é de apenas 30\%.

Devido ao caráter extremamente tradicional e formal da sociedade japonesa, em que a relação professor-aluno (sensē-oshiego) é extremamente valorizada, as técnicas e tecnologias de educação a distância ainda estão em fase de implantação e crescimento, o que representa um flagrante descompasso com o desenvolvimento tecnológico do país, especialmente em relação a computadores e telefones celulares, já que nesta área, desde 1980, o Japão é um dos líderes mundiais, ao lado dos Estados Unidos.

Até 1998 a educação a distância era proibida em todo o país para instituições de ensino superior, sendo que, por $\mathrm{EaD}$ entendiam-se, principalmente, os cursos por correspondência, bilaterais e assíncronos. Com o advento e a popularização da internet, o MEXT (Ministério da Educação, Cultura, Esportes, Ciência e Tecnologia) sentiu a necessidade de relaxar as regras e começou a permitir que 30 dos 124 créditos obrigatórios para se obter o grau de bacharel (Gaikushi) pudessem ser realizados por cursos de EaD síncronos (principalmente através de teleconferência). Já em 1999 esse número aumentou para 60 créditos a serem obtidos dessa forma. Novamente, em 2000, com a popularização do acesso à internet através de banda larga, o governo possibilitou que 60 créditos pudessem ser obtidos pela $\mathrm{EaD}$ na forma assíncrona e bilateral (ou seja, os professores são obrigados a monitorar os estudantes de alguma forma, ainda que não em tempo real, e a responder às dúvidas enviadas por e-mail pelos estudantes). Do mesmo modo, foi permitida a colaboração de universidades estrangeiras através de módulos que pudessem ser integrados à carga horária. Finalmente, em 2001, o MEXT relaxou as regras do ensino a distância e permitiu que todos os 124 créditos obrigatórios 
ao Gaikushi pudessem ser realizados através de alguma forma de comunicação a distância.

Para a escola secundária ${ }^{178}$ (que é dividida em Normal, Técnica e Integrada $^{179}$ ), estão previstos dois tipos de regime escolar: um totalmente presencial e outro misto, de meio período, no qual se divide a carga horária em 50\% cumprida através de aulas presenciais e 50\% através de cursos a distância (síncronos ou assíncronos), sendo esta última modalidade especialmente destinada aos alunos que já ingressaram no mercado de trabalho e que, desse modo, necessitam de um esquema mais flexível em que possam se encaixar. Todas as escolas de $\mathrm{EaD}$ secundaristas são privadas, de acordo com o relatório do MEXT divulgado em dez./2005.

Também na área de treinamento corporativo ou capacitação de trabalhadores, em que o e-learning seria uma das principais e mais eficazes formas de $\mathrm{EaD}$, podemos observar um período de crescimento (início dos anos 90) seguido por outro de grande depressão, quando começou a se observar que a oferta criada nos primeiros anos de disseminação da internet não refletia a verdadeira demanda do mercado corporativo. Desse modo, muitos sistemas foram implantados em diversas empresas para jamais serem usados, o que alertou os especialistas para a necessidade de se criar uma cultura de e-learning, para que as metodologias de $\mathrm{EaD}$ fossem eficazes e conquistassem o consumidor final, que, em última análise, é o trabalhador com necessidade de especialização.

O desafio de se fazer isso no Japão é representando, em grande parte, pelo problema do isolamento cultural do país, além da falta de profissionais especializados e, em grande medida, pelo fato de que as maiores ofertas de serviços e de capacitação tecnológica provêm de países de língua inglesa (tradicionalmente associados à EaD), como Estados Unidos e Austrália, quando apenas uma pequena parte da população é fluente no idioma $^{180}$. No entanto, esse quadro pode vir a mudar rapidamente nos próximos anos

\footnotetext{
${ }^{178}$ A escola secundária no Japão, genericamente chamada Koko, apresenta três formas distintas: Chugako, ou ginásio (3 anos de duração, idade ideal 12 anos), Kotto-Gakko, ou segundo grau (após 9 anos de estudo, idade ideal de entrada aos 15 anos), e Chutto-kyoku-Gakko, criado a partir de 1999, uma combinação dos anteriores, com 6 anos de duração.

${ }^{179}$ O Normal e o Técnico são similares àqueles existentes no ensino brasileiro; o Integrado foi introduzido em 1994 e é uma combinação dos dois, destinado a melhor adequar-se à crescente diversidade de interesses dos alunos.

180 "Language is surely the main factor that explains why the Japanese have been slow on the whole to embrace the internet technology despite their very strong sight-tech manufacturing base (...). Given a population with a roughly similar level of ability in English, Korea has made better progress, sued it seems, to greater commitment on the part of the government. In Korea there are already - as of March 2001 - nine 'cyberuniversities' in operation with a further seven scheduled to begin operation in 2003" (BUSH, Martin. E-learning in Japanese Universities. Revista
} 
devido às novas políticas educacionais postas em prática pelo MEXT, que determinam que todos os estudantes que terminam o ensino secundário (ou seja, que estão deixando o Kotto-Gako para entrar na Universidade) devam ser capazes de se comunicar eficientemente em inglês e que, adicionalmente, aqueles que terminam os cursos de graduação devam ser capazes de utilizar o inglês como uma ferramenta de comunicação e aperfeiçoamento em seus trabalhos.

Na figura abaixo podemos ver um resumo do sistema educacional do Japão, segundo o último relatório do MEXT:

Organização do Sistema Educacional Japonês (MEXT):

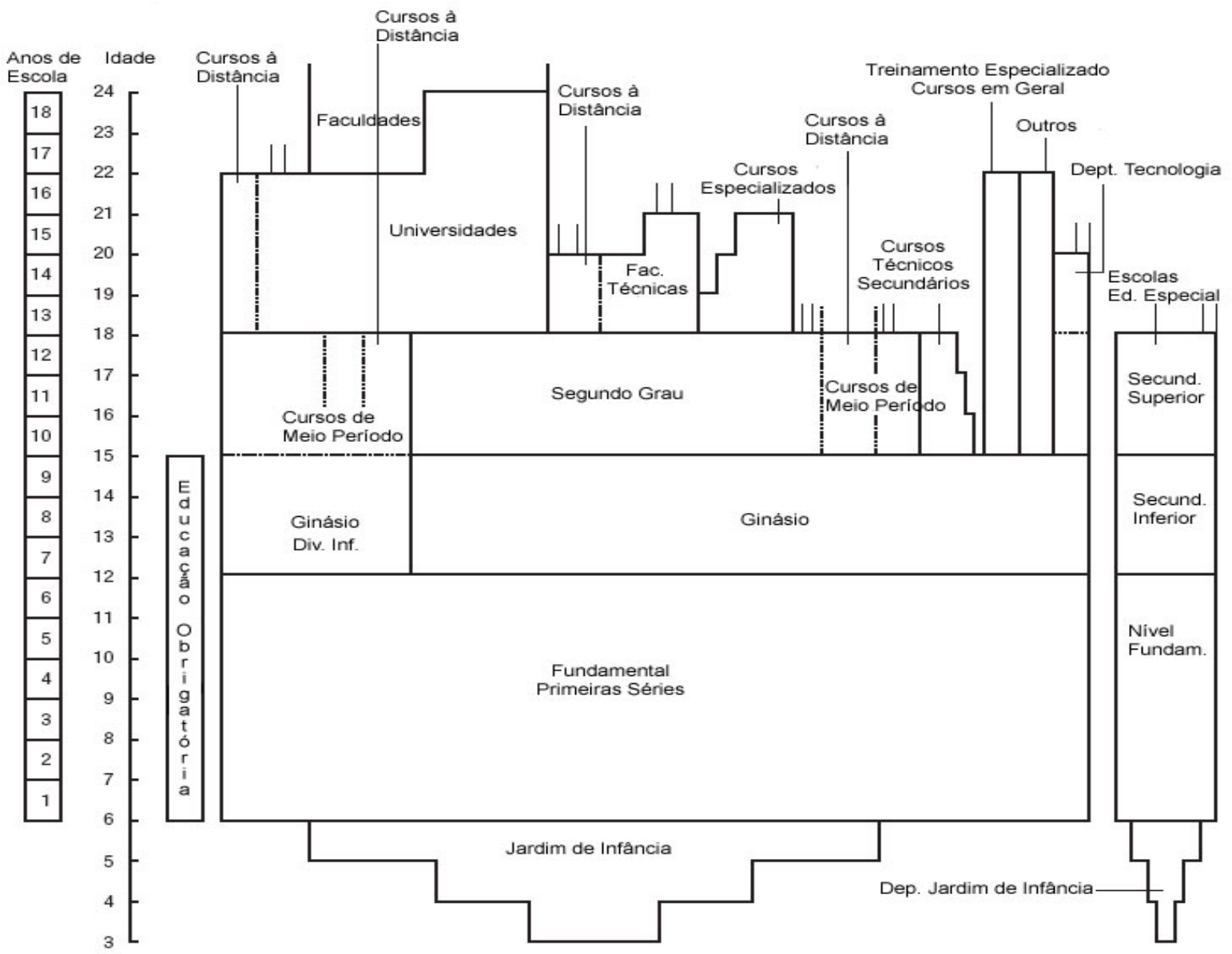

Figura 25 - Organização do Sistema Educacional Japonês (MEXT) Fonte: Japan's Education at a Glance 2005

Embora possua várias universidades que oferecem cursos por correspondência, o Japão possui apenas uma universidade cujo objetivo principal é fornecer cursos de graduação

eLearn Magazine. Disponível em: http://www.elearnmag.org/subpage.cfm?section=tutorials\&article=7-1. Acesso em: 9 jan. 2005.). 
a distância: a University of the Air. Ao lado dessa iniciativa do governo japonês, podemos destacar, ainda, o SOI - School on the Internet (Escola na Internet) -, uma iniciativa do projeto WIDE (Widely Integrated Distributed Environment) que visa a capacitação de profissionais de internet pela internet. A seguir, detalhamos cada uma dessas instituições.

\section{a) University of the Air}

\section{Endereço}

Wakaba, Mihama-ku

Chiba City

Zip Code 261-8586

Japão

E-mail: webmaster@u-air.ac.jp

Tel.: +81-43-276-5111

\section{Contexto histórico}

A universidade foi fundada em 1985 em Wakaba, Mihama-ku, Chiba City. Como parte da reforma educacional do plano de escolas charter (semigovernamental), em outubro de 2003 a universidade converteu-se em uma fundação, assimilando as táticas de gestão e as estratégias das empresas privadas para responder às necessidades da população.

\section{Objetivos}

Seus objetivos principais são: fornecer oportunidades educativas de ensino superior a todos os setores da sociedade; oferecer um sistema educativo flexível que possibilite acesso à educação superior a todos os graduados de ensino médio e cooperar com as universidades existentes para fazer uso de tecnologia educacional em todo o sistema de ensino superior. 


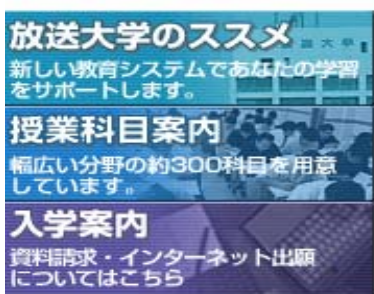

II 大学案内

学習方法・案内

学部

\section{大学院}

施設案内

各地の学習センター

学生・卒業生の声

学園(法人)からのお知らせ

D広報誌 ON AIR

】このサイトについて

口閏連団体リンク

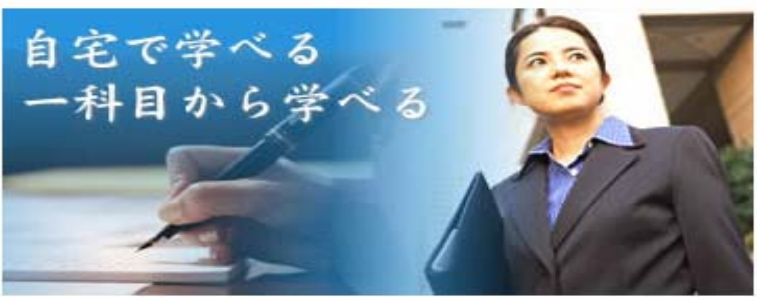

お知らせ

】一筧はこちら

2005年 故送大学ホームページー時停止のお知らせ（訂 月13日 正) Now

2005年 放送大学テレヒ・・ラジオ 1月番組ガイド

1月5日 New

12月10日新晹県中越地䍐被苑者に対する授業料等の兔除 措置沉して Now

11月15日平成 17 年度第 1 学期放送大学教虂学部・大学 院学生募集について Topics

現職教亘の皆椂八(專修兔許状・特殊教育教㻅 兔許状の取得にう(て)

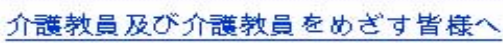

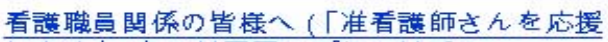
します」、ャリアアップについで)

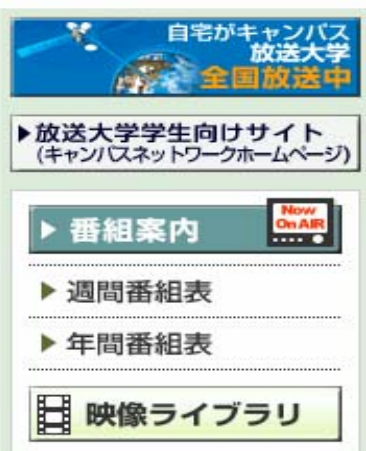

$$
\text { スームサイト }
$$

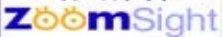

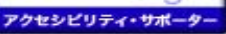

文字・画像サイズや色房 变更してこ綐になれます Zoomsight心使い方兵見る

PDFファイルをこ䮓いただく ちめに Reader」が必要です。下の ボタン定クリックしてダウン

ロート゚してくだきい。

7dobe Get Adobe"

Figura 26: Portal da University of the Air. Disponível em: < http://www.u-air.ac.jp/index.html $>$. Acesso em: 24/09/2006.

\section{Público-Alvo}

O perfil dos estudantes da universidade, como podemos observar nos gráficos abaixo, é de $69 \%$ de pessoas entre 20 e 40 anos e $31 \%$ de pessoas entre 50 e 60 anos $^{181}$.

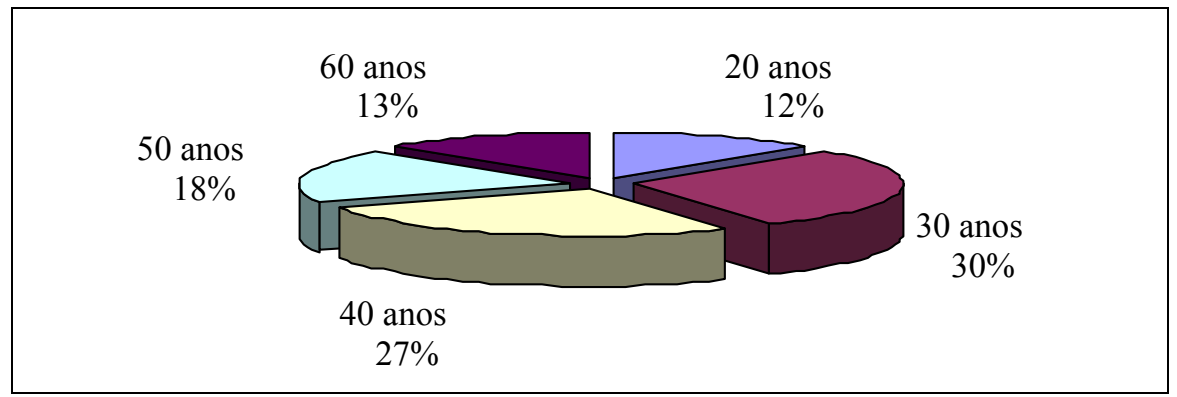

Gráfico 14: Perfil de idade dos estudantes da University of the Air

\footnotetext{
${ }^{181}$ Overview of Students. Student Profile. Disponível em: http://www.u-air.ac.jp/eng/table/09 ove2.html. Acesso em: 10 jan. 2005.
} 
Com uma população preferencialmente feminina - 61\% (só 39\% masculina):

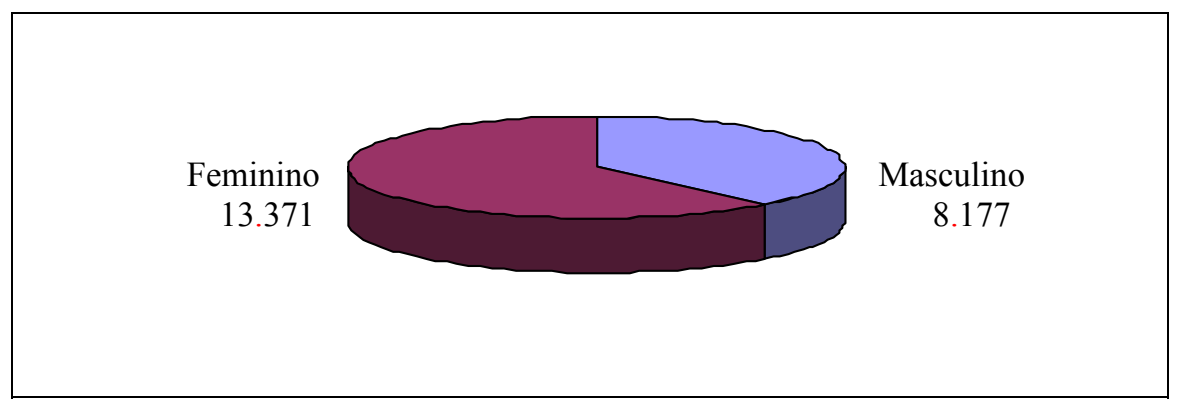

Gráfico 15: Perfil dde sexo dos estudantes da University of the Air

O público é formado preferencialmente por pessoas que se encontram trabalhando 49\% (executivos 29\%, funcionários públicos $16 \%$ e autônomos $4 \%$ ) - e por desempregados $-28 \%$. Somando os que trabalham e os que se encontram desempregados, tem-se um total de $57 \%$ dos estudantes:

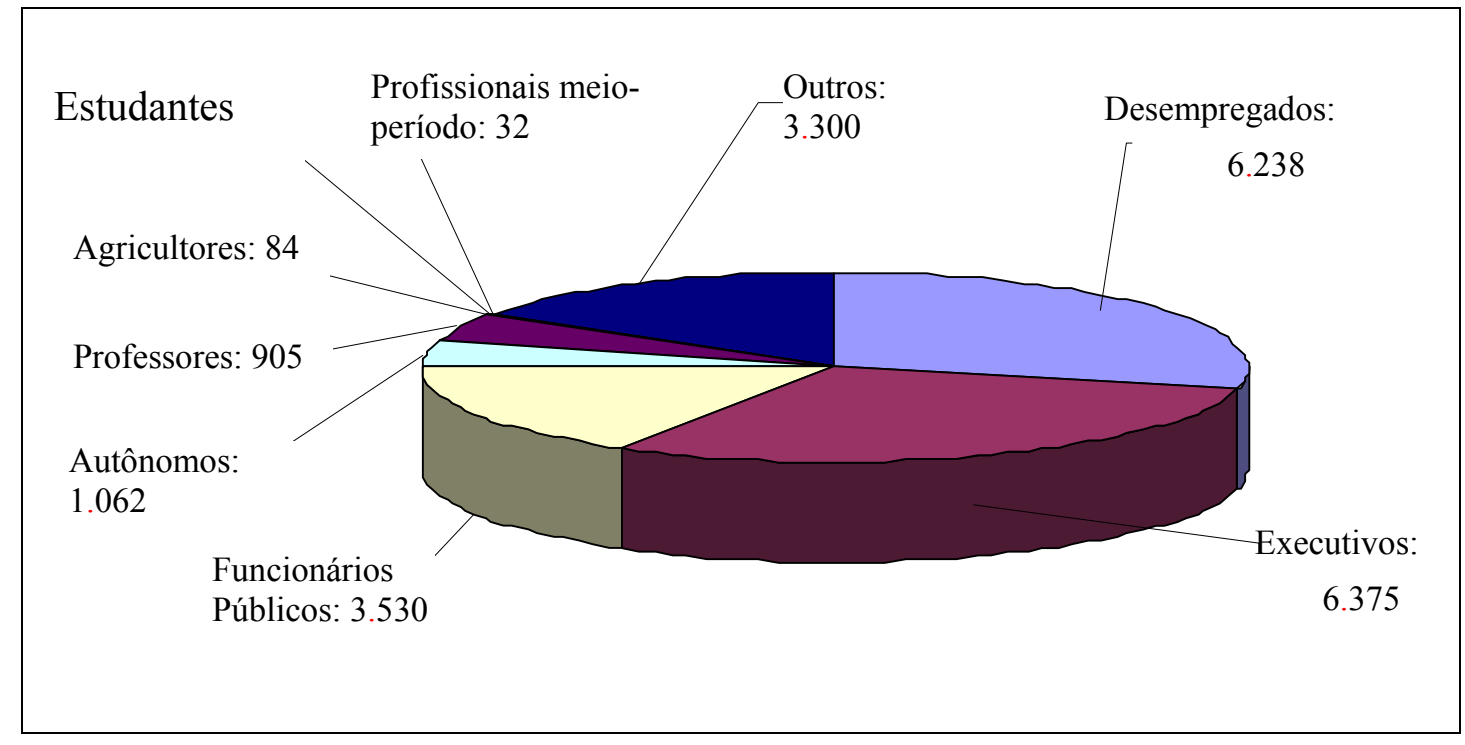

Gráfico 16: Perfil de ocupação dos estudantes da University of the Air 
A maioria dos estudantes $-69 \%$ - se divide em três cursos: Ciências humanas $20 \%$; Bem-estar e sociedade $21 \%$ e Desenvolvimento humano e educação $28 \%$.

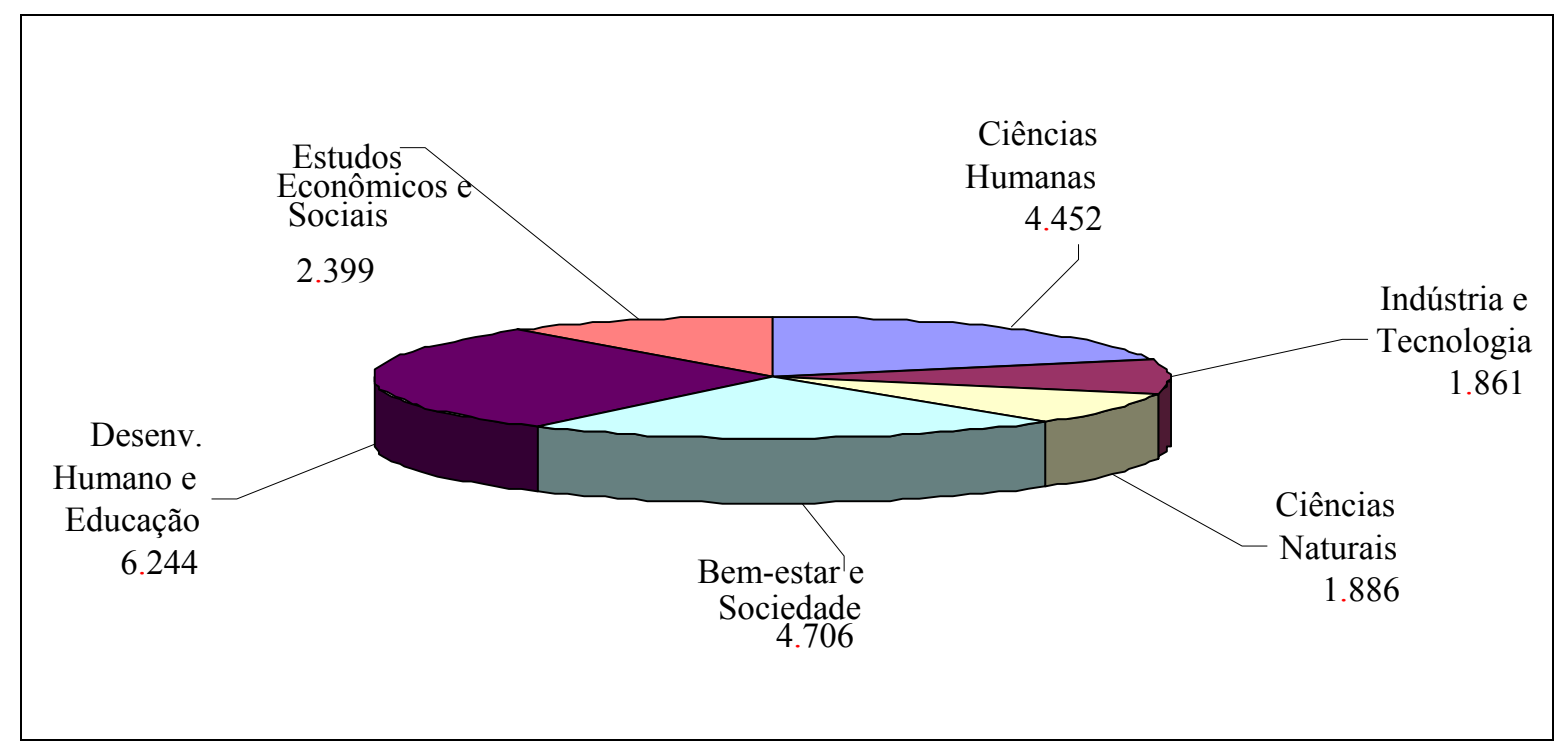

Gráfico 17: Divisão dos estudantes entre os cursos da University of the Air

A universidade apresenta um forte crescimento, passando de uma inscrição de 17.038 alunos anuais em 1985 para uma inscrição de 96.962 estudantes em 2002. Esses dados revelam um percentual de crescimento de aproximadamente 469\% em 20 anos de existência da modalidade de ensino, e com uma média de crescimento anual de 9,08\%, com uma matrícula total de alunos acumulada em mais de 780 mil pessoas (ver tabela a seguir) ${ }^{182}$ :

\section{Mudanças na inscrição anual}

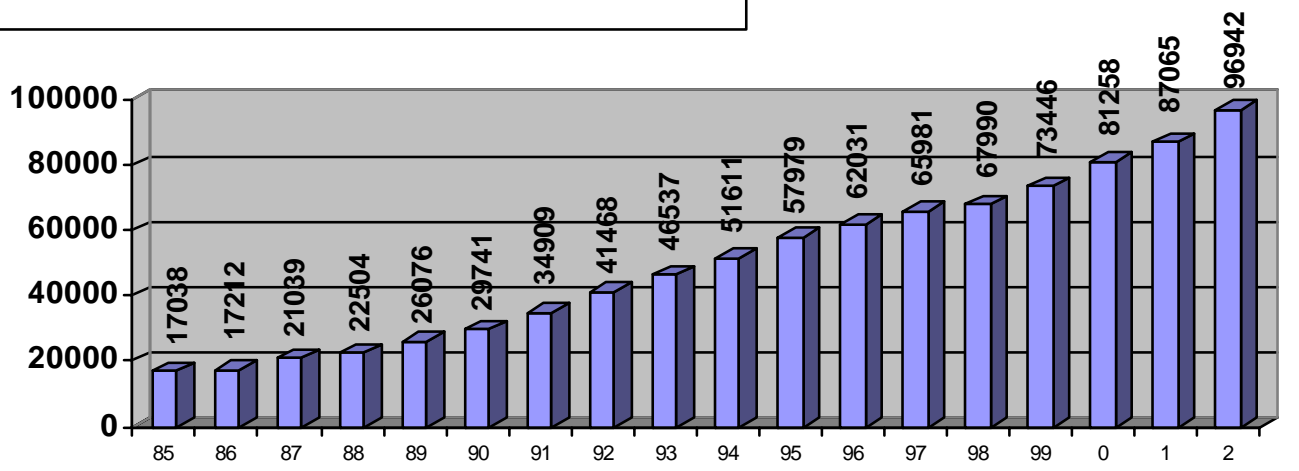

Gráfico 18: Registro de Estudantes da UA. Fonte: Overview of Students. The University of the Air. Disponível em: http://www.u-air.ac.jp/eng/table/09_ove1.html. Acesso em: 17 jan.2005.

\footnotetext{
${ }^{182}$ University of the Air. Disponível em: <http://www.u-air.ac.jp/eng/>. Acesso em: 14 jan. 2005.
} 
O número de graduados anuais reflete um crescimento de mais de 423\%, desde seus 605 alunos da primeira promoção em 1989 para mais de 3.170 na décima quarta promoção, no primeiro semestre de 2002. Esta instituição já formou desde a sua criação até o primeiro semestre de 2002 aproximadamente 21.548 alunos (cf. tabela no 23).

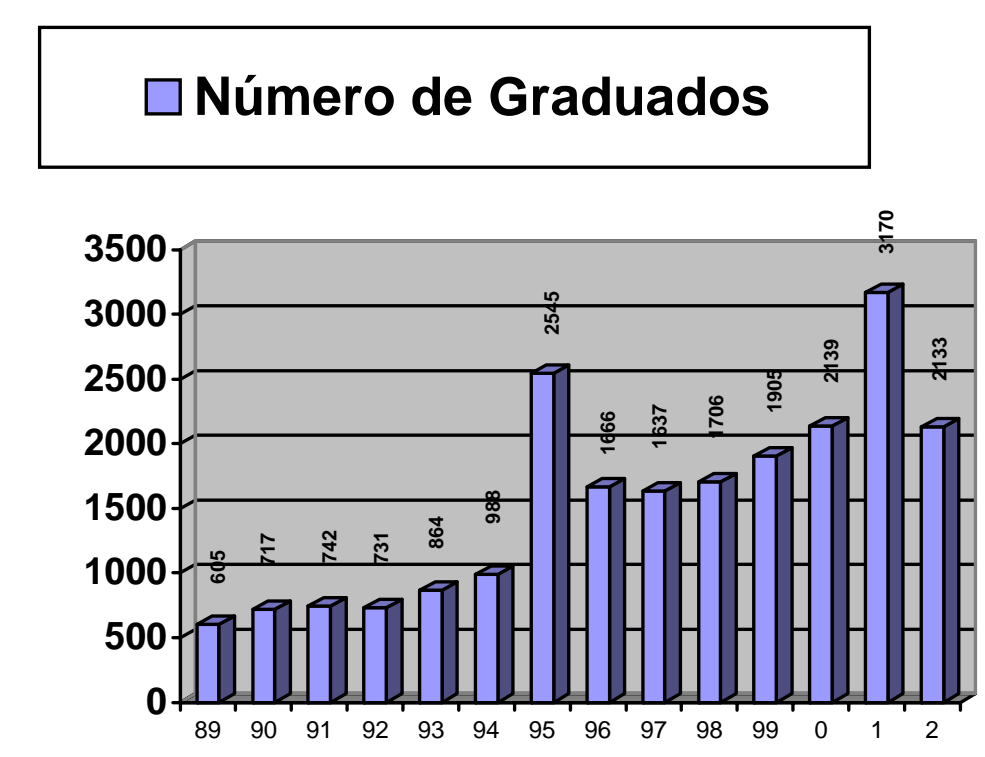

Gráfico 19 : Número de graduados 1989-2002 na UA

Obs.: Em 2002 só foram computadas as estatísticas referentes ao primeiro semestre.

\section{Recursos Humanos e Materiais}

A equipe desta instituição é formada por 348 pessoas - 91 da área acadêmica, contabilizando 59 professores e 29 professores associados - e 252 pessoas nas áreas administrativa e técnica.

Assim mesmo a universidade dispõe de um portal com informações de inscrição, avaliações, recursos didáticos, entre outras. Para prover um adequado suporte aos alunos, a rede tem introduzido, além do atendimento nos centros de estudo, uma plataforma tecnológica que provê acesso on-line aos recursos de aprendizagem, consulta a tutores, grupos de estudo, recursos didáticos digitais, entre outros.

\section{Cursos oferecidos}

Os cursos oferecidos pela University of The Air dividem-se em Cursos de Formação Geral e Cursos de Formação Específica, nos seguintes ramos do conhecimento:

- Ciências Humanas 
- Ciências Sociais

- Ciências Naturais

- Línguas Estrangeiras

- Saúde e Educação Física

- Bem-estar e Sociedade

- Desenvolvimento Humano e Educação

- Estudos Econômicos e Sociais

\section{Sistema de Estudos}

A University of the Air adota um sistema semestral de admissão (abril/setembro e outubro/março). Todo ano os estudantes têm a oportunidade de se inscrever na universidade, seja no início de abril, seja no início de outubro. A seleção se baseia na documentação submetida para análise. Não há exames de admissão, e cada estudante pode escolher em qual Centro de Estudo pretende fazer seu curso.

Uma vez aceito pela universidade, o aluno pode se encaixar em dois sistemas de admissão, de acordo com a natureza de seu curso: regular ou non-degree. Para os cursos regulares, aplica-se o seguinte fluxograma:

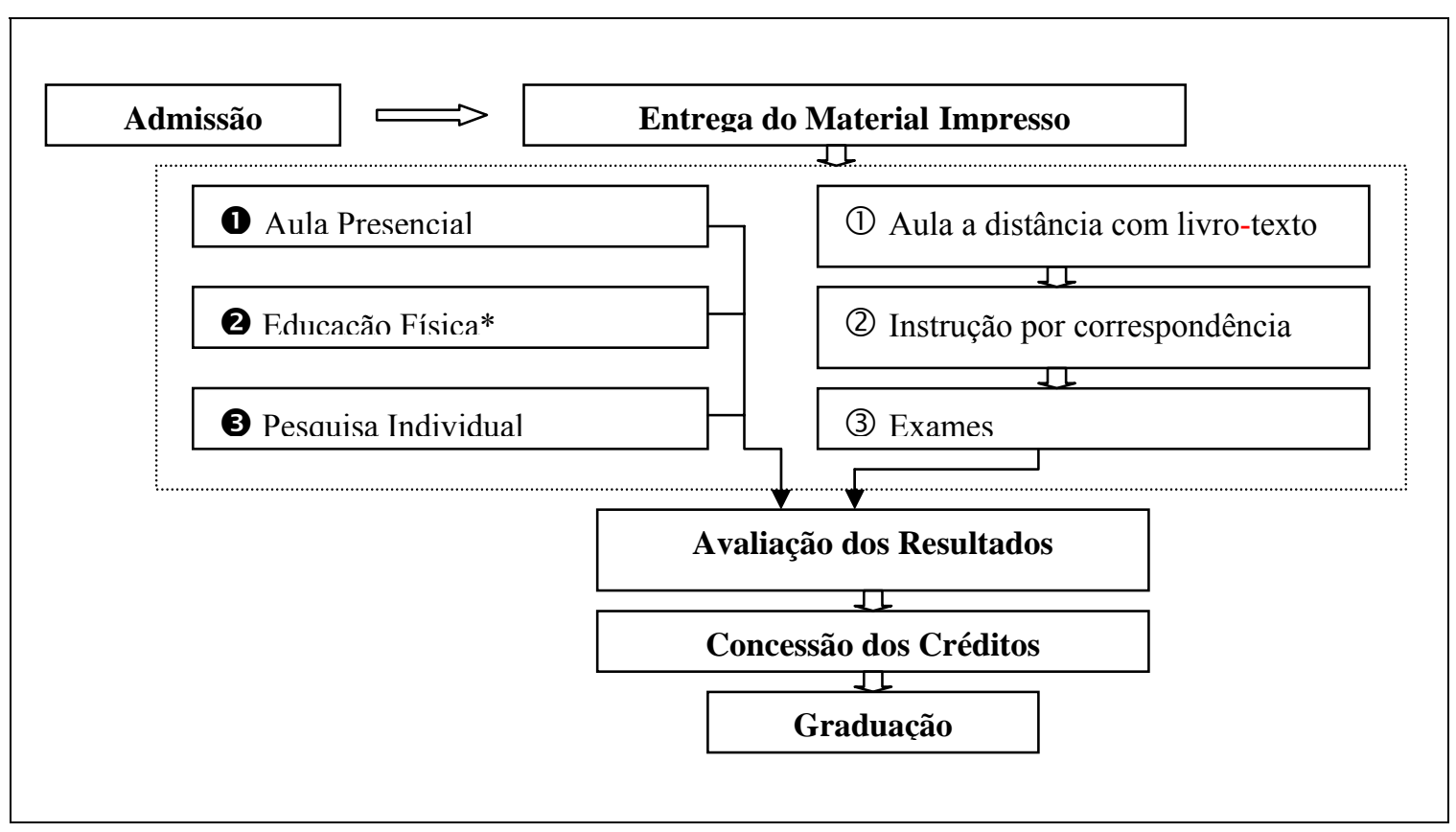

Figura 27: Fluxograma dos cursos regulares 
Para os outros estudantes, que não irão receber o grau de Gaikushi ao final do curso, aplica-se o seguinte fluxograma:

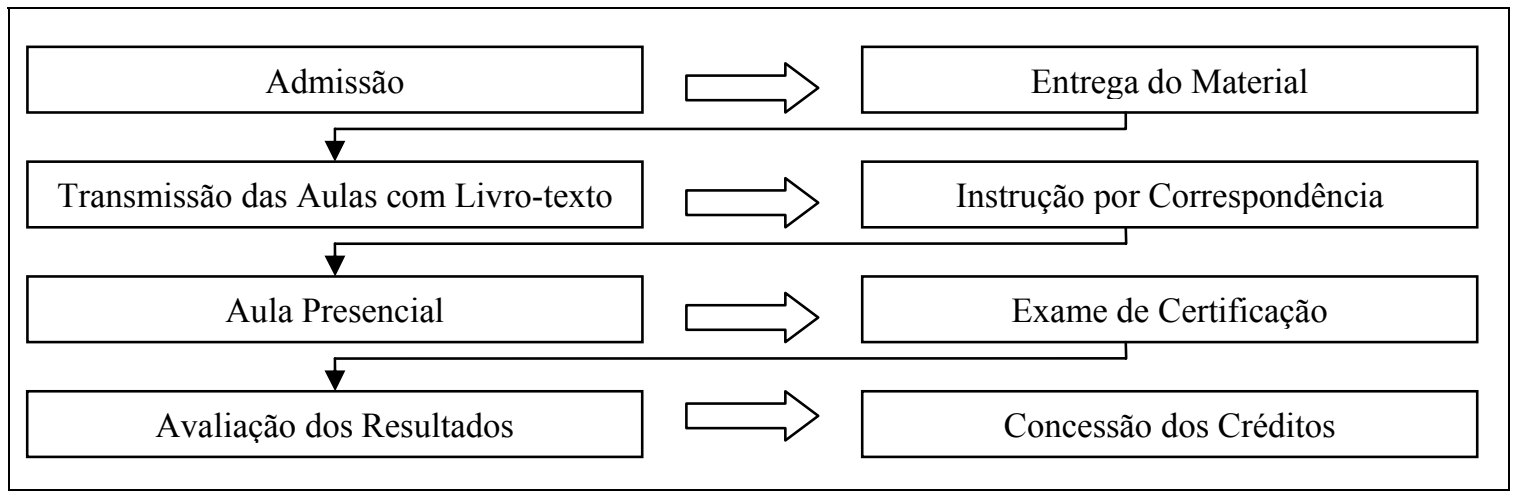

Figura 28: Fluxograma para os outros estudantes, que não irão receber o grau de Gaikushi ao final do curso

Para os alunos que desejam obter o grau de bacharel (Gaikushi) em uma determinada área específica, requer-se que pelo menos 20 créditos dos 124 obrigatórios sejam adquiridos na forma de aulas presenciais, na própria universidade. É possível, no entanto, inscrever-se para um ano de estudos na categoria de non-degree, ou seja, o estudante, ao final do curso (geralmente de um semestre ou até um ano), não recebe diploma de bacharel em sua área de estudos.

Cada semestre possui 15 semanas. Os alunos que desejem concluir os estudos de graduação em 4 anos devem, por semana: assistir a 7 aulas de 45 minutos por TV ou rádio; ler de 45 a 60 páginas de material impresso e assistir a uma reunião presencial de 2 horas e 15 minutos na universidade ou nos centros de estudo. Os estudantes que perderem alguma aula podem requisitar a fita de vídeo ou áudio na seção de alunos de seu centro de estudo.

Acordos mútuos de transferência de créditos foram estabelecidos entre a University of the Air e outras universidades do país a fim de enriquecer o ambiente educacional dos estudantes. De fato, a promoção de um ambiente educacional mais rico, a partir da transferência de créditos entre diversas universidades, foi uma das principais finalidades da criação da University of the Air. Os estudantes das universidades com acordo mútuo de transferência de créditos são aceitos na University of the Air como estudantes de transferência de crédito. A característica mais importante desta universidade é que os cursos são transmitidos através do rádio e da TV. A universidade empresta os videotapes e outros materiais de estudo de forma totalmente gratuita aos alunos de 
universidades parceiras. Até 2002 a universidade tinha assinado acordos de transferência de créditos com 236 universidades convencionais em todo o país.

\section{Materiais de Estudo e Estratégia Instrucional}

A University of the Air transmite aulas através da TV e do rádio todos os dias, desde cedo pela manhã até à meia-noite. A transmissão das aulas se dá por meio de radiodifusão (eletromagnética ou digital). Através do satélite JCSAT3, transmitem-se as aulas em sistema digital CS para todo o país. Em terra, a transmissão ocorre da Torre de Tóquio, em modulação UHF e FM, através da retransmissão do sinal pela estação de radiodifusão de Maebashi, para toda a área de Gunma.

Abaixo podemos ver uma representação esquemática do processo:

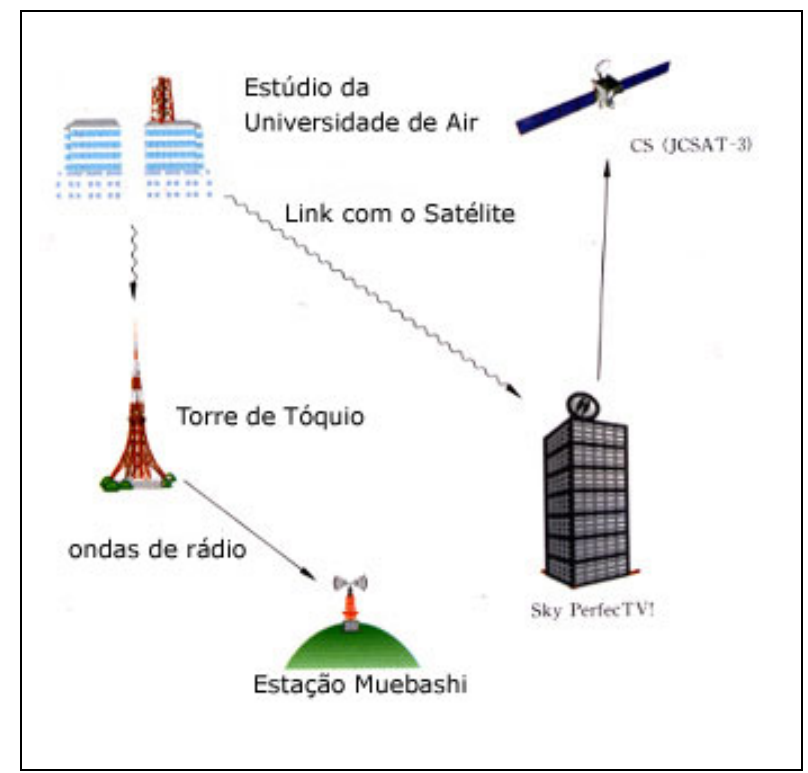

Figura 29: Representação esquemática do processo de transmissão de aulas através da TV e rádio

Os cursos transmitidos são suplementados com materiais impressos. Normalmente, um curso de 2 créditos é acompanhado por um livro-texto de 200 páginas, que é enviado para os estudantes após o pagamento da taxa de inscrição no curso, mas antes do início das transmissões. Esses livros, escritos pelos próprios professores que ministram os cursos, também podem ser encontrados em livrarias normais. 
E, como já vimos, o sistema de estudo também apresenta encontros presenciais obrigatórios (aproximadamente 20\% da carga horária total do curso).

Para cada assunto tratado nas aulas, os estudantes podem receber tarefas por correspondência, que geralmente são enviadas no meio de cada semestre e referem-se aos assuntos tratados ao longo do período. Aqueles que cumprem todas as tarefas estão qualificados para realizar o exame final que lhes dará direito aos créditos do curso.

\section{Desenvolvimento de Cursos}

O Instituto Nacional de Educação Multimídia ajuda a universidade na produção de programas televisivos. Os professores visitantes são especialistas de diversos campos do conhecimento, provenientes de universidades públicas e privadas do país.

O corpo docente e o diretor do programa elaboram todos os aspectos de produção baseando-se no plano de leituras do curso, incluindo a seleção de imagens e gráficos, entre outros.

\section{Avaliação Institucional}

Ao final de cada curso de 15 semanas, o aluno deverá realizar um exame de certificação que lhe dará direito aos créditos do curso para o qual se inscreveu. Esse exame é realizado no Centro de Estudos de cada estudante.

\section{Centros de Estudo}

A universidade possui 50 centros de estudo que oferecem aos alunos aulas presenciais, avaliação presencial de certificação, assessoria de tutores, uma biblioteca completa e áudios e vídeos das palestras apresentadas.

\section{Valor dos Cursos}

Para os estudantes regulares (que pretendem obter o grau de Bacharel), a taxa de admissão é de $¥ 22.000,00$ e, posteriormente, há uma taxa de $¥ 5.000,00$ por crédito 
cursado. Os valores para os outros tipos de estudantes, non-degree, são de $¥ 8.000,00$ (1 ano), $¥ 6.000,00$ ( 1 semestre) e $¥ 3.000,00$ (curso intensivo), sendo que estes pagam também o valor de $¥ 5.000,00$ por crédito. Há um desconto de $20 \%$ para inscrições de grupos superiores a 30 alunos ou para companhias que fechem um pacote para grupos de funcionários na mesma proporção.

Como todas as aulas transmitidas somam pelo menos 2 créditos, a taxa por curso fica em $¥ 10.000,00$ por curso. O custo de livros e demais materiais impressos já está incluído nesse valor.

\section{b) Projeto WIDE: SOI - School on the Internet}

\section{Contexto histórico}

WIDE - Widely Integrated Distributed Environment - é um projeto que está sendo desenvolvido desde 1998. Trata-se de um consórcio de pesquisas integrado por indústrias, institutos públicos e universidades, formado por mais de 700 pesquisadores e engenheiros, de mais de 100 companhias privadas e de mais de 40 universidades. $\mathrm{O}$ projeto opera uma rede nacional de pesquisa e desenvolvimento e uma plataforma de desenvolvimento e testes conectada a outras redes no Japão e no mundo.

O projeto tem como objetivo criar tecnologias para o desenvolvimento social. As pesquisas são realizadas em seis campos de conhecimento, e cada grupo trabalha próximo dos outros para descobrir novos campos de pesquisa. A pesquisa realizada por cada grupo é examinada com cuidado pelos 20 membros da diretoria em reuniões mensais.

Um dos projetos da WIDE foi a SOI - School on the internet. Ao contrário da University of the Air, os objetivos da SOI (http://www.soi.wide.ad.jp) são bem mais ambiciosos e menos ortodoxos, tentando tirar o máximo proveito das tecnologias de aprendizagem via internet. A SOI (em japonês) iniciou suas atividades em setembro de 1997, baseando-se num projeto da WIDE com a meta de "prover educação superior e oportunidades a todas as pessoas do mundo interessadas em estudar utilizando as tecnologias baseadas na internet e eliminando as limitações tradicionais". 
Desde então os idealizadores do projeto têm realizado pesquisas sobre as diferentes técnicas de implementação de $\mathrm{EaD}$ através da internet. Atualmente, o foco principal de ensino da SOI é a própria internet, as tecnologias dela advindas e o novo paradigma de educação representado por elas.

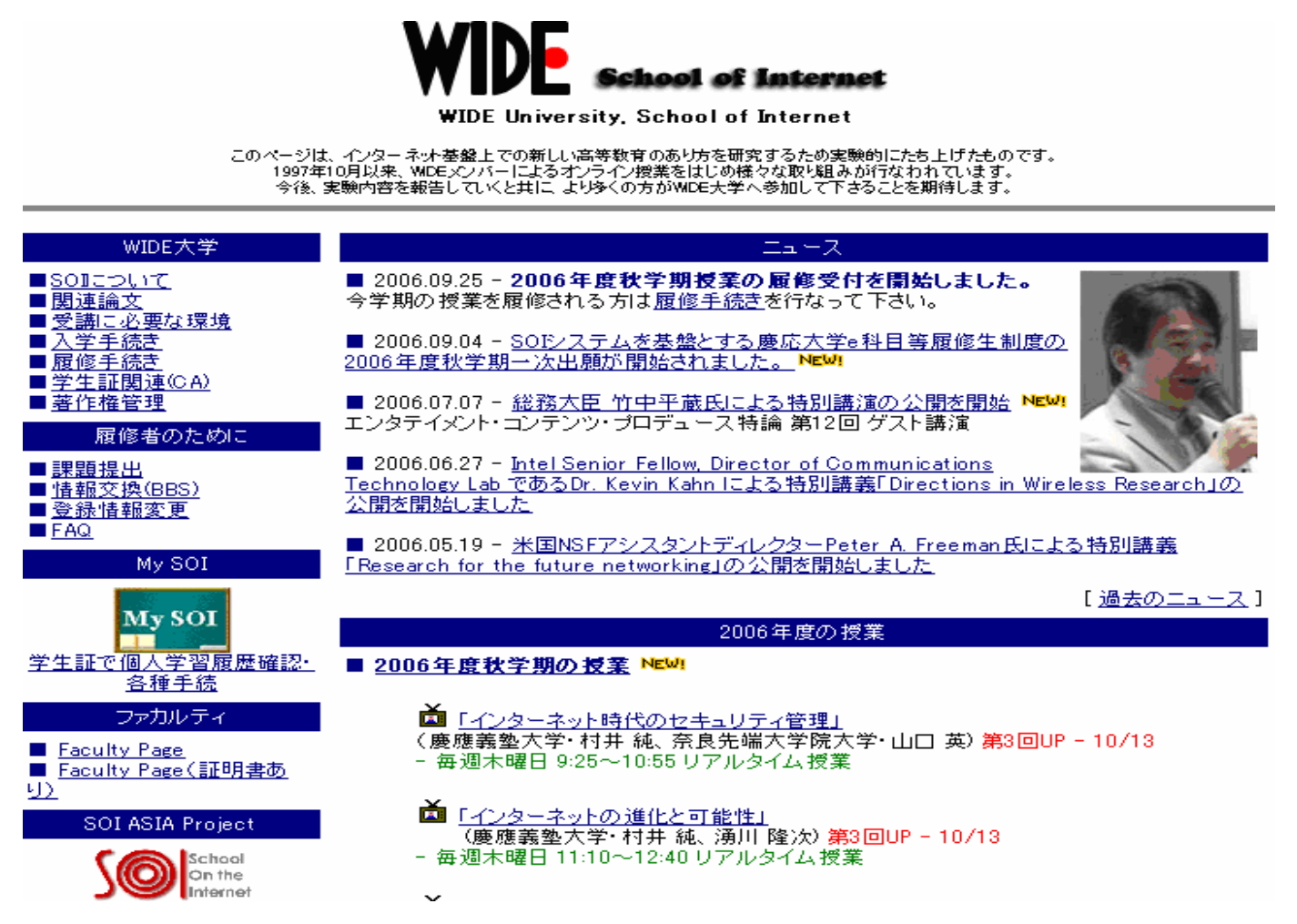

Figura 30: Portal da SOI - Escola da Internet. Disponível em: http://www.soi.wide.ad.jp. Acesso em: 18/09/2006

\section{Objetivos da SOI}

Fazem parte dos objetivos da SOI possibilitar que estudantes, em qualquer lugar do mundo, possam assistir às aulas a qualquer hora e que possam construir seu currículo assistindo a aulas de universidades de qualquer lugar do mundo; que as faculdades, distribuídas em todo o mundo, possam unir forças para estabelecer uma nova área acadêmica; que os estudantes possam obter créditos que comprovem sua experiência através das atividades realizadas em diferentes cursos.

\section{Público-alvo}

Suas atividades concentram-se, principalmente, em aulas e palestras sobre diferentes temas, transmitidas unicamente através da rede por meio de um sistema on demand. 
Estima-se que cerca de 2.903 pessoas já tenham se inscrito para os cursos disponibilizados pela SOI, sendo que a média mensal de page views de cada palestra pode chegar a 350.000 .

\section{Recursos humanos e materiais}

A SOI foi desenvolvida dentro de um organograma que confere funcionalidade tanto aos estudantes quanto aos professores. Para tanto, foram criados os seguintes "sistemas" (classes de identificação de operações):

1. Sistema de Admissão e Matrícula

2. Sistema de Aulas on demand

3. Sistema Aberto de Tarefas Compartilhadas

4. Sistema de Avaliação de Cursos

O Sistema de Admissão e Matrícula permite aos estudantes e às faculdades registrarem e manterem atualizadas suas informações. O Sistema de Aulas on demand permite que as aulas ministradas em diferentes salas de aulas de diferentes universidades sejam armazenadas e digitalizadas, de modo que os estudantes possam assistir a elas através da internet por meio de tecnologias de streaming de áudio e vídeo. Além disso, os alunos contam com o Sistema de Tarefas Compartilhadas, um portal de gerenciamento focado em dar suporte para o aprendizado colaborativo entre os estudantes. Basicamente, ele fornece as ferramentas necessárias para se submeter e revisar tarefas de estudo on-line. E o Sistema de Avaliação de Cursos, um gerenciador de pesquisas, permite e encoraja cada professor ou administrador de um determinado curso a realizar uma avaliação dos resultados do curso entre os alunos, servindo, assim, como uma ferramenta de aperfeiçoamento do ensino de acordo com as necessidades e expectativas dos alunos.

\section{Sistema de estudos}

O sistema de admissão é bastante simples: a inscrição pode ser feita on-line e qualquer um que atenda a estes requisitos mínimos pode participar: 
1. Ter um endereço de e-mail e poder se comunicar por meio dele.

2. Ter acesso à internet.

Os alunos diferenciam-se em duas categorias: estudantes propriamente ditos, que participam dos cursos com a intenção de obter o grau de bacharel, e os - assim chamados dentro da SOI - "auditores", que, embora assistam aos cursos e eventualmente possam obter alguma espécie de certificação, não têm direito à colação de grau (isto é, estudantes non-degree).

\section{Materiais de estudo e estratégia instrucional}

As seguintes atividades fazem parte dos processos de aprendizado da SOI: Aulas - as faculdades ministram as aulas. Os estudantes assistem às aulas pela internet. A SOI fornece a tecnologia para obter, armazenar e distribuir o conteúdo das aulas. Tarefas Compartilhadas - uma tarefa compartilhada é um modo efetivo de partilhar opiniões e informações entre os estudantes. Foi implementado um sistema de submissão de tarefas e feedback on-line a fim de proporcionar um modo de interação mais rico que o clássico e um unidirecional relacionamento entre professor-aluno. Este sistema permite que os alunos se comuniquem entre si, tirem dúvidas, proponham tarefas e soluções uns aos outros, independentemente de qual universidade cada um deles esteja cursando.

Avaliação Discente dos Cursos - na medida em que a SOI se preocupa primordialmente com a satisfação dos alunos, pesquisas desse tipo entre os estudantes são uma ferramenta muito importante para obter um feedback acerca da qualidade das aulas, da faculdade e da própria SOI. Defesas e Exames de Colação de Grau diferentes graus são conferidos por membros de uma banca examinadora através da própria internet. A SOI providencia um ambiente on-line específico para tais atividades.

As aulas, que se constituem basicamente de palestras, podem ser solicitadas diretamente do arquivo da universidade (e assim assistidas a qualquer hora), através do sistema de streaming de áudio e vídeo. Além disso, de acordo com o plano de desenvolvimento do projeto, a SOI está trabalhando para desenvolver um sistema que permita a transmissão de aulas, palestras e cursos ao vivo, em tempo real, por meio do uso de RealVideo, Internet Phone e vídeo digital (DV sobre IP). 
As diferentes faculdades podem distribuir pesquisas entre os estudantes, sendo eles independentes para fazê-lo, de modo a melhorar a qualidade do ensino e manter o nível e os assuntos das diferentes palestras dentro das expectativas dos alunos.

Cada aula tem sua própria página dentro do servidor (fig. abaixo), que fornece todas as informações estáticas da página, possuindo: a) um catálogo de endereços de estudantes; b) um catálogo de endereços de faculdades e c) comunicação através da internet.

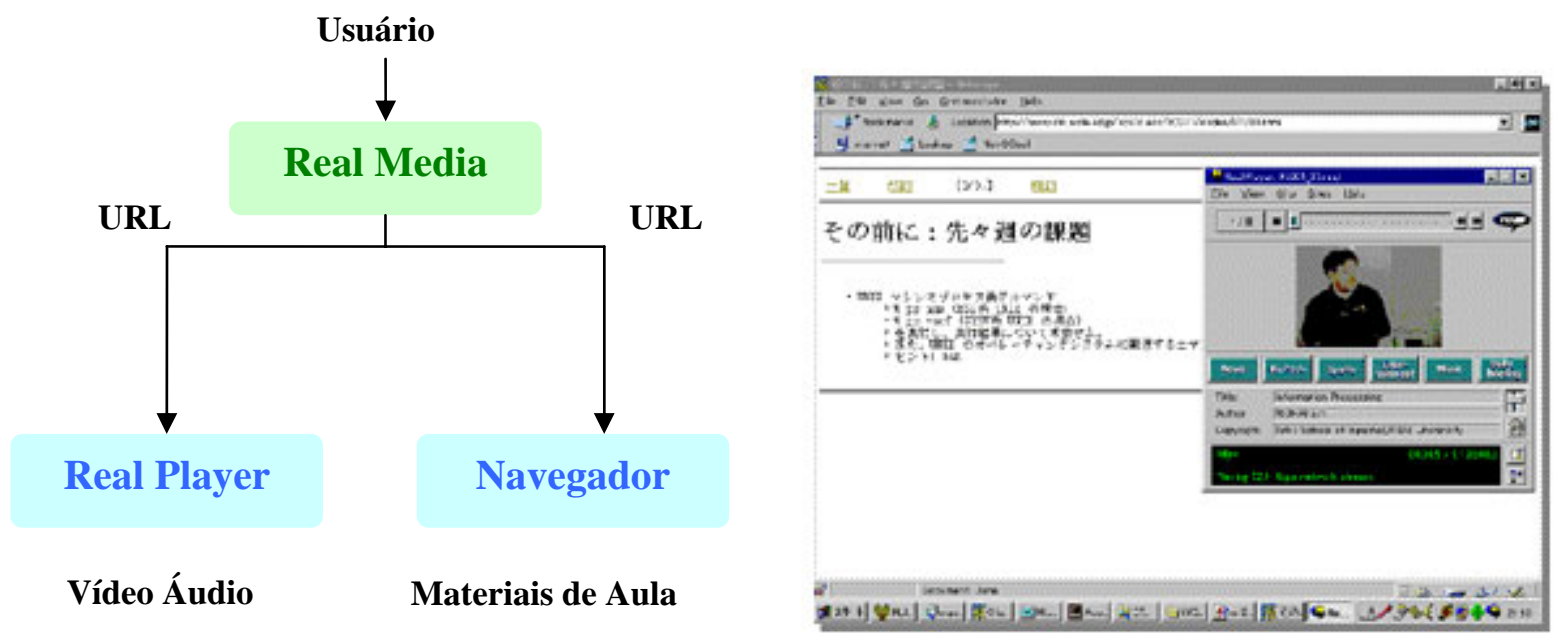

Figura 31: Representação esquemática de aula através da internet

\section{Avaliação da Iniciativa}

A SOI foi avaliada com a distribuição de questionários para os estudantes e as faculdades. Mais de $79 \%$ dos membros expressaram sua satisfação com as aulas e serviços disponibilizados pela internet. $85 \%$ dos membros participantes disseram que gostariam de continuar com essa atividade.

A seguir alguns resultados significativos acerca do sistema de tarefas compartilhadas:

(1) Total de Estudantes Entrevistados: 141 pessoas

(2) Estudantes que submeteram tarefas: $47(33,3 \%)$

(3) Estudantes que responderam com algum tipo de comentário: 32 (22,7\% de (1), 
$68,1 \%$ de (2)).

(4) Número de Comentários: 97

(5) O sistema de tarefas compartilhadas lhe pareceu efetivo?

Sim: $28(88 \%)$

Não sei: $3(9 \%)$

Não: $0(0 \%)$

Não respondeu: $1(3 \%)$

(6) O sistema é de fácil acesso?

Sim: $24(75 \%)$

Não sei: $7(22 \%)$

Não: $1(3 \%)(7)$ Você teve alguma dificuldade em postar seus comentários?

Sim: $4(13 \%)$

Não: 27 (84\%)

Não respondeu: 1 (3\%)

\section{SOI Ásia}

O projeto SOI Asia é um subprojeto da WIDE, iniciativa de interconexão da Ásia pela internet. Trata-se de um projeto de pesquisa internacional estabelecido em 1995, com a colaboração da WIDE e da corporação JSAT, a maior

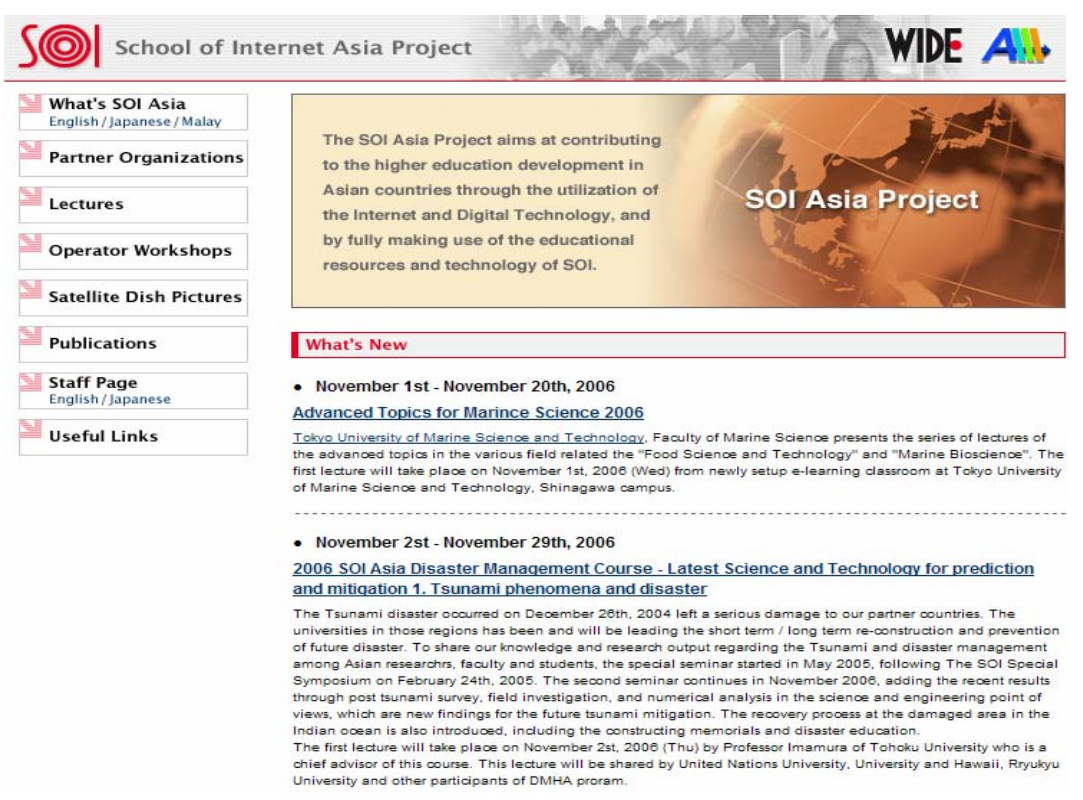

Figura 32: Portal da SOI - School of internet Asia Project. Disponível em: http://www.soi.wide.ad.jp/soi-asia/. Acesso em: 18/09/2006 
Desde então, 11 instituições e universidades de pesquisa da Ásia se uniram a este projeto: 4 universidades da Tailândia; 1 de Laos; 1 de Mianmar; 5 da Indonésia; 2 da Malásia; 1 do Vietnã; 2 das Filipinas; 1 do Nepal; 2 do Camboja; 2 da Mongólia e 4 do Japão.

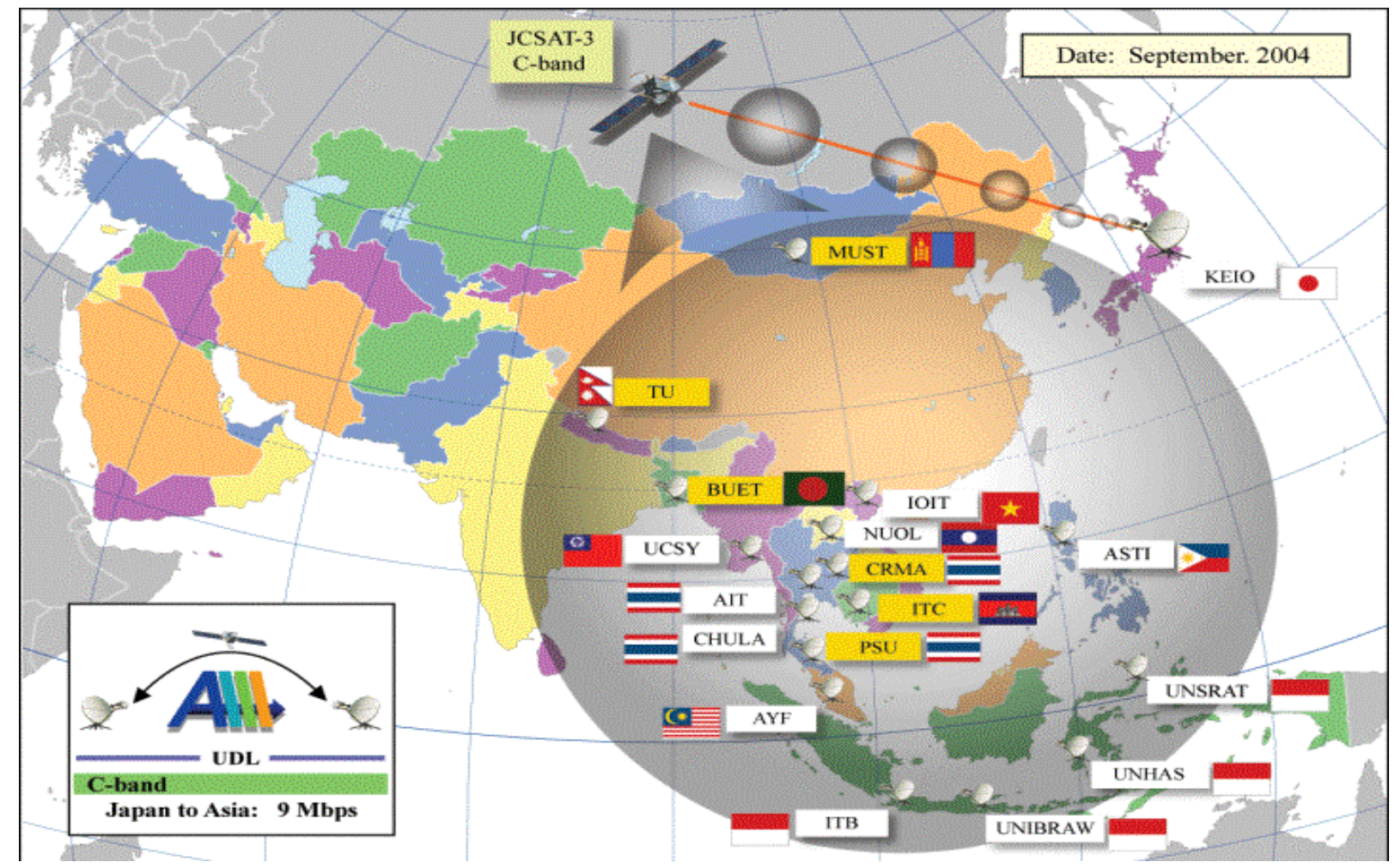

Figura 33: Instituições e Universidades que se uniram ao projeto SOI

Este projeto pretende dar forma a um grupo de pesquisa para desenvolver tecnologias de ponta usando internet via satélite.

A fim de desenvolver uma infra-estrutura de internet a baixo custo e baixa quantidade de spam nos sites parceiros e desenvolver um ambiente de ensino a distância, o SOI Asia projetou um sistema em três instâncias: 1) o local do professor, 2) o local de entrada do sinal e 3) o local dos estudantes.

Usando este ambiente, pode-se entregar o vídeo e o áudio de ótima qualidade no local em que está o estudante e se fazer gabaritos através de várias aplicações baseadas em infra-estrutura de internet. O sistema também conta com servidores espelhos usando Linux no local onde estão os estudantes de modo que eles possam consultar as suas aulas arquivadas sem a necessidade de se conectar ao servidor remoto. 


\subsubsection{Paquistão}

\section{Contexto Nacional}

O Paquistão, como o resto dos países-membros do E-9, ${ }^{183}$ possui um enorme desafio educacional, devido ao seu tamanho e à sua pobreza de recursos. O país possui 117 milhões de habitantes; $33 \%$ da população está abaixo da linha da pobreza, com um nível de analfabetismo de aproximadamente 43\%; há um número insuficiente de escolas e de professores; a matrícula é escassa em todos os níveis educativos, principalmente nas áreas rurais do país; assim como há escassez de materiais educativos, livros de textos e recursos, como hardware e software, além das poucas oportunidades para as mulheres em uma cultura ainda muito restrita.

O governo paquistanês, reconhecendo a importância da educação, está desenvolvendo uma série de esforços para tentar resolver um problema endêmico do país, considerando que atualmente só $2,9 \%$ da população em idade escolar - aproximadamente 21 milhões de pessoas - tem acesso ao ensino universitário. Esse país de mais de 117 milhões de habitantes só conta com 114 universidades, das quais 64 são públicas ${ }^{184}$.

Por isso a educação a distância tem sido, há 30 anos, muito importante para o Paquistão: através da Allama Iqbal Open University, criada em 1974 sobre a base da Open University inglesa, milhões de alunos puderam cursar o seu ensino primário, secundário e universitário, principalmente as mulheres, através de projetos como o "Women's Secondary Education Programme" (WSEP)185, criado pela universidade em 1986 com a intenção de tornar disponível a educação secundária a mulheres que não tiveram o acesso a ela. Para este projeto, com o apoio dos governos do Paquistão e dos Países Baixos, foram planejados e desenvolvidos materiais de estudo específicos para as necessidades especiais daquelas mulheres, com conteúdos engajados ao cotidiano das mulheres rurais. Um projeto, executado entre 1986 e 1995, que conseguiu

\footnotetext{
${ }^{183}$ Grupo de megapaíses que possuem as maiores populações do mundo, entre os que se encontram: Bangladesh, Brasil, China, Egito, Índia, Indonésia, México, Nigéria e Paquistão.

${ }^{184}$ Education in pakistan. A white paper. National education policy review team. Disponível no site do Ministério da Educação Paquistanês. <www.moe.gov.pk>. Acesso em: Dez 2006

${ }^{185}$ Climbing the ladder: a case study of the women's secondary education programme of allama iqbal open university, pakistan. Riffat Haque and Syeda Najeeba Batool. Published in 1999 by the International Bureau of Education, Geneva 20, Switzerland. Internet: <http://www.ibe.unesco.org>. Printed in Switzerland by PCL.C) UNESCO:IBE 1999.
} 
institucionalizar um programa regular chamado Certificado da Escola Secundária (SSC), oferecido pela Allama Iqbal Open University.

Em 1975, um ano depois de inaugurada, a Universidade Allama Iqbal elaborou uma série de programas de alfabetização, baseados em pesquisas de campo, especialmente em áreas rurais. Exemplos disto são os programas de "Educação Funcional Integrada" (IFE), o "Projeto de Educação Funcional para as Áreas Rurais" (FEPRA) e o "Projeto de Alfabetização Funcional Integrado" (IFLP).

Esses projetos foram fundamentados na metodologia de estudo de grupo, tendo por base os problemas comunitários, com materiais elaborados exclusivamente pela universidade, com recursos como videocassetes, aulas pela televisão, apostilas, flipcharts, modelos demonstrativos, etc. Os conteúdos, além de ensinar a ler, incorporavam dimensões como saúde básica, aves domésticas, administração de animais domésticos, cuidados com crianças e outros temas propostos pelas comunidades, inclusive de geração de renda.

A educação a distância também tem sido utilizada na formação de professores. A Allama Iqbal fornece uma variedade de programas de treinamento para eles. O curso de Formação de Professores de Nível Primário (PTOC), destinado a recrutar novos professores, formou 86.650 novos profissionais entre 1976 e 1986 (Perraton, 2000, p. 72). O curso era integrado por 18 unidades por correspondência, 18 programas de rádio e 2 programas de televisão. Esses programas continuam funcionando, com a adição de mais programas de rádio e televisão, incluindo a formação de professores em serviço e de novos tutores pertencentes ao projeto $^{186}$.

O governo do Paquistão, tendo a visão do potencial que as novas tecnologias podem oferecer para o desenvolvimento do país, criou, em 2002, a Universidade Virtual do Paquistão, a segunda universidade a distância do país, mas esta, diferentemente da Allama Iqbal, é baseada na internet.

\footnotetext{
${ }^{186}$ Distance Education in the E-9 Countries. The Development and Future of Distance Education Programmes in the Nine High-Population Countries. UNESCO. France. UNESCO 2001. Printed in France. P. 52.
} 


\section{a) Allama Iqbal Open University}

\section{Endereço}

Block $n^{\circ} 3$ - Sector H-8 - Islamabad

Telefone: \# (92-51) 435748-435762-435749-435750

Fax: \# (92-51) 435766

Internet: http://www.aiou.edu.pk

\section{Contexto histórico}

Criada em 1974, na cidade de Islamabad, com o estatuto de uma universidade nacional, é considerada a segunda universidade aberta do mundo e a primeira na Ásia e na África. Foi construída com o apoio da Open University inglesa.

\section{Objetivos}

A universidade foi fundada com o objetivo de fornecer oportunidades educativas à classe popular, especialmente àqueles que não tiveram acesso à educação por não poderem deixar as suas casas ou locais de trabalho, como as mulheres e os trabalhadores, de acordo com as informações do site:

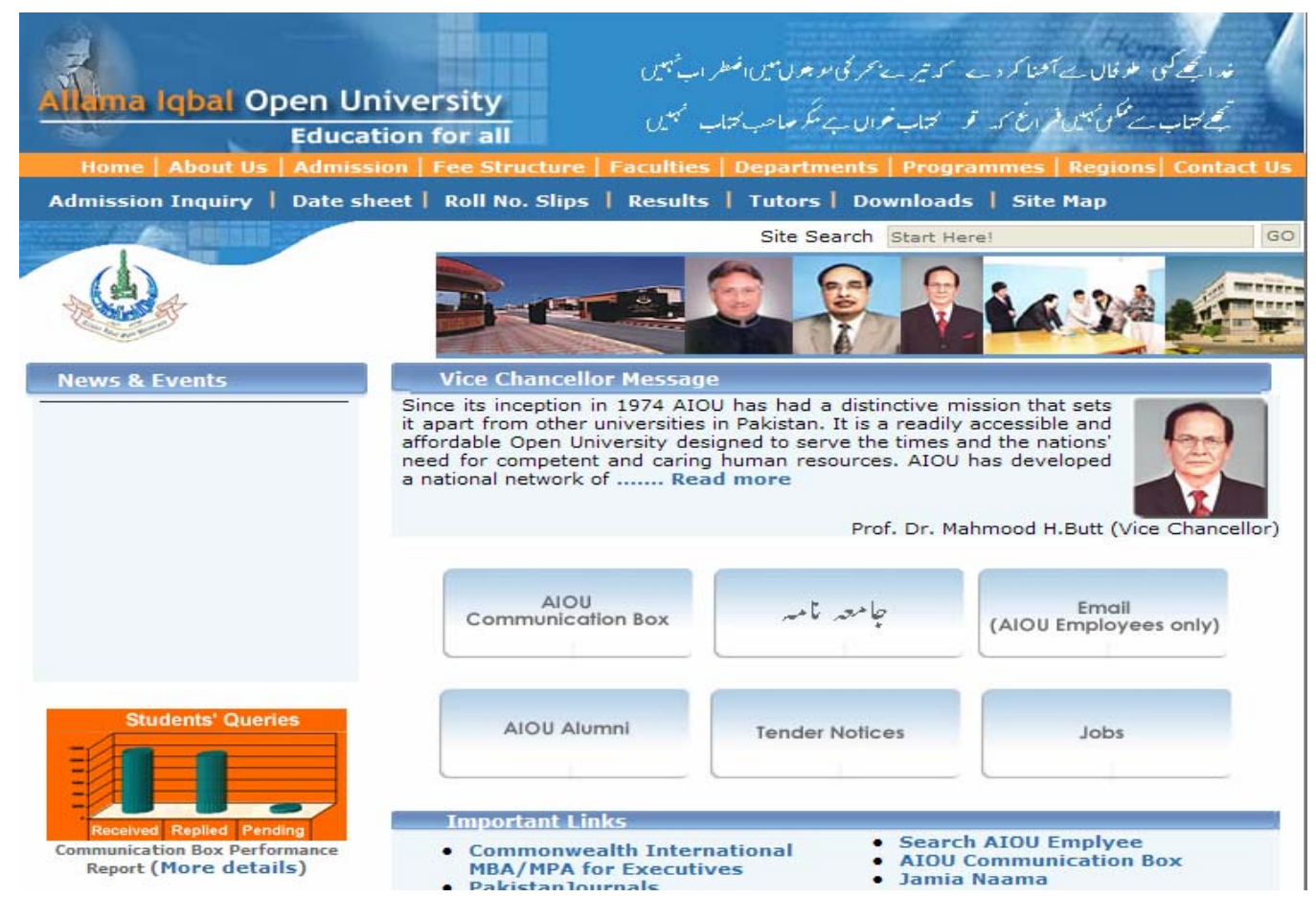

Figura 34: Portal da Allama Iqbal Open University. Fonte: Allama Iqbal Open University. Disponível em: <http://www.aiou.edu.pk/advertisement.htm>. Acesso em: 12 jan. 2007. 


\section{Público-alvo}

É a maior universidade do país, com mais de 1,8 milhão de alunos matriculados no período 2004-05. Oferece mais de 950 cursos $^{187}$. De uma inscrição de 420.429 alunos anuais no período 1993-94, passou a ter uma inscrição anual de 1.806.241 estudantes no período 2004-05, revelando um percentual de crescimento de 330\% em 11 anos de existência, com uma média de crescimento anual de $14,17 \%$, conforme a tabela:

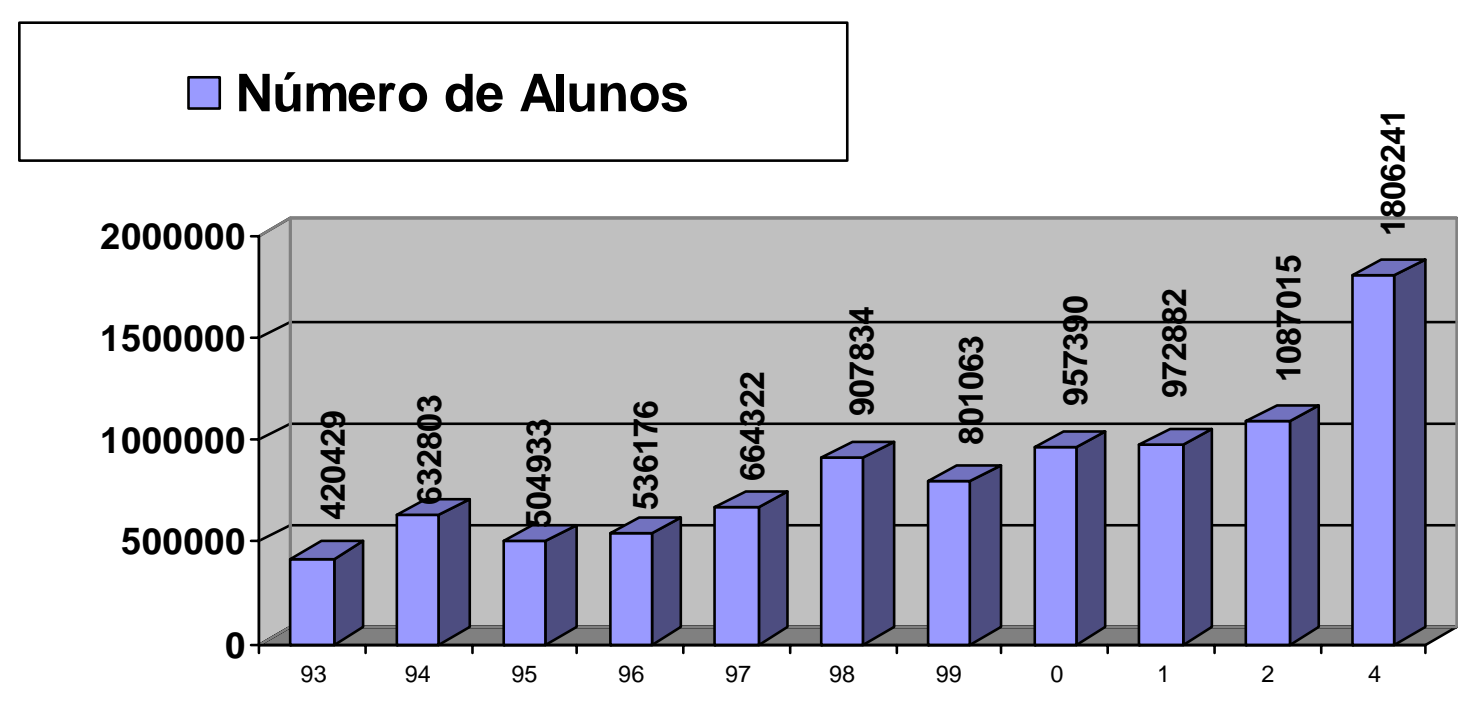

Gráfico 20: Enrolment in Allama Iqbal Open University 1993-2003. Fonte: Gráfico construído pelo autor com dados da Pakistan Statistical Year Book 2004. Chapter 6. EDUCATION. P137-140. Disponível em: $\quad<$ http://www.statpak.gov.pk/depts/fbs/publications/yearbook 2004/education.pdf $>$. Acesso em: 20 jan. 2005, e com dados do site da universidade, disponível em: $<$ http://www.aiou.edu.pk/SalientFeatures.asp $>$. Acesso em 13/1/2007.

Segundo dados da própria universidade, mais de 70\% dos seus estudantes são trabalhadores em período integral, dos quais mais de $50 \%$ são mulheres, predominantemente de áreas rurais (58\%).

\section{Recursos humanos e Materiais}

A universidade dispõe de um portal com informações de inscrição, avaliações, notas, recursos didáticos, entre outras. Também possui uma publicação com tiragem anual de mais de 1,8 milhão de exemplares de materiais de estudo.

\footnotetext{
187 Allama Iqbal Open University. Institutional Profile. Disponível em: $<$ http://www.aiou.edu.pk/salientfeatures.htm>. Acesso em: 27 nov. 2005.
} 


\section{Cursos Oferecidos}

Em 2004-2005 foram oferecidos pela universidade mais de 950 cursos, entre os quais se encontram cursos de graduação, de doutorado e especializações; doutorados em Urdu, Educação a Distância, Economia, Matemáticas, Estatística, Alimentação e Nutrição, entre outros. Mestrados em Estudos Islâmicos, Urdu, Planejamento Educacional e Administração Educativa, Física, Comunicação de Massas, Economia, Alimentação e Nutrição, Química, Formação de Professores, Estudos da Mulher, Educação Especial, Sociologia, Extensão Agrícola, Educação a Distância, História, Informática, Saúde e Nutrição, Inglês. Graduações em Comércio, Comunicação de Massas, Administração de Negócios, Engenharia e Telecomunicações, Física, Artes.

Além dos cursos tradicionais, a universidade oferece cursos de nível secundário com ênfase em Comércio, Saúde Familiar e Comunitária e Economia Doméstica e pósgraduações em Computação Gráfica, Formação de Professores para Ensino Primário e Secundário, entre outras.

\section{Sistema de estudos}

O sistema de estudo está organizado em semestres, chamados primavera e outono. A maioria dos cursos é oferecida nos dois semestres, salvo os de doutorado e os mestrados, que têm uma data de ingresso anual. Cada semestre é formado por 18 semanas, mais duas semanas para preparação para exames, totalizando 20 semanas de estudo por semestre. Os alunos não têm idade mínima ou máxima para ingressar na universidade.

\section{Materiais de estudo e estratégia instrucional}

A universidade emprega a metodologia por correspondência, rádio, televisão e materiais impressos especialmente preparados para o estudo a distância. Os estudantes dispõem de um tutor para responder às suas dúvidas nos centros de estudo espalhados por todo o país.

A utilização de correspondência está sendo gradualmente suplementada por programas de rádio e TV. Os programas de TV são exibidos regularmente e também estão 
disponíveis nos centros de estudo, em formato de áudio e videocassetes para consulta dos alunos.

Com seu desenvolvimento, as tecnologias de informação e comunicação particularmente o satélite e a internet - estão sendo usadas como meio de instrução, substituindo gradualmente o sistema por correspondência.

Com o intuito de guiar os estudantes durante o semestre, existe um grupo de tutores especialistas no conteúdo, que, nos centros de estudo ou nos escritórios regionais, atende, de forma presencial ou por correspondência, às demandas dos alunos. Cada grupo de alunos possui um tutor específico.

Os estudantes devem enviar aos tutores, durante o curso, entre duas e quatro avaliações, para que eles façam seus comentários positivos a fim de acompanhar a aprendizagem dos alunos.

Em algumas disciplinas, os alunos têm de realizar treinamento prático para desenvolver as habilidades necessárias. Para isso, ao finalizar o curso, devem participar de uma série de oficinas que, além de melhorar sua aprendizagem na prática, possibilitam uma interação não só com seus pares, mas também com os especialistas no tema.

Ao término do curso há um exame final, com o mesmo padrão dos realizados pelas universidades convencionais.

\section{Avaliação}

A avaliação dos estudantes é feita de duas formas: avaliação contínua e avaliação final. $\mathrm{Na}$ avaliação contínua os estudantes têm de realizar duas tarefas por cada meio crédito e 4 atividades por cada crédito completo. Os alunos não podem tirar menos que $40 \%$ nos mestrados e $50 \%$ nos doutorados. As notas obtidas nas avaliações contribuem para o resultado final do curso.

Os estudantes que falham na avaliação contínua não podem se apresentar para a avaliação final. A avaliação final força os estudantes a rever toda a disciplina. Ao final de cada semestre os estudantes têm uma prova escrita de 3 horas de duração para cada 
disciplina cursada. Os que não são aprovados devem se inscrever novamente na disciplina depois de pagar a taxa correspondente.

Para o cálculo da nota final, considera-se $70 \%$ da nota do exame final e $30 \%$ da média das notas tiradas nas avaliações em processo, sendo a classificação dos alunos realizada de acordo com o seguinte esquema:

$\begin{array}{lc}80 \% \text { ou mais } & \text { A+ } \\ 70 \% \text { a } 79 \% & \text { A } \\ 60 \% \text { a } 69 \% & \text { B } \\ 50 \% \text { a } 59 \% & \text { C } \\ 40 \% \text { a } 49 \% & \text { D } \\ \text { Menos de } 40 \% & \text { Reprovado }\end{array}$

\section{Centros de Estudo}

A universidade possui nove campi regionais, 23 centros, 90 escritórios de coordenação e mais de 1.400 centros de estudo ${ }^{188}$. Destes, 60 são modelos, para coordenar e facilitar o sistema descentralizado de operação. Nos campi são realizados os treinamentos práticos, as oficinas, os seminários e os exames de credenciamento.

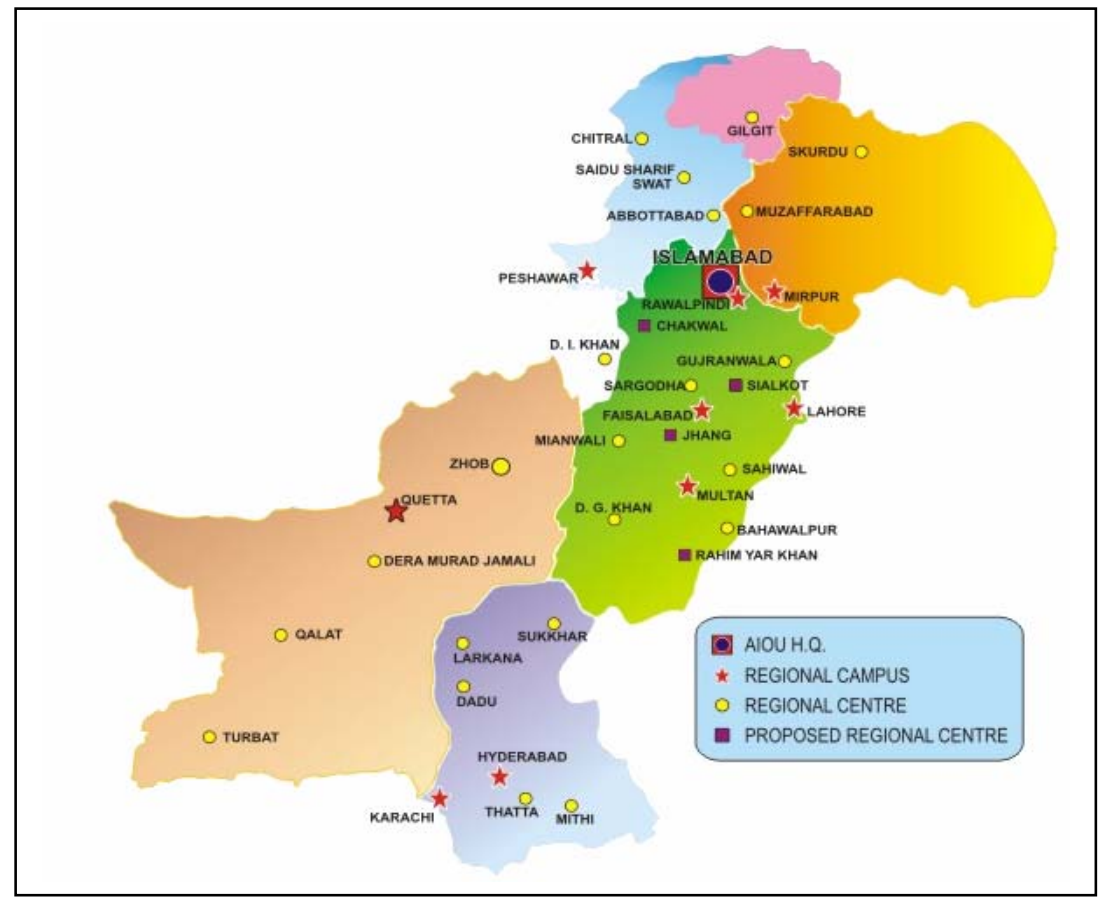

Figura 35: Infraestrutura da Allama Iqbal Open University

\footnotetext{
${ }^{188}$ Centros de Estudo: Fonte: Site da universidade: Disponível em: $<$ http://www.aiou.edu.pk/RegionalOffices.asp>. Acesso em: 12 out. 2006.
} 


\section{b) Universidade Virtual do Paquistão}

\section{Endereço}

Virtual University of Pakistan

M.A. Jinnah Campus - Defence Road - Off Raiwind Road,

Lahore - Pakistan

Telefone: +92 (42) 111880880

Fax: +92 (42) 9200604

\section{Contexto histórico}

A Universidade Virtual do Paquistão, primeira universidade do país baseada completamente em modernas tecnologias de informação e comunicação, foi estabelecida pelo governo com estatuto de universidade federal, pública e sem fins lucrativos, tendo um investimento inicial de 16 milhões de dólares. A universidade abriu suas portas virtuais em 2002 e, em curto espaço de tempo, alcançou 60 cidades do país, com mais de cem instituições associadas que fornecem o suporte de infra-estrutura aos estudantes.

A universidade identifica os melhores professores do país e, sem importar sua filiação institucional, solicita-lhes a elaboração de cursos a distância, fornecendo assim os melhores cursos não somente para os estudantes presenciais das grandes cidades mas também para os estudantes de todas as outras universidades do país.

\section{Objetivos}

A universidade possui uma clara missão: prover, a um preço acessível, educação de nível internacional a todos os estudantes do país, visando aliviar a falta da capacidade física das universidades existentes e, simultaneamente, superar a dificuldade existente pela carência de professores qualificados no país. 


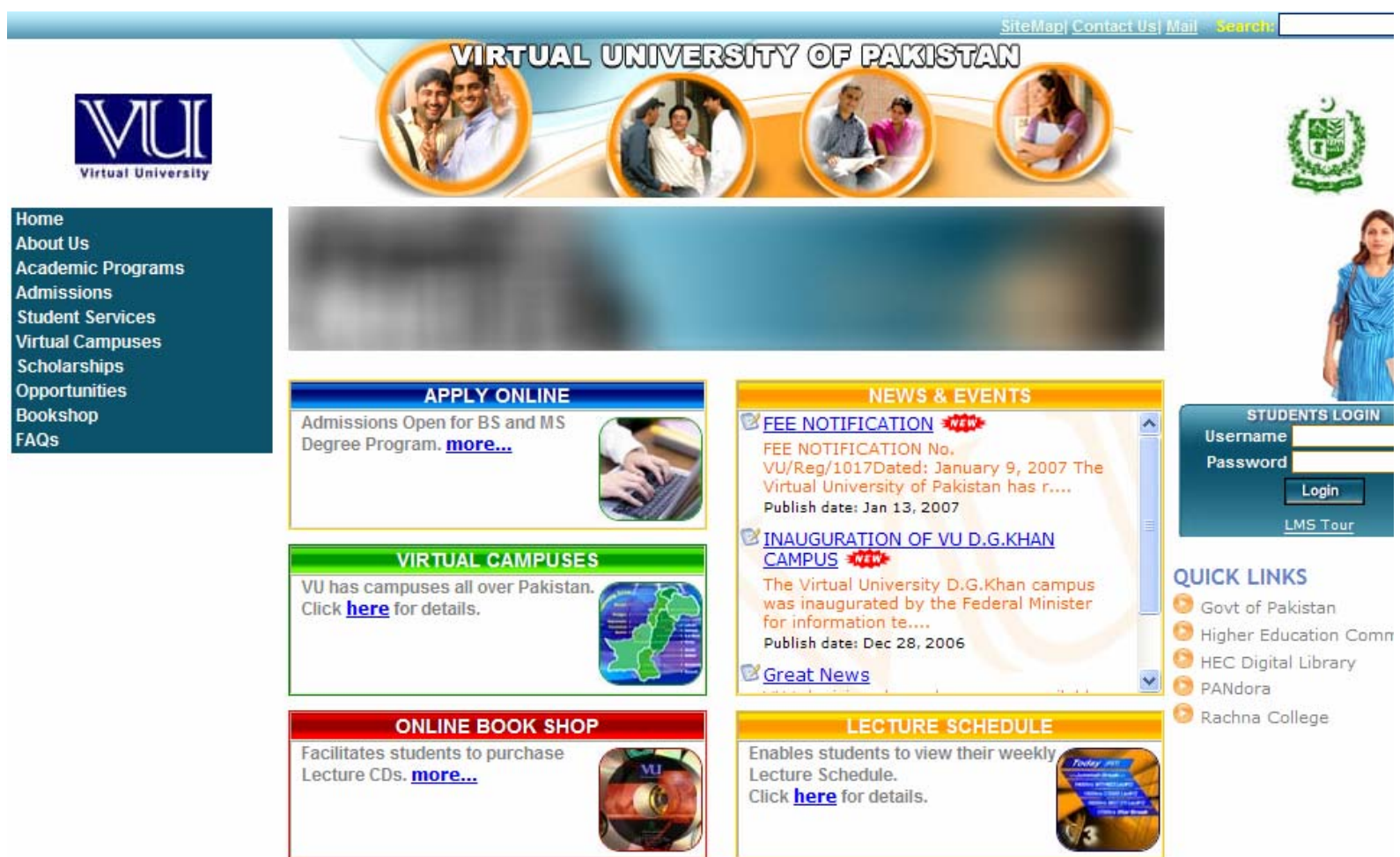

Figura 36: Portal da Universidade Virtual do Paquistão. Disponível em: <http://www.vu.edu.pk/> .

\section{Materiais de estudo e estratégia instrucional}

A universidade virtual utiliza uma metodologia de transmissão por televisão e internet através do LMS “intralearn”. Todos os cursos são elaborados por uma equipe de especialistas, e os programas são gravados em estúdios profissionais, com uso de slides, vídeos e outros recursos, como se pode observar na figura abaixo.
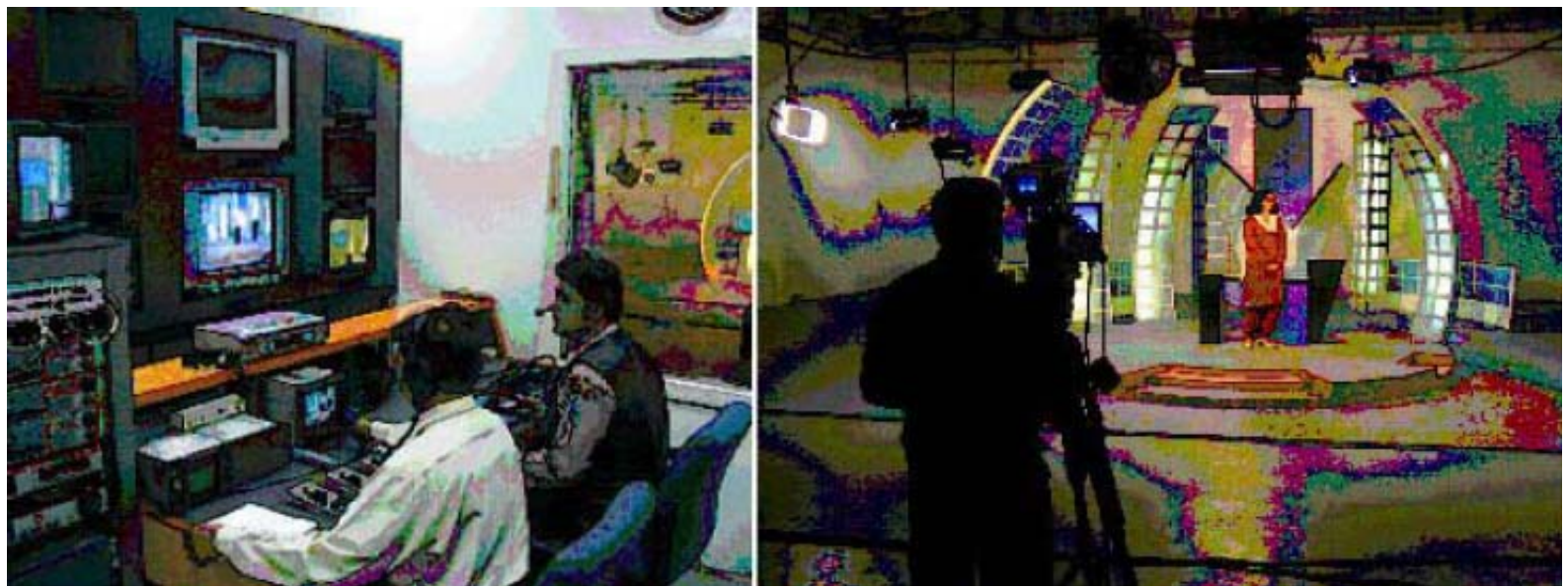

Figura 37: Estúdio de transmissão Universidade do Paquistão. Fonte: Hybrid Model for e-Learning at Virtual University of Pakistan. Saba Khalil Toor. Pakistan. 2005. Disponível em: <www.ejel.org/volume-3/v3-i1/v3-i1-art7-toor.pdf $>$. 
Os cursos são transmitidos por televisão aberta e podem ser adquiridos em CDs ou através de download do servidor da universidade. Além disso, os alunos contam com material impresso, acessível pela internet no LMS. Esta ferramenta também ajuda na comunicação com os tutores e com outros alunos, através de e-mail e fórum de discussão.

\subsubsection{Indonésia}

\section{a) Universitas Terbuka (UT)}

\section{Endereço}

Jalan Cabe Raya Pondok Cabe Pamulang

I N D O N E S I A

Jakarta 10001

Telefone: $+62.021 .7490941-$ Fax: +62.021 .7490147$

E-mail: info@p2m.ut.ac.id

\section{Contexto histórico}

Fundada em 1984 pelo governo da Indonésia, na cidade de Jacarta, com status de universidade pública, a Universitas Terbuka (UT) é a única instituição estatal que emprega recursos modernos de educação direcionados inteiramente à concepção de educação a distância como estratégia de ensino e aprendizagem. Foi inicialmente criada para ser uma universidade pública, flexível e gratuita, focada para atender a pessoas que muitas vezes não tiveram oportunidades de realizar seus estudos superiores nos moldes tradicionais do ensino presencial.

\section{Objetivo}

Seu objetivo principal é expandir as oportunidades educativas no território nacional, tornando a educação mais atrelada às necessidades do país, particularmente no que diz respeito à formação de professores em atividade profissional, trabalhadores em geral, 
recém-graduados do ensino médio e a todos aqueles que, por qualquer motivo, não puderam ter acesso ao ensino superior em suas vidas.

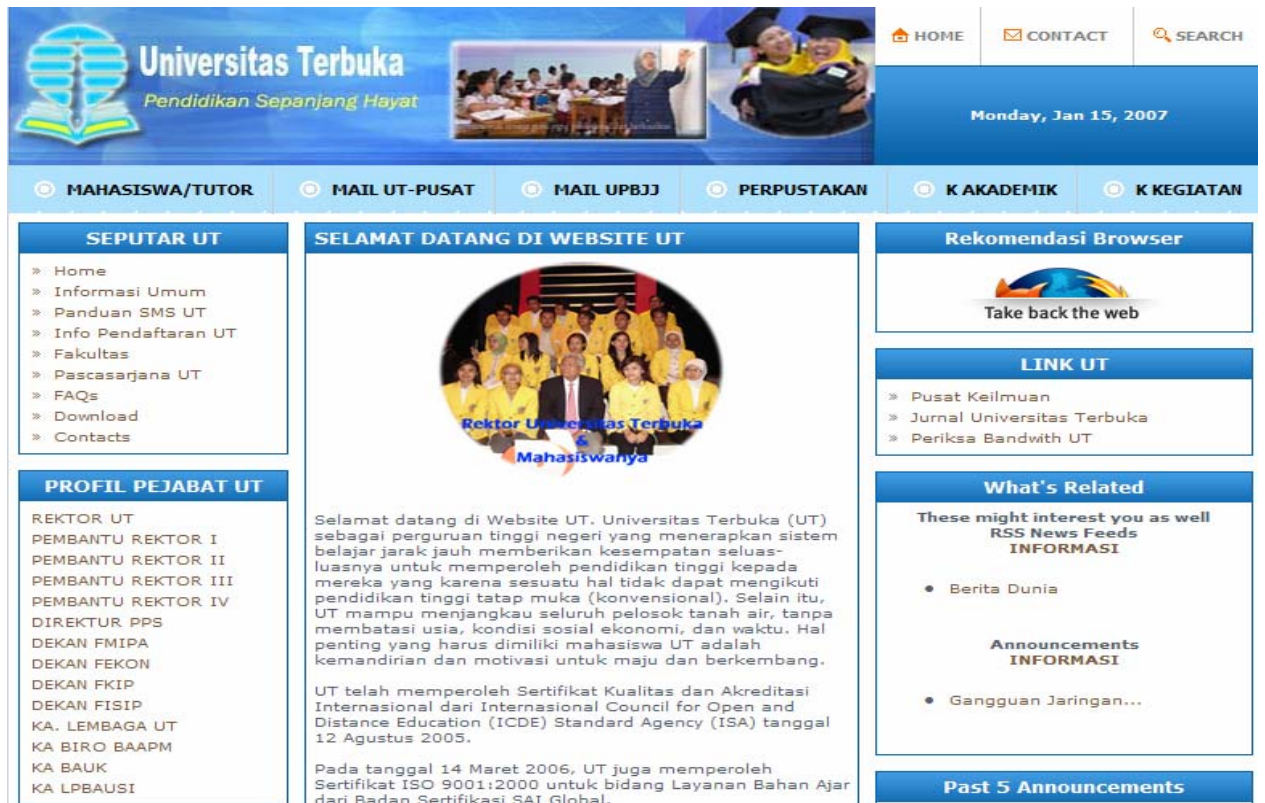

Figura 38: Portal da Universitas Terbuka. Fonte: Universitas Terbuka. Disponível em: <http://www.ut.ac.id/>. Acesso em: 25 jan. 2005.

\section{Público-alvo}

O ingresso à universidade é flexível, porém exige-se, para a inscrição em um determinado curso de graduação, que se tenha pelo menos o ensino médio concluído. Nela há também dois tipos de alunos: a) os institucionais e b) os individuais. Os primeiros são alunos de outras instituições parceiras que se inscrevem em algum determinado curso da universidade; já os individuais são aqueles inscritos diretamente na universidade, e integram o corpo de alunos regulares.

Em 1984, a universidade possuía 84.000 alunos; já em 1998, passou a contar com cerca de 442.000. Em 2003, o número de alunos regularmente matriculados diminuiu para cerca de 222.000 estudantes. Conforme dados apresentados na tabela n, percebe-se que a universidade teve primeiramente um crescimento significativo de cerca de $426 \%$, o que representou uma taxa média de crescimento de 12,59\% até 1998. Posteriormente, constatou-se que houve um percentual de decrescimento de 49,10\% em menos de 6 anos, o que equivale a um decréscimo médio anual de 10,64\%. 


\section{$\square$ Número de Alunos}

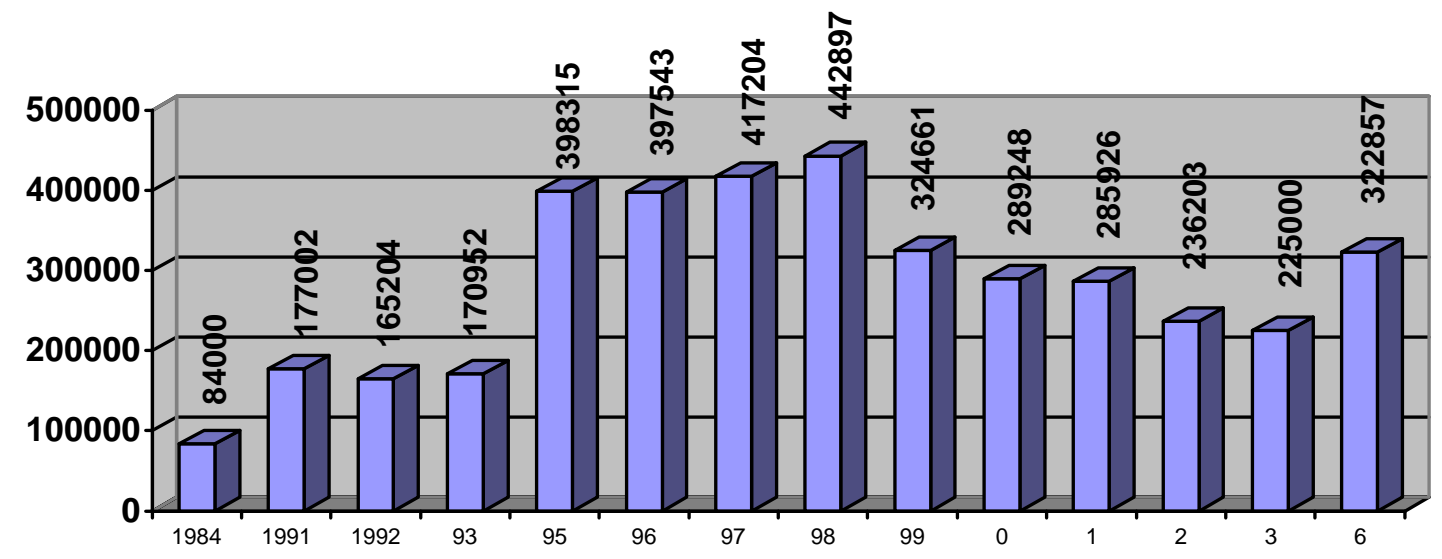

Gráfico 21: Número de alunos da Universidade Terbuka. Fonte: Tabela construída pelo autor a partir dos dados de Pannen. P. Distance education public policy and practice in the higher education: The Case of Indonesia. 2003. ${ }^{189}$

Esta tendência pode presumivelmente ser atribuída à crise econômica que desde 1998 se abateu sobre o país, afetando as pessoas com menos recursos financeiros, aquelas que correspondem ao nicho de clientes tradicionais da universidade. Um outro fator pode ser, segundo Pannen (2003), a diminuição significativa das matrículas de professores em atividade profissional, os quais já teriam concluído seus programas de graduação.

O número de alunos regularmente matriculados cresceu novamente até o período de julho de 2006, ano em que foram matriculados cerca de 322.857 alunos, sendo que aproximadamente $75 \%$ deles compreendiam professores que atuam no ensino fundamental da Indonésia.

Desde a fundação da Universitas Terbuka, matricularam-se mais de 1 milhão de alunos, graduando-se mais de 500.000 estudantes. ${ }^{190}$

\footnotetext{
189 In: Revista Brasileira de Aprendizagem Aberta e a Distancia. Disponível em: http://www.abed.org.br/publique/cgi/cgilua.exe/sys/start.htm?UserActiveTemplate=1 por\&infoid=817\&sid=70 ZUHAIRI, A. e SUPARMAN. Managing quality and accessibility in open and distance learning: the experience of indonesia's universitas terbuka. Terbuka University: 2002. Disponível em: http://www.ignou.ac.in/theme3\%5CAmin\%20Zuhairi\%20and\%20Atwi\%20Suparman.htmSoleiman

N; SRI LISTYARINI \& ZUHAIRI. Networking and Partnership for Strengthening Collaboration in Open and Distance Education. In: A Improving quality services of open and distance education through networking and partnership in the distribution management of course materials. Terbuka University paper presented to the 17th Annual Conference of the Asian Association of Open Universities (AAOU) Bangkok, Thailand, 12-14 November 2003.

${ }^{190}$ SOLEIMAN, N; SRI LISTYARINI \& ZUHAIRI. Networking and Partnership for Strengthening Collaboration in Open and Distance Education. A Improving quality services of open and distance education through networking and partnership in the distribution management of course materials. Terbuka University.Paper presented to the 17th Annual Conference of the Asian Association of Open Universities (AAOU) . Bangkok, Thailand, 12-14 November 2003.
} 
95\% dos estudantes da universidade são trabalhadores em tempo integral, estando distribuídos pelos cursos da seguinte maneira: $60 \%$ na faculdade de educação, $17 \%$ na administração pública, $13 \%$ cursando economia e 10\% na área de ciências básicas (SOLEIMAN, N; SRI LISTYARINI \& ZUHAIRI: 2003).

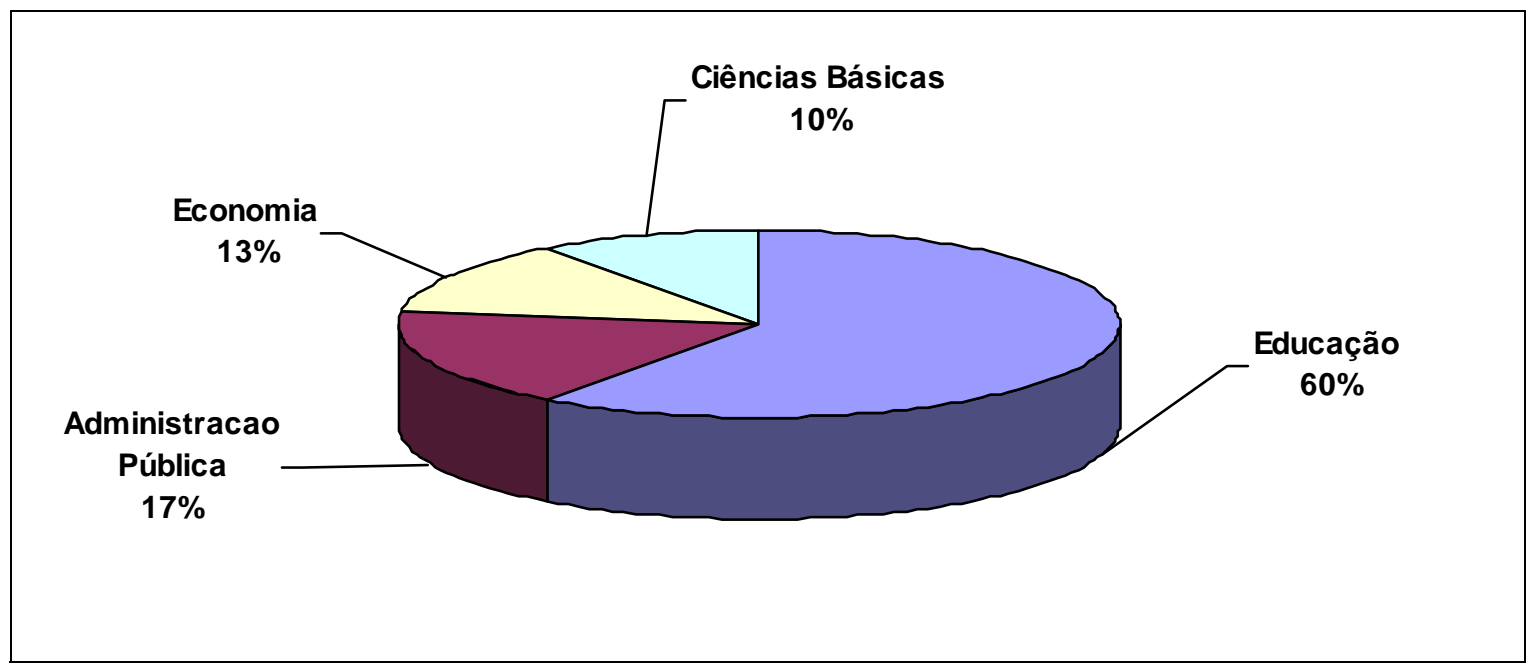

Gráfico 22: Divisão de estudantes por área na Universitas Terbuka

\section{Recursos Humanos e Materiais}

Segundo ZUHAIRI e SUPARMAN (2002), a universidade já empregou diversos funcionários acadêmicos e administrativos para dar suporte às suas atividades educacionais, perfazendo um total de 1.471 pessoas. 789 delas representam notadamente profissionais acadêmicos, sendo que 355 desenvolvem atividades no campus da universidade, enquanto 434 atuam distribuídas em vários escritórios regionais. Já o pessoal administrativo contabiliza 682 pessoas, das quais 395 se encontram na universidade, ao passo que 287 se distribuem por centros regionais.

O desenvolvimento de recursos humanos, por parte da UT, tem se mostrado um imenso desafio ao governo da Indonésia, principalmente no que se refere ao incremento necessário de professores e tutores voltados à expansão do ensino superior. Nos anos 70, professores de escolas secundárias costumavam ser treinados por programas de formação sem continuidade, o que os levava a um processo gradativo de desqualificação profissional. Somente nos anos 80 é que houve, de fato, uma forte necessidade de atualizar o conhecimento e as competências dos professores, de modo que o governo se viu obrigado a desenvolver estratégias efetivas de retreinamento por via da educação a distância. 
A UT possui um serviço on-line integrado, para estudantes, que permite o suporte de informação acadêmica geral (programas de estudos e currículos, anúncio de notas de exames, criação de autotestes, horários para tutorias em rádio), além de informações administrativas acadêmicas (matrícula, transferência de créditos, verificação de certificados), tutoriais on-line (com base na infra-estrutura da web), bem como cursos básicos na infra-estrutura da web. Além disso, todos os serviços on-line da UT podem

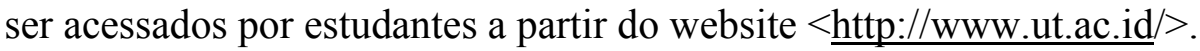

\section{Cursos oferecidos}

Inicialmente, a UT oferecia quatro programas de formação básica com cursos nas áreas de Administração Pública, Administração Empresarial, Economia e Estudos para o Desenvolvimento e Estatística Aplicada. Outros programas foram formalmente assumidos mediante o Projeto de Educação a Distância voltado à Formação de Professores.

A UT possui atualmente quatro faculdades que oferecem 28 programas, organizados a partir de 1.200 cursos. Possui ainda uma rede de 34 centros regionais que oferecem serviços acadêmicos e administrativos. ${ }^{191}$

A Universitas Terbuka oferece programas de estudos em vários níveis e campos de estudos, que vão desde bacharelado e cursos de graduação a programas de curta duração de 1 a 3 anos, com provimento de certificados para quem tem ensino médio concluído. Os programas de estudos são desenvolvidos e implementados sob os auspícios das faculdades e escolas que compõem a rede institucional da universidade aberta. A Universidade conta com as seguintes faculdades congregadas ao seu campus em EaD: Faculdade de Economia e Estudos do Desenvolvimento; Faculdade de Ciências Sociais e Políticas; Faculdade de Treinamento para Professores e Estudos Educacionais; Faculdade de Matemática e Ciências Naturais; Faculdade de Estudos para Graduados.

\footnotetext{
${ }^{191}$ Universitas Terbuka. Disponível em: $<$ http://www.ut.ac.id/> Acesso em: 27 jan. 2005.

* Todos estes programas foram previstos para serem iniciados a partir de 2006
} 
No início, foram designados os seguintes cursos para funcionarem regularmente:

- Faculdade de Economia e Estudos do Desenvolvimento - cursos de Graduação em Economia e Estudos do Desenvolvimento, Administração e Contabilidade.

- Faculdade de Ciências Sociais e Políticas - cursos de Graduação em Administração Pública, Administração de Empresas, Ciências Governamentais e Políticas, Ciências da Comunicação, Sociologia da Economia e Aspectos Sociais; cursos de 3 anos em Tradução e Tributos Públicos; cursos de 2 anos em Biblioteconomia.

- Faculdade de Treinamento para Professores e Estudos Educacionais - cursos de Graduação em Educação em Língua Indonésia e Língua Inglesa; Educação Matemática, Ensino de Física, Ensino de Química, Ensino de Biologia, Educação para Professores do Ensino Fundamental, Educação Econômica e Cooperativa; cursos de 2 anos em Certificado de Ensino e Língua Indonésia para Falantes de Língua Estrangeira; e Programas Especiais (Programa para Professores de Ensino Fundamental; Programa para Professores de Educação Infantil; Programa para Professores de Esportes).

- Faculdade de Matemática e Ciências Naturais - cursos de Graduação em Matemática, Estatística, Biologia, Extensão Agrícola e Comunicação (com especialização em Agricultura, Criação de Gado e Pesca) e Tecnologia de Alimentos; cursos de Especialização (com diploma) em Gerenciamento Ambiental e cursos de curta duração (com certificado) em Pós-graduação em Tecnologia de Alimentos.

- Faculdade de Estudos para Graduados - programas de Pós-Graduação em Administração Pública e em Administração Financeira.

\section{Sistema de Estudos}

Como a UT foi criada para ampliar as oportunidades de estudos para todos os cidadãos indonésios, a política de admissão de alunos obedece a critérios máximos de flexibilidade e acessibilidade. Não há teste para pré-ingresso universitário nem limites 
de idade, tampouco tempo de escolaridade mínimo exigido para ingresso em seus cursos. Alunos de qualquer idade são bem-vindos à Universidade, desde que possuam diploma de ensino médio, independentemente do ano de conclusão de seu curso, não havendo necessidade de se submeter a teste para ingresso.

\section{Materiais de Estudo e Estratégia Instrucional}

Os programas de estudos da UT tem crescido muito, chegando a mais de 900 cursos por semestre. Tendo em vista este imenso número de cursos, a Universidade definitivamente tem necessitado procurar modelos de auto-instrução e auto-regulação dos estudos, sem ou com pouca interferência dos tutores. Muitas mídias e metodologias são utilizadas na UT como parte integral do seu processo de instrução, a saber: reuniões presenciais, material impresso, TV e programas de rádio.

Os materiais impressos (produzidos em módulos) servem como mídia principal, suplementados pela utilização de materiais gravados (audiocassetes e videocassetes), material de radiodifusão (programas de rádio e televisão) e materiais baseados no uso do computador e internet.

O suporte à aprendizagem dos alunos se realiza por diversas formas: tutorias, trabalhos de cunho prático, trabalhos de campo supervisionados e orientação acadêmica.

O serviço de tutoria tem por objetivo auxiliar os estudantes a superar dificuldades de aprendizagem, ou seja, dar um suporte complementar ao processo de auto-instrução. Na maior parte dos cursos, as tutorias não são obrigatórias, contudo os alunos são estimulados a formar grupos de estudos, desenvolvendo a capacidade de colaboração. A Universidade também fornece orientação acadêmica e individual para ajudar na solução de problemas pessoais e emocionais dos seus alunos, de acordo com os relatos feitos durante o processo de estudos.

Para abranger todas as realidades do país em relação à capacidade de comunicação, a UT tem elaborado um plano de suporte aos alunos muito diverso, empregando envio de correspondência, encontros presenciais e uso de rádio e televisão.

O método por correspondência é geralmente o meio mais acessível a todos os estudantes. Trata-se de textos escritos encaminhados via serviço postal. Este modelo 
objetiva atingir estudantes em áreas isoladas cobertas por serviços postais. A disponibilidade dos serviços de fac-símile em quiosques locais de telecomunicações também tem ajudado a reduzir o tempo gasto com o envio de correspondências.

O método presencial só é utilizado por aqueles que residem em áreas urbanas e que têm acesso aos centros de estudo, que geralmente são distritais. Contudo, este modelo requer que os alunos possam pagar taxas extras.

Também se realizam tutorias por rádio, que tem uma enorme penetração social, alcançando os rincões mais remotos do país, já que quase todos os lares da Indonésia possuem pelo menos um rádio. Por isso, a UT emprega programas de áudio prégravados, que são enviados aos escritórios regionais da instituição para que sejam radiodifundidos por meio de estações de rádio locais. Após a pré-gravação dos tutoriais, os alunos têm a oportunidade de telefonar para levantar questões ou ainda fazer comentários, que poderão ser respondidos por um tutor a partir de estações de rádio.

Tutorias via internet permitem aos estudantes interagir tanto com tutores quanto com seus pares. Como as interações muitas vezes não acontecem em tempo real, os alunos podem postar suas perguntas, levantar questões e ler as respostas dos tutores e de outros alunos, respondendo ainda às questões apresentadas de acordo com as suas conveniências de tempo de uso. Os tutores têm a mesma flexibilidade para programar seus horários de tutoria, bem como o conforto necessário para preparar seus materiais e, ainda, pesquisar respostas mais adequadas às perguntas feitas por determinados alunos.

A princípio, as tutorias eram feitas a partir de aplicações de listas de discussões eletrônicas por correio eletrônico, e cada curso possuía sua própria lista eletrônica. Contudo, a partir de 2002, as tutorias passaram a ser realizadas com o emprego da infraestrutura básica da web, por meio da qual se emprega um software livre de gerenciamento da aprendizagem chamado Manhattam Virtual Classroom (MVC). Com base nesta nova infra-estrutura de ensino e aprendizagem, a UT passa a oferecer tutoriais via internet, designados para atender a 191 cursos.

O atual desenvolvimento das tecnologias de informação e comunicação bem como toda a infra-estrutura de apoio tecnológico na Indonésia, abriu um novo campo de possibilidades para a UT oferecer a seus alunos um canal bidirecional de comunicação mais rápido, confiável e confortável para as atividades de estudos. Acredita-se que haja 
na Indonésia, atualmente, cerca de 2.500 redes corporativas que permitem acesso à internet dentro de custos razoáveis para o público em geral. As chamadas Warnets, por exemplo, são redes que atendem a comunidades de negócios e são operadas de modo independente por indivíduos que vivem em comunidades e distritos indonésios. Sua distribuição abrange todo o país, especialmente as ilhas mais populosas, como Sumatra, Java e Bali. A respeito disso, foi realizado um levantamento em relação à disponibilidade destas redes aos estudantes da UT, revelando que 30\% dos alunos pesquisados moravam a 30 minutos de distância da rede Warnet mais próxima de suas residências. Além disso, $40 \%$ dos estudantes também disseram que poderiam ter acesso à internet, empregando, para isso, as facilidades de infra-estrutura em seus escritórios de trabalho (HARDHONO \& BELAWATI, 1999).

A Universitas Terbuka percebeu que o acesso dos alunos à internet ainda é bastante limitado, pois grande parte deles não possui computador próprio e muito menos estão conectados à internet. Por isso, desenvolveu uma estratégia colaborativa com os três maiores provedores de acesso à internet na Indonésia, instituindo-se um consórcio com a Warnet Association (AWARI), que possui mais de 2.500 membros, o Ministério de Pesquisa e Tecnologia, que possui 116 quiosques de tecnologia da informação, e a Corporação dos Correios Indonésios, que possui quiosques de correios eletrônicos nos 60 maiores postos de correios do país. Isso equivale a dizer que todas as principais cidades da Indonésia e quase todos os distritos em Java e Bali são cobertos por esta imensa rede de comunicação digital.

Além das tutorias, são realizados trabalhos práticos de campo, de modo a aprimorar as habilidades e as experiências práticas dos estudantes. Tanto tutorias quanto trabalhos de campo práticos supervisionados são realizados em parceria com agências locais de destaque. Os tutores e os supervisores são recrutados por meio das equipes acadêmicas da UT, conferencistas mais antigos e professores universitários oriundos das universidades estatais, especialistas credenciados e profissionais liberais.

Porém o problema reside na distribuição de riqueza no interior do país, como ocorre com a Índia, a China e o Paquistão: as regiões ricas possuem centros de estudo de excelência; as pobres dificilmente têm prática educativa. Geralmente, os bons laboratórios estão disponíveis em universidades públicas nos grandes centros urbanos e raramente podem ser utilizados por estudantes da UT. E mesmo que estejam 
disponíveis, eles são geralmente obrigados a arcar com taxas para seu uso. Outros laboratórios estão disponíveis ainda em escolas (de primeiro e segundo graus), mas as facilidades de acesso e uso também nem sempre são também satisfatórias. O mesmo se aplica aos supervisores qualificados nos centros regionais.

Para o trabalho prático, a UT tem desenvolvido os chamados "laboratórios secos" "192 (uso de simulações baseadas em computador) e também laboratórios móveis que possam ser empregados para percorrer todo o território geográfico da Indonésia.

Naturalmente, os laboratórios móveis podem ser vistos como uma escolha mais adequada em termos de configuração de um laboratório real para estudantes, especialmente em regiões remotas. A partir de um laboratório móvel, são providas certas facilidades para se conduzir experimentos científicos requisitados por alguns cursos. Além disso, sempre haverá um computador conectado à internet que possa ser empregado para estabelecer comunicação com o servidor da UT e com outros estudantes, para acesso aos recursos de aprendizagem disponíveis. Um laboratório móvel, já que ele não se fixa em uma determinada posição geográfica, pode ser alcançado por um imenso contingente de pessoas durante seu trajeto, o que torna seu procedimento mais valioso em termos de demanda.

\section{Pesquisa}

A UT possui um Centro de Pesquisa com o objetivo de desenvolver estudos relacionados a várias questões voltadas ao desenvolvimento da sociedade da Indonésia como um todo. Para isso foi criada uma base de dados distribuídos para disseminar informação a vários indivíduos ou grupos de pessoas interessadas. O Centro também publica revistas científicas, cada uma seguindo um foco de assunto bem específico, como a das áreas de educação a distância e educação aberta, estudos indonésios e educação.

O Journal for Open and Distance Education, por exemplo, se destina aos praticantes, pesquisadores e acadêmicos envolvidos no desenvolvimento e na implementação da educação a distância na Indonésia. É publicado duas vezes ao ano, nos meses de maio e

\footnotetext{
192 Os "laboratórios secos" podem ser voltados a estudantes que trabalham com exercícios práticos e repetitivos, bem como analíticos que visem desenvolver certas competências que requerem trabalhos eminentemente práticos.
} 
setembro. Já o Journal of Indonesian Studies é mais destinado à publicação de relatos e artigos de estudos, análises teóricas, meta-análises de relatórios de pesquisa, resenhas de livros sobre o desenvolvimento de ciência e tecnologia na Indonésia. Esta revista científica inclui especificamente análises teóricas e empíricas interdisciplinares das áreas de política, economia e cultura da sociedade da Indonésia, sendo publicada durante os meses de janeiro e agosto. Por último, o Journal of Education se destina a ser um meio de comunicação entre educadores, pesquisadores e acadêmicos interessados nas práticas educativas desenvolvidas na Indonésia, geralmente publicado nos meses de março e setembro.

\section{Desenvolvimento de cursos}

O desenvolvimento dos materiais de aprendizagem da UT exige esforços múltiplos no que diz respeito à elaboração de conteúdos altamente qualificados por meio de especialistas de conteúdos, roteiristas instrucionais, especialistas em mídias e programadores de computador. Dentro desta filosofia pedagógica, a partir do trabalho da equipe de educadores e especialistas, a UT tem conseguido assegurar adequadamente a qualidade na elaboração de seus materiais instrucionais adequados aos aprendizes a distância.

Como a filosofia educacional de utilização dos materiais produzidos pela UT não os restringe apenas ao acesso de seus estudantes, eles acabam também por ser empregados por alunos de instituições convencionais de ensino superior. Deste modo, a metodologia de ensino e aprendizagem da Universidade tem também contribuído para padronizar o uso de materiais de aprendizagem em um nível nacional. Tais materiais podem ser eventualmente obtidos nos centros regionais da UT, em algumas livrarias locais ou, ainda, encaminhando-se um pedido direto ao escritório central da UT em Jacarta.

\section{Avaliação Educacional}

A UT realiza exames duas vezes ao ano, no fim do semestre de cada programa. Os locais dos exames ficam geralmente a uma curta distância das residências dos seus alunos, o que permite fácil acesso às instalações educacionais. Para diversificar o serviço de exames voltado aos alunos, foram realizados testes piloto para os exames nos 
moldes on-line em sete escritórios regionais em setembro de 2005. Dezessete cursos foram então incluídos neste teste piloto de exame. A idéia é que os esquemas de exames on-line, na UT, tornem-se cada vez mais versáteis e adaptáveis às necessidades dos alunos, sem que haja perda da demanda por questões de credibilidade e integridade.

Os materiais voltados aos testes são desenvolvidos por especialistas de conteúdos oriundos de universidades renomadas, sendo que, para se conseguir as qualificações necessárias à obtenção de certificados ou diplomas da UT, os alunos precisam se submeter a exames escritos abrangentes.

O nível de avaliação dos alunos pode ser obtido de duas formas: em um nível do programa e em um nível do curso. No nível do programa, os estudantes devem ser aprovados em um exame bem amplo para obterem uma nota satisfatória. Já no nível do curso, a nota necessária é determinada pela combinação do alcance do aluno em vários tipos de avaliações e atividades, além dos pontos obtidos no exame final.

Os procedimentos que estabelecem a avaliação são:

\begin{tabular}{|ll|}
\hline 1. & Mínima porcentagem de $40 \%$ no exame final. \\
\hline 2. & Porcentagem de $15 \%$ no autoteste. \\
\hline 3. & Avaliações na forma de tutoriais face a face, com porcentagem de $30 \%$. \\
\hline 4. & Avaliações na forma de tutoriais escritos, com porcentagem de $15 \%$. \\
\hline 5. & Trabalho prático, com porcentagem de $30 \%$. \\
\hline 6. & Porcentagem prática de $30 \%$. \\
\hline 7. & Atividades em cada curso, com porcentagem de $30 \%$. \\
\hline
\end{tabular}

A determinação da nota necessária para aprovação em cada curso cabe a cada faculdade responsável, contudo os resultados dos exames, bem como o processo de cálculo para as notas, são obtidos por meio de um sistema computadorizado, disponível no Centro de Exames, com exceção do teste dissertativo, cuja nota é fornecida à mão pelos membros da faculdade. As notas são também anunciadas aos estudantes de vários modos, incluindo e-mails regulares, uso do website institucional, resposta por serviço de voz interativa (IVR - Interactive Voice Response) e serviço de mensagens breves (SMS Short Messages Service).

Quanto à transferência de créditos, os estudantes prospectivos podem se candidatar à obtenção de créditos por unidades de cursos, retirados de outras universidades e instituições com cursos reconhecidos, nas quais estudaram previamente. Caso seja 
aprovada a transferência de créditos por parte do comitê responsável, os alunos não precisam fazer curso similar na UT.

\section{Centros de Estudos}

Como uma das grandes aspirações da UT é se tornar rapidamente um centro de excelência em educação superior a distância intercontinental e, posteriormente, mundial, todo um esforço conjunto tem sido realizado no sentido de conjugar recursos e atividades de uma forma detalhada, que integre programas anuais com um claro foco e definição de prioridades.

Os planos de programas objetivam servir como meios de se estabelecer um gerenciamento integrado em todas as linhas previstas ao longo do seu desenvolvimento, o que inclui, conseqüentemente, as várias unidades que compõem o escritório central, bem como os trinta e sete escritórios regionais espalhados pelo território da Indonésia.

A Universitas Terbuka obteve credenciamento e autorização para o seu sistema de gerenciamento a partir do ISA $^{193}$ (ICDE $^{194}$ Standard Accreditation - Credenciamento Padrão do ICDE), em setembro de 2005. Este processo de reconhecimento internacional ajudou a validar a educação a distância como um sistema aceitável para se prover ensino superior de qualidade, tanto na Indonésia quanto em outras partes do mundo. O que se espera, significativamente, a partir desta iniciativa da UT é convencer acadêmicos responsáveis por diretrizes educacionais e a comunidade em geral, tanto na Indonésia como em outras partes do mundo, de que são necessários mais investimentos em

\footnotetext{
${ }^{193}$ ISA - Institute of Standard Accreditation (Instituto de Padrões ICDE. Dada a necessidade de criação de padrões de qualidade em EAD e e-learning, com reconhecimento internacional, o ICDE (Conselho Internacional de apoio à Educação a Distância) optou por criar um instituto nos moldes do ISA, cuja missão é promover a divulgação de padrões de qualidade e confiabilidade em EAD, de modo a garantir que tais padrões possam ser atingidos por instituições de ensino a distância que empreguem diversas modalidades instrucionais e recursos pedagógicos. A auditoria do ISA implica um grande rigor avaliativo do processo de aprendizagem dos alunos matriculados em cursos a distância, assumindo o fato de que as instituições avaliadas operam dentro das conformidades educacionais estabelecidas pelas autoridades competentes de seus respectivos países. Os serviços do ISA estão disponíveis em todo o mundo. Para se obter mais informações, basta escrever para o e-mail Admin@icde.standardsagency.org.

${ }^{194}$ ICDE - International Council for Distance Education (Conselho Internacional de apoio à Educação a Distância). O ICDE é uma das mais importantes instituições dedicadas ao desenvolvimento internacional da EAD, por isso, tem significativa representatividade para estabelecer padrões de qualidade educacional internacionalmente reconhecidos. Disponível em: http://www.icde.org/.

Para mais informações, acessar o endereço: http://www.cidade.usp.br/redemoinhos/0303/noticias.php do Boletim Informativo da Cidade do Conhecimento/USP. Área de Notícias, Seção "Lançamento da ISA-ICDE busca padronização na avaliação de qualidade em educação a distância e e-learning", ano III, No.03, 01 a 15 de março/2003. Acesso em 7 fev. 2005.
} 
educação a distância, de modo que se resolva com o tempo o problema de acesso à educação de qualidade no âmbito nacional e mundial.

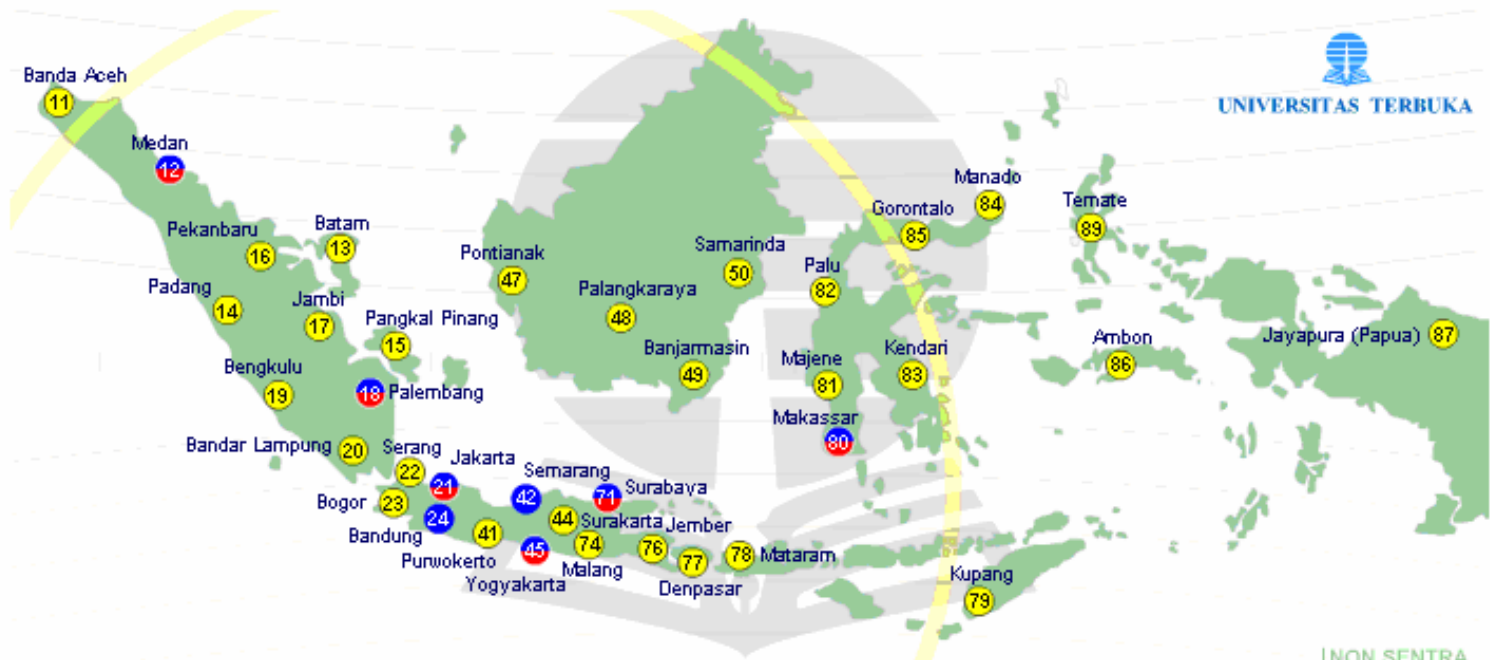

Figura 39: Relação de Centros de Estudos da Universitas Terbuka. Fonte: Universitas Terbuka. Disponível em: < http://www.ut.ac.id/>. Acesso em: 20 nov. 2006.

\subsubsection{Coréia}

\section{Contexto Nacional}

Até alguns anos a Coréia possuía somente uma universidade de educação a distância, a Universidade Nacional Aberta da Coréia. Em 1998, o governo estabeleceu um projeto experimental de universidade virtual de dois anos, a Virtual University Trial Project (VUTP), do qual participam 65 universidades e 5 empresas. Oito universidades convencionais têm participação independente, sem se filiarem a nenhum consórcio, enquanto 57 universidades e as cinco empresas formaram sete consórcios.

Três estratégias foram encontradas para ajudar a reduzir custos para as instituições que oferecem programas virtuais: maximização no uso da tecnologia existente, compartilhando recursos físicos e humanos, e treinamento extensivo dos recursos humanos (Jung \& Rha, 2000). Segundo o Insung Jung (2002), o projeto estimulou experiências novas com tecnologias avançadas, como a transmissão de satélite, videoconferência, internet e intranet, e ajudou a integrar mais firmemente a educação a distância no sistema de educação superior formal. 
Como resultado desta experiência, o Ministério de Educação revisou sua legislação de educação a distância, aprovando 9 universidades em 2001, 6 em 2002, 1 em 2003 e 1 em 2004.

Em 2005, mais de 70 mil estudantes, em 17 universidades, estavam recebendo educação terciária pela internet, segundo dados do Ministério da Informação e Comunicação, como pode se ver na tabela:

\section{University Name \& URL}

1. Korea Cyber University http://www.kcu.or.kr

2. Korea Digital University http://www.koreadu.ac.kr 3. Kunghee Cyber University http://www.khcu.ac.kr 4. Open Cyber University http://www.ocu.ac.kr 5. Sejong Cyber University http://www.cybersejong.ac.kr 6. SeMin Digital College http://www.kcc.ac.kr

7. Seoul Cyber University http://www.iscu.ac.kr 8. Seoul Digital University http://www.sdu.ac.kr

9. World Cyber University http://www.world.ac.kr 10. Dongseo Cyber University http://www.dongseo.ac.kr/ 11. Wonkwang Digital University http://www.wdu.ac.kr/intro/06_01.jsp 12. Hanyang Cyber University http://www.hanyangcyber.ac.kr 13. Hansung Digital University http://www.hsdu.ac.kr/

14. Daegu Digital University http://www.sgdu.ac.kr 15. International Digital University 16. Cyber University of Foreing language http://icu.ewha.ac.kr

16. Youngjin Cyber College http://www.ycc.ac.kr

\section{Areas of Study}

Venture Management, Digital Multimedia

Design, Entertainment

Digital Education, Digital Information, Media

Design, Practical Languages

Media Literature, E-Business, Cyber NGO,

Hotel and Tourism Management

Internet Management, Computer Design,

Digital Contents

Hotel and Tourism Management, EBusiness, the Internet, Cartoon Animation

English Translation, Hotel and Convention

Management, Digital Media, Game \&

Animation

Schools of Social Science, Information

Technology, and E-Commerce

Law and Police Administration, EBusiness,

Multimedia, Animation and Game Design,

China and Japan Studies

Social Welfare, Hotel Foods, Health Foods E-

Business, Theology

Internet Contents, Digital Multimedia Desig

E-Business, Management Information, Educational Contents, Digital Design

Internet, IT Design, E-management, Integrated Education

Cultural and Social History of Korea; Themes and Forms in Korean Art; Geography of Korea; Introduction to Korean Society \&

LiteratureWomen's Studies -Introduction to

Women's Studies in Korea; Sex, Gender and

Sexuality in Korea

Computer Programming, Computer Media, EBusiness
Establishing Body

Consortium of 36

universities

Consortium of 7

universities

Conventional

university

Consortium of 14

universities

Conventional

university

2-yr. community college

Non-profit

corporation

Consortium of 14

universities

Conventional theologica school Conventional university

Conventional university

Conventional university

Conventional university

Community college

Tabela 15: Universidades Virtuais na Corea. Tabela construída pelo autor com dados de: Jung. Minseung. The chronological analysis of cyber culture in Korean odl. Korea National University. Seul. 2005. ICD International Conference, New Delhi. Disponível em: www.ignou.ac.in/ICDE2005/PDFs/theme2pdf/theme2 81.pdf, Insung Jung. Virtual Education at the Tertiary Level: The Experience of Korea. Ewha Womans University, S. Korea. 2002. Disponível em: http://techknowlogia.org/ 
Essa nova modalidade instaurada pelo governo, caracterizada por instituições totalmente virtuais, tem fornecido uma alternativa de formação superior e treinamento para o trabalho a adultos trabalhadores. Além disso, os estudos indicam que mais de 100 instituições de ensino superior convencionais introduziram cursos virtuais baseados na internet no currículo em nível institucional (Jung, 2005 ${ }^{195}$ )

Essas experiências, segundo Jung (2005) tem levantado uma série de reflexões acerca dos elementos que podem gerar qualidade nos sistemas de educação a distância baseados na internet. Entre as questões de extrema importância para o desenvolvimento de projetos similares, está o estabelecimento de uma administração da qualidade do sistema que possibilite ter um monitoramento constante do desenvolvimento e da operacionalização de cursos on-line. Isso requer um forte investimento em infraestrutura tecnológica, para possibilitar a construção de sistemas de administração, monitoramento e avaliação que ajudem a identificar problemas em programas em curso e nos serviços de suporte ao aluno, procurando em todo momento solucioná-los e melhorar os serviços.

A avaliação externa, segundo o autor, tem se mostrado uma ferramenta muito eficaz para comparar o desempenho das universidades on-line com as universidades tradicionais.

Um segundo elemento levantado nas experiências é a necessidade de formação de tutores e professores para adquirir as competências necessárias para dar o suporte de qualidade que o processo educativo demanda, fundamentalmente porque são sistemas baseados na comunicação aluno-aluno, aluno-tutor e aluno-conteúdo. Os programas de formação contínua de funcionários que enfatizam o conceito de qualidade são o eixo de melhoramento contínuo que as universidades buscam.

$\mathrm{Na}$ experiência coreana podemos observar que as parcerias resultaram de enorme importância para desenvolver sistemas com custos reduzidos, possibilitando, ao mesmo tempo, um maior avanço tecnológico e maior qualidade no desenvolvimento dos programas de estudo. As parcerias entre universidades e empresas têm sido fundamental para este rápido processo de desenvolvimento das universidades on-line.

\footnotetext{
195 Jung. Minseung. The chronological analysis of cyber culture in Korean odl. Korea National University. Seul. 2005. ICD International Conference, New Delhi. Disponível em: www.ignou.ac.in/ICDE2005/PDFs/theme2pdf/theme2 81.pdf. Acesso em: 8 out. 2006.
} 
Os problemas que o sistema ainda apresenta resultam, por um lado, da ausência de um sistema aberto de educação. As universidades digitais ainda não são sistemas abertos: para serem admitidos, os alunos precisam possuir credenciais de ensino secundário. Para ser um sistema realmente efetivo, segundo Jung (2005), a universidade tem que se abrir com novas políticas de acesso, novos currículos, novos métodos e processos mais flexíveis. Por outro lado, há o problema da acessibilidade, embora o governo coreano, nesse sentido, seja um líder no desenvolvimento da sociedade da informação: tem regulado políticas a respeito de melhoramento do acesso a tecnologias de informação da população; tem realizado investimentos no estabelecimento de uma rede nacional, ADSL, entre outras ações que têm melhorado o acesso à internet na educação em um período de tempo relativamente curto (Jung, 2005).

Ao mesmo tempo, o governo, através do Ministério da Informação e Comunicações ${ }^{196}$, no seu planejamento de política para o ano 2006, tem colocado como objetivo expandir as habilidades de usar e aplicar a tecnologia de informação em um nível avançado a $90 \%$ da população do país, para uso da internet. Para isso continuam os programas de alfabetização tecnológica, incluindo fazendeiros, pescadores, pessoas idosas, desempregados, entre outros.

O sistema está baseado em níveis e quem conclui o nível básico tem a oportunidade de participar de níveis mais avançados, nos quais se analisa como a tecnologia pode ajudar em cada área de atuação profisssional.

\section{a) Korea National Open University (KNOU)}

\section{Contexto histórico}

A história da KNOU está intimamente vinculada à criação da Faculdade Coreana para Correspondência e Radiodifusão (Korean Air \& Correspondence College - KACC), ou seja, o primeiro instituto nacional para educação ao longo da vida (First Lifelong Education Institute), fundado em março de 1972, a partir de um decreto da presidência da república sul-coreana. Mas bem antes, já em 1968, começam a se desenvolver os

\footnotetext{
${ }^{196}$ Ministério da Informação e Comunicações.e-KOREAVISION2006. Promoting National Informatization. 2006. Disponivel em: unpan1.un.org/intradoc/groups/public/documents/APCITY/UNPAN008974.pdf.
} 
procedimentos legais necessários para a criação deste instituto, nos moldes desejáveis de abrangência nacional.

Já faz 30 anos que a universidade vem tomando forma em função de muitas mudanças. Uma universidade que começou como faculdade, com menos de 12.000 alunos, e que agora conta com mais de 180.000 estudantes; que contava com 5 departamentos que ofereciam cursos de 2 anos e passou a ter 18 departamentos que oferecem cursos de 4 anos, além das suas graduações. Uma universidade que já supera o número de 280 mil graduados, tendo evoluído do ensino por correspondência para a educação tecnológica através de satélites, programas de TV e internet.

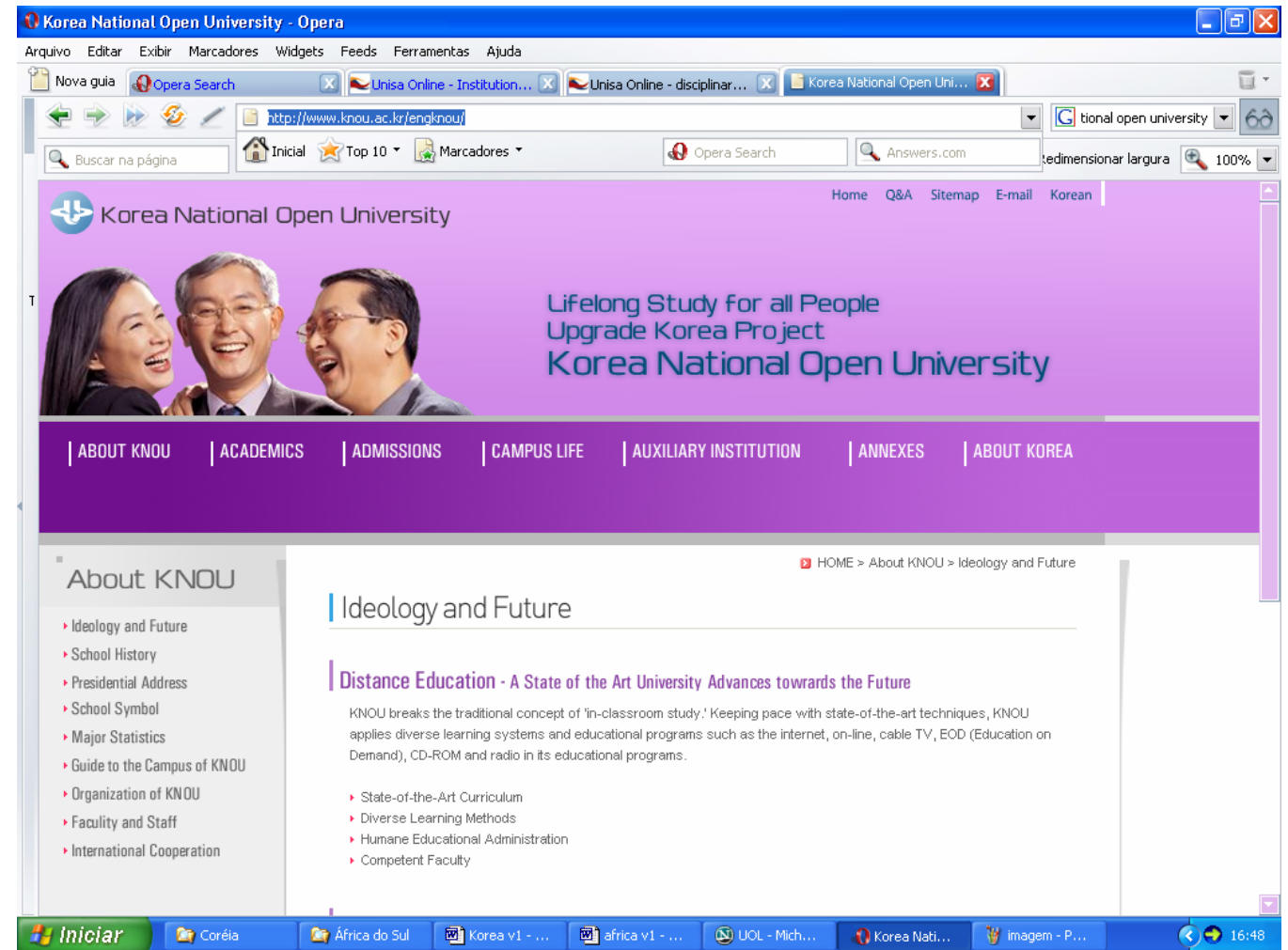

Figura 40: Versão em língua inglesa do Portal da Korea National Open University. Fonte: Korea National Open University. Disponível em: $<$ http://www.knou.ac.kr/engknou/>. Acesso em: 2 nov. 2006. 


\section{Objetivos}

O objetivo principal da Korea National Open University é expandir as oportunidades de educação superior voltadas aos cidadãos coreanos de modo a oferecer a todos a capacidade de receber educação ao longo da vida, a qualquer hora e em qualquer lugar. $\mathrm{Na}$ verdade, a KNOU (Korea National Open University) procura, de certa forma, romper com o conceito tradicional do estudo em sala de aula, principalmente ao incorporar técnicas avançadas em termos de materiais pedagógicos e de tecnologias educacionais.

A Universidade Nacional Aberta da Coréia tem como objetivo prover educação nacional, contribuindo para ajudar a resolver as diferenças e desigualdades entre a Coréia do Sul e a Coréia do Norte, que favoreça com o passar do tempo a reunificação dos dois países.

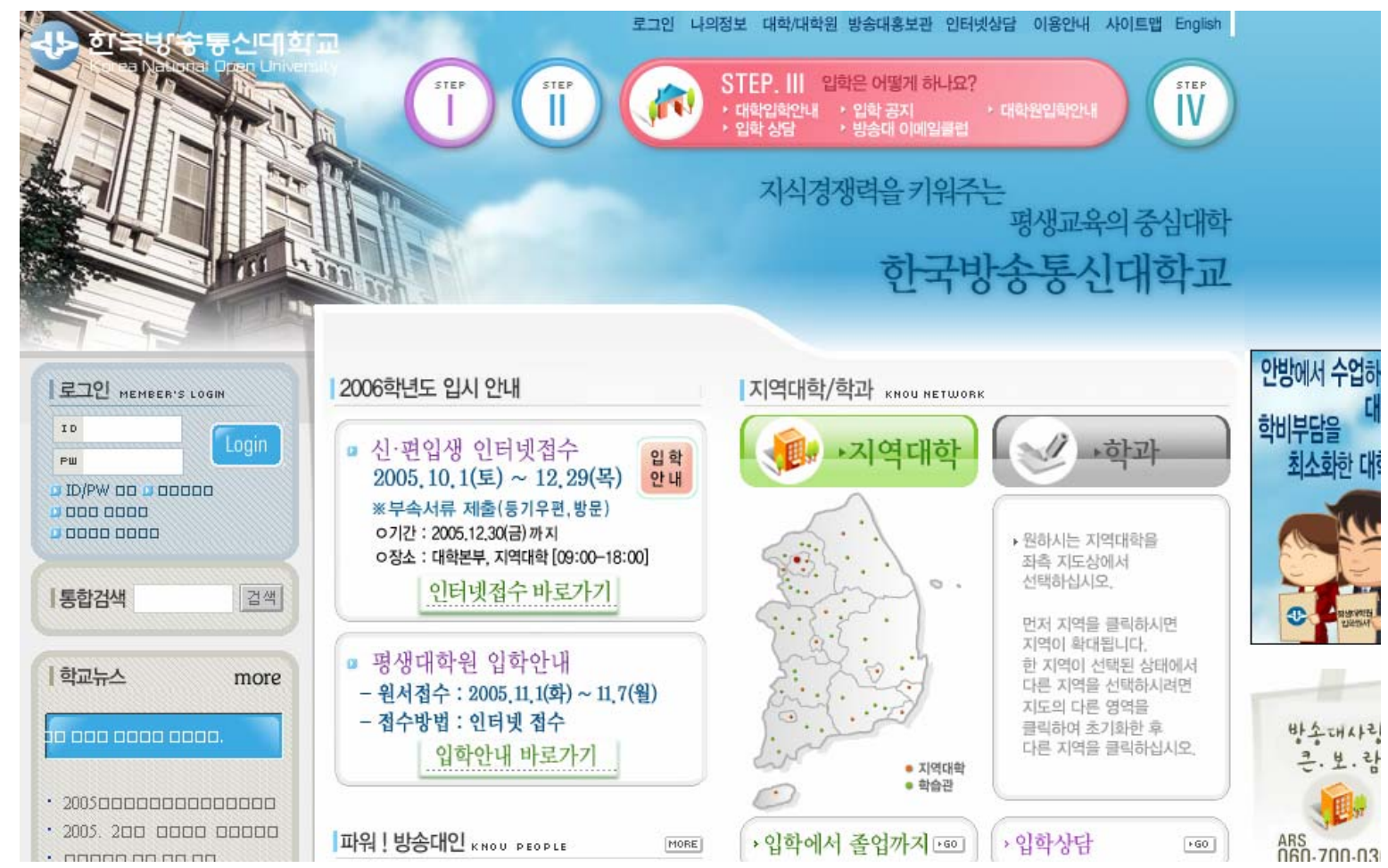

Figura 41: Portal da Korea National Open University, na língua coreana. Fonte: Korea National Open University. Disponível em: $<$ http://www.knou.ac.kr/>. Acesso em: 25 jan. 2005.

\section{Público-alvo}

Embora atualmente a Korea National Open University tenha mais de $180 \mathrm{mil}$ estudantes por semestre, sabemos por pesquisas de Jung (2005) que a universidade 
chegou a ter mais de 350 mil alunos no ano 2000. Dados mais atuais, segundo documentos da própria universidade e checados com a pesquisa de Jung (2005), mostram que são, na realidade, hoje, aproximadamente 184 mil alunos.

O histórico do número de alunos inscritos por ano, de 1981 a 1998, mostra um forte crescimento, passando de 36 mil alunos a mais de 184 mil, em 17 anos, ou seja um crescimento de $475 \%$, com uma média anual de $10,84 \%$, como pode ser observado no gráfico abaixo:

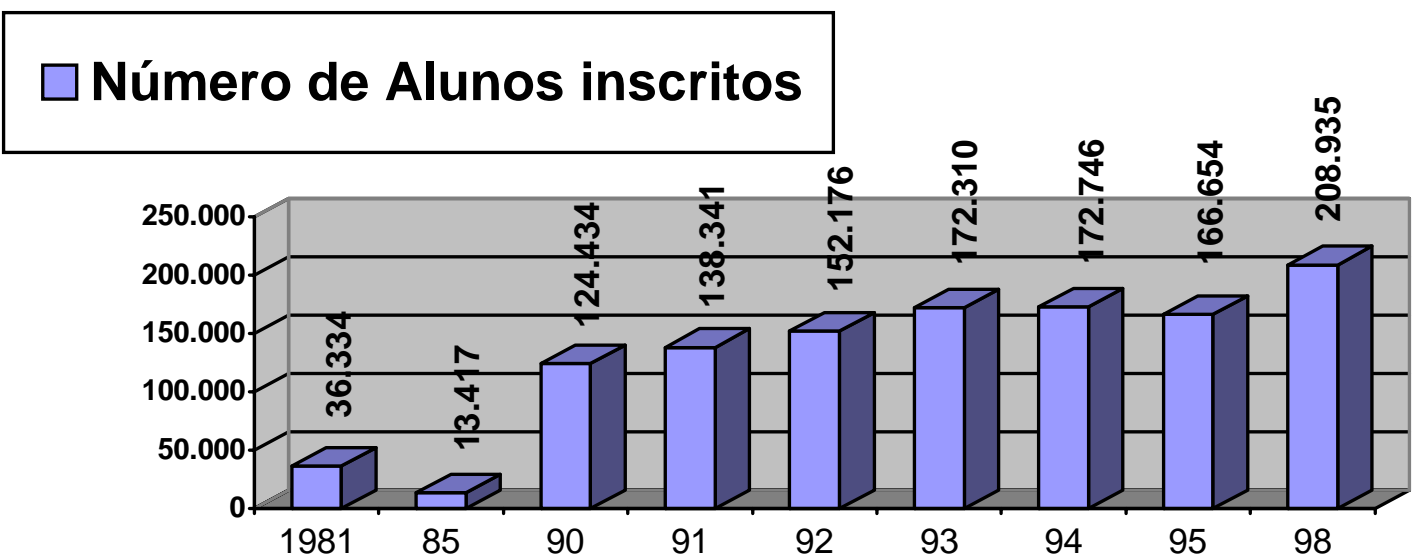

Gráfico 23: Número de alunos inscritos por ano na Universidade da Corea Fonte: alternative approaches to financing lifelong learning country report. Korea. 1998. Disponível em: www.oecd.org/dataoecd/24/14/2670761.pdf.

Segundo Young-Ja Youn e Hyo-Soon You (2005) ${ }^{197}$, a partir do ano 2000, a universidade teve um forte processo de decrescimento na matricula anual. E uma evasão do primeiro para o segundo semestre de $40 \%$.

Grosso modo, de um número de 1.973 alunos graduados em 1994, a universidade passou a ter 4.325 no ano de 2001, refletindo, assim, um percentual de $119 \%$ em 7 anos, uma vez que a taxa de crescimento médio anual foi de 11,86\%. No entanto, verifica-se que o número de alunos em 1999 (3.130 alunos) teve uma queda de $-13 \%$, se comparado ao ano de 1998 (3.615 alunos). E uma queda ainda maior a partir do ano 2001, período no qual, segundo dados da própria universidade, os graduados anuais

\footnotetext{
${ }^{197}$ Young-Ja Youn and Hyo-Soon You. Korea National University. How can help students to complete their study in open university: A case of study of korea national open university. ICDE INternational Conference. 2005. Disponível em: www.ignou.ac.in/icde2005/PDFs/theme3pdf/theme3 245.pdf.
} 
caíram a 250 alunos, o que reflete uma queda de 58\% anual, evidenciando uma profunda queda da inscrição anual e do número de alunos da faculdade.

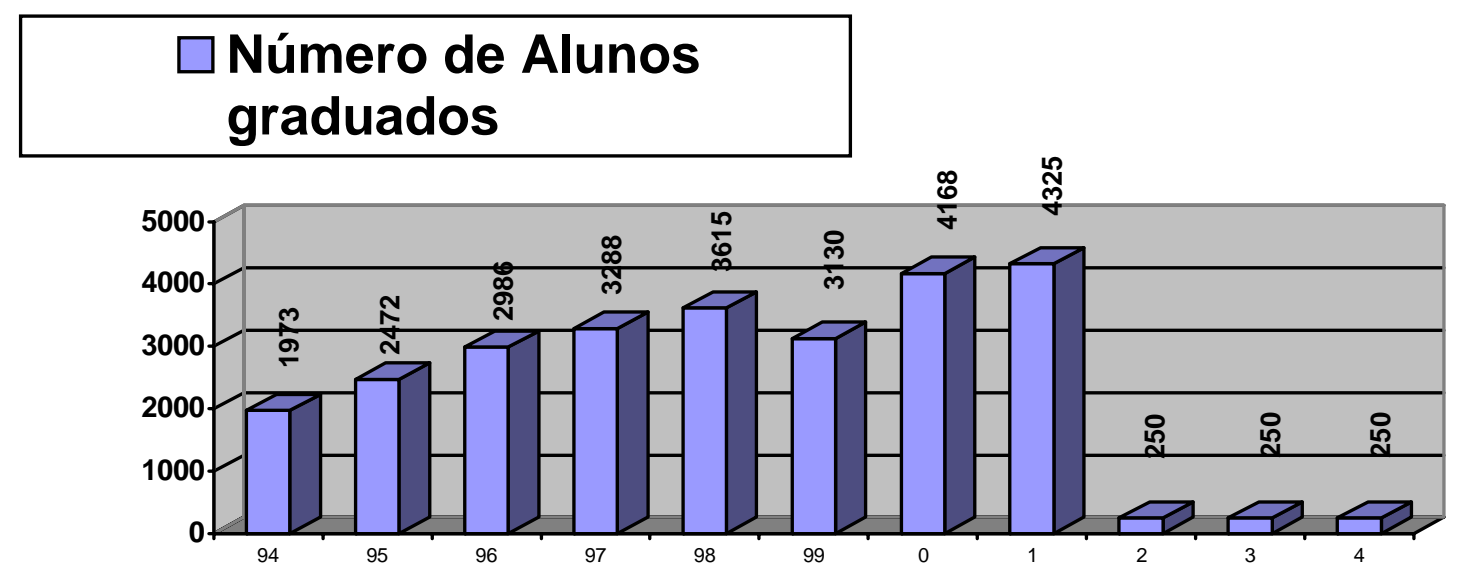

Gráfico 24: Número de estudantes de graduação da KNOU. Disponível em:

<http://www.knou.ac.kr/engknou/about/HEStatistics.html>. Acesso em: 3 nov. 2006.

Pode-se também fazer uma análise do perfil dos alunos graduados nesta universidade a partir da identificação de suas ocupações. Verifica-se, pela tabela a seguir, que um número significativo dos estudantes é formado por trabalhadores provenientes de diversas áreas:

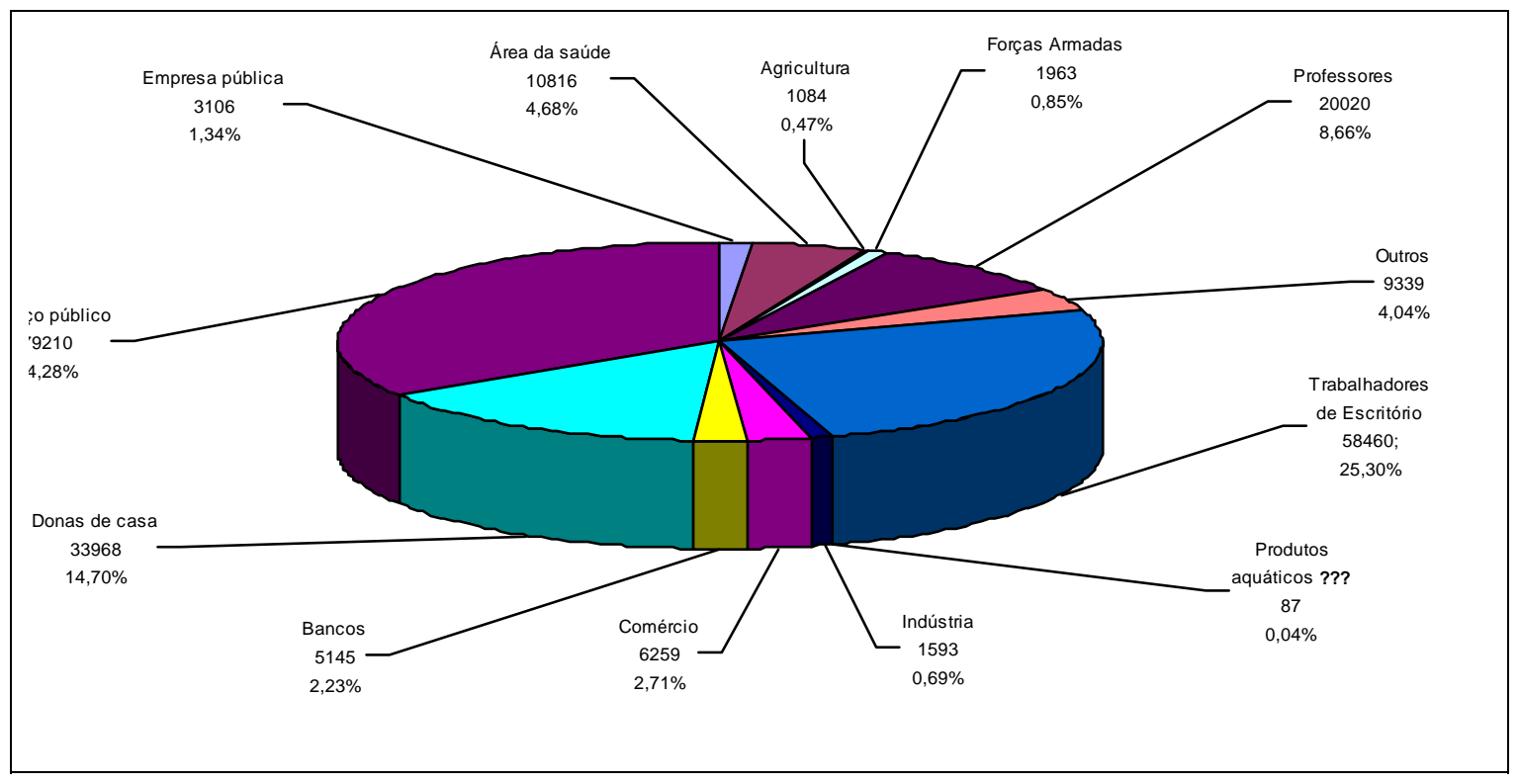

Gráfico 25: Distribuição dos graduandos da KNOU por ocupação. Disponível em <http://www.knou.ac.kr/engknou/about/HEStatistics.html>. Acesso em: 3 nov. 2006. 
A maioria dos estudantes possui mais de 30 anos, sendo $62,71 \%$ deles mulheres, como mostram as tabelas a seguir:

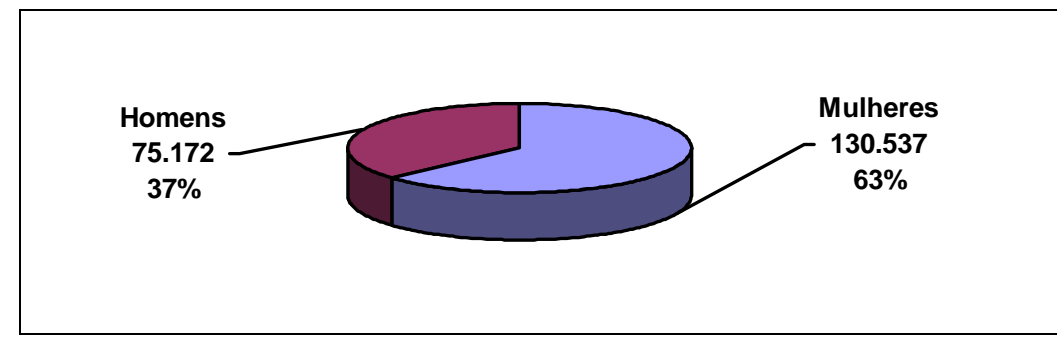

Gráfico 26: Distribuição dos alunos da KNOU por sexo

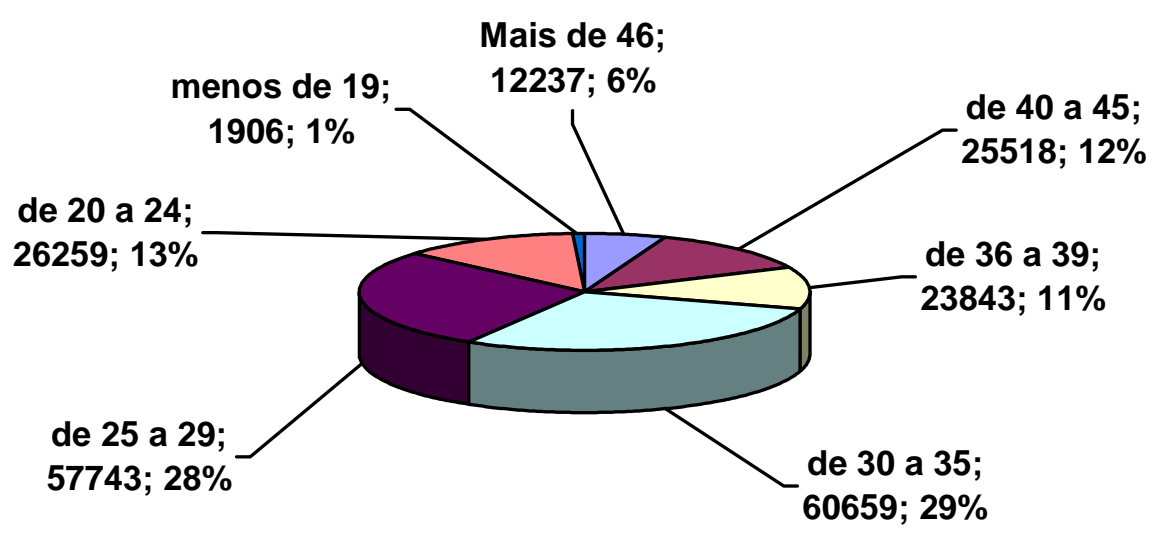

Gráfico 27: Distribuição dos alunos da KNOU por gênero. Disponível em <http://www.knou.ac.kr/engknou/about/HEStatistics.html>. Acesso em: 3 nov. 2006.

\section{Cursos oferecidos}

A universidade possui diversas escolas que oferecem graduações e cursos de curta duração em artes e graduações e cursos curtos nas áreas de línguas e literaturas inglesa, chinesa, francesa e japonesa; escola de ciência social, com cursos em leis, administração pública, economia, administração, comércio internacional, turismo e meios de comunicação; escola de ciências naturais, com cursos nas áreas de agricultura, economia doméstica, saúde ambiental e enfermagem, além da escola de educação, com cursos nas áreas de educação, educação infantil e cultura, entre outros. 


\section{Materiais de estudos e estratégia instrucional}

A KNOU oferece cursos em diversas áreas de conhecimentos, empregando para isso os mais diferentes tipos de mídias: programas de rádio e televisão aberta, TV a cabo, áudio e videocassete, videoconferência, CD-ROM, internet, acesso a outras redes de computadores e ensino presencial.

As aulas transmitidas por canais de rádio e televisão são gravadas e disponibilizadas em fitas de vídeo por meio de bibliotecas, podendo os alunos solicitar uma cópia delas para serem entregues em seu domicílio.

Além da educação a distância, a universidade ministra aulas presenciais, que são solicitadas a cada unidade de três matérias ministradas por semestre, perfazendo oito horas-aula, incluindo trabalhos em sala de aula. Elas são realizadas nos centros de estudos regionais durante toda a semana, de dia e à noite, e também durante os finais de semana. Os estudantes que não podem comparecer a estas aulas presenciais devem realizar aulas substitutivas ou ainda passar diretamente por exames finais.

O sistema de videoconferência conecta a matriz de KNOU a 13 centros de estudos regionais, atendidos por intermédio de redes ultravelozes. Este tipo de sistema propicia um ambiente educacional como no estilo das aulas presenciais (face a face), nas quais o aluno pode participar ativamente, assistindo a aulas expositivas, recebendo orientações, etc.

A cada semestre, duas ou três matérias de cada departamento são agendadas para serem estudadas por meio de fita cassete. E, no mínimo uma vez por semestre, são realizadas aulas expositivas especiais, muitas vezes transmitidas por videoconferências.

Os alunos também são providos de materiais impressos, como livros didáticos, especialmente os desenvolvidos para educação a distância, apostilas e jornais escolares, que são distribuídos uma vez por mês e servem para introduzir um assunto novo ou complementar a respeito de uma determinada matéria do curso.

Os tutores acompanham o desempenho de cada estudante motivando-o constantemente a estudar, auxiliando-o no desenvolvimento de teses e na preparação para os exames do curso. 
Os métodos de ensino e aprendizagem empregados são basicamente os seguintes:

Aulas expositivas veiculadas por radiodifusão (TV e rádio): Sistema da Rede de Televisão da Universidade Aberta da Coréia (OUN TV - Open University Network Television); Sistema de Radiodifusão Educacional (EBS - Educational Broadcasting System); Aulas expositivas levadas ao ar e que estejam gravadas em áudio ou vídeo, mantidas pela biblioteca da KNOU e pelos centros regionais de estudos, para todos os interessados, sendo que estudantes da instituição podem requerer uma cópia para entrega em casa.

Sistema de Biblioteca Digital: Materiais de áudio e vídeo, cobrindo um total de 580 assuntos, provenientes de aulas expositivas, ora apresentadas na televisão da Universidade Aberta da Coréia, ora transmitidas pelo sistema radiofônico educativo, ora gravadas de eventos importantes. Aulas expositivas disponíveis via on-line pela internet (desde 1998), para que os alunos possam baixar os conteúdos das aulas expositivas desejadas. Com o crescimento dos usuários da internet, bem como com o aumento da velocidade de transmissão das redes, a KNOU começa a preparar o processo de radiodifusão via internet para prover serviços educacionais aprimorados. Deste modo, o Sistema de Bibliotecas Digitais para aulas expositivas pretende veicular conteúdos do melhor modo possível para permitir aprendizagem em qualquer lugar a qualquer momento.

Aulas expositivas presenciais: Além de educação a distância, a KNOU oferece formação educacional presencial (ou face a face). Oito horas de aulas expositivas e trabalhos em sala de aula por semestre são requeridos para cada uma entre três disciplinas. As horas dedicadas à sala de aula ocorrem em centros regionais de estudos, disponíveis dia e noite, durante o fim do dia e nos fins de semana. Alunos que não conseguem freqüentar as sessões regulares em sala de aula podem realizar um trabalho substituto para compensar suas ausências, de modo que estejam habilitados a prestar os exames necessários.

Apostilas: Para matérias provenientes de aulas não expositivas. Neste caso, os professores preparam e distribuem suas apostilas próprias com vistas a ajudar os alunos a estudar sozinhos. Os autores de conteúdo são principalmente professores que trabalham em tempo integral na KNOU, e que são responsáveis pela radiodifusão de 
aulas expositivas. As apostilas são distribuídas por meio de livrarias que fornecem os livros-textos da KNOU.

Aulas expositivas em formato áudio-gráfico: A cada semestre, duas ou três matérias de cada departamento são programadas para estudos e gravadas em fita cassete.

Aulas expositivas veiculadas pelo Jornal Universitário: Para matérias que necessitam de aulas expositivas complementares, existe um calendário suplementar e flexível, disponível antes ou depois dos cursos regulares, destinado a introduzir novas matérias em estilo rápido. Cada departamento recebe a aula expositiva do jornal escolar uma vez por mês, oito vezes ao ano. A Faculdade de Educação Geral recebe, particularmente, a aula expositiva duas vezes por mês, 16 vezes ao ano, para ajudar os estudantes que estejam obtendo créditos na área de Educação Geral.

Cursos via internet e Comunicação por Computador: A KNOU oferece ainda cursos exclusivamente criados no ambiente internet e em formato de CD-ROM. Neste sistema a universidade possui 3 tipos diferentes de conteúdos:

- 1) Modelo multimídia - Centrado no professor, consiste na transmissão de uma aula, através de vídeo e áudio. É muito utilizado como suporte ao estudo de cada aluno, ou para nivelação de conhecimentos em um tema, como pode se observar na figura ${ }^{198}$.

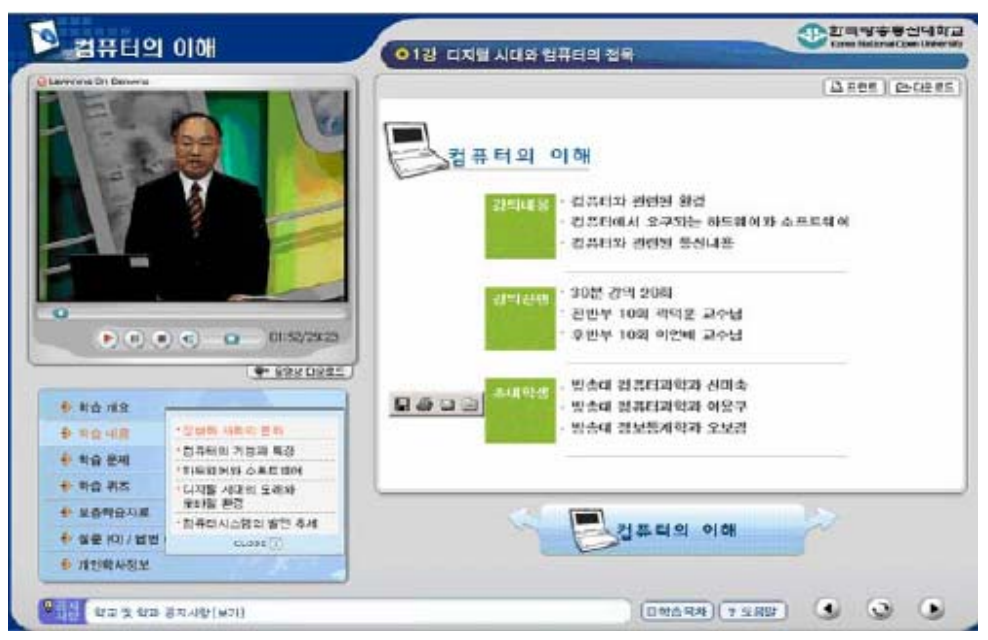

Figura 42: Modelo multimídia da KNOU

\footnotetext{
${ }^{198}$ Kwak, Duk Hoon. Current Status and Development Strategy of e-Learning Focusing on KNOU. Korea National Open University. 2005. Disponível em: thaicyberu.go.th/officialtcu/.../register/paper_bangkok_2006_07_27.pdf
} 
- 2) Modelo Tutorial - Apresenta um ambiente virtual através do qual o aluno encontra objetivos, conteúdos, seminários, etc., como pode ser observado na figura.

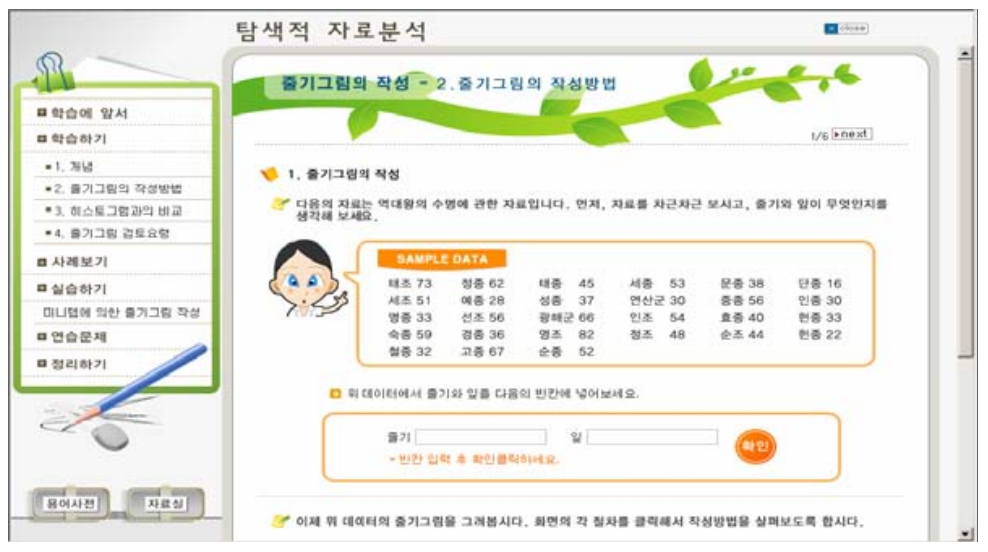

Figura 43: Modelo tutorial da KNOU

- 3) Modelo de Pesquisa e Trabalho Prático - Os alunos resolvem casos, realizam experiências, fazem pesquisas, etc. , como se pode observar na figura.

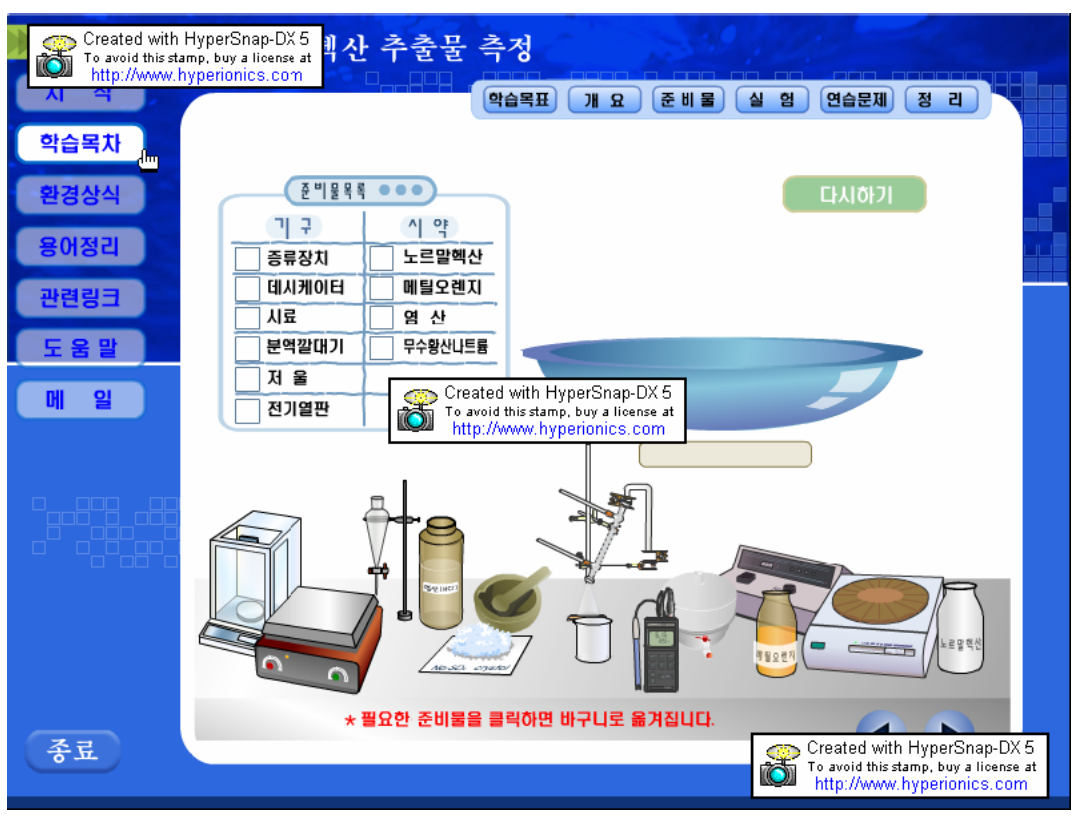

Figura 44: Modelo de Trabalho Prático da KNOU

Sistema de Tutoria: A função do tutor na KNOU é encorajar cada aluno a desenvolver seus estudos a partir de um processo de aprendizagem autodirigida. Para tanto, a instituição mantém serviços de educação continuada, contando com um grupo de consultoria e assessoria para escrever teses, de modo a preparar alunos para os exames da Universidade. Os tutores são profissionais qualificados que atendem a cada centro 
regional de estudos. Normalmente, o sistema de tutoria está disponível nos 11 centros de estudos regionais, exceto Seul, e destinados inicialmente a atender matérias relacionadas a tópicos de Educação Geral. No entanto, este sistema se expande a cada ano, em função da demanda crescente de estudantes interessados em realizar seus estudos pelo método da educação aberta e a distância na Coréia.

Livros-textos: O Departamento Editorial da KNOU produz diretamente os textos empregados para as aulas expositivas da instituição. A elaboração do material instrucional é realizada também por profissionais externos à Universidade. Todos os textos elaborados se destinam ao auto-estudo.

Aulas Expositivas Especiais: A cada semestre, pelo menos, especialistas altamente renomados em várias áreas do conhecimento são convidados a dar aulas expositivas especiais, relacionadas a tópicos de Educação Geral e a disciplinas básicas. Algumas destas aulas expositivas costumam ser transmitidas via sistema de videoconferência.

\section{Centros de Estudos}

Os Campos Regionais da KNOU foram criados objetivando prover formas de educação aberta para estudantes, independentemente das áreas em que eles possam residir. Tais Centros compreendem 13 cidades e províncias, incluindo a cidade de Seul. No caso de estudantes residentes em locais mais distantes dos campos previamente definidos, 34 centros de estudos estão opcionalmente abertos para atender cidades grandes e do interior do país.

Cada Campus Regional é provido de condições adequadas ao ambiente educacional, equipado com salas de vídeo a distância, salas de computadores e biblioteca multimídia.

Existem tutores espalhados por todos os Campos Regionais da Universidade, os quais podem ser constantemente consultados pelos alunos quando têm dúvidas a respeito de procedimentos pedagógicos, realização de exames, etc. Os Centros em que não há aulas expositivas relacionadas aos conteúdos de aulas, podem ser utilizados como espaço para estudos em grupo ou ainda como centro comunitário para alunos residentes. 


\subsubsection{Irã}

\section{a) Payame Noor University (PNU)}

\section{Endereço}

Payame Noor University

POB 19395-4697

Tehran

Iran

Telephone: +982122442060-69

Fax: +98212244 1511

E-mail: int@pnu.ac.ir

\section{Contexto histórico}

Fundada em 1987, a Payame Noor University define-se como uma universidade estatal e está sob a coordenação do Ministério da Ciência, Pesquisa e Tecnologia do Irã. Por sua natureza e escala operacional, a PNU é, sem dúvida, a instituição educacional iraniana de ensino superior mais flexível, oferecendo a melhor relação custo-benefício em termos de educação superior no país. É também considerada a maior universidade estatal iraniana em termos do número de estudantes regularmente matriculados e da cobertura dada a toda a extensão do território iraniano.

\section{Objetivos}

Seu objetivo principal é democratizar as possibilidades de acesso à educação, visando atender às necessidades vitais para o desenvolvimento do Irã, contribuindo significativamente na resolução dos problemas sociais do país.

A princípio, a PNU foi criada de modo a atender aos seguintes objetivos básicos: cooperação com outras instituições no sentido de popularizar o ensino superior para promover os níveis científicos e culturais da sociedade iraniana; diminuição das restrições de acesso ao ensino superior, possibilitando novas formas de se realizar a educação continuada no país; fornecimento da base educacional para o desenvolvimento 
de potenciais humanos que tenham sido ignorados durante os sistemas de educação convencional; qualificação de mão-de-obra especializada para atender às necessidades de desenvolvimento da sociedade iraniana; cooperação com outras instituições no sentido de popularizar o ensino superior para promover os níveis científicos e culturais da sociedade iraniana; qualificação de mão-de-obra especializada para atender às necessidades de desenvolvimento da sociedade iraniana; facilitação na expansão das fronteiras do conhecimento e na criação de conhecimento científico; colaboração na solução de questões sociais.

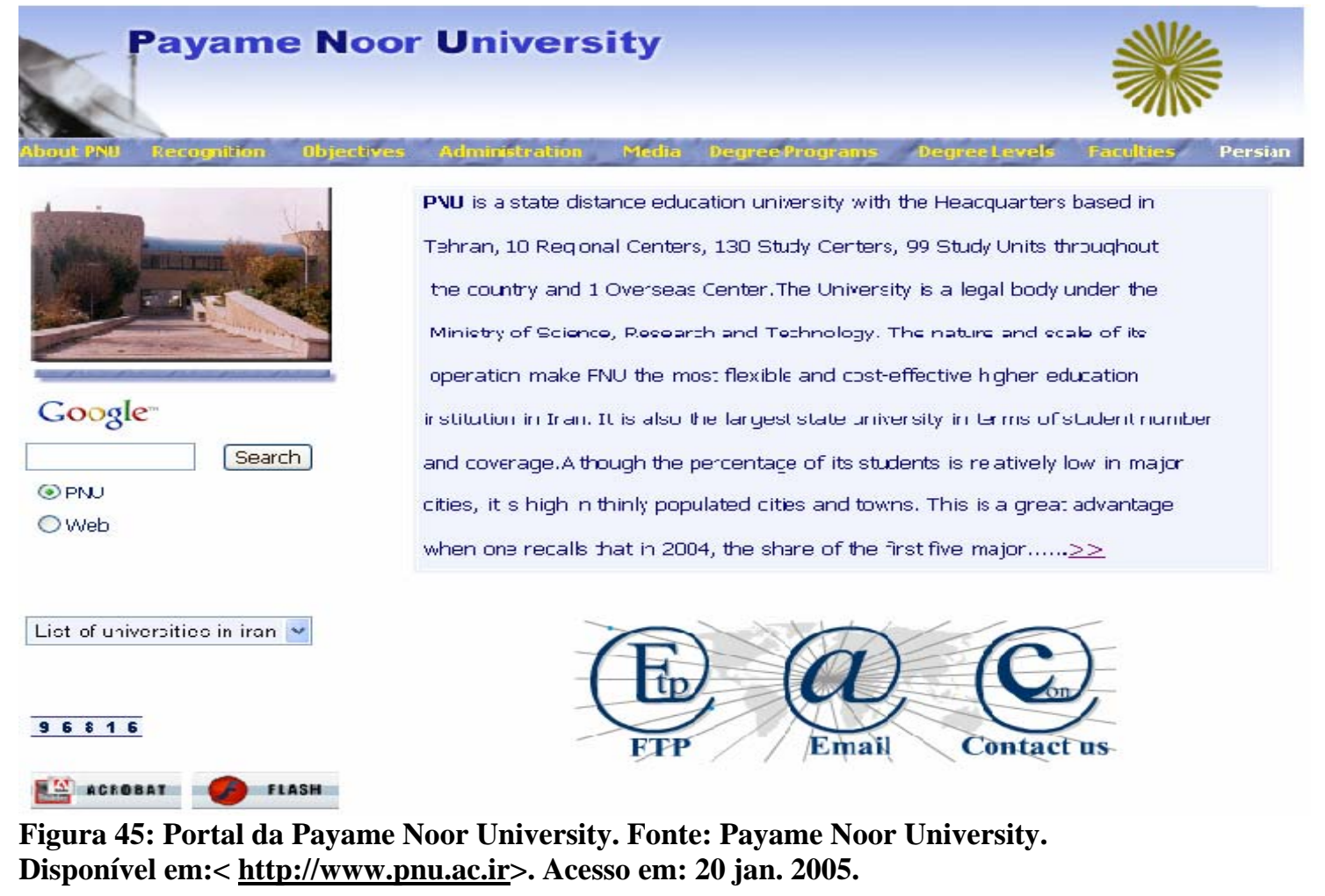

\section{Público-alvo}

Dos 4 programas de graduação e 8 mil alunos iniciais de 1988, a PNU passou a ter, em 2006, 74 programas de graduação e 467.000 alunos matriculados em 257 centros e unidades de estudos, apresentando um impressionante crescimento de 5737\% em 16 anos de vida, com uma taxa média de crescimento anual de $28,94 \%$.

Embora a porcentagem de estudantes seja relativamente baixa no que diz respeito às cidades principais, ela é consideravelmente bem mais alta em cidades e centros menos populosos. Essa é uma vantagem, se lembrarmos que, em 2004, o grupo das cinco 
províncias principais (Tehran, Esfahan, Khorasan, Mazandaran e Fars) possuía um total de $49 \%$ de matrículas, enquanto as outras 23 províncias, por outro lado, possuíam um total de $51 \%$. $^{199}$

A PNU conta também com um alto nível de profissionais qualificados, oriundos de diversas instituições acadêmicas, os quais respondem pelas concessões dadas a seus alunos em termos de incentivos a seus estudos. Por exemplo, se um aluno graduado estiver desempregado, fornece-se a ele um novo emprego no local de origem do seu trabalho, de modo tanto a atender às suas necessidades advindas da nova especialidade recém-adquirida, como de modo a atender às próprias necessidades da sua unidade de estudo de origem. Deste modo, alunos desempregados poderão encontrar um emprego adequado de acordo com suas qualificações acadêmicas. Normalmente, um número considerável de alunos formados acaba por tornar-se professores de escolas secundárias. E quando recebem um novo emprego, são também tratados e pagos de forma semelhante a outros funcionários que trabalham nas universidades convencionais.

\section{Cursos oferecidos}

A universidade oferece aproximadamente 70 cursos de graduação e de pós-graduação, tanto de mestrado como de doutorado.

Graduação - Bacharelado: Contabilidade; Engenharia Agrícola - Economia Agrícola, Maquinaria Agrícola e Mecanização, Ciências da Agricultura, Criação de Animais, Administração para o Desenvolvimento Rural, Ciências Naturais e Meio Ambiente, Água e Solo. Língua e Literatura Árabe; Engenharia da Arquitetura; Biologia - Biologia Geral e Botânica; Administração de Empresas; Química - Química Aplicada e Química Pura; Engenharia da Computação - Desenvolvimento de Software, Tecnologia da Informação. Ciência da Computação; Educação - Administração e Planejamento Curricular para Pré-escola e Educação Escolar; Tradução em Língua Inglesa; Língua e Literatura Inglesa; Engenharia da Arquitetura; Biologia - Biologia Geral e Botânica; Administração de Empresas; Química - Química Aplicada e Química Pura; Engenharia da Computação - Desenvolvimento de Software, Tecnologia da Informação. Ciência da Computação; Educação - Administração e Planejamento Curricular para Pré-escola e

\footnotetext{
${ }^{199}$ Payame Noor University. Disponível em: $<$ http://www.pnu.ac.ir $>$. Acesso em: 20 jan. 2005.
} 
Educação Escolar; Tradução em Língua Inglesa; Língua e Literatura Inglesa; Psicologia Geral; Geologia - Geologia Aplicada e Geologia Pura; Artesanato; Saúde - Saúde Ambiental, Saúde Profissional e Saúde Pública. História; Geografia Humana Geografia Urbana e Geografia Rural. Engenharia Industrial; Direito; Biblioteconomia; Matemática - Matemática Aplicada e Matemática Pura; Geografia Natural Geomorfologia e Ecologia; Língua e Literatura Persa; Educação Física e Ciências dos Esportes; Física - Física Sólida, Física Nuclear, Física Atômica e Física Molecular; Ciências da Política; Administração Pública; Ciências Sociais - Assistência Social e Cooperação, Pesquisa em Ciências Sociais; Estatística; Teologia e Estudos Islâmicos Jurisprudência e Bases do Direito Islâmico; Tradição e Ciências do Alcorão; Filosofia e Retórica; Tradição e Ciências do Alcorão; Filosofia e Retórica; Economia Teórica.

Pós-Graduação - Mestrado; Biologia, Bioquímica, Botânica e Zoologia. Química Química Analítica, Química Pura, Química Orgânica e Físico-Química. Engenharia da Computação - Desenvolvimento de Software.Economia; Educação - Planejamento Curricular, História e Filosofia da Educação. Ética; Lingüística Geral; Psicologia Geral; Geografia - Geografia Urbana e Planejamento Rural; Geologia - Geologia Econômica, Estratigrafia e Paleontologia; Direito - Criminologia, Direito Penal, Direito Internacional, Direito Privado; Matemática - Álgebra, Matemática Aplicada e Matemática Pura; Estudos Religiosos - Fundamentos da Religião Islâmica; Língua e Literatura Persa; Educação Física e Ciências dos Esportes; Física - Física Sólida e Física Nuclear; Administração Pública; Ciências Sociais - Sociologia; Estatística; Ensino de Língua Inglesa; Ensino de Língua Persa; Teologia e Estudos Islâmicos Jurisprudência e as Bases das Leis Islâmicas; Tradição e Ciência do Alcorão; História do Xiismo; Filosofia e Retórica.

Pós-Graduação - Doutorado: Planejamento de Educação a Distância; Biologia Botânica; Geografia Humana; Direito Internacional; Lingüística; Língua e Literatura Persa; Educação Física e Ciências do Esporte; Psicologia. 


\section{Sistema de estudos}

O período de estudo destinado aos alunos compreende até 20 semestres, dependendo do progresso e andamento do estudo realizado. Normalmente, cada ano acadêmico no Irã inclui dois semestres, nos períodos do outono e primavera, o que compreende um total de 18 semanas: 16 a 17 semanas de ensino e uma ou duas para o período de exames. Quanto ao sistema de crédito, é empregado com base em um crédito para cada 18 horas de ensino e exames por semestre. Esse sistema se destina a todos os tipos de programas de estudos, sendo que um total de 132 a 141 créditos é requisitado durante um curso em nível de bacharelado.

A universidade possui dois tipos de programas: os Programas Regulares de Graduação - oferecidos para aqueles que são aprovados no exame de admissão realizado anualmente pela Organização Nacional de Avaliação Educacional - e os Programas de Graduação Adaptáveis - considerados os programas mais flexíveis já oferecidos por uma universidade iraniana.

Os interessados em cursos de bacharelado precisam ter pelo menos concluído o ensino médio, além de obter uma pontuação de nota, no exame escrito, aceitável para o ingresso na Universidade. Esta nota de corte é definida pela PNU anualmente. Contudo, uma relevante mudança no processo de ingresso universitário é que os candidatos não precisam mais atender rigidamente às regras definidas pelo Exame Nacional de Admissão Universitária. Esta política de admissão é a primeira mudança ocorrida na história do ensino superior iraniano: a partir dela, os estudantes admitidos poderão estudar sem obrigatoriedade do exame durante um primeiro semestre de curso. O exame será realizado no final do primeiro semestre e, caso obtenham êxito, tirando a nota mínima desejada, poderão vir a continuar seus estudos normalmente. Por outro lado, se não forem aprovados no exame final, serão obrigados a interromper seus estudos.

Cada estudante poderá fazer de 5 a 20 créditos durante cada semestre, ao final do qual um exame supervisionado será devidamente aplicado. O mínimo de pontos a ser obtido é 10 (50\% do total). Contudo, a média de todos os pontos em cada semestre não deverá ser menos do que 12 (60\% do total), sendo que o período máximo para se completar este programa é de 10 anos, devendo os alunos pagar por todos os serviços institucionais que receberem. 


\section{Materiais de estudo e estratégia instrucional}

Diversos tipos de mídias e metodologias são utilizados na PNU, como parte integral durante o seu processo de instrução. A mídia instrucional inclui desde apostilas desenvolvidas para auto-estudo até programas de TV, fitas e videocassetes, slides, filmes, CD-ROMs, além de encontros tutoriais individuais, ou ainda em grupo, realizados nos finais de semana. Por último são empregados programas de TV educacionais, transmitidos pelo canal 7 da rede de televisão iraniana.

\section{Avaliação Educacional}

Todos os alunos da Payame Noor University são avaliados por meio de um exame escrito final, que se realiza na maior parte das vezes na organização central da Universidade, ao final de cada semestre. As questões do exame são baseadas nos planos de ensino que foram aprovados pelo Alto Conselho de Planejamento da Universidade. Devido a este processo de avaliação, a qualidade da educação a distância tem se mantido e, como resultado, as notas recebidas pela Universidade são aceitas pelo Ministério da Cultura e Ensino Superior do Irã sem questionamentos.

\section{Centros de Estudos}

Para atender aos seus objetivos, logo no seu primeiro ano de existência, a PNU implementou 40 centros de estudos ao longo do país, com $25 \%$ deles tendo como base várias províncias iranianas.

Atualmente, a Payame Noor University possui 256 centros de estudos e unidades espalhadas por todas as regiões do continente iraniano, sendo que $10 \%$ deles estão presentes apenas em megacidades. Por isso, 90\% dos centros de estudos e unidades baseiam-se em pequenas cidades ou vilarejos.

A dispersão dos centros de estudos da PNU ao longo da península iraniana tem permitido aos trabalhadores e classes com baixa renda da sociedade se beneficiarem com o acesso ao ensino superior, que é um direito legal de todo cidadão iraniano. 
Enquanto mais de $80 \%$ das universidades convencionais iranianas, entre elas a Universidade de Tehran, a Isfehan, a Tabriz e a Mashhad, estão em megacidades, 90\% dos centros de estudos da PNU se localizam em pequenas cidades e vilarejos. Esta comparação demonstra que, com a criação da Payame Noor University, a distribuição da população de estudantes mudou significativamente no Irã desde então, pois mais de $50 \%$ dos candidatos que passaram no exame de admissão da Instituição se matricularam nos centros de estudos da PNU nos períodos letivos de 2005 a 2006.

\subsubsection{Tailândia}

\section{a) Sukhothai Thammathirat Open University (STOU)}

\section{Endereço}

Bangpood - Pakkret - Nonthaburi 11120

Tel.: 6625047777 - Fax: 6625033607

E-Mail: stou@stou.ac.th

\section{Contexto histórico}

Fundada oficialmente em 5 de setembro de 1978, por um decreto real como universidade estatal, foi a $11^{\mathrm{a}}$ universidade estatal do país e a primeira universidade aberta do sudeste asiático.

Durante o período de 1979 a 1983, a Universidade não possuía ainda sua sede própria, compartilhava seu espaço físico com outras instituições públicas, como a Comissão Nacional de Educação, as Forças Aéreas da Tailândia, a Faculdade de Economia da Universidade de Chulalongkorn e o Ministério de Finanças do Ensino Superior. Em 1981, um benfeitor tailandês doou à Universidade uma faixa de área equivalente a $208.000 \mathrm{~m}^{2}$, localizada nas províncias de Tambon Bangpood, Amphur Pakkred e Nonthaburi. Como isso ainda não era suficiente para atender aos objetivos essenciais da Universidade, foi necessário adquirir outras áreas, até completar aproximadamente $216.000 \mathrm{~m}^{2}$. Por isso a construção da Universidade Aberta de Sukhothai Thammathirat se iniciou em 1982 e somente em março de 1983 é que seu espaço físico oficial foi enfim inaugurado. 


\section{Objetivos}

A STOU foi criada com o propósito de estender as oportunidades de ensino superior aos adultos, bem como contribuir para o desenvolvimento do país, preservando a cultura e a identidade da nação tailandesa. Nesse sentido, a princípio, a STOU identifica os seguintes objetivos básicos de sua missão institucional: oferecer programas educacionais e promover cursos acadêmicos e profissionais de alto nível para que os cidadãos tenham oportunidade de aprimorar seu nível de conhecimento de acordo com necessidades individuais e sociais; comprometer-se com a pesquisa visando o avanço do conhecimento para desenvolver a Tailândia; suprir serviços públicos a partir da disseminação de conhecimento de forma a aprimorar a qualidade de vida dos cidadãos em geral; preservar a cultura e promover o desenvolvimento de práticas atitudinais que possibilitem manter a identidade da nação tailandesa.

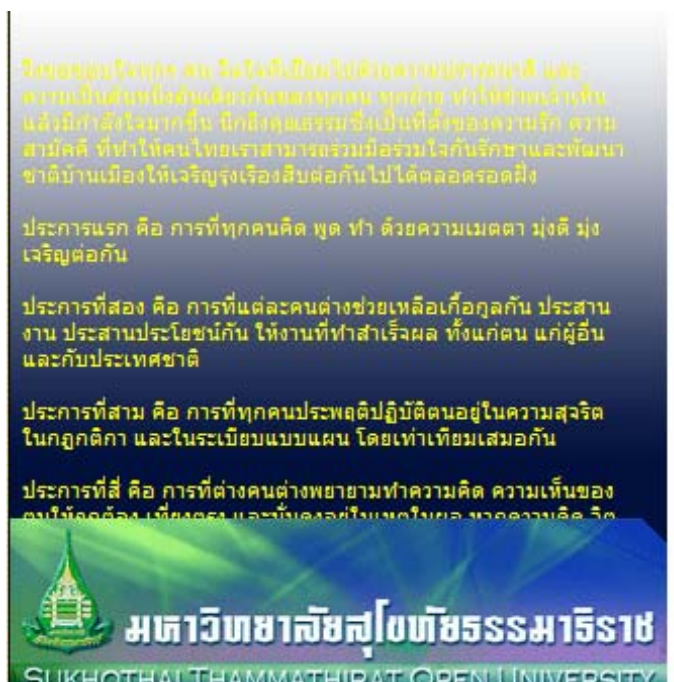

SUKHOTHAI THAMMATHIRATT OPEN UNIVERSITY
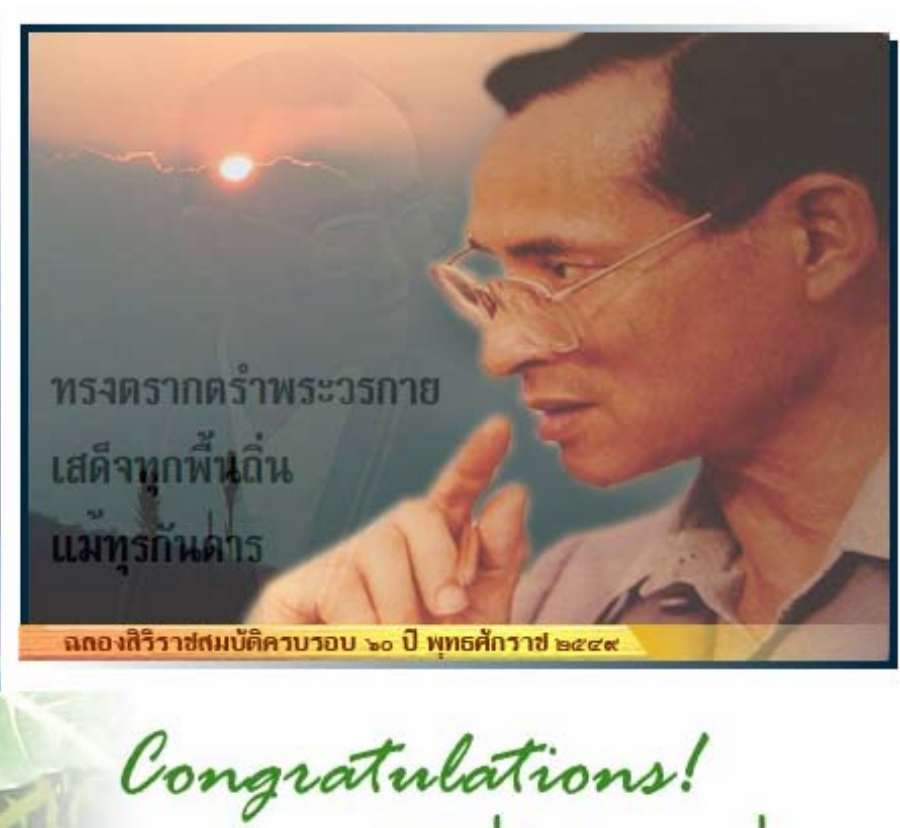
ขอแสดงความยินดีแกบัณฑิต มสธ. รุ่น 24
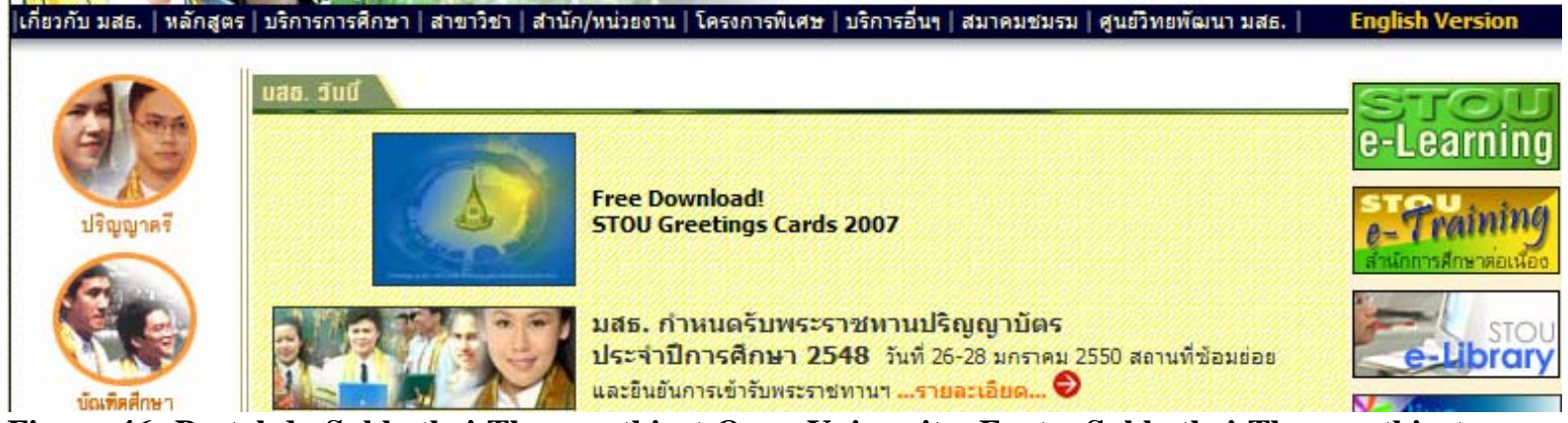

Figura 46: Portal da Sukhothai Thammathirat Open University. Fonte: Sukhothai Thammathirat

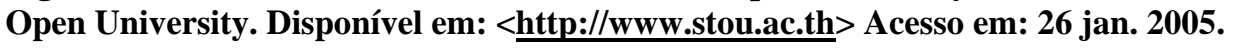




\section{Público-alvo}

Nos últimos 20 anos, a Universidade formou mais de 220.000 estudantes. Em 2004, segundo o Relatório Anual de 2005 da $\mathrm{STOU}^{200}$, foram realizadas aproximadamente 172.984 matrículas no primeiro semestre e 150.214 no segundo, o que significou um índice de $14 \%$ de evasão.

Em 2004, a universidade possuía uma matrícula anual de 61.883 alunos novos e 22.385 alunos graduados anualmente.

\section{Recursos humanos e materiais}

A universidade possui um corpo de 2.160 funcionários, dos quais 1.710 são financiados pelo governo e 750 pela universidade. A STOU oferece serviços de informações e notícias para seus estudantes sob diversas formas, incluindo programas de televisão e rádio e um boletim com as notícias da Universidade. A instituição também dissemina informações por intermédio do seu website oficial. Além disso, foi criado um Centro de Informações para responder a perguntas de estudantes ou do público em geral via telefone.

\section{Cursos oferecidos}

A STOU oferece cursos de graduação de 4, 3 e 2 anos, cursos de pós-graduação, mestrado e cursos de curta duração. Nos Programas em nível de bacharelado com duração de 4 anos, encontramos cursos de graduação em Ciência Geral da Informação e Serviços de Automação; Bacharel em Educação; Bacharel em Administração de Empresas; Bacharel em Administração Pública; Bacharel em Direito; Bacharel em Saúde Pública; Bacharel em Economia; Bacharel em Economia do Lar; Bacharel em Ciências Políticas; Bacharel em Agricultura; Bacharel em Extensão Agrícola e Cooperativas; Bacharel em Comunicações e Artes e Bacharel em Extensão Agrícola e Cooperativas.

\footnotetext{
${ }^{200}$ Annual Report. Sukhothai Thammathirat Open University. Ano 2005. Disponível no portal da universidade. http://www.stou.ac.th
} 
Nos Programas em nível de bacharelado com duração de 3 anos, há Direito; Administração Pública; Economia e Comunicações e Artes.

Já entre os programas de 2 anos de duração aparecem os cursos de bacharel em Artes; Educação; Administração de Empresas; Administração Pública; Saúde Pública; Economia do Lar; Agricultura; Extensão Agrícola e Cooperativas; Ciências e Ciências da Enfermagem.

Como programas de Mestrado, os cursos de: Educação; Administração de Empresas; Saúde Pública; Economia e Economia do Lar.

Além disso, a Universidade possui cursos de curta duração, como Inglês para Carreiras Específicas; Estudos Tailandeses; Serviços Informacionais; Educação Geral; Educação; Direito de Terras e de Propriedade; Saúde Ocupacional e Segurança; Comunicações e Artes.

\section{Sistema de Estudos}

A organização dos estudos na Universidade Aberta tailandesa compreende quatro níveis instrucionais: Nível de Graduação; Nível de Mestrado; Cursos de Curta Duração e Educação Continuada.

Os alunos recebem o diploma de bacharel somente após 4 anos de estudos. No caso de alunos que já possuem diplomas, certificados ou mesmo outro curso de bacharel, o curso pode ser completado em um período de 2 a 3 anos. A duração mínima é de 2 anos para cursos de mestrado, sendo que os alunos precisam ser bacharéis e possuir experiência profissional comprovada.

\section{Materiais para Estudos e Estratégia Instrucional}

A Universidade disponibiliza e envia materiais educacionais para cada estudante via correio. São utilizados diversos materiais multimídia, incluindo apostilas, agendas de trabalho e tutoriais, fitas cassetes, vídeos, programas de televisão e rádio, além de informativos e resultados de exames. As apostilas contêm as descrições dos cursos, os 
objetivos, bem como uma lista com os títulos das unidades a serem estudadas, além dos métodos de estudo e do planejamento de ensino para as diferentes unidades.

A Universidade aplica os exames em um ou mais lugares e em todas as províncias do país, facilitando o acesso de seus recursos aos alunos. Os exames são aplicados duas vezes por semestre, incluindo um exame regular e um exame final. Os resultados são enviados aos alunos por e-mail após 30-45 dias. Os alunos, se preferirem, podem acessar o site da universidade ou, ainda, ligar para o telefone de mensagem automática para obter o seu resultado.

Os meios instrucionais empregados se caracterizam por duas categorias básicas: meios principais e meios suplementares.

Os meios principais compreendem livros-textos contendo descrições dos cursos, objetivos do curso, lista de títulos das unidades de ensino, métodos de estudo e planos de ensino para as diferentes unidades de estudos, além de instruções de como eles devem ser utilizados, unidades de ensino, auto-avaliação antes e após os estudos, espaços para escrever informações importantes, exercícios e relatórios, em conjunto com testes para cada unidade.

Já os meios suplementares abrangem: programas de rádio e televisão, programas por satélite, métodos de aprendizagem com auxílio de computador, áudio e vídeo sob demanda, aprendizagem on-line, atividades de experiência profissional e tutoriais.

\section{Avaliação Educacional}

A STOU congrega basicamente duas modalidades de cursos: Graduação (bacharelado em diversas áreas do conhecimento) e Mestrado.

No caso dos cursos em nível de bacharelado, a Universidade dividiu o conteúdo das grades curriculares seguindo os seguintes critérios específicos:

1) Cursos Teóricos - pelo menos $80 \%$ do total de pontos são obtidos a partir da realização de exames escritos, com um máximo de $20 \%$ deles destinados à componente prática do exame.

2) Cursos Práticos - a avaliação educacional é feita por intermédio da capacidade 
argumentativa. Determina-se a proporção de pontos de acordo com a adequação a cada assunto relacionado.

Os cursos de bacharelado são avaliados a cada bloco de curso, sendo aplicados os seguintes critérios de notas:

\begin{tabular}{|l|l|}
\hline Nota & Significado \\
\hline H (acima de $76 \%)$ & Com honra ao mérito \\
\hline S (de 60 a 75\%) & Satisfatório \\
\hline $\mathbf{U}($ menos de $60 \%)$ & Não Satisfatório \\
\hline $\mathbf{I}$ & Incompleto \\
\hline
\end{tabular}

Tabela 16: Crotérios de Notas para os cursos de graduação da STOU

Já nos cursos de Mestrado são aplicados os seguintes critérios de notas avaliativas:

\begin{tabular}{|c|c|c|}
\hline Nota & Ponto por Crédito & Significado \\
\hline A & 4 & Excelente \\
\hline B+ & 3,5 & Muito Bom \\
\hline B & 3 & Bom \\
\hline C + & 2,5 & Quase Bom \\
\hline C & 2 & Regular \\
\hline D & 1 & Fraco \\
\hline F & 0 & Insuficiente \\
\hline
\end{tabular}

Tabela 17: Crotérios de Notas para os cursos de mestradoda STOU

\section{Centros de Estudos}

A Universidade fundou um Centro Regional de Educação a Distância em cada região do país, tanto para expandir serviços acadêmicos como para aumentar a efetividade do sistema de educação a distância. A intenção dos centros regionais de estudos é alcançar estudantes de todas as províncias, fornecendo serviços acadêmicos para o público em geral. Esses serviços incluem: bibliotecas, serviços de mídias educacionais, orientação para encontros entre professores e alunos, serviços de aconselhamentos acadêmicos e profissionais, entre outros. Tais centros utilizam unidades móveis para cobrir áreas de serviços num raio de $200 \mathrm{~km}$.

Em cooperação com várias instituições, agências centrais e regionais do governo, a Universidade desenvolveu vários tipos de centros de serviços educacionais, entre eles:

Centros Regionais de Educação a Distância; Centros de Estudos Provinciais; Centros de 
Estudos Especiais; Centros em Locais Remotos; Entrega de materiais educacionais; Consultoria; Informação; Serviços de Biblioteca e Informação e Centros Regionais para aplicação de exames nos cursos a distância.

Os Centros de Estudos Provinciais compreendem 18 unidades distribuídas por diversas instituições educacionais espalhadas pelo país, provendo vários serviços aos estudantes universitários, o que inclui desde orientação a novos estudantes até tutoriais, exames e serviços de informações.

Já os Centros de Estudos Especiais foram desenvolvidos em cooperação com várias agências governamentais diretamente vinculadas, visando atividades em áreas específicas de estudos, que são oferecidas a partir dos cursos da Universidade, tendo em vista a possibilidade de se aprimorar o conhecimento dos alunos aliando compreensão e experiência a partir de treinamento, práticas laboratoriais e campos de estudos.

Os Centros em Locais Remotos são também Centros de Estudos Especiais. Eles perfazem 18 bibliotecas públicas provinciais espalhadas ao longo do país, que visam prover serviços tanto de bibliotecas quanto de mídias educacionais a estudantes e ao público em geral. As mídias educacionais nestes centros incluem vários livros-textos instrucionais voltados para cursos, livros de exercícios e outros materiais instrucionais impressos, livros de referência, leitura suplementar, romances, contos, além de mídia audiovisual e fitas cassetes que acompanham os cursos e que também servem como tutoriais para aconselhamento acadêmico.

Quanto à entrega de materiais educacionais, a STOU se responsabiliza por arrumar e enviar vários conteúdos impressos para alunos, individualmente, por meio do serviço postal tailandês. As mídias educacionais e os materiais impressos dizem respeito a livros-textos de cursos, livros de exercícios, fitas cassetes, manual do estudante, formulário de matrícula e manual de inscrição, informes periódicos, calendários de radiodifusão de programas de rádio e televisão, calendários de tutoriais, divulgação de datas de exames e resultados.

A Universidade oferece ainda serviços de aconselhamento e orientação educacional/vocacional para estudantes, desde o início de sua matrícula até o fim dos seus estudos. Esses serviços incluem: Orientação Educacional/Vocacional para pessoas interessadas em geral; Orientação Educacional para alunos da STOU; Serviços de 
aconselhamento educacional e profissional; Serviços de Aconselhamento para alunos graduandos. O Escritório de Documentação e Informação da Universidade é responsável por prover os serviços de bibliotecas e acesso a informações, atendendo a três níveis básicos: Serviços Centrais, Serviços Regionais e Serviços Provinciais.

Além disso, a Universidade organiza exames em um ou mais locais em cada província do país, provendo aos estudantes serviços mais convenientes e econômicos de acordo com os interesses da demanda educacional. Os exames são definidos duas vezes a cada semestre, o que inclui exames regulares e provas substitutivas. A cada semestre a instituição envia os informes relativos aos exames com antecedência, incluindo detalhes, regulamentos, locais, datas e períodos. A Universidade também encaminha os resultados aos estudantes dentro de 30-45 dias após a realização do exame, via correio. O estudante pode vir a obter ainda os resultados por meio do website da STOU ou pelo serviço telefônico informatizado via voz.

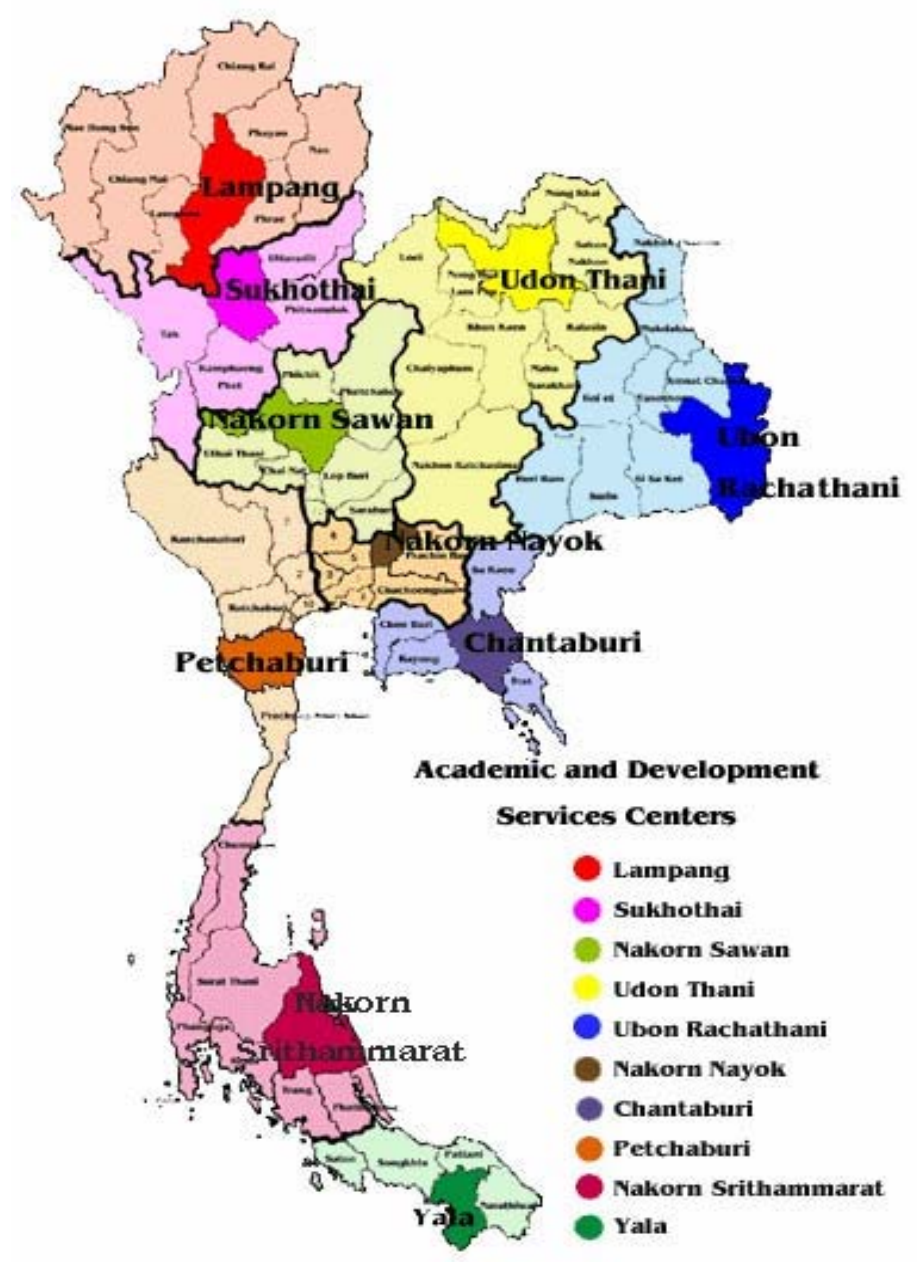

Figura 47: Locais de realização dos exames da STOU 


\subsection{Megauniversidades do continente africano}

\subsection{1 África do Sul}

\section{a) University of South Africa}

\section{Endereço}

University of South Africa

340 Preller Street - Muckleneuk Hill

Pretoria - South Africa.

UNISA call center: 0861670411 (chamadas nacionais)

+27 11 670-9000 (chamadas internacionais)

\section{Contexto Histórico}

A Universidade da África do Sul - University of South Africa (UNISA) -, considerada a mais antiga universidade da África do Sul, comemorou em 2003 seu $130^{\circ}$ aniversário de existência, em plena atividade educacional. Fundada em 1873 como University of the Cape of Good Hope, teve nova denominação em 1916 e posteriormente passou a figurar como universidade a distância, em 1946, estando sua matriz localizada na cidade de Pretória.

\section{Objetivos}

Sua missão é participar do desenvolvimento da comunidade local utilizando seus recursos potenciais a favor do desenvolvimento da população de baixa renda, ou seja, dos excluídos em geral. Além disso, foi dimensionada de modo a atender a todos os estudantes em geral, especialmente aqueles oriundos do continente africano, para que a população possa responder às necessidades e aos desafios impostos pelo mercado global $^{201}$.

\footnotetext{
${ }^{201}$ Portal University of South Africa. Disponível em:

$<\mathrm{http} / / /$ www.unisa.ac.za/default.asp?Cmd=ViewContent\&ContentID=16241>. Acesso em: 27 jan 2005.
} 


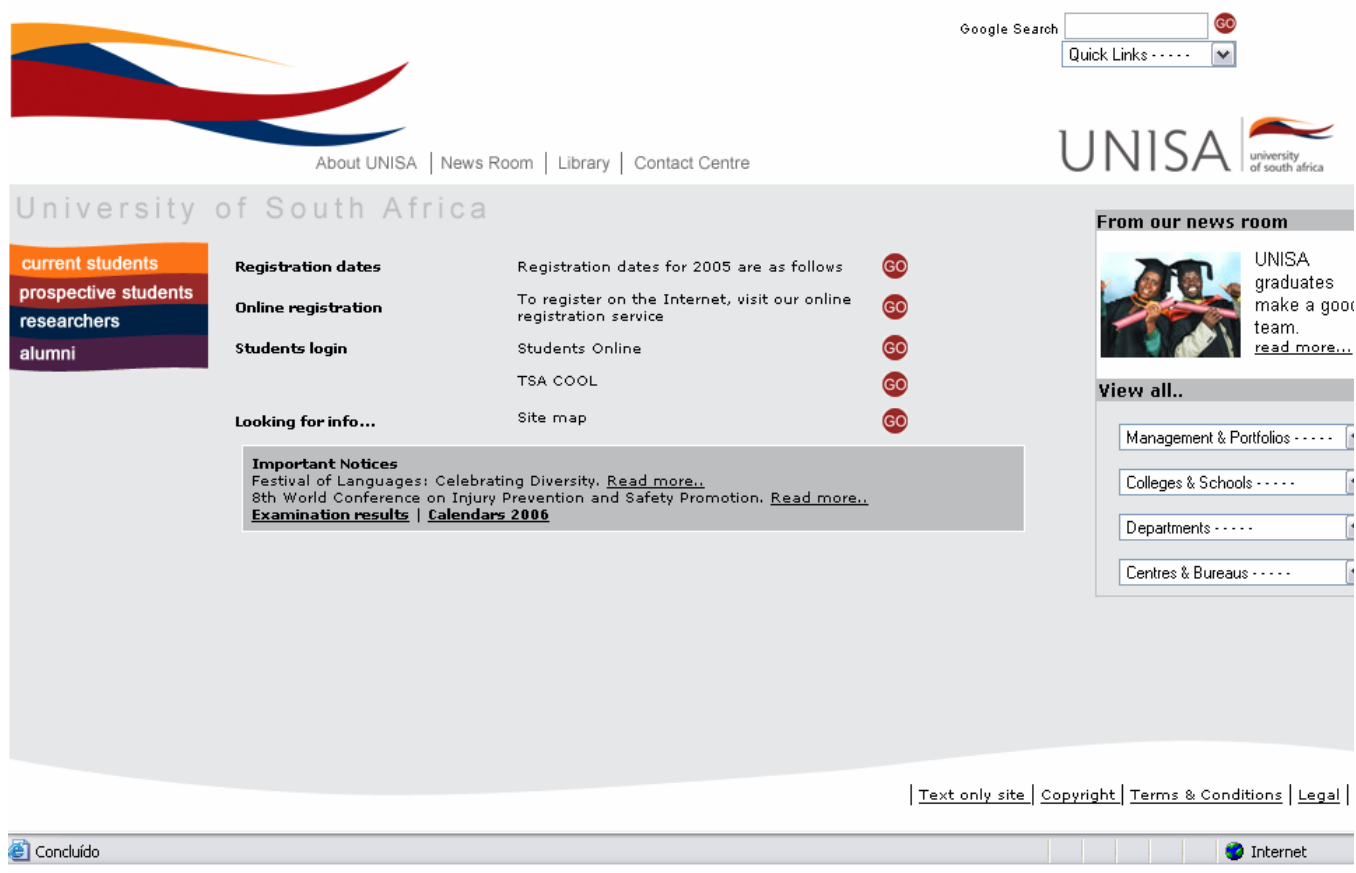

Figura 48: Portal da University of South Africa. Fonte: University of South Africa. Disponível em:

http://www.unisa.ac.za/default.asp?Cmd=ViewContent\&ContentID=16241>. Acesso em: 27 jan 2005.

\section{Público-alvo}

De acordo com informações contidas no site ilustrado, a Universidade possui aproximadamente 226.424 alunos matriculados em cursos de graduação, mestrado, doutorado e cursos profissionalizantes, não só da África do Sul, mas também de outros países da África, além de alunos do exterior.

A UNISA cresceu 84\% nos últimos 5 anos, com uma média anual de 12,99\%, como se pode observar no gráfico:

\section{Número de Alunos}

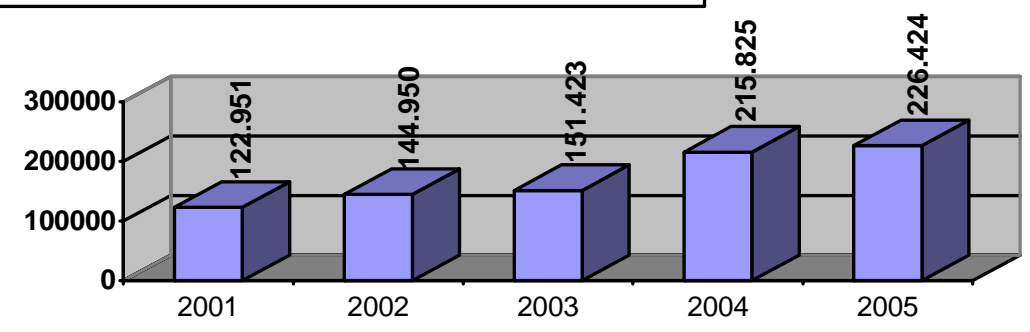

Gráfico 24: Relatórios anuais da UNISA dos anos 2001, 2002, 2003, 2004 e 2005. Gráfico criado pelo autor com dados da UNISA: Disponível em:

<http://www.unisa.ac.za/Default.asp?Cmd=ViewContent\&ContentID=16452\&P_ForPrint=1 >. Acesso em: 10 fev 2007. 
Em relação ao número de graduados, a Universidade também apresenta um crescimento de $91 \%$, no período 2001 a 2005, ou seja, um crescimento anual de 13,83\%. Como podemos observar, o crescimento dos graduados acompanha o crescimento do número de alunos quase na mesma proporção:

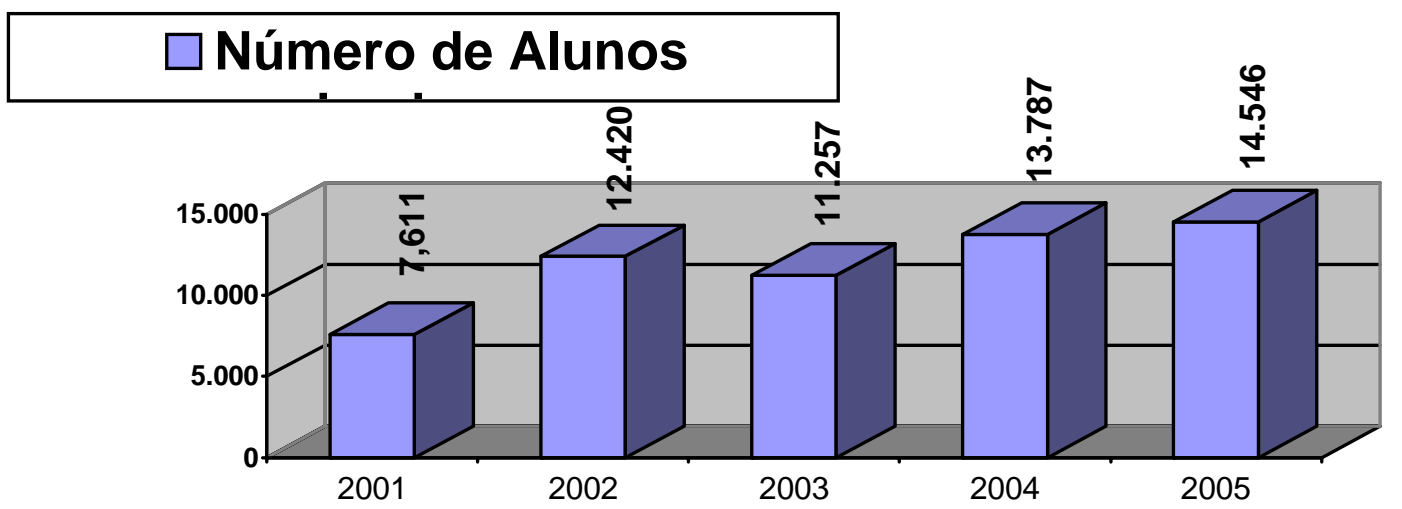

Gráfico 25: Número de alunos graduados pela UNISA nos anos 2001, 2002, 2003, 2004 e 2005. Disponível em: <http://www.unisa.ac.za/Default.asp?Cmd=ViewContent\&ContentID=16452\&P_ForPrint=1 >. Acesso em: 10 fev 2007.

\section{Recursos Humanos e Materiais}

A UNISA conta com uma equipe de mais de 4.000 funcionários, que trabalham em serviços administrativos e de tutoria para dar suporte às atividades de ensino e aprendizagem dos alunos. Os recursos da Universidade chegam a exceder R $\$ 2$ bilhões, sendo que ela geralmente possui um orçamento anual estimado em R\$ 1,8 bilhão.

Além disso, em termos de infra-estrutura, a UNISA desenvolveu um portal de apoio às suas atividades de comunicação entre professores, alunos e instituição, denominado myUNISA. Por este portal de serviços é possível ter acesso a informações administrativas, como dados biográficos, arquivos acadêmicos contendo dados sobre as atribuições do corpo docente, resultados de exames, calendário de atividades e dados sobre financiamento institucional.

Os arquivos acadêmicos trazem geralmente a relação de materiais educacionais que podem ser utilizados via computador, guia acadêmico relativo às matérias ministradas, a relação de grupos de discussão, boletim informativo, diretório de empregos e bolsas de estudos, relação de centros de apoio à aprendizagem, além de livros recomendados para estudos complementares. Na verdade, o portal abrange uma série de facilidades 
informacionais no que diz respeito a supostas dúvidas que os alunos possam ter a respeito de procedimentos necessários para iniciarem o curso, direitos e obrigações do corpo discente, procedimentos para obtenção de títulos e diplomas, formatura, etc., como pode ser visto em https://my.unisa.ac.za/portal/.

\section{Cursos Oferecidos}

Os alunos estão distribuídos em diferentes cursos, da seguinte forma: $49 \%$ nos cursos de Economia, 24\% nos cursos de Ciências Humanas, 12\% nos cursos de Direito, 7\% nos cursos de Tecnologia e Profissionalizantes e 1\% em cursos de Agricultura e Ciências Ambientais.

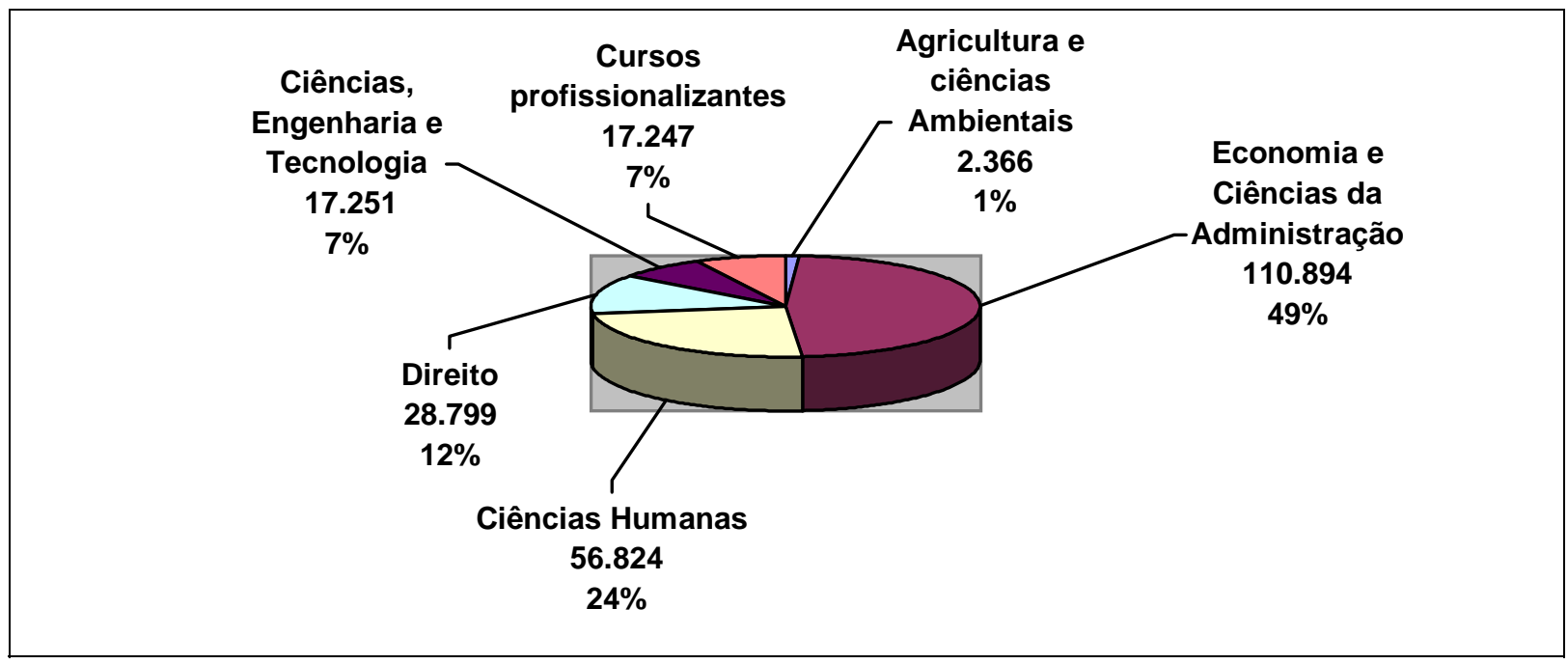

Gráfico 26: Distribuição dos alunos nos diferentes cursos da UNISA.Fonte: Relatório anual de 2005. Disponível em:

$<$ http://www.unisa.ac.za/Default.asp?Cmd=ViewContent\&ContentID=16452\&P_ForPrint=1 $>$. Acesso em: 10 fev 2007.

\section{Sistema de Estudos}

Para ingressar na universidade, os alunos precisam ter concluído no mínimo o ensino médio. O sistema de ensino é flexível, pois o aluno não necessita realizar um exame nacional de admissão. As matrículas podem ser feitas diretamente nos escritórios da UNISA, por correio ou via internet, duas vezes por ano, já que a universidade adotou um sistema semestral de ensino. 


\section{Materiais para Estudos e Estratégia Instrucional}

No campus virtual oferecido pela UNISA a seus estudantes, eles podem se inscrever em cursos e tutorias, ter acesso às notas de provas e, principalmente, aos materiais para estudos.

Assim que os estudantes são matriculados, recebem guias de estudos que contêm os materiais necessários às aulas. Durante o decorrer do curso, devem realizar diversas atividades e enviá-las aos tutores nos Centros de Estudos, onde elas são corrigidas e devolvidas, para que possam avaliar seu processo de aprendizagem. Os exames finais são realizados duas vezes por ano. Se o aluno estiver inscrito no módulo semestral, ele fará os exames em junho e em outubro/novembro.

A Universidade possui tutorias presenciais, que podem ser feitas em grupo ou individualmente. Para alunos que moram em lugares afastados, é utilizado o sistema de videoconferência.

\section{Avaliação Educacional}

Quanto à avaliação educacional, A UNISA possui uma estrutura complexa voltada à administração de exames, que vai desde os centros distribuídos para aplicação de exames em moldes diversificados até a própria categorização dos tipos de exames mediante a variedade de interesses e necessidades dos seus alunos, já que é uma instituição superior de ensino a distância que conta com inúmeros centros credenciados espalhados por todos os continentes do mundo. Além disso, também oferece cursos para presidiários, utilizando a infra-estrutura disponível nas próprias detenções da África do Sul. Foi criado também um Código Disciplinar para Estudantes, no qual constam direitos e obrigações dos alunos da UNISA.

Os estudantes podem indicar o centro de exames que julgar mais próximo à sua residência, fornecendo o código de um dos vários centros disponíveis na lista de locais designados, a partir da sua ficha de matrícula.

Os exames práticos, destinados a estudantes dos cursos de Arte Visual e Multimídia, são normalmente feitos em casa ou em local de escolha do aluno. Neste caso, o estudante 
deve atender categoricamente aos requisitos definidos para o exame prático, o que inclui submeter o trabalho realizado à apreciação institucional, acompanhado de duas declarações de juramento, contendo fotos assinadas que atestem o processo de criação do trabalho no local em que foi desenvolvido.

Solicitações para remarcação de exames incluem sempre uma taxa adicional de R200,00 (200 randes sul-africanos ou o equivalente a \$25,92 dólares americanos) por cada roteiro de exame requerido. A taxa para remarcar uma unidade de estudo, que consiste dos documentos 1 e 2, custa R400.00 (400 randes sul-africanos ou o equivalente a \$51,84 dólares americanos). Já solicitações feitas sem o pagamento da taxa determinada não são consideradas. Também nenhuma solicitação em atraso é considerada.

Há uma taxa básica inclusa para cada exame de acordo com a unidade de estudo.

\begin{tabular}{|l|r|}
\hline $\begin{array}{l}\text { Taxas Adicionais são pagas nos seguintes casos: } \\
\text { (Referência: Ano Acadêmico de 2006) }\end{array}$ \\
\hline Exame Aegrotat & $\$ 14,19$ \\
\hline Exame especial & $\$ 14,19$ \\
\hline Exame suplementar & $\$ 14,19$ \\
\hline Reverificação do roteiro para exame & $\$ 9,03$ \\
\hline Remarcação do roteiro para exame & $\$ 14,19$ \\
\hline Aula extra (por hora ou equivalente) & $\$ 3,22$ por hora ou equivalente \\
\hline Local especial definido & $\$ 7,74$ por sessão \\
\hline
\end{tabular}

Tabela 29: Custos dos exames oferecidos pela UNISA, convertidos do seu valor original em randes (moeda oficial da África do Sul) para dólar americano, a partir da equivalência monetária: \$1,00 = 7,7475RA . (taxa do dia 25 de outubro de 2006).

A Universidade possui um rígido código disciplinar que regula a conduta dos alunos, definindo as condutas impróprias, os procedimentos no caso de denúncia por conduta imprópria; os Comitês Disciplinares e as normas de implementação de veredictos.

O código entende como conduta imprópria desvios de conduta acadêmica por parte do aluno como: contravenção de códigos, regulamentos e instruções acadêmicas da UNISA; incitação à prática de violação destes mesmos códigos e regulamentos; conduta violenta e desrespeitosa a membros da equipe acadêmica, estudantes e funcionários; porte de drogas e de armas de fogo no espaço educacional; furto de pertences da comunidade acadêmica; veiculação de informações incorretas e falsas a membros da equipe acadêmica; distribuição de materiais de circulação (impressos, panfletos, 
circulares, etc.) sem o consentimento do reitor; reprodução e transmissão de quaisquer materiais (guias, tutoriais, dissertações, teses, livros, artigos, etc.) por quaisquer meios (impressos ou eletrônicos) que violem termos dos direitos autorais; coleta de dinheiro, venda e oferta de mercadorias empregando a infra-estrutura da Universidade, sem a autorização expressa do reitor; uso indevido do nome da instituição para fins pessoais, etc.

\section{Centros de Estudos}

Atualmente, existem nove centros de estudos pelo país, mediante os quais os alunos têm acesso aos serviços de tutoria. O programa de tutoria começa no mês de fevereiro e se estende até o final de setembro do ano em curso.

Os centros de estudos, além de oferecer o serviço de tutoria semanal aos alunos, dispõem ainda de laboratórios de informática, bibliotecas, serviços de informações, local de estudos, grupos de estudos e serviços de preparação para exames.

O departamento de apoio ao estudante pode ser contatado por telefone, correio, e-mail ou pessoalmente.

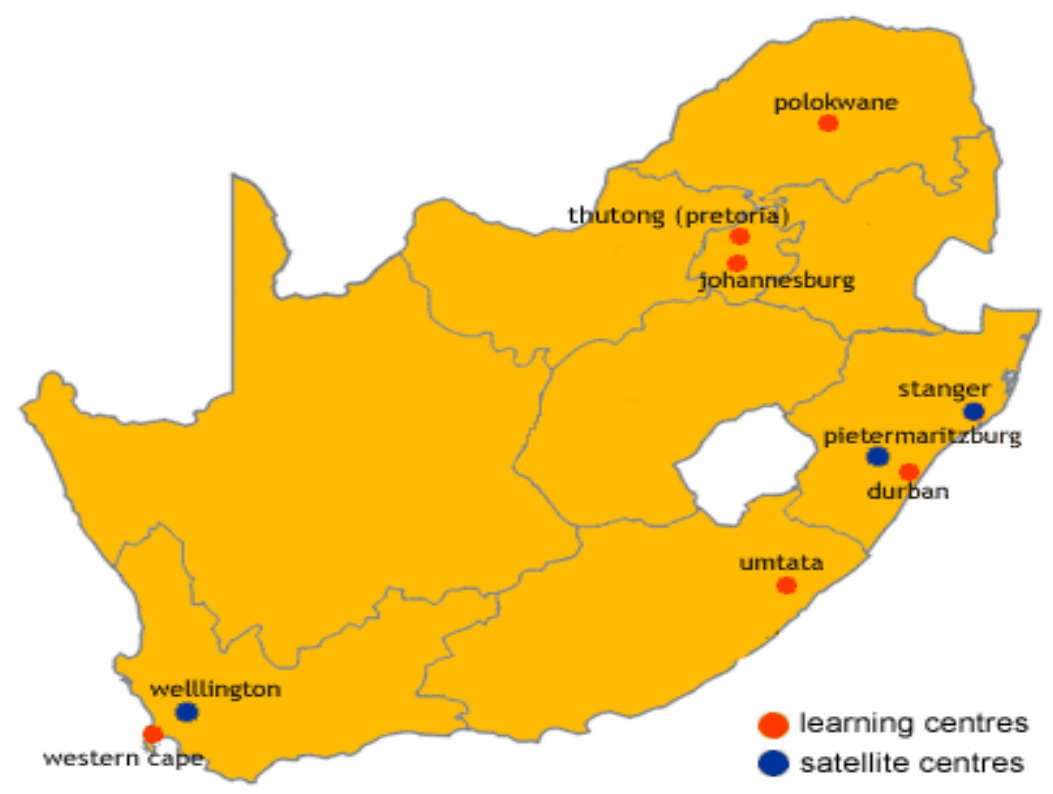

Figura 49: Centros de Estudo da UNISA. Fonte: UNISA, Annual Report 2004. 


\subsubsection{Inglaterra}

\section{a) UK Open University}

\section{Endereço}

The Open University

Walton Hall

Milton Keynes

MK7 6AA

Tel.: +44 (0) 1908274066

E-mail: general_enquiries@open.ac.uk

Internet: http://www.open.ac.uk

\section{Contexto Histórico}

Esta é, sem dúvida, uma das mais tradicionais instituições de Educação a Distância do Ocidente, tendo iniciado suas atividades oficialmente em 1971, com o ingresso de aproximadamente 25 mil estudantes. Sua matriz está localizada em Walton Hall, Milton Keynes, na região de Buckinghamshire, Inglaterra, possuindo diversos centros regionais de ensino e aprendizagem espalhados pelo país.

\section{Objetivos}

A Open University foi instituída basicamente para promover oportunidades de educação e justiça social no Reino Unido, oferecendo educação universitária de alta qualidade para todos que desejassem realizar suas ambições de formação educacional de modo a desenvolver seus potenciais humanos. 


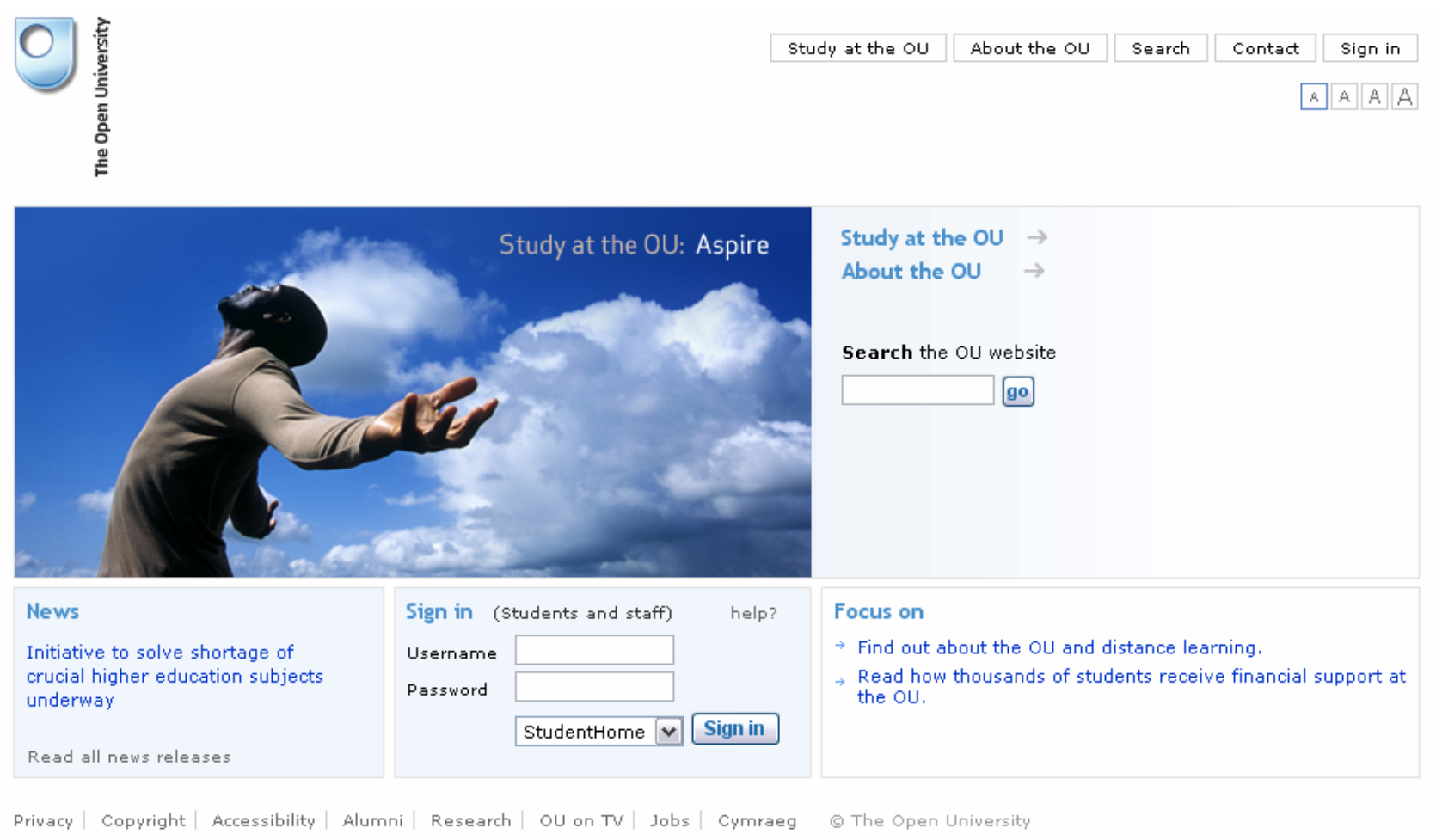

Figura 50: Portal da UK Open University. Fonte: UK Open University. Disponível em: <www.open.ac.uk>. Acesso em: 27 jan 2006.

\section{Público-alvo}

Com mais de 200.000 alunos matriculados por ano e abrangendo um contingente de mais de 3 milhões de alunos desde a sua fundação, a OU é considerada atualmente a maior instituição acadêmica e a única dedicada exclusivamente à prática da educação a distância na Inglaterra.

A Universidade possui cerca de 200 mil estudantes, sendo que aproximadamente 10.000 são portadores de necessidades especiais. Em 1996, mais de 150.000 alunos chegaram a se matricular em cursos de graduação e pós-graduação da OU. Também foram vendidos mais de 50.000 pacotes de materiais para aprendizado a distância.

A Universidade, desde a sua criação, cresceu mais de $700 \%$, com uma média de crescimento anual de $6,31 \%$, como se pode observar na tabela a seguir. 


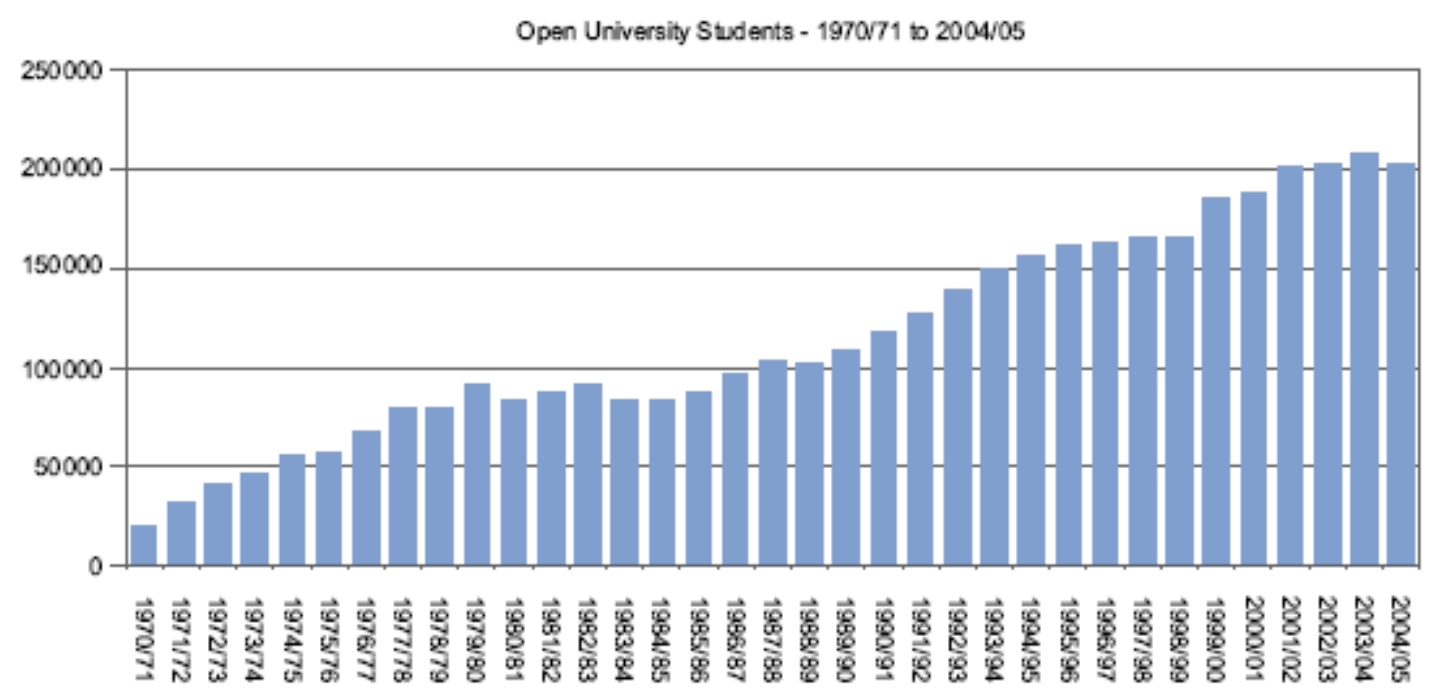

Gráfico 27: Crescimento da Open University de 1970 a 2005. Fonte: CNED, Facts \& Figures. 20042005. Disponível em: <http://www.open.ac.uk/foi/p7_1.shtml>. Acesso em: 19 jan 06

\section{Recursos Humanos e Materiais}

A Open University emprega atualmente mais de 500 profissionais envolvidos na área de pesquisa em cerca de 25 áreas de estudo, havendo pelo menos 1.200 estudantes pesquisadores que desenvolvem atividades na instituição.

A Universidade conta também com um orçamento anual de 20 milhões de libras esterlinas, ou seja, o equivalente a US\$ 39.234.000,00 (trinta e nove milhões, duzentos e trinta e quatro mil dólares americanos), sendo que somente 6 milhões de libras (US\$ 11.770.200,00 - onze milhões, setecentos e setenta mil e duzentos dólares americanos) provêm do Conselho de Fomento ao Ensino Superior da Inglaterra (Higher Education Funding Council for England), enquanto o restante vem de fundos externos e privados.

\section{Cursos oferecidos}

Quanto aos cursos oferecidos, a OU divide-os em nível de abrangência, a partir das seguintes áreas de conhecimentos: Negócios e Administração; Educação e Treinamento de Professores; Meio Ambiente; Saúde, Assistência Social/Estudos da Saúde; Humanidades: Artes, Linguagens, História; Tecnologia da Informação e Computação; Direito e Criminologia; Matemática e Estatística; Psicologia, Filosofia, Política, Economia; Ciências; Ciências Sociais; Tecnologia, Engenharia e Produção; Desenvolvimento Profissional Contínuo. 
A maior parte das competências, habilidades e atitudes desenvolvidas ao longo dos cursos da Open University está definida de forma modular a partir de estruturas de conteúdos, sendo que o número apropriado de cursos em cada nível pode ser combinado de modo a se obter a qualificação acadêmica desejada, como título, certificado ou diploma. Abaixo estão listados os vários cursos oferecidos pela $\mathbf{O U}$, com os níveis de formação dados e as titulações possíveis de serem obtidos.

\section{Sistema de Estudos}

Para ingressar na OU, é necessário apenas ter mais de 18 anos, não importando a formação escolar anterior. Quase todos os alunos estudam durante meio período, sendo que aproximadamente $75 \%$ trabalham em período integral - o que comprova a característica do sistema flexível de ensino adotado pela Universidade. É interessante notar também que mais de 25 mil estudantes residem fora da Inglaterra, o que demonstra o fato de a Open University ter se firmado ao longo de décadas como uma instituição internacionalmente reconhecida em termos de qualidade de educação a distância.

Como a Open University está fisicamente subdividida em várias faculdades, centros, escolas e institutos, os estudos de apoio pedagógico são realizados individualmente por meio de cada faculdade, escola ou instituto da Universidade. Isso decorre tanto das atribuições formativas de cada unidade como das especificidades dos estudos empreendidos, levando-se em conta o nível de abrangência e as áreas de conhecimento tratadas.

Nesse sentido, os grupos de trabalho em pesquisa compreendem as seguintes unidades particulares de apoio: Faculdade de Artes; Escola de Negócios; Faculdade de Educação e de Estudos da Linguagem; Instituto de Tecnologia Educacional; Faculdade de Saúde e Assistência Social; Instituto de Mídias do Conhecimento; Faculdade de Matemática e Computação; Faculdade de Ciências; Faculdade de Ciências Sociais; Faculdade de Tecnologia. 
Além disso, a Universidade conta com uma série de centros: para Cidadania, Identidades e Governança ${ }^{202}$; Internacional para Pesquisa Criminológica Comparativa $^{203}$; para Pesquisa em Computação ${ }^{204}$; para Pesquisa em Educação e Tecnologia Educacional; de Estudos da Terra, Planetas, Espaço e Astronomia ${ }^{205}$.

\section{Materiais de Estudos e Estratégia Instrucional}

A OU possui um estilo de ensino próprio chamado supported open learning. Segundo a definição exposta no próprio site, “Open Learning” (Aprendizado Aberto) significa, em certa medida, a idéia de o aluno aprender segundo o seu próprio ritmo, principalmente ao estudar o material ao longo do curso, quando ele é solicitado a desenvolver uma variedade de atividades realizando múltiplas tarefas individuais e em grupo".

Quanto à metodologia de ensino-aprendizagem, a Open University se utiliza de diversos recursos multimídia que favorecem o aprimoramento do aprendizado, como apostilas, agendas impressas, fitas de áudio e vídeo, programas de TV, CD-ROMs, softwares, websites e kits com experiências vivenciais.

É importante salientar que os programas de radiodifusão da Open University são produzidos em parceria com a $\mathrm{BBC}$ de Londres, o que qualifica em grande parte a qualidade dos materiais produzidos e empregados nos vários cursos a distância. Esses cursos têm sido aos poucos incrementados com o suporte de DVDs, com o estilo de produção audiovisual baseando-se no formato de teledocumentários, com qualidade de

\footnotetext{
${ }^{202}$ Trata-se de um esforço interdisciplinar de pesquisa em ciências sociais, cujo principal objetivo visa conduzir e promover pesquisa, diálogo e debate que contribuam para um maior entendimento em relação às múltiplas conexões entre cidadania, processos de formação de identidades e práticas governamentais no mundo contemporâneo.

${ }^{203}$ É um centro interdisciplinar de pesquisa criminológica cujo objetivo visa unir pesquisa baseada em práticas contemporâneas e análise de fundamentos críticos com uma consciência de contexto histórico-social. Seus membros provêm de um número diversificado de faculdades e disciplinas da Open University, sendo que atualmente duas áreas significativas de especialização estão sendo desenvolvidas: Política de Segurança e Segurança Comunitária.

204 Este centro empreende pesquisa de fronteira no desenvolvimento de software e processos que apóiam o gerenciamento de conhecimento, comunicação, aprendizagem e interações entre pessoas e máquinas. Seu objetivo básico está relacionado a tópicos como: Mídia do Conhecimento, Web semântica e Ontologias, Interação HumanoMáquina, Hipermídia, Processamento de Linguagem Artificial, Inteligência Artificial, Software Social, Engenharia de Desenvolvimento de Software e Design, Estudos Empíricos de Desenvolvimento de Software.

${ }^{205}$ Este centro estuda as origens, os sistemas e os processos relativos à evolução e à química de materiais que formam as estrelas e os corpos planetários, os processos e os sistemas naturais responsáveis pelo ambiente do mundo que habitamos agora e no passado, assim como as propriedades essenciais de um sistema solar capaz de permitir o desenvolvimento dos planetas. Para tanto, realiza diversas alianças colaborativas inter e transdisciplinares, integrando toda uma cultura abrangente e multifacetada de esforços multidisciplinares, o que inclui um comprometimento com lideranças internacionais neste campo de pesquisa. Também compreende a união de três diferentes departamentos: Ciências da Terra, Instituto de Pesquisa em Ciências Espaciais e Planetárias (PSSRI) e o Grupo de Pesquisa Astronômica do Departamento de Física e Astronomia.
} 
imagem e conteúdo, tendo, ainda, caráter inovador na abordagem dos temas, selecionados principalmente aqueles com enfoque científico.

Atualmente, a Open University produz mais programação para rádio e televisão, dedicada ao grande público, sendo seus programas tradicionalmente feitos para abordar temas científicos, ou seja, voltados a um público com interesses mais específicos, retransmitidos de tempos em tempos, enquanto sua programação mais antiga continua sendo levada ao ar pela BBC Learning Zone (http://www.bbc.co.uk/learningzone/), um segmento da rede $\mathrm{BBC}$ de Londres que trata de temas mais educacionais e acadêmicos e de grande interesse por parte de professores e educadores em geral.

Muitos materiais educacionais são elaborados por especialistas em conteúdos que atuam como colaboradores acadêmicos externos, executando suas atividades profissionais em outros locais de trabalho fora do espaço físico da $\mathbf{O U}$, principalmente em casa, e que acabam por ser responsáveis pela grande qualidade e originalidade na autoria dos materiais empregados pela Open University. Há ainda outros materiais complementares aos conteúdos, que são obtidos a partir da concessão de licenças autorais para uso dos estudantes da Instituição.

Grande parte dos cursos conta também com o suporte de tutores, que pertencem a um grupo de conferencistas associados da $\mathbf{O U}$ e fornecem retorno às atividades de ensino $\mathrm{e}$ aprendizagem dos alunos, estando disponíveis para contato com eles de diversos modos: presencial, por telefone ou via internet.

No entanto, já existem cursos de curta duração, que valem até 10 créditos, que não prescindem mais de tutores oficialmente nomeados pela instituição. Esses cursos são oferecidos por serviços de conferência on-line, a partir do uso de fóruns eletrônicos via internet, que têm como suporte e auxílio aos alunos a intermediação de moderadores virtuais. $\mathrm{O}$ aluno que se inscreve em um desses cursos, ministrados obrigatoriamente durante os períodos normais da instituição, cumpre longas sessões diárias de aula para poder ser aprovado nos exames solicitados.

Um exemplo ilustrativo desses cursos é o "Certificado Avançado em Promoção da Saúde", que determina obrigatoriamente dois dias de aula normal com um curso intenso, e que pode incluir seminários, oficinas, aulas práticas, etc., focando ainda habilidades de comunicação, orientação educacional e questões práticas relacionadas à 
promoção da saúde. Neste caso, este curso não exige a necessidade de um componente presencial, a rigor, para aulas práticas com freqüência, já que o conteúdo tratado, do ponto de vista da área da saúde, não requer um conhecimento prático muito abrangente.

Do mesmo modo, muitos cursos tradicionalmente oferecidos durante o período letivo do verão têm sido remodelados pela Open University, para atender às necessidades de cursos de menor duração, já que muitas vezes os alunos preferem contatos mais intensos e próximos com seus tutores e colegas do que as formas de contato habitualmente oferecidas por cursos extensivos, pois consideram as escolas e as instalações da instituição um forte elemento de experimentação educacional, que agrega conhecimento e enriquece a vida social com base nas atividades de convívio presencial.

Contudo, devido a questões orçamentárias, a $\mathbf{O U}$ tem se dedicado à busca de estratégias de ensino e aprendizagem que cada vez mais dispense a prática obrigatória de cursos intensivos de verão na sua grade curricular, adotando o caráter de oferta de tais cursos, preferencialmente, em separado dos obrigatórios, servindo eles mais como categorias complementares de ensino e aprendizagem. Uma razão para se manter ainda a oferta de tais cursos reside no fato de que eles trazem aos alunos, comprovadamente, uma experiência significativa em termos de estratégias pedagógicas adotadas pela Open University, principalmente para aqueles que estão se iniciando em um curso de graduação a distância.

No caso de estudantes portadores de necessidades especiais, são utilizados materiais produzidos em formatos alternativos, de acordo com seus interesses de aprendizagem. Um dado importante é também o nível de acessibilidade informacional que o portal da OU oferece para usuários com dificuldades visuais, o que pode ser devidamente atestado logo na página inicial da instituição, no seu canto superior esquerdo, que contém três níveis de amplitude. Esta característica denota claramente uma preocupação de caráter ergonômico com a diversidade de usuários que a instituição pretende atender.

Além do fornecimento de materiais, os cursos incluem um certo número de tarefas (TMA - Tutor Marked Assignments) e um exame final. Um estudante regularmente matriculado na OU tem bastante flexibilidade para planejar seus estudos, definindo os objetivos relacionados a ele, para poder se organizar de modo mais sistemático. Pode escolher desde os cursos e as disciplinas que orientam para uma determinada 
qualificação profissional até realizar cursos simplesmente pelo interesse no assunto que deseja aprender.

Para orientar o aluno no planejamento dos seus estudos, existe uma seção no portal da Open University especialmente dedicada a este tópico. Nela são apresentadas quatro perguntas essenciais. Para cada uma delas, o aluno irá encontrar respostas que o ajudarão a identificar o curso de estudo mais de acordo com seus objetivos. São elas:

- Quais são os seus objetivos para o estudo universitário?

- Qual nível de curso é adequado a você?

- Quanto tempo você pode gastar, estudando, a cada semana?

- Qual disciplina você está interessado em aprender?

Para cada uma dessas perguntas há uma lista de respostas sugeridas que permitem ao aluno escolher seu curso de acordo com seus objetivos de estudos:

Quais são os seus objetivos para o estudo universitário?

Eu quero estudar principalmente porque eu estou interessado no assunto.

Eu quero experimentar um curso para ver se o estudo universitário é próprio para mim.

- Eu quero receber uma qualificação que me ajude a prosseguir com minha carreira profissional.

E Eu quero obter um grau de formação em um assunto específico.

Eu quero desenvolver ou aprimorar minhas qualificações profissionais.

Conforme a opção, o sistema devolve uma série de considerações que poderão servir de orientação ao aluno, passo a passo, tentando responder a seus interesses potenciais para os cursos oferecidos pela OU. E a cada opção escolhida abre-se um leque de outras questões, encadeadas por subdomínios, que procuram especificar cada vez mais o interesse do aluno, de modo que a orientação ao estudo possa ser respondida adequadamente de acordo com seus interesses e expectativas. 


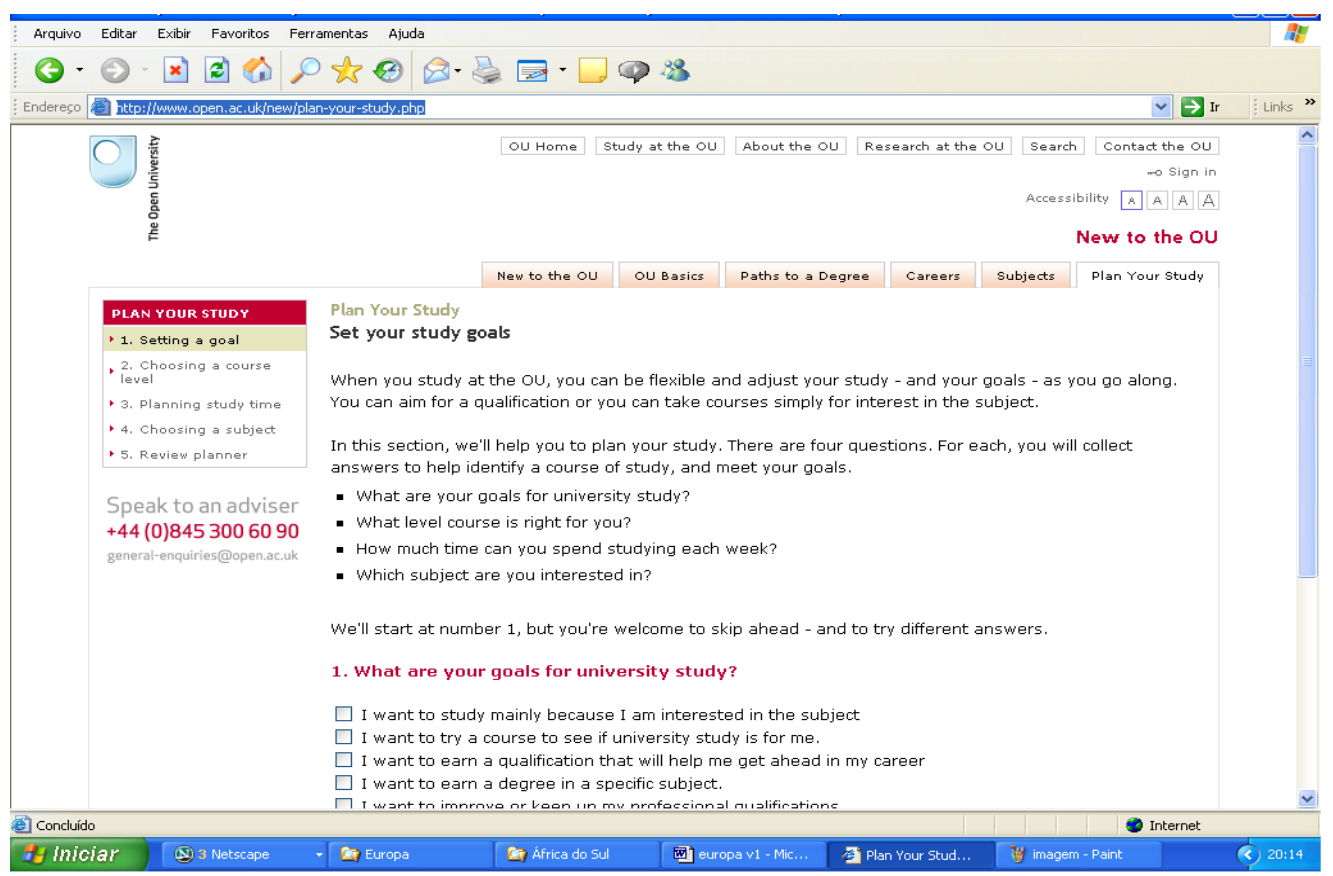

Figura 51: Página da UK Open University que indica os passos para se planejar o estudo e seus objetivos. Fonte: UK Open University. Disponível em: <http://www.open.ac.uk/new/plan-yourstudy.php>. Acesso em: 27 jan. 2006.

O ensino na Open University tem sido apontado como de excelente qualidade pela Agência de Controle da Qualidade do Ensino Superior na Inglaterra (Quality Assurance Agency for Higher Education - QAA). Também o levantamento nacional sobre o nível de satisfação dos alunos universitários pôs a $\mathbf{O U}$ duas vezes em primeiro lugar entre várias instituições de ensino superior pesquisadas na Inglaterra.

Em outubro de 2006, a OU se associou ao Movimento de Recursos para a Educação Aberta (Open Educational Resources), uma iniciativa criada pela Fundação HewlettPackard nos Estados Unidos e apoiada pela ONU desde 2002, cujo objetivo é disseminar publicamente o uso de materiais instrucionais que favoreçam $o$ desenvolvimento de países subdesenvolvidos ou de economias emergentes. São materiais digitalizados oferecidos livremente a educadores, estudantes e indivíduos interessados em processos de auto-instrução, desenvolvidos de modo a serem reutilizados para os objetivos de ensino, aprendizagem e pesquisa. Incorporam como características básicas: 
Conteúdos de Aprendizagem: foco na produção de materiais completos para uso em computadores, módulos de conteúdos, objetos de aprendizagem, coleções, revistas científicas, etc.

Ferramentas: pacotes de programas para o desenvolvimento de aplicações educacionais, aplicativos que permitem a reutilização de conteúdos de aprendizagem, programas tanto para busca, organização e gerenciamento de bases de conteúdos como para o desenvolvimento de conteúdos e criação de comunidades de aprendizagem.

Recursos de Implementação: licenciamento da propriedade intelectual de programas de modo a favorecer a publicação livre dos materiais empregados, utilização dos melhores princípios de design instrucional para o apoio à infraestrutura de cursos abertos a distância e formas de favorecer a localização de conteúdos relevantes.

Para participar firmemente dos objetivos deste movimento multilateral de apoio livre à educação aberta, a Open University criou seu próprio projeto de disseminação de conteúdos livres, o OpenLearn ${ }^{206}$. Por meio dele, disponibiliza uma seleção de materiais de cursos a distância que já foram empregados pela instituição em seus cursos no passado.

Esses materiais são deixados no portal para livre acesso, incluindo diversas versões que podem ser baixadas por educadores, com a facilidade de serem modificadas de acordo com suas necessidades, desde que sejam obedecidas certas normas de licença definidas para seu uso. As normas, por sua vez, seguem critérios adotados pela Creative Commons $^{207}$, uma iniciativa internacional criada para promover o desenvolvimento do trabalho criativo no mundo sob uma ótica de distribuição de conhecimento compartilhado por redes computacionais, a partir do acesso livre aos benefícios oriundos do uso das novas tecnologias de informação e comunicação para todos que queiram usufruir uma plataforma comum de ferramentas para suporte à aprendizagem colaborativa.

O projeto Open University prevê ainda uma parceria com diversos colaboradores na produção e disseminação de seus materiais em todas as partes do mundo. Para fazer uso dos recursos oferecidos, o indivíduo deve se cadastrar no portal, onde há uma série de

\footnotetext{
${ }^{206}$ Disponível em <http://openlearn.open.ac.uk/mod/resource/view.php?id=1581>. Acesso em: 23 fev 06.

${ }^{207}$ Para mais informações, consultar $<$ http://en.wikipedia.org/wiki/Creative_Commons_License $>$. Acesso em: $23 \mathrm{fev}$ 06.
} 
dicas para a utilização dos materiais para diversos fins, inclusive para o processo de auto-instrução.

\section{Avaliação Educacional}

As avaliações são feitas tanto ao longo quanto ao final do curso, sempre por trabalhos escritos, enviados via internet ou por correio convencional, não havendo qualquer necessidade da presença do aluno em algum centro credenciado para aplicação de exames, como acontece em algumas outras instituições dedicadas ao ensino a distância em outras partes do mundo.

Os cursos são geralmente avaliados a partir de um peso comum atribuído aos exames e às atividades disciplinares. Cada componente do curso abrange duas ou mais tarefas designadas pelo tutor, também chamadas de TMAs - Tutor Marked Asssignments -, que podem incluir ocasionalmente exercícios de múltipla escolha por computador, os CMAs - Computer Marked Assignments. O componente de exame é geralmente um questionário que leva três horas para ser respondido, independentemente da abrangência do curso.

\section{Centros de Estudos}

A Open University possui 13 centros regionais distribuídos pela Inglaterra. Por meio da equipe de apoio dos centros regionais, o aluno recebe assistência acadêmica da Universidade antes, durante e após o curso. O sistema de suporte tutorial, disponível nos centros, visa facilitar a aprendizagem por meio de apoio individualizado ou em grupo. Os contatos com tais centros são feitos por e-mail, telefone, fax, carta ou pessoalmente. Os Centros de Estudos regionais também prestam serviços administrativos aos alunos, como, por exemplo, solicitação de requerimentos e matrículas, entre outros. 


\subsubsection{França}

\section{a) Centre National d'Enseignement à Distance (CNED)}

\section{Endereço}

Cned Direction générale

2. bd Nicéphore-Niepce

\section{Téléport 2}

BP 80300 - 86963 Futuroscope - Chasseneuil Cedex - Tel.: 0549493400 - Fax: 05 49490584

\section{Contexto Histórico}

O Centre National d'Enseignement à Distance (CNED), localizado na França, é um órgão público associado ao Ministério da Educação. Criado em 1939, tem como objetivo promover a formação a distância na França, caracterizando-se por ser o único órgão oficial a oferecer alternativas educacionais para as diferentes faixas etárias do país.

É também considerado atualmente o maior centro nacional de educação a distância em operação no continente europeu e o maior no mundo com o uso da língua francesa.

\section{Objetivos}

Em razão da sua larga experiência com métodos de ensino e know-how no desenvolvimento de projetos de ensino a distância, o CNED tem conseguido atender às necessidades de várias demandas diversificadas: interesses individuais, corporativos e de agências governamentais, formação para professores e acordos bilaterais com parceiros de outros países e continentes. A princípio, são três os fundamentos da proposta pedagógica do CNED: criação de cursos voltados a treinamentos específicos; formulação de programas de treinamento e transferência de habilidades, competências e atitudes profissionais. 


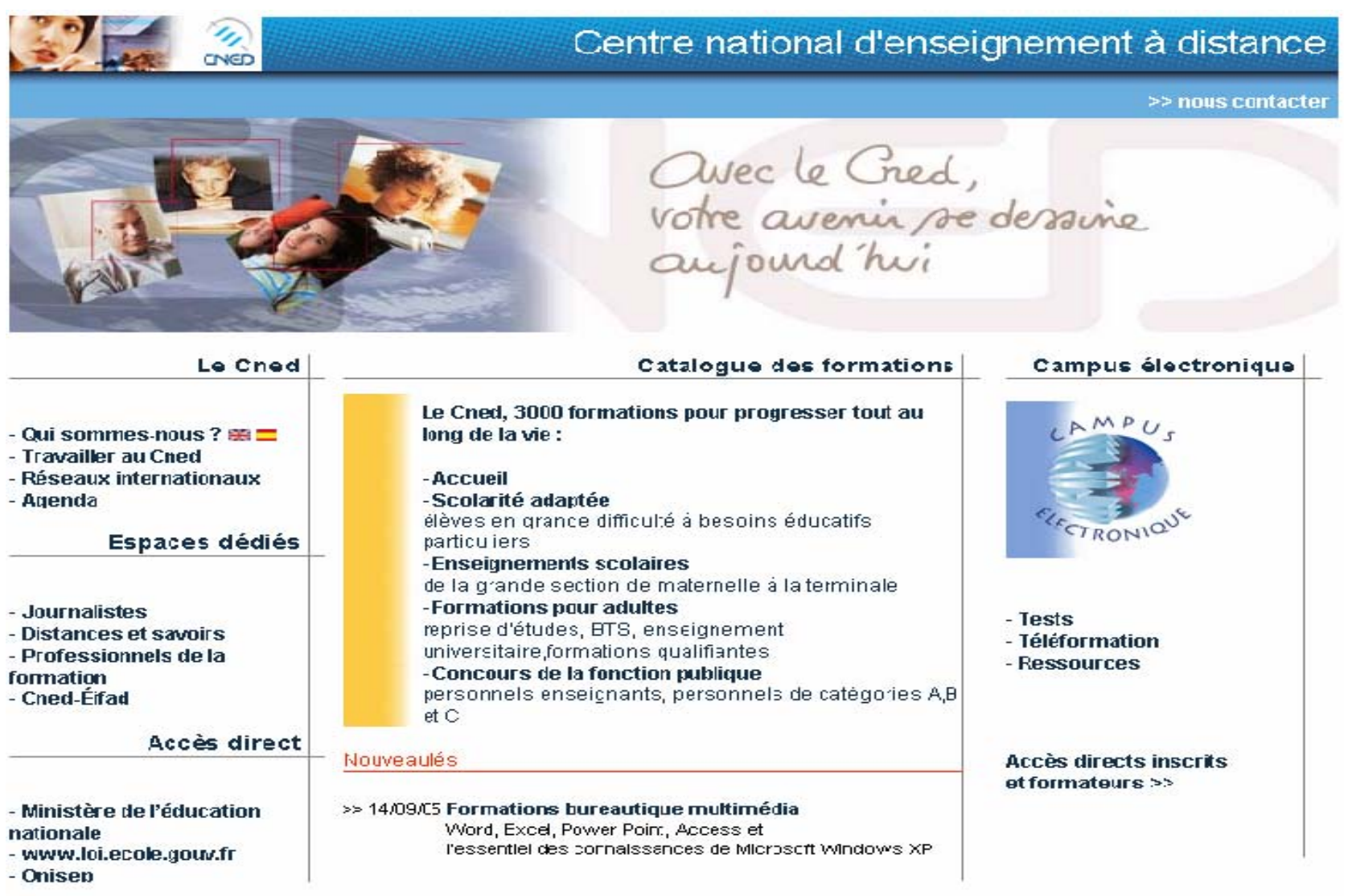

Figura 52: Portal do Centre National d'Enseignement à Distance. Fonte: Centre National d’Enseignement à Distance. Disponível em : <http://www.cned.fr/> Acesso em: 27 jan. 2005.

\section{Público-alvo}

O CNED tem uma oferta de ensino superior em parceria com mais de cinqüenta universidades e escolas superiores. A instituição também oferece cursos de formação profissional contínua a públicos diversos. Todos os cursos programados são, de certa forma, subsidiados pelo Ministério da Educação da França, sendo que o valor de cada curso se eleva, naturalmente, de acordo com o nível de formação desejado pelo aluno, que pode variar desde a alfabetização primária até o pós-doutorado a distância.

Uma parte importante da atividade deste centro educacional se refere à ênfase dada à formação ao longo de toda a vida. Pode-se dizer que das 320.000 pessoas inscritas no CNED, mais de dois terços são constituídas por adultos, havendo 24.000 que se preparam para concursos na área administrativa e 66.000 para concursos destinados ao recrutamento de professores. Além disso, 38.000 estão na graduação e mais de 41.000 freqüentam cursos visando obter uma formação profissional. 
Os dados da tabela abaixo mostram que, em 1995, o Centro chegou a ter 184.614 estudantes, número que, em 2000 passou a 368.163 alunos matriculados, o que indica um crescimento de $99 \%$ neste período e um crescimento médio anual de $14,80 \%$. Porém, a partir de 2000, o número de alunos diminuiu, chegando em 2004 a 317.796 estudantes, o que representa uma redução de $14 \%$ sobre o seu contingente (considerando-se como base os dados do ano 2000). A média de redução anual foi de 2,90\%. Esta redução, segundo análise apresentada a partir do relatório da instituição com base no ano de 2004, ocorreu em virtude do crescimento da concorrência de sistemas a distância de várias universidades públicas.

\begin{tabular}{|c|c|c|c|c|c|c|}
\hline Niveaux & $\begin{array}{l}\text { Total } \\
2004\end{array}$ & $\begin{array}{l}\text { Evolution } \\
2004 / 2003^{5}\end{array}$ & $\begin{array}{l}\text { Total } \\
2003^{5}\end{array}$ & $\begin{array}{l}\text { Total } \\
2002\end{array}$ & $\begin{array}{l}\text { Total } \\
2001\end{array}$ & $\begin{array}{l}\text { Total } \\
2000\end{array}$ \\
\hline $\begin{array}{l}\text { Formations réglementées } \\
\text { de l'élémentaire au baccalauréat }\end{array}$ & 103662 & $-2,7 \%$ & 106571 & 114077 & 119037 & 123085 \\
\hline Elémentaire & 12021 & $-5,5 \%$ & 12725 & 12284 & 12224 & 12506 \\
\hline Collegge & 30229 & $-7,2 \%$ & 32579 & 35234 & 37729 & 38441 \\
\hline Lycée général & 42179 & $+2,9 \%$ & 40989 & 45676 & 48673 & 51497 \\
\hline Lycée technologique & 6045 & $-11,8 \%$ & 6855 & 7712 & 7412 & 8043 \\
\hline Lycée professionned & 13188 & $-1,8 \%$ & 13423 & 13171 & 12999 & 12598 \\
\hline DAEU, capacité en droit & 4719 & $-6,1 \%$ & 5025 & 5540 & 5757 & 6004 \\
\hline BTS & 18826 & $-11,0 \%$ & 21146 & 23953 & 25104 & 28044 \\
\hline BTS industrieds & 1363 & $-25,5 \%$ & 1830 & 2160 & 2176 & 2461 \\
\hline BTS tertiaires & 12129 & $-14,2 \%$ & 14131 & 16365 & 17583 & 19683 \\
\hline BTS sante, social & 5334 & $+2,9 \%$ & 5185 & 5428 & 5345 & 5900 \\
\hline $\begin{array}{l}\text { Formations réglementées } \\
\text { del'enseignement supérieur }\end{array}$ & 17620 & $-1,0 \%$ & 17790 & 19130 & 19300 & 19177 \\
\hline Concours d'entrée aux grandes écoles et instituts & 2197 & $-0,4 \%$ & 2206 & 2340 & 2213 & 2230 \\
\hline Cycles Deug & 6992 & $-15,5 \%$ & 8274 & 9306 & 9614 & 9947 \\
\hline Cycles licence & 5681 & $+28,0 \%$ & 4438 & 4609 & 4198 & 3647 \\
\hline Cycles maitrise & 1352 & $+4,3 \%$ & 1296 & 1195 & 1265 & 932 \\
\hline Cycles bac +5 et plus & 128 & $+20,8 \%$ & 106 & 98 & 112 & 287 \\
\hline Autres diplömes del'enseignement supérieur ${ }^{1}$ & 1270 & $-13,6 \%$ & 1470 & 1582 & 1998 & 2134 \\
\hline $\begin{array}{l}\text { Concours de recrutement } \\
\text { des personnels enseignants }\end{array}$ & 63459 & $-2,6 \%$ & 65141 & 68421 & 67959 & 73418 \\
\hline CRPE & 28103 & $+7,0 \%$ & 26274 & 28467 & 25909 & 27785 \\
\hline Capes, Copet, CAPLP, Capeps & 23024 & $-10,8 \%$ & 25814 & 26176 & 27752 & 30357 \\
\hline Agrégation & 8661 & $-8,5 \%$ & 9461 & 9650 & 10089 & 10618 \\
\hline$C P E, C O P$ & 3671 & $+2,2 \%$ & 3592 & 4128 & 4209 & 4658 \\
\hline $\begin{array}{l}\text { Concours et examens de la } \\
\text { fonction publique (hors enseignants) }\end{array}$ & 23737 & $+2,6 \%$ & 23126 & 25269 & 26579 & 28902 \\
\hline Concours cotégorie $A$ & 8347 & $-1,9 \%$ & 8510 & 7871 & 7196 & 8035 \\
\hline Concours cotegorie B & 9233 & $-4,3 \%$ & 9651 & 11410 & 12195 & 11945 \\
\hline Concours cotégorie $C$ & 6157 & $+24,0 \%$ & 4965 & 5988 & 7188 & 8922 \\
\hline Formations professionnelles & 17232 & $-2,2 \%$ & 17615 & 18737 & 20872 & 24282 \\
\hline Con cours et exomens du dom oine sonitaire et socid & 11543 & $-2,3 \%$ & 11815 & 12553 & 14743 & 17539 \\
\hline Préparations de diplömes professionnels & 4328 & $-1,7 \%$ & 4402 & 4717 & 4650 & 5256 \\
\hline Préparations aux examens ef tests de langues & 1361 & $-2,6 \%$ & 1398 & 1467 & 1479 & 1487 \\
\hline Formations spécifiques & 48461 & $+6,7 \%$ & 45437 & 51423 & 42705 & 37097 \\
\hline Intec & 31153 & $+16,5 \%$ & 26751 & 26833 & 22492 & 21589 \\
\hline SNCF & 6947 & $-18,5 \%$ & 8523 & 11128 & 8406 & 8179 \\
\hline Amees (CML1 et CML2) & 3088 & $-22,8 \%$ & 3998 & 6020 & 6899 & 3897 \\
\hline Police ${ }^{2}$ & 6664 & $+10,8 \%$ & 6016 & 6234 & 4099 & 3189 \\
\hline Tutelec & & & - & 1085 & 580 & \\
\hline Autres & 609 & $+308,6 \%$ & 149 & 123 & 229 & 243 \\
\hline Formations libres tous secteurs ${ }^{3}$ & 5171 & $-6,3$ & 5518 & 6783 & 7033 & 8922 \\
\hline Formations libres en langues ${ }^{4}$ & 5186 & $-13,7 \%$ & 6008 & 6925 & 7851 & 8348 \\
\hline Produits sans suivi de formation & 9723 & $+2,5 \%$ & 9484 & 11748 & 11357 & 10884 \\
\hline Total & 317796 & $-1,8 \%$ & 322861 & 352006 & 353554 & 368163 \\
\hline
\end{tabular}

Tabela 30: Distribuição 2004 e evolução das inscrições por níveis e tipos de formação. Fonte: CNED - Disponível em: <http://www.cned.fr/fr/lecned/pdf/rapport2004.pdf >. Acesso em: 7 nov. 2005. 
Sem dúvida este setor representa uma das principais vias de desenvolvimento do CNED. Esforços foram empreendidos em 2004 para harmonizar a oferta a fim de estimular a capacidade de responder às necessidades do mercado.

\section{Cursos oferecidos}

O CNED oferece uma variedade de formações específicas para grandes instituições, como o exército francês e a Société Nationale des Chemins de Fer Français (SNCF), cujo fundamento está na criação de formações adaptadas, na construção de novos percursos de formação e nas transferências de competências. Tais formações são resultado da significativa experiência pedagógica da instituição e do seu know-how em engenharia de formação a distância. Atualmente, o CNED prepara indivíduos tanto do ponto de vista pedagógico como tecnológico, visando satisfazer os pedidos de diferentes formações particulares, atendendo às necessidades prementes de empresas privadas, instituições públicas, diversos setores administrativos, comunidades, estabelecimentos de ensino e/ou ainda interesses de países parceiros.

Estas são as principais categorias de cursos superiores atendidas pelo CNED: BTS $^{\mathbf{2 0 8}}$ voltado para o setor de Serviços, Indústria, área de Saúde e Trabalho Social; Deug estudos de graduação com licenciatura (bacharel em Artes Plásticas, Design de produtos culturais, etc.); DU - Diploma Universitário nas áreas de Astronomia, Direito de Propriedade Industrial, Multimídia, Gerenciamento de Projetos, etc.; Maîtrise - grau de mestre nas áreas de ensino de Francês como língua estrangeira, Contabilidade e Finanças, etc.; DESS - estudos avançados em nível de graduação nas áreas de Análise das Necessidades de Treinamento e Métodos, Psicologia Clínica e Patológica, Economia, Gerenciamento, etc.

Cada tipo de formação recebe uma designação própria que atende às especificidades do modelo vigente do ensino francês, com princípios de adaptação sem restrições formativas, uma vez que o CNED procurar efetivamente não distinguir formação aberta e a distância de formação tradicional, ou seja, realizada nos moldes presenciais, o que contribui muitas vezes para depreciar os objetivos e a seriedade da educação a distância.

\footnotetext{
${ }^{208}$ BTS - Sigla para Brevet deTechnicien Supérieur. É um diploma nacional concedido por instituições francesas de ensino superior, que sancionam dois ou três anos de estudos em uma determinada área de especialização. Um brévet de génie mécanique, por exemplo, é de um diploma de engenharia mecânica. Na França, há diplomas para vários campos de especializações técnicas e, principalmente, na área de serviços, como turismo, hotelaria, economia familiar, etc.
} 
A ênfase do processo pedagógico do CNED está nas possibilidades de expansão de oportunidades de formação educacional diante das necessidades diversificadas do mundo contemporâneo: necessidades locais/regionais, urbanas, rurais, nacionais, globais e necessidades educacionais, acadêmicas, profissionais e de formação geral.

Desse modo, o Centro procura promover formação em diversos níveis tradicionais de ensino, que vão desde o fundamental, passando pelo médio normal, pelo profissionalizante e o superior (ciência e tecnologia, ciências humanas), pós-graduação (várias especialidades), até passar por formações mais flexíveis e menos tradicionais, sem a necessidade de diplomas ou certificados: aulas de reforço para alunos da rede de ensino francês, cursos preparatórios para concursos públicos, aulas de conhecimentos gerais para a população, assim como cursos de requalificação profissional para atender às demandas crescentes do mercado de trabalho francês e global.

Grosso modo, o CNED atende especificamente a quatro principais domínios de formação educacional: Educação Escolar; BTS - Ensino Superior em nível de graduação; Formação para Adultos e Preparação para Concursos.

\section{Sistema de Estudos}

Para os cursos de ensino maternal, fundamental e médio, técnico e profissionalizante, as condições para ingresso são: ser de um estabelecimento público ou privado, contratante dos serviços do CNED; esclarecer os motivos pelos quais deseja cursar o nível de escolaridade demandado (com exceção feita à $1^{\mathrm{a}}$ série ou seu término); se tiver interrompido seu curso após um ano de estudos, apresentar seu boletim de notas do período. Para cursar o ensino fundamental, é necessário ter de 5 a 12 anos de idade e receber autorização/orientação do conselho de ciclo do ensino fundamental; para cursar o ensino médio, ter pelo menos 16 anos e estar cursando o ensino médio, ou então mais de 16 anos, no caso de ter interrompido seus estudos colegiais e ficar sob inspeção do corpo acadêmico, que acompanha o aproveitamento escolar do aluno. No caso de aluno do exterior, é preciso estar com inscrição autorizada no CNED para a entrega dos serviços culturais via embaixada da França no país do residente.

Há ainda outros cursos que não determinam a obtenção de títulos ou diplomas, sendo oferecidos a todos os interessados em formação aberta a distância, sem exceção. No 
caso destes cursos, não há necessidade premente de requisitos básicos, pois eles apenas servem para fornecer qualificações adicionais ou ainda para aprimorar $o$ desenvolvimento pessoal dos indivíduos.

A universidade a distância do CNED possui mais de 3.000 módulos de formação, recebendo mais de 10.000 ligações telefônicas diárias, o que perfaz um total de mais de 1,5 milhões de ligações anuais. ${ }^{209}$

\section{Materiais de estudos e estratégia instrucional}

O CNED coloca à disposição dos alunos ferramentas pedagógicas indispensáveis para os seus cursos, especificamente: materiais impressos, fitas e videocassetes, programas de televisão, assessoramento pedagógico via telefone ou internet, treinamento on-line, cursos baseados em páginas web, salas de aula virtuais pelo campus eletrônico (Campus Électronique $\left.{ }^{210}\right)$.

$\mathrm{Na}$ tabela abaixo, podemos observar que o suporte principal dos cursos continua sendo o material impresso, contando com um forte componente audiovisual, e uso de recursos da internet.

\section{Utilisation des différents supports dans les produits de formation}

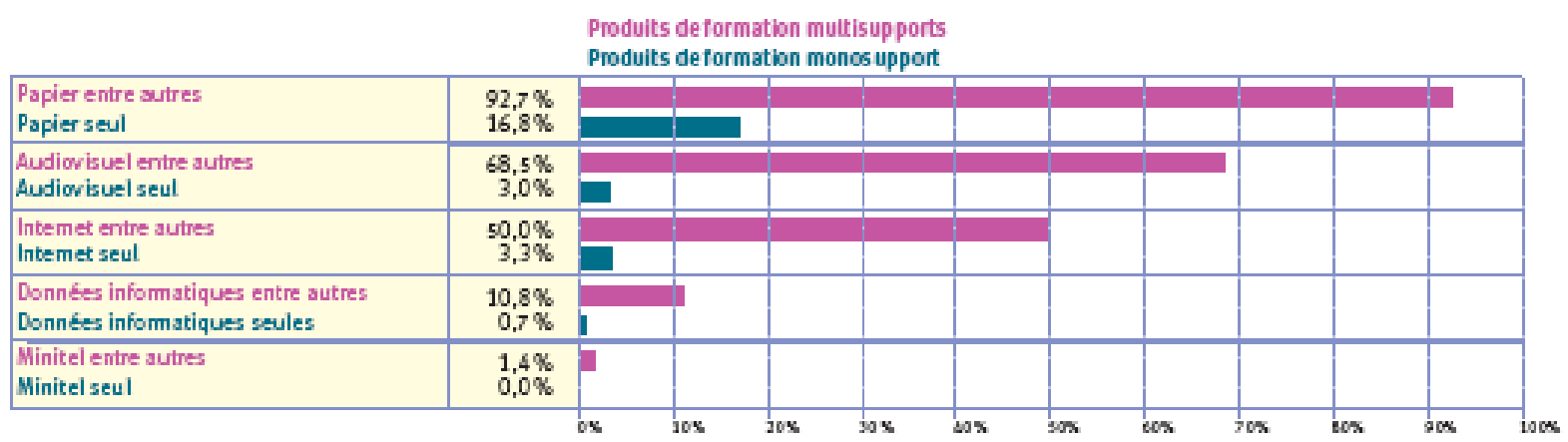

Tabela 20: Utilização dos diferentes suportes nos produtos de formação do CNED.

A princípio, a estratégia pedagógica do CNED permeia as seguintes facilidades dadas a seus alunos: informação completa para propiciar também formação educacional completa do aluno; ensino a distância como forma complementar de acesso ao conhecimento; formação profissional contínua a distância; acompanhamento com

\footnotetext{
${ }^{209}$ Centre National d'Enseignement à Distance. Disponível em : <http://www.cned.fr/> Acesso em: 27 jan. 2005.

${ }^{210}$ Trata-se de uma plataforma de serviços de formação proposta pelo CNED.
} 
bastante proximidade (inclusive presencial) para responder às necessidades vitais de cada aluno.

A capacidade de fornecer informação completa ao aluno se define pela própria caracterização do material instrucional que é disponibilizado a ele durante suas aulas, de modo gratuito, ou seja, sem obrigatoriedade de pagamento ou reembolso incluso. Os materiais fornecidos obedecem sempre ao seguinte modo de organização: pesquisa por objetivos; pesquisa por temas; pesquisa por referências; pesquisa por palavras-chave.

Isso acompanha de certo modo as tendências contemporâneas de elaboração de materiais em função dos atuais avanços tecnológicos que permitem uma compreensão mais complexa dos processos de construção e inter-relação de conhecimentos. Também neste sentido, o aluno recebe um prospecto de todos os cursos contendo o mesmo tipo de organização. Assim ele pode escolher as disciplinas mais compatíveis com seus interesses de formação. Vários tipos de prospectos são fornecidos, definindo os estabelecimentos de ensino parceiros do CNED, contendo suas principais áreas de formação, disciplinas, programas e objetivos de cada curso. No caso de interesse específico na área de educação escolar, o aluno recebe um livreto para rever todas as suas noções essenciais, além do acesso a um site da internet para testar e avaliar seus conhecimentos interativamente.

Quanto à complementaridade educacional que o CNED se propõe oferecer, três elementos são apontados como significativos na sua contribuição para incluir socialmente seus alunos: 1) o método CNED pressupõe a busca do êxito profissional e acadêmico de seus estudantes; 2) há uma série de facilidades durante o processo de matrícula dos alunos no instituto, sendo fornecidas as devidas orientações a eles de como agir, em cada caso, para defender seus direitos e cumprir seus deveres como estudantes; 3) os alunos têm direito à seguridade social estudantil, sendo dada toda a orientação adequada no sentido de assegurar a eles o uso de tal benefício, quando necessário.

Já no que diz respeito à formação profissional contínua a distância, o CNED fornece este tipo de formação profissional em um de seus próprios institutos credenciados. Procura também facilitar nas condições de pagamentos e encargos financeiros por parte de seus alunos, cuida de organizar todo o acompanhamento relativo ao processo de 
formação contínua dos alunos inscritos, bem como informa ainda a respeito de todos os cursos disponíveis com suas grades curriculares e os custos envolvidos.

Em relação ao tipo de acompanhamento dado aos alunos, naturalmente ele segue uma norma de execução de acordo com a idade do aluno, o tipo de curso designado a ele, bem como suas necessidades pedagógicas. Em todos esses casos, há um profissional definido como uma espécie de "formador educacional" (formateur) que, de tempos em tempos, realiza encontros presenciais e acompanha todo o processo de ensino e aprendizagem dos alunos, cuidando inclusive de integrá-los aos poucos às atividades de outros inscritos, o que, de certa forma, acaba por contribuir, com o tempo, para a inserção deles em outros métodos pedagógicos abertos e a distância, desenvolvidos pelo próprio instituto. Toda a rede de centros de formação que opera em parceria com o CNED pode receber alunos que residam próximos a eles, que queiram cumprir suas atividades pedagógicas, compartilhar suas experiências ou ainda pôr em prática as aprendizagens teóricas adquiridas, pois o CNED parte do princípio de que o aluno aprende mais quando recebe acompanhamento pedagógico presencial.

Em detrimento do processo de adaptação institucional às necessidades dos alunos inscritos, o CNED se propôs estruturar seus cursos de formação de acordo com três fórmulas essenciais, visando permitir com que cada uma delas apresentasse toda a extensão dos seus conteúdos e norteasse a relação de competências e habilidades desejadas, além do acompanhamento pedagógico de base necessária. À fórmula "clássica" acrescentou-se atualmente uma fórmula "aligeirada", completada por uma "reforçada", com a mesma qualidade, mas com um volume de deveres e serviços variáveis e a utilização mais ou menos acentuada das tecnologias de informação e comunicação.

O CNED também trabalha na criação de uma marca e no lançamento de um catálogo chamado "CNED empresas". O catálogo terá por objetivo o desenvolvimento de um curso de formação operacional, certificando ou qualificando profissionais, por meio de módulos de curta e/ou média durações que sejam capazes de responder às necessidades expressas por parte dos setores contratantes destes serviços.

Para completar suas aspirações de treinamento vocacional dedicado a todos os tipos de alunos, o CNED desenvolveu uma quantidade de produtos voltados exclusivamente 
para treinamentos profissionais contínuos, acompanhados por serviços especiais que procuram atender às especificidades e às exigências de cada demanda, quer seja formada por profissionais de setores públicos quer seja por privados. Deste modo, foram criados segmentos de produtos para treinamento completamente customizados, assim como programas específicos de conteúdos e sistemas de entrega de materiais instrucionais para cada nicho mercadológico.

Entre os recursos tecnológicos empregados na infra-estrutura de ensino e aprendizagem do CNED, há, sem dúvida, dois que favorecem muito os resultados obtidos no desempenho da qualidade dos cursos que a Instituição oferece: o sistema Minitel e a TV Interativa da França.

O Minitel é um aparelho de baixo custo, lançado em 1982 na França, no início das experimentações com o uso da tecnologia do videotexto. Trata-se de uma tecnologia genuinamente francesa, cuja grande relevância está justamente no processo de inclusão social desta tecnologia na vida cotidiana dos cidadãos franceses muito antes do acesso à internet para fins comerciais, e muito antes do surgimento das primeiras grandes redes acadêmicas de informações por computador. Sua vantagem é permitir ao usuário conectar-se a diversos serviços de acesso a informações. Com isso, o Minitel propiciou um cenário inovador de uso social da tecnologia, de modo antecipado aos norteamericanos, asiáticos e outros europeus, lançando os franceses numa posição de destaque e vanguarda no modo de apropriação coletiva desta tecnologia informacional, o que, de certa forma, também, a princípio gerou uma grande resistência por parte dos franceses quanto à adoção da internet como rede principal de acesso à informação e à comunicação, seguindo somente bem mais tarde a tendência mundial comum de globalização desta tecnologia. A cultura de uso do Minitel, já que ele criou as bases de ambientação da população para aderir às novas tecnologias, torna-o ainda um instrumento indispensável para o acesso à educação e ao aprendizado em larga escala na França, o que justifica a sua significativa utilização por parte do CNED para disseminar informações e recursos pedagógicos a um grande contingente populacional.

Já a TV Interativa Francesa (ETI - Émissions de Télévision Interactives) é uma tecnologia bem mais recente. Sua incorporação para fins pedagógicos e instrucionais tem sido feita desde 1998, quando começaram a ser realizados e testados os primeiros programas educativos franceses com a apropriação desta tecnologia emergente. Desde 
então foram determinados também os primeiros relatórios em relação ao nível de satisfação que este recurso propiciava aos alunos do CNED. A grande vantagem desta tecnologia está em ampliar o acesso à educação, independentemente de se ter ou não um microcomputador pessoal. Ela também re-aproveita uma base tecnológica já bastante disseminada em grande parte do mundo, a televisão. Ou seja, o conceito de TV Interativa tanto pressupõe novos avanços tecnológicos de última geração, com alta capacidade de definição ou resolução de imagens com tratamento digital, e com recursos interativos imediatos (on-line) e assíncronos, como também faz valer o uso de aparelhos antigos a partir do processo de codificação e decodificação de informações e imagens. Nesse sentido, a não-obsolescência tecnológica dos recursos de informação e comunicação torna ainda mais expansível o atendimento a demandas cada vez mais heterogêneas de alunos por todos os meios que favoreçam seu acesso à educação em termos gerais.

\section{Centros de Estudos}

Por meio de seus parceiros, o CNED conseguiu desenvolver uma infra-estrutura de apoio à sua estratégia pedagógica que possibilitasse a criação de cursos intensivos completamente personalizados, podendo deste modo estar presente em toda a França e também no território das ex-colônias francesas, a partir da seguinte estrutura organizacional: 8 institutos com filiais no exterior e cerca de 500 locais correspondentes para o desenvolvimento de trabalhos práticos e serviços individuais.

Cada um dos institutos é responsável por dar suporte às atividades do CNED dentro das suas atribuições e vocações específicas, ou seja, conforme as necessidades das demandas de cada região às quais eles servem em termos de formação educacional e profissional. Abaixo estão descritos todos os cursos oferecidos por cada um dos institutos que formam o complexo do CNED na França.

A partir de um sistema de parcerias nacionais e internacionais, o CNED permite que cidadãos franceses, residentes em locais distantes dos grandes centros urbanos ou mesmo residentes em outros países, continuem seus estudos de um modo mais flexível. Isso inclui relações de parcerias com centenas de escolas francesas e não francesas no exterior, principalmente para favorecer o treinamento de professores de francês como 
língua estrangeira (FLE), bem como para a transferência de know-how e métodos de ensino a distância para seus parceiros e colaboradores.

As parcerias internacionais incluem também acordos de cooperação com universidades, empresas de tecnologia educacional e $\mathrm{EaD}$, bem como organizações internacionais (órgãos multilaterais), de modo que o CNED contribua para marcar significativamente a presença da França dentro da área de educação a distância no exterior. 


\subsubsection{Espanha}

\section{a) Universidad Nacional de Educación a Distancia}

\section{Contexto Histórico}

A UNED é uma universidade pública de âmbito estatal, criada em agosto de 1972, com o objetivo de fornecer serviço de qualidade a mais de 180.000 alunos que estudam e se formam nela, constantemente.

A UNED possui numerosos centros associados, espalhados por todo o território nacional e também em outros países do mundo. Trata-se da universidade com maior número de alunos de toda a Espanha.

Seu modelo de universidade pública e aberta se baseia na concepção original da Open University da Inglaterra, procurando sempre manter a mesma qualidade na tradição de ensino superior de outras instituições espanholas renomadas. Seu grande diferencial está justamente no nível de abrangência territorial, no emprego de diferentes metodologias de ensino e aprendizagem e na forte influência social que desperta com o uso de programas transmitidos por rádio e televisão.

Considerada atualmente a segunda maior universidade em todo o continente europeu, desde 1997 se destaca como instituição associada à UNESCO para a promoção da pesquisa, do desenvolvimento e da documentação no campo da educação a distância, em termos mundiais. Nesse aspecto, salienta-se que a UNED congrega duas cátedras importantes da UNESCO: uma de educação a distância, conforme já mencionado, e outra na área de educação ambiental e desenvolvimento sustentável.

Apesar de ser de caráter público, a UNED cobra mensalidades, já que na Espanha apenas o ensino obrigatório deve ser gratuito. Assim, 75\% do orçamento da instituição provém de captações de recursos próprios, enquanto os outros $25 \%$ vêm do Estado $(\text { MARQUES, 2004) })^{211}$. Em 2004, a universidade obteve um orçamento de $€ 153.791,26$.

\footnotetext{
211 Disponível em: <http://portal.webaula.com.br/noticia.aspx?sm=noticias\&codnoticia=327>. Acesso em: $10 \mathrm{fev}$ 2007.
} 


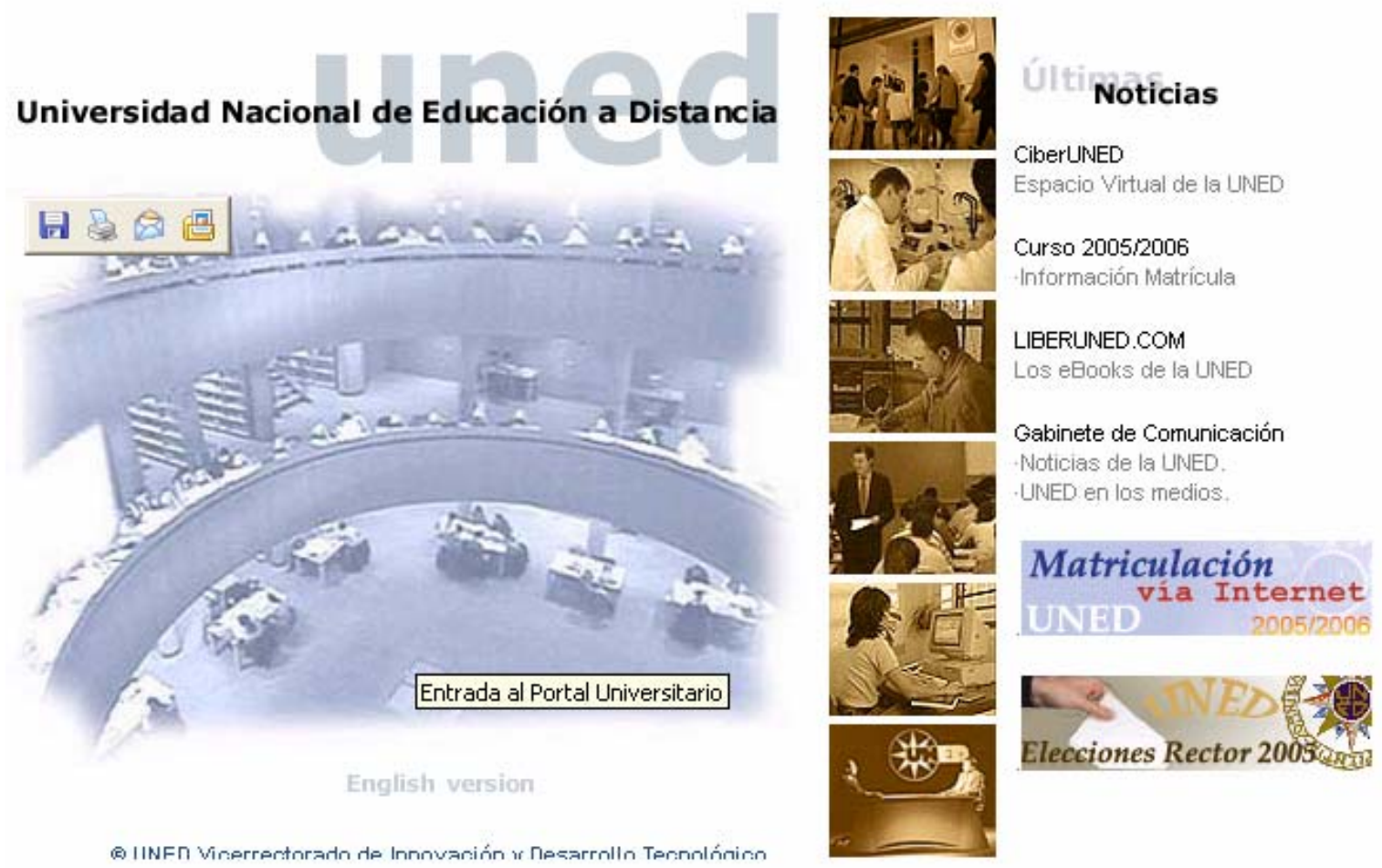

Figura 53: Portal da Universidad Nacional de Educación a Distancia. Fonte: Universidad Nacional de Educación a Distancia. Disponível em: <http://www.uned.es >. Acesso em: 28 jan 2005.

\section{Objetivos}

A princípio, a UNED tem como missão prover acesso ao serviço público de educação superior na Espanha por meio da modalidade de educação a distância. Para isso, emprega diversas estratégias de apoio pedagógico, a fim de facilitar o acesso ao ensino universitário e a continuidade de estudos para os alunos interessados, desde que atendam a certos requisitos básicos de formação.

\section{Público-alvo}

Os alunos escolhem a UNED por diversas razões: por seus recursos laboratoriais, por motivos de ordem econômica e, principalmente, pelas dificuldades de acesso regular a outras instituições, muitas vezes distantes tanto do local de trabalho quanto do lugar onde residem, impossibilitando o deslocamento fácil e culminando na perda da qualidade do tempo livre para o estudo e o lazer em consonância com outras atividades importantes.

Atualmente a UNED conta com 25.406 alunos em cursos de educação permanente matriculados, sendo que, destes, 1.437 estudam em centros localizados no exterior. 
No período de 2005-2006, aproximadamente 15.000 estudantes fizeram parte do chamado Curso de Acesso para maiores de 25 anos - uma categoria de cursos criada pela instituição para expandir o acesso a vários cursos superiores ao maior contingente possível de jovens e adultos com dificuldades de freqüentar cursos presenciais, com poucos recursos econômicos ou com necessidades especiais de ensino e aprendizagem.

\section{Recursos Humanos e Materiais}

A Universidade possui cerca de 1.270 funcionários atuando em diversos setores de apoio às atividades acadêmicas, além de contar com mais de 1.400 professores, distribuídos por 9 faculdades, 2 escolas técnicas e pelo CAD (Curso de Acesso a la Universidad), localizado na sede acadêmica da instituição. São 6.253 os professorestutores, dos quais pelo menos 1.000 deles costumam desenvolver suas atividades na sede central da Universidade, enquanto por volta de 5.000 deles atuam diretamente nos vários Centros Associados à Universidade.

A estrutura acadêmica da Universidade perfaz diferentes Comunidades Autônomas, que integram 60 Centros Associados, com mais de 80 locais de extensão de aulas a distância, além de 25 centros nos limites da própria Comunidade de Madri, onde são realizadas tutorias e provas presenciais, normalmente elaboradas pelas equipes de docentes da instituição.

\section{Cursos oferecidos}

A UNED é atualmente líder na Espanha em termos de tecnologias de vanguarda aplicadas ao processo de aprendizagem, possuindo a maior oferta de cursos virtuais do país.

São oferecidos programas de doutoramento nas principais áreas do conhecimento. No campo da formação continuada, existem mais de 380 cursos de pós-graduação e mais de 250 na área de atualização de conhecimentos. Há ainda vários cursos de extensão universitária, compreendendo mais de 270 cursos de verão, entre outros, e diversos cursos de idiomas, sob coordenação do Centro Universitário de Idiomas da UNED.

A universidade possui ainda 25 titulações oficiais, 115 doutorados, 599 cursos de educação permanente, 4.796 publicações impressas em periódicos e 1.038 publicações 
eletrônicas. O número total de professores na sede central é de 1.433 , sendo que nos centros associados o número sobe para 7.765 profissionais. ${ }^{212}$

\section{Sistema de Estudos}

Com o passar do tempo, a UNED procurou aprimorar seu sistema de ensino, tornando-o cada vez mais flexível. Por isso são oferecidos cursos em diversas áreas, que vão desde Licenciatura Plena (formação de professores de Matemática, Física, Biologia, etc.) até Psicologia, Direito e Administração de Empresas.

Sem dúvida, um dos grandes alicerces institucionais da UNED é sua Fundação Geral (Site: http://www.fundación.uned.es). A Fundação UNED tem por objetivos delinear, promover e realizar todas as atividades possíveis de colaboração e apoio às funções de docência e pesquisa, tendo em vista os princípios que regem a legislação universitária espanhola e seus estatutos vigentes. Desse modo é um instrumento eficaz para que a Universidade Nacional de Educação a Distância (UNED) consiga levar a cabo sua missão em prol do desenvolvimento científico, cultural, social e econômico, a partir do incentivo à pesquisa e à formação profissional, tanto na sociedade espanhola como nos países com os quais mantêm atividades e relações de cooperação mútua, principalmente os que fazem parte da chamada Iberoamérica, ou seja, países da América Latina cujo idioma oficial é o espanhol ou o português.

A Fundação UNED oferece cursos de mestrado universitário (com base fundamentalmente teórica), de especialização universitária base teórico-prática, de perito universitário (com base fundamentalmente prática) e de perito profissional (mais vinculado às necessidades do mercado de trabalho), nas seguintes áreas: Ciência e Engenharia; Direito; Economia e Empresa; Educação; Humanidades; Novas Tecnologias; Psicologia; Saúde.

Para se inscrever tanto no curso de mestre como no de especialista universitário, o aluno precisa possuir a titulação mínima em Licenciatura, Engenharia ou Arquitetura. Já no caso do curso de perito universitário, ele precisa apenas do diploma de Engenheiro ou Arquiteto Técnico.

\footnotetext{
${ }^{212}$ Universidad Nacional de Educación a Distancia. Disponível em:

$<$ http://apliweb.uned.es/comunicacion/plantilla2.asp?pag=34> Acesso em: 25 jul 2005
} 
O ingresso nos cursos pode ser feito de dois modos: do modo habitual e com redução de taxas. O aluno pode conseguir uma redução de até $90 \%$ do valor pago em taxas acadêmicas e atividades de docência (incluindo isenção com os custos do material instrucional), logo na primeira matrícula dos estudos de Formação Contínua, desde que atenda a um dos seguintes critérios: possuir renda igual ou inferior a 33\% dos custos do curso; ser oficialmente reconhecido na condição de vítima de terrorismo; ser beneficiário de família numerosa de categoria especial.

Para obter os benefícios de redução de custos, o interessado deve apresentar oficialmente os documentos comprobatórios originais e fotocópias no ato de sua matrícula, quando terá direito a escolher apenas um dos cursos dentro do Programa de Especialização (Mestre, Especialista e Perito Universitário), além de um outro do Programa de Desenvolvimento Profissional (Perito Profissional). A isenção será válida para se concorrer apenas a um dos cursos selecionados, não podendo ser empregada como ajuda para outros estudos.

$\mathrm{Na}$ segunda matrícula, caso ainda mantenha as mesmas condições anteriormente assinaladas, para se matricular em uma mesma atividade formativa, o aluno deverá arcar com pelo menos 50\% dos custos com taxas acadêmicas e atividades de docência. A partir da terceira matrícula sucessiva, não terá mais direito à isenção de taxas.

A Fundação UNED permite a inscrição em até dois cursos oferecidos. Solicitações acima disto serão sempre desconsideradas. Além disso, o aluno que receber, de algum modo, desconto de matrícula de até 90\%, em qualquer um dos cursos, deverá encaminhar a solicitação por correio, com o impresso de matrícula e a fotocópia do documento que lhe dá direito a tal abatimento.

A maior parte dos cursos oferecidos possui duas opções de estruturas curriculares: estrutura modular e não modular. Somente os cursos de formação para perito profissional é que possuem estrutura única e modular.

A UNED possui também um Centro Universitário de Idiomas a Distância, o CUID, uma unidade especializada pertencente à Faculdade de Filologia da UNED e subordinada ao Vice-reitorado de Coordenação e Extensão Universitária, cuja finalidade é, principalmente, promover o ensino das línguas espanholas co-oficiais e de idiomas estrangeiros, com destaque para as línguas européias mais comuns. Ao aluno que 
concluir seu curso será concedido um título dos centros associados da UNED em colaboração com o CUID.

A metodologia do CUID foi desenvolvida pela equipe da própria UNED, que adota uma modalidade semipresencial de ensino e aprendizagem, combinando diversos meios de formação, como tutoriais presenciais, materiais didáticos pensados para uma aprendizagem autônoma em diferentes suportes tecnológicos (impressos multimídia), aulas virtuais voltadas ao trabalho colaborativo e aulas telemáticas com o uso de computadores, recursos de multimídia e conexão à internet, disponíveis nos diversos centros associados à UNED.

O ensino-aprendizagem de línguas é estruturado tendo como base as seguintes áreas:

- Línguas co-oficiais da Espanha (espanhol como língua estrangeira, galego, catalão e basco).

- Línguas estrangeiras (inglês, francês, alemão, italiano, português, chinês e árabe).

Qualquer aluno com mais de 18 anos pode matricular-se em um dos cursos oferecidos pelo centro de línguas da UNED. Alunos que já tenham um nível inicial ou intermediário de conhecimento da língua estrangeira podem ascender para o nível seguinte, desde que realizem uma prova específica de nivelação em um dos centros associados da UNED. As avaliações são realizadas anualmente, no período de maio e junho e excepcionalmente em setembro, compreendendo duas provas: uma escrita e outra oral.

Cada curso custa em média 266,50 euros. O aluno poderá obter uma redução ou isenção dos custos de matrícula desde que atenda aos seguintes critérios: ser estudante e funcionário da UNED ou de um dos seus centros associados (custo de 167 euros); ser beneficiário, no caso de pertencer a família numerosa (desconto de 50\%).

\section{Materiais de estudo e estratégia educacional}

Ao ingressar na universidade, os alunos passam a ter direito aos seguintes materiais instrucionais: acesso a sistemas de comunicação multimídia (videoconferência, CDROM, suporte em informática), materiais impressos (livro-texto, agendas), fitas de vídeo e programas de rádio e TV. 
Os exames finais só podem ser realizados no Centro de Estudos no qual o aluno se inscreveu.

Todos os Centros de Estudos são devidamente equipados para suprir as necessidades dos alunos, que podem contar ainda com o apoio de tutores qualificados para quaisquer esclarecimentos, podendo contatá-los por telefone, e-mail, fax ou correio convencional.

Há também, destinado aos alunos, um Centro de Orientação, Informação e Emprego (COIE - Centro de Orientación, Información y Empleo), cujo objetivo é oferecer um serviço especializado em orientação acadêmica e profissional para qualquer estudante ou aluno formado pela UNED que deseje receber ajuda ao longo de seus estudos, visando o seu desenvolvimento profissional e a posterior inserção no mercado de trabalho. Esse serviço é gratuito e possibilita às empresas colaboradoras com o Centro receber candidatos com um perfil competitivo. Desse modo eles podem cumprir tanto suas necessidades profissionais como o exercício prático, que compreende parte do processo pedagógico da instituição.

Quanto ao apoio e suporte ao corpo docente, o Instituto Universitário de Educação a Distância (IUED) promove diferentes cursos internos voltados à formação e à qualificação dos professores da UNED, tanto para aqueles pertencentes ao núcleo da sede central da instituição quanto para os professores-tutores distribuídos nos vários centros de estudos. Esse suporte se relaciona principalmente com a metodologia de ensino a distância aplicada na UNED.

Desde o período de 2000-2001, está em processo crescente o plano de virtualização da UNED, sendo que o IUED tem sido responsável por atender fundamentalmente às necessidades de formação das equipes docentes da sede central da Universidade, tendo em vista o desenho e a administração de todos os cursos virtuais, assim como a preparação dos tutores que irão desempenhar o acompanhamento do processo de ensino e aprendizagem nesses cursos, com a utilização da plataforma WebCT.

Todos os novos tutores recebem formação pelo IUED, por meio de cursos realizados anualmente, que lhes dão a titulação de Venia Docendi (título de autorização para exercício docente). Esses cursos combinam sessões presenciais com sessões de encontros e interações pela internet, havendo a possibilidade de alguns deles ser cursados integralmente a distância. 


\section{Avaliação Educacional}

Toda a avaliação institucional da UNED está sob a responsabilidade do IUED, e é realizada pela Unidade Técnica de Avaliação Institucional (UTEVI - Unidad de Evaluación Institucional), criada pelo Vice-reitorado de Avaliação e Qualidade durante o período de 2003-2004. Atualmente, é a Direção Técnica de Qualidade que se encarrega do processo de avaliação institucional, sendo tal órgão subordinado também ao IUED, por meio do Vice-reitorado de Qualidade e Inovação Docente. Todo o trabalho feito pelo IUED neste campo profissional tem como base a avaliação de diversos títulos concedidos pela UNED como marco do Programa de Qualidade das Universidades, uma vez que o Instituto colabora com diversos comitês de autoavaliação e participa da elaboração dos informes de diversos títulos da UNED. Entre os mais recentes, destacam-se:

- Ciências Políticas e Sociologia

- Engenharia Técnica em Informática de Sistemas

- Engenharia Técnica em Informática de Gestão

Já o plano de avaliação institucional externa da UNED está sob a responsabilidade da Agência Nacional de Avaliação da Qualidade e Credenciamento (ANECA - Agencia Nacional de Evaluación de la Calidad y Acreditación. Site: http://www.aneca.es), que realiza as avaliações de instituições de ensino superior na Espanha, provendo certificações e credenciamentos, além de analisar a qualidade de todo o contingente do seu professorado. Inicialmente, o plano de avaliação institucional manteve seu foco na recompilação dos dados referentes às titulações nas áreas de Administração e Direção de Empresas e Economia.

O Instituto Universitário de Educação a Distância (IUEC) continua a realizar a avaliação metodológica dos materiais didáticos da UNED, participando ativamente durante o desenvolvimento de diversos protocolos de avaliação da qualidade e da metodologia própria da UNED.

A avaliação do conteúdo dos materiais instrucionais fica a cargo da Unidade Técnica de Materiais Didáticos (MADI), cuja finalidade é contribuir para a melhor qualidade dos materiais empregados nos cursos da UNED. Pode-se dizer que a atividade de avaliação se completa com outras formas de investigação, assessoramento e formação, que se relacionam com a elaboração do material didático voltado à prática de educação a 
distância, não só no que diz respeito ao que é produzido e empregado pelos docentes da UNED como também por outras instituições nacionais e internacionais solicitantes deste serviço de acompanhamento profissional.

Nesse aspecto, a Unidade Técnica de Materiais Didáticos procura dar assessoria individualizada para quaisquer docentes que solicitem trabalhar com diversos materiais de apoio às suas atividades pedagógicas, sejam eles oriundos de instituições nacionais ou internacionais. Esta assessoria da MADI considera, grosso modo, a utilização dos materiais elaborados pela própria UNED, por parte de outras instituições e/ou profissionais em educação, prevendo apoio pedagógico em cada estrutura de uma unidade didática da UNED, além de fornecer a estrutura de um guia didático da instituição.

Com o grande acúmulo de experiência ao longo de muitos anos, a MADI, enquanto unidade de apoio do IUED, desenvolveu os protocolos de avaliação atualmente empregados para se avaliar os materiais didáticos da UNED, de acordo com suas especificidades de mídias: um protocolo de avaliação de materiais impressos e outro para avaliação de materiais audiovisuais, por exemplo. Atualmente já existe uma outra fase de protocolo de avaliação sendo desenvolvida, aquela aplicada à avaliação de cursos virtuais. A MADI avalia também uma grande quantidade de materiais impressos destinados ao ensino a distância em outras instituições, a saber:

- Ministério da Defesa da Espanha

- Instituto Nacional de Administrações Públicas (Espanha)

- Ministério de Educação e Ciência (Espanha): Curso de Especialista Universitário em Administração da Educação

- Universidade de São Paulo (Brasil): Escola de Enfermagem, campus Ribeirão Preto

O IUED atua ainda como instituto de pesquisa, realizando estudos sobre a própria metodologia da UNED, assim como sobre o enfoque da educação a distância em geral. Seus estudos e investigações servem de base para muitas das atividades avaliativas do instituto, assim como para prover a UNED com um campo de informações relevantes para estratégias a serem adotadas futuramente em educação a distância.

Quanto ao campo de investigação institucional, o IUED produz regularmente um Anuário Estatístico, contendo dados significativos para a adoção de estratégias e 
metodologias educacionais na UNED. O Anuário já contemplou uma série de dados sobre os aspectos quantitativos da atividade acadêmica e investigativa da UNED e de seus vários centros associados. Entre os estudos concluídos mais recentes figuram:

- Estudos sobre a valorização e uso dos guias didáticos da UNED

- Estudos sobre o corpo discente da UNED em centros penitenciários

- Estudos sobre perfis e opiniões dos alunos da UNED

- Estudos sobre o sistema educativo formal nos centros penitenciários: estudo comparativo dos perfis de homens e mulheres

- Estudos sobre os valores de formação presentes nos cursos virtuais da UNED

- Estudos sobre os valores e atitudes relacionado aos alunos matriculados nas áreas de Ciência e Tecnologia do Curso de Acesso da UNED, destinadas a maiores de 25 anos

Está em curso a realização de um estudo abrangente sobre os perfis psicológicos dos alunos da UNED, levando em conta o nível de repetência e o rendimento acadêmico. Esse estudo pretende considerar mais de 51.000 questionários, encaminhados durante o curso e o processo de matrícula dos alunos. Neste sentido, existem inúmeros projetos em andamento, como, por exemplo, um em cooperação com a Direção Técnica de Qualidade, com o qual se deseja a contribuição de especialistas de diversas áreas na análise dos dados coletados, como os professores da Faculdade de Políticas e Sociologia e da Faculdade de Psicologia. Acredita-se que tais profissionais poderão ter condições mais adequadas de realizar um estudo sobre a desistência dos estudantes da UNED, assim como desenvolver um estudo a respeito das expectativas dos alunos recémingressantes na Universidade.

Outro projeto em andamento é a elaboração de protocolos de investigação sobre a prática docente na UNED. Tal documento poderá facilitar o desenvolvimento de um guia com instrumentos para que os professores tenham condições de analisar e investigar sua própria prática docente. 


\section{Centros de Estudos}

A UNED possui 60 Centros de Estudos na Espanha, 20 Centros que operam no exterior e um escritório em Washington para desenvolvimento internacional.

Já os 20 Centros no exterior estão distribuídos pela Europa, América e África, contando ainda com 4 Centros dedicados exclusivamente à realização de exames presenciais. Os Centros operam graças a um sistema de cooperação com várias instituições locais, as quais promovem sessões de aulas face a face com professores pelo menos uma vez por semana.

Os Centros Internacionais da UNED estão localizados nos seguintes países: Alemanha (Berlim, Munique); Argentina (Buenos Aires, Rosário); Bélgica (Bruxelas); Brasil (São Paulo); Estados Unidos (Miami, Nova York, Washington); França (Paris); Guiné Equatorial (Malabo e Bata); Itália (Roma); Japão (Tóquio); Marrocos (Tanger); México (Cidade do México); Reino Unido (Londres); Suíça (Berna); Venezuela (Caracas); Peru (Lima).

Essa grande rede de distribuição, com centros espalhados por vários continentes, e responsável por manter a oferta educativa da UNED em vários pontos do mundo, só é possível em virtude de inúmeros convênios firmados com as seguintes instituições: o antigo Instituto Espanhol de Imigração e a Direção-Geral de Imigração do Ministério do Trabalho e Assuntos Sociais. No caso da Guiné Equatorial, por exemplo, os centros localizados em Malabo e Bata são mantidos graças à colaboração que a UNED recebe da Agência Espanhola de Cooperação Internacional - AECI (Agencia Española de Cooperación Internacional).

Em todos os Centros Estrangeiros são realizadas as provas presenciais, assim como as matrículas dos alunos. Cada aluno poderá selecionar o centro que mais atender às suas necessidades de desenvolvimento dos seus estudos, pois, em cada um deles, a UNED se propõe garantir a mesma qualidade de atendimento profissional e personalizado. $\mathrm{Na}$ maioria deles, o aluno também terá à sua disposição tutorias e orientação geral sobre estudos e carreiras profissionais com maior perspectiva no mercado.

Em geral, todos os alunos têm à sua disposição, nos Centros de Estudos, serviços que incluem: tutorias, que acontecem à tarde, uma ou duas vezes por semana para cada matéria, sempre em um horário compatível com o horário de trabalho dos alunos; 
arquivos de mídia e bibliotecas; compra e recebimento de formulários de matrícula; encontros com professores de vários departamentos nas filiais; recepção, agendamento e retorno de testes de avaliação a distância; diversas atividades culturais organizadas pelo Centro; contato com outros alunos; lições práticas; exames; acesso à sala de informática; compra de materiais de estudos da UNED; informações referentes a todas as atividades da universidade, entre outros.

Alguns centros oferecem sessões de videoconferência, sendo que todos eles provêem a transmissão de programas de televisão educativa realizados pela UNED, por meio do canal 2 da TVE (Televisão Educativa da Espanha). 


\subsection{Megauniversidades do continente americano}

\subsubsection{México}

a) Universidad Virtual - Tecnológico de Monterrey

\section{Endereço}

Av. Eugenio Garza Sada 2501 Sur - C.P. 64849 - Monterrey - Nuevo León - México

Tel.: Lada internacional 52, lada nacional 01-81, número 8358-2000.

\section{Centro de Serviços para Usuários da Universidade Virtual:}

Chat: http://www.tecvirtual.itesm.mx/chat

E-mail: atencionuv@itesm.mx

FAQ: http://www.tecvirtual.itesm.mx/atencionuv

Tel.: (Monterrey) (81) 83-284010 / 83-284034

Tel.: (nacional e sem custo) 01800-4393939 / 01800-1122832

Tel.: (EUA) 18774837842

\section{Contexto Histórico}

A Universidad Virtual foi fundada em 1989 pelo Centro Tecnológico de Monterrey, com a finalidade de fornecer educação de qualidade, independentemente das limitações geográficas impostas pela vasta extensão territorial do país, propiciando um ambiente educacional mais atraente e inovador.

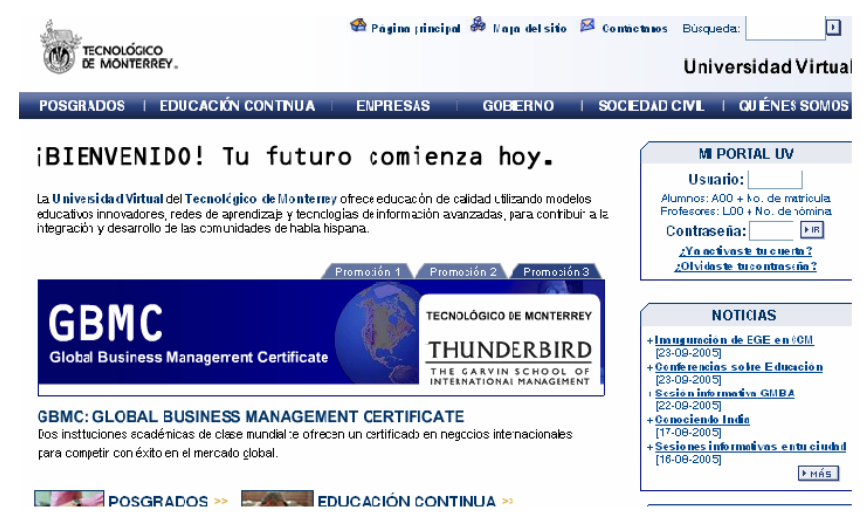

Figura 54: Portal da Universidad Virtual - Centro Tecnológico de Monterrey. Fonte: Universidad Virtual - Centro Tecnológico de Monterrey. Disponível em: <http://www.ruv.itesm.mx/>. Acesso em: 12 fev 2005 


\section{Objetivos}

A Universidade Virtual do Centro Tecnológico de Monterrey tem por objetivo fundamental formar indivíduos comprometidos com o desenvolvimento de suas comunidades, de modo a interferir significativamente na qualidade de seu meio social, econômico e político. Propõe-se também desenvolver campos de estudo relevantes que subsidiem o desenvolvimento sustentável do México.

Em razão de seus objetivos gerais, foram delineadas, a princípio, as seguintes metas a serem alcançadas ao longo da sua trajetória de desenvolvimento:

- Realizar uma reengenharia do processo de ensino-aprendizagem da instituição.

- Reiterar a importância das atividades de pesquisa e extensão universitária.

- Desenvolver cuidadosamente a plataforma tecnológica e comunicativa da Universidade Virtual.

- Promover o crescimento do Instituto do Centro Tecnológico de Monterrey.

- Continuar com o processo de aprimoramento contínuo da instituição.

- Internacionalizar o instituto.

- Reconhecer a importância crescente do desenvolvimento de novos modelos educativos apoiados na plataforma de telecomunicações, tendo como base as redes computacionais e a técnica dos multimeios.

- Promover a evolução da aprendizagem com base no uso de novas tecnologias de informação e comunicação.

- Inovar na utilização de modelos educativos que propiciem a criação de redes de aprendizagem apoiadas por avançadas tecnologias de informação.

- Contribuir para o desenvolvimento das comunidades de língua espanhola.

- Requalificar continuamente seu corpo docente e o de outras universidades do mundo.

- Levar educação de alto nível a novos espaços, interligando cada vez mais pessoas em lugares remotos. 


\section{Público-alvo}

A universidade possui mais de 85.000 estudantes matriculados em diversos cursos de graduação, pós-graduação e programas de treinamentos para desenvolvimento educacional. A UV oferece também programas de workshop para professores, educação continuada, programas gerenciais, conferências, além do AVE (Virtual Business Room), com um programa para negócios voltados aos interesses de empresas.

Segundo dados levantados pelo próprio ITESM - Instituto Tecnológico y de Estudios Superiores de Monterrey (Instituto Tecnológico e de Ensino Superior de Monterrey), em 2002 graduaram-se 1.342 alunos, tornaram-se mestres 19 e somente 1 aluno formouse doutor pela Universidade Virtual de Monterrey.

Além disso, 3.956 profissionais chegaram a obter um grau acadêmico pela instituição, em nível de especialização, mestrado ou doutorado. Ainda durante o ano letivo de 2002, foram registrados 24.389 alunos regularmente matriculados em programas acadêmicos e 56.581 matriculados em programas de extensão universitária.

\section{Recursos Humanos e Materiais}

A Universidade possui vários centros de pesquisa e diversas revistas eletrônicas especializadas nas áreas de educação, educação com uso de novas tecnologias e educação a distância. Periodicamente são publicados no portal da Universidade muitos eventos relacionados à educação a distância, realizados em todo o mundo, para conhecimento de seu corpo docente e como estímulo para que participem ora como ouvintes ora como congressistas, compartilhando suas experiências com outros parceiros e colegas envolvidos com o mesmo processo de ensino e aprendizagem na universidade virtual.

\section{Cursos oferecidos}

O Instituto Tecnológico de Ensino Superior de Monterrey define cinco categorias básicas de atendimento a demandas educacionais: pós-graduação, educação continuada, empresas, governo e sociedade civil. Os cursos em geral procuram relacionar necessidades contemporâneas de formação educacional e profissional. Por exemplo, no 
campo da administração pública, são focadas questões como transparência governamental, finanças públicas, controle da corrupção e governo eletrônico. No campo da sociedade civil, demonstra-se preocupação com a formação de líderes de comunicação, requalificação de professores e inserção da informática no cotidiano das pessoas. Há cursos oferecidos em quase todas as categorias, visando atender às demandas em diferentes níveis de abrangência de conhecimento tácito e teórico.

Com análise realizada percebe-se uma demanda bem mais significativa por cursos de nível profissionalizante do que por programas de especialização, mestrado e doutorado, o que demonstra como a demanda do instituto é essencialmente constituída de indivíduos com interesses mais vinculados ao seu dia-a-dia profissional. E quanto mais o curso está vinculado à formação essencialmente acadêmica, menor é a sua procura, segundo o que se constata.

Em relação aos programas de extensão, nota-se maciçamente um interesse maior por cursos seqüenciais em detrimento dos cursos modulares (15.370 contra 1.980 inscritos), ou seja, quase 10 vezes mais alunos preferem cursos exclusivamente seqüenciais.

\section{Sistema de Estudos}

Para se inscrever em qualquer um dos cursos oferecidos, o aluno precisa atender a certos requisitos de admissão, como $_{2}$ por exemplo, ter título de licenciatura, engenharia ou formação equivalente para se candidatar ao curso de mestrado, ou ter título de mestre para se inscrever no doutorado.

Para o ingresso na pós-graduação, o aluno deverá se submeter a uma prova de admissão aos estudos de pós-graduação do Centro Tecnológico de Monterrey, a não ser que ele já tenha feito pelo menos um curso no Centro e obtido uma pontuação igual ou superior a 500 pontos. Notadamente, cada curso possui uma pontuação mínima, ou seja, uma nota de corte que define se o solicitante foi aprovado ou reprovado na sua admissão ao curso pretendido. 


\section{Materiais para Estudos e Estratégia Educacional}

A Universidade Virtual do ITESM transmite cursos via satélite e por meio de videoconferências. Os alunos têm à sua disposição acesso a biblioteca e videoteca digitais, bem como a programas de TV ao vivo e a conselheiros acadêmicos, cuja função é acompanhar os alunos durante seus estudos, desde a matrícula até sua formação, auxiliando-os nos diferentes processos que viverão em um programa de formação a distância.

$\mathrm{Na}$ Universidad Virtual existem tanto cursos semestrais como trimestrais. Normalmente o tempo de conclusão de um determinado curso depende de quantas matérias poderão ser cursadas durante o período acadêmico. Nos cursos semestrais, podem ser cursadas apenas duas matérias por semestre e mais uma no verão, sendo que a opção de matéria no verão dependerá da oferta de curso durante o período desejado.

A modalidade de ensino-aprendizagem baseada no uso da internet, a partir da infraestrutura da Universidade Virtual, oferece flexibilidade em relação ao tempo e ao espaço para estudo.

O corpo docente é altamente especializado, compreendendo profissionais experts em várias áreas do conhecimento, oriundos tanto do Centro Tecnológico de Monterrey como de outras universidades e empresas nacionais e estrangeiras. Eles são também responsáveis pela elaboração dos conteúdos instrucionais, trabalhando sempre em equipes interdisciplinares que repensam continuamente os recursos didáticos $\mathrm{e}$ tecnológicos utilizados nos cursos a distância.

Os conteúdos instrucionais são apresentados por meio de ferramentas dinâmicas de apoio ao aprendizado, como vídeos, animações, gráficos, simulações e outros materiais designados (leituras de apoio, listas de interesses, glossários e analogias), que procuram aproveitar as características primordiais da internet de modo a assegurar um aprendizado ativo e significativo para os alunos.

Portanto, o professorado da universidade virtual de Monterrey desempenha uma participação ativa em todo o processo de aprendizagem, desenvolvendo atividades de 
auto-estudo e também colaborativas, no sentido de tornar o aprendizado o mais significativo possível para o desempenho profissional de seus alunos.

Quando os alunos ingressam em um determinado curso, eles são instruídos de modo a rever o conteúdo ministrado para saber como organizar o seu tempo, para que sejam responsáveis ativamente por todo o seu processo de aprendizagem. No transcorrer do curso, são disponibilizadas atividades a serem realizadas de modo autônomo, como revisão de leituras, busca de informações, realização de tarefas, exames e exercícios práticos ${ }_{2}$ etc.

Já durante as atividades colaborativas, também os colegas de turma participam do processo de aprendizagem ${ }_{2}$ que deixa de ser apenas individualizado para se tornar coletivizante. Deste modo, por meio de recursos de comunicação síncrona e assíncrona, todos os alunos participantes do curso trocam idéias, opiniões, realizam seus projetos em grupo, resolvem problemas e estudos de casos $\mathrm{e}_{2}$ sobretudo, aprendem a trabalhar e a aprender de modo colaborativo, compartilhando seus processos de aprendizado coletivamente com os colegas de turma, o que determina um outro nível de acesso ao conhecimento por meio de redes de aprendizagem significativas.

Empregando adequadamente todos os recursos possíveis, impressos e digitais, o aprendizado do aluno torna-se mais enriquecido em termos de conteúdos e relações de significados e valores. Os recursos de comunicação mediada por computador (CMC) fazem com que o aluno jamais se sinta só no ambiente de aprendizagem, pois durante toda a trajetória do curso ele tem à sua disposição um professor facilitador a seu processo de aprendizagem contínua e, naturalmente, também os colegas, que podem apóia-lo sempre que possível, atuando, em muitos casos, como uma extensão do professor-tutor da disciplina e do seu monitor.

Isso traz a idéia de uma assessoria personalizada com participação orientadora em diversas instâncias do processo de aquisição de conhecimentos, já que torna as atividades de auto-estudo e colaborativas um compartilhamento de interesses comuns de aprendizagem. Além disso, há toda uma equipe de profissionais que oferecem serviços de assessoria técnica e administrativa, permanentemente.

É justamente dentro deste aspecto que a estratégia instrucional da Universidade Virtual do Centro Tecnológico de Monterrey se organiza, basicamente a partir do tripé 
conceitual: aprendizagem autodirigida, aprendizagem colaborativa e aprendizagem significativa. Isso equivale a dizer que a aprendizagem está centrada no aluno e em sua participação ativa durante o seu processo de construção de $\operatorname{conh} \operatorname{ccimentos}_{2}$ de modo a tornar sua aprendizagem o mais significativa possível, ou seja, com significado e valor para a vida e o trabalho profissional.

O modelo educacional da Universidad Virtual se define como essencialmente conceitual e operativo, ou seja, concebido a partir de um esquema de sistemas e subsistemas pelos quais se interconectam e se determinam uns em relação aos outros. Tal sistema conceitual apresenta as idéias que fundamentam o processo educativo e o sistema operativo, bem como as estratégias e os procedimentos que permitem efetivamente o seu funcionamento, em termos pedagógicos.

O Sistema Conceitual da Universidad Virtual é composto basicamente por três subsistemas: o filosófico, o pedagógico e o tecnológico.

O sistema filosófico aborda a maneira como a Universidade Virtual conceitua a educação em relação aos propósitos da cultura, da globalização, do rápido desenvolvimento tecnológico, da democratização do conhecimento e das necessidades de se prover educação ao longo da vida. O subsistema pedagógico compreende a problemática particular da educação voltada à formação de jovens e adultos, tendo em vista os novos papéis que professores e alunos desempenham dentro de um contexto inovador de teorias e princípios pedagógicos. Por último, o subsistema tecnológico analisa o papel das tecnologias da comunicação e da informática nos processos educativos a distância, tendo em vista seu papel mediador e suas características interativas.

Complementarmente, o Sistema Operativo é responsável pelas estratégias e pelos procedimentos operativos que viabilizam o funcionamento do modelo educacional como um todo. Ele se subdivide basicamente nos seguintes subsistemas integrados: desenho instrucional, docência, pesquisa em educação, tecnologia educacional e subsistema administrativo.

O subsistema de desenho instrucional compreende o modelo educativo que dá sustentação às estratégias pedagógicas da Universidade Virtual, uma vez que todo curso elaborado exige um processo de desenho instrucional, que inclui o planejamento, o 
desenvolvimento e a avaliação dos projetos educacionais traduzidos em práticas pedagógicas inovadoras em termos de ensino virtual.

Já o subsistema de docência diz respeito à prática reflexiva durante todo o processo de ensino-aprendizagem dos cursos virtuais. Nesse sentido, cabe ao professor três funções primordiais durante o desenrolar do curso: o desenho, a administração, a avaliação e a retroalimentação do sistema instrucional a distância, o que se constitui em uma atividade extremamente complexa, pois ele precisa atuar como facilitador e orientador da aprendizagem dos alunos, além de cuidar da elaboração dos programas curriculares e da seleção das tecnologias interativas, atuando sempre que possível como um potencial indagador sobre processos de ensino e estratégias inovadoras de usos das tecnologias disponíveis.

Já o subsistema de pesquisa educacional leva em consideração três funções básicas do modelo educativo virtual: a contínua alimentação do ambiente que caracteriza o espaço virtual de educação, o fluxo informacional que define o desenho curricular dos programas acadêmicos da universidade virtual e o processo de coordenação dos futuros recursos humanos que advirão por meio da adoção de novas linhas de investigação que aprimorem o processo de ensino-aprendizagem da universidade virtual.

O subsistema de tecnologia educacional, de modo complementar, analisa as características tecnológicas que tornarão a aprendizagem a distância mais adequada dentro dos parâmetros que incorporam os avanços tecnológicos, facilitando $\mathrm{o}$ incremento da interação didática no meio virtual.

Particularmente, o subsistema de administração está presente em todas as fases do processo de gestão educativa, desde o momento em que se concebe a sua implementação. Este subsistema cuida de cumprir quatro funções específicas: planejamento, programação, elaboração do que foi pré-concebido e avaliação de resultados. 


\section{Centros de Estudos}

Os centros de estudos da Universidad Virtual de Monterrey perfazem duas características distintas: alguns locais representam sedes da universidade virtual, enquanto outros operam apenas como seus centros receptores de ensino e aprendizagem.

A Universidad Virtual de Monterrey possui basicamente duas sedes transmissoras ${ }_{1}$ localizadas na região de Monterrey, no México. Além disso, conta com mais 1.430 sedes receptoras, dentre as quais 1.270 se localizam no território mexicano, enquanto 160 se distribuem por pelo menos dez países da América Latina.

Atualmente, o Centro Tecnológico de Monterrey conta com 33 campi espalhados por todo o México para atender à universidade virtual, possuindo ainda sedes em 8 países da América Latina, além de Canadá, Estados Unidos, Espanha e França. Na América Latina, algumas de suas sedes se localizam em países como Colômbia, Peru, Panamá, Equador, El Salvador, Costa Rica, Venezuela e Chile, sendo que há um número considerável de centros localizados particularmente na Colômbia. 


\subsubsection{Canadá}

\section{a) Athabasca University}

\section{Endereço}

Athabasca University

1 University Drive - Athabasca AB T9S 3A3

Tel. (Canadá/EUA): 1-800-788-9041 - (Internacional): (780) 675-6100

Fax: (780) 675-6437

Internet: http://www.athabasca.ca/

\section{Contexto Histórico}

A Athabasca University (AU) foi criada pelo governo do Estado de Alberta, no Canadá, em 1970, sendo hoje considerada líder em educação a distância em seu país, por ser uma instituição completamente especializada na oferta de cursos e programas a distância, desde o seu início.

Sua instauração representou uma ruptura na tradição do ensino superior canadense, pois já não se justificava o surgimento de mais uma universidade presencial entre tantas outras existentes no país, perfazendo um montante de 14 instituições de ensino superior atuando no território canadense. Para muitos especialistas em educação isso não ajudaria a solucionar problemas que exigiam a necessidade de um pensamento educacional mais desafiador em termos de políticas públicas de inserção social.

Desse modo, novas idéias e estratégias de ensino e aprendizagem que estavam sendo discutidas na época foram decisivas para a iniciativa de criação da Universidade de Athabasca. Inicialmente, foi desenvolvido um projeto piloto de modo a verificar como a comunidade local reagiria a toda essa nova concepção de ensino. Em 1978, em decorrência do sucesso obtido com a oferta preliminar de cursos, a Universidade veio a adquirir status de instituição pública permanente, com direito a autonomia de gestão.

Em razão disso, sua missão foi definida como tendo em vista a capacidade de se diminuir ou amenizar as barreiras impostas ao acesso e ao bom êxito nos estudos de 
nível universitário no Canadá. Para isso, a instituição procura promover oportunidades iguais de educação para todos os cidadãos canadenses, independentemente da sua localização geográfica e do seu currículo acadêmico anterior.

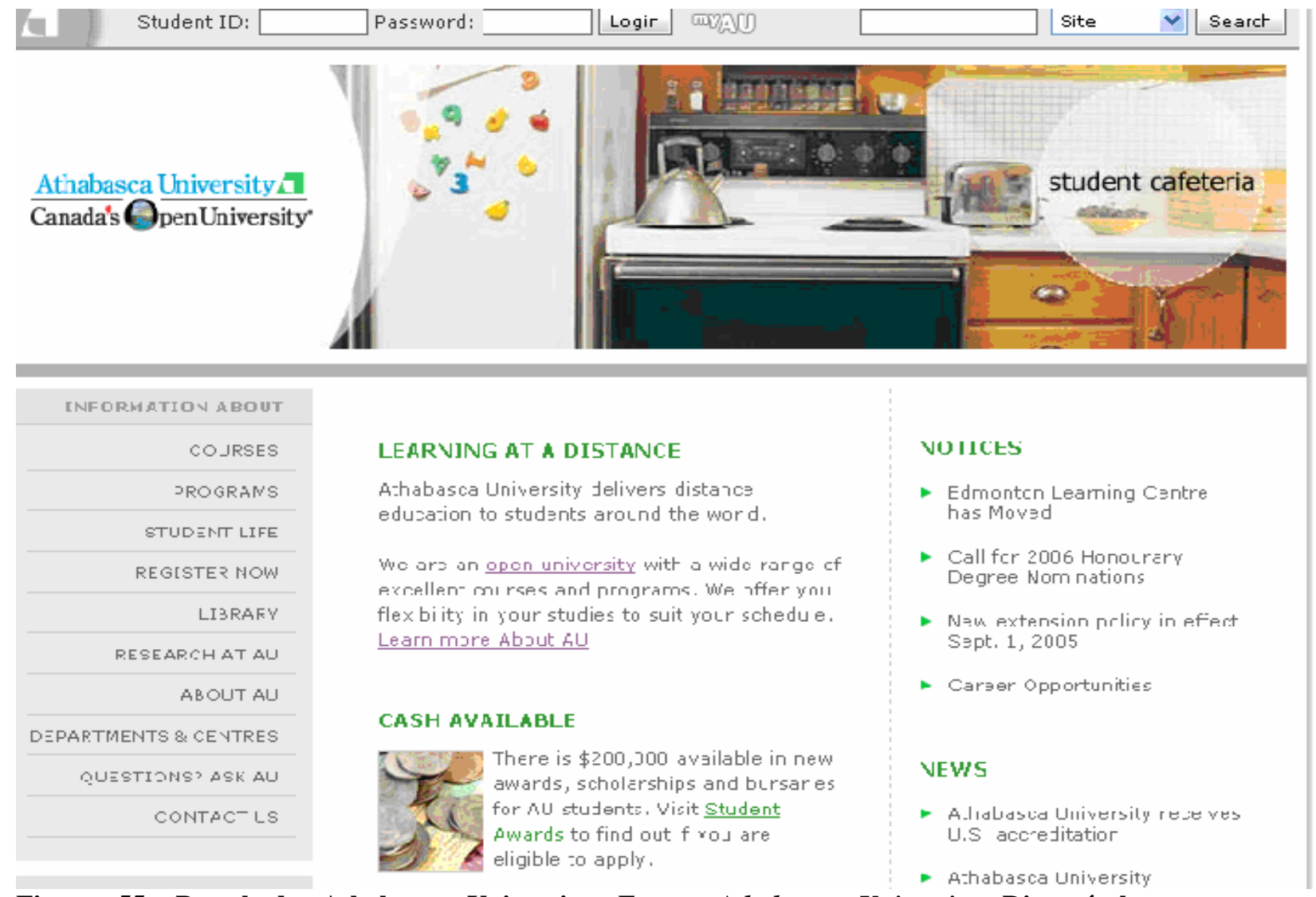

Figura 55: Portal da Athabasca University. Fonte: Athabasca University. Disponível em: <http://www.athabascau.ca/>. Acesso em 25 mai 2005.

\section{Objetivos}

Os objetivos da Universidade de Athabasca aparecem intimamente atrelados àqueles que caracterizam uma universidade essencialmente aberta. Nesse sentido, a instituição define alguns parâmetros que considera relevantes para se firmar como universidade aberta em amplo aspecto, a saber: acessibilidade, baixo custo e flexibilidade.

A acessibilidade diz respeito ao alcance dado a quaisquer alunos que não têm condições de freqüentar o campus de uma universidade presencial. A idéia de acesso não se restringe ao aspecto físico: abrange, especialmente, o modo de estudo, o conteúdo ministrado, o processo de ensino e aprendizagem, a avaliação e as instalações que dão suporte ao aprendizado contínuo. Para a Universidade de Athabasca, isso significa permitir o acesso livre ao estudo de modo individualizado, com cursos a qualquer hora 
do dia e de forma adequada para os seus alunos. É por isso que a política de admissão de novos alunos em uma universidade aberta, segundo os princípios defendidos pela $\mathrm{AU}$, não devem se basear prioritariamente em certos objetivos acadêmicos de ensino, exceto quando um pré-requisito se torna evidentemente necessário para atender às necessidades de formação dos alunos. Dentro dessa concepção, o aluno deve se sentir livre para escolher o período que lhe for mais conveniente para se inscrever no curso que desejar, sem restrições de períodos anuais, semestrais, início de cada ano ou semestre, por exemplo.

Já o baixo custo nas taxas que normalmente são cobradas também é uma característica que a instituição considera essencial em uma universidade tida como aberta. A Universidade de Athabasca cobra uma das menores taxas canadenses com custos de matrículas, mensalidades, exames, livros e outros materiais utilizados - isso considerando as taxas que envolvem os custos com despesas de deslocamento que os alunos normalmente têm de realizar para estudar muito longe de suas residências, em instituições tradicionais. Como os alunos da AU não têm esse tipo de problema, podendo estudar em casa ou no trabalho, quando querem, reduzem-se significativamente os custos envolvidos com tais despesas. Este é um dado relevante para a instituição definir as taxas mais apropriadas à sua demanda.

Flexibilidade, no sentido defendido pela AU, significa ter o direito opcional de se obter um certificado, diploma, realizar seu curso de bacharelado de 3 ou 4 anos ou, ainda, ter a facilidade de acesso a um curso em nível de mestrado, que são os cursos oferecidos pela instituição até o momento. Outro aspecto da flexibilidade adotada pela Universidade de Athabasca diz respeito à possibilidade do aproveitamento de créditos cursados e de transferência institucional em amplo aspecto. A Universidade entende que sua missão é facilitar a vida educacional e profissional de seus alunos, em várias circunstâncias previstas e em outras que devem ser estudadas, posteriormente, para atender às novas necessidades ainda não previstas no seu currículo educacional. Flexibilidade sugere ainda, segundo a visão da Universidade, o direito de escolha dos cursos que são realmente do interesse de cada aluno, quer seja em termos profissionais, quer para o seu desenvolvimento pessoal, cultural, aperfeiçoamento acadêmico, estudos complementares, revisão de conhecimentos prévios, naturalmente sem criar empecilhos indesejáveis para o acesso a mais de um curso ao mesmo tempo. 


\section{Público-alvo}

A AU (University Athabasca) é também reconhecida como uma das universidades que mais cresceram no Canadá num curto período de tempo. Atualmente, a Universidade atende a cerca de 32.000 estudantes por ano, e desde sua fundação 260.000 estudantes já se formaram. Oferece mais de 600 cursos e mais de 60 programas de graduação e pósgraduação.

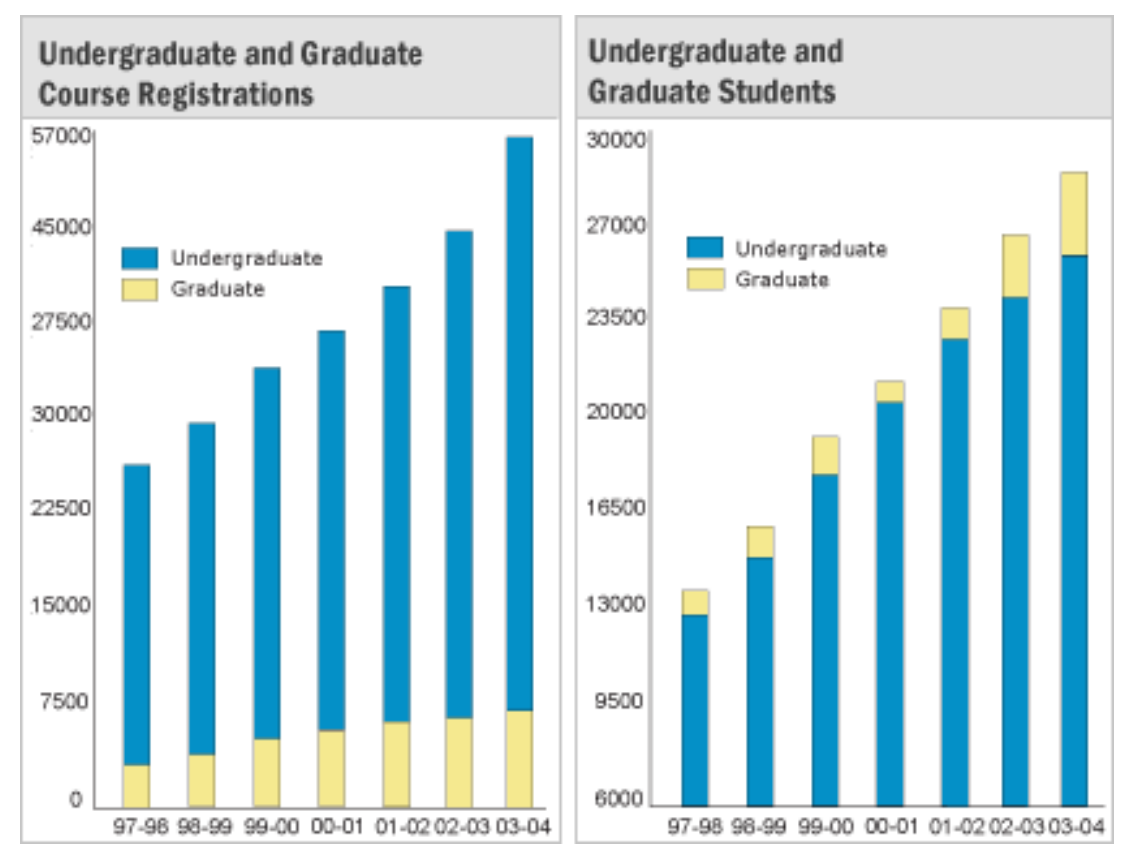

Gráifco 28: Número de estudantes de graduação e graduados da Athabasca University (2003-2004)

A partir da tabela acima, é possível observar que a Universidade apresentou um crescimento significativo, passando de aproximadamente 25.000 alunos em 1997/98 para 57.000 em 2003/04. Com isso, o número de alunos teve um aumento médio anual de $14,72 \%$ e um crescimento total de aproximadamente $128 \%$ num período de seis anos (1997-2004). É interessante ressaltar que este crescimento foi acompanhado também por um aumento na oferta de cursos, demonstrando como a população tem se interessado cada vez mais por novos métodos de ensino e aprendizagem que possam facilitar sua vida cotidiana e como mais e mais indivíduos estão se abrindo para a percepção de que a educação a distância pode ser um método bastante eficaz de acesso educacional. 


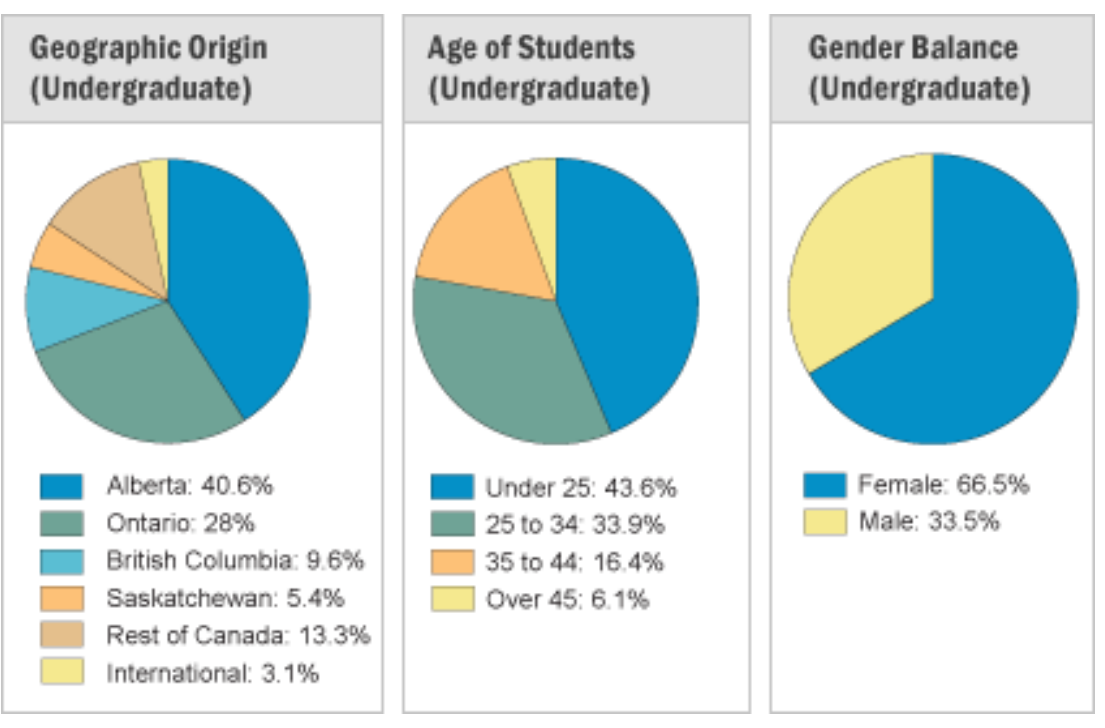

Gráfico 29: Estudantes de graduação da Athabasca University, contendo dados relativos à sua localização, idade e gênero

De acordo com as três tabelas apresentados acima, a maioria dos estudantes provém da cidade de Alberta (cerca de 40,6\%A); em segundo lugar vem a cidade de Ontário, de onde provêm pelo menos $28 \%$ de seus alunos. A faixa etária dos estudantes matriculados varia de 25 a 44 anos, sendo que $43,6 \%$ deles possuem menos de 25 anos, ao passo que $6,1 \%$ se inserem na faixa acima de 45 . O contingente maior é de mulheres - cerca de $66,5 \%$ dos alunos regularmente matriculados em diversos cursos - contra $33,5 \%$ dos homens. Outro dado importante, contudo não revelado pelo gráfico, mas disponível no portal, é que $60 \%$ dos alunos inscritos no programa trabalham tempo integral enquanto estudam, e 36\% deles pertencem à categoria de estudantes visitantes, ou seja, estão inscritos em outras instituições conveniadas, onde realizam normalmente seus cursos, mas preferem realizar cursos da $\mathrm{AU}$ a fim de transferirem mais tarde os créditos obtidos para sua instituição de origem.

A Universidade de Athabasca tornou-se muito popular por atender, em grande parte, a estudantes portadores de necessidades especiais, estudantes residentes no exterior, órfãos de pai e mãe, pais solteiros, membros das forças armadas canadenses, atletas, indivíduos que trabalham em tempo integral e estudantes que precisam de cursos complementares à sua formação universitária tradicional. 


\section{Recursos Humanos e Materiais}

Notadamente no período de 2004-2005, a Universidade chegou a operar com um orçamento aproximado de US\$ 79,6 milhões, que não pára de crescer vertiginosamente em razão do aumento da demanda por cursos de grande aceitação e em detrimento da exigência de novos cursos e novas estratégias pedagógicas.

Em 31 de março de 2005, a Universidade de Athabasca contava com 1.075 profissionais, sendo que a equipe acadêmica englobava 111 funcionários em regime de período integral e 148 em regime de meio-período, além de 276 professores tutores.

A Universidade de Athabasca conta com o apoio de inúmeros órgãos associados, como institutos, universidades, associações e consórcios, dentre os quais se destacam:

- Associação de Universidades do Reino Unido

- Associação de Universidades e Faculdades do Canadá

- $\quad$ Associação Canadense para a Educação a Distância

- $\quad$ Associação Canadense para Estudos de Graduação

- $\quad$ Universidade Virtual Canadense

- Consórcio Interamericano de Educação a Distância

- Conselho Internacional para Educação Aberta e a Distância

Além disso, a AU possui vários centros de estudos que realizam pesquisas em muitas áreas distintas do conhecimento, como análises globais e sociais, gerenciamento em inovação tecnológica, estudos integrados, linguagem e literatura, psicologia, enfermagem, estudos na área de saúde, negócios, computação e sistemas de informação, direito público e privado, ciências puras e aplicadas.

Em 2004, foram criados pela Universidade o Instituto Canadense de Pesquisa em Educação a Distância (Canadian Institute for Distance Education Research) e a Revista Internacional de Pesquisa em Aprendizagem Aberta e a Distância (The International Review of Research in Open and Distance Learning). Esses instrumentos possibilitaram novos avanços nas pesquisas desenvolvidas em educação a distância pela universidade, além de um espaço autônomo para divulgação dos estudos realizados pelos profissionais da instituição. 


\section{Sistema de Estudos}

O credenciamento e a autorização de cursos da Universidade de Athabasca dependem sempre do aval do Ministério de Educação Superior do Canadá, e toda a infra-estrutura da Universidade é financiada pela província de Alberta.

Os certificados que atestam os créditos cursados são fornecidos de acordo com a mesma estrutura curricular que compõe os cursos tradicionais de programas de graduação. Desse modo, da mesma forma como a Universidade de Athabasca aceita créditos de outras instituições com cursos oficialmente reconhecidos, ela oferece a oportunidade de seus alunos virem a completar seus estudos em outras instituições com enfoque pedagógico tradicional, podendo aproveitar bem seus créditos cursados e concluir seu curso em outra instituição de sua escolha, obtendo seu diploma oficial sem entraves burocráticos ou institucionais criados por entidades educacionais ou órgãos governamentais. A Universidade parte da filosofia de que o reconhecimento de seus cursos, bem como a equiparação de créditos entre cursos a distância e presenciais, deve ser plenamente reconhecida, a fim de atender às necessidades diversificadas dos alunos em uma sociedade em transformação.

Como a Universidade de Athabasca é parceira da Universidade de Alberta, empregando parte do espaço físico de seu campus universitário para dar suporte às atividades de educação a distância, ela também atende aos estudantes regularmente matriculados em seus institutos. Neste caso, a Universidade prevê tanto o aproveitamento de créditos como a obtenção de diplomas em nível de graduação, expandindo esse critério a todas as instituições fora dos limites da província de Alberta. A Universidade, no entanto, não provê cursos de educação continuada sem a concessão de créditos de disciplinas cursadas.

Já no que diz respeito a cursos de pós-graduação, a Universidade oferece programas de educação a distância que contemplam basicamente as seguintes áreas de conhecimentos: Educação, Saúde e Administração de Empresas. Também neste caso, os programas são estruturados do mesmo modo que em uma universidade presencial, de maneira a facilitar a vida educacional e profissional dos alunos que optam pela modalidade de ensino a distância da Universidade de Athabasca. Ou seja, o que vale para os cursos de graduação também efetivamente se aplica aos cursos de pós-graduação, pois a 
Universidade procura sempre desenvolver uma política educacional que não distancie seus cursos e estratégias de formação da realidade do mercado profissional, dos métodos tradicionais de ensino e aprendizagem incorporados por outras instituições tradicionais e das implicações e dos preconceitos que advêm ainda do uso do ensino a distância em qualquer instância pedagógica.

Por isso, dada toda essa preocupação com o fato de a educação a distância ser bemaceita nos meios educacionais canadenses e internacionais, a AU tenta cada vez mais se destacar em termos de excelência nos seus cursos a distância, sempre oferecidos com um perfil individualizado para atender às necessidades específicas de cada aluno, sem, contudo, perder o nível de qualidade desejado. Além disso, a Universidade possui uma coordenação especialmente dedicada à concessão e à transferência de créditos disciplinares, realizando com freqüência uma avaliação prévia da aprendizagem dos alunos, bem como de diversas formas de desenvolvimento da aprendizagem que possam ser incorporadas em benefício da qualidade educacional de seus cursos. Ou seja, partese do princípio de que o sucesso do ensino a distância esteja centrado no processo de avaliação contínua, que deve ser intensamente aprimorado.

Nesse tocante, a Universidade de Athabasca tem uma política educacional de vincular ensino e pesquisa, oferecendo bolsas de estudos para estudantes e pesquisadores em várias áreas do conhecimento, naturalmente com um foco especial nas atividades associadas aos estudos em educação a distância e tecnologias de aprendizagem a ela associadas. Desse modo, a instituição tem conseguido se projetar como uma liderança mundial em métodos de educação a distância individualizada de forma crescente.

Em 2004, pela segunda vez em seguida, o curso de MBA para Executivos da Universidade de Athabasca foi considerado pelo Financial Times, de Londres, um dos 100 melhores cursos existentes em todo o mundo, ocupando a 75- posição de destaque, sendo o único a figurar entre os cursos realizados de modo inteiramente a distância (curso on-line). Também é a primeira e única universidade canadense a conseguir autorização e reconhecimento de seus cursos nos Estados Unidos pela Comissão de Ensino Superior da Associação de Faculdades e Escolas de Estados do CentroAmericano. 
Recentemente, um levantamento realizado sobre os alunos formados pela AU indicou que $98,5 \%$ deles recomendariam seus cursos para outras pessoas, enquanto $93 \%$ estavam completamente satisfeitos com a qualidade geral dos cursos, bem como com a experiência educacional que vieram a adquirir ao estudar na Universidade de Athabasca.

\section{Cursos}

Com um foco definido em artes liberais, ciências e programas profissionais, a Universidade de Athabasca oferece mais de 700 cursos de graduação e pós-graduação em diversas áreas, em nível de bacharelado, mestrado, especialização e aperfeiçoamento profissional, todos com emissão de diplomas e certificados.

$\mathrm{Na}$ área de graduação, existem os bacharelados em Administração (curso normal e pósgraduação), Artes (duração: 3 ou 4 anos), Comércio (duração: 4 anos, opcionalmente em nível de pós-graduação), Estudos Gerais, Administração da Saúde (curso normal e pós-graduação), Recursos Humanos e Relações do Trabalho (curso normal e em nível de pós-graduação), Gerenciamento (curso normal de 3 ou 4 anos, opcionalmente oferecido também em nível de pós-graduação em ambas durações), Enfermagem, Artes Profissionais, Ciências (curso normal e pós-graduação), Ciências da Computação e Sistemas de Informação (curso normal e pós-graduação), Diploma em Artes da Universidade de Athabasca e Diploma em Educação Inclusiva da Universidade de Athabasca.

Como se verifica na área de graduação, são oferecidos cursos formatados para vários tipos de clientelas: cursos de duração mínima, cursos mais extensivos e cursos para quem já completou sua graduação e deseja uma formação complementar diferenciada para atuar no mercado de trabalho.

Quanto aos cursos de pós-graduação, os principais são: Mestre em Artes (Estudos Integrados), Mestre em Administração de Empresas, Mestre em Administração de Empresas em Tecnologia da Informação, Diploma de Graduação Avançada em Gerenciamento de Tecnologia da Informação, Diploma de Graduação Avançada em Gerenciamento de Projetos, Diploma de Graduação em Gerenciamento, Mestre em Aconselhamento Educacional, Mestre em Educação a Distância, Diploma Avançado de Graduação em Educação a Distância (na área de Tecnologia), Diploma Avançado de 
Graduação em Prática de Enfermagem, Mestre em Estudos da Saúde, Mestre em Enfermagem e Mestre em Ciências na área de Sistemas de Informação.

Pelos títulos oferecidos, percebe-se uma variedade de opções de formação profissional, em que se têm cursos mais tradicionais que fornecem a titulação de mestre aos alunos, assim como cursos com direito a diploma que servem para complementar a formação de quem prefere algo mais direcionado aos interesses do mercado de trabalho. Neste caso, naturalmente, o aluno poderá optar por um curso de pós-graduação stricto sensu (mestrado tradicional) ou de lato sensu (diploma de graduação avançada).

\section{Materiais de estudo e estratégia instrucional}

A Universidade tem como estratégia instrucional fornecer cursos e programas individualizados que permitam ao aluno aprender de acordo com o seu próprio ritmo.

Conforme já reiterado e segundo informações publicadas no site ${ }^{213}$ da instituição, seu sistema de ensino é bastante flexível: o aluno é dispensado de exigências como horários específicos de aulas e agendas institucionais rígidas. Normalmente os cursos se iniciam no começo de cada mês, sendo que a matrícula pode ser efetuada durante o ano inteiro. Qualquer pessoa acima de 16 anos pode ingressar na universidade, sem que seja levada em conta sua formação educacional anterior - como pré-requisito de seleção - ou a necessidade de ser portadora de diploma de educação escolar.

Os alunos recebem pacotes de estudos individualizados, contendo um manual do estudante, guia de estudos, apostilas, CD-ROM/software, fitas de áudio e de vídeo. Os cursos são elaborados pela equipe docente da Universidade e por especialistas em determinados campos do conhecimento, que atuam constituindo um esforço interdisciplinar de apoio à produção de materiais e ao desenvolvimento de estratégias pedagógicas. Em alguns locais, exige-se que os alunos desenvolvam suas atividades também em salas de aula.

Os cursos têm estratégias que mesclam estudo individual com estudo em grupo. No caso do estudo individual, o aluno recebe todo um roteiro de como deve ler e assimilar o material instrucional. Ele tem a liberdade, portanto, de definir o seu ritmo e o tempo de

\footnotetext{
${ }^{213}$ Athabasca University . Disponível em <http://www.athabascau.ca/ >. Acesso em: 12 jan 2005.
} 
estudo de acordo com as instruções fornecidas, lembrando-se de que tem até seis meses para concluir as disciplinas do curso, a não ser que haja uma sobrecarga de atividades. Mesmo assim, neste caso, ele tem no máximo quatro meses para concluir as disciplinas em que se inscreveu, além do prazo normal previsto (cada curso inicia, como já dito, no começo de cada mês). Já no caso do estudo em grupo, o aluno tem também a possibilidade de contato presencial com outros colegas no campus designado, o que os aproxima mais do método tradicional presencial. Para o estudo em grupo, o aluno tem até quatro meses para a conclusão (neste caso, o início se dá em setembro e em janeiro de cada ano).

Para auxiliar os alunos em seus estudos a distância, a Universidade oferece vários serviços, bem abrangentes, como orientação educacional e pedagógica, pareceres instrucionais, suporte tecnológico, acesso a bibliotecas para apoio aos estudos, etc.

Os centros de estudos são devidamente equipados, e os alunos, durante todo o curso, têm à sua disposição um suporte acadêmico com tutores qualificados facilmente contatados por telefone ou e-mail.

Para dar suporte às atividades de ensino e aprendizagem a distância, a Universidade de Athabasca estabeleceu, ao longo dos anos, diversas parcerias com instituições que colaboram com seus serviços de aprendizagem individualizada. Tais parcerias incluem: programas colaborativos entre instituições de ensino superior no Canadá, arranjos para transferência de créditos, acordos comerciais para o desenvolvimento profissional dos alunos, cursos em salas de aula em locais cedidos por parceiros institucionais e alianças e outras parcerias de cunho estratégico.

Os programas colaborativos dizem respeito aos convênios firmados com instituições que possam colaborar com o oferecimento de cursos em parceria, bem como com o uso de suas instalações físicas para a realização de atividades pedagógicas. Os arranjos para transferência de créditos também envolvem a realização de inúmeras parcerias e convênios para a aceitação plena de créditos obtidos em todas as instituições interligadas ao sistema de ensino da Universidade de Athabasca. A Universidade também estabelece acordos com entidades e empresas, para que os alunos possam realizar seus estágios complementares à formação profissional e ser encaminhados para uma possível contratação. Já os cursos em sala de aula compreendem estudos em grupos 
realizados com o uso de videoconferências, teleconferências e outros recursos de suporte on-line.

Para desenvolver e atualizar suas estratégias e seus objetivos instrucionais, a Universidade elabora uma série de documentos estratégicos, que poderão ser empregados para o planejamento de ações em médio e longo prazos. Entre esses documentos estão os relatórios anuais, os planos de negócios, os planos estratégicos, os planos de pesquisa e o plano operacional de sistemas aplicados ao uso de tecnologias da informação.

Muitos desses documentos têm sido continuamente reelaborados de modo a ampliar o prazo determinado para o cumprimento de metas e objetivos da instituição, passando-se inicialmente de bianuais para qüinqüenais e transformando-se, recentemente, em planos decenais. Isso se justifica pelo aumento da complexidade dos desafios a serem enfrentados futuramente pela instituição, uma vez que ela deseja continuar avançando na sua posição de destaque em termos nacionais e mundiais no foco da educação a distância.

O fato de a pesquisa em educação a distância com o uso de novas tecnologias ser bastante intensa na universidade tem impulsionado a pedagogia canadense a se transformar rapidamente. Os estudos na área de educação a distância já valeram à instituição um prêmio de excelência da Associação Canadense de Educação a Distância por um trabalho a respeito de como as identidades dos alunos se transformam quando eles participam de comunidades on-line.

\section{Avaliação Educacional}

O Centro de Educação a Distância da Universidade de Athabasca mantém um site especialmente dedicado à avaliação de todo o processo educacional de seus cursos, contendo ferramentas colaborativas de avaliação contínua do processo de ensino e aprendizagem dos alunos. Nele são apresentadas as principais técnicas definidas para avaliação formativa, os principais produtos e fabricantes de softwares empregados, suas funções e características pedagógicas.

Além disso, são gerados sistematicamente relatórios a respeito do desempenho educacional dos alunos em cada atividade colaborativa. Os relatórios do projeto de 
avaliação educacional contêm um índice com questões gerais, que podem ser úteis para diagnosticar problemas e definir soluções pedagógicas; tipos de atividades colaborativas desenvolvidas ao longo de vários cursos; estudos de casos envolvendo comunidades de prática on-line e dados comparativos em relação ao uso de vários softwares pedagógicos, para se ter uma visão mais sistêmica de como cada um deles pode ser empregado em vários cursos. No índice, ainda são fornecidos artigos que os professores e pesquisadores elaboram a partir do desenvolvimento de suas práticas pedagógicas com vários softwares e técnicas comunicativas e pedagógicas. Assim, toda a equipe pedagógica tem às mãos um ferramental que possibilita avanços tecnológicos e aprimoramento educacional relacionados ao uso da educação a distância na Universidade de Athabasca.

\section{Centros de Estudos}

A AU possui escritórios e centros de estudos em Edmonton, Calgary e St. Albert, e nas cidades da província de Alberta. Nesses centros são oferecidos aos alunos conselho acadêmico, exames supervisionados, serviços de registros, laboratórios de informática, acesso a materiais multimídia em geral e assistência do Sindicato dos Estudantes da Athabasca University. $\mathrm{O}$ atendimento ocorre de segunda a sexta-feira, em horário comercial.

\section{Valor dos Cursos e Financiamento do Sistema}

Em 2005, 175 dos cursos de ensino on-line mais populares foram completamente reestruturados para acompanhar os novos avanços das tecnologias educacionais, projeto que só foi possível por intermédio de US\$1,5 milhão conseguido pelo setor de Educação Avançada de Alberta.

Já no campo da pesquisa, a Universidade investiu mais de US\$2 milhões somente no período de 2004-2005. Em aproximadamente três anos, o investimento em pesquisa aumentou mais de 400\%, em média, considerando-se o período de 1999-2000 e o de 2003-2004. 


\subsubsection{Estados Unidos}

\section{a) University of Phoenix}

\section{Endereço}

Phoenix, Arizona, USA

Tel. Geral: 866-766-0766

Tel. Suporte Técnico: 877-822-4867

Tel. Serviços de Suporte Acadêmico: (480) 446-4600

Campus on-line: (800) 366-9699

Internet: http://www.phoenix.edu

\section{Contexto Histórico}

Fundada em 1976, a Universidade de Phoenix (UOP - University of Phoenix) é uma Instituição de Ensino Superior privado que conseguiu captar uma atmosfera de transformação social e econômica, nos Estados Unidos e no mundo, ainda no final dos anos 70, e que marcaria fundamentalmente as próximas décadas, em termos de mudanças educacionais urgentes. Neste aspecto, a Universidade foi pioneira, buscandose especializar na área de educação de adultos, ou seja, uma área que se tornaria cada vez mais prioritária para a sociedade contemporânea, em função dos rápidos avanços tecnológicos e científicos das décadas seguintes.

Logo no começo dos anos 70, os fundadores da UOP resolveram realizar várias pesquisas de campo aplicadas à área de educação de adultos. O objetivo desses estudos era compreender como seria possível desenvolver sistemas de ensino e aprendizagem capazes de disponibilizar programas educacionais e serviços voltados para estudantes adultos e trabalhadores que desejassem completar sua formação, de modo a atender objetivos relacionados a suas experiências e necessidades profissionais. Os estudos indicaram que não havia um empenho satisfatório por parte das instituições tradicionais de ensino em prover condições adequadas para alunos de cursos noturnos, por exemplo, que passavam grande parte do dia trabalhando. Não havia também departamentos e secretarias para atendimento, nem ao menos bibliotecas abertas à noite: os estudantes precisavam sempre dispor de parte do dia para resolver problemas com questões relacionadas à matrícula e às disciplinas do seu curso. Ou seja, mesmo a aquisição de 
livros para estudos, bem como a consulta a professores e orientadores, precisava ser realizada durante o dia, o que inviabilizava o curso para muitos estudantes que não conseguiam adequar seus horários nem mesmo serem dispensados do trabalho para resolver problemas de âmbito educacional.

Tais empecilhos gerados pelo sistema educacional americano faziam com que os alunos muitas vezes só conseguissem concluir um programa de curso com duração de dois anos em quatro anos, ou num período maior; e um de quatro, em oito anos ou mais. Isso representava tanto um gasto maior despendido por esses alunos com recursos econômicos quanto um desgaste físico e mental, o que acabava culminando, conseqüentemente, na evasão maciça de muitos cursos.

Vale a pena lembrar que, naquela época, as faculdades e universidades americanas eram organizadas de modo a atender exclusivamente às necessidades de alunos graduandos na faixa de 18 a 22 anos.

A Universidade de Phoenix rompeu definitivamente com esse paradigma educacional, incorporando uma demanda significativa de alunos originários de instituições tradicionais que já há algum tempo estavam completamente fora da escola. Essa iniciativa evidenciou como os estudantes adultos e os trabalhadores eram muitas vezes negligenciados por grande parte das instituições tradicionais, estando, de certa forma, invisíveis para elas e sendo tratados quase sempre como cidadãos de segunda classe.

Desde sua criação, a Universidade de Phoenix provou ser única nos Estados Unidos no que diz respeito a atender às características dos trabalhadores adultos, principalmente quando se trata de considerar não só os modelos de ensino e aprendizagem, mas também os serviços de apoio aos estudantes e a estrutura acadêmica e administrativa peculiar.

Com apenas um quarto de século de existência, a UOP se firmou líder em educação superior a distância e também um forte agente de mudanças educacionais em seu país. Isso se deveu muito a seu comprometimento especial como instituição facilitadora de educação profissional para jovens e adultos trabalhadores e muito também em detrimento de uma cultura organizacional pautada sempre pela busca da inovação em termos pedagógicos. 


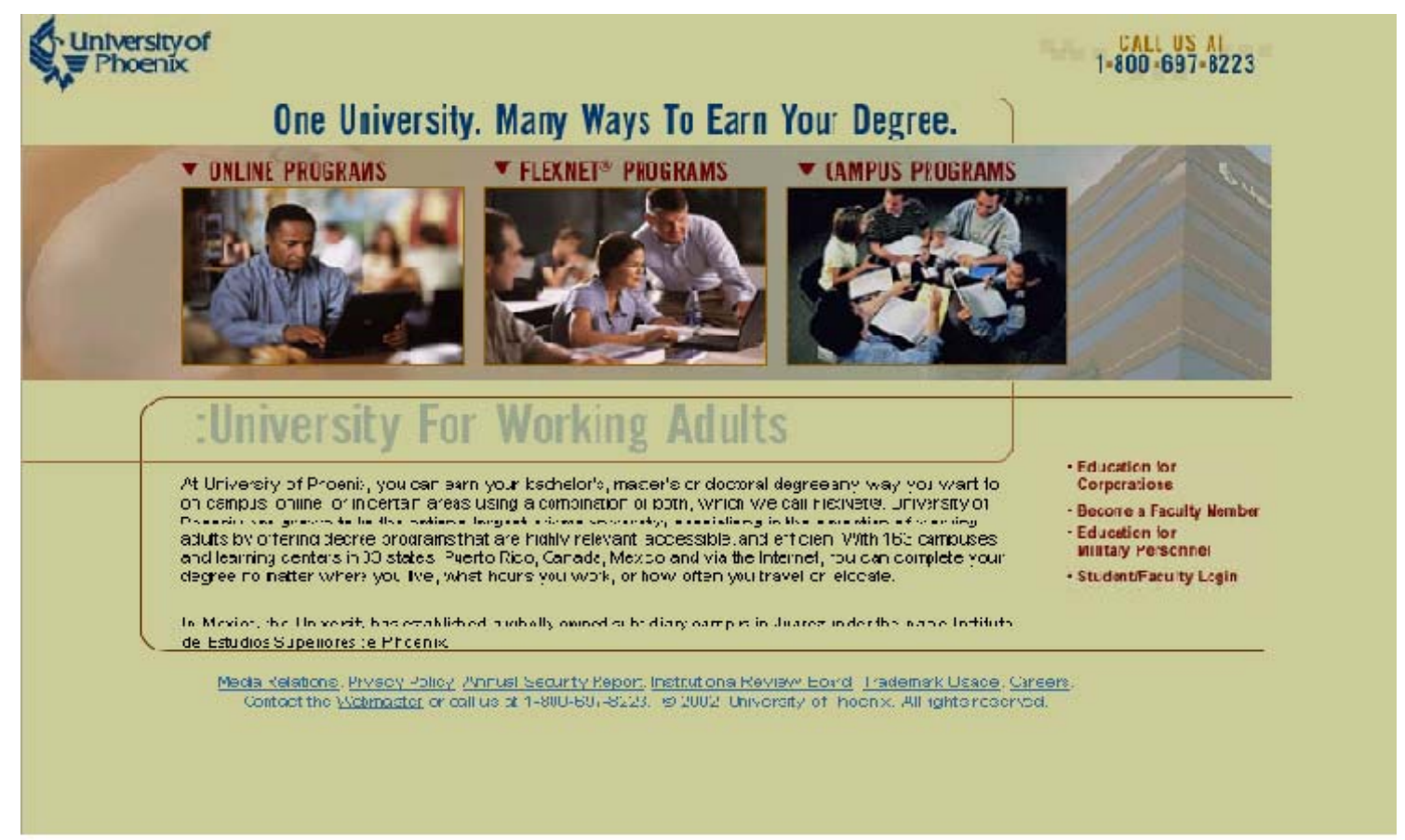

Figura 36: Portal University of Phoenix. Fonte: University of Phoenix. Disponível em: <www.phoenix.edu>. Acesso em: 22 fev 2005.

\section{Objetivos}

Conforme já dito, o foco principal da Universidade de Phoenix, desde a sua fundação, é fornecer educação de alta qualidade para jovens e adultos trabalhadores que muitas vezes não possuem condições de freqüentar um curso normal de formação educacional por uma série de razões acumulativas e excludentes.

Em linhas gerais, a Universidade de Phoenix se propõe enfrentar os seguintes desafios diante do cenário educacional estadunidense:

- Facilitar, tanto cognitiva quanto afetivamente, a seus estudantes o acesso a uma base de conhecimento, de modo que desenvolvam habilidades e valores.

- Promover o uso do conhecimento formal no ambiente de trabalho de seus alunos.

- Desenvolver competências em comunicação, pensamento crítico, colaboração e emprego de informações, dentro de uma estratégia baseada na educação ao longo da vida, permitindo aos alunos avançar em suas oportunidades em termos de carreiras de sucesso profissional.

- Prover instrução que inter-relacione teoria com prática por meio de um corpo docente altamente qualificado, que não apenas prepare suas turmas em termos de 
conhecimento acadêmico inovador, mas também desenvolva habilidades que poderão ser úteis na prática corrente de suas atividades profissionais.

- Prover formação educacional aliada à aquisição de conhecimentos fundamentais por meio de uma infra-estrutura de serviços que prepare seus estudantes para se adaptar a uma variedade de propostas curriculares de ensino superior.

- Empregar tecnologias inovadoras que desenvolvam modos efetivos e meios instrucionais que permitam expandir o acesso a recursos de aprendizagem com o objetivo de aprimorar as atividades de colaboração e comunicação que contribuem para a qualidade da aprendizagem dos alunos.

- Avaliar o processo de aprendizagem dos alunos e empregar dados avaliativos de modo a aprimorar o sistema de ensino e aprendizagem institucional, levando em consideração aspectos relacionados a currículo, atividades instrucionais, recursos de aprendizagem, métodos de orientação e acompanhamento pedagógico e outros serviços destinados aos alunos.

- Organizar-se como instituição educacional com fins privados, de modo a desenvolver um espírito de inovação pedagógica focado na busca de qualidade e excelência de serviços acadêmicos e profissionais mediante as necessidades prementes de estudantes adultos que trabalham.

- Gerar recursos financeiros necessários para dar suporte à missão da UOP diante dos desafios educacionais e dos entraves socioinstitucionais.

\section{Público-alvo}

A partir de informações publicadas no site da instituição, verificou-se que a Universidade teve um crescimento no número de matrículas, passando de $100.900 \mathrm{em}$ agosto de 2000 para 255.600 alunos em agosto de 2004. Dessa forma, é possível constatar que o crescimento médio anual de matrículas foi de 26,16\%, com um crescimento total de $153 \%$. Além disso, desde 1976, mais de 171.000 profissionais já obtiveram oficialmente seus diplomas de graduação na UOP. 

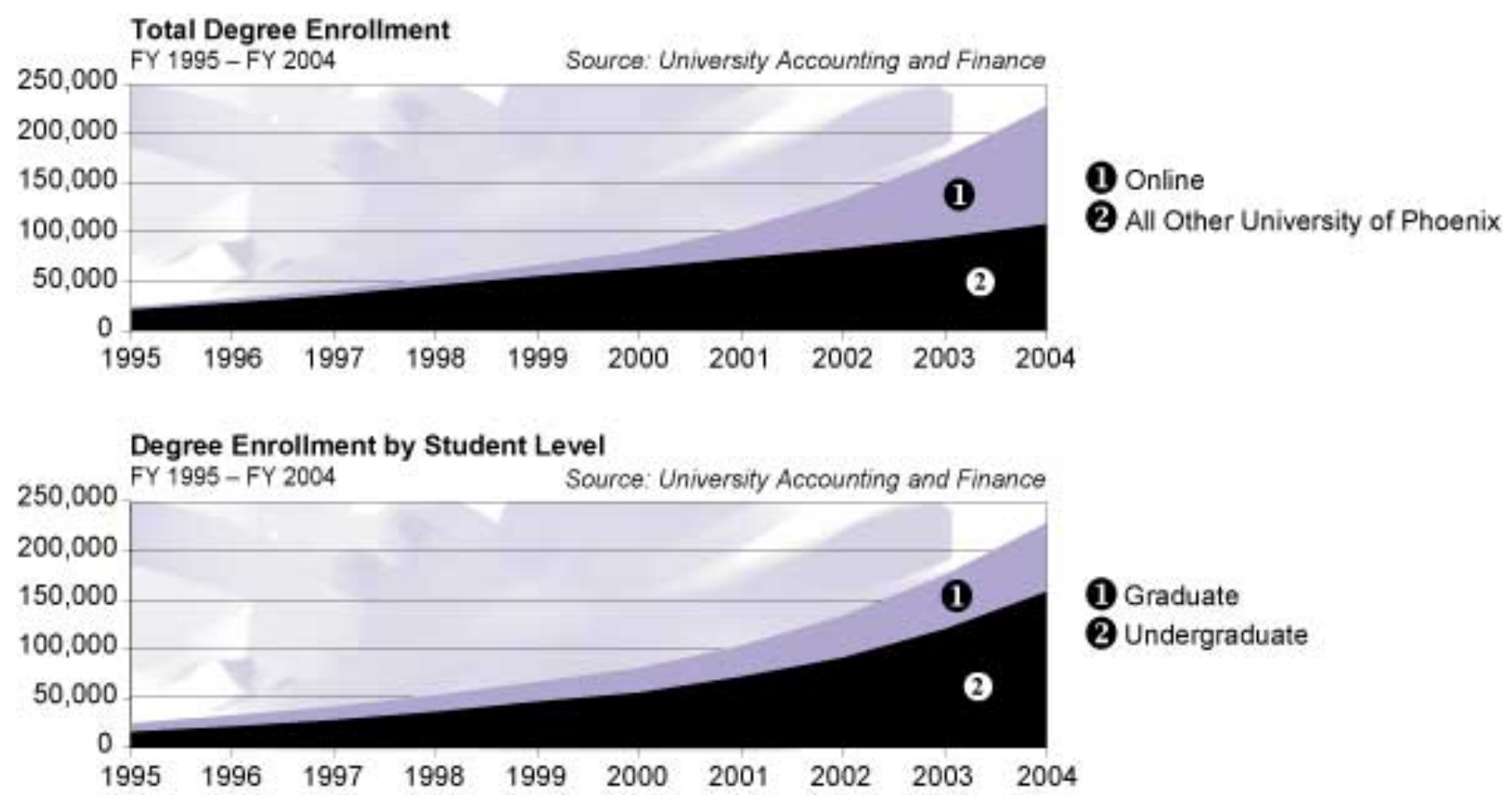

Gráfico 30: Registro do número de estudantes presenciais e on-line da Universidade de Phoenix

De acordo com o gráfico a seguir, verifica-se um leve declínio em relação à idade dos alunos com o passar do tempo. Em 1995, a faixa etária dos alunos estava acima de 35 anos; já em 2003 passou para 34 anos. A Universidade, desde sua fundação, sempre investiu em alunos com maior experiência profissional.

\section{Average Age of Entering Students}

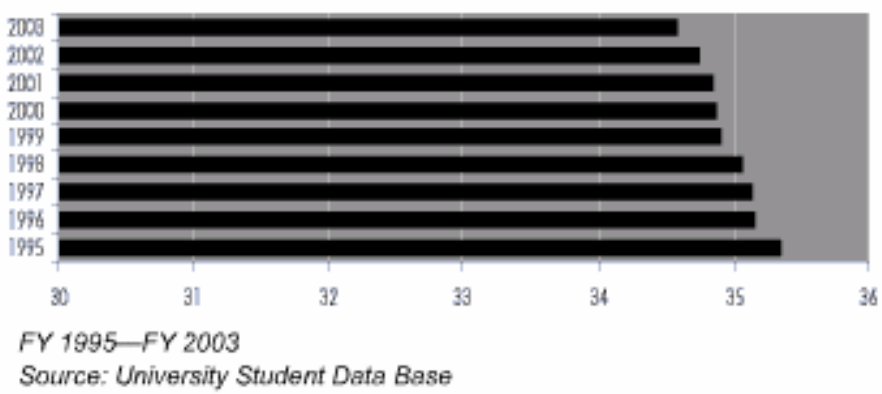

Gráfico 31: Cálculo de estudantes por média de idade da Universidade de Phoenix de 1995 a 2003

É interessante notar que a maioria dos alunos a partir de 35 anos ingressa em cursos de graduação, enquanto alunos de até 34 anos optam por outros cursos. 


\section{Average Age of Entering Students by Level}

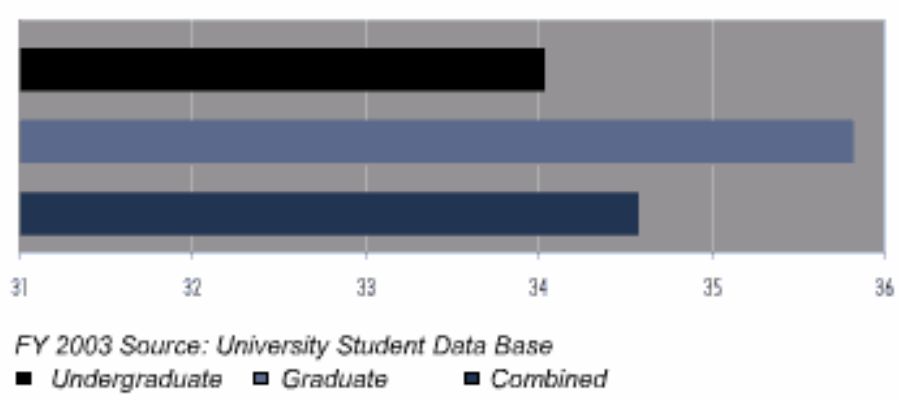

Gráfico 32: Cálculo de estudantes por média de idade e nível de curso. Universidade de Phoenix, 2003

Em relação aos aspectos étnicos, a Universidade de Phoenix é constituída basicamente de alunos brancos, perfazendo $61 \%$ do total de inscritos. Outras etnias possuem pouco destaque em relação a este total, conforme demonstra o gráfico:

\section{Ethnicity of Entering Students}

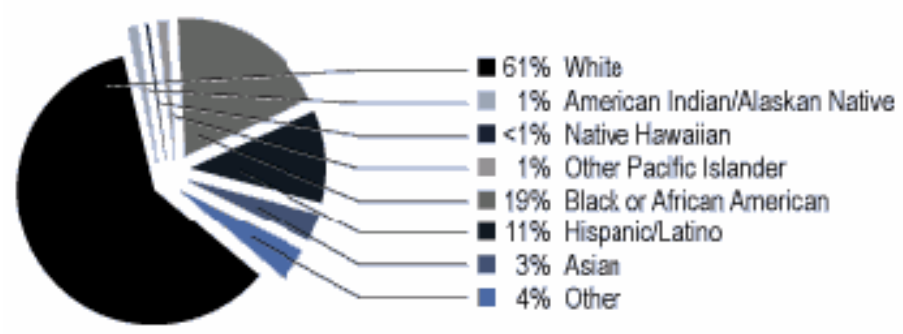

Gráfico 33: Entrada de estudantes por etnia. Universidade de Phoenix (2003).

\section{Recursos Humanos e Materiais}

Em vista de sua audaciosa proposta educacional, a Universidade de Phoenix procurou formar um corpo docente que privilegiasse a inter-relação entre o mundo acadêmico e o profissional, ou seja, entre formação educacional e mundo do trabalho. Contando com uma estrutura essencialmente acadêmica, que vai além dos aspectos curriculares e instrucionais, a UOP se pautou por incorporar profissionais com alta titulação acadêmica que atuassem ativamente no mercado profissional nas áreas em que lecionam, partindo do princípio de que educar é, antes de tudo, uma questão pessoal e um interesse profissional de cada um.

Por isso, sua estrutura organizacional reflete, de certa forma, o comprometimento com a produção dos materiais educacionais direcionados a seu público-alvo, ou seja, alunos 
adultos e trabalhadores com pouco tempo para se dedicar aos estudos realizados nos moldes tradicionais. Portanto, estabelecer pontes conceituais entre o campo teórico e o prático, neste aspecto, torna-se de vital importância dentro dos objetivos de se levar um conhecimento imediatamente relevante em relação aos conteúdos ministrados.

Dentro desse espírito profissional, a UOP congrega atualmente mais de 19.000 membros em seu corpo docente altamente qualificado, incluindo mais de 9.600 profissionais que atuam diretamente no seu campus on-line, além dos 170 campi espalhados por regiões dos Estados Unidos, Canadá, México e Porto Rico. Além disso, aproximadamente 1.500 profissionais são membros permanentes do corpo docente, estando diretamente envolvidos em atividades de liderança e de supervisão e avaliação da qualidade acadêmica em relação aos resultados com o processo de ensino e aprendizagem dos seus alunos.

Para participarem das atividades de treinamento e desenvolvimento educacional, seus docentes são avaliados regularmente por pareceristas altamente gabaritados, bem como por colegiados de estudantes e acadêmicos da Universidade. Vale lembrar que muitos dos instrutores da UOP são encorajados a dedicar longo período de tempo a suas atividades pedagógicas.

Mais de 50\% dos educadores da UOP que ministram cursos de mestrado possuem títulos de doutores e desenvolvem ao mesmo tempo atividades profissionais relacionadas a sua área no mercado de trabalho.

\section{Cursos oferecidos}

Tendo recebido autorização e credenciamento para seus cursos da Comissão de Ensino Superior dos Estados Unidos (Higher Learning Comission), a Universidade de Phoenix é atualmente membro da Associação de Faculdades e Escolas do Centro-Norte dos Estados Unidos. No entanto, até o momento só tem permissão para operar regionalmente, sendo que muitos de seus cursos não estão ainda devidamente autorizados, principalmente os seus programas de MBA.

Em 1989, a Universidade passou a oferecer seus cursos on-line, e hoje é uma das primeiras universidades credenciadas nos Estados Unidos na área de educação a distância, com graduações $100 \%$ on-line. 
Em 2002, a Universidade de Phoenix recebeu autorização para estender seus cursos ao Estado da Columbia, por meio da Comissão de Educação Privada de Ensino Pós-Médio (PPSEC - Private Post-Secondary Education Comission), que atualmente recebe o nome de Agência de Instituições de Treinamento de Carreiras do Setor Privado (PCTIA - Private Career Training Institutions Agency).

Existem três segmentos mais significativos de cursos oferecidos pela Universidade de Phoenix, a saber: os programas na área de Negócios e de Enfermagem e os de mestrado na área Social. Outras áreas também significativas são: educação, tecnologia, etc. Há cursos tanto de graduação como de pós-graduação, inclusive em nível de doutorado, contudo os mais procurados ainda são os de graduação e mestrado, em campos bem específicos de formação profissional.

Os cursos na área de Negócios não possuem até o momento credenciamento profissional, embora a Universidade esteja já em processo de credenciamento junto ao órgão competente dos Estados Unidos. A instituição alega que o intuito de muitos trabalhadores inscritos em seus cursos não é necessariamente obter um diploma na sua área profissional: estão mais interessados na aquisição de conhecimentos que possam ser devidamente úteis no desenvolvimento de seu trabalho. Nesse sentido, os alunos da UOP estão mais preocupados em se beneficiar do ensino de um corpo docente especializado, com mais conhecimento tácito nos seus campos de atuação profisssional. Isso permite aos alunos da Universidade aplicar, de forma mais integrada, os conteúdos do conhecimento adquirido durante o curso nas suas respectivas áreas profissionais. E é justamente neste sentido que a Universidade de Phoenix defende a posição de que, por não ter tais cursos credenciados, é que consegue tornar seu modelo educacional mais aderente às necessidades de sua demanda, sem empecilhos legais e burocráticos que advêm de um regimento acadêmico mais rígido e moroso.

No entanto, um estudo realizado pelo Consórcio de Universidades On-line dos Estados Unidos (OUC - Online University Consortium), disponível em http://www.onlineuc.net/, revela que os melhores programas de educação a distância se caracterizam por ter, em grande parte, seus cursos reconhecidos legalmente, tanto do ponto de vista regional como do ponto de vista profissional. A autorização e o reconhecimento legais para funcionamento de tais cursos estão subordinados à análise e à aceitação do Departamento de Educação dos Estados Unidos. Já os cursos voltados à 
área de negócios prescindem do reconhecimento da Associação de Escolas Colegiadas de Ensino Superior dos Estados Unidos (AACSB - Association to Advance Collegiate Schools of Business) e do Conselho Internacional do Colegiado em Educação de Negócios (IACBE - International Assembly for Collegiate Business Education), como pode ser observado no endereço http://www.onlineuc.net.warning.html. Há um padrão de aceitação em larga escala do mercado de ensino superior voltado à área de negócios, como é o caso dos cursos de MBA, por exemplo.

Quanto ao programa na área de Enfermagem, são oferecidos dois cursos oficialmente autorizados pela Comissão do Colegiado de Educação Superior em Enfermagem (CCNE - Comission on Collegiate Nursing Education): bacharelado em Ciências da Enfermagem e mestrado em Ciências da Enfermagem.

Por último, o curso mais popular na área Social é o programa de Orientação e/ou Aconselhamento. São oferecidas duas modalidades de cursos: mestrado em Orientação Comunitária, realizado nos campi da Universidade de Phoenix, Tucson e Arizona, e mestrado em Orientação para Doenças Mentais, realizado no campus da Universidade de Utah. Os dois tipos de cursos estão também oficialmente autorizados pelo Conselho de Credenciamento de Programas de Aconselhamento e de Questões Educacionais (CACREP - Council for Accreditation of Counselling and Related Educational Programs).

\section{Sistema de Estudos}

Para se inscrever em um dos cursos de graduação oferecidos pela UOP, o aluno precisa atender aos seguintes requisitos: possuir diploma regular de educação escolar em instituição americana ou diploma que ateste a continuidade de seus estudos posteriormente à idade escolar habitual, ou seja, após os 16 anos; apresentar comprovante de que está efetivamente empregado e atestar o fato de ser cidadão ou residente permanente nos Estados Unidos, ou ainda possuir um visto aprovado por órgão competente para freqüentar um campus universitário nos Estados Unidos. Se não estiver empregado, deve possuir acesso a um ambiente organizacional que lhe possibilite aplicar as estratégias pedagógicas dos cursos oferecidos pela Universidade de Phoenix. 
Os solicitantes à matrícula devem atender a todos os requisitos predefinidos para admissão na Universidade, inclusive submetendo-se a testes de pontuações e à aquisição de documentos comprobatórios de faculdades ou universidades com cursos reconhecidos no território americano ou de instituições estrangeiras que tenham acordos firmados com a Universidade de Phoenix. Estudantes afastados ou expulsos de outras instituições, independentemente das razões para o fato, deverão entrar em contato com o Conselho de Admissão para Apelações de Estudantes, a fim de levantar as condições de admissão permitidas e os procedimentos para reivindicar seus direitos estudantis.

No que diz respeito ao aproveitamento de créditos, a UOP permite a seus alunos ingressantes considerar trabalhos de conclusão de cursos realizados em instituições com reconhecimento regional ou nacional, ou exames com validade nacional, aos quais muitos alunos americanos se submetem ao longo de seus cursos, a fim de atestar seu nível de aprendizado durante o processo de formação escolar. São também igualmente considerados válidos para admissão ou aproveitamento de créditos: certificados de treinamento profissional, fornecidos por corporações, ou o comprovante de alistamento militar, os quais também podem ser convertidos, enquanto experiências anteriores significativas, em créditos acadêmicos de vários cursos.

\section{Materiais de estudo e estratégia educacional}

A Universidade de Phoenix possui experiência acumulada de mais de dez anos na oferta de cursos baseados na infra-estrutura da web. Além de cursos on-line, a Universidade tem um dos currículos mais atualizados e relevantes em relação a cursos de outras instituições de educação a distância.

Seus cursos foram formatados em parceria com diversas organizações que atuam na área de negócios e indústria nos Estados Unidos, sendo que os cursos on-line obedecem a estratégias de formação acadêmica e profissional que incorporam habilidades e conhecimentos muito demandados atualmente no mercado de trabalho. Já a estrutura curricular é continuamente adaptada, de modo a refletir os conceitos mais inovadores em termos de métodos e práticas pedagógicas existentes no mercado, contudo testados criteriosamente, de antemão, por um grupo de especialistas altamente qualificados da Universidade no campo da educação a distância. 
O sistema de ensino on-line adotado pela Universidade permite ao aluno completar $100 \%$ de suas atividades administrativas e educacionais, como, por exemplo, participar de reuniões de classe e atividades da equipe de aprendizado; comunicar-se com o instrutor; interagir com colegas de classe; conduzir suas pesquisas de modo autônomo; etc. Para ter acesso aos materiais de estudos, os alunos precisam basicamente de: um computador, uma conexão telefônica e um provedor de serviços da internet.

Além disso, o aluno pode completar seu curso de graduação a distância num período de dois a três anos.

A Universidade de Phoenix exige que o aluno tenha, no mínimo, 3 anos de experiência profissional significativa. Ela investe consideravelmente em serviços de tutoria, que são acompanhados um a um, sempre de forma personalizada. Caso um aluno deixe de fazer um exame na data marcada, no dia seguinte um tutor lhe envia uma mensagem para saber o que aconteceu. Isso faz com que a taxa de evasão em cursos a distância na Universidade seja a mínima possível.

Quanto às modalidades de aulas, a UOP desenvolve atualmente três tipos básicos: aulas de cursos de base (ground classes), aulas on-line e FlexNet.

As aulas de um curso de base são, de certa forma, muito parecidas com as aulas desenvolvidas em faculdades tradicionais. Normalmente, nelas os alunos assistem à aula contando com a ajuda de um professor-facilitador, que se encarrega de mediar uma discussão em classe. As aulas duram de 5 a 6 semanas em média, dependendo do tipo de programa de estudo feito pelo aluno. Se o aluno desejar programar suas aulas pelo período de um ano, desde que o intervalo entre elas não seja maior do que uma semana, poderá ter a opção de receber créditos do mesmo modo como se fosse um estudante de um curso universitário tradicional que estudasse em tempo integral. Essas aulas são definidas uma vez por semana em média, com quatro horas de duração cada. Espera-se, neste caso, que os alunos também se predisponham a dedicar um período extra para atividades com grupos de estudos (learning teams), formados, em geral, por 3 a 5 estudantes, que participam da atividade para cumprir os créditos atribuídos às suas disciplinas de curso. No final, cada grupo de estudos tem a incumbência de apresentar sua atividade em sala, como parte do processo avaliativo do curso.

As aulas on-line são realizadas via internet a partir da infra-estrutura disponibilizada pelo portal da UOP. É definido um facilitador de aprendizagem, que organiza a 
discussão na sala de aula virtual a partir da formulação de um elenco de questões que são postadas nos grupos de notícias (newsgroups). Cada aluno tem a incumbência de responder às perguntas postadas e discutir as respostas de cada um do grupo, coletivamente, via internet, o que possibilita uma interação on-line com uma variedade de tópicos, que, passo a passo, se multiplicam, por conta dos referenciais de análise que vão sendo desencadeados no calor das discussões. Comparativamente, em termos de formato, essas aulas se assemelham à primeira modalidade analisada (ground classes). Nesse tipo de modalidade, os alunos precisam participar ativamente, on-line, pelo menos quatro dias por semana, sendo que, normalmente, podem precisar de até 15 horas de estudos por semana para realizar as atividades previstas, durante o curso, embora tenham a possibilidade de vir a distribuir o tempo empregado durante a semana por meio de um calendário próprio para cumprir as atividades previstas para cada disciplina. Já a FlexNet é uma modalidade híbrida que conjuga tanto aspectos das chamadas "ground classes" como das aulas on-line. Durando em média seis semanas, os alunos têm uma primeira aula presencial e as quatro semanas seguintes destinadas exclusivamente para o uso do ambiente on-line, voltando, na última semana, a se encontrar presencialmente. Ou seja, a FlexNet mistura estratégias de encontros presenciais com encontros on-line, o que permite testar a eficiência, em parte, dos dois métodos anteriores.

Logo no primeiro encontro, os alunos recebem do instrutor de curso a lista de atividades que deverão realizar, que serão cumpridas em um formato on-line com base no uso de salas de aulas virtuais. Originariamente, este método foi designado para que os alunos freqüentassem salas de aulas normais com o uso do aparato tecnológico disponível para interação com alunos e instrutores, tendo sido recentemente adaptado para incorporar as práticas pedagógicas dos dois outros métodos.

Quanto à incorporação de tecnologias inovadoras de ensino e aprendizagem, a Universidade de Phoenix desenvolveu um portal de recursos digitais ( $r$ Esource), através do qual os alunos têm à sua disposição uma variedade de sistemas e ferramentas informacionais, provenientes de fontes acadêmicas e profissionais. Com esse recurso tecnológico, os alunos da UOP aprendem a inter-relação presente entre objetivos informacionais, formas de disponibilização de recursos de acesso à informação e métodos de avaliação do conhecimento produzido. Dentre os recursos mais empregados, destacam-se: coleções de e-books; relatos de experiências e estudos de casos 
empresariais, que exigem dos alunos soluções aplicadas a situações reais; organizações virtuais fictícias, que estimulam os alunos a empregar estratégias para resolver problemas complexos; simulações de casos eletrônicos voltados à resolução de problemas e ao desenvolvimento de cenários em um ambiente seguro de trabalho.

Além disso, o portal de recursos digitais da UOP disponibiliza um acervo informacional amplo, que engloba coleções on-line com mais de 20.000 revistas especializadas contendo mais de 20.000.000 de artigos completos e indexados, registros financeiros, enciclopédias, diretórios de livros, teses e dissertações, atualização de materiais novos feita diariamente, equipe profissional de bibliotecários e especialistas em tecnologia da informação para dar suporte aos alunos, tutoriais para realização de pesquisa on-line, bases de dados em espanhol, etc.

\section{Pesquisa}

Quanto ao nível de satisfação dos alunos da Universidade de Phoenix, segundo levantamento recente, provou-se que $94 \%$ dos alunos recomendariam os cursos da Universidade para outros trabalhadores adultos. Muitos deles ainda reconhecem o real impacto do curso em suas vidas profissionais, demonstrando como é importante existir cursos feitos para que se possa empregar o conhecimento aprendido no local de trabalho.

Em vista disso, 90,2\% dos alunos disseram que o curso atende perfeitamente às suas expectativas; $89,3 \%$ disseram que aprenderam como aprender conhecimento de outros, e $88,6 \%$ disseram que o curso os prepara bem para desenvolver atividades em equipe.

Com relação ao impacto que a formação educacional produziu em seus empregos, podese dizer que: 97\% dos entrevistados disseram que a educação que receberam foi um fator significativo para o aumento de salário; $90 \%$ disseram que ela foi um fator relevante para obter uma promoção profissional; $88 \%$ já disseram que, com o curso, obtiveram uma nova posição de destaque em sua empresa; e, finalmente, $89 \%$ disseram que, ao iniciar seu próprio negócio, a formação foi significativa para o alcance de seus objetivos. 


\section{Avaliação Educacional}

A UOP possui três instrumentos básicos de avaliação educacional: um Sistema de Avaliação Institucional, um Sistema de Gerenciamento da Qualidade Acadêmica e um Projeto de Avaliação de Resultados com a Aprendizagem de Adultos.

O Sistema de Avaliação Institucional tem por objetivo assegurar a consistência na qualidade educacional em vista dos recursos disponíveis e dos investimentos realizados. Medindo e avaliando a efetividade da Universidade em termos de consecução dos seus objetivos e dos seus processos de aprimoramento institucional, o sistema acabou sendo refinado por volta de 1990, quando foram incorporados os outros dois sistemas avaliativos que completam o processo de avaliação educacional da Universidade de Phoenix.

Já o Sistema de Gerenciamento da Qualidade Acadêmica (ALOA - Academic Quality Management System) tem por finalidade a obtenção de informações relativas aos processos acadêmicos, fornecendo feedback para que haja um contínuo aprimoramento no modo de empregar os instrumentos avaliativos. Ele monitora os processos educacionais dos alunos, o corpo docente, o currículo e os serviços administrativos, no sentido de se ter um instrumento eficiente para a tomada de decisões, tendo em vista diagnósticos contínuos que servem como indicadores de qualidade do processo educacional de toda a instituição. Completam a análise de dados outros levantamentos periódicos, destinados a estender o campo das análises dos dados, considerando aspectos como alunos matriculados, perfil dos alunos, alunos ao final do curso, corpo docente ao final do curso, término do programa de curso, alunos diplomados, alunos desistentes.

Por último, o Projeto de Avaliação de Resultados da Aprendizagem de Adultos (AQMS - Adult Learning Outcomes Assessment Project) procura avaliar os processos cognitivos e afetivos dos alunos da UOP, que envolvem as seguintes habilidades: pensamento crítico, habilidades comunicativas, valores profissionais e educacionais, portfólio dos alunos (certificados, cursos, etc.). 
No que diz respeito a seus sistemas avaliativos, a Universidade de Phoenix tem sido reconhecida como uma grande liderança em termos de pesquisa institucional e de avaliação de resultados na aprendizagem de alunos.

\section{Centros de Estudos}

A Universidade de Phoenix possui 37 centros de estudos espalhados pelo território americano em área continental, além de outros centros em Porto Rico, no Havaí e no Canadá.

Os centros de estudos estão localizados nos seguintes Estados americanos: Arizona (onde também fica a sede da Universidade de Phoenix), Arkansas, Califórnia, Carolina do Norte, Carolina do Sul, Colorado, Connecticut, Flórida, Georgia, Illinois, Indiana, Iowa, Kentucky, Lousiana, Maryland, Massachusetts, Michigan, Minnesota, Missouri, Nebraska, Nevada, Nova Jersey, Novo México, Oklahoma, Oregon, Pensilvânia, Texas, Utah, Wisconsin e Wyoming.

Cada um desses centros possui cursos bem específicos, que completam a rede de cursos oferecidos pela Universidade de Phoenix.

\section{Valor dos Cursos e Financiamento do Sistema}

Do ponto de vista financeiro, a Universidade passou de um rendimento econômico de US\$ 610 milhões em 2000 para US\$ 1,8 bilhão em 2004.

Os custos com instrução variam de campus para campus e de curso para curso, já que as universidades associadas à UOP têm autonomia própria para definir os custos mais adequados às suas necessidades e aos encargos diferenciados previstos. Para saber os custos e as taxas relacionadas a determinados cursos e instituições de ensino filiadas à Universidade de Phoenix, é recomendável que o aluno entre em contato com o profissional responsável pelo campus em que deseja se matricular.

No entanto, comparando os custos de uma instituição tradicional com os da Universidade de Phoenix, chega-se à conclusão de que os custos envolvidos são bem menores. Leve-se em consideração também o fato de que o tempo previsto para o 
término de um curso na UOP costuma ser ainda menor, o que diminui os custos para seus alunos, com um retorno mais rápido para o investimento realizado.

Há também bastante flexibilidade e disposição para se negociar as formas de pagamento dos cursos oferecidos. O aluno pode optar por pagar à vista ou parcelar o pagamento, durante o semestre ou ainda durante o ano. Muitas empresas também costumam reembolsar seus empregados com parte dos custos relacionados a seus estudos. A Universidade tem uma linha de financiamento com várias opções disponíveis, mesmo para alunos matriculados em cursos com altas taxas e encargos acadêmicos. Além disso, oferece um montante de bolsas de estudos, com valores variáveis, que podem ser pleiteadas a qualquer momento, em qualquer um de seus centros de apoio educacional.

A Universidade definiu um modelo padrão para a elaboração do orçamento de custos com o atendimento fornecido aos seus alunos. Baseado em informações coletadas pelo escritório central da Universidade sobre estatísticas sobre custos com trabalho acadêmico, o orçamento serve como base para a concessão de financiamentos federais e fundos para estudantes, e representa, em média, as despesas que os estudantes costumam ter. Os custos incluem despesas diárias particulares, taxas com materiais educacionais e outros encargos decorrentes. A média mensal estimada classifica os custos de seus alunos da seguinte forma:

\begin{tabular}{|l|l|}
\hline Despesas comuns: & Menos de US\$ 1.798,00 \\
\hline Taxas com financiamento educacional: & $\begin{array}{l}\text { US\$ 10,00 (graduandos) } \\
\text { US\$ 23,00 (pós-graduandos) }\end{array}$ \\
\hline Taxas com materiais educacionais: & $\begin{array}{l}\text { US\$ 50,00 (graduandos) } \\
\text { US\$ 63,00 (pós-graduandos) }\end{array}$ \\
\hline Taxas com serviços para acesso: & US\$ 40,00 \\
\hline
\end{tabular}

A distribuição dos custos com despesas comuns incluem dados sobre alimentação e moradia (55\%), bem como despesas com transporte, saúde, cuidados pessoais, vestuário e lazer (45\%). Essas taxas servem como base para um acompanhamento mensal dos custos, de modo a aprimorar o auxílio financeiro concedido aos alunos da Universidade, levando em conta a variedade de taxas em cada curso. As taxas correntes relativas a gastos com materiais de estudo e serviços para acesso aos recursos do campus virtual 
são, respectivamente, US\$ 75,00 para alunos graduandos e US\$ 95,00 para pósgraduandos, e US\$ 60,00 para o acesso geral à infra-estrutura de apoio virtual.

Produz-se também um relatório mensal relacionado especificamente aos custos com instrução no que diz respeito ao custo local de cada campus e de cada programa de estudos.

\subsubsection{Brasil}

\section{Contexto Nacional}

O Brasil possui uma longa história de educação a distância que remonta a princípios de século 20. Já em 1927, é criada a Comissão de Cinema Educação. Na década de 30, destacam-se quatro projetos principais de grande repercussão: em 1934, Edgard Roquete Pinto cria a Rádio-Escola Municipal; em 1936, é fundado o Instituto Nacional do Cinema Educativo; em 1937, inaugura-se o Serviço de Radiodifusão Educativa do Ministério da Educação e, em 1939, é instalado o primeiro instituto brasileiro para a oferta de cursos de iniciação profissionalizante a distância por correspondência - o conhecido Instituto Monitor.

Na década seguinte, houve também outros projetos significativos, como em 1941, quando se cria o Instituto Universal Brasileiro e a Universidade do $\operatorname{Ar}(\mathrm{RJ})$ e se emprega o processo de radiodifusão para formar professores leigos, e em 1947, quando é inaugurada a Universidade do Ar (SP), primeira experiência do Serviço Nacional de Aprendizagem do Comércio (SENAC), que conta com técnicas de educação a distância, em parceria com o Serviço Social do Comércio (SESC), que chegou a alcançar mais de 90 mil alunos, em 318 cidades cobertas por estações de rádio, durante o período de 1947 a 1962, quando finalmente foi desativada.

$\mathrm{Na}$ década de 50, surge o Sistema Radioeducativo Nacional (SIRENA), que desenvolve uma notável produção de programas educativos, veiculados por emissoras espalhadas por todo o país.

Nos anos sessenta, iniciam-se definitivamente as experiências com a TV Educativa brasileira, por meio do Ministério da Educação. Em 1964, por exemplo, são criados 48 
canais de VHF e 50 de UHF, com o objetivo de se implantar emissoras de televisão educativa no país. É nesse sentido, por exemplo, que a Fundação João Batista do Amaral desenvolve o seu programa de alfabetização de adultos e de aperfeiçoamento de professores transmitido pela TV Rio, até 1965, e a FUNTEVÊ-MEC (Fundação Nacional de Televisão Educativa) - atual TVE do Rio - é criada pelo Ministério da Educação em 1967, enquanto a TV Cultura é criada pela Fundação Padre Anchieta (atual TV Cultura de São Paulo), com o objetivo de promover atividades educativas e culturais a partir do uso do rádio e da televisão.

Já na década de 1970 é desenvolvido o projeto SACI (Satélite Avançado de Comunicações Interdisciplinares), uma iniciativa conjunta do Ministério da Educação e do Centro Nacional de Pesquisas e Desenvolvimento Tecnológico (CNPq), contando ainda com o apoio do Instituto Nacional de Pesquisas Espaciais (INPE). O relatório final deste projeto é elaborado em 1976, no qual se registra um total de 1.241 programas de rádio e TV realizados, com recepção em 510 escolas de 71 municípios brasileiros.

Nessa década emergem numerosas propostas de educação a distância. Uma das mais conhecidas, sem dúvida, é o chamado projeto Minerva, criado pelo Ministério da Educação, em 1970, dando ênfase à educação de jovens e adultos. O Projeto Minerva, transmitido em rede nacional por 1.200 emissoras de rádio e 63 emissoras de televisão, visava preparar alunos para os exames supletivos de Capacitação Ginasial e Madureza (supletivo ginasial e colegial, que atendia a alunos na faixa dos 16 aos 19 anos). Com base nesta proposta pedagógica, foram atendidos 17.246 alunos, de outubro de 1970 a dezembro de 1971.

Outras experiências relevantes foram também a Telenovela Educativa, como a de João da Silva, dirigida por Jacy Campos, entre 1973 e 1974; os programas de Supletivo de $1^{\circ}$ grau: Fase I, transmitidos pelo sistema radiofônico brasileiro; o teleensino do Exército, realizado em 1974; as teleaulas da Televisão Educativa do Ceará (TVE/CE) e o Projeto Acesso, criado pelo CETEB/FUBRAE (RJ e DF).

Em novembro de 1977, por exemplo, cria-se a Fundação Roberto Marinho, ligada às Organizações Globo, que, com a Fundação Padre Anchieta, em 1978, passa a oferecer o Telecurso $2^{\circ}$ Grau. Neste projeto, são então aproveitados vários atores da equipe de teledramaturgia comercial da Rede Globo de Televisão. Outra experiência importante 
que seguiu a mesma linha conceitual, nesse mesmo período, foi o Projeto Conquista, criado pela Fundação Centro Brasileiro de Televisão Educativa (FCBTVE, futura FUNTEVÊ) e pelo Ministério da Educação/TVE, que se compunha basicamente de uma telenovela feita para o ensino supletivo de $5^{\mathrm{a}}$ a $8^{\mathrm{a}}$ série, além de programas voltados para a alfabetização, com o uso da televisão, em parceria com o projeto do Movimento Brasileiro de Alfabetização (Mobral).

Na década de 80, surgiu o projeto Seringueiro, compreendendo a produção de 230 programas educativos, veiculados pela Rádio Nacional de Brasília, em convênio com a rádio Cruzeiro do Sul, no Acre. Outros programas importantes com o uso de tecnologia educacional foram ainda: o projeto Universidade Aberta, baseado em um convênio entre a Universidade de Brasília e a Open University da Inglaterra; o Programa de Aperfeiçoamento do Magistério, oferecido pela ABT e voltado a professores do $1^{\circ} \mathrm{grau}$, e o programa Patati-Patatá, da TVE-RJ, com programas destinados a estimular atividades de sala de aula, com professores do $1^{\circ}$ grau.

Em 1983, a partir de um convênio entre o jornal O Povo, de Fortaleza (CE), e a Universidade de Brasília (UnB), cria-se a Universidade Aberta do Nordeste, dando-se início a uma série de cursos publicados em jornais de todo o país. Os cursos normalmente faziam parte do pacote que a UnB havia traduzido da Open University (Inglaterra), nas áreas de Política e Filosofia.

Ainda em 1983, a partir de uma parceria entre o Centro Educacional de Niterói (CEN), da FUBRAE, e a Faculdade do Centro Educacional de Niterói (FACEN), é realizado o projeto "Educando o Educador", para atender à rede educacional da Secretaria de Educação e Cultura do Estado de Goiás. No mesmo ano, é criada a TVE/MT (Televisão Educativa do Estado do Mato Grosso).

Já em 1987, mais algumas novas iniciativas importantes são realizadas, como o Primeiro Encontro de Educação e Televisão no país e o lançamento do Projeto Universidade Vídeo, pelo CNPq, durante a $39^{\mathrm{a}}$ Reunião da SBPC, cujo objetivo era estimular a produção em vídeo, bem como o emprego deste recurso nas Instituições de Ensino Superior (IES).

Em 1989, cria-se o Instituto Nacional de Educação a Distância (INED), que atuou até 1996 no desenvolvimento e na implantação de projetos de cursos a distância, em 
cooperação com a Conferência Nacional dos Bispos do Brasil (CNBB), o Instituto Brasileiro de Análises Sociais e Econômicas da Escola de Administração Fazendária (ESAF) e a prefeitura da cidade de Curitiba.

Na década de 1990, mais projetos são desenvolvidos, porém dentro da ótica mais tradicional da $\mathrm{EaD}$, como cursos técnicos (ensino por correspondência), oferecidos pelo CETEB; matemática por correspondência, oferecido para professores de $1^{\circ}$ grau até o ano de 1991, realizado com a parceria entre o Instituto Nacional de Estudos e Pesquisas Educacionais (INEP) e a Fundação Brasileira para o Desenvolvimento do Ensino de Ciência (SBPC), empregando mídia impressa e veiculado no jornal do próprio INEP; cursos profissionalizantes a distância, promovidos pelo Centro de Ensino de Niterói da Fundação Brasileira de Educação, com certificação de $2^{\circ}$ grau; Um Salto para o Futuro, programa de atualização de docentes das séries do $1^{\circ}$ grau, criado pela Fundação Roquete Pinto (TVE-Rio) em parceria com a Secretaria Nacional de Educação Básica e articulado às secretarias estaduais de educação; criação de uma cátedra da UNESCO especialmente voltada para Educação a Distância, o que impulsionou a criação de um novo grupo de trabalho em EaD na UnB e criação do Sistema Nacional de Radiodifusão Educativa (SINEAD), pelo Ministério da Educação, por meio da portaria 344/93.

Já em 1994, deu-se início ao Telecurso 2000, uma remodelação do antigo Telecurso $1^{\circ}$ Grau e $2^{\circ} \mathrm{Grau}$; TV SENAC, projeto realizado inicialmente por meio de teleconferência e videoconferência; Infovia, projeto criado pela Rede Nacional de Pesquisa (RNP) em parceria com a Confederação Nacional das Indústrias (CNI) e o Serviço Nacional de Aprendizagem Industrial (SENAI), visando implementar uma rede de dados interligando todas as unidades do sistema CNI/SENAI com vistas a oferecer infraestrutura de internet e serviços avançados de acesso a informação e comunicação, como videoconferência e TV Corporativa (a infovia é estruturada a partir de sistema integrado por satélite e uso de fibras terrestres, permitindo capilaridade suficiente para ações de educação a distância e uso administrativo).

Lançado pelo Governo Federal em setembro de 1995, com o objetivo de equipar escolas públicas de todo o Brasil com kits tecnológicos para recepção e gravação de sinal de TV por antena parabólica, o Programa TV Escola visava a veiculação de programação educativa. Em operação a partir de março de 1996, em três anos (em junho de 1999), 56 mil escolas públicas já haviam instalado seus kits tecnológicos. 
Pode-se dizer que, dentre os programas com o objetivo de formação geral, o Projeto Minerva foi um dos que, sem dúvida, maior impacto tiveram no país, segundo LIMA (1990). Afirma Alonso (1996) ${ }^{214}$ que o projeto se estendeu até o início dos anos 80, mas durante todo o tempo de sua transmissão sofreu severas críticas. Apesar disso, algo em torno de 300.000 pessoas tiveram acesso às emissões radioeducativas. Destas, 60.000 solicitaram o exame de Madureza; no entanto, somente 33\% delas foram aprovadas. As críticas a esse projeto, segundo Lima (1990), estão "localizadas" basicamente nos seguintes aspectos:

- Currículos: as equipes não estavam bem preparadas para esta tarefa, elaborando currículos extremamente simplificados

- A radiodifusão: as horas destinadas à programação do projeto não foram cumpridas

- A tecnologia utilizada: as pessoas não reconheciam o rádio e a TV como meios educativos

- Conteúdos: os conteúdos não foram adaptados à realidade da população das diferentes regiões do país

- O atendimento sistemático aos alunos: as equipes regionais não foram suficientes para suportar a demanda de solicitações por parte dos alunos

Outro projeto significativo foi o IRDEB (Instituto de Radiodifusão do Estado da Bahia), através do rádio, da TV, do correio e de materiais escritos. O IRDEB surgiu em 1969 e se estendeu até o ano de 1977, sendo que 78.106 pessoas foram atendidas dentro desta perspectiva educacional.

Assim podemos mencionar o projeto LOGOS, nascido em 1973 por meio do parecer 699/72 do Ministério da Educação; o projeto FUNTEVÊ, que nasceu em 1985 já na “abertura política" brasileira; o projeto Crescer, destinado à formação de magistério de $2^{\circ}$ grau, no Estado de Goiás e em convênio com a Secretaria de Educação, entre outros.

Segundo Romiszowski (2004), a década seguinte, de meados de 1980 a meados de 1990, mostrou uma forte retração no lançamento de novos projetos de $\mathrm{EaD}$ e muitos dos projetos previamente estabelecidos desapareceram (inclusive a maioria dos projetos bem-sucedidos, lançados pelo setor público).

\footnotetext{
${ }^{214}$ Disponível em: <http://www.nead.ufmt.br/documentos/Ident.doc >. Acesso em: 26nov06.
} 
Já a partir do ano 2000, iniciaram-se os projetos como o EducaDi, que objetivou as aplicações da internet em $\mathrm{EaD}$ para o atendimento de populações de regiões marginais urbanas, além de estar voltado à formação de professores. Outra experiência relevante é a Escola do Futuro, núcleo de pesquisa desenvolvido pela USP para a investigação e a disseminação das novas tecnologias de comunicação aplicadas à educação, bem como dos recursos da internet para apoio à pesquisa de estudantes e professores. Finalmente, tem-se ainda o Telecurso 2000, uma iniciativa da Fundação Roberto Marinho em parceria com o Sistema FIESP/CIESP/SESI/SENAI/IRS, dirigido a jovens e adultos, com uma proposta direcionada à formação para o mundo do trabalho por meio da educação a distância, com uso de multimeios (TV, vídeo, material impresso, monitoria, prática de oficina, entre outros).

Atualmente, no Brasil, oferecem cursos superiores a distância tanto as instituições públicas quanto as privadas, legalmente credenciadas, para o ensino superior a distância $^{215}$, por intermédio do parecer do Conselho Nacional de Educação, homologado pelo Ministro da Educação, tendo em vista a Portaria publicada no Diário Oficial, nos termos da Lei 9.394/96 (LDB) e do Decreto 2.494/98; e a Portaria MEC no 4.361/2004 (que revoga a Portaria MEC n 301/98) e a Portaria MEC no 4.059/04 (que substitui a Portaria 2253). ${ }^{216}$

Também em 2004, a Portaria $n^{0} 4.059$ possibilita às instituições de ensino superior introduzir na organização pedagógica e curricular de seus cursos superiores reconhecidos a oferta de disciplinas integrantes do currículo que utilizem também a modalidade semipresencial, até cerca de $20 \%$. No entanto, a portaria deixa claro que esta oferta deverá incluir métodos e práticas de ensino-aprendizagem que incorporem o uso integrado de tecnologias de informação e comunicação para a realização dos objetivos pedagógicos, bem como para prever encontros presenciais e atividades de tutoria.

Já a partir de 2006, com a Portaria n 873 de 7 de abril, o Ministro da Educação autoriza, em caráter experimental, a oferta de cursos superiores a distância nas

\footnotetext{
${ }^{215}$ Definição de Educação a Distância do MEC: "Educação a Distância é uma forma de ensino que possibilita a auto-aprendizagem, com a mediação de recursos didáticos sistematicamente organizados, apresentados em diferentes suportes de informação, utilizados isoladamente ou combinados, e veiculados pelos diversos meios de comunicação" (Decreto 2.494, de 10.02.1998). Portal MEC.

Disponível em: <http://www.mec.gov.br/Sesu/educdist.shtm\#quem\%20pode\%20oferecer>. Acesso em: 28 nov 2004. ${ }^{216}$ Disponível em: <http://www.mec.gov.br/Sesu/educdist.shtm\#quem\%20pode\%20oferecer>. Acesso em: 28 nov 2004.
} 
instituições federais de ensino superior, no âmbito dos programas de indução da oferta pública de cursos superiores a distância fomentados pelo MEC, o que possibilita o seu engajamento nos programas da Universidade Aberta do Brasil e da "Pró-Licenciatura".

A partir de 1998, observa-se um crescente envolvimento das instituições de ensino superior, como ilustra bem o aumento de pedidos de credenciamento e autorização de cursos superiores de educação a distância:

\begin{tabular}{|c|c|c|c|c|c|}
\hline Período & 1998 & 1999 & 2000 & 2001 & 2002 \\
\hline $\mathrm{N}^{\mathrm{o}}$ Pedidos & 08 & 14 & 05 & 10 & 47 \\
\hline
\end{tabular}

Fonte: MEC/SESu/DEPES, maio de 2002.

Ao final de 2002, o número de alunos distribuídos em 60 cursos superiores a distância (graduações e especializações, registradas perante os órgãos oficiais) alcançava 84.713 (UNESCO, 2003, p. 14) nas universidades públicas brasileiras, sendo que, nas particulares, o número era de apenas 831. Ainda segundo o mesmo relatório, sobre um total de Instituições de Ensino Superior (IES) de 1.391, só 33 foram credenciadas para a EaD até o ano 2002, sendo que a relação de alunos presenciais e a distância nesse ano era de 3.030 .754 presenciais e 84.713 a distância. Destes, as matrículas se distribuíam em 60 carreiras superiores, da seguinte forma:

\begin{tabular}{|l|l|}
\hline Carreira & Alunos \\
\hline 13 Licenciaturas para Ensino Fundamental & 65.315 \\
\hline 07 Licenciaturas para o Ensino Médio & 16.462 \\
\hline 36 Pós-Graduações lato sensu & 2.225 \\
\hline 02 Superiores de curta duração (seqüenciais) & 201 \\
\hline 02 Graduações (Administração e Química) & 630 \\
\hline Total: & $\mathbf{8 4 . 7 1 3}$ \\
\hline
\end{tabular}

Tabela 21: A Universidade Virtual no Brasil, Os números do ensino superior a distância no país em 2002. Instituto Internacional da UNESCO para a Educação Superior na América Latina e no Caribe. Seminário Internacional sobre Universidades Virtuais na América Latina e Caribe. Quito, Equador, 13 e 14 de fevereiro de 2003, p.14. Fonte: UNESCO.

Já no ano de 2004, o número de alunos chegou a 309.957, e 166 instituições foram autorizadas pelo Ministério de Educação a oferecer tais cursos. No ano de 2005, o número de alunos chegou a 504.204, denotando um crescimento de $62,7 \%$ acima do ano anterior. Já o número de instituições autorizadas pelo Ministério da Educação a oferecer estes cursos aumentou em 30,7\% no mesmo período, passando de 166, em 2004, para 217 , em 2005. 


\section{a) Universidade Aberta do Brasil}

\section{Endereço}

A princípio, não se pretende definir uma sede para o funcionamento da Universidade Aberta, com localidade física, uma vez que a UAB é mais vista com uma iniciativa de articulação de frentes de parcerias distribuídas por todo o território do país, estando subordinada diretamente à Secretaria de Educação a Distância do Ministério da Educação do Brasil (MEC-SEED).

\section{Contexto Histórico}

A UAB foi criada em 2005, pelo Ministério da Educação do Brasil (MEC), no âmbito das chamadas "Estatais pela Educação", com o objetivo de articular e integrar experiências em EaD a partir do Sistema Nacional de Educação Superior. Formado por instituições públicas de ensino superior, este sistema pretende ser um instrumento eficaz para expandir as possibilidades de acesso ao ensino público gratuito de qualidade, levando-o a municípios brasileiros em que não haja tal oferta ou nos quais ela não seja suficiente para atender às necessidades de todos os cidadãos brasileiros.

O Sistema Educacional da Universidade Aberta do Brasil (UAB) é uma iniciativa do Governo Federal brasileiro. Voltada à pesquisa e à educação superior, abrange tanto a formação inicial como a contínua, e que pretende ser um órgão de articulação de um conjunto de pólos municipais de apoio presencial espalhados por todo o território brasileiro, de modo a apoiar estratégias pedagógicas em educação a distância a serem desenvolvidas com o uso de diversas tecnologias de ensino e aprendizagem.

A UAB nasce inicialmente como fruto de uma parceria entre o MEC-SEED (Secretaria de Educação a Distância do Ministério de Educação), o Banco do Brasil (integrante do Fórum das Estatais pela Educação) e Instituições Federais e Estaduais de Ensino Superior. 


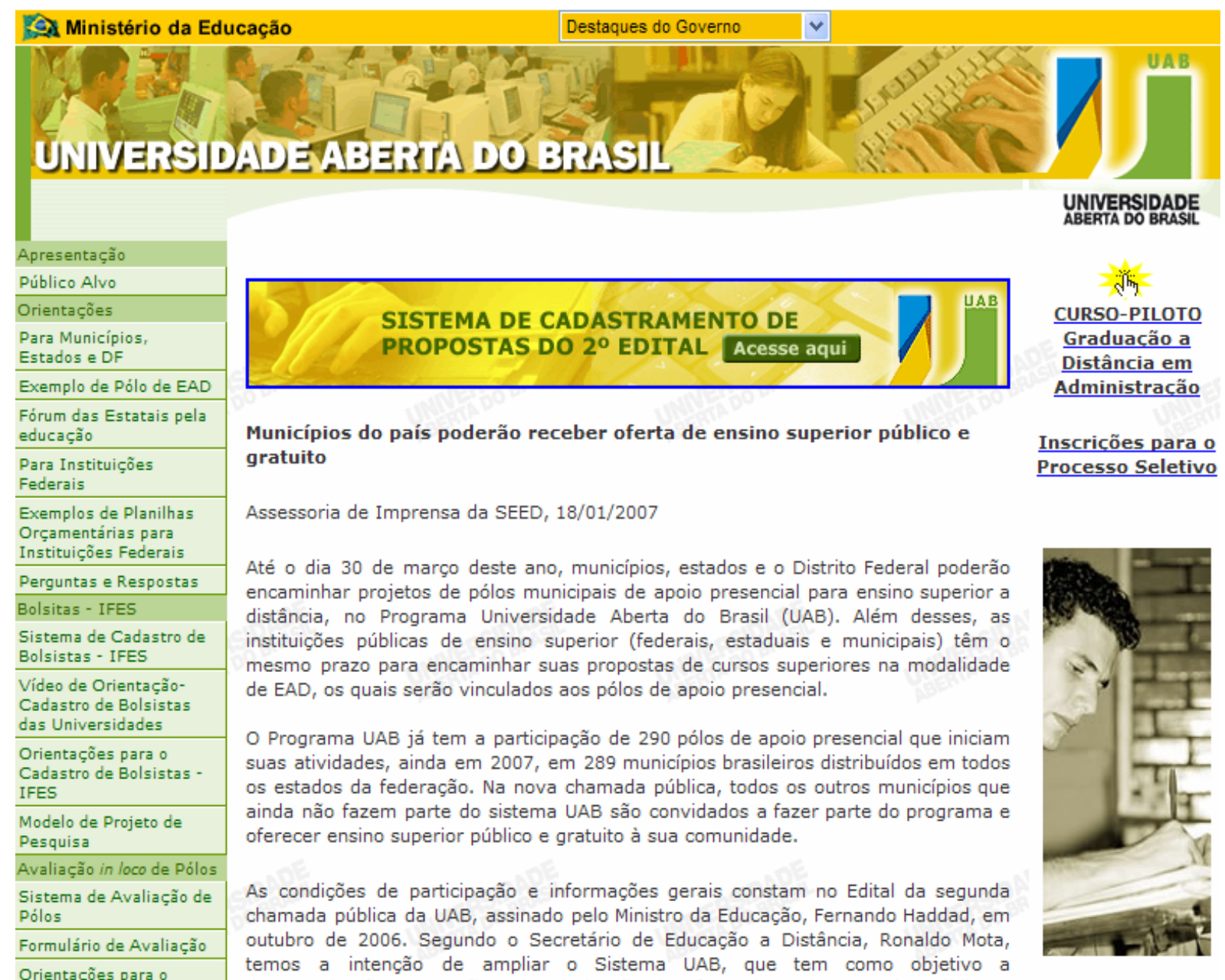

Orientações para o

Preenchimento do

democratizac̃ão, expansão e int.

Figura 57: Apresentação da Universidade Aberta do Brasil (UAB). Disponível em: $<$ http://mecsrv70.mec.gov.br/webuab/>. Acesso em 06 jan 07.

\section{Objetivos}

Os principais objetivos delineados pelo Sistema UAB são: democratizar e expandir a interiorização da oferta de ensino superior público e gratuito no Brasil e desenvolver projetos de pesquisa e de metodologias inovadoras de ensino, com destaque para a área de formação inicial e contínua de professores da educação básica.

\section{Público-alvo}

Os cursos oferecidos destinam-se a qualquer cidadão que já concluiu o curso de educação básica (ensino fundamental e médio), desde que também aprovado no processo seletivo e que atenda aos requisitos exigidos pela instituição pública vinculada ao sistema educacional da Universidade Aberta do Brasil (UAB). A demanda inicial 
prevista para o primeiro curso piloto é de 10.000 vagas, para atender a alunos de todas as regiões do país.

\section{Recursos Humanos}

A definição dos Recursos Humanos da UAB está ainda condicionada às estratégias de ofertas de cursos e à estruturação dos principais pólos de apoio que estão por se realizar a partir da formação de parcerias e consórcios.

A princípio, esta seria a relação de Recursos Humanos necessários para atender a um determinado pólo de apoio presencial às atividades da UAB:

\begin{tabular}{|l|l|}
\hline \multicolumn{2}{|l|}{ RECURSOS HUMANOS } \\
\hline $\begin{array}{l}\text { Coordenador de Pólo de Apoio Presencial, } \\
\text { responsável pela parte administrativa e gestão } \\
\text { acadêmica }\end{array}$ & 1 coordenador de pólo \\
\hline $\begin{array}{l}\text { Técnico em informática, responsável pela } \\
\text { manutenção e assistência aos equipamentos de } \\
\text { informática }\end{array}$ & 1 técnico em informática \\
\hline $\begin{array}{l}\text { Bibliotecário(a), para organizar, armazenar e } \\
\text { divulgar o acervo, visando otimizar o uso do } \\
\text { material bibliográfico e especialmente } \\
\text { proporcionar serviços bibliográficos e de } \\
\text { informação. }\end{array}$ & 1 bibliotecário(a) ou auxiliar \\
\hline $\begin{array}{l}\text { Auxiliar para Secretaria para serviços gerais de } \\
\text { secretaria. }\end{array}$ & 1 secretário(a) \\
\hline Tutor Presencial & $\begin{array}{l}1 \text { tutor presencial (para } 25 \\
\text { alunos) }\end{array}$ \\
\hline $\begin{array}{l}\text { Tutor Presencial para Laboratório Pedagógico } \\
\text { de Ensino }\end{array}$ & $\begin{array}{l}1 \text { tutor } \\
\text { presencial/laboratório/curso }\end{array}$ \\
\hline
\end{tabular}

Tabela 22: Recursos Humanos para atender atividade da UAB. Fonte: Portal da UAB. Disponível em: <http://mecsrv70.mec.gov.br/webuab/polo.php>.

Acesso em: 05 jan 2007.

Naturalmente, esta infra-estrutura ainda é um modelo idealizado, que poderá sofrer mudanças à medida que se torne complexo o sistema de oferta de cursos, a demanda por novos profissionais e a entrada de novos parceiros no projeto pedagógico da UAB.

Durante o desenvolvimento do projeto da UAB, os municípios, os Estados ou mesmo o Distrito Federal, quer seja na forma de parceria, quer seja na de consórcio, poderão definir a carga horária a ser empregada por seus servidores (docentes, funcionários 
técnicos e administrativos) na atribuição de tarefas necessárias, a serem devidamente remuneradas no pólo de apoio presencial às atividades de $\mathrm{EaD}$, ou mesmo prever ainda a contratação de pessoal necessário.

A UAB define um pólo de apoio presencial como sendo um espaço constituído por laboratórios de ensino e pesquisa, laboratórios de informática, biblioteca, recursos tecnológicos modernos, dentre outros elementos julgados necessários para a oferta de cursos a distância em condições adequadas para o desenvolvimento do processo de ensino e aprendizagem a distância. Seu espaço físico deve permitir a execução descentralizada de funções didático-administrativas relacionadas à implantação de cursos a distância organizados segundo a integração de esforços múltiplos de várias instituições públicas, inclusive contando com apoio determinante de governos municipais e estaduais com interesses diretamente vinculados à requalificação de demandas locais de cidadãos brasileiros.

Caso um município brasileiro não tenha a oferta de cursos superiores presenciais, a prefeitura deste município poderá construir um pólo de apoio presencial, que servirá como base de apoio para o atendimento dos estudantes locais do curso oferecido.

\section{Cursos Oferecidos}

A princípio, foi prevista a oferta de cursos para o primeiro semestre de 2006, cobrindo pelo menos 17 Estados da Federação e o Distrito Federal. Para organizar o processo pedagógico e de gestão do projeto, foram definidas cinco Comissões de Trabalho, responsáveis por analisar os projetos de cursos: uma Comissão Pedagógica, uma Comissão Editorial, uma Comissão do Processo de Seleção, uma Comissão de Acompanhamento e Avaliação e uma Comissão de Acompanhamento de Convênios.

Entre os pólos inicialmente aprovados pela comissão da UAB, está a oferta de cursos nas áreas de: Pedagogia, Administração, Computação, Teatro, Música, Biologia, História, Química, Geografia, Filosofia, Filosofia e Psicanálise, Filosofia e Educação no Ensino Religioso, Artes Visuais, Artes Plásticas, Física, Metodologia do Ensino Fundamental, Pedagogia - Normal Superior, Educação Básica, Práticas Pedagógicas, Práticas de Letramento e Alfabetização, Ensino de Ciências por Investigação, Educação Especial, Educação Musical, Educação: Métodos e Técnicas de Ensino, Saúde para 
Professores de Educação, Formação de Professores de Tradução, Letras - Português, Espanhol, Francês e Inglês, Ciências Naturais e Matemática, Desenvolvimento de Sistemas para Web, Gerência de Conteúdo Web, Design Instrucional para EaD Virtual, Saúde Indígena, Ciências Contábeis, Ciências Biológicas, Hotelaria, Sistemas de Informação, Gestão em Saúde, Ativação de Processos de Mudança na Formação, Educação Física, Infância e Educação Inclusiva, Computação, Hospedagem, Gerenciamento Ambiental, Gestão Ambiental, Ciências Agrárias, Secretariado Executivo, Logística, Controle da Administração Pública, Formação do Educador Rural, Gestão de Entidades sem Fins Lucrativos, Desenvolvimento Sustentável, Gestão de Agronegócios, Agricultura Familiar, Planejamento e Gestão para o Desenvolvimento Rural, Ciências Agrárias, Gestão de Pessoas e Projetos Sociais, Formação de Profissionais em Enfermagem, Educação Empreendedora, Empreendedorismo e Inovação, Gestão em Projetos de Investimento em Saúde, Saúde da Família, Gestão em Saúde, Saúde Pública, Gestão Pública, Engenharia de Controle e Automação, Tecnologias no Ensino de Matemática, Educação Tecnológica, Educação a Distância, Tecnologia Sucroalcooleira, Engenharia Ambiental, Informática em Saúde, Gestão Educacional, Tecnologia de Informação e Comunicação na Educação, Gestão Pública, Gestão de Arquivos, Direito e Diversidade, Museologia Científica, Divulgação Científica.

Mesmo em tão pouco tempo de existência, percebe-se como a iniciativa da UAB já foi frutífera no sentido de articular diversas propostas de cursos de formação em muitas áreas do conhecimento, abrangendo áreas distantes do país, levando em conta tanto aspectos de formação tradicional quanto a sensibilidade necessária para atender a novas demandas educacionais.

Ao todo, é possível mapear cerca de 80 títulos de cursos diferentes que estão sendo oferecidos por 197 instituições credenciadas em todo o país, naturalmente com uma demanda maior para cursos de formação em áreas tradicionais do conhecimento (Matemática, Biologia, Química, Física, Letras, etc.), nas áreas de formação de professores, na área tecnológica e, principalmente, em áreas que reconhecem a demanda e a vocação regional para o desenvolvimento econômico, cultural e tecnológico, a saber: desenvolvimento rural e sustentável, agronegócios, agricultura familiar, etc. Há também alguns cursos que tratam da formação de profissionais para atuar na área de EaD: cursos 
de design instrucional, prática de ensino a distância, tecnologias de informação e comunicação aplicadas à educação, etc.

Os cursos, a princípio, obedecem às seguintes categorias de formação educacional: nível tecnológico, licenciatura, lato sensu, bacharelado e seqüencial.

Algumas das instituições inscritas e autorizadas como pólos já identificaram suas demandas locais por cursos, o que nos dá uma idéia, grosso modo, de como estão se formando as demandas iniciais por curso, estado e região do país. Por exemplo, no caso do Rio de Janeiro, há uma quantidade de cursos demandados pelo Estado em torno de 197, com um total de vagas demandadas perfazendo cerca de 11.208. Já em São Paulo, a quantidade de cursos demandados cai para 70, e o total de vagas demandadas perfaz apenas 4.255. Ao analisar os dados identificados até o momento, verifica-se uma tendência de demanda maior ainda em regiões mais populosas e desenvolvidas. No entanto, a questão cultural de como se vê a educação a distância e aberta tem sido também crucial no equacionamento das demandas locais. O Estado de São Paulo, por exemplo, tem uma demanda significativamente inferior ao Estado do Rio de Janeiro, levemente inferior ao Estado do Rio Grande do Sul, quase que equivalente à demanda do Estado do Paraná e quatro vezes maior do que a demanda do Estado de Pernambuco. No caso da Região Norte, por exemplo, a demanda pela EaD ainda é bastante ociosa, nos termos diagnosticados pelas instituições ofertantes, até o momento. Lembre-se que o projeto ainda está em um estágio bem embrionário de articulação de propostas e de sensibilização de demandas.

\section{Sistema de Estudos}

Os cursos a distância devem ser apresentados pelas instituições públicas de ensino superior junto ao MEC. As propostas serão avaliadas por uma comissão de especialistas encarregada de julgar a viabilidade dos cursos apresentados, levando-se em conta a infra-estrutura disponível a partir dos pólos municipais de apoio presencial necessários para dar cobertura a eles. Além disso, será também verificada a existência ou não de tais cursos em determinados pólos municipais, tendo em vista a possibilidade da extensão de ofertas de novos cursos ou de expansão de oferta de acordo com os interesses demandados, segundo as necessidades de cada região. 


\section{Materiais para Estudos e Estratégia Instrucional}

Segundo o modelo de pólo projetado pela equipe da UAB, o município que participar como pólo de apoio presencial deverá, a princípio, oferecer 3 cursos de graduação a distância: Administração, Licenciatura em Biologia e Turismo, por exemplo.

Cada curso terá 150 vagas para apoiar 450 alunos presencialmente, devendo eles ser divididos em turmas de 150 alunos, perfazendo 9 turmas de 50 alunos cada. Cada grupo de 25 alunos será acompanhado por 1 tutor presencial, que exercerá a tarefa de orientador acadêmico. Os cursos serão organizados para que cada aluno estude quatro módulos de disciplinas ao mesmo tempo, em média.

O corpo de tutores presenciais deve estar dividido para poder apoiar adequadamente os diferentes conteúdos e as temáticas relacionados a cada curso elaborado. Tais tutores deverão ser contratados pelo município ao qual irão prestar serviços, tendo de ter uma formação de nível superior compatível com as áreas de conhecimento relacionadas ao curso pelo qual serão responsáveis como docentes, devendo, ainda, preferencialmente, residir no município ou em região próxima ao município do pólo de apoio presencial.

A princípio, foi definido um curso piloto a distância na área de Administração. Ele terá duração de quatro anos, sendo os três primeiros anos regidos por uma estrutura de base comum, enquanto o quarto e último ano dará ênfase ao curso em si, mediante os critérios definidos pelas instituições ofertantes.

Nesta etapa inicial, as universidades de cada unidade da Federação responsáveis pela oferta do curso irão definir os locais em que vão estar os pólos regionais e qual será a infra-estrutura adequada para dar suporte às atividades previstas, bem como de que forma será feito o atendimento aos estudantes nos encontros presenciais que se seguirão. Neste caso, o estudante receberá um serviço de tutoria, durante todo o seu processo de ensino e aprendizagem, que fará o monitoramento direto do seu desempenho e do fluxo de atividades. O tutor será basicamente um facilitador de interatividade entre alunos e instituição, procurando sempre identificar uma série de dificuldades durante a aprendizagem, interferindo em todo o processo de desenvolvimento das aulas do curso, com mediações e orientações.

Uma das tecnologias que se pretende empregar como apoio ao Sistema UAB é o ambiente e-Proinfo (http://www.eproinfo.mec.gov.br/). O e-Proinfo é um ambiente 
colaborativo de aprendizagem baseado na tecnologia da internet, que auxilia na concepção, na administração e no desenvolvimento de várias ações relacionadas a cursos a distância, como complemento de formação presencial, desenvolvimento de projetos colaborativos de pesquisa e outras formas de suporte a distância e ao processo de ensino e aprendizagem. Basicamente, compõe-se de dois web sites: o do Participante e o do Administrador do sistema de EaD. Possui ainda um mural para avisos e notícias, um ícone para se inscrever no curso, um para a opção de visitante, outro para entidades cadastradas no curso, um de suporte ao aprendizado e um para baixar arquivos disponíveis no curso.

\section{Avaliação Educacional}

Previamente, foi elaborado um sistema de avaliação dos pólos de apoio presencial que poderá ser consultado constantemente a partir do acesso ao próprio portal da UAB. Deste modo, será possível monitorar individualmente o desempenho de cada pólo durante o processo de realização do projeto de EaD da UAB.

No portal, está também disponibilizado um formulário de avaliação dos pólos de apoio presencial, com identificação e natureza do pólo (municipal, estadual, parceria ou consórcio), horário de funcionamento do pólo, endereço, formas de contato, responsável, especificações dos cursos (IFES, tipo de curso, denominação do curso, número de vagas solicitadas, avaliador do curso), objetivos institucionais e justificativa do pólo, características gerais, adequação da infra-estrutura aos projetos dos cursos (adequação global e qualitativa da infra-estrutura do pólo ao desempenho instrucional dos cursos a serem implementados), comentário a respeito de cada curso oferecido, estágios supervisionados determinados pela legislação ou atividades práticas, infraestruturas física e logística (dependências existentes no pólo, sala de coordenação do pólo, equipamentos, sala da secretaria acadêmica, sala de tutoria, sala de aula presencial típica, laboratório de informática, sala de videoconferência, biblioteca, sanitários, laboratórios pedagógicos $1,2,3,4,5$ e 6), recursos humanos de tutoria, recursos humanos referentes à equipe de apoio ao estudante, manutenção e funcionamento do pólo, planejamento logístico e de gestão do pólo, outros equipamentos e serviços presentes no pólo, relação da capacidade do pólo versus número e perfil do curso versus número de alunos, parecer conclusivo sobre a viabilidade de implementação do pólo com oferta dos cursos articulados com as IFES. 
Em cada um destes itens, o parecerista encarregado de vistoriar cada pólo tem a incumbência de fornecer detalhes referentes a cada ambiente analisado, como equipamentos e mobiliário de uso para trabalho pedagógico e administrativo. Para cada ambiente analisado, deverão ser elaborados comentários específicos sobre cada elemento: mobiliário, equipamentos, dependências, etc.

\section{Centros de Estudos}

Como tudo está ainda começando, em termos de organização da infra-estrutura que deverá compor a UAB futuramente, a Secretaria de Educação a Distância (MEC-SEED) elaborou um exemplo conceitual de como deve figurar um determinado pólo de apoio presencial, com base no Edital $n^{0}$ 01/2005. Nele estão definidas as orientações acadêmicas necessárias para se fornecer um atendimento adequado nos pólos que irão compor a espinha dorsal do projeto de $\mathrm{EaD}$ da $\mathrm{UAB}$ : ele deve ser a base para as universidades federais e estaduais participarem dos processos seletivos pelos quais elas se candidataram a possíveis pólos de apoio presencial no projeto.

O exemplo apresentado serve para ilustrar como deve ser a organização de um pólo característico para prover educação a distância de qualidade e tem por objetivo auxiliar os dirigentes de municípios, Estados e Distrito Federal que estejam interessados em participar do sistema educacional dentro da concepção da Universidade Aberta do Brasil. A partir desse modelo de pólo, são consideradas estimativas e levantamentos básicos para se iniciar o projeto pedagógico dentro da concepção da UAB.

Contudo vale a pena frisar que os itens e os valores empregados são meramente idealizados, servindo apenas como referenciais de apoio às decisões de se conjugar parcerias e consórcios de apoio ao projeto da UAB. Cabe lembrar que cada região ou localidade tem suas particularidades, que variam de lugar para lugar e de cultura para cultura, devendo ser um elemento a ser considerado durante a proposta de realização de cada projeto regional. Além disso, há também a questão relativa às particularidades decorrentes dos cursos que se queira oferecer em cada local.

A definição que consta no edital da UAB sobre pólo de apoio presencial é: estrutura para execução descentralizada de algumas funções didático-administrativas de curso, consórcio, rede ou sistema de educação a distância, geralmente organizada com o 
concurso de diversas instituições, bem como com o apoio dos governos municipais e estaduais.

Ou seja, um local só pode ser caracterizado como pólo de apoio quando sua estrutura comporta elementos suficientemente adequados para atender de modo satisfatório os estudantes de um curso a distância. Isso diz respeito ao local onde ele tenha acesso a biblioteca, laboratório de informática para acessar os módulos de cursos via internet, tutoria permanente, infra-estrutura para assistir às aulas desejadas, possibilidade de realizar práticas de laboratório, trabalhos em grupo, pesquisas, etc. Em outras palavras: um pólo é basicamente o "braço operacional" da Instituição de Ensino Superior que pretende se firmar como um centro de estudos de uma universidade aberta e em expansão.

De certa medida, já foram realizadas diversas pesquisas que comprovam que um pólo de apoio presencial, ou um centro de estudos, segundo o termo mais corrente empregado por diversas universidades abertas do mundo, define as condições para que o aluno permaneça no curso a distância.

Um centro de estudos é um elemento determinante de vínculo mais próximo com a universidade de verdade, presencial ou a distância. É um ponto de referência inquestionável para quem estuda e quer pertencer a uma instituição muito importante, idônea e de prestígio reconhecido. Esta natureza de contato próximo é que tem contribuído para se interiorizar e regionalizar cada vez mais as ofertas de educação superior pública e gratuita, dentro de uma concepção aberta de ensino. É o que, sem dúvida, aproxima a educação a distância de todos, sem restrições, ou seja, sem distanciamento, no sentido educacional mais pleno.

Desse modo, a UAB espera que cada pólo de apoio presencial possa, com o passar do tempo, se constituir como um centro de integração e desenvolvimento regional, possibilitando a geração de emprego e renda para a sua população local. Por isso é que há uma preocupação e um cuidado redobrado por parte da UAB em se tentar projetar cada pólo de apoio presencial do melhor modo possível, para que ele tenha condições de atender às necessidades das instituições federais de ensino, bem como às expectativas dos alunos envolvidos no processo de ensino. Neste aspecto, o acesso aos meios mais modernos de informação e comunicação deve ser considerado e continuamente repensado, para se oferecer sempre o melhor aos alunos dos cursos a distância. 
A princípio, um pólo de apoio a educação a distância, nos termos ainda idealizados pela UAB, deve conter os seguintes ambientes: 1 sala para Secretaria Acadêmica, 1 Sala de Coordenação do Pólo, 1 Sala para Tutores Presenciais, 1 Sala de Professores e Reuniões, 1 Sala de Aula Presencial Típica, 1 Laboratório de Informática, 1 Sala de Videoconferência e 1 Biblioteca.

O programa UAB de educação a distância já teve a adesão de 290 pólos de apoio presencial em todo o país para iniciar suas atividades até 2007, operando já em 289 municípios brasileiros distribuídos por todos os Estados da Federação, sendo que ainda haverá novas chamadas públicas, por meio de editais de convocação, de modo que outros municípios possam vir a fazer parte, aos poucos, deste programa inovador de oferta de ensino no país a um grande contingente populacional.

Para tirar dúvidas a respeito da incumbência de cada pólo de apoio presencial, a UAB oferece, por meio de seu portal, um ambiente de debate interativo, no qual se discutem itens como: bolsistas do projeto, repasse de recursos, avaliação in loco dos pólos, sistema UAB, etc. A cada debate é disponibilizada uma série de perguntas e respostas que foram veiculadas durante a reunião virtual.

De acordo com o edital divulgado no portal da UAB, já foram desenvolvidos dois grupos de pólos de apoio presencial: o primeiro contendo 150 projetos aprovados, com previsão para início de funcionamento a partir de junho de 2007; o segundo contendo 147 projetos aprovados, com previsão para início de funcionamento a partir de setembro de 2007. Todos os pólos aprovados deverão ter a incumbência de criar as condições para recebimento, instalação e utilização dos computadores doados ao Sistema UAB.

\section{Valor dos Cursos e Financiamento do Sistema}

Para se ter um controle dos recursos gastos com a consecução do projeto, são previamente definidas planilhas orçamentárias contendo a relação de recursos empregados, detalhadamente. A princípio, foram estabelecidas quatro planilhas básicas, disponíveis no portal da $\mathrm{UAB}$, com as várias partes componentes do cronograma físicofinanceiro de execução do projeto do Sistema UAB, como preparação dos cursos e gastos com bolsistas e a execução do projeto.

Entre as principais despesas consideradas, estão: gastos relacionados à capacitação dos docentes das instituições participantes (conteudistas e coordenadores); custos com 
metodologia do ensino, produção de material didático e plataforma de apoio instrucional; despesas com hospedagem, alimentação e transporte dos profissionais envolvidos nos encontros presenciais; seleção e treinamento de tutores; seleção de monitores acadêmicos; despesas com o processo seletivo de alunos (elaboração das provas, editais de convocação); custos em decorrência da oferta progressiva dos cursos.

O valor previsto para as bolsas-auxílio é de $\mathrm{R} \$ 1.200,00$, no caso de professor participante do projeto, o qual deverá ter responsabilidade direta pela preparação dos cursos. Já os tutores a distância receberão uma bolsa-auxílio de R $\$ 600,00$.

Se a continuidade do projeto determinar uma ampliação de atividades que justifiquem novos gastos com a obtenção de mais docentes, ela deverá ser devidamente computada no âmbito do Projeto UAB, para que possa ser contemplada em futuro edital, prevendo a solicitação ou a distribuição de novas vagas para docentes. 


\subsection{Associações profissionais de educação aberta e a distância ${ }^{217}$}

Além do aumento das universidades abertas, consideramos um forte indicador da crescente institucionalização da educação a distância no campo da educação mundial o surgimento de numerosas organizações nacionais e internacionais de EaD. Elas têm apoiado o desenvolvimento dos sistemas educacionais a distância em todos os continentes, colaborando na formação de redes de profissionais que fazem intercâmbio de informações sobre experiências, artigos, análises teóricas, além de efetivamente colaborarem com definições de políticas nacionais e regionais na área de $\mathrm{EaD}$.

\begin{tabular}{|c|c|}
\hline Continente & Associações \\
\hline \multirow{8}{*}{ ÁFRICA } & $\begin{array}{lllllll}\text { Association Africaine } & \text { Francophone } & \text { de } & \text { Formation } & \text { à } & \text { Distance } & \text { (ASSAFAD) } \\
\text { COSTA DO MARFIM }\end{array}$ \\
\hline & Distance Education Association of Southern Africa (DEASA) SUAZILÂNDIA \\
\hline & Distance Education Association of Tanzania (DEATA) TANZÂNIA \\
\hline & Ghanaian Distance Education Association (GHADEA) Winneba. GANA \\
\hline & $\begin{array}{l}\text { National Association of Distance Education Organisations of South Africa } \\
\text { (NADEOSA) ÁFRICA DO SUL } \\
\text { University of South Africa - UNISA } \\
\text { Web: www.nadeosa.org.za }\end{array}$ \\
\hline & The West African Distance Education Association (WADEA) GANA \\
\hline & Zambia Association for Distance Education (ZADE) ZÂMBIA \\
\hline & $\begin{array}{l}\text { Zimbabwe National Association of Distance and Open Learning (ZINADOL) } \\
\text { ZIMBÁBUE }\end{array}$ \\
\hline \multirow{7}{*}{ AMÉRICA } & $\begin{array}{l}\text { Inter-American Distance Education Consortium (CREAD) c/o The Pennsylvania State } \\
\text { University ESTADOS UNIDOS } \\
\text { Web: http://www.outreach.psu.edu/ }\end{array}$ \\
\hline & $\begin{array}{l}\text { Canadian Association for Distance Education (CADE) CANADÁ } \\
\text { Web: www.cade-ace7d.ca }\end{array}$ \\
\hline & $\begin{array}{l}\text { NODE } \quad \text { Learning } \\
\text { (Network for Ontario Distance Educators) CANADÁ } \\
\text { Web: www.thenode.org }\end{array}$ \\
\hline & Saskatchewan Association of Distance Learning CANADÁ \\
\hline & Caribbean Association for Distance and Open Learning (CARADOL) JAMAICA \\
\hline & $\begin{array}{l}\text { Jamaican Association for Distance and Open Learning (JADOL) JAMAICA } \\
\text { Web: http://raim.tripod.com/jadol.htm/jadol.htm }\end{array}$ \\
\hline & Colombian Association for Distance Higher Education (ACESAD) COLÔMBIA \\
\hline \multirow{3}{*}{ ÁSIA } & $\begin{array}{l}\text { Asian Association of Open Universities (AAOU) Seul, CORÉIA DO SUL } \\
\text { Web: www.ouhk.edu.hk/ AAOUNet }\end{array}$ \\
\hline & Indian Distance Education Association (IDEA) ÍNDIA \\
\hline & Malaysian Association of Distance Education (MADE) MALÁSIA \\
\hline \multirow[t]{2}{*}{ EUROPA } & $\begin{array}{l}\text { British Association for Open Learning Limited (BAOL) REINO UNIDO } \\
\text { Web: www.baol.co.uk }\end{array}$ \\
\hline & Consortium International Francophone de Formation a Distance (CIFFAD) F \\
\hline
\end{tabular}

217 Tabela construída com dados de: The Commonwealth of learning. Disponível em: $<$ http://www.col.org/resources/weblinks/associations.htm.> Acesso em 20 dez. 2004. 


\begin{tabular}{|c|c|}
\hline & $\begin{array}{l}\text { European Association for Distance Learning (EADL) ÁUSTRIA. Formerly: Association } \\
\text { of European Correspondence Schools (AECS) } \\
\text { Web: www.eadl.org }\end{array}$ \\
\hline & $\begin{array}{l}\text { European Association of Distance Teaching Universities (EADTU) HOLANDA } \\
\text { Web: www.eadtu.nl }\end{array}$ \\
\hline & $\begin{array}{l}\text { European Distance and E-Learning Network (EDEN) HUNGRIA. Formerly: European } \\
\text { Distance Education Network (EDEN)" } \\
\text { Web: www.eden.bme.hu }\end{array}$ \\
\hline & $\begin{array}{l}\text { European Federation for Open and Distance Learning (EFODL) BÉLGICA } \\
\text { Web:www5.vdab.be/vdab/test/efodl/top.htm }\end{array}$ \\
\hline & $\begin{array}{l}\text { International Council for Open and Distance Education (ICDE) NORUEGA } \\
\text { Web: www.icde.org }\end{array}$ \\
\hline & National Distance Education Council IRLANDA \\
\hline & $\begin{array}{l}\text { Open and Distance Learning Association of Australia (ODLAA) AUSTRÁLIA } \\
\text { Web: www.odlaa.org }\end{array}$ \\
\hline & $\begin{array}{l}\text { Papua New Guinea Association for Distance Education (PNGADE) PAPUA-NOVA } \\
\text { GUINÉ }\end{array}$ \\
\hline OCEANIA & $\begin{array}{l}\text { Pacific Islands Regional Association for Distance Education (PIRADE) SAMOA } \\
\text { Web: www.col.org/pirade }\end{array}$ \\
\hline & $\begin{array}{l}\text { Distance Education Association of New Zealand (DEANZ) NOVA ZELÂNDIA } \\
\text { Web: www.deanz.org.nz }\end{array}$ \\
\hline & $\begin{array}{l}\text { Australasian Council on Open, Distance and E-learning (ACODE) } \\
\text { Web: www.acode.edu.au }\end{array}$ \\
\hline
\end{tabular}

\subsection{Posição dos Organismos Internacionais}

O forte apoio dado pelos organismos internacionais à educação a distância tem colaborado para a aceitação, o desenvolvimento e a consolidação desta modalidade educativa. No campo da educação mundial, vem se firmando a perspectiva da função social da educação com uma imagem de possível alternativa, emergente da sociedade do conhecimento, para resolver o problema de acesso à educação e à democratização das oportunidades educativas em um mundo com um crescimento contínuo da população.

\subsubsection{UNESCO}

\section{a) Posição Global}

A UNESCO considera a educação aberta e a distância

uma força que contribui claramente com o desenvolvimento social e econômico e que tem se convertido numa parte indispensável da educação. Esta modalidade tem ganhado aceitação dentro dos sistemas educativos tradicionais, tanto nos países desenvolvidos como em desenvolvimento, mas particularmente nestes últimos. Este auge tem sido estimulado, em parte, pelo crescente interesse de educadores e tutores nas novas tecnologias vinculadas à internet e a outras plataformas multimídia e, em parte, devido ao crescente consenso sobre necessidade de se apoiar as formas tradicionais de educação, valendo-se de meios mais 
inovadores para garantir o direito fundamental de cada indivíduo a ela. (UNESCO, 2002. p. 5). ${ }^{218}$

\section{b) The Virtual University and e-learning}

O Instituto para o Planejamento Educacional (IPE) tem realizado pesquisas exploratórias baseadas em estudos de casos de universidades virtuais, assim distribuídos: três na América, dois na África, dois na Europa, dois na Ásia e um na Oceania.

Desde janeiro de 2004 o instituto tem desenvolvido, por meio de fórum, um debate sobre universidades virtuais e educação transnacional, softwares abertos para e-learning e recursos para a educação aberta.

O sistema realiza uma pesquisa com um acompanhamento permanente de 10 universidades virtuais, com o objetivo de extrair conclusões sobre critérios de qualidade, metodologias, pedagogia, estratégias, uso de mídias e sistemas tecnológicos, entre outras categorias.

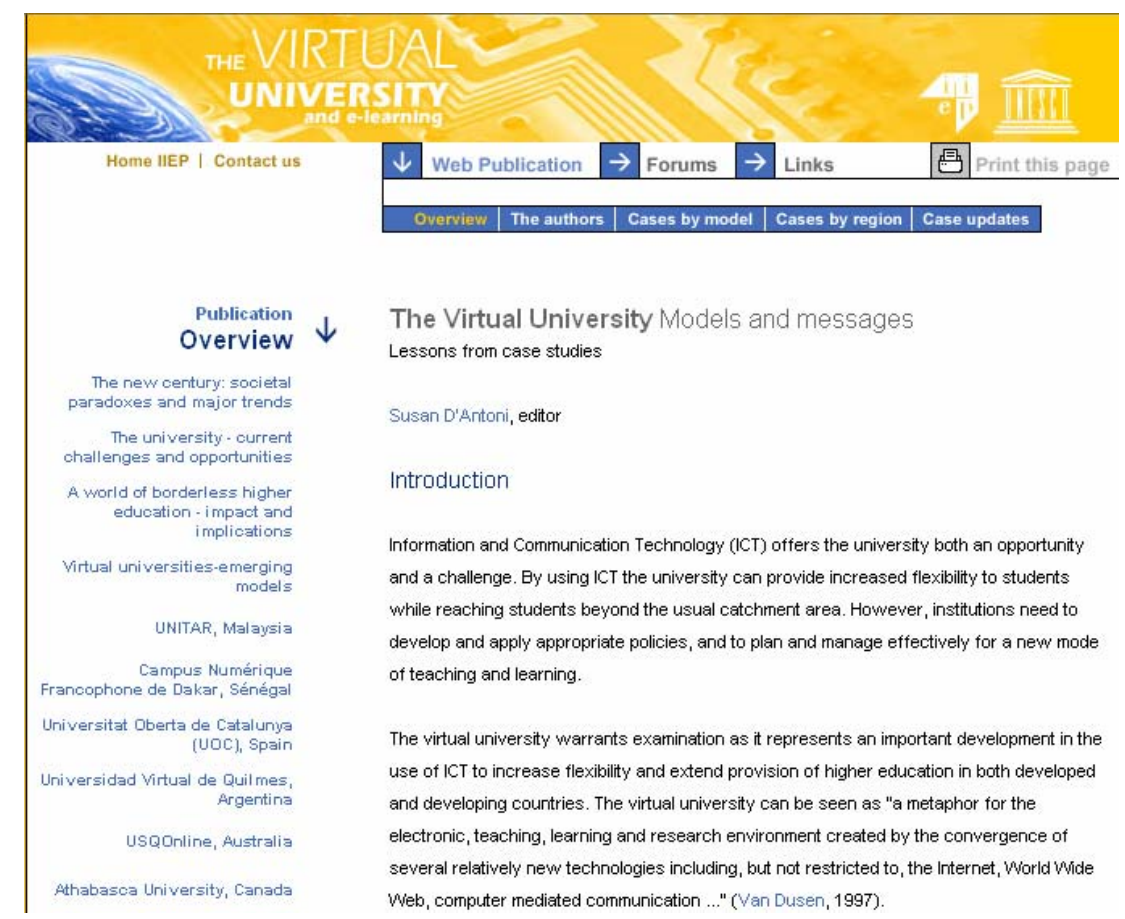

Figura 58: Portal da The Virtual University and e-learning. Fonte: The Virtual University and elearning Disponível em: <http://www.unesco.org/iiep/virtualuniversity/>. Acesso em: 15 ago. 2005

\footnotetext{
${ }^{218}$ Disponível em: <unesdoc.unesco.org/images/0012/001284/128463s.pdf>. Acesso em 27 nov 2005
} 


\section{c) AVICENNA}

A UNESCO é um forte impulsor da educação a distância na Europa: tem em funcionamento o projeto do centro Avicenna, organizado com a Comunidade Européia e a participação das principais universidades e centros de educação a distância da região. Seu objetivo é acelerar a adoção e o melhor uso da educação aberta e a distância nos 11 países mediterrâneos.

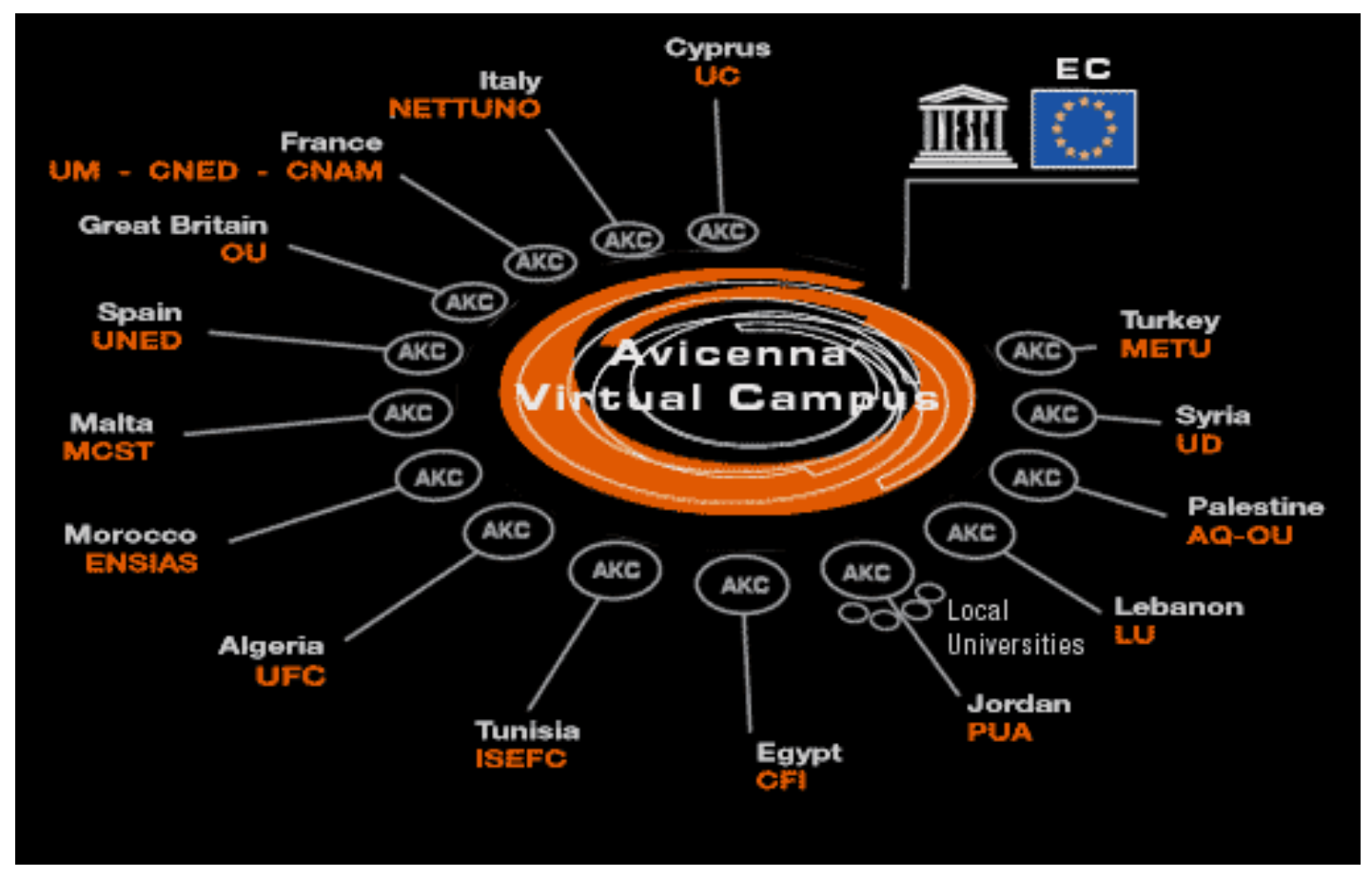

Figura 59: Portal AVICENNA Virtual Campus: Fonte: $<$ http://avicenna.unesco.org/>. Acesso em: 30 out06

Com as universidades européias foi criada uma rede de 15 centros de conhecimento que oferecem cursos, partilham conteúdos e criam condições para o sucesso na implementação da educação aberta e a distância. 


\section{d) Global Distance Educatio}

É o componente regional da África do Sul do escritório Global Distance Educatio.Net, produto da equipe de educação e tecnologia da rede de desenvolvimento humano do banco mundial e da UNESCO. ${ }^{219}$
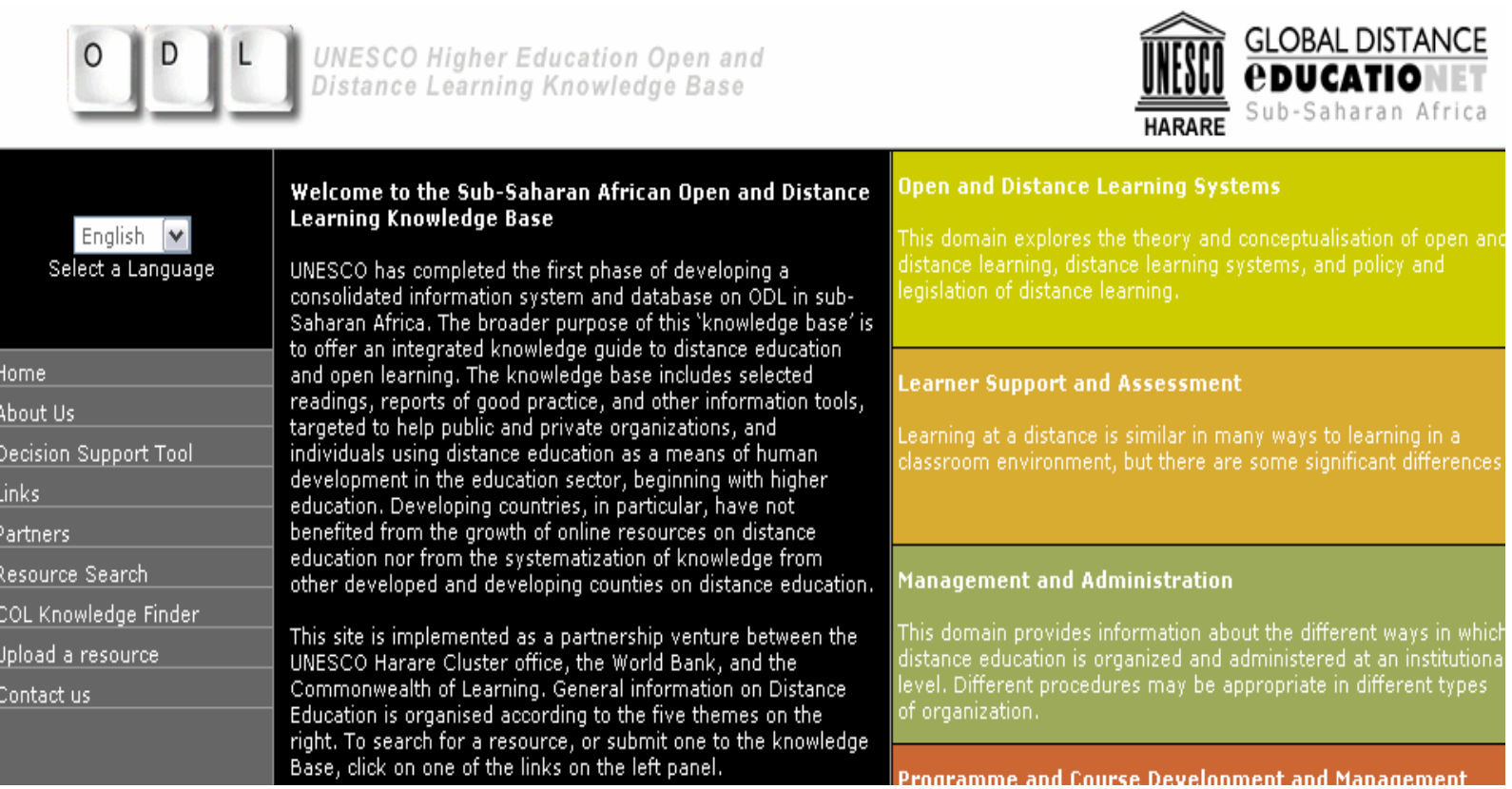

\section{Figura 60: Portal da Global Distance Educatio.Net}

O site apresenta ferramentas e serviços de intercâmbio de informação e conhecimento, criados para servir os países clientes do banco mundial, as organizações públicas e privadas e os indivíduos interessados em usar a educação a distância como meio do desenvolvimento humano.

\section{e) Centro de Cooperação Regional para a Educação de Adultos na América Latina e no Caribe (CREFAL/UNESCO)}

O CREFAL é um organismo internacional fundado em 1950 pela UNESCO com o objetivo de

impulsionar a cooperação regional na educação de adultos, mediante a formação de pessoal especializado, pesquisa documental e básica, sistematização, análises e intercâmbio de

\footnotetext{
${ }^{219}$ Fonte: Site Unesco. Disponível em: <http://www.africaodl.org/frontend/default.asp> Acesso em: 20 nov. 2005
} 
documentos e materiais, resultado das pesquisas realizadas internamente com a colaboração de especialistas dos organismos e das instituições da região (CREFAL) ${ }^{220}$.

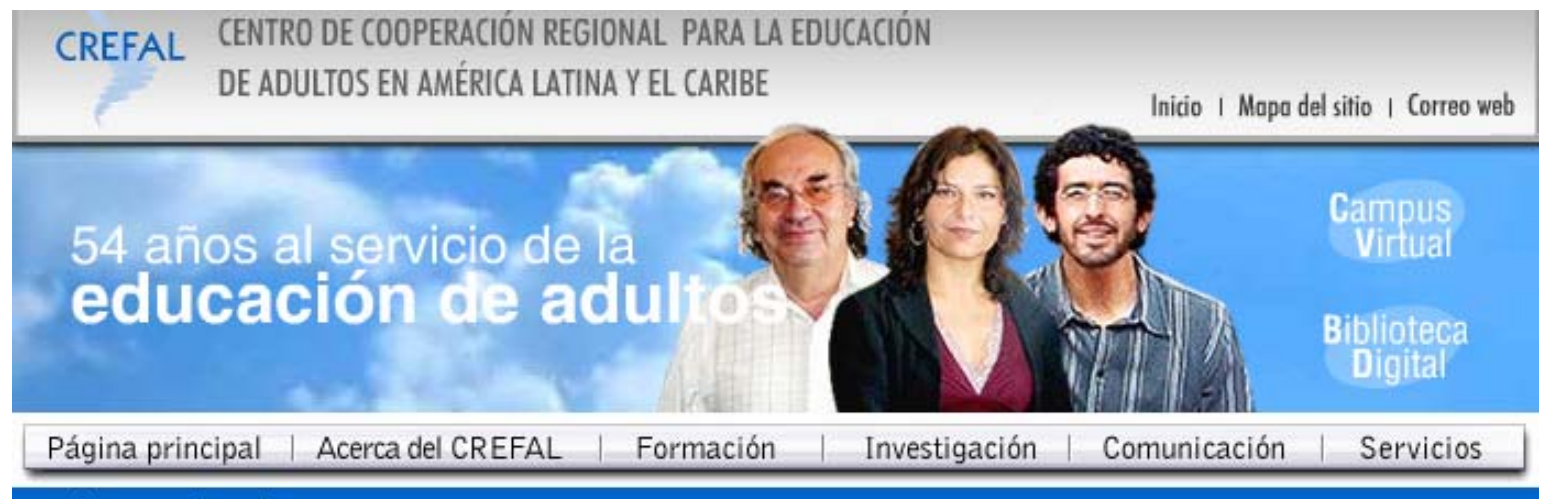

20 de noviembre de 2005

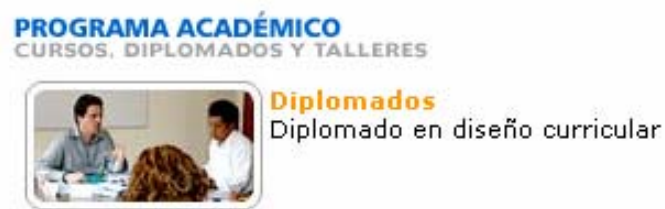

\section{NOVEDADES EN CREFAL}

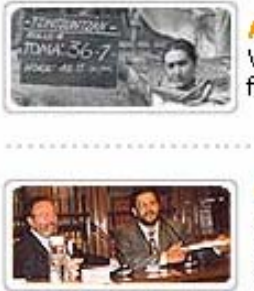

Archivo fímico del Crefal Vea en línea la película Tzintzuntzan film producido en 1955.

Gira de trabajo

Directivos del CREFAL Firman

importante convenio con el IIPE

en gira de trabajo por Sudamérica.
PROGRAMA CREFAL DE APOYO A LA INVESTIGACIÓN EN EDUCACIÓN DE JÚVENES Y ADULTOS

El CREFAL convoca a participar en el Premio CREFAL a las mejores tesis de licenciatura y maestría sobre EDJA, así como a concursar para ingresar al Programa de Apoyo a la Investigación en los temas de EDJA.

\section{NOTICIAS}

Por la nifiez, el trabajo de Santiago de Tuxpan Por medio de padrinos, el apoyo a menores en condiciones adversas.

Figura 61: Centro de Cooperação Regional para a Educação de Adultos na América Latina e no Caribe (CREFAL/UNESCO)

Para enfrentar a problemática da educação e atender a um número cada vez maior de pessoas, foi desenvolvido um sistema flexível de educação a distância para grupos com necessidades específicas, com o qual se pretende organizar comunidades virtuais de interação entre professores, alunos e pessoas interessadas.

\section{f) Instituto Latino-americano da Comunicação Educativa (ILCE/ UNESCO)}

É um organismo internacional sem fins lucrativos, fundado em 1954 em Montevidéu, Uruguai, e integrado por 13 países latino-americanos: Bolívia, Colômbia, Costa Rica, Equador, El Salvador, Guatemala, Haiti, Honduras, México, Nicarágua, Panamá, Paraguai e Venezuela, sendo o México o país-sede.

\footnotetext{
${ }^{220}$ CREFAL. Disponível em: <http://www.crefal.edu.mx.> Acesso em: 20 nov. 2005.
} 


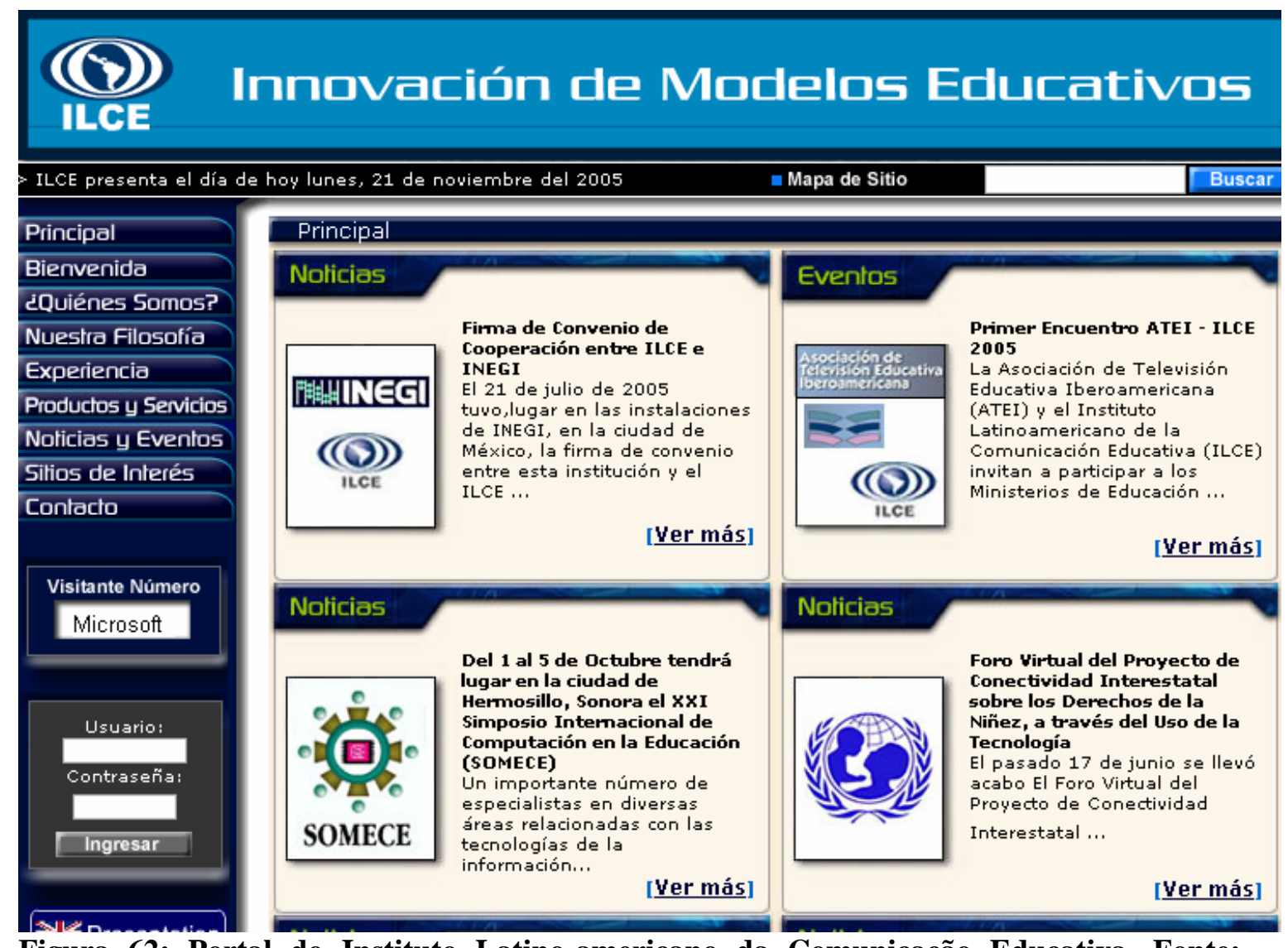

Figura 62: Portal do Instituto Latino-americano da Comunicação Educativa. Fonte: ILCE. Disponível em: <http://www.ilce.edu.mx>. Acesso em: $1^{\circ}$ dez. 2004.

O ILCE é uma das instituições de vanguarda da região, dedicada a satisfazer as exigências em educação, capacitação e formação de instituições e sociedades latinoamericanas. Potencializa a aplicação de tecnologias da informação e comunicação através de pesquisa, desenvolvimento, produção de materiais e modelos educativos inovadores que facilitem a formação integral das pessoas, incidindo na melhora da sua qualidade de vida, de suas comunidades e seus países ${ }^{221}$.

\section{g) Instituto para a Conectividade das Américas (ICA)}

O ICA foi criado na Cúpula das Américas 2001. A Cúpula exortou os países-membros a utilizar tecnologias da informação e comunicação com o propósito de formar redes, estabelecer o intercâmbio de idéias e associações mais efetivas com os governos e o setor privado, para permitir aos cidadãos maior participação no desenvolvimento político, social e econômico das suas respectivas sociedades ${ }^{222}$.

\footnotetext{
${ }^{221}$ ILCE. Disponível em: <http://www.ilce.edu.mx>. Acesso em: $1^{\text {o dez. }} 2004$.

${ }^{222}$ ICA. Disponível em: <http://www.icamericas.net>. Acesso em: 20 nov. 2005.
} 


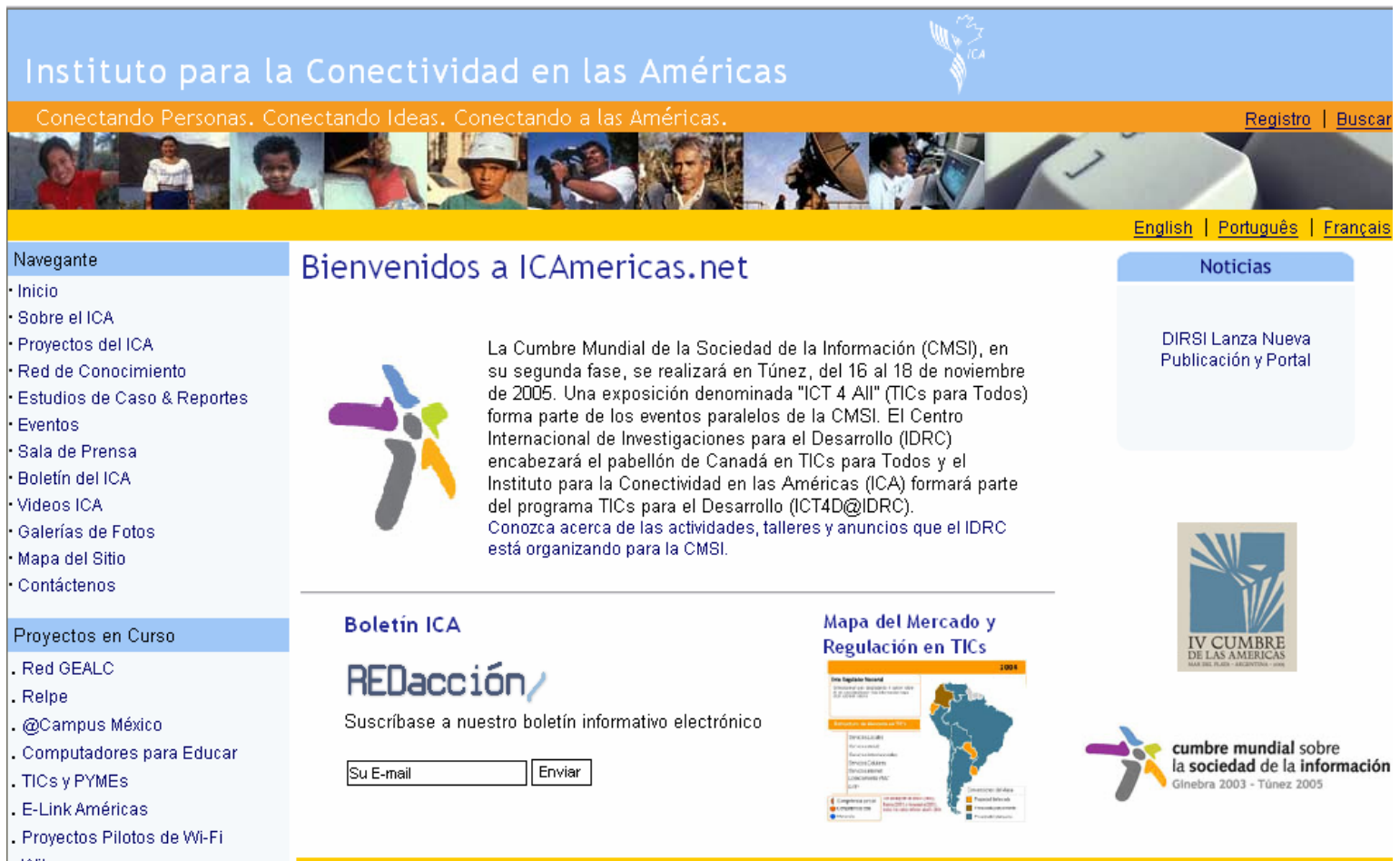

Figura 43: Portal do Instituto para a Conectividade das Américas. Fonte: ICA. Disponível em: <http://www.icamericas.net>. Acesso em: 20 nov. 2005.

O Instituto é uma organização mundial que promove a implementação de aplicações inovadoras de tecnologias de informação e comunicação para o desenvolvimento de seus países-membros. Essa idéia está bem expressa nos dizeres do próprio site, quando é destacado que:

Un postulado distintivo del ICA radica en que todos los programas que cuenten con su apoyo deben tener como resultado intensificar la capacidad de la región para participar en una sociedad basada cada vez más en el conocimiento. Toda la labor del ICA radica en el apoyo a las ideas innovadoras enfocadas en la aplicación de TICs para resolver problemas tradicionales y que ofrecen soluciones prácticas para derribar las barreras que han obstaculizado el desarrollo socio-económico de la región (Op. Cit.).

\section{h) Cátedras UNESCO de educação a distância}

Além dessas ações, a UNESCO tem fundado cátedras focadas no ensino e aprendizagem abertos e a distância, concebidas "como um plano de ação internacional para fortalecer o ensino superior nos países em desenvolvimento por meio de mecanismos apropriados para aumentar a cooperação interuniversitária"223.

223 In Portal UNESCO; Cátedras UNESCO. Disponível em: <http://portal.unesco.org/en/ev.phpURL_ID=10248\&URL_DO=DO_PRINTPAGE\&URL_SECTION=201.html > Acesso em: 20 nov. 2005. 
O Programa tem como meta estimular a formação de redes de universidades e instituições de ensino superior, promover o desenvolvimento institucional, compartilhar recursos e facilitar o intercâmbio de conhecimento técnico.

A UNESCO assinou acordos com instituições de ensino superior e suas associações para a criação de cátedras em mais de 20 países no mundo.

Sua função consiste em ajudar os países em desenvolvimento a fortalecer suas capacidades de formação e pesquisa de nível superior por meio de programas internacionais destinados a consolidar ensino, formação e pesquisa.

$\mathrm{Na}$ área de ensino a distância, a UNESCO criou as seguintes cátedras:

\begin{tabular}{|c|c|}
\hline África & $\begin{array}{l}\text { UNESCO Chair in Open and Distance Learning (563), established in } 2001 \text { at the } \\
\text { University of Botswana, Gaborone (Botswana) }\end{array}$ \\
\hline Brazil & $\begin{array}{l}\text { UNESCO Chair in Distance Education (32), established in } 1994 \text { at the University } \\
\text { of Brasilia (Brazil) } \\
\text { UNESCO Chair in Teacher Training through Distance Education (34) established } \\
\text { at the Federal University of Minas Gerais (Brazil) } \\
\text { UNESCO Chair in Sciences of Education (35), established in } 1994 \text { at the Federal } \\
\text { University of Mato Grosso (UFMT) (Brazil) } \\
\text { UNESCO Chair in Education Sciences (43), established in } 1997 \text { at the Catholic } \\
\text { University of Goias, Goiânia (Brazil) } \\
\text { of Castelo Branco, Distance Education Centre (Brazil) }\end{array}$ \\
\hline China & $\begin{array}{l}\text { UNITWIN Network in Distance and Open Learning (337), established in } 1997 \text { at } \\
\text { Shanghai TV University (China) }\end{array}$ \\
\hline Finland & $\begin{array}{l}\text { UNESCO Chair in Global E-Learning with applications to multiple domains (571), } \\
\text { established in } 2002 \text { at the University of Tampere, (Finland) }\end{array}$ \\
\hline Georgia & $\begin{array}{l}\text { UNESCO - INCORVUZ Chair for the Development of Non-Governmental } \\
\text { Organizations in Countries in Transition (513), established in } 2000 \text { at Tbilissi State } \\
\text { University, (Georgia) }\end{array}$ \\
\hline India & $\begin{array}{l}\text { UNESCO Chair in Teacher Education through Distance Mode (107), established in } \\
1996 \text { at Indira Gandhi National Open University (IGNOU), (India) }\end{array}$ \\
\hline Japan & $\begin{array}{l}\text { A.P.D.E.M. Asia-Pacific Distance and Multimedia Education Network (350), } \\
\text { established in } 1999 \text { at Waseda University (Japan) }\end{array}$ \\
\hline Mexico & $\begin{array}{l}\text { UNESCO Chair on Regional Integration and University (139), established in } 1995 \\
\text { at the National University of Mexico (Mexico) }\end{array}$ \\
\hline Nigeria & $\begin{array}{l}\text { UNESCO Chair in Open and Distance Learning (611), established in } 2002 \text { at the } \\
\text { National Open University of Nigeria (Nigeria) }\end{array}$ \\
\hline Pakistan & $\begin{array}{l}\text { UNESCO Chair in Distance Education (161), established in } 1995 \text { at Allama Iqbal } \\
\text { Open University (Pakistan) }\end{array}$ \\
\hline Russian & UNESCO Chair on Distance Education in Engineering (420), established in 1999 \\
\hline
\end{tabular}




\begin{tabular}{|c|c|}
\hline Federation & at St Petersburg State University of Aerospace Instrumentation (Russian Federation) \\
\hline Spain & $\begin{array}{l}\text { UNESCO Chair in Distance Education (241), established in } 1997 \text { at the UNED- } \\
\text { Universidad Nacional de Educación a Distância (Spain) } \\
\text { UNESCO Chair on new information technologies for e-learning education(593), } \\
\text { established in } 2002 \text { at the Open University of Catalonia (Spain) }\end{array}$ \\
\hline Tanzania & $\begin{array}{l}\text { UNESCO Chair in Distance Education (250), established in } 1994 \text { at the Open } \\
\text { University of Tanzania (Tanzania) }\end{array}$ \\
\hline Thailand & $\begin{array}{l}\text { UNITWIN Network in Distance Education for Development (Greater Mekong } \\
\text { Subregional and South-Eastern Asia) (30), established in } 1998 \text { at Sukhothai } \\
\text { Thammathirat Open University (Thailand) }\end{array}$ \\
\hline Togo & $\begin{array}{l}\text { ENESCO Chair in distance education (257), established in } 1997 \text { at the Centre of } \\
\text { Distance Education of the University of Benin in Togo, Lomé (Togo) }\end{array}$ \\
\hline Venezuela & $\begin{array}{l}\text { UNAMAZ Amazonian Universities Association (319), established in } 1993 \text { at the } \\
\text { CENAMB, Central University of Venezuela (Venezuela) }\end{array}$ \\
\hline Zimbabwe & $\begin{array}{l}\text { UNESCO Chair in Distance Education (291), established in } 1996 \text { at the University } \\
\text { of Zimbabwe, Centre for Distance Education (Zimbabwe) }\end{array}$ \\
\hline
\end{tabular}

Tabela 23: Cátedras da UNESCO em diversos países

\subsubsection{Organização dos Estados Americanos (OEA)}

O Portal das Américas é uma iniciativa da Agência Interamericana para a Cooperação e o Desenvolvimento (AICD) da Organização dos Estados Americanos.

O Portal das Américas tem como objetivo apoiar os povos das Américas na promoção de seu próprio desenvolvimento pessoal e profissional, facilitando o acesso informativo a uma educação de qualidade e diversas oportunidades de capacitação e atualização profissional a distância (OEA) ${ }^{224}$.

Com links que levam a mais de 4.000 oportunidades de educação a distância, bolsas de estudo, cursos de atualização profissional para educadores e outros sites de interesse, o portal estimula estudantes, pesquisadores, educadores e a população adulta em geral a ampliar seus conhecimentos em seus próprios lares ou escritórios, no horário que eles mesmos estabelecerem.

O Portal Educacional das Américas (www.educoea.org) foi lançado em setembro de 2001 para apoiar o desenvolvimento dos recursos humanos por intermédio da internet, tanto na modalidade a distância como na presencial ou pela multimídia. Até o presente o portal recebeu mais de 184 milhões de acessos originados de diversas partes do mundo.

\footnotetext{
${ }^{224}$ Disponível em: <http://www.educoas.com>. Acesso em: 1 dez. 2004
} 
Dados estatísticos mostram que ${ }^{225}$ :

$\checkmark$ Mais de 200 países e territórios acessaram o Portal Educacional das Américas.

$\checkmark$ Mais de 184.000.000 de acessos foram realizados desde o lançamento, em setembro de 2001.

$\checkmark \quad$ Média de 9.451.866 acessos por mês em 2004, 5.145.919 acessos em 2003 e 1.953.703 acessos em 2002.

$\checkmark \quad$ Média de 990 novos usuários cadastrados por mês no Portal.

$\checkmark \quad$ Média de páginas vistas por mês de 932.753 .

$\checkmark \quad$ Média mensal de visitantes que retornam de 4.850.164.

$\checkmark \quad$ Média de 2.050 diferentes sites enviam visitantes ao Portal Educacional.

\section{The Educational Portal of the Americas}

Traffic Growth during 3 years

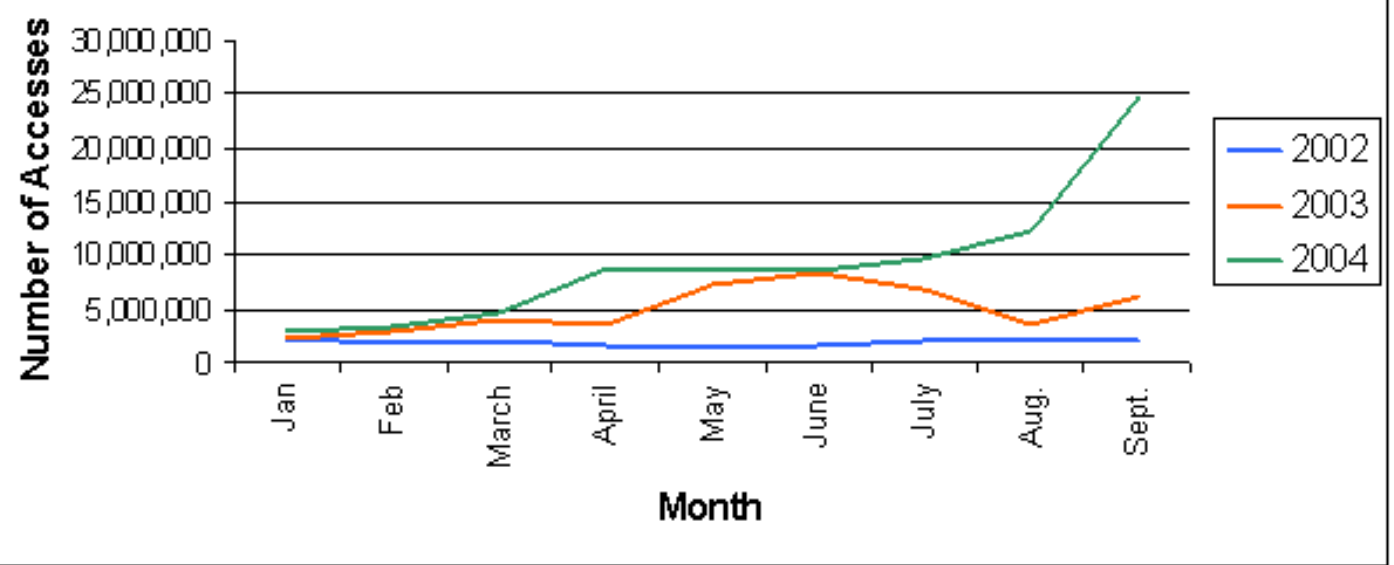

Gráfico 34: Número de acessos ao Portal Educacional das Américas por mês nos anos de 2002, 2003 e 2004.

Nas tabelas seguintes podemos observar dados detalhados de acesso ao Portal Educacional das Américas.

\footnotetext{
${ }^{225}$ Dados do site http://www.educoas.org.
} 


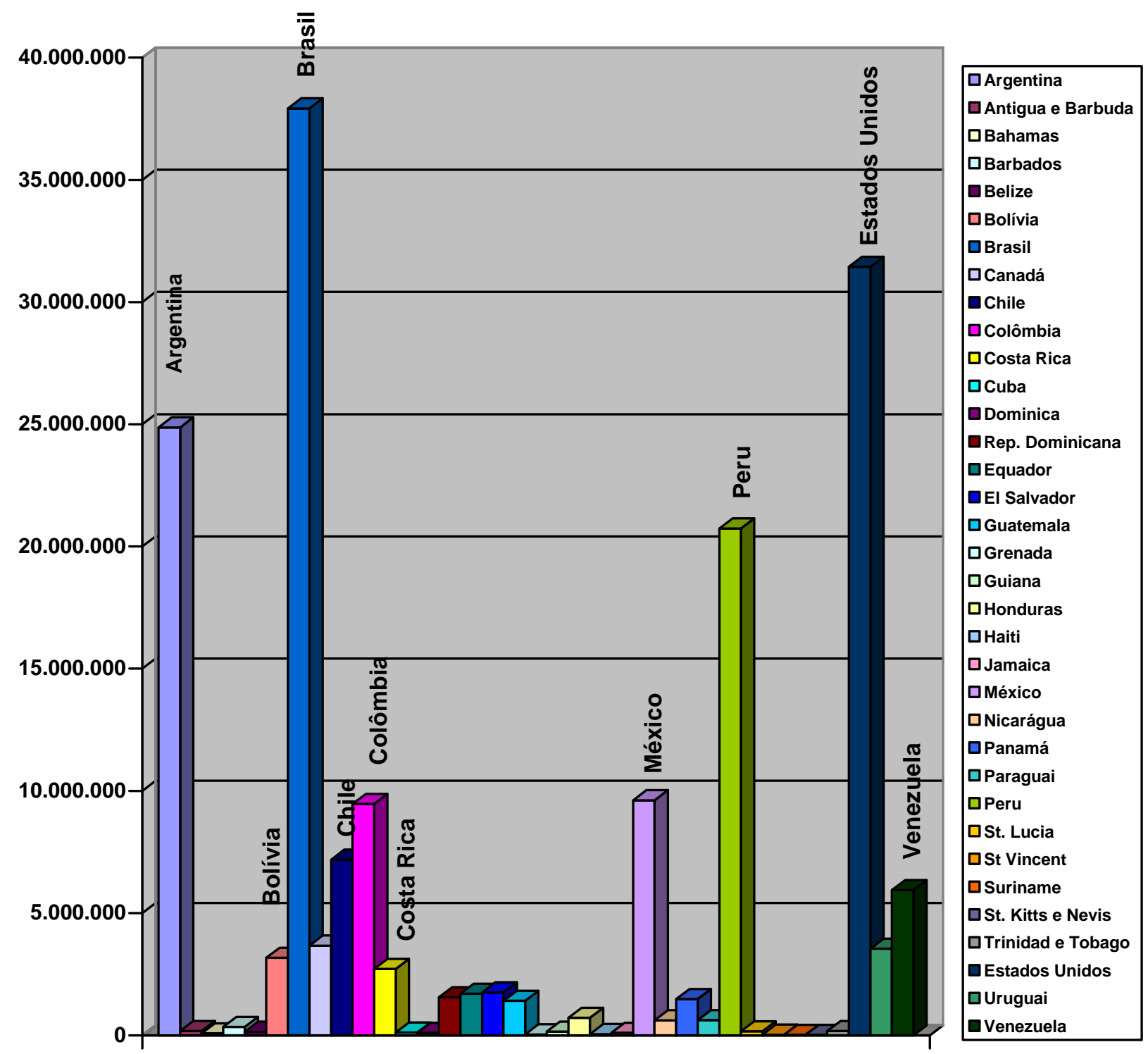

Gráfico 35: Número de acessos ao Portal Educacional das Américas por países. Fonte: <http://www.educoas.org/portal/en/tema/editorial/dic04.aspx?culture=en\&navid=36>. Acesso em: 23out06. 


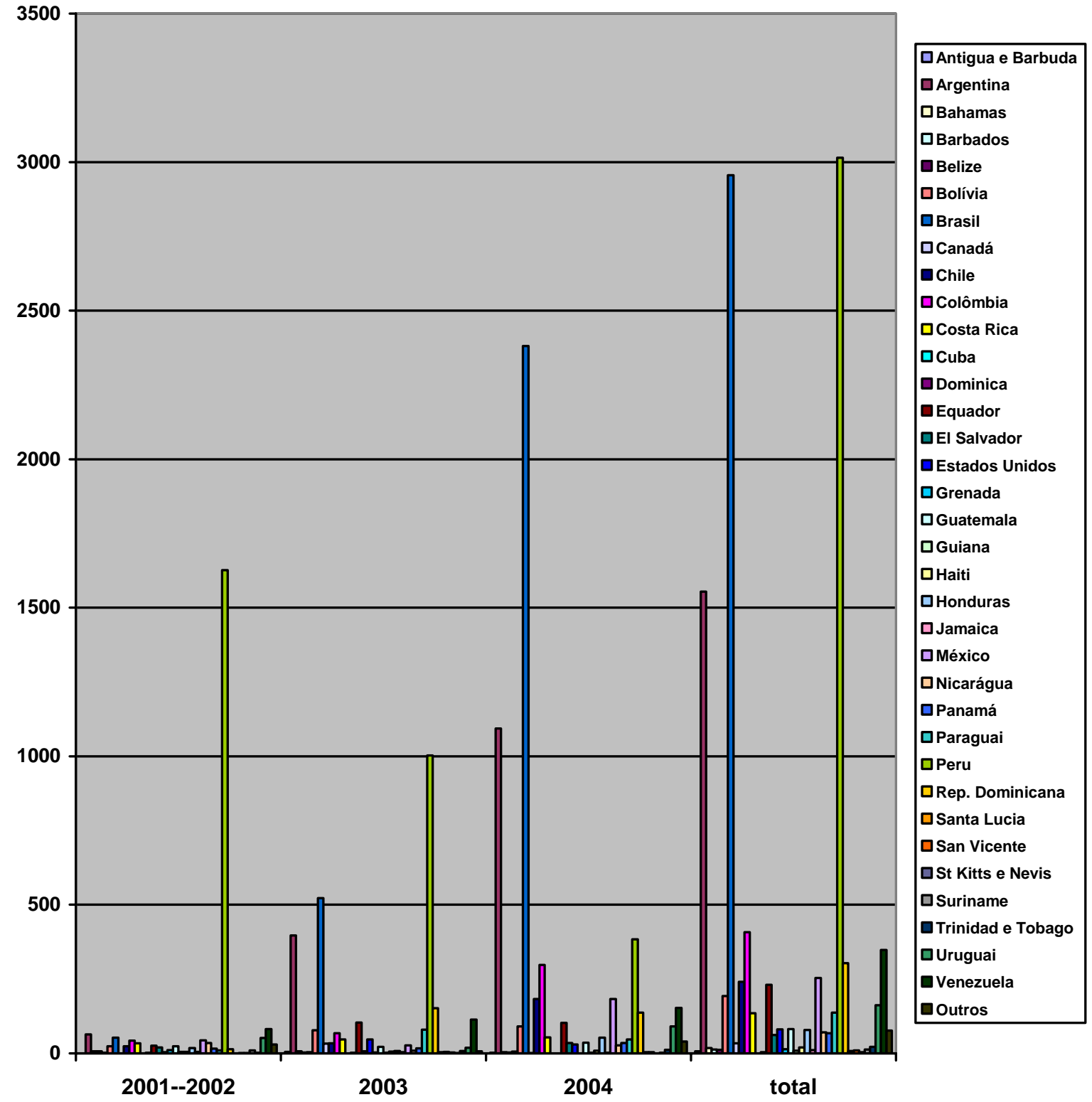

Gráfico 36: Número de Participantes Capacitados por País 2001-2004 Portal Educacional das Américas. Fonte:

$<$ http://www.educoas.org/portal/en/tema/editorial/dic04.aspx?culture=en\&navid=36 $>$. Acesso em: 23out06. 


\subsection{0 À guisa de conclusão}

Como pudemos observar nesta breve aproximação com o estudo da educação superior a distância nas megauniversidades, coexistem hoje no mundo diversas tendências: de posições que definem a educação a distância como uma alternativa compensatória para a educação tradicional, até visões que enxergam a educação a distância como uma forma de mudança qualitativa da educação superior; de perspectivas em que a educação a distância é considerada uma estratégia de posicionamento geopolítico no mundo globalizado, até estratégias que só a consideram como um bom negócio; de instituições que usam métodos baseados no material impresso como principal meio de ensino, a outras que utilizam uma grande variedade de recursos didáticos, como vídeo, conteúdos on-line, material impresso, rádio, entre outros; de experiências nas quais existe pouca ou nenhuma interação com tutores e colegas, ate outras nas quais se redobram os esforços para criar uma comunicação de duas vias entre alunos e professores.

O certo é que a educação a distância não tem parado de crescer nos últimos 30 anos, com índices que vão de 5\% ao ano a quase 18\%, quando se considera o período 1995 2005 .

Também temos podido ver emergir as universidades digitais, single mode, que apresentam uma oferta totalmente a distância e que, no futuro, sem dúvida, veremos crescer no Brasil e no mundo.

Fica evidente a magnitude com a qual a educação a distância está se desenvolvendo no mundo, não só no que se refere ao número de universidades abertas a distância e na matrícula global desta forma de estudo, mas também nas universidades tradicionais e na emergência das universidades digitais.

Este capítulo apresentou alguns dados interessantes para o planejamento de estratégias de educação a distância em relação à pesquisa de experiências, das quais podemos obter elementos de reflexão em relação à análise de estratégias que deram certo, às que se mostraram inviáveis - e por quê -, assim como os movimentos estratégicos de países e regiões que certamente definiram tendências do amanhã. 


\section{Capítulo 4}

\section{Análise, discussão de resultados e conclusões}

No intuito de investigar o papel da educação a distância na mudança de paradigma educativo no contexto da sociedade do conhecimento, abordamos o estudo do contexto social, seus principais problemas e seus elementos constitutivos; levantamos algumas das definições mais conhecidas de educação a distância e analisamos as tendências que nelas se encontram; por último realizamos um estudo exploratório sobre as principais Universidades Abertas e a Distância do mundo, procurando caracterizá-las tanto do ponto de vista quantitativo como qualitativo, apontando) tanto as experiências negativas como as positivas que possam ser aproveitadas no desenho de políticas educativas na área.

Neste capítulo procuraremos analisar o papel que a educação a distância pode representar na sociedade atual e futura, bem como as possibilidades que a tecnologia educacional oferece para consolidar um paradigma educativo já não voltado para o professor como especialista em conteúdo, mas para a figura do educador como um facilitador pedagógico e didático da aprendizagem.

Como já apontamos, neste momento da civilização, é de enorme importância a reflexão sobre o papel que a educação e o pensamento educativo podem ter na construção de uma sociedade da aprendizagem sustentável, justa e eqüitativa.

\subsection{O papel da educação no século XXI}

Fica claro que a educação que um povo desenvolve, de alguma maneira se encontra determinada pelos desafios do momento histórico, pela visão do mundo de uma época e pelas características sociais, avanço científico-tecnológico, como Dilthey (1968, p.14) já apresentou claramente.

Estamos vivendo na emergência de uma crise sinalizada pelos indicadores socioambientais, expressa por meio do conceito de Sociedade de Risco, de Beck (1986) e de Giddens (1991). Uma crise que nos coloca numa encruzilhada: ou tomamos 
consciência e mudamos nossa forma de viver, ou o mundo que conhecemos mudará drasticamente, gerando o desenvolvimento de cenários futuros nada alentadores. Por outro lado, assistimos à tragédia humana, com $40 \%$ da população do mundo excluída do presente e do futuro, gerando uma sociedade cada vez mais irracional, injusta e violenta.

No entanto, a gravidade da situação atual não reside nos fatos assinalados. $\mathrm{O}$ desprezível é o motivo: temos criado essa realidade para que um reduzido número de pessoas viva uma vida de filme de Hollywood à custa do sofrimento, da dor e da morte de bilhões de pessoas.

O mais terrível possivelmente seja a hipocrisia social e a frieza com que se consideram esses problemas. A realidade se apresenta muito crua e cruel para quase metade da humanidade. Muitos a vêem só pela televisão, outros em estatísticas... Mas a maioria a experimenta na própria carne.

Não podemos deixar de fazer uma reflexão valorativa do que significam estes números, sob pena de cometermos o mesmo pecado que a ciência moderna. Cada número expressa a manifestação de vida ou morte de um ser humano. São pessoas que não tiveram a mínima possibilidade de luta pela vida, como cada criança que morre a cada três segundos, de quem alguém roubou o seu futuro. Uma pessoa importa!!! Uma vida importa!!! Isso, a nosso ver, seria a primeira coisa que deveríamos aprender na escola.

O certo é que o modelo social baseado no livre mercado, no consumo e no crescimento econômico está se esgotando, e não por uma luta ideológica de classes como antigamente, mas por uma luta que a modernidade travou com a natureza para dominála e foi vencida, tendo agora que aceitar suas regras e limites. Todos os dados indicam que, se a economia mundial continuar sua expansão, destruirá o sistema físico sobre o qual se sustenta o planeta Terra.

Neste cenário, faz-se necessário distinguir entre crescimento e desenvolvimento. Crescimento, segundo o dicionário Aurélio, é a multiplicação ou aumento em dimensão, volume ou quantidade; desenvolvimento, também segundo o dicionário Aurélio, é a ação ou efeito de desenvolver(-se); é o aumento da capacidade ou das possibilidades de algo. 
Em uma palavra: o crescimento é o incremento quantitativo da escala física; o desenvolvimento é a melhora qualitativa, é o desenrolamento das potencialidades das pessoas. Uma sociedade pode crescer sem desenvolver-se, como aconteceu na década de 90; ou desenvolver-se sem crescer, como no caso cubano. Ou fazer ambas as coisas... Ou não fazer nenhuma delas.

Por isso Giddens (2000) afirma que a sustentabilidade ambiental ${ }^{226}$ exige que se produza uma descontinuidade: de uma sociedade para a qual a condição normal de saúde tem sido o crescimento da produção e do consumo material para uma sociedade capaz de se desenvolver diminuindo tanto a produção quanto o consumo. Já que a economia humana é um subsistema de um ecossistema global que não cresce, ainda que se desenvolva, está claro que o crescimento da economia não é sustentável em um período longo de tempo.

Fica evidente que esta crise, mais do que ecológica, como diz Leff (1994), é uma crise cultural, do estilo de pensamento por meio do qual a sociedade modelou o mundo, os imaginários sociais e o conhecimento que sustentaram a modernidade, dominando a natureza e mercantilizando a Terra.

Esse modelo de desenvolvimento está sustentado na dicotomia social êxito-fracasso, na cultura individualista do salve-se quem puder, que nos envolve numa luta visceral para sobreviver. A competição, que teoricamente deveria retirar o melhor de nós, tem consolidado, no meio da globalização, dois mundos: um de depredadores e outro de vítimas. O darwinismo social da sobrevivência dos mais aptos tem se convertido no estandarte do livre-mercado, na ética que guia as ações cotidianas, promovendo uma realidade irracional e destrutiva.

Uma crise do ser no mundo, que se manifesta em toda sua plenitude: tanto nos espaços internos do sujeito - nas condutas sociais autodestrutivas (fumo, álcool); no consumo como parâmetro de felicidade; no individualismo; na negação do outro; na solidão; no estresse, na depressão, na violência - como nos espaços externos - na degradação da natureza e da qualidade de vida das pessoas.

\footnotetext{
${ }^{226}$ Uma sociedade sustentável é aquela nas quais as taxas de extração de recursos naturais devem ser iguais às taxas de regeneração (produção sustentável) e as taxas de emissão de resíduos devem ser iguais às capacidades naturais de assimilação dos ecossistemas onde se lançam os resíduos.
} 
Os problemas socioambientais encontram-se arraigados no centro do modelo de crescimento sobre o qual tem se organizado a sociedade globalizada, caracterizada principalmente pelas formas de produção e de consumo, pela racionalidade instrumental meios-fins e pelo cálculo econômico, pelo esquecimento do ser, da alma, dos sentimentos; pela redução da vida ao trabalho e do ser humano à dimensão racional.

A resolução deste problema requer um amadurecimento da espécie humana, a ruptura das hipocrisias sociais, a construção de novos desejos, de novos horizontes, de novos estilos de pensamento e de sentimento. A humanidade chegou a uma encruzilhada que exige examinar-se para tentar achar novos rumos, refletindo sobre a cultura, as crenças, os valores e os conhecimentos em que se baseia o comportamento cotidiano, assim como sobre o paradigma antropológico-social que persiste nas nossas ações e sobre o qual a educação tem um enorme peso.

Deste modo, a educação deve produzir seu próprio "giro copernicano", tentando formar as gerações atuais não somente para aceitar a incerteza e o futuro, mas para gerar um pensamento complexo, crítico, aberto às mudanças, à diversidade, à possibilidade de construir e reconstruir em um processo contínuo de novas interpretações do já pensado, configurando possibilidades de ação naquilo que ainda há por se pensar.

Isso demanda a formulação de novas estratégias para uma (re)educação da sociedade toda. Temos que gerar as condições de formação de sociedades sustentáveis, o que requer a formação intensiva das pessoas, tanto em idade escolar como não escolar, com o objetivo de prepará-las para atuar como cidadãos ativos desta transformação em curso. Temos que propor novos valores, novas formas de enxergar o mundo, novas formas de pensamento, de comportamento, enfim, uma nova sociedade. A emergência da educação ambiental pode ser vista como uma reflexão sobre o papel que a educação deve assumir neste século, orientando-a para a formação de uma nova cidadania.

Como se fosse pouco esta mudança, a educação tem um papel central na luta contra a pobreza, gerando alternativas de formação para pessoas adultas que, com ou sem educação fundamental e média, possam adquirir os conhecimentos necessários para a sua inserção profissional, tanto no mercado de trabalho como no desenvolvimento de alternativas a ele, como pode ser a formação de empreendedores. 
Especialmente os jovens - que, como vimos, são o grupo social mais excluído, seja que tenham ou não educação fundamental e média, dentro e fora do mercado de trabalho. Os jovens reclamam uma nova educação, que possa dotá-los de ferramentas para lutar por uma vida melhor; para que possam recuperar a esperança perdida, para que muitos sejam resgatados da marginalidade. Um nova educação para não continuar criando gerações de desempregados em um modelo de crescimento econômico sem emprego.

Necessitamos de uma educação que abranja a sociedade toda, que esteja engajada na resolução dos desafios que a sociedade apresenta hoje, que colabore na resolução dos problemas de saúde (como fazer uma alimentação adequada com pouco dinheiro, como proteger as crianças dos riscos ambientais da comunidade e das doenças como a dengue) que, em muitas ocasiões, são gerados por falta de conhecimento; uma educação engajada na redução da desigualdade extrema.

Estaria a solução para os problemas atuais em uma sociedade que possua ensino fundamental, médio e superior? Pensamos que não. Nesse sentido, as experiências da China, com as suas escolas vocacionais, e seu ensino superior de curta duração, com uma tendência orientada ao mercado de trabalho, quem sabe responda melhor à nova sociedade do conhecimento. Universidades de grande prestígio e tradição, como a de Tsinghua, encontram-se totalmente orientadas para formar profissionais para a demanda do mercado, além de se voltar para a formação de professores e de recursos humanos para a administração pública. Também cumprem uma função social ao desenvolver estratégias completas para o treinamento de comunidades na luta contra a pobreza.

Ou então as experiências do Paquistão, onde a universidade Allama Iqbal desenvolve cursos de ensino médio focados nos problemas concretos do cotidiano das pessoas, como saúde básica, administração de animais domésticos, cuidado de crianças e outros temas propostos pelas comunidades, inclusive geração de renda e problemas de gênero especialmente criados para as mulheres.

Ou a rede de ensino vocacional da Coréia, na qual, já em 2005, reúne mais de 17 que estavam oferecendo educação terciária pela internet a um contigente cada vez maior de alunos. Essa nova modalidade, caracterizada por instituições totalmente virtuais, tem fornecido uma alternativa de formação superior e treinamento para o trabalho a adultos trabalhadores. 
Ou, ainda, os programas nas prisões, da universidade Dr. B.R. Ambedkar, na Índia, para fornecer aos presos alternativas de continuidade dos estudos e posteriormente uma melhor inserção na sociedade.

E muitas outras experiências que nos mostram uma universidade mais engajada na sociedade e nas demandas sociais, com programas que desenvolvem os conhecimentos da educação fundamental e média, mas aplicados ao cotidiano das comunidades, cumprindo uma importante função social do ponto de vista da saúde, da cultura, da família e do trabalho.

Como se fosse pouco, a universidade tem que fazer frente a uma dinâmica do conhecimento como nunca antes vivida na história da humanidade. A sociedade da aprendizagem demanda uma formação permanente para acompanhar a velocidade de transmissão de informação e de avanço tecnológico, enquanto a dinâmica do mercado de trabalho demanda uma contínua formação em serviço. É tão grande e tão diversa a demanda permanente de conhecimento social na atualidade, que a maioria dos países está desenvolvendo estratégias universitárias para acompanhar as mudanças sociais.

$\mathrm{Na}$ maioria dos países analisados, entre os objetivos das universidades abertas, encontram-se numerosas menções à formação de trabalhadores para o mercado, para o governo, para a sociedade civil e para os professores - muitas delas, inclusive, tem um forte relacionamento com as empresas, não só no que se relaciona à formação de funcionários em serviço, mas também ao desenvolvimento tecnológico das universidades.

O Instituto Tecnológico de Ensino Superior de Monterrey, por exemplo, apresenta uma ampla oferta de cursos - pós-graduação, educação continuada, empresas, governo e sociedade civil -, com conteúdos relacionados às necessidades contemporâneas de formação educacional e profissional. No entanto, na análise realizada de sua matrícula, percebe-se uma demanda bem mais significativa por cursos de nível profissionalizante do que por programas de especialização, mestrado e doutorado, o que demonstra como a demanda do instituto é essencialmente constituída de indivíduos com interesses mais vinculados ao seu dia-a-dia profissional.

Nesse aspecto, a Universidade Phoenix foi pioneira, buscando se especializar na área de educação de adultos, disponibilizando programas educacionais e serviços voltados para 
estudantes adultos e trabalhadores que desejassem completar sua formação, de modo a atender objetivos relacionados a suas experiências e necessidades profissionais. A tal ponto, que a maioria dos professores são acadêmicos, mas também profissionais em exercício dentro das áreas de conhecimento que ensinam, gerando um processo educativo teórico-prático com experiências concretas do dia-a-dia da organização.

Também no que se relaciona à pesquisa - como aponta o presidente da universidade Tsinghua, na China -, na sociedade do conhecimento, as universidades têm um papel fundamental como suas principais produtoras, ocupando um papel cada vez maior no desenvolvimento das sociedades do conhecimento, através de numerosas ações em todos os níveis educativos, alfabetização, ensino fundamental, médio, terciário e universitário.

O debate atual sobre o papel da educação no contexto atual está aberto. De acordo com a UNESCO (2005), existe uma genuína preocupação com a terceirização do ensino universitário e com o crescimento das universidades particulares. Fica claro para a UNESCO que as universidades possuem um importante papel no desenvolvimento das sociedades do conhecimento, e que elas não podem se desvirtuar deste caminho, posição com a qual concordamos plenamente, porém nos interrogamos se há necessidade de todas as instituições de ensino superior serem universidades; se a oferta clássica de cursos de graduação, especialização, mestrado e doutorado pode dar conta das demandas da sociedade atual ou se se faz necessário analisar novas estratégias e papéis das chamadas faculdades que não possuem produção de conhecimento cientifico e que, portanto, acabam se revelando instituições de segundo nível, ficando entre a formação profissional e a formação acadêmica, terminando por não servir adequadamente a nenhum dos objetivos assinalados.

Evidentemente concordamos plenamente com a UNESCO quando se trata de analisar o enorme crescimento das universidades particulares, principalmente quando se trata da análise de qualidade. Em muitas ocasiões estamos observando a formação de profissionais pouco preparados com títulos universitários, que sequer são aprovados nos exames dos órgãos profissionais que regulam a sua profissão - basta observar as universidades e as faculdades que oferecem cursos de direto, com um índice de reprovação no ano de 2006 de 62,88\%. O que é pior: o MEC continua agindo como se nada estivesse acontecendo, autorizando cada vez mais cursos de direito. 
Na sociedade atual, a oferta educativa já não pode se restringir aos tradicionais cursos de educação fundamental, média e superior. A demanda da sociedade é muito maior e muito mais diversificada e cambiante; não só no que se refere à educação permanente que a sociedade do conhecimento reclama, ou à formação de uma cidadania ambiental e socialmente responsável exigida pela sociedade de risco, mas também no que se refere à flexibilidade e à adequação aos contextos de inserção e colaboração com os desafios sociais e à degradação da qualidade de vida das pessoas, como o desemprego, o subemprego, a saúde, a pobreza, a violência, e, em especial, à problemática dos jovens.

Não é mais possível reduzir a educação a um papel instrumental dedicado à satisfação das necessidades atuais através de conhecimento e ação; é necessário reconhecer que toda a sociedade, ou pelo menos parte dela, define as suas ações educativas com vistas a resolver problemas sociais emergentes. Nesse sentido, temos que recuperar a essência do ser, coisificado pela ciência moderna: a educação tem que se preocupar com as outras dimensões do ser, dos valores, do afeto, da ética, da formação do caráter; ir ao encontro dos alunos consigo mesmos, com os outros - na formação de comunidades - e com o entorno, em um mundo no qual vemos crescer as chamadas doenças da alma.

Entendemos que uma reflexão valorativa deve acompanhar todo conhecimento, toda descoberta, todo processo de intervenção comunitário. Na sociedade atual, deixamos os valores fora do debate: o mais importante - que é o encontro de sim mesmo no mundo não constitui tema de estudo da educação.

Por último, podemos falar do novo papel que as instituições de educação superior devem cumprir em relação à sociedade do conhecimento. A educação tem também um papel preponderante na construção de uma sociedade engajada no seu futuro, assim como muitos países e regiões do mundo, que estão se preparando para fazer frente não só à sociedade do conhecimento, mas à sociedade do conhecimento globalizada, que parece que dividirá o mundo novamente, mas desta vez em função de outras características: os produtores e os consumidores de conhecimento.

A Ásia representa um bom exemplo disto. No Japão, apesar da calorosa defesa da cultura tradicional, encontramos políticas governamentais do Ministério da Educação para posicionar o país na sociedade do conhecimento. Reconhecendo que a maioria das ofertas educacionais e de informação de vanguarda é feita para os falantes de língua 
inglesa, o MEXT determinou que todos os estudantes que terminam o ensino secundário (ou seja, que estão deixando o Kotto-Gako para entrar na Universidade) devam ser capazes de se comunicar eficientemente em inglês e que, adicionalmente, aqueles que terminam os cursos de graduação devam ser capazes de utilizar o inglês como uma ferramenta de comunicação e aperfeiçoamento em seus trabalhos.

Além do Japão, também a China deixa bem claro que, na sociedade da informação e do conhecimento, existe um novo papel para as universidades: participar ativamente do desenvolvimento do país como unidades de produção do conhecimento.

\subsection{Meios, a ciência, a tecnologia e a cultura}

Além da reflexão sobre o papel da educação em geral, e da educação superior em particular para adequar as suas ofertas às demandas e aos desafios da sociedade contemporânea, acreditamos que toda e qualquer reflexão séria sobre o devir dos sistemas de educação e formação na cibercultura devem apoiar-se numa análise prévia da mutação contemporânea da relação com o saber. A esse respeito, a primeira constatação envolve a velocidade do surgimento e da renovação dos saberes e do knowhow (LEVY, 1999, p. 166), ao qual já fizemos referência. Mas esse não é o único elemento característico da mudança: estamos transitando de uma educação baseada na transmissão de informação do professor ao aluno, com o uso da memória repetitiva do aluno para lembrar a informação, para uma sociedade na qual, com o livro, primeiro, e agora, com a internet e os diversos suportes de armazenamento de informação, inicia-se um acentuado declínio na relevância social da memória.

Da dificuldade para obter informação, passamos a ter dificuldade de processar a enorme quantidade de informação que necessitamos para viver o dia-a-dia das sociedades modernas. Esta necessidade de aprendizagem permanente, como Pozo (2001, p.40) já mostrou, satura a nossa capacidade de aprendizagem: há um ritmo acelerado, quase neurótico, no qual não temos tempo para entender um assunto direito, ou praticar um conhecimento; não podemos consolidar o que aprendemos e o esquecemos com facilidade.

Esse fato nos faz refletir sobre a concepção de currículo como um depósito no qual vamos agregando mais e mais conhecimentos, à medida que estes se tornam relevantes 
socialmente. Mas, será que por que queremos ensinar tanto em tão pouco tempo produzimos aprendizagens de baixa qualidade, matamos a curiosidade e transformamos o processo de ensino e aprendizagem em algo mecânico?

Isso nos leva a uma reflexão dupla. Em primeiro lugar, temos que começar a regular a quantidade de informação, verificar o que é verdadeiramente importante para ensinar e aprender, e para quem. Não podemos aprender tudo, ou ensinar tudo, temos que ter consciência disso. Às vezes as pessoas não sabem não porque o ensino foi deficitário, mas porque saturamos a capacidade de recepção de informação dos alunos, impondo o esquecimento imediato das informações que não foram significativas para eles depois dos exames.

Em segundo lugar merecem uma reflexão os métodos. Já faz tempo que em pedagogia sabemos que o método é tanto um conteúdo, assim como o clima de intercâmbios entre alunos, e deles com os professores, é dizer, a cultura institucional. No entanto, na educação, continua primando a transmissão de informação do professor ao aluno, gerando alunos passivos, descomprometidos e acríticos. Entendemos que são necessárias novas competências para que os alunos estejam preparados para as mudanças presentes e futuras. Pozo (2001) enumera algumas delas: fomentar nos alunos capacidades de gestão do conhecimento ou, se preferirmos, de gestão metacognitiva - já que, para além da aquisição de conhecimentos pontuais concretos, esse é o único meio de ajudá-los a enfrentar as tarefas e os desafios que os aguardam na sociedade do conhecimento -, além de muitas outras competências interpessoais, afetivas e sociais. Competências metacognitivas para a aquisição, interpretação, análise, compreensão e comunicação da informação.

Todavia, mudar as formas de aprender dos alunos requer também mudar as formas de ensinar de seus professores. Por isso, a nova cultura da aprendizagem exige um novo perfil de aluno e de professor, exige novas funções discentes e docentes, as quais só se tornarão possíveis se houver uma mudança de mentalidade, uma mudança nas concepções profundamente arraigadas de uns e de outros sobre a aprendizagem e o ensino para encarar essa nova cultura da aprendizagem. Esse é um dos maiores desafios a serem enfrentados por nossos sistemas educacionais nas próximas décadas. 
Essa crise geral, no contexto de uma sociedade da informação, globalizada, nos faz pensar no fato de que o papel da educação não pode continuar sendo o de proporcionar aos alunos informações como verdades absolutas, transmitidas por um professor em uma sala, com uma lousa e um livro como única tecnologia, durante horas, sem parar, e ainda acharmos que isso é qualidade educativa.

O tédio dos alunos é real, o nível de abstração do conhecimento tem chegado a tal ponto que tudo está perdendo sentido para eles. Nada importa, se estuda com a mesma frieza tanto o milagre da vida, os ecossistemas, a história do seu país como os logaritmos ou as regras gramaticais. Utilizando o conceito de Kant, podemos afirmar que o interesse atual que constitui o conhecimento dos alunos é obter um título, um certificado que possibilite sair pela vida a trabalhar; não aprender.

O paradoxo é que, na época de suas vidas em que mais necessitam explorar o mundo, trancamos os alunos em salas. Exigimos que fiquem quietos e de boca calada, enquanto mostramos os reflexos do mundo, da vida, encadeados, desta vez, ao mundo das idéias, das letras, dos números, dentro de uma caverna, sem deixar-lhes experimentar o sabor das coisas. Construímos um mundo sem sabor, insosso, onde tudo é igual e nada importa, exatamente quando a educação deveria ajudá-los a construir seu próprio ponto de vista, sua verdade particular a partir de tantas verdades parciais. Como diz Morin (2001, p. 76): “conhecer e pensar não significa chegar à verdade absolutamente certa, mas sim dialogar com a incerteza".

Mas também porque a cibercultura é a emergência da inteligência coletiva, o que significa a formação de uma nova sociedade, na qual, como diz Levy (1999, p.166): esse ideal passa evidentemente pela colocação em comum da memória, da imaginação e da experiência, por novas formas, flexíveis e, em tempo real, de organização e coordenação; e a educação continua a ser um espaço de escassa ou nula participação dos alunos, ou seja, um contra-senso.

Por isso é que acreditamos que a educação a distância traz a possibilidade de libertar alunos e professores de um papel monótono, passivo e centralizador no professor como meio de transmissão de informação. A educação a distância tem desenvolvido estratégias e está utilizando recursos que propiciam a interação, a exploração e a construção da própria aprendizagem, regulando o seu próprio ritmo, gerando 
possibilidades de escolher em função dos próprios interesses. Em suma: assumir a gestão dos próprios processos de aprendizagem. Esses ecossistemas cognitivos podem vir a representar a concretização dos ideais construtivistas, criando uma enorme área de desenvolvimento potencial para os alunos e capacidades de processamento da informação que acreditamos ser indispensáveis para ser um cidadão da sociedade atual.

Nesse sentido a articulação de tecnologias apropriadas, como o rádio interativo, a TV interativa, os administradores de conteúdos on-line (LMS), o telefone, os materiais impressos, os encontros presenciais, os sistemas de teleconferência e videoconferência, está abrindo espaço para a formação de uma nova educação, mais flexível, significativa, participativa e motivadora que a educação tradicional.

Uma forma de educação que articula especialistas de diversas áreas na reflexão do processo educativo, tirando o professor do isolamento e dotando-o de recursos com os quais gera estratégias diversas, para públicos diversos, mas adequadas aos contextos locais, e mais reflexivas também.

Enxergamos a educação a distância como uma forma na qual o professor deixa de ocupar o papel de transmissor e passa a ocupar o papel de mediador pedagógico entre o conhecimento (apresentado através de diversas mídias) e os alunos (através de diversas mídias e ferramentas), aprofundando o diálogo pedagógico.

Em muitas experiências analisadas no documento, podemos observar como a educação a distância tem permeado a educação nacional como um todo, mesmo nos países mais resistentes a ela, como o Japão, que permitiu a educação a distância recentemente e hoje possibilita a educação superior $100 \%$ a distância, e o ensino médio $50 \%$ distância para as pessoas que trabalham.

Ou a China, na qual o sistema moderno de educação aprovado para o período 20032007, chamado "moderno sistema educativo", foi combinado com o sistema de educação formal, e o sistema presencial com o sistema a distância. Isso significa que as instituições de educação formal (escolas, faculdades e universidades) estão se articulando para responder às demandas da sociedade de aprendizagem e ao crescimento de demanda por educação permanente, atendendo, por sua vez, às diversas necessidades educativas da sociedade - educação superior, educação permanente, educação corporativa e educação governamental, tentando superar a visão dicotômica da 
educação e gerando uma distribuição de recursos educativos com maior eficiência no sistema educativo.

Experiências que começam a marcar tendências no sentido de considerar a educação a distância não como uma atividade compensatória de educação para as populações normalmente excluídas dos sistemas educativos, mas como a possibilidade de construir novas formas educativas mais adequadas aos contextos atuais.

\subsection{Conceitualização de Educação a Distância}

Como temos podido observar na análise comparativa de definições de educação a distância, vários elementos, em diferentes graus, fazem parte do universo conceitual da educação a distância. Mas, da nossa perspectiva, estes elementos não ajudam a caracterizar a educação a distância - talvez, em algum momento histórico, estes elementos tenham servido para a conceitualização, mas entendemos que, na sociedade atual, muitos deles estão perdendo significação.

Para analisar este aspecto, vamos tentar comparar a educação presencial e a distância, considerando que ambas as definições, como categorias do conceito educação, são consideradas como mutuamente excludentes. Dessa forma, educação "presencial" representaria uma categoria oposta à educação a "distância", tal como apresenta Dohmem (1967).

Assim, para pôr à prova esta afirmação, vamos enumerar as características mais marcantes da educação a distância, e começar a definir seus opostos. O resultado terá que coincidir com a caracterização da educação presencial, caso contrário estaremos abrindo espaço para a sua refutação.

Se tomarmos as principais variáveis que caracterizam, na literatura, a $\mathrm{EaD}-\mathrm{a}$ ) separação física professor-aluno; b) utilização de meios tecnológicos; c) organização de apoio e tutoria; d) organização independente e flexível; e) comunicação bidirecional - e levarmos cada uma a seu oposto, para tentar caracterizar a educação presencial, obteremos o seguinte descritivo da educação presencial:

- Um sistema no qual não existe distância entre o professor e o aluno (como se a distância entre professor e aluno fosse uma variável física que pode ser medida em 
metros, e não uma variável psicossocial que faz parte de um ato pedagógico; como se os alunos, nas salas de aula abarrotadas, a poucos metros do professor, não sentissem a distância na pele, logo de partilhar anos de incompreensão mútua.

- Um processo que não usa tecnologia educacional (quando as mais diversas tecnologias já fazem parte do cotidiano das organizações educacionais, desde os sistemas de administração de alunos, de notas, de cadastro on-line, de informação através de correio eletrônico; as bibliotecas digitais; o uso de recursos como datashow, lousa eletrônica, videoconferências, tarefas on-line, incluindo jogos, conteúdos on-line, etc.).

- Uma educação na qual não é possível achar sistemas de tutoria, flexibilidade nos estudos ou comunicação bidirecional (quando sabemos que o conceito "tutor" tem sua origem na educação presencial inglesa e que atualmente existem sistemas de ensino presencial flexíveis, com sistemas de orientação (tutorias) presenciais e virtuais. Em muitas salas de aula, os professores abandonaram parcialmente a técnica de conferência para abrir espaço para uma comunicação bidirecional mais ampla, pesquisas exploratórias, aprendizagens por descoberta orientadas, entre outros).

- Uma educação que não usa material instrucional (quando o ensino presencial se baseia no estudo de livros de texto, apostilas, que, infelizmente, na sua grande maioria, não apresentam tratamento didático nenhum, assim como muitos cursos a distância).

- Um processo que não possui orientação pedagógica e foco no indivíduo (quando as metodologias pedagógicas cognitivistas e interacionistas já se encontram orientadas para tal fim e na busca de uma pedagogia que atenda às singularidades dos alunos, desenvolvendo atividades significativas).

- Uma educação que não tem uma estrutura administrativa própria (quando a educação presencial tem uma estrutura administrativo-burocrática mais que consolidada).

Essa definição de educação presencial obtida evidentemente apresenta um contra-senso com o contexto atual, no qual estão emergindo instituições que incorporam um conceito 
de ensino-aprendizagem mais flexível, com possibilidades de escolhas curriculares, trilhas e cursos modulares; comunicação bidirecional, com maior foco nos alunos; uso intensivo de tecnologias e maior ênfase na auto-aprendizagem. Sistemas nos quais a sala de aula se amplia além dos espaços formais e presenciais, incorporando papéis como tutores e orientadores, além dos professores regulares, por meio de tecnologias como o correio eletrônico, os fóruns de discussão, os chats programados, entre outros. Assim como encontramos experiências de educação a distância nas quais não se apresenta comunicação bidirecional, ou possibilidade de escolha por parte do aluno, ou uso de tecnologias educacionais além das mídias impressas tradicionais, sem interação entre professor e aluno, sem tutoria ou orientação alguma.

Podemos concluir, então, que a educação a distância não é uma categoria oposta à educação presencial, como muitas definições apresentam. Pode ter sido em algum momento histórico, à luz da realidade de alguma época histórica, mas já não o é. $\mathrm{O}$ mundo mudou e a educação chamada presencial também está mudando e se adaptando à sociedade da informação e do conhecimento. Partilhamos, neste sentido, a visão de Lévy (1999, p. 170), que já assinalava:

Os especialistas neste campo reconhecem que a distinção entre ensino "presencial" e ensino "a distância" será cada vez menos pertinente, já que o uso das redes de telecomunicação e dos suportes multimídia interativos vem sendo progressivamente integrado às formas mais clássicas de ensino.

Isso sem considerar que ambas as modalidades de educação partilham de bases filosóficas, epistemológicas, pedagógicas, didáticas, administrativo-organizacionais, entre outras, que as configuram dentro de uma mesma lógica educacional, e não como pólos opostos, ou categorias mutuamente excludentes.

Por isso podemos afirmar que as características que parecem definir a educação a distância e a educação presencial, na verdade não são mutuamente excludentes e não diferenciam a educação a distância da educação presencial moderna.

\section{a) A distância como eixo diferenciador}

Entendemos que se faz necessário um exercício interpretativo para compreender estas definições, analisando o contexto no qual foram formuladas, a visão de educação e o processo educativo que tem assentado as bases das suas formulações. 
A maioria destas definições está sendo comparada com uma educação presencial em vias de extinção, que já não representa de modo algum a realidade educativa de nenhum país, inclusive dos países em desenvolvimento.

A própria insistência na distância física, nos meios de comunicação e nos materiais instrucionais nos fala de uma educação baseada num modelo explicativo do fenômeno educativo centrado no conteúdo; uma visão de instituição educativa centrada no currículo e em um processo didático centrado no professor, como principal transmissor do conteúdo escolhido.

Ou seja, a educação a distância, em muitas instituições, está sendo criada à imagem e à semelhança da educação presencial tradicional, por isso não nos surpreendem as definições dicotômicas da educação a distância: baseada nas tecnologias mais modernas, ela intenta reproduzir os modelos tradicionais de se fazer educação.

Assim sendo, podemos compreender por que o eixo da EaD está colocado na distância: no passado, com base em uma visão de educação centrada no conteúdo e no professor, era razoável considerar como principal obstáculo a ser vencido a distância entre professor e aluno, para que aquele transmitisse os conteúdos.

Entretanto, em uma sociedade da informação, na qual o conhecimento se encontra descentrado, já não está só nas mãos do professor, mas numa rede virtual que se amplia ano a ano, e com uma tendência crescente nas relações desencaixadas dos espaços físicos, não vemos sentido em continuar considerando a separação professor-aluno como um problema a resolver: com tecnologia e estratégias pedagógicas e didáticas adequadas, a distância pode vir a desaparecer, trasladando os relacionamentos a outros espaços que não mais somente os físicos.

Essas análises nos obrigam a fazer a seguinte interrogação: efetivamente, existe a educação a distância? Uma vez que o único elemento diferenciador com a educação presencial, no caso, "a distância", se desvanece?

Por outro lado, na visão atual, em alguns casos, essa distância até poderia ser positiva, possibilitando um crescimento gradual na independência, na autonomia e na 
responsabilidade dos alunos pela sua própria aprendizagem; cidadãos que aprendam a aprender e professores que deixem de ser máquinas de transmitir informação.

Atualmente, dado o nível de desenvolvimento tecnológico no qual nos encontramos, existem poucos elementos que podem nos ajudar na diferenciação entre educação presencial e a distância, ou na definição da própria educação a distância.

\section{b) A tecnologia como eixo principal: o enfoque mediacional centrado no computador}

O segundo elemento que, com freqüência, mais caracteriza a educação a distância nas definições analisadas reside na dimensão tecnológica. Para Landim (1997) e Garcia Aretio (1994), esta definição coincide com um modelo fordista e behaviorista da educação a distância, manifestando uma visão que, do ponto de vista pedagógico, tem estado baseada, explícita ou implicitamente, nas teorias de aprendizagem $\operatorname{associacionistas}^{227}$.

Assim mesmo, nos últimos dez anos, nas mãos dos tecnólogos tem se fortalecido a chamada Educação a Distância Mediada por Computador, que, baseada no conceito de “Computer-Mediated Communication”, procura desenvolver uma metodologia na qual a pedagogia se reduz a uma "ferramenta" e o meio converte-se em um mediador. Metodologias que, com roupagens cognitivistas e construtivistas, rememoram os projetos de corte positivista, que, além dos microcomputadores, incorporam os processos técnicos rigorosos, as programações rígidas, os objetivos fechados e concretos, as provas objetivas em avaliação e tudo aquilo que, na aparência, dá seguridade e eficácia educativa.

Fazendo um paralelo com os modelos explicativos da "vida da sala aula"228, poderíamos classificar o foco tecnológico e os métodos de educação mediada por computador na

\footnotetext{
${ }^{227}$ Essas teorias se baseiam na administração das contingências do reforço por meio da correção das respostas do aluno, pela ação interativa do docente, ou por meio do material auto-instrutivo pré-empacotado. Em ambos os casos, por isolamento ou pela prescrição, existe pouca possibilidade de negociar os objetivos de aprendizagem, de tomar decisões em colaboração, ou, para os aprendizes, de assumir a responsabilidade de construir significados próprios, baseados nas estruturas de conhecimento prévio.

${ }^{228}$ Vida de sala de aula: Conceito que envolve os diversos modelos explicativos sobre as relações e as trocas físicas, afetivas e intelectuais que constituem a vida do grupo na sala de aula e condicionam os processos de aprendizagem (Cf. SACRISTAN \& PEREZ GÓMEZ, 1998, p70).
} 
categoria dos modelos mediacionais ${ }^{229}$ da linha neocondutivista. Por isso, poderíamos chegar a definir o modelo prevalecente na educação a distância atual como um "modelo mediacional centrado no computador" ${ }^{230}$. Para este modelo, são variáveis independentes e determinantes as ferramentas tecnológicas de administração de conteúdos e o tipo de conexão (largura da banda) dos alunos para explicar os fatores intervenientes nos processos de ensino-aprendizagem.

Entendemos que a excessiva obsessão pela tecnologia educativa considerada como processo, como padrão para transmissão de conteúdos a grandes massas de pessoas, uma tecnologia baseada em conceitos como $\mathrm{SCORM}^{231}$ ou ICC, que determina o ideário educativo em função das análises do custo-benefício embutido no conceito de reutilização, limita o potencial educativo das próprias tecnologias e produz mais cegueira que elucidação.

Concordamos com Escudero, que, em 1995, dizia:

la Tecnología Educativa debe contribuir... a ampliar los márgenes de acción, decisión, intercomunicación entre profesores y alumnos, no a reducirlos, así como a permitir el acceso a nuevos modos de explorar, representar y tratar el conocimiento, no a empaquetarlo y reducirlo sólo a unos determinados modos de expresión y tratamiento del conocimiento (1995c:171).

Os modelos teóricos analisados apresentam, na sua grande maioria, explicações que se centram em algumas variáveis, seja a tecnológica, a industrial, a comunicacional, a de conteúdos, a função social, ou outras, porém estes modelos não chegam a captar a complexidade do ato educativo.

\footnotetext{
${ }^{229}$ Entre os conceitos explicativos das inter-relações na sala de aula, encontramos os modelos:

Processo-Produto - Desenvolvido entre os anos 40 e 70, sustenta uma explicação simples dos fenômenos de ensino aprendizagem que ocorrem na sala de aula. Segundo este modelo, as relações que se estabelecem entre o comportamento observável do professor quando ensina e o rendimento acadêmico do aluno são as únicas variáveis a serem consideradas.

Mediacional: A inconsistência das investigações no âmbito do modelo processo-produto originou modelos mediacionais, que incorporam a variável mediadora do aluno e do professor como uma das principais responsáveis pelos efeitos da vida de sala de aula. Neste modelo encontra-se uma variedade de pontos de vista: os mediacionais centrados no professor, os mediacionais centrados no aluno e os modelos ecológicos.

230 "Mediacional centrado no computador": Conceito que descreve a visão mais comum no campo da educação a distância atual, na qual se considera como variável independente a tecnologia utilizada, que poderia explicar as relações entre aluno/aluno, aluno/conteúdo, grupo e professor, ou seja, a vida da sala de aula virtual.

${ }^{231}$ O SCORM é um conjunto unificado de padrões e especificações para conteúdo, tecnologias e serviços para elearning. Define um modelo de agregação de conteúdo (content aggregation model) e um ambiente de execução (runtime environment) para objetos educacionais baseados na web.
} 
Não se trata de homogeneizar a realidade em uma totalidade, mas de dar conta do caráter multidimensional dela, conforme o que propõe Souto (1993) acerca do ato educativo:

El acto pedagógico articula lo social con lo individual, lo pasado con lo presente y lo futuro; lo conocido con lo desconocido; lo pensado con lo sentido y actuado". Es entonces una instancia donde el alumno puede verse como sujeto individual, como sujeto en interrelación con los otros del grupo, como sujeto en un grupo inserto en una Institución y a su vez atravesado por el macro-contexto social ${ }^{232}$,

Um marco teórico que pode ser de grande utilidade para uma leitura crítica da complexidade do ato educativo a distância.

O primeiro nível é o social (refere-se à população de alunos e professores e às representações compartilhadas: da sociedade, da educação, da universidade); o segundo nível é o institucional, que envolve a forma e a distribuição do espaço e do tempo, as normas, a cultura envolvida nos intercâmbios e as opções pedagógicas. O próximo nível é o grupal, no qual se analisam variáveis espaciais, temporais, culturais, psicossociais; a seguir o nível interpessoal, a partir do qual se analisam as interações, as freqüências de trocas de ações entre os atores do processo educacional; posteriormente o nível pessoa, que se refere à singularidade de cada pessoa (aluno e/ou professor), suas características, necessidades, estilo de comunicação, estilo de aprendizagem, e, por último, o nível instrumental, que envolve os programas de estudo, objetivos, conteúdos, propostas pedagógicas, organização, logística, etc.

Todas essas variáveis atuam em conjunto com as situações de ensino e aprendizagem, por isso se faz necessário um modelo explicativo mais abrangente e realista do ato pedagógico a distância, que possa capturar a complexidade do fenômeno. Nesse sentido, consideramos muito pertinente a adoção do modelo ecológico proposto por Doyle e Tikunoff, que analisa o espaço de uma perspectiva "sistêmica e aberta"233 de comunicação e troca, que pode capturar a vida complexa da aula na sua riqueza, levando em conta três tipos de variáveis, uma vez que, por meio delas, podemos depreender as interações que configuram todo ato de aprendizagem.

\footnotetext{
${ }^{232}$ SOUTO, 1993, p. 33.

${ }^{233}$ Como todo sistema aberto, não pode explicar o comportamento de cada um de seus elementos sem conhecer a estrutura e o funcionamento do conjunto, bem como suas conexões com outros sistemas externos com os quais se estabelecem relações. Por outro lado, para conhecer a estrutura e o seu funcionamento, é necessário identificar o comportamento e a participação relativamente autônoma de cada uma das suas partes. Bertalanffy, 1976; Bunge, 1980.
} 
As variáveis situacionais - por elas se analisam o clima de objetivos e as expectativas que se criam no grupo - tanto as expectativas do professor como as dos alunos; o cenário, o marco de convivência, formado pela configuração do espaço e a estrutura de atividades que se desenvolvem, os papéis que as pessoas desempenham e a organização e distribuição do tempo. Dessa forma, abrange-se o cenário físico e o clima psicossocial em que se desenvolvem as trocas entre os alunos/alunos e entre eles e os professores.

Já as variáveis relacionadas às experiências vividas referem-se aos significados e aos modos de atuação que carregam professores e alunos, enquanto as variáveis comunicativas referem-se aos conteúdos das trocas na sala de aula, tanto em nível intrapessoal como interpessoal e grupal.

O modelo de Doyle analisa a aprendizagem como resultado das interações dos indivíduos dentro do grupo social em que vivem, a partir de um contexto determinado por dois subsistemas interdependentes, mas com relativa autonomia. Um desses subsistemas refere-se à estrutura das tarefas acadêmicas, ou seja, ao conjunto de tarefas nas quais se envolve o indivíduo, os grupos de estudantes e a coletividade como um todo. O segundo subsistema constitui-se pela estrutura de participação social, isto é, pelas normas e pelos padrões culturais explícitos ou tácitos que regem as trocas e as relações sociais no grupo da sala de aula.

Seja qual for o modelo que adotemos para analisar a educação e as novas tecnologias a distância, o certo é que não podemos esquecer que a aprendizagem não envolve só comunicação ou conteúdos, ou tecnologia. Inúmeros são os fatores que se encontram envolvidos em uma situação de ensino/aprendizagem e que acabam por determinar a aprendizagem significativa de cada aluno, construída segundo o espaço, o tempo, a pedagogia, a didática, a psicologia, a comunicação, a arte e a tecnologia adotados.

Como já mencionado anteriormente, se, em algum momento da história, a educação a distância foi caracterizada como o sistema educacional oposto à educação presencial, que se define a partir da distância física entre aluno e professor, hoje a fronteira entre educação a distância e educação presencial encontra-se cada vez menos nítida.

Em um futuro bem próximo, já não ouviremos mais falar de ensino presencial e a distância de forma dicotômica, mas sim de sistemas de ensino-aprendizagem que 
possam auxiliar as pessoas de qualquer idade, sexo, raça e condição social a crescer e se aperfeiçoar constantemente e com a velocidade que a sua própria realidade demande.

Nesse sentido, emerge uma nova hipótese do estudo, que indica que a chamada educação a distância, antes de mais nada, é uma educação que questiona a categoria formal de presença física como pré-requisito de ensino.

Porém o problema principal está nas tendências fordista e mercantilista que estão determinando que a variável independente do processo educativo seja a análise custobenefício.

Faz-se necessário, dessa forma, construir uma definição de educação centrada no aluno e na aprendizagem, considerando o professor como um mediador no processo de construção de conhecimento, com base em paradigmas ecológicos e nos modelos de análise da complexidade.

Por último, achamos imprescindível que sejam realizadas pesquisas que busquem clarear os limites da educação a distância, ou seja, apontar em que etapas evolutivas e de que forma podemos utilizar este tipo de modalidade educacional. Que tipos de saberes, conhecimentos, valores, sentimentos, atitudes são possíveis de aprender a distância e quais necessitam de espaços presenciais para a sua construção ou desenvolvimento.

Tal atitude poderia, de certa forma, marcar os limites entre ambas as modalidades de estudo, revelando, de forma consistente, como, quando e por que adotá-las para a melhoria dos sistemas educacionais.

Está claro que existe aprendizagem sem ensino, assim como existe ensino sem aprendizagem, por isso a educação deveria ter como objetivo central gerar as melhores condições para a aprendizagem das pessoas, utilizando os meios e os agentes mediadores mais eficazes em cada caso, diante de cada necessidade.

É nesse sentido que temos desenvolvido o estudo exploratório de universidades a distância, tentando capturar elementos concretos que possam servir de elementos de reflexão para a elaboração de estratégias educativas. 


\section{3) Educação a distância na educação superior}

Como observamos, a educação a distância nas megauniversidades tem acumulado um enorme know-how, que pode servir não só para o desenvolvimento de sistemas operacionais, perspectivas de financiamento, logística de pesquisa, mas também de metodologias e estratégias educativas, entre outros.

\section{a) Crescimento}

As duas primeiras constatações que pudemos fazer referem-se à dimensão quantitativa; em primeiro lugar, podemos testemunhar um enorme crescimento da matrícula dessas universidades, algumas com mais de três milhões de alunos acumulados desde a sua fundação e com programas sociais que vêm atendendo a mais de 40 milhões de pessoas. A segunda constatação do crescimento desta modalidade de estudo refere-se ao crescimento de universidades virtuais, abertas e a distância no mundo, que passaram de apenas algumas dezenas nos anos 90 a centenas na década seguinte.

Porém o crescimento está se apresentando com características diversas, dependendo do período histórico que analisemos. A maioria das universidades teve um crescimento maior entre a sua fundação e 1995, com índices que, salvo a UNED $(5,75 \%)$ e a Open UK (7,64\%), apresentaram crescimento acima dos 10\%: CCRTVU (11\%), UA e KNOU (13\%), UT (15\%), BRAOU (21\%), IGNOU (28\%) e PNU (46\%).

Já no período de 1995 a 2004, encontramos um crescimento menos acentuado e muitas universidades com taxas de crescimento negativas. Só uma universidade nesse período cresceu em comparação ao período anterior - a CCRTVU da China - e uma se manteve praticamente sem variação - a UNED. O restante teve quedas acentuadas, como a IGNOU, que foi de $28 \%$ a $16 \%$; a BRAOU, que foi de $21 \%$ a $2,88 \%$; a UA, que foi de $13 \%$ a $5 \%$; a PNU, que foi de $46 \%$ a $16 \%$, e a Open UK, que foi de $7 \%$ a $3 \%$. Houve também um grupo de universidades que apresentou uma forte queda nas matrículas, como a UT, que foi de $15 \%$ a $-5 \%$, e a KNOU, que foi de $13 \%$ a $-0,7 \%$. 


\begin{tabular}{|c|c|c|c|c|c|c|c|c|c|c|c|}
\hline Continente & País & $\begin{array}{l}\text { Nome da } \\
\text { Instituição }\end{array}$ & $\begin{array}{c}\text { Fundada } \\
\text { em }\end{array}$ & $\begin{array}{c}\text { Estudantes } \\
\text { matriculados } \\
\text { na sua } \\
\text { fundação }\end{array}$ & $\begin{array}{l}\text { Estudantes } \\
\text { matriculados } \\
\text { em } 1995\end{array}$ & $\begin{array}{c}\% \text { de } \\
\text { crescimento } \\
\text { anual } \\
1987 / 1995\end{array}$ & $\begin{array}{c}\text { Estudantes } \\
\text { matriculados } \\
2004\end{array}$ & $\begin{array}{c}\% \text { de } \\
\text { crescimento } \\
\text { anual } \\
1995 / 2004\end{array}$ & $\begin{array}{c}\text { Alunos } \\
\text { Ativos } \\
2004\end{array}$ & $\begin{array}{c}\text { Matricula } \\
\text { dos } \\
\text { desde a } \\
\text { sua } \\
\text { fundação }\end{array}$ & $\begin{array}{c}\text { Graduado } \\
\text { s } \\
\text { dede a sua } \\
\text { fundação }\end{array}$ \\
\hline África* & $\begin{array}{l}\text { África do } \\
\text { Sul* }\end{array}$ & $\begin{array}{l}\text { Universidade de } \\
\text { África do sul }\end{array}$ & 1873 & & 130.000 & & 226.424 & $6,36 \%$ & & & \\
\hline \multirow[t]{2}{*}{ América } & Canadá* & $\begin{array}{l}\text { Universidade de } \\
\text { Athasbasca }\end{array}$ & 1970 & & 10.874 & & 29.542 & 11,74 & & & 260.000 \\
\hline & $\begin{array}{l}\text { Estados } \\
\text { Unidos }\end{array}$ & $\begin{array}{l}\text { Universidade de } \\
\text { Phoenix }\end{array}$ & 1976 & & 25.000 & & 255.600 & $29,47 \%$ & & & 171.600 \\
\hline \multirow{9}{*}{ Ásia } & \multirow{2}{*}{ Índia } & $\begin{array}{l}\text { (IGNOU)* } \\
\text { *Inscrição anual } \\
\text { de alunos }\end{array}$ & 1985 & 4.528 & 91.000 & $28,92 \%$ & 492.542 & $\begin{array}{r}16,59 \\
\text { (dados de 2006) }\end{array}$ & $\begin{array}{r}1.013 .631 \\
\text { milhões }\end{array}$ & $\begin{array}{r}2.545 .377 \\
\text { milhões }\end{array}$ & 468.196 \\
\hline & & (BRAOU) & 1982 & 6.231 & 79.825 & $21,67 \%$ & $\begin{array}{r}102.317^{*} \\
\text { (dados de } \\
2000) \\
\end{array}$ & 2,88 & 450.000 & $\begin{array}{r}1.000 .338^{*} \\
(\text { dados de } \\
2002) \\
\end{array}$ & $\begin{array}{r}47.134^{*} \\
\text { (dados de } \\
2002) \\
\end{array}$ \\
\hline & China & CCRTV & 1979 & 97.502 & 530.000 & $11,16 \%$ & $\begin{array}{r}1.500 .000^{*} \\
\text { (dados de } \\
2002) \\
\end{array}$ & 12,25 & 2.300 .000 & & $\begin{array}{r}3.337 .000 \\
\text { (dados de } \\
2002) \\
\end{array}$ \\
\hline & Japão & \begin{tabular}{|l|} 
(UA)* \\
*Inscrição anual \\
de alunos \\
\end{tabular} & 1985 & 17.038 & 57.979 & $13,03 \%$ & 96.924 & $5,88 \%$ & & 780.000 & 21.548 \\
\hline & Paquistão & (AIOU) & 1974 & & 504.933 & & 1.806 .241 & $15,21 \%$ & & & \\
\hline & Indonésia & (UT) & 1984 & 84.000 & 353.000 & $15,44 \%$ & 222.068 & $-5,02 \%$ & $\begin{array}{r}322 . .857^{*} \\
\text { (dados de } \\
2006) \\
\end{array}$ & 1.000 .000 & 500.000 \\
\hline & $\begin{array}{l}\text { Coréia do } \\
\text { Sul }\end{array}$ & (KNOU) & 1972 & $\begin{array}{r}36.334 \\
\text { (dados de } \\
1981) \\
\end{array}$ & 210.578 & $13,37 \%$ & 196.402 & $-0,77$ & & & 280.000 \\
\hline & Irã & (PNU) & 1987 & 8.000 & 117.000 & $46,70 \%$ & 467.000 & $16,63 \%$ & & & \\
\hline & Tailândia & (STOU) & 1978 & & 216.800 & & 181,372 & $-1,96 \%$ & & & 220.000 \\
\hline & Inglaterra & OPEN (UK) & 1971 & 25.000 & 157.450 & $7,64 \%$ & 220.000 & $3,79 \%$ & 203,744 & 3.000 .000 & \\
\hline Europa & França & (CNED) & 1939 & & 184.614 & & $\begin{array}{r}368163^{*} \\
(2002) \\
\end{array}$ & $7,97 \%$ & & & \\
\hline & Espanha & (UNED) & 1972 & 74.388 & 110.000 & $5,75 \%$ & 171.973 & $5.09 \%$ & & & \\
\hline
\end{tabular}

Tabela 24: Crescimento de Megauniversidades entre sua fundação e 1995 e entre 1995 e 2004.

Fonte: Tabela criada pelo autor, 2007. 
Os autores consultados de vários países concordam em assinalar como fatores que produziram estas quedas acentuadas: o crescimento de novas ofertas educativas no país (como o caso da KNOU, na Coréia, que deixou de ser a única com ofertas de educação a distância) - entre 2000 e 2006, foram criadas no país 17 universidades digitais, com metodologias de estudo baseadas na internet; o encerramento de alguns programas massivos das universidades, especialmente de formação de professores, os quais constituíam uma parte majoritária da matrícula da universidade, e, em algumas universidades, a crise econômica, que impossibilitou muitas pessoas de continuar seus estudos.

Isso nos faz refletir acerca da concepção de universidade aberta focada especialmente na formação de professores, os quais, uma vez formados, fazem cair dramaticamente a matrícula da universidade, como, por exemplo, a Open da Coréia, que passou de mais de 4 mil graduados ao ano para 250 de 2001 a 2002.

\section{b) Público-alvo}

Além da análise dos objetivos dessas universidades, do papel que estão cumprindo na sociedade atual e de seu crescimento, tanto em número de instituições como do ponto de vista da matrícula, o estudo exploratório realizado nos oferece alguns dados que ilustram bem as tendências destes programas na sociedade do conhecimento.

Em relação ao público-alvo, a maioria das universidades dirige as ações educativas para as pessoas que não tiveram a possibilidade de aceder a uma educação tradicional, por questões de distância física, de dedicação ao trabalho ou por motivos financeiros. O perfil de idade oscila de uma universidade a outra, no entanto a faixa etária mais importante encontra-se entre 25 e 45 anos; no México, $70 \%$ dos graduados têm menos de 40 anos; no Canadá, $50 \%$ têm entre 25 e 45 anos, e os 50\% restantes têm menos de 25 anos; nos Estados Unidos, a faixa etária média é de 34 anos.

Quanto aos alunos que trabalham, as porcentagens variam: 52\% no Japão, 70\% no Paquistão, quase $100 \%$ na Coréia e nos Estados Unidos, dois terços na França e 75\% na Inglaterra. 


\section{c) Sistema de Estudos}

Os sistemas de estudo encontrados são diversos, mas podem ser agrupados entre os que não exigem diploma algum para entrar na universidade, os que exigem diploma e os que exigem, além do diploma, um exame de ingresso.

O que podemos observar é que existe uma tendência de flexibilização das condições de ingresso dos alunos nas universidades, na sociedade do conhecimento. O Estado não tenta selecionar os melhores para ir à universidade: tenta fazer do país uma grande instituição educativa, dando possibilidades de aprendizagem a todas as pessoas, deixando de lado burocracias, exames, idade e estudos anteriores. Em algumas faculdades, até se deixa de lado a data de ingresso, podendo o aluno entrar na faculdade em qualquer mês do ano.

Fica claro que na sociedade do conhecimento a universidade já não é algo para poucos: é algo para todas as pessoas. Desta forma, a universidade ajuda as pessoas a entrar nela, ajuda a reter os alunos nela e a produzir conhecimentos valiosos para o posicionamento do país no mundo globalizado.

Nesse sentido, na Indonésia, a política de admissão de alunos obedece a critérios máximos de flexibilidade e acessibilidade: não há teste para pré-ingresso universitário nem limites de idade, tampouco tempo de escolaridade mínimo exigido para ingresso em seus cursos. A OU inglesa, entretanto, partilha dos mesmos princípios, mas exige um mínimo de idade de 18 anos para ingressar. No Japão e na África do Sul, a seleção se baseia na documentação submetida para análise; exigem ensino médio completo, mas não há exames de admissão. $\mathrm{O}$ Irã também está flexibilizando a política de admissão: a partir de agora, os alunos admitidos poderão estudar sem obrigatoriedade do exame durante um primeiro semestre de curso. $\mathrm{O}$ exame é realizado no final do primeiro semestre e, caso obtenham êxito, tirando a nota mínima desejada, poderão continuar seus estudos normalmente.

Na China, na França, na Espanha, no México e nos Estados Unidos, os alunos devem ter educação secundária completa e prestar exame de ingresso. 


\section{d) Materiais de estudos e estratégia educacional}

Do ponto de vista dos materiais utilizados e das estratégias educacionais, fica evidente uma tendência geral para a utilização de uma ampla gama de recursos, na busca constante de enriquecer a aprendizagem e de gerar mecanismos de aproximação e diálogo entre os alunos e destes com os professores.

As universidades mais antigas migraram do ensino por correspondência, para o rádio, e logo para a televisão, e agora estão buscando sistemas que possibilitem uma comunicação bidirecional entre estudantes e professores para aumentar a qualidade do estudo e a retenção dos alunos no sistema - internet, fibra ótica, satélite, entre outros recursos.

$\mathrm{Na}$ Índia, por exemplo, tanto a IGNOU como a BRAOU utilizam um sistema multimídia flexível que incorpora tanto material impresso (por correio) como rádio e TV interativa (transmissão central), videocassete, práticas em laboratórios, encontros presenciais nos centros de estudo, sessões de aconselhamento tutorial e teleconferências, através da rede construída em 1991. Dada a ainda baixa penetração da internet no país, o sistema está baseado fortemente nos materiais impressos, no rádio e na televisão interativa. A BRAOU, junto ao governo de Andhra Pradesh, participou na criação da MANA TV, que apresenta cinco canais com o propósito de promover educação a distância para agricultores, governo, universidade, entre outros públicos. O interessante desta rede é a flexibilidade nas possibilidades de recepção: a clássica via sinal de TV; a outra via sinal de TV somada à capacidade telefônica para realizar as interações com os alunos; o recebimento do sinal pelo computador pessoal e a possibilidade de voz sobre IP, facilitando as interações, entre outras.

A Índia está em processo de desenvolvimento de um satélite educacional, o EduSAT, que, quando concluído, possibilitará a implementação de até de 70 canais de TV educativa e de um repositório nacional de recursos didáticos digitais para suportar a integração de recursos de aprendizagem em formatos diferentes (programas de áudio, vídeo, arquivos de sessões ao vivo), que possam ser usados tanto nos programas presenciais como a distância.

A China está vivendo o mesmo processo. Depois de um longo histórico de educação a distância via televisão, atualmente o país transita na integração de duas poderosas redes: as TVUs e a rede CERNET, criada e administrada pela universidade de Tshingua, possibilitando 
a combinação entre internet, comunicação por satélite, TV a cabo e TV sobre IP. Ao mesmo tempo, além do uso do satélite, do material audiovisual e do material impresso, o sistema oferece aos alunos ajuda direta (pessoal) e biblioteca, bem como outros serviços de suporte, como a internet através da rede CERNET. Além disso, as pesquisas estão se orientando para a criação de tecnologia de ponta que possibilite mudar totalmente a forma de dar aulas presenciais, dando indícios concretos da tendência ao desaparecimento das fronteiras entre o modelo presencial e o modelo a distância.

Nesse sentido, destacam-se as pesquisas de sala de aula inteligente (smart class), um sistema de transmissão simultânea, em tempo real, que possibilita a interação bidirecional entre o professor e os alunos dispersos por todo o país, dotando o professor de maior liberdade de expressão na comunicação, incorporando a dimensão gestual de professores e alunos na comunicação a distância e permitindo que cada microcomputador seja como uma espécie de sala de videoconferência. Esse sistema inclui salas de trabalho onde os alunos apresentam seus trabalhos individuais e os tutores os avaliam, fazendo comentários, chat síncrono, fórum de discussão, e-mail, encontros presenciais e telefone.

No Japão, como comentamos, existe um descompasso entre o desenvolvimento tecnológico do país e a aplicação dessas tecnologias na educação. A University of the Air é a única universidade a distância do país e transmite através da TV e do rádio todos os dias, desde o início da manhã até a meia-noite. Os cursos transmitidos são complementados com materiais impressos. O sistema de estudo também apresenta encontros presenciais obrigatórios (aproximadamente 20\% da carga horária total do curso).

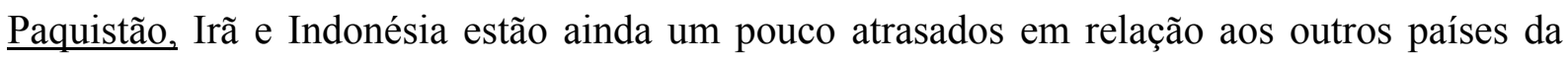
região, recém-transitando do ensino por correspondência a sistemas de TV e rádio educativa. $\mathrm{Na}$ Indonésia, a universidade busca o desenvolvimento de sistemas que cada vez mais possibilitem uma melhor comunicação entre professor e aluno, para encurtar as distâncias, e encontra-se na busca de modelos de auto-instrução e auto-regulação dos estudos, sem ou com pouca interferência dos tutores, e de um sistema baseado em material impresso, com suportes de programas de TV e rádio. Não obstante, observam-se os esforços de todos estes países no sentido de criar possibilidades de comunicação com os tutores, através do rádio interativo e agora através da internet. O Paquistão, por exemplo, já está realizando experiências de universidades virtuais com metodologia de transmissão por televisão e internet, através de um 
LMS “intralearn”. Esta ferramenta também ajuda na comunicação com os tutores e com outros alunos, através de e-mail e fórum de discussão.

$\mathrm{Na}$ Coréia, melhor que em qualquer outro lugar, podemos observar as tendências na passagem das universidades abertas às universidades digitais, totalmente a distância, mostrando como a internet articulada com outras mídias e estratégias pode vir a possibilitar uma comunicação mais fluida entre professores e alunos. A Open Coreana está atualmente utilizando uma estratégia que articula aulas expositivas veiculadas por radiodifusão (TV e rádio); um sistema de biblioteca digital, com materiais de áudio e vídeo; aulas expositivas presenciais; apostilas; aulas expositivas em formato áudio-gráfico; aulas expositivas veiculadas pelo jornal universitário e cursos via internet e comunicação por computador, com modelos multimídia, modelo centrado no professor; modelo tutorial e modelo de pesquisa e trabalho prático.

Esta mesma tendência pode ser observada na Inglaterra e na França. Na OU, utilizam-se diversos recursos multimídia que favorecem o aprimoramento do aprendizado, como apostilas, agendas impressas, fitas de áudio e vídeo, programas de TV, CD-ROMs, softwares, web sites e kits com experiências vivenciais. É importante salientar que os programas de radiodifusão da Open britânica são produzidos em parceria com a BBC de Londres, o que qualifica em grande parte a qualidade dos materiais produzidos e empregados nos vários cursos a distância. Esses cursos têm sido aos poucos incrementados com o suporte de DVDs, com o estilo de produção audiovisual baseando-se no formato de teledocumentários, com qualidade de imagem e conteúdo, tendo, ainda, caráter inovador na abordagem dos temas, selecionando principalmente aqueles com enfoque científico.

Na França, entretanto, o CNED coloca à disposição dos alunos materiais impressos, fitas e videocassetes, programas de televisão, assessoramento pedagógico via telefone ou internet, treinamento on-line, cursos baseados em páginas web e salas de aula virtuais pelo campus eletrônico (Campus Électronique ${ }^{234}$ ). Entre os recursos tecnológicos empregados na infraestrutura de ensino e aprendizagem do CNED, há, sem dúvida, dois que favorecem muito os resultados obtidos no desempenho da qualidade dos cursos que a Instituição oferece: o sistema Minitel e a TV Interativa da França. A cultura de uso do Minitel mostrou-se muito importante, já que criou as bases de ambientação da população para aderir às novas tecnologias, tornando-o ainda um instrumento indispensável para o acesso à educação e ao

\footnotetext{
${ }^{234}$ Trata-se de uma plataforma de serviços de formação proposta pelo CNED.
} 
aprendizado em larga escala na França, o que justifica a sua significativa utilização por parte do CNED para disseminar informações e recursos pedagógicos a um grande contingente populacional.

Já a TV Interativa Francesa (ETI - Émissions de Télévision Interactives) é uma tecnologia bem mais recente. A grande vantagem desta tecnologia está em ampliar o acesso à educação, independentemente de se ter ou não um microcomputador pessoal. Ou seja, o conceito de TV Interativa tanto pressupõe novos avanços tecnológicos de última geração como alta capacidade de definição ou resolução de imagens com tratamento digital, com recursos interativos imediatos, síncronos (on-line) e assíncronos, como também faz valer o uso de aparelhos antigos a partir do processo de codificação e decodificação de informações e imagens.

Na América, tanto no México como nos Estados Unidos, na Costa Rica, na Argentina e no Chile, encontramos esforços similares para aumentar a comunicação entre alunos e professores. A Universidade Virtual do México, por exemplo, escolheu como metodologia cursos via satélite e por videoconferências. Os alunos têm à sua disposição acesso à biblioteca e às videotecas digitais, bem como a programas de TV ao vivo e a conselheiros acadêmicos, cuja função é acompanhar os alunos durante seus estudos, desde a matrícula até sua formação, auxiliando-os nos diferentes processos que viverão em um programa de formação a distância.

No Canadá, os alunos dispõem de uma metodologia elaborada em função de pacotes de estudos individualizados, contendo um manual do estudante, guia de estudos, apostilas, $C D$ $R O M / s o f t w a r e$, fitas de áudio e de vídeo. Os cursos têm estratégias que mesclam estudo individual com estudo em grupo. No caso do estudo individual, o aluno recebe todo um roteiro de como deve ler e assimilar o material instrucional.

Na Universidade de Phoenix, a infra-estrutura da web predomina. O sistema de ensino on-line adotado pela universidade permite ao aluno completar $100 \%$ de suas atividades administrativas e educacionais, como, por exemplo, participar de reuniões de classe e atividades da equipe de aprendizado; comunicar-se com o instrutor; interagir com colegas de classe; conduzir suas pesquisas de modo autônomo. Para ter acesso aos materiais de estudos, os alunos precisam basicamente de um computador conectado à internet. 


\section{e) Evasão}

Esta tendência global de buscar enriquecer a aprendizagem através de uma oferta variada de recursos didáticos e sistemas que aproximam os alunos dos professores, criando uma comunicação bidirecional, em parte entendemos que está se dando não tanto pelas análises teóricas, mas pela realidade da evasão nestas experiências. Na IGNOU, por exemplo, a evasão alcança $62 \%$ dos alunos nos cursos de três anos de duração, com uma evasão do primeiro ao segundo semestre de mais de $40 \%$. Na STOU, a evasão entre o primeiro e o segundo semestre alcança 14\%; na Open Coreana, a evasão é de $40 \%$ entre o primeiro e segundo semestre.

Infelizmente é muito difícil obter dados confiáveis de evasão, pois a maioria das universidades não publica seus índices. Em geral, esses dados são encontrados em análises de professores pesquisadores que participam ativamente dos projetos nas universidades. Mas, além de constatar um problema que já foi suficientemente levantado nas análises teóricas sobre educação a distância, é interessante observar as pesquisas que trazem dados acerca dos motivos da evasão. Nesse sentido, e coincidindo com o que já apresentamos, na maior parte das vezes o estudante deixa a faculdade por falta de comunicação com os professores e os alunos.

Apesar da grande quantidade de centros de estudo criados nos países pesquisados, principalmente na Índia, os centros ainda ficam longe demais das pessoas, fazendo com que $64 \%$ dos entrevistados indiquem este problema como motivação para o abandono. A falta de comunicação com o tutor alcança o segundo lugar, com 58\% dos entrevistados dizendo sentir falta de suporte acadêmico nos centros de estudo. Um outro problema, já identificado anteriormente, diz respeito ao planejamento do tempo de estudo, apontado por $55 \%$ dos entrevistados. As cargas horárias das disciplinas e as atividades requeridas, quando somadas, excedem muito o tempo de dedicação comunicado na hora da inscrição.

Por último, podemos notar outros fatores, como a ausência de interação com outros estudantes, insuficiente número de encontros presenciais e falta de responsabilidade do centro de estudos, com uma freqüência de $47 \%$.

Como podemos observar, é grande a busca que fazem todos estes países com uma longa tradição em educação a distância por sistemas que possibilitem tirar o aluno do isolamento e da passividade e criar ambientes ricos, bidirecionais, com suporte permanente dos professores tutores. 


\section{f) Pesquisas}

Nesse sentido, ou seja, na busca permanente por qualidade, numerosas universidades constituem grupos de pesquisa que acompanham as experiências desenvolvidas. A pesquisa aplicada nesta área torna-se fundamental, pois, na sociedade do conhecimento, não podemos querer inventar a roda o tempo todo: devemos estar cientes de que o conhecimento acumulado permite adiantar anos e poupar numerosos recursos no desenvolvimento de políticas e experiências. Faz-se necessário criar um banco de pesquisas nas quais possamos confiar que possam, por sua vez, ser traduzidas em políticas, em sistemas de planejamento.

Por exemplo, em relação ao uso de TV educativa como um recurso didático, encontramos dados que mostram que aspectos de logística muitas vezes põem por terra enormes esforços de produção - vide as pesquisas de Basu $(2005)^{235}$ sobre o grau de satisfação sentida com os programas da TV educativa através do canal de Doordarshan. A contribuição de Basu nos permite ter uma idéia do impacto que isso significa: falta de informação dos alunos sobre a programação do canal, um elemento simples, mas que ao mesmo tempo envolve um complexo processo de planejamento, produção e comunicação, o qual nem sempre é fácil de se resolver, em se tratando de sistemas com tal magnitude, quantidade de cursos e longas distâncias geográficas do país. Assim, não só as programações não chegam a tempo, fazendo com que as pessoas não assistam, mas também muitas vezes essas transmissões estão fora de sincronismo em relação ao planejamento geral do curso e aos conteúdos que estão sendo estudados nesse momento; a falta de relevância dos programas de TV, devido ao escasso orçamento de produção, ou à baixíssima qualidade destes por serem desenvolvidos por professores, ou, ainda, por questões orçamentárias.

Temos relatos, como o da Mana $\mathrm{TV}$, na qual foi desenvolvida uma infra-estrutura importantíssima - estúdios de TV profissionais, satélite de transmissão próprio, rede de receptores para TV interativa -, mas não foi considerado o custo da elaboração dos programas para desenvolver conteúdos de qualidade, fazer a manutenção dos terminais ou garantir a segurança dos equipamentos. As pesquisas mostram que os programas produzidos pela universidade não são de qualidade elevada de conteúdo e de planejamento visual quando comparados ao padrão de programas para a televisão comercial.

${ }^{235}$ Commonwealth of Learning. Perspectives on Distance Education. Educational Media in Asia. Vancouver, 2005. Página 131. 
Temos que estar cientes de que os professores são profissionais da educação. Não constituem um recurso que pode, com baixo custo, substituir roteirista, designer, programador, apresentador de TV, produtor de TV, etc. Estas funções também requerem bons profissionais, se queremos desenvolver educação de qualidade. A tecnologia educativa e a educação a distância não são baratas. Este mito de educação a distância como modalidade com custo reduzido está levando à perda de qualidade e à enorme evasão.

Também podemos destacar que existem tecnologias apropriadas que, bem usadas, podem constituir-se em reais alternativas para um país continental como o Brasil. O rádio interativo tem se mostrado, nas diferentes pesquisas analisadas, como um recurso eficaz e atrativo para os estudantes, mais do que áudio, vídeo e teleconferências, por uma simples razão: a facilidade na recepção, já que qualquer um pode receber o sinal em sua casa. As pesquisas ainda ressaltam que, para a estratégia funcionar corretamente, é preciso haver uma quantidade de números telefônicos gratuitos para que os alunos se comuniquem com os tutores. $\mathrm{O}$ rádio também tem se mostrado importante para realizar atualizações em relação ao conteúdo quando é impossível atualizar os materiais impressos já distribuídos - ou para realizar uma tutoria corretiva.

Na elaboração de um bom programa de educação a distância, não se trata só dos recursos de que se dispõem, mas de que utilidade vai se fazer deles, como vão ser utilizados. Muitas vezes, o problema não são os recursos disponíveis, mas o escasso conhecimento de como tirar máximo proveito deles. Um bom exemplo é a formação de bibliotecas de recursos em centros de estudo. Em princípio, é importante dotar os alunos de materiais em áudio e vídeo para complementar seus estudos, porém a utilização tem se mostrado quase inexistente. Parece que, embora os estudantes tenham interesse nos recursos, não os usam por diversos motivos: falta de instalações físicas e falta das habilidades necessárias dos coordenadores e dos tutores em usar os recursos eficazmente. Agora quando se emprestaram as cópias por longos períodos para levar para casa, e se entregaram as programações com tempo, os resultados foram completamente distintos das experiências anteriores: 95\% dos alunos escutaram as fitas de áudio e todos viram as fitas de vídeo.

Como podemos observar, faz-se necessário avaliar as diversas estratégias elaboradas para analisar quais delas se adaptam melhor aos diferentes públicos-alvos educativos. Nesse sentido, as pesquisas sobre sistemas de avaliação em processo, como as experiências da universidade de Tsinghua, mostram-se importantes, já que nos permitem interpretar as trilhas 
percorridas pelos alunos on-line, em tempo real, para analisar caso a caso o que acontece com cada aluno, tentando criar sistemas semi-automáticos que possibilitem criar uma imagem de cada usuário.

Estas e outras experiências, sem dúvidas, devem enriquecer um sistema global de conhecimento para aumentar a reflexão teórica e prática e elevar a qualidade educativa.

\section{g) Financiamento e estratégias de articulação}

Um último elemento destacável neste estudo exploratório pode estar relacionado às estratégias elaboradas para articular as redes de centros de estudo, com uma reflexão acerca do financiamento dos mesmos.

As estratégias que mais chamaram nossa atenção foram as chinesas, as indianas e as paquistanesas. Com elas podemos aprender o que pode ser interessante fazer e o que não fazer para garantir uma aprendizagem de qualidade. Por exemplo, em vez de criar novas estruturas para os centros de estudo, a estratégia mais utilizada nestes países foi articular escolas primárias e secundárias. Além dos centros em fábricas e municípios, a rede da universidade está integrada por uma ampla quantidade de escolas que foram equipadas com recepção de satélite e infra-estrutura de laboratórios de computação, de ambientes de práticas profissionais, bibliotecas, recursos digitais, salas de videoconferência, entre outros. Cada escola foi convertida em um centro de formação pleno, não só para as crianças, mas também para seus pais e a comunidade toda, com cursos destinados a superar a pobreza, manter a saúde e desenvolver o empreendedorismo.

Porém o problema ainda reside nas estruturas de administração que estes países têm utilizado, centralizadas academicamente e descentralizadas financeiramente, com cada nível financiando as escolas que se encontram sob sua órbita. Há relatos de experiências dolorosas de diretores de centros de regiões pobres da China falando das péssimas condições de ensino, de locais sem laboratórios ou infra-estrutura adequada, reproduzindo as desigualdades sociais do país. Enquanto as regiões ricas possuem centros de estudo de excelência, com ótimos professores, as pobres dificilmente têm prática educativa. Geralmente, os bons laboratórios estão disponíveis em universidades públicas nos grandes centros urbanos e raramente podem ser utilizados por estudantes. E mesmo que estejam disponíveis, muitas vezes, como na UT, eles são geralmente obrigados a arcar com taxas para seu uso. 
Faz-se necessário refletir sobre a criação de centros de estudo em todas as regiões do país com a mesma qualidade, sob pena de se reproduzirem as desigualdades e a injustiça social existente.

\section{5) Conclusões}

Esta pesquisa iniciou com o objetivo de avaliar em que sentido a educação a distância pode colaborar com a mudança de paradigma educativo que está em curso, defendendo a hipótese de que esta modalidade não pode ser entendida como um método alternativo ou compensatório do ensino presencial, mas como uma verdadeira oportunidade de repensar toda a educação.

Pudemos observar que os limites entre a educação presencial e a educação a distância têm se desvanecido gradualmente com o avanço científico e a incorporação de recursos tecnológicos nas estruturas educacionais. A tal ponto que chegamos a conclusão de que só a distância em verdade pode diferenciar clara e indistintamente ambas modalidades de estudo; distância esta que dia-a-dia tem também ido se encurtando através da utilização de numerosos meios de comunicação bidirecionais. Realmente se a distância alguma vez definiu esta modalidade, com a multiplicação de sistemas como a aula inteligente, que incorporam na comunicação a distância a gestualidade e convertem qualquer microcomputador em uma sala de videoconferência; ou com ecossistemas cognitivos e repositórios nacionais e internacionais de recursos didáticos multimídia, podemos imaginar uma educação totalmente distinta da que conhecemos atualmente.

Nesse sentido emergem visões que vão da teoria à prática, como a chinesa, que unificou a educação presencial e a distância, formal e não formal, fundamental, média e superior; com o objetivo de melhorar a qualidade do sistema fundamental e médio, vocacional e profissionalizante, utilizando os melhores recursos das universidades para dar respostas às demandas educativas da população. E ao mesmo tempo, melhorar a infra-estrutura tecnológica e educativa das escolas, convertendo cada escola em um centro de conhecimento da sua comunidade.

Entendemos que a tecnologia educativa está possibilitando quebrar velhas fronteiras educacionais, possibilitando criar uma educação mais dinâmica, desafiadora e motivadora; flexível, significativa e reflexiva; mais adequada às necessidades de comunidades concretas, e 
desde uma perspectiva aberta, tanto na possibilidade de escolha, como na construção de conhecimento coletivo e a formação de comunidades de prática, constituindo uma verdadeira sociedade da aprendizagem que gere oportunidades educativas a todas as pessoas durante toda a vida.

Esse panorama nos fala de uma reflexão do papel da universidade na realidade atual. Entendemos que se faz necessária uma completa reforma educativa, para adequar a educação às demandas específicas que a sociedade do conhecimento nos impõe. Uma reforma cosmética já não poderá dar conta deste desafio.

Nesse sentido, é importante considerar o desenvolvimento da sociedade do conhecimento como uma estratégia nacional, que posicione ao Brasil no mundo globalizado como um produtor de conhecimento, e não como um simples consumidor.

As lições aprendidas nos falam da importância de considerar o desenvolvimento de infraestruturas poderosas de comunicação bidirecional, ao longo de todo o país; mas também de reconhecer a importância dos conteúdos educativos e dos recursos didáticos multimídia com os quais enriquecer as nossas atividades educativas, sejam estas presenciais, semi-presenciais ou a distância.

Existem atualmente em construção vários repositórios de conhecimento, tanto nacionais como regionais, como o caso do PANDORA, na Ásia; de Merlot, nos Estados Unidos; da biblioteca Alexandria, no Chile; e numerosas experiências na Open UK, no MIT, na Índia, entre outras.

Faz-se urgente considerar o desenvolvimento de recursos de alta qualidade, investindo no país, nos jovens e na possibilidade de construir um ambiente livre, aberto, 24 x 7, 365 dias ao ano, para facilitar a aprendizagem das pessoas.

Nesse sentido, e aproveitando as lições aprendidas em outros países, recomendamos:

1) Que a estrutura financeira da UAB contemple os municípios sem recursos, para não replicar as condições sociais na educação aberta, ou seja, municípios ricos têm centros de excelência, municípios pobres, recursos escassos e qualidade educativa baixa; 
2) Considerar na estrutura financeira da $U A B$, os custos reais de produção com equipes profissionais, deixando ao professor no papel que lhe compete, planejamento, mediação didática, avaliação em processo;

3) Investir em um repositório nacional de recursos didáticos multimídia digitais, para toda a educação nacional;

4) Fazer uma pesquisa permanente de todas as experiências desenvolvidas, índices de evasão, análise de retenção, entre outras informações importantes acerca da qualidade dos sistemas de aprendizagem virtual, com o objetivo de compartilhar as melhores práticas e aprender com os erros, tão comuns quando se trata da criação de novos paradigmas.

5) Desenvolver uma política de integração entre as universidades e as escolas de todo o país, com foco no atendimento das verdadeiras demandas de comunidades e pessoas. 


\section{5) Bibliografia}

ABED. Educação a Distância e seu Emprego no Ensino Contábil no Brasil. Disponível em: $<$ http://www2.abed.org.br/visualizaDocumento.asp?Documento_ID=42>. Acesso em: 18 nov. 2006.

ABRAEAD/ABED. Anuário Estatístico de Educação Aberta e a Distância. Ministério de Educação. Secretaria de Educação a Distância MEC. Instituto Monitor. São Paulo, 2006. p. $118,138$.

ADORNO, Th. W. et. al. La disputa del positivismo em la sociologia alemana. Barcelona: Grijalbo, 1973. p. 123.

ALLAMA IQBAL OPEN UNIVERSITY. Disponível em: $<$ http://www.aiou.edu.pk/advertisement.htm>. Acesso em: 12 jan. 2007.

ALLAMA IQBAL OPEN UNIVERSITY. Institutional Profile. Disponível em: <http://www.aiou.edu.pk/salientfeatures.htm>. Acesso em: 27 nov. 2005.

ALONSO, Katia Morosov. Educação a distância no Brasil: a busca de identidade. Disponível em: <http://www.nead.ufmt.br/documentos/Ident.doc>. Acesso em: 26nov06.

ALTERNATIVE APPROACHES TO FINANCING LIFELONG LEARNING COUNTRY REPORT. Korea, 1998. Disponível em: <www.oecd.org/dataoecd/24/14/2670761.pdf>. Acesso em: $1 \mathrm{dez} 06$.

ALUJA, A. Burnout. Profesional en maestros y su relación con indicadores de salud mental. Boletín de Psicología. Apostilla, FE-USP, p. 47-61, 1997.

ALVAREZ GALLEGO, E.; RIOS FERNÁNDEZ, L. El síndrome de "Burnout" o el desgaste profesional. Revisión de Estudios. Revista Assoc. Esp. Neuropsiquiatria. Disponível em: http://www2.uel.br/ccb/psicologia/revista/textov2n15.htm. Acesso em: 30 nov. 2005.

AMERICAN INSTITUTES FOR RESEARCH (AIR). National Survey by the The literacy of America's College students, 2006. p.10. Disponível em: <http://www.pewtrusts.com/ideas>. Acesso em: 25 fev. 2006.

ANNUAL REPORT. Sukhothai Thammathirat Open University. 2005. Disponível em: $<$ http://www.stou.ac.th>. Acesso em: 26 jan. 2005.

ARTE HISTORIA. Ediciones Dolmen, S. L. Madrid. España. Disponível em: $<$ http://www.artehistoria.com>. Acesso em: 21 out. 2006.

ASPECTOS DISTINTIVOS de la Educación a Distancia. UNAM. México. Disponível em: $<$ http://www.filos.unam.mx/POSGRADO/seminarios/pag_robertp/paginas/educ_distancia.ht m>. Acesso em: 25 nov. 2006.

PORTAL DA ATHABASCA UNIVERSITY. Disponível em: <http://www.athabascau.ca>. Acesso em: 12 jan. 2005. 
REDDI, Usha e MISHRA, Sanjaya. Commonwealth of Learning. Perspectives on Distance Education. Educational Media in Ásia. Vancouver, 2005. p. 173

BAGWELL, George. Prof. Colorado Mountain College. Disponível em: $<$ http://faculty.coloradomtn.edu/bagwell/>. 12 jan. 2007.

BALLONE, G.J. Violência e Saúde. In: PsiqWeb. Disponível em: $<$ http://gballone.sites.uol.com.br/temas/violen_inde.html>. Acesso em: 15 jan. 2005.

Estresse. Psiquiatria Geral, 2002. Disponível em:

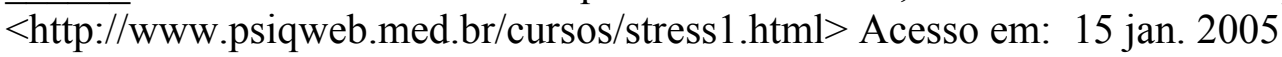

BARONA, E. G. Estudio preliminar ao síndrome de Burnout. Ciencia Psicológica. Cidade: Editora, 1991. p. 63-76.

BARRETO, Lina Sandra (org.). Fundamentos da Educação a Distância. Leituras Obrigatórias. Projeto CEAD/UNOESC. Brasília: Centro de Educação Aberta, Continuada a Distância, s.d., p. 2-23.

BASU, In: Commonwealth of Learning. Perspectives on Distance Education. Educational Media in Asia. Vancouver, 2005. Página 131.

BECK, U. La sociedad de riesgo. Buenos Aires: Ediciones Paidos, 1998, p. 31.

- Conferência Risk Society, realizada na Escola Nacional de Saúde Pública, FIOCRUZ, em 21 de novembro de 1995. Disponível em: $<$ http://www.ensp.fiocruz.br/projetos/esterisco/maryfim5.htm>. Acesso em: 14 jun. 2005.

Sociedad de Risco. Barcelona: Paidos Editora, 1986. p.16.

BELLONI, M. Educação a distância mais aprendizagem aberta GT 16. Educação e comunicação. 2001. Disponível em: $<$ http://www.educacaoonline.pro.br/art_educacao_a_distância.asp?f_id_artigo=42.>. Acesso em: 12 fev. 2006.

BIFANI. P. Medio Ambiente y Desarrollo. Universidad de Guadalajara. Guadalajara: Jalisco, 1997. p. 35.

BOLETIM DA EDUCAÇÃO NA AMÉRICA LATINA. Quantidade sem Qualidade. Programa de Promoção da Reforma Educativa na América Latina e Caribe, 2006. Disponível em: <http://www.preal.org>. Acesso em: 17 nov. 2006.

BOLETIM INFORMATIVO da Cidade do Conhecimento/USP. Área de Notícias, Seção "Lançamento da ISA-ICDE busca padronização na avaliação de qualidade em educação a distância e e-learning". Ano III, n.3. 1 a 15 de março, 2003. Disponível em: $<$ http://www.cidade.usp.br/redemoinhos/0303/noticias.php>. Acesso em 7 fev. 2005.

BRETON, 2000. p. 137. Ver página 20. 
BRUNER. Acts of meaning. Cambridge, MA: Harvard Univ. Press. castellano: Actos de significado. Más allá de la revolución cognitiva. Madrid: Alianza, 1991.

BRUNO, Lúcia (org.). Educação e Trabalho no Capitalismo Contemporâneo. Editora Atlas: São Paulo, 1996. Disponível em: $<$ http://ppbr.com/ld/conhec.asp >. Acesso em: 17 mai. 2005.

BUSH, Martin. E-learning in Japanese Universities. Revista eLearn Magazine. Disponível em: http://www.elearnmag.org/subpage.cfm?section=tutorials\&article=7-1. Acesso em: 9 jan. 2005

CANDAU, V. In: Furiati G. Educação, uma corrida contra o tempo. Tecnologia Educacional, v. 25. Pagina 129, mar/abr, 1996. Disponible em: abed.org.br/publique/cgi/cgilua.exe/sys/start.htm?infoid=195\&.... Acesso em: 15 jan. 2005

CAPRA, F. O ponto de mutação. A ciência, a sociedade e a cultura emergente. São Paulo, Cultrix, 1982.

CARR, W.; S. KEMMIS. Teoría crítica de la enseñanza. La investigación-acción en la formación del profesorado. Libros universitarios y profesionales. Barcelona: Martínez Roca, 1988. p. 150, 169.

CARRETERO, Enrique. Reacciones a la modernidad. Una lectura de las respuestas de lo social al ejercicio del poder. Theoria: portal crítico de ciencias sociales. Universidad Complutense de Madrid. 2003.2 Disponível em: $<$ http://www.ucm.es/info/nomadas/7/ecarretero.htm>. Acesso em: 23 nov. 2006.

CASTELlS. M. A Sociedade em Rede. A Era da informação: economia, sociedade e cultura. 3. ed. São Paulo: Editora Paz e terra, vol. 1, p.505, 2000.

CASTRO, Flávio. Educação a Distância e Políticas Públicas no Brasil. Uma Experiência do Núcleo de Educação a Distância da Universidade de Brasília, 2001. Disponível em: $<$ http://www.abed.org.br/publique/cgi/cgilua.exe/sys/start.htm?UserActiveTemplate=4abed\&i nfoid=165\&sid=106>. Acesso em: 17 nov. 2006.

CATAPAN, A. Hack; FIALHO, F. Pereira. Pedagogia e Tecnologia: A Comunicação Digital no Processo Pedagógico. Universidade Federal de Santa Catarina/UFSC. Disponível em: $<$ http://www.abed.org.br/antiga/htdocs/paper_visem/araci_hack_catapan.htm $>$. Acesso em: 1 fev. 2005.

CATAPAN, A. Hack; FIALHO, F. Pereira., 2001. Ver p. 87.

CENTRAL BROADCAST TELEVISION UNIVERSITY. China TV University. (Tradução Tu Ling). Disponível em: <http://www.crtvu.edu.cn/.> Acesso em: 3 jan. 2005.

CENTRE NATIONAL D'ENSEIGNEMENT À DISTANCE. Disponível em : $<$ http://www.cned.fr/> Acesso em: 27 jan. 2005, 24 mar. 2005, 17 set. 2004. 
CEPAL. Panorama social de América Latina. 2005. p. 3. Disponível em: $<$ http://www.cepal.org/publicaciones/xml/4/23024/PSE2005_Cap1_Pobreza.pdf $>$ Acesso em: 12 out. 2006.

CERDA GONZÁLEZ, C. Educación a distância: principios y tendencias. Revista Perspectiva Educacional. Instituto de Educación UCV. n. 39-40, I y II Semestres, 2002. p. 11-30, 22. Disponivel em: <http://euv.cl/archivos_pdf/.../perspectiva_articulo_39-40.pdf $>$. Acesso em: 26/05/2005.

CHAVES, E. Conceitos Básicos: Educação a Distância. EdutecNet: Rede de Tecnologia na Educação, 1999. Disponível em: http://www.edutecnet.com.br/. Acesso em: 17 nov. 2005.

- Tecnologia na Educação, Ensino a Distância e Aprendizagem Mediada pela Tecnologia: Conceituação Básica. 1999. Disponível em: $<$ http://www.chaves.com.br/TEXTSELF/EDTECH/EAD.htm > Acesso em: 18 nov. 2005.

CHINA CENTRAL RADIO AND TV UNIVERSITY. Tradução Tu Ling. Disponível em:

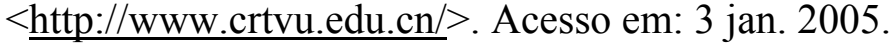

CHINA EDUCATION and Research Network. Distance education. 2001. Disponível em: $<$ http://www.edu.cn/HomePage/english/education/disedu/index.shtml. $>$ Acesso em: 10 jan. 2005 .

CIUDADES MÁS SEGURAS. Programa de las Naciones Unidas para asentamientos Urbanos. UN-Habitat. Disponível em: <http://www.unhabitatrolac.org/default.asp?pag=areas_programaticas.asp\&id_secao $=12 \&$ id_idioma $=2>$. Acesso em: 15 out. 2006.

CODO, W.; SAMPAIO, J.; HITOMI, A. Indivíduo, trabalho e sofrimento. Petrópolis: Vozes, 1993. p.280.

COMMONWEALTH OF LEARNING. Perspectives on Distance Education. Educational Media in Ásia. Vancouver, 2005. p. 131. Disponível em: $<$ http://www.ignou.ac.in/schools/soet/nautical\%20science/prospectus'06/Prospectus_Aug06_n ew.doc>. 17 out. 2006.

CONVERSOR DE MOEDAS. Yahoo Finanças. Taxa de câmbio: 0.0002376. Disponível em: $<$ http://br.finance.yahoo.com/currency/convert?amt $=2000 \&$ from $=I D R \&$ to $=B R L>. \quad$ Acesso em: 16 dez. 2006.

CREATIVE COMMONS LICENSE. Disponível em: $<$ http://en.wikipedia.org/wiki/Creative_Commons_License>. Acesso em: 23 fev 06.

CREFAL. Disponível em: < http://www.crefal.edu.mx.> Acesso em: 20 nov. 2005.

DANIEL, John. Mega-universities - Mega-impact on Access, Cost and Quality. UNESCO. First Summit of Mega-universities. Shanghai, China. 7-9 novembro, 2003. In: UNESCO. Disponível em: $\quad<$ http://portal.unesco.org/education/en/ev.php-

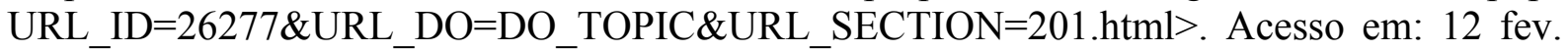
2006 . 
Mega Universities and Knowledge Media: Technology Strategies for Higher Education. London: Kogan Page, 1996.

DAVIS, S. Becoming a knowledge-based bussines. Local: Editora, 1999. p. 56

DE LA GÁNDARA, J. Comprar por comprar. Madrid: Cauce Editorial, 1996. p.130-131.

DEL GROSSI, Mauro Eduardo; SILVA, José Graziano da; TAKAGI, Maya. Evolução da Pobreza no Brasil, 1995/99. Texto para Discussão. IE/UNICAMP. n. 104, novembro, 2001. Disponível em: <http://www.eco.unicamp.br/publicacoes/textos/download/texto104.pdf > Acesso em: 16 out. 2006.

DILTHEY, G. História de la pedagogía. Buenos Aires: Losada, 1968. p.14.

DISTANCE LEARNING IN THE KNOWLEDGE. Age: Beyond the Digital Gap. A Perspective from Tsinghua University. The School of Continuing Education, Tsinghua University. Dr. Song Gilsun (Sunny). October 5th, 2005. Disponivel em: $<$ http://www.fenu.ru/?a=page\&id=524>.

DOWBOR, 2001. Os Novos Espaços do Conhecimento. Disponível em: < http://dowbor.org/conhec.asp>. Acesso em: 18 out. 2006.

DOWBOR, Ladislau. Tecnologias do conhecimento: os desafios da educação. Disponível em: $<$ http://dowbor.org/tecnconhec.asp>. Acesso em: 13 nov. 2006.

DR. B.R. AMBEDKAR OPEN UNIVERSITY. Disponível em: $<$ http://www.braou.ac.in/profile.htm>. Acesso em: 2 jan. 2005.

DURKHEIM, In: MARDONES, José Maria. Filosofía de las ciencias humanas y sociales. Colombia: Ediciones Anthropos, 1994. p.19-57.

EDUCATION IN PAKISTAN. A white paper. National education policy review team. December, 2006. Disponível em: <http://www.moe.gov.pk>. Acesso em: 10 Dez 2006

E-KOREAVISION. Ministério da Informação e Comunicações. Promoting National Informatization. $2006 . \quad$ Disponivel em: $<$ http://unpan1.un.org/intradoc/groups/public/documents/APCITY/UNPAN008974.pdf $>$.

Acesso em: 12 Dez 2006

EL HAMBRE y el aprendizaje. Naciones Unidas. Programa Mundial de Alimentos. 2006. Roma. p.18. Disponível em: <http://www.lpp-uerj.net/olped/documentos/1754.pdf >. Acesso em: 17 out. 2006.

EL SUICIDIO, un problema de salud pública enorme y sin embargo prevenible, según la OMS. Día Mundial para la Prevención del Suicidio, 10 de septiembre. Disponível em: $<$ http://www.who.int/mediacentre/news/releases/2004/pr61/es/>. Acesso em: 25 out. 2006.

ENROLMENT IN ALLAMA IQBAL OPEN UNIVERSITY. Pakistan Statistical Year Book, 2004. Chapter 6. Education. p.137-140. Disponível em: 
$<$ http://www.statpak.gov.pk/depts/fbs/publications/yearbook_2004/education.pdf $>$. Acesso em: 20 jan. 2005.

FERREIRA, Aurélio Buarque de Holanda. Novo Aurélio Século XXI. Nova Fronteira: São Paulo, 1999.

FILMUS, Daniel. Biblioteca virtual de la OEI. El Papel de la Educación Frente a los Desafíos de las Transformaciones Científico-Tecnológicas. Educación Técnico Profesional. Cuaderno de Trabajo 1. Disponível em: <http://www.oei.org.co/oeivirt/fp/cuadla06.htm>. Acesso em: 21 out. 2006.

FOZDAR, Bharat Inder; KUMAR, Lalita S.; KANNAN, S. A Survey of a Study on the Reasons Responsible for Student Dropout from the Bachelor of Science Programme at Indira Gandhi National Open University. Indira Gandhi National Open University. Índia, 2006. In: International Review of Research in Open and Distance Learning. vol. 7, n.3. Dezembro, $2006 . \quad$ Disponivel em: $<$ http://www.irrodl.org/index.php/irrodl/article/viewPDFInterstitial/291/755>. Acesso em: 21 out. 2006.

FREIRE, Paulo. Educação como prática da liberdade. 15.ed. Rio de Janeiro: Paz e Terra, 1984.

GADAMER, H. G. El giro hermenéutico. Madrid: Editora, 1998.

GADOTTI, Moacir. História das idéias pedagógicas. São Paulo: Ática, 1992. p.87-93.

GALEANO, Eduardo. De Pernas para o ar. A escola do mundo ao revés. São Paulo: L\&PM Editores, 1999.

GARCIA, 1986. Ver p. 78.

GARCIA, Aretio. Hacia una Definición de Educación a Distancia. Boletín informativo de la Asociación Iberoamericana de Educación a Distancia. Abril. Año 4. n. 18. p. 4, 1987. Disponível em: $\quad<$ http://www.uned.es/catedraunescoead/articulos/1987/hacia\%20una\%20definicion\%20de\%20educacion\%20a\%20distancia.pdf $>$. Acesso em: 20 nov. 2006.

Educación a distância hoy.. Universidad Nacional de Educación a Distância. Madrid: Editora, 1994. p. 24, 70. (Serie educación permanente)

GARDNER, Howard. Estructuras de la mente. Teorìa de las inteligencias múltiples. Fondo de cultura económica: México, 1997. p. 53.

GARLANDIA, Juan de la. Manual universitário. In: RODRÍGUEZ DE LA PENA, Alejandro. Los orígenes de la Universidad: las piedras y las almas de las universidades medievales. Revista Arbil, Espanha, nº 85, p. 18. 2000.

GIDDENS, Anthony. As conseqüências da modernidade. São Paulo: UNESP, 1991. p. 16, 38. 
GIL, Antonio Carlos. Métodos e Técnicas de Pesquisa Social. São Paulo: Atlas, 1999. p. 43.

GLOBAL FOREST Resources Assessment 2005. 15 KEY FINDINGS. FAO, 2005. Disponível em: <http://www.fao.org>. Acesso em: 12 mai. 2005.

GODDARD INSTITUTE FOR SPACE Studies (GISS) at Columbia University. GISS is a division of the NASA Goddard Space Flight Center. Disponível em: $<$ http://www.giss.nasa.gov>. Acesso em: 20 jan. 2006.

GOMES DOS SANTOS, E.; CRUZ, D.; PAZZETTO, V. Ambiente educacional rico em tecnologia: a busca do sentido. Universidade Federal de Santa Catarina. 2001. Disponível em: $<$ http://www.abed.org.br/publique/cgi/cgilua.exe/sys/start.htm?infoid=187\&sid=102\&UserAc tiveTemplate $=4$ abed $>$. Acesso em: 2 fev. 2004.

GUIMARÃES, André Sathler. Novo Ecossistema Cognitivo: Pensamentos sobre Tecnologias de Informação e Comunicação e a Metamorfose do Aprender. Associação Brasileira de Educação a Distância - ABED. Publicada em: 30/08/2002. Disponível em: $<$ http://www.abed.org.br/publique/cgi/cgilua.exe/sys/start.htm?UserActiveTemplate=1por\&in foid=25\&sid=69>. Acesso em: 18 nov. 2005.

GUJARAT, CHAUDHARY, BEHARI, 1994. In:Commonwealth of Learning. Perspectives on Distance Education. Educational Media in Ásia. Vancouver, 2005, p. 131.

GUO, Ling; XIANG, Xin; SHI, YuanChun. Use Web Usage Mining to Assist Online ELearning Assessment. State Key Lab of Intelligent Technology and Systems. Computer Science Department. Tsinghua University. Beijing, China, 2004. Disponível em: csd12.computer.org/persagen/DLAbsToc.jsp?resourcePath=/d1/...Acesso em: 1 nov. 2006.

GUTIÉRREZ, Haydée. Paradigmas educativos y el uso de medios audiovisuales. Escuela de bibliotecología. Escuela de diseño universidad tecnológica metropolitana. Chile, 2000. Disponível em: <http://www.utem.cl/deptogestinfo/haydeepubli.doc $>$. Acesso em: 2 nov. 2006.

HACIA LAS SOCIEDADES DEL CONOCIMIENTO. UNESCO, 2005. Disponível em: $<$ http://firgoa.usc.es/drupal/node/23044>. Acesso em: 9 mar. 2006.

HACK CATAPAN, A.; PEREIRA FIALHO, F. Pedagogia e Tecnologia: A Comunicação Digital no Processo Pedagógico. Universidade Federal de Santa Catarina/UFSC. 2001. Disponível em: $<$ http://www.abed.org.br/antiga/htdocs/paper_visem/araci_hack_catapan.htm>. Acesso em: 01 fev. 2005.

HAQUE, Riffat; BATOOL, Syeda Najeeba. Climbing the ladder: a case study of the women's secondary education programme of allama iqbal open university. Pakistan. Published in 1999 by the International Bureau of Education, Geneva 20, Switzerland. Disponível em: <http://www.ibe.unesco.org>. Acesso em: Dez 2006

HARDHONO; BELAWATI, 1999. Electronic Tutorials: Indonesian experience. Universitas Terbuka. In: International Review of Research in Open and Distance Learning. Volume 3, Number $1 . \quad$ April $\quad$ - $\quad 2002 . . \quad$ Disponível em: 
http://www.irrodl.org/index.php/irrodl/article/view/74/545. Acesso em Acesso em: 16 fev. 2005.

HEIDEGGER, Martin. Carta sobre o humanismo. Tradução de Helena Cortés e Arturo Leyte. Madrid: Alianza Editorial, 2000. Disponível em: $<$ http://personales.ciudad.com.ar/M_Heidegger/carta_humanismo.htm $>$. Acesso em: 20 jun 2005

In: LEFF, E. Saber Ambiental: Sutentabilidad, racionalidad, complejidad, poder. Siglo XXI. Coedición UNAM, PNUMA: Mexico, 1998. p. 150.

Ser e Tempo. Vol 1. Petrópolis: Vozes, 1995.

HORKHEIMER, Max. In: MARDONES, José Maria. Filosofía de las ciencias humanas y sociales. Colombia: Ediciones Anthropos, 1994. p.19-57.

Eclipse da razão. Tradução Sebastião Uchoa Leite. Rio de Janeiro: Editorial Labor do Brasil, 1975. p. 19.

HUIFEN, Liu e LING, He. STRATEGIES FOR ENHANCING INSTRUCTOR IMMEDIACY IN E-LEARNING. Tsinghua University. School of Journalism and Communication, Tsinghua University, Beijing, P. R. China. 2004. Disponível em:

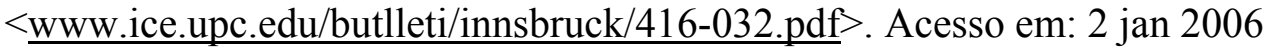

HYBRID MODEL FOR E-LEARNING AT VIRTUAL UNIVERSITY OF PAKISTAN. Saba Khalil Toor. Pakistan, 2005. Disponível em: <www.ejel.org/volume-3/v3-i1/v3-i1-art7toor.pdf>. Acesso em: 4 jan. 2006.

Portal do ICA, Instituto para la Conectividad en las Américas. OEA. Disponível em: http://www.icamericas.net/. Acesso em: 20 nov. 2005.

ICDE. International Council for Distance Education (Conselho Internacional de apoio à Educação a Distância). Disponível em: <http://www.icde.org/>. Acesso em: 5 jan. 2005.

IGNOU Portal. Milestones, 2004. Disponível em: <http://www.ignou.ac.in/default.htm>. Acesso em: 4 jan. 2005.

ILCE. Disponível em: <http://www.ilce.edu.mx>. Acesso em: 1 dez. 2004.

INFORME MUNDIAL sobre la violencia y la salud. Organización Mundial de la Salud 2002. Ginebra. Disponível em: $<$ http://www.who.int/violence_injury_prevention/violence/world_report/en/index.html $>$. Acesso em: 16 out. 2006.

IUCN. Red List of Threatened Species 2006. A Global Species Assessment. The IUCN Species Survival Commission. Disponível em: $<<$ http://www.redlist.org $>$. Acesso em: 7 out. 2006. 
JUNG, Insung. Innovative and Good Practices of Open and Distance Learning in Asia and the Pacific. (A study commissioned by UNESCO, Bangkok). Professor International Christian University Tokyo, 2005.

JUNG, Minseung. The chronological analysis of cyber culture in Korean odl. Korea National University. Seul, 2005. ICD International Conference, New Delhi. Disponível em: $<$ http://www.ignou.ac.in/ICDE2005/PDFs/theme2pdf/theme2_81.pdf $>$. Acesso em: 8 out. 2006.

KOREA NATIONAL OPEN UNIVERSITY. Disponível em: $<$ http://www.knou.ac.kr/engknou/>. Acesso em: 2 nov. 2006.

KUMAR, Sandhya. From the national, to international ARENA. The emergence of NIOS. National Institute of Open Schooling (NIOS). 2005. Disponível em: $<$ http://www.ignou.ac.in/icde2005/PDFs/contents.htm>. Acesso em: 25 mar. 2006.

KWAK, Duk Hoon. Current Status and Development Strategy of e-Learning Focusing on KNOU. Korea National Open University. 2005. Disponível em: $<$ http://thaicyberu.go.th/officialtcu/.../register/paper_bangkok_2006_07_27.pdf $>$. Acesso em: 5 jan. 2007.

LABORATÓRIO DE POLÍTICAS PÚBLICAS/UERJ. Observatório Latino-Americano de Políticas Educacionais. Programa Políticas da Cor na Educação Brasileira. Carta n ${ }^{\circ} 179$ del CEAAL. Carta abierta a los gobiernos y pueblos latinoamericanos: el tunel y la luz. Disponível em: <http://www.lpp-uerj.net/olped/documentos/1766.pdf>. Acesso em: 17 out. 2006.

LANDIM, Cláudia Maria das Mercês Paes Ferreira. Educação a distância: algumas considerações. Rio de Janeiro: Edições 70, 1997. p. 30.

LEFF, Enrique. Sociología y Ambiente: Formación socioeconómica, racionalidad ambiental y transformaciones del conocimiento. In: Ciencias Sociales y formación ambiental. Ediciones Gedisa: Barcelona, 1994. p. 65, 87.

LEFF, Enrique. A Complexidade Ambiental”, Cortez, Editora. São Paulo. 2003. p, 34.

LEFF, E. Saber Ambiental: Sutentabilidad, racionalidad, complejidad, poder. Siglo XXI. Coedición UNAM, PNUMA: Mexico, 1998. p. 150.

LEMOS, A. Cibercultura, Cultura e Identidade. Em direção a uma "Cultura Copyleft"?, 2004. Disponível em: <http://twiki.im.ufba.br/bin/view/GEC/SociCibercon>. Acesso em: 19 jun. 2005.

LEVY, P. Cibercultura. Editora 34: São Paulo, 1999. p. 166.

LIMA, Geni Aparecida de. Identification des conditions de réussite d'un système de formatión à distance de enseignemants “leigos” du Pantanal au Brésil. 1990. Dissertação de Mestrado - Université de Laval. Québéc, 1990. 
MACHADO SOUSA, E. C. B. "Panorama internacional da educação à distância". Em Aberto, Brasília, v. 16, n. 70, p. 9-16, abr.-jun. 1996.

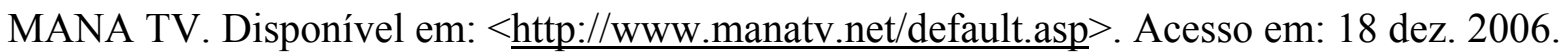

MANA. Receive Terminals Installed. Disponível em: < $<$ http://www.manatv.net/terchart.asp $>$.

Acesso em: 18 dez. 2006.

MANIFIESTO por una Ética para la Sustentabilidad. Séptima Reunión del Comité Intersesional del Foro de Ministros de Medio Ambiente de América Latina y el Caribe. Sao Paulo, Brasil, 15 a 17 de maio de 2002. Disponível em: <www.pnuma.org/educamb/esp/mantexto.php>. Acesso em: 13 mai. 2005.

MARCOS LEGAIS. Ministério da Educação Fundescola. Brasília, 2000. p 189. Disponível em:

$<$ http://www.fnde.gov.br/home/fundescola/manuais_tecnicos_operacionais/marcos_legais.pdf >. Acesso em: 18 nov. 2006.

MARCUSE, Herbert. El Hombre unidimensional. Editora Planeta. Buenos Aires. 1985 p. 19.

MARDONES, José Maria. Filosofía de las ciencias humanas y sociales. Colombia: Ediciones Anthropos, 1994. p.19-57.

Filosofía de las ciencias humanas y sociales. Colombia: Ediciones Anthropos, 1991. Pág. 24.

MARQUES, Camila. Universidade de EaD na Espanha atende mais de 200 mil alunos. Folha Online, Rio de Janeiro. Disponível em: $<$ http://portal.webaula.com.br/noticia.aspx? $\mathrm{sm}=$ noticias\&codnoticia $=327>$. Acesso em: 02 dez. 2004.

MARTINS, Onilza Borges; POLAK, Ymiracy Nascimento de Souza (org.). Educação a Distância na UFPR: Novos caminhos e novos Rumos. 2. ed. Curitiba: Editora da UFPR, 2001. Disponível em: <http://vitoria.upf.tche.br/ teixeira/2002-2/material/Aula-20-8-2002.pdf>. Acesso em: 22 nov. 2006.

MARX, C. Writing of the Young Marx on Philosophy and Society. In: CARR, W.; S. KEMMIS. Teoría crítica de la enseñanza. La investigación-acción en la formación del profesorado. Libros universitarios y profesionales. Barcelona: Martínez Roca, 1988. p. 150.

MEC. Educação Superior a Distância. Quem pode oferecer cursos de graduação a distância, Portal MEC. Disponível em: http://www.mec.gov.br/Sesu/educdist.shtm\#quem\%20pode\%20oferecer. Acesso em: 28 nov. 2004.

MEGA-UNIVERSITIES \& KNOWLEDGE MEDIA. Technology Strategies for Higher Education. London: Kogan Page. Disponível $<$ http://www.columbia.edu/ mar178/def.htm>. Acesso em: 18 nov. 2006. 
MINISTÉRIO DE EDUCAÇÃO DA ÍNDIA. Relatório anual, 2004-2005. p. 1. Disponível em: <http://www.education.nic.in/htmlweb/Annualreport2004-05/EduDev.pdf $>$. Acesso em: 27 jul. 2006.

MISHRA, 1999. In:Commonwealth of Learning. Perspectives on Distance Education. Educational Media in Ásia. Vancouver, 2005, p. 131.

MIZUKAMI, M.G.N. Ensino, as abordagens do processo. São Paulo: EPU, 1986. p. 87.

MORAN, José Manuel. Avaliação do Ensino Superior a Distância no Brasil. Disponível em: $<$ http://www.eca.usp.br/prof/moran/avaliacao.htm>. Acesso em: 13 mar. 2006.

- Avaliação do Ensino Superior a Distância no Brasil. Disponível em: $<$ http://www.eca.usp.br/prof/moran/avaliacao.htm>. Acesso em: 17 jun. 2005.

Tendências da educação on-line no Brasil. Disponível em: $<$ http://www.eca.usp.br/prof/moran/textos.htm. 2005>. Acesso em: 1 jan. 2006.

MORIN, E. Introducción al Pensamiento Complejo. Editorial Gedisa: Barcelona, 1998. p. 21.

MUSETTI, Rodrigo. Neoliberalismo, globalização e direito à educação da não exclusão. Pontifícia Universidade Católica de Campinas, 1999. Disponível em: $<$ http://www.infojus.com.br/area15/rodrigo3.html>. Acesso em: 16 out. 2006.

NIETZSCHE, F. La genealogía de la moral. Cidade: Tecnos, 2003. p. 103.

NOBRE JÚNIOR, Edilson Pereira. O direito brasileiro e o princípio da dignidade da pessoa humana. Disponível em: <http://www.infojus.com.br/area3/edilsonnobre.htm>. Acesso em: 10 out. 2006.

Portal Do Ministério de Cultura e Educação. Disponível em: $<$ http://www.mec.gov.br/Sesu/educdist.shtm\#quem\%20pode\%20oferecer $>$. Acesso em: 28 nov. 2004.

Portal da OEA. Disponível em: <http://www.educoas.org>. Acesso em: 12 out. 2006.

Portal da Allama Iqbal Open Uniuversity. Centros de Estudo: Fonte: Site da universidade: Disponível em: <http://www.aiou.edu.pk/RegionalOffices.asp>. Acesso em: 12 out. 2006.

NUNES, Ivônio Barros. Noções de Educação a Distância. In: BARRETO, Lina Sandra (org.). Fundamentos da Educação a Distância. Leituras Obrigatórias. Projeto CEAD/UNOESC. Brasília: Centro de Educação Aberta, Continuada a Distância, s.d. p. 2-23.

OEA. El adelanto tecnológico al servicio del potencial humano. Disponível em: $<$ http://www.educoas.org/portal/es/acerca/documentos/documentos.aspx?culture=es\&navid= 27>. Acesso em: 24 mar. 2005.

. Portal Educativo das Américas: Disponível em: $<$ http://www.educoas.com>. Acesso em: 1 dez. 2004 
OIT. Organización Internacional del Trabajo. Tendencias mundiales del empleo juvenil. Ginebra, 2006. p.9. Disponível em: <http://www.ilo.org/trends>. Acesso em: 12 out. 2006.

OPEN LEARN. Learning Space. Disponível $<$ http://openlearn.open.ac.uk/mod/resource/view.php?id=1581>. Acesso em: 15 out. 2006.

ORGANIZAÇÃO METEREOLOGICA MUNDIAL. Disponível em: $<$ http://www.wmo.ch/index-sp.html $>$. Acesso em: 21 jan. 2006.

OVERVIEW OF STUDENTS. Student Profile. Disponível em: <http://www.uair.ac.jp/eng/table/09_ove2.html>. Acesso em: 13 out. 2006.

PARKER, L.; RICCOMINI, B. (eds.). A report on university applications of satellitelcable technology. University of Wisconsin: Local???, 1975. p. 125-133.

PAYAME NOOR UNIVERSITY. Disponível em:< http://www.pnu.ac.ir $>$. Acesso em: 20 jan. 2005.

PÉREZ GÓMEZ, Á. I. La cultura escolar en la sociedad neoliberal. Madrid: Morata, 1998. p.19.

PNUD. Relatório do Desenvolvimento Humano. Programa das Nações Unidas para o Desenvolvimento. New York, 2006. p.42.

. Informe Sobre el Desarrollo Humano 2001. Programa de las Naciones Unidas para el Desarrollo. Ediciones Mundi-Prensa: Madrid, 2003.

Informe sobre Desenvolvimento Humano. Programa das Nações Unidas para o Desenvolvimento. New York, 1999.

Informe sobre Desenvolvimento Humano. Programa das Nações Unidas para o Desenvolvimento. New York, 1998.

Programa de las Naciones Unidas para el Desarrollo. Informe sobre Desarrollo Humano. Mundi Prensa: Madrid, 1998. p. 1.

POTASHNIK, M.; CAPPER, J. Distance Education: Growth and diversity. Finance \& Development. 1998. In: CERDA GONZALEZ, C. Educación a Distancia: Principios y Tendencias. Revista Perspectiva Educacional. Instituto de Educación. UCV. n. 39-40, I e II Semestres. Chile, 2002. p. 22.

POZO, Teorias Cognitivas da Aprendizagem. Artmed. Porto Alegre. 1998. p, 38.

POZO, J. Aprendices y Maestros. Alianza: Madrid, 1996. p. 40.

POZO, J. I. A sociedade da aprendizagem e o desafio de converter informação em conhecimento. Disponível em: <http://www.diretoriabarretos.pro.br/patio online2.htm $>$ Acesso em: 20 jan 2006. 
QUALIDADE NA EDUCAÇÃO BÁSICA. Agenda de trabalho a ser desenvolvida a partir de abril de 2005 até a aprovação do Fundeb. Ministério da Educação. Assessoria de Comunicação Social. Brasília, 2005. Disponível em: $<$ http://portal.mec.gov.br/arquivos/pdf/progr_qualidadenaeducacao.pdf $>$. Acesso em: 12 nov. 2006.

QUÉ ES LA EDUCACIÓN A DISTANCIA. Faculdade de Sociología. Universidad de Buenos Aires. Disponível em: <http://www.catedras.fsoc.uba.ar/edudist/brevead.htm>. Acesso em: 24 nov. 2006.

RAMOS, Nogueira. Boletim técnico do SENAC. vol. 27. n. 3. Setembro/Dezembro, 2001. Disponível em: <http://www.senac.br/informativo/BTS>. Acesso em: 26 nov. 2006.

REIS, Márcia Lopes. A educação como indústria cultural: um negócio em expansão. Revista Iberoamericana de Educación. n. 36, Stembro-Dezembro, 2004. Disponível em: $<$ http://www.rieoei.org/rie36a04.htm>. Acesso em: 22 out. 2006.

REVISTA BRASILEIRA de Aprendizagem Aberta e a Distancia. Disponível em: $<$ http://www.abed.org.br/publique/cgi/cgilua.exe/sys/start.htm?UserActiveTemplate=1por\&in foid $=817 \&$ sid=70>. Acesso em: 26 nov. 2006.

RIVERA-PORTO, Eduardo. Sobre Educación a Distancia, conceptos, problemáticas y tendencias. Texas A\&M International University, 1999. Universidad de Guadalajara, México. Disponível em: $<$ http://www.quadernsdigitals.net/datos_web/hemeroteca/r_1/nr_10/a_121/121.html $>$. Acesso em: 26 nov. 2006.

ROCHA, Sílvio (org.). Ciclos de Formação - Proposta Político Pedagógica da Escola Cidadã. Prefeitura Municipal De Porto Alegre. Secretaria Municipal de Educação. Caderno Pedagógico 9. 3. ed. Porto Alegre : Gráfica do DMAE, 2003.

RODRIGUES, Rosângela Schwarz. Modelo de avaliação para cursos no ensino a distância. Universidade federal de Santa Catarina. Departamento de Engenharia de Produção. Programa de pós-graduação em Engenharia de Produção, 1998. Disponível em: $<$ http://www.deps.ufsc.br/disserta98/roser/>. Acesso em: 22 nov. 2006.

RODRÍGUEZ DE LA PENA, Alejandro. Los orígenes de la Universidad: las piedras y las almas de las universidades medievales. Revista Arbil, Espanha, nº 85, p. ????? 2000.

RUIZ, Antonio Campuzano. Algunas consideraciones sobre la formación del receptor crítico. Revista de la Asociación de Profesores/as Usuarios de Medios Audivisuales (A.P.U.M.A.). Madrid, vol.2, p. 8, 1999.

SACRISTAN, J.; PEREZ GÓMEZ, A. Vida de sala de aula. Artmed. Porto Alegre, 1998, p. 70 .

SCHAFF, A. A Sociedade Informática: as conseqüências sociais da segunda revolução industrial. 3. ed. São Paulo: Editora da UNESP, 1992. p.43. 
SHALE, D. Innovation in International Higher Education: The Open Universities. University of Alaska. Journal of Distance Education. 1987. Disponível em: $<$ http://cade.athabascau.ca/vol2.1/shale.html >. Acesso em: 30 nov. 2004.

SOBRAL, Fernanda A. da Fonseca. Educação para a competitividade ou para a cidadania social?. São Paulo Perspectiva, São Paulo, v. 14, n. 1, 2000. Disponível em: $<$ http://www.scielo.br/scielo >. Acesso em: 23 out 2006.

SOLEIMAN, N; SRI LISTYARINI; ZUHAIRI. Networking and Partnership for Strengthening Collaboration in Open and Distance Education. A Improving quality services of open and distance education through networking and partnership in the distribution management of course materials. Terbuka University. Paper presented to the 17th Annual Conference of the Asian Association of Open Universities (AAOU) . Bangkok, Thailand, 1214 November 2003.

SOUZA, Luswarghi de, A. A Reinvenção das Organizações Educacionais na Sociedade do Conhecimento: o uso da internet em Associações de Educação a Distância. Dissertação de mestrado apresentada ao Programa de Pós-graduação em Engenharia de Produção da Universidade Federal de Santa Catarina (UFSC). Florianópolis, março de 2000. p.75. Disponível em: <http://das-rheingold.rnagardas.info/a-reinveno-das-organizaeseducacionais-na-sociedade-do-conheci>. Acesso em: 28 nov. 2006.

STATE OF WORLD POPULATION 2006. United Nations Population Fund. New York, 2006. Disponível em: <http://www.globalaging.org/elderrights/world/2006/unfpa.pdf>. Acesso em: 10 out. 2006.

STRAMELLO, Clara Inés. Historia General de la Educación II. Ilustración y Educación en una época de revoluciones. Universidad Católica Argentina (UCA). Buenos Aires, 2003. Disponível em: $<$ http://www.ideasapiens.com/filosofia.sxx/feducacion/hist\%20educ.II_la._\%20ilustracion.ht m>. Acesso em: 29 nov. 2006.

STREAMING SUPPORT for Multimodal Data in Smart Spaces. Multimedia Lab of Tsinghua University, 2003.2 Disponível em: <www.cse.ucsd.edu/ yamao/publications/Stream_MYH.pdf $>$. Acesso em: 2 dez. 2006.

TAYLOR, C. La ética de la autenticidad. Barcelona: Paidós, 1994, p.40.

TAYLOR, J.C. Fifth Generation: Distance Education. University of Southern Queensland Australia. 2001. p. 3. Disponível em: $<<$ http://www.usq.edu.au/users/taylorj/>. Acesso em: 12 jan. 2006.

TERZIAN, Françoise. SENAC. Ensino a distância ajuda a cortar custos. Disponível em: $<$ http://www.rj.senac.br/ead/portalcte/areas/ajuda\%20a\%20cortar\%20custos.htm $>$. Acesso em: 19 jan. 2006.

THE COMMISSION ON COLLEGES SOUTHERN ASSOCIATION OF COLLEGES AND SCHOOLS (SACS). Distance education: definition and principles - a policy statement. Maio, 2000. Disponível em: <http://www.sacscoc.org/pdf/081705/distance\%20education.pdf $>$. Acesso em: 22 nov. 2006. 
THE COMMONWEALTH OF LEARNING (COL). Disponível em: http://www.col.org/colweb/site/pid/3095. Acesso em: 23 nov. 2006.

. Disponível em: <http://www.col.org/resources/weblinks/associations.htm.> Acesso em: 20 dez. 2004.

THE EUROPEAN COMMISSION'S MEMORANDUM on Open Distance Learning in the European Community, 1991. Disponível em: <http://www.city.ac.uk/ictop/distance.html>. Acesso em: 20 nov. 2006.

TOFFLER, A. A terceira onda. Record: São Paulo, 1995. p. 20.

TSINGHUA UNIVERSITY. Modern Distance Education. Disponível em: $<$ http://www.sce.tsinghua.edu.cn/e_edition/long_distance/long_distance.htm $>$. Acesso em: 24 nov. 2006.

UNESCO. Cátedras UNESCO. Disponível em: <http://portal.unesco.org/en/ev.phpURL_ID $=10248 \& U R L \_D O=D O \_P R I N T P A G E \& U R L \_S E C T I O N=201 . h t m l>$. Acesso em: 20 nov. 2005.

UNESCO. Distance Learning Resource Network. Disponível em: $<$ http://portal.unesco.org/education/en/ev.php-

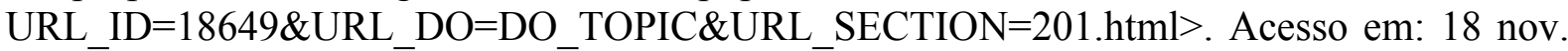
2006 .

- Hacia las Sociedades del Conocimiento, 2005. p.19. Disponível em:

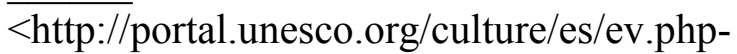
URL_ID=29619\&URL_DO=DO_TOPIC\&URL_SECTION=201.html>. Acesso em: 13 fev. 2006.

Perspectives on distance education: Lifelong Learning and Distance Higher Education. Disponible em: unesdoc.unesco.org/images/0014/001412/141218E.pdf, 2005. p. 81.

Aprendizaje abierto y a distancia. Consideraciones sobre tendencias, políticas y estratégias. División de Educación Superior, 2002. p. 5. Disponível em: <unesdoc.unesco.org/images/0012/001284/128463s.pdf>. Acesso em: 27 nov. 2005.

. Portal AODL. Disponível em: $<$ http://www.africaodl.org/frontend/default.asp $>$ Acesso em: 20 nov. 2005.

Instituto para o planejamento educacional (IIEP). Distance Education Courses. Disponível em: http://www.unesco.org/iiep/ss2005/sschool.htm, 2004.

Distance Education Courses. Disponível em: $\overline{<h t t p: / / w w w . u n e s c o . o r g / i i e p / e n g / t r a i n i n g / v i r t u a l / d i s t a n c e . h t m>. ~ A c e s s o ~ e m: ~} 30$ nov. 2004.

A Universidade Virtual no Brasil, Os números do ensino superior a distância no país em 2002. Instituto Internacional da UNESCO para a Educação Superior na América Latina e 
no Caribe. Seminário Internacional sobre Universidades Virtuais, na América Latina e Caribe. Equador, Quito, 13 e 14 de fevereiro de 2003. p.14.

Distance Education in the E-9 Countries. The Development and Future of Distance Education Programmes in the Nine High-Population Countries. France, 2001. p. 52.

UNICEF. Campanha el futuro es hoy: son nuestros niños. Movimiento Nacional de los Chicos del Pueblo, 2006. Disponível em: <http://www.pelotadetrapo.org.ar/>. Acesso em: 10 out. 2006.

Situação Mundial da Infância. The United Nations Children's Fund, Nova Iorque, Dezembro de 2005. Disponível em: <http://www.unicef.org/brazil/cap1_sowc06.pdf/>. Acesso em: 9 out. 2006.

O progresso das Nações 2001. UNICEF. New York. USA. In: LUZZI, D. Educação Ambiental: Pedagogia, Política e Sociedade. Em educação ambiental e sustentabilidade. São Paulo: Edição USP e Manole, 2005. p. 383.

. El progreso de las Naciones, 1999. Disponível em: $<\mathrm{http}: / /$ www.unicef.cl/centrodoc/ficha.php?id=74>. Acesso em: 12 mai. 2005.

UNIVERSIDAD NACIONAL DE EDUCACIÓN A DISTANCIA. Disponível em: $<$ http://apliweb.uned.es/comunicacion/plantilla2.asp?pag=34> Acesso em: 25 jul. 2005.

UNIVERSITAS TERBUKA. Disponível em: <http://www.ut.ac.id/> Acesso em: 27 jan. 2005.

UNIVERSITY OF SOUTH AFRICA. Disponível em: $<$ http://www.unisa.ac.za/default.asp?Cmd=ViewContent\&ContentID=16241>. Acesso em: 27 jan.2005.

UNIVERSITY OF THE AIR. Disponível em: <http://www.u-air.ac.jp/eng/>. Acesso em: 14 jan. 2005.

VÁSQUEZ MARTÍNEZ, R. Deserción en Educación a Distancia en Educación Superior. Universidad de Guadalajara. Mexico, 2000. p. 9. Disponível em: $<$ http://www.innova.udg.mx/redes/docs/proyecto/desercion.pdf>. Acesso em: 13 mar. 2006.

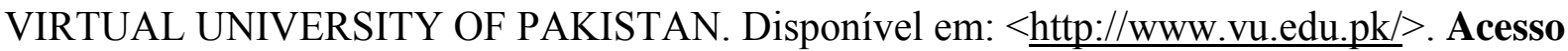
em: 13 mar. 2006.

VIVAS, J. Psicología y Nuevas Tecnologías. Una perspectiva cognitivo constructivista en educación a distancia. Documento Base curso "Bases conceptuales y Modelos organizativos a distancia". S.U.A. UNMdP. Disponível em: $<$ http://www.mdp.edu.ar/uabierta/ead/bases/documentos/Vivas.doc $>$. Acesso em: 10 mar. 2006.

WEDEMEYER, C.A. Implications of open learning for independent study. In: L. Parker \& B. Riccomini (Eds.). A report on university applications of satellitelcable technology University of Wisconsin: Local???, 1975. p. 125-133. 
WHO. Air quality guidelines for particulate matter, ozone, nitrogen dioxide and sulfur dioxide. Global update, 2005. Summary of risk assessment. World Health Organization 2006. Disponível em: $<<$ http://www.who.int/phe/health_topics/outdoorair_aqg/en/index.html $>$. Acesso em: 8 out. 2006.

Informe sobre la salud en el mundo 2005. Organización Mundial de la Salud. Disponível em: <http://www.who.int/whr/2005/es/>. Acesso em: 8 out. 2006.

WIKIPÉDIA. Disponível em: <http://pt.wikipedia.org $>$.

WILLCOX, James; KLINE, Joanne. Distance Education in China. Universidade de Stanford. Yoko Nagashima. Disponível em: <http://ldt.stanford.edu/ jkline/China-final.ppt $>$. Acesso em: 18 mar. 2006.

WORLD SUMMIT of Mega Universities. Innovation and Collaboration - Joint Action for the Future of Distance Education. Shanghai, China. 6-7 de novembro, 2003. Disponível em: $<$ http://03summit.shtvu.edu.cn/web/Mega-Universities/ctvu.htm $>$. Acesso em: 31 jan. 2005.

YOUN, Young-Ja; YOU, Hyo-Soon. Korea National University. How can help students to complete their study in open university: A case of study of Korea national open University. ICDE INternational Conference. 2005. Disponível em: www.ignou.ac.in/icde2005/PDFs/theme3pdf/theme3_245.pdf. Acesso em: 18 mar. 2006.

YUHUI, Zhao. China: Its Distance Higher-Education System. Prospects 18 (2). p. 217-28. 1988. Disponível em: <http://www1.worldbank.org/disted/Technology/broadcast/tv-02.html>. Acesso em: 12/8/2005.

YUILL; JOSCELYNE. In: Narciso Barrero González y Miguel Ma Reyes Rebollo. Enfoque multimedia de los programas metacognitivos de lectura: tecnología educativa en la práctica. Revista Pixel-Bit. $\mathrm{n}^{\mathrm{o}}$ 15. Junho, 2000. Revista de Medios y Educación. Universidad De Sevilla. Disponível em: <http://www.sav.us.es/pixelbit/articulos/n15/n15art/art159.htm>. Acesso em: 2 nov. 2006.

ZUHAIRI, A.; SUPARMAN. Managing quality and accessibility in open and distance learning: the experience of indonesia's universitas terbuka. Terbuka University, 2002. Disponível em: <http://www.ignou.ac.in/theme3\%5CAmin\%20Zuhairi\%20and\%20Atwi\%20Suparman.htmSoleiman>. Acesso em: 2 nov. 2006. 